Міністерство освіти і науки України

Сумський державний педагогічний університет

імені А. С. Макаренка

\title{
Педагогічні науки: теорія, історія, інноваційні технології
}

\author{
Науковий журнал \\ Виходить десять разів на рік
}

Заснований у листопаді 2009 року

№ 3-4 (97-98), 2020

CEJSH

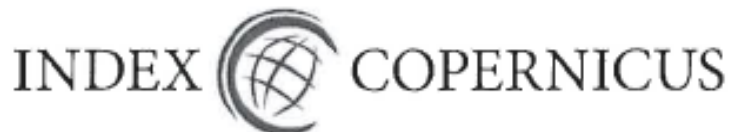

Crossref

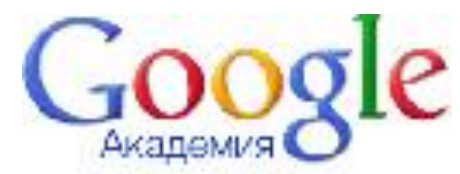

Суми

СумДПУ імені А. С. Макаренка

2020 
Засновник та редакція

Сумський державний педагогічний університет імені А. С. Макаренка

Друкується згідно з рішенням вченої ради Сумського державного педагогічного університету імені А. С. Макаренка (протокол № 13 від 17.08.2020)

Редакційна колегія:

А. А. Сбруєва - доктор педагогічних наук, професор (головний редактор) (Україна);

М. А. Бойченко - доктор педагогічних наук, доцент (заступник головного редактора) (Україна);

О. А. Біда - доктор педагогічних наук, професор (Україна);

Ю. А. Бондаренко - доктор педагогічних наук, професор (Україна);

О. А. Заболотна - доктор педагогічних наук, професор (Україна);

О. В. Кучай - доктор педагогічних наук, доцент (Україна);

М. П. Лещенко - доктор педагогічних наук, професор (Польща);

І. М. Литовченко - доктор педагогічних наук, доцент (Україна);

О. В. Михайличенко - доктор педагогічних наук, професор (Україна);

Є. А. Панченко - кандидат педагогічних наук (Україна);

О. Є. Реброва - доктор педагогічних наук, професор (Україна);

О.В. Семеніхіна - доктор педагогічних наук, професор (Україна);

О.М. Семеног - доктор педагогічних наук, професор (Україна);

I. А. Чистякова - кандидат педагогічних наук, доцент (Україна)

П. Пласкура - кандидат інженерних наук, доцент (Польща) (P. Plaskura - Dr. Eng. (Poland));

B. Зоріч - доктор педагогічних наук, професор (Чорногорія) (V. Zorić - Associate Professor (Montenegro));

Е. Протнер - доктор педагогічних наук, професор (Словенія) (Protner E. - DSc. (Pedagogy), Prof. (Slovenia));

Рецензенти:

В. С. Бугрій - доктор педагогічних наук, професор (Україна);

М. Кісєль - доктор хабілітований (Польща) (М. Kisiel - dr. hab. (Polska))

О. Г. Козлова - кандидат педагогічних наук, професор (Україна);

Ц. Курковський - доктор гуманітарних наук (Польща) (С. Kurkowski - dr. nauk humanistycznych (Polska));

Г. Ю. Ніколаї - доктор педагогічних наук, професор (Україна);

О. І. Огієнко - доктор педагогічних наук, професор (Україна);

К. Стахира - доктор педагогічних наук (Польща) (К. Stachyra - dr hab. (Polska))

О. С. Чашечникова - доктор педагогічних наук, професор (Україна)

Затверджено як фаховий журнал категорії Б з педагогічних наук (наказ МОН України № 886 від 02.07.2020)

Журнал індексується в Crossref, Index Copernicus Master List, Google Scholar ma CEJSH.

У журналі відображено результати актуальних досліджень 3 проблем порівняльної педагогіки, загальної педагогіки, історії педагогіки, педагогіки вищої школи, спеціальної освіти, а також мистецької освіти.

(C) СумДПУ імені А. С. Макаренка, 2020 


\title{
РОЗДІЛ І. ПРОБЛЕМИ ПЕДАГОГІКИ ВИЩОЇ ШКОЛИ
}

удк 378.147:640

\author{
Наталія Бахмат \\ Кам'янець-Подільський національний \\ університет імені Івана Огієнка \\ ORCID ID 0000-0001-6248-8468
}

DOI 10.24139/2312-5993/2020.03-04/003-012

\section{ПІДГОТОВКА ВЧИТЕЛІВ ДО ФОРМУВАННЯ ПІДПРИЕМНИЦЬКОЇ КОМПЕТЕНТНОСТІ УЧНІВ ЗАКЛАДІВ ЗАГАЛЬНОЇ СЕРЕДНЬОЇ ОСВІТИ}

У статті розглянуто сучасні аспекти професійної підготовки педагогів до формування підприємницької компетентності учнів закладів загальної середньої освіти. З'ясовано, що формування підприємницької компетентності учнів закладів загальної середньої освіти відбувається через зміст навчального предмета, через форми, методи та технології. Установлено, що основною метою підприємницької підготовки здобувачів освіти $\epsilon$ ознайомлення ї із підприємницькою діяльністю, фрормування первинних знань і вмінь. Запропоновано комплекс заходів щодо підготовки педагогів до формування підприємницької компетентності учнів закладів загальної середньої освіти.

Ключові слова: професійна підготовка, підприємницька діяльність, мотивація, методи активного навчання, діяльнісний підхід, особистісно орієнтований підхід.

Постановка проблеми. У процесі переходу до суспільства, де підприємницька психологія охоплює всі сфери діяльності, зміна галузевої структури економіки й перерозподіл робочої сили, одним із аспектів якого $\epsilon$ розвиток малого бізнесу та малого підприємництва, веде за собою істотну зміну в змісті навчання випускників закладів загальної середньої освіти (33СО) та спеціальної підготовки педагогів до формування підприємницької компетентності.

Аналіз стану нових соціально-економічних відносин в Україні неминуче призвели до змін у всіх сферах суспільного життя, у тому числі науці, мистецтві й освіті. Перехід до ринкової економіки, відродження природних ринкових відносин висувають завдання виховання активної особистості, яка має знання в економічній та підприємницькій сферах, що прагне до цілеспрямованої реалізації своїх можливостей.

Поставлені завдання актуалізують необхідність у підготовці компетентних педагогів, здатних реалізовувати програми підприємницької освіти учнів, їх удосконалення в мінливих соціально-економічних і політичних умовах. У контексті цих вимог зростає роль підготовки педагога до формування підприємницької компетентності учня 33СО, покликаного забезпечити їх підготовку до перетворювальної діяльності в суспільному виробництві. Сучасна освітня галузь інтегрує зміст підприємницької та економічної освіти, і, формуючи підприємницьку компетентність, педагогу 
важливо компетентно реалізовувати в своїй професійно-педагогічній діяльності економічні знання, уміння, навички, цінності, досвід здійснення підприємницької діяльності. Ці вимоги визначають актуальність проблеми підготовки педагога до формування підприємницької компетентності учня, тому тема дослідження є актуальною й перспективною.

Аналіз актуальних досліджень. Проблему формування компетентності в сфері підприємництва на різних рівнях освіти висвітлено в наукових дослідженнях: Н. Городоцької, Т. Елісіной, Н. Шевиріна та ін. (заклади загальної середньої освіти); В. Анісімова, М. Савіної, І. Смирнова, О. Читаєв та ін. (професійно-технічна освіта); Є. Барижікової, А. Іванової, С. Куликової, М. Нікулаєвої, Л. Семушина та ін. (фаховий молодший бакалавр); М. Меліхової, Т. Обухової, І. Федорової та ін. (вища освіта).

Економічна підготовка до підприємницької діяльності представлена роботами А. Велігона, О. Смирнова, С. Чернер, Н. Шадріної та ін. Підготовка підприємців у різних сферах професійної діяльності вивчалася Н. Анохіною, М. Блюм, Р. Коробковим, М. Нюшенковою та ін. Психологічні аспекти підготовки до підприємницької діяльності розглядалися Д. Аміряном, Л. Бурцевою, Є. Дячковою, О. Приваловою, Л. Шураєвим та ін.

Проблеми формування професійної компетентності здобувачів освіти розглядалися у працях Н. Бахмат, О. Брусєнцевої, Т. Бурлаєнко, О. Гури, О. Дубініної, Л. Карташової, В. Любарець, М. Морозової, О. Мурашко, О. Постоєвої та ін.

Мета статті полягає в аналізі наукових здобутків щодо визначення сучасних вимог професійної підготовки педагогів до формування підприємницької компетентності учнів 33СО. Відповідно до мети визначено такі завдання статті: здійснити аналіз проблеми професійної підготовки педагогів до формування підприємницької компетентності учнів 33СО; уточнити сутність поняття «підприємницька компетентність»; визначити критерії сформованості підприємницької компетентності учнів 33СО; систематизувати кроки щодо ефективної підготовки педагогів до формування підприємницької компетентності учнів 33СО.

Методи дослідження. У представленому дослідженні ми спиралися на положення системного, компетентнісного, діяльнісного й організаційного підходів, використовували загальнонаукові принципи щодо систематизації сучасних вимог професійної підготовки педагогів до формування підприємницької компетентності учнів 33СО. У процесі дослідження використовувалися загальнонаукові та спеціальні методи, основними з яких $€$ : методи аналізу та синтезу, порівняльний, термінологічний аналіз, узагальнення.

Виклад основного матеріалу. У законі Україні «Про повну загальну середню освіту» окреслено, що головною метою загальної середньої освіти $\epsilon$ формування різнобічно розвиненої особистості, здатної реалізувати творчий 
потенціал у динамічних соціально-економічних умовах як у власних життєвих інтересах суспільства. Реалізація цієї мети передбачає розвиток безперервної системи освіти; спадкоємність рівнів та ступенів освіти; підтримку інноваційної діяльності тощо («Про повну загальну середню освіту», 2020).

Формування підприємницької компетентності в процесі підготовки учнів $є$ ланкою в ланцюзі неперервної системи освіти. Важливим чинником $\epsilon$ i те, що саме на вік 14-15 років припадає початок сплеску підприємницької активності (Леонтьев, 2001), тобто прагнення підлітків займатися підприємницькою діяльністю, а схильність до підприємницької діяльності має суттєвий вплив на розвиток підприємливості.

Сучасний погляд на підприємницьку підготовку школярів як проблему формування підприємницької компетентності випускників 33СО, що дозволяє інтегруватися 3 соціально-економічним середовищем, викликав необхідність проведення цього дослідження.

Для того, щоби молодь могла скористатися правом займатися підприємницькою діяльністю, наданою їй новою соціально-економічною системою, державою, вона повинна ще в 33 СО готуватися до цього вибору (стати підприємцем або найманим працівником), отримувати відповідні компетентності, тим більше, що 33СО покликана передавати підростаючому поколінню соціальний досвід і готувати до життя.

Однак, дослідження в цій галузі показують, що у випускників 33СО, як і раніше, не сформована позитивна мотивація до трудової діяльності в сфері малого бізнесу, до відкриття своєї справи в одній зі сфер професійної праці, вони, як і раніше, не володіють необхідним обсягом знань для самостійного самовизначення у професії.

Реальне ознайомлення молоді 3 підприємницькою діяльністю здійснюється, в основному, у системі позашкільної освіти, де передбачається підприємницька підготовка учнів. Крім того, відсутність іноді в педагогів спеціальних знань у сфері ринкової економіки і досвіду підприємницької діяльності також знижує ефективність навчання здобувачів освіти.

Основною метою підприємницької підготовки є ознайомлення учнів із підприємницькою діяльністю, формування первинних знань і вмінь. Найбільш значущим у навчанні $€$ початковий досвід практичної діяльності як визначальний чинник у виборі випускниками З3СО сфери професійної діяльності, пов'язаної з підприємництвом. Ми вважаємо, що цілісність підходу, що включає і знання, і вміння, і практичний досвід ефективніше забезпечить підприємницьку підготовку старшокласників і створить умови для усвідомленого вибору підприємництва як професійного виду діяльності.

Багатогранність досліджень сутності підприємницької компетентності (економічні, соціологічні, психологічні, освітні тощо) зумовлена різностороннім характером цього явища. Економічний напрям, 
як первинний у трактуванні згаданого поняття, розкривається через вивчення окремих аспектів у сфері підприємництва, тобто в працях, присвячених економічним питанням (створення бізнес-плану та власного бізнесу, ініціативність, правова обізнаність тощо). Однак, процеси глобалізації й інтеграції в сучасній науці створили передумови для значно ширшого трактування поняття «підприємницька компетентність», яке не може бути пов'язано тільки зі створенням бізнесу. Виявилося, що існують навички, які забезпечують необхідність спостереження, попереднього дослідження, передбачення, планування майбутньої ініціативи з метою ії ефективного втілення. Зокрема, Б. Бірд окреслила вміння та навички, якими повинна володіти підприємлива особистість: толерантність, самоконтроль, готовність до ризику, сильна мотивація до досягнення поставленої мети, наполегливість, упевненість у своїх силах, готовність долати труднощі, прагнення до якісного виконання роботи, фахові знання, комунікабельність тощо (Bird, 1995). Як бачимо, наявний також психологічний напрям дослідження. У цьому напрямі Ю. Білова вважає, що «Підприємницька компетентність - це інтегральна психологічна якість особистості, яка проявляється в мотивованій здатності до творчого пошуку та реалізації нових ідей та дає змогу вирішувати різноманітні проблеми в повсякденному, професійному, соціальному житті» (Білова, 2013, с. 16). Сучасні зарубіжні дослідники підкреслюють важливість розуміння підприємницької компетентності як здатності до досягнення мети за допомогою інноваційних засобів. Пошук нетрадиційних та ефективних методів діяльності означає, що підприємлива особистість повинна бути креативною та передбачливою (Lans et al., 2010).

у Європейській довідковій системі (Кеу Competences for Lifelong Learning. AEuropean Refrence Framework) підприємницька компетентність трактується як здатність особистості втілювати ідеї у сферу економічного життя, як інтегрована якість, що базується на креативності, творчості, інноваційності, здатності до ризику, а також спроможності планувати та організовувати підприємницьку діяльність.

Формування підприємницької компетентності здобувачів освіти відбувається через зміст навчального предмета, через форми, методи та технології. Ефективність освіти залежить саме від упровадження в освітній процес таких форм, методів і технологій навчання, які створюють можливості школярам виконувати ті ролі, завдання, шукати такі розв'язки проблем, робити такі відкриття, які їм доведеться застосовувати в повсякденному житті. Інноваційні форми роботи сприятимуть формуванню підприємницької компетентності. Такі уроки можна назвати уроками 3 підприємницьким тлом (Гельбак, 2017).

Учителеві в досягненні цілей допоможе застосування різноманітних методів навчання, за використання яких учитель забезпечуватиме практичне 
застосування отриманих знань учнів. Їх можна згрупувати залежно від бажаних ефектів (рис. 1) (Гельбак, 2017):

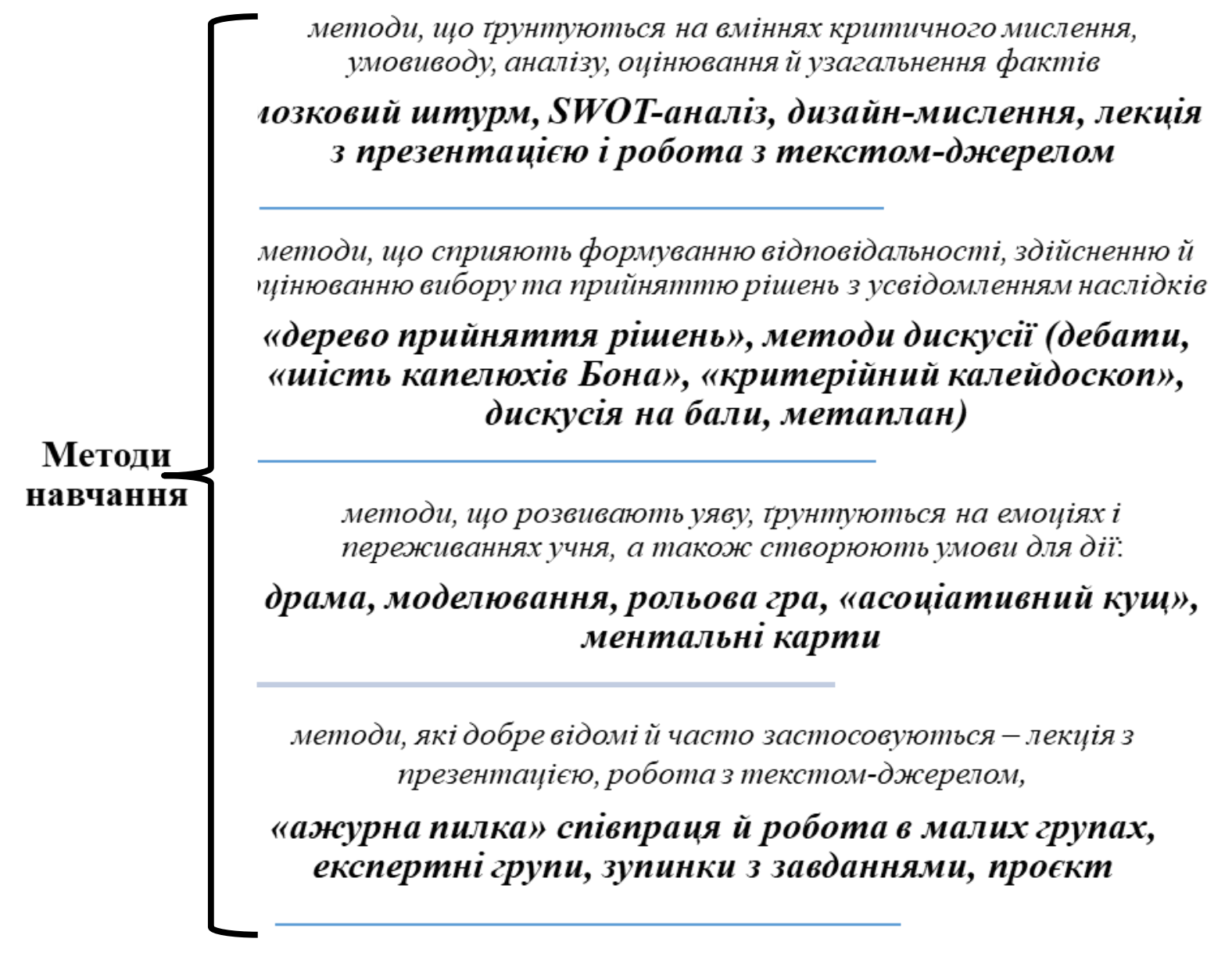

Рис. 1. Методи навчання здобувачів освіти, що забезпечують формування підприємницької компетентності.

Зазначимо, що «на початку вивчення нової теми доцільним є створення проблемної ситуації, що викличе в дітей здивування та пробудить інтерес і зацікавленість. На початковому етапі уроку бажано застосовувати нескладні інтерактивні вправи - «Мозковий штурм», «Мікрофон», «Коло ідей» тощо. Повідомлення, словесно оформлене устами учнів, під час мотивації навчальної діяльності стає своєрідним «містком» для розуміння нового.

Підприємницьку компетентність варто розвивати за допомогою роботи в групах і парах. Така навчальна діяльність формує відповідальність за спільний результат, а ще навчає учнів співпрацювати - спілкуватися між собою, бути лідерами й підлеглими, дискутувати, переконувати, відстоювати власні позиції, іти на компроміс тощо.

Щоб заохотити до активності й почути думку кожного учня, слід упроваджувати такі техніки, як «Метаплан», «Продовж речення», «Оксфордські дебати», дискусії тощо. Викликають зацікавленість до вивчення предмета такі творчі завдання: «Доповни сюжет», «Листзвернення», «Залиш останнє слово для мене» тощо. 
Рекомендовано використання різних форм ігрових технологій. На уроках, де впроваджують гру, немає одноманітності, монотонності; створюються умови для всебічного розвитку дитини, її здібностей. Досить ефективними для розвитку підприємницьких якостей $є$ рольові ігри, які допомагають учням уявити себе експертами в певній сфері, продемонструвати знання, уміння, часто здобуті завдяки методу випереджувальних завдань» (Гельбак, 2017).

Метод проєктів уважається основною технологією формування ключових життєвих компетентностей учнів, зокрема й підприємницької. Адже діти, працюючи над створенням проєктів, навчаються критично мислити, чітко усвідомлювати, де і як можна застосовувати набуті знання, генерувати нові ідеї, бути комунікабельним, постійно самовдосконалюватися.

Вибір конкретного методу, а також спосіб його реалізації залежить від того, з якою групою учнів ми працюємо. Адже групи різні щодо зацікавлень, потреб, можливостей тощо. Отже, ми повинні пізнавати учнів - зокрема через розмови з ними, спостереження й обмін думками з іншими вчителями. Крім цього, на вибір методу мають вплив такі фактори, як кількість учнів у класі, попередній досвід учнів, матеріальне середовище (напр., розташування меблів у класі) (Гельбак, 2017).

Активний пошук змісту, форм і методів навчання школярів підприємницької діяльності (основам підприємництва) має бути заснований на діяльнісному та особистісно-орієнтованому підходах. Підприємницька діяльність - це творча інноваційно-проєктна діяльність. Тому одним із шляхів реального навчання підприємництву, адекватності формування знань і підприємницької компетентності сучасним вимогам суспільного розвитку й вимогам освіти $€$ введення в навчальну практику різноманітних методів активного навчання, що дозволяє організувати практичний складник формування підприємницької діяльності учнів.

За використання різних форм і технік у процесі формування підприємницької компетентності в учнів 33СО використовується система показників: мотивація на підприємницьку діяльність; уміння вирішувати підприємницькі завдання; уміння самостійно отримувати необхідну інформацію; відповідальність; «включеність» у підприємницьку діяльність; мобільність; схильність до ризику; уміння керувати людьми; уміння доводити розпочату справу до успішного завершення; уміння чітко організовувати, планувати і контролювати хід робіт; здатність установлювати ділові контакти; рівень економічної та правової підготовки в сфері підприємництва; уміння використовувати інформаційні технології для здійснення підприємницької діяльності; уміння проектувати підприємницьку діяльність; рівень розвитку індивідуальності в соціальному «Я»; ініціативність; наполегливість.

Зазначену роботу необхідно проводити вже в початковій школі, також необхідний і подальший розвиток цієї якості у старших класах, коли 
відбувається активне вироблення світогляду, переконань, характеру, життєвого самовизначення, поглядів, тому відбувається розвиток підприємливості саме в середніх класах 33СО.

Практична підготовленість педагога означає сформованість у нього готовності діяти в конкретній педагогічній ситуації, застосовуючи відповідні обставинам засоби, методи, прийоми діяльності. Цей параметр включає ще й такі складові, як умілість педагога та його технологічну озброєність. Останні насамперед пов'язані з виділеними етапами виховної діяльності (Прищепа, 2017). Кожен із них вимагає від учителя адекватних умінь у вигляді цілісної ієрархізованої системи та технології їх застосування 3 урахуванням передбачуваних і непередбачуваних виховних задач (Bird, 1995). Майстерність педагога в поєднанні з володінням сучасними технологіями дослідження, конструювання, взаємодії, контролю дає йому можливість ефективно розв'язувати основні класи виховних задач. Серед них задачі, що пов'язані з виробленням загальних стратегій виховання учнів, побудови системи відносин вихованців, громадських якостей особистості, конструюванням виховної інформації і засобів виховної взаємодії з учнями, організацією виховного процесу у вигляді сукупності практичних ситуацій, оцінюванням результатів навчальної діяльності (Унгурян та Куриш, 2016).

Виділяємо й таку складову підструктури професіоналізму діяльності педагога під час формування підприємницької компетентності учнів, як професіоналізм самовдосконалення. Цей компонент надає динамічності всій системі професійної підготовки педагога шляхом постійної самовиховної і самоосвітньої роботи (Lackeus, 2013).

Ураховуючи вищезазначене, важливим аспектом у формуванні підприємницької компетентності учнів $33 \mathrm{CO} €$ безпосередньо підготовка педагогів до зазначеної діяльності. Пропонуємо такий комплекс заходів щодо підготовки вчителів до формування підприємницької компетентності учнів 33СО:

а) розробка та впровадження елективного курсу з формування підприємницької компетентності;

б) організація підприємницького проєктування для вчителів у практико-інтегрованому навчанні;

в) застосування педагогами рефлексивних крос-технологій ситуаційного центру в процесі проєктування підприємницьких ситуацій.

При цьому етапами формування підприємницької компетентності учнів $33 \mathrm{CO} €$ :

- формування внутрішньої мотивації учнів, розуміння важливості здобутих знань, умінь і навичок;

- цілепокладання, щоб цілі навчання стали їх особистими цілями, навчання їх самостійної постановці цілей; 
- активізація діяльності учнів у формуванні відповідних знань, умінь, особистісних якостей і ціннісних орієнтацій;

- організація діяльності 3 формування підприємницької компетентності з орієнтацією на оцінку й усвідомлення учнями результатів власної діяльності, рефлексія досягнень і недоліків з метою подальшої корекції діяльності тощо.

Отже, модернізація системи освіти виступає як невід'ємна частина інноваційного розвитку України в цілому. Увагу в цьому процесі слід приділяти не тільки підвищенню якості освітніх послуг, але й удосконаленню професіоналізму педагогів, що надають ці послуги, зокрема формуванню підприємницької компетентності учнів 33СО.

Тому особливістю сучасного розвитку сфери освіти $€$ необхідність комплексного застосування якісного підходу до професійного становлення спеціаліста під час формування та диференціюванні його компетентностей.

Висновки та перспективи подальших наукових розвідок. Таким чином, сутність професійної підготовки вчителів до формування підприємницької компетентності учнів 33СО полягає у формуванні особистості, яка володіє професійно орієнтованими знаннями 3 підприємництва та економіки, уміннями та навичками і планує досягти вершин професіоналізму в індустрії підприємництва.

Якісне навчально-методичне забезпечення й застосування різних професійно-орієнтованих форм навчання сприяє створенню умов для глибокого і повного засвоєння учнями навчального матеріалу, вирішення навчальних і ситуаційних задач підприємництва, розвитку творчих та організаторських здібностей учнів, підвищення їх комунікативної активності, умінню застосовувати ефективні форму роботи, сприяють формуванню інтересу до навчального процесу.

Перспективним напрямом для досліджень залишається створення цілісної методики формування підприємницької компетентності учнів 33СО та професійна підготовка учителів для ведення даної освітньої діяльності.

\section{ЛITEPATУРА}

Білова, Ю. А. (2013). Поняття та структура підприємницької компетентності майбутніх фахівців економічного профілю. Оновлення змісту, форм та методів навчання і виховання в закладах освіти: збірник наукових праць. Наукові записки Рівненського державного гуманітарного університету, (7 (50), 15-17. Режим доступу: http://nbuv. gov.ua/UJRN/Ozfm_2013_7_7 (дата звернення: 10.03.2019). (Bilova, Yu. A. (2013). The concept and structure of entrepreneurial competence of future economic professionals. Updating the content, forms and methods of teaching and education in educational institutions: a collection of scientific papers. Scientific notes of Rivne State University for the Humanities, 7 (50), 15-17).

Гельбак, А. М. (2017). Формування підприємливості учня як ключової компетентності для життя. Кропивницький: КЗ «КОІППО імені Василя Сухомлинського», 24 (Gelbak, A. M. (2017). Formation of student entrepreneurship as a key competence for life. Kropyvnytskyi, 24). 
Леонтьев, А. (2001). Дети и бизнес. Народное образование, 10, 171-173 (Leontiev, А. (2001). Children and business. Public Education, 10, 171-173).

Про повну загальну середню освіту: Закон України від 13.07.2020 № 764-IX. Режим доступу: https://zakon.rada.gov.ua/laws/show/463-20\#Text. (On full general secondary education: Law of Ukraine of 13.07.2020 № 764-IX).

Прищепа, С. М. (2017). Шляхи формування підприємницької компетентності учнів у сучасному інформаційному суспільстві. Наукова молодь-2017: збірник матеріалів V Всеукраїнської науково-практичної конференції молодих учених (14 груд. 2017 р., м. Київ) / за ред. Спіріна О. М. та Яцишин А. В. Київ: ІІТЗН НАПН України, 353. Режим доступу: http://lib.iitta.gov.ua/view/ divisions/ gen=5Fres=5Fiitzn/2017.html (Pryshchepa, S. M. (2017). Ways of formation of entrepreneurial competence of students in the modern information society. Scientific youth-2017: collection of materials of the V All-Ukrainian scientific-practical conference of young scientists (December 14, 2017, Kyiv) / ed. by Spirina O. M. and Yatsyshyn A. V. Kyiv: IITZN NAPS of Ukraine, 353).

Про основні компетенції для навчання протягом усього життя: рекомендація 2006/962/ЄС Європейського Парламенту та Ради (ЄC) від 18 грудня 2006 року. Режим доступу: https:// zakon.rada.gov.ua/laws/show/994_975 (On core competences for lifelong learning: Recommendation 2006/962 / EU of the European Parliament and of the Council (EU) of 18 December 2006).

Унгурян, І., Куриш, Н. (2016). Формування ключової компетентності підприємливості та ініціативності у навчально-виховному процесі загальноосвітнього навчального закладу. Педагогічні інновації: ідеї, реалії, перспективи, 2, 99-102. Режим доступу: http:// nbuv.gov.ua/UJRN/ ped_in_2016_2_18 (Ungurian, I., Kurysh, N. (2016). Formation of key competence of entrepreneurship and initiative in the educational process of a secondary school. Pedagogical innovations: ideas, realities, perspectives, 2, 99-102).

Bird, B. (1995). Towards a theory of entrepreneurial competency. In J. A. Katz, R. H. Brockhaus (Ed.), Advances in entrepreneurship, firm emergence and growth. Greenwich: CT: JAI Press, 51-72.

Lackeus, M. (2013). Developing entrepreneurial competencies. An action-based approach and classification in entrepreneurial education. Chalmers University of Technology, Gothenburg, Sweden. URL: http://vcplist.com/wp-content/uploads/ 2013/11/Lackeus-Licentiate-Thesis2013-DevelopingEntrepreneurial-

Competencies.pdf.

Lans, T., Biemans, H., Mulder, M., Verstegen, J. (2010). Self-awareness of mastery and improvability of entrepreneurial competence in small businesses in the agrifood sector. Human Resource Development Quarterly, 21 (2), 147-168. DOI: 10.1002/hrdq. 20041.

\section{PEЗЮME}

Бахмат Наталья. Подготовка педагогов к формированию предпринимательской компетентности учащихся учреждений общего среднего образования.

В статье рассмотрены современные аспекты профессиональной подготовки педагогов к формированию предпринимательской компетентности учащихся учреждений общего среднего образования. Установлено, что формирование предпринимательской компетентности учащихся учреждений общего среднего образования происходит через содержание учебного предмета, через формы, методы и технологии. Установлено, что основной челью предпринимательской подготовки учащихся учреждений общего среднего образования является ознакомление их с предпринимательской деятельностью, формирование первичных 
знаний и умений. Предложен комплекс мероприятий по подготовке педагогов к формированию предпринимательской компетентности.

Ключевые слова: профессиональная подготовка, предпринимательская деятельность, мотивация, методы активного обучения, деятельностный подход, личностно ориентированный подход.

\section{SUMMARY}

Bakhmat Nataliia. Preparation of teachers for the formation of entrepreneurial competence of students of general secondary education institutions.

The article considers modern aspects of professional training of teachers for the formation of entrepreneurial competence of students of general secondary education. It was found that formation of entrepreneurial competence of students of general secondary education institutions occurs through the content of the subject, through forms, methods and technologies. It is established that the main purpose of entrepreneurial training of students of general secondary education institutions is to acquaint them with entrepreneurial activity, formation of basic knowledge and skills. It is outlined that integrity of the methodological approach to professional training of teachers to the formation of entrepreneurial competence of students of general secondary education institutions, which includes knowledge, skills and practical experience more effectively - will provide entrepreneurial training for high school students and create conditions for conscious choice of entrepreneurship.

The modern requirements to professional training of teachers are analyzed; the meaning of the concept of "entrepreneurial competence" is clarified, which is an integral psychological quality of personality, manifested in a motivated ability to creatively seek and implement new ideas and allows solving various problems in everyday, professional, social life. The criteria for the formation of entrepreneurial competence of students of general secondary education institutions are determined. A set of measures for the preparation of teachers for the formation of entrepreneurial competence of students of general secondary education institutions, namely: development and implementation of an elective course on the formation of entrepreneurial competence; organization of entrepreneurial design for teachers in practice-integrated learning; application by teachers of reflective crosstechnologies of the situation center in the process of designing business situations.

Key words: professional training, entrepreneurial activity, motivation, methods of active learning, activity approach, personality-oriented approach.

удк 378.091.31-059.1:[811.111'36:005.336.2

Оксана Даниленко

Тернопільський національний педагогічний

університет імені Володимира Гнатюка

ORCID ID 0000-0003-3937-9110

DOI 10.24139/2312-5993/2020.03-04/012-026

\section{САМОСТІЙНА РОБОТА 3 ФОРМУВАННЯ ПРОДУКТИВНОӦ ГРАМАТИЧНОӦ КОМПЕТЕНТНОСТІ МАЙБУТНІХ УЧИТЕЛІВ У ПРОЦЕСІ НАВЧАННЯ АНГЛІЙСЬКОЇ МОВИ ПІСЛЯ НІМЕЦЬКОї}

у статті розглядається питання самостійної роботи з фрормування продуктивної граматичної компетентності майбутніх учителів, які вивчають англійську мову як другу іноземну мову. Відзначено, що необхідність удосконалення продуктивної граматичної компетентності з другої іноземної мови зумовлює пошук ефрективних стратегій навчання, здатних сприяти розвиткові автономії студентів 
та формуванню рефлексивних умінь. Проаналізовано підходи до визначення понять самостійна робота, автономія та рефлексія, уточнено роль навчальностратегічної компетентності, охарактеризовано й визначено стратегії навчання граматики другої іноземної мови.

Ключові слова: самостійна робота, автономія, ресллексія, самоочінка, навчально-стратегічна компетентність, стратегії навчання, граматична навчальна стратегія, граматична компетентність, друга іноземна мова.

Постановка проблеми. На сучасному етапі іншомовна підготовка майбутніх учителів іноземних мов реалізується в межах концепції студентоцентризму, коли відбувається зміщення акценту на процес навчання студента, а не викладання. Набуває важливого значення самостійна робота студента над удосконаленням і поглибленням знань із іноземних мов, підвищенням рівня володіння іноземними мовами. Оскільки вивчення граматики другої іноземної мови є процесом, який вимагає постійності й регулярності в опрацюванні навчального матеріалу студентами, вважаємо за необхідне дослідити проблему формування у студентів умінь самостійної роботи з другої іноземної мови, розвитку їх автономії, уміння самостійно визначати цілі навчання та брати відповідальність за їх реалізацію, уміння використовувати стратегії навчання, розвитку рефлексії студентів.

Аналіз актуальних досліджень. Проблеми самостійної роботи у сфері підготовки майбутніх учителів іноземних мов досліджувалися у працях вітчизняних науковців. Зокрема, І. П. Задорожна (Задорожна, 2012) обґрунтувала та розробила теоретико-методичні засади організації самостійної роботи майбутніх учителів англійської мови з оволодіння англомовною комунікативною компетенцією; А. В. Долина (Долина, 2012) розробила методику вдосконалення фонетичної компетенції в майбутніх учителів англійської мови в самостійній роботі; Л. В. Шевкопляс (Шевкопляс, 2017) дослідила формування англомовної компетенції в аудіюванні майбутніх учителів у процесі самостійної роботи.

у сфері навчання іноземних мов для професійних цілей проведено дослідження особливостей організації самостійного позааудиторного навчання майбутніх економістів ділового англомовного говоріння та письма (Биконя, 2017). Здійснено вивчення використання інформаційних технологій у формуванні німецькомовної лексичної компетентності майбутніх юристів у процесі самостійної роботи (Соломко, 2014). Розглянуто питання навчання майбутніх фахівців із міжнародної економіки професійно орієнтованого англомовного аудіювання у процесі самостійної роботи (Гупка-Макогін, 2016).

Серед зарубіжних науковців питаннями самостійної роботи та автономії в навчанні іноземних мов займалися Ф. Бенсон, Д. Літтл, Л. Дам, Л. Легенхаузен, Р. Оксфорд, М. Павлак (Benson, 2011; Little, 1991; 2007; Little et al., 2017; Oxford, 2017; Pawlak, 2017) та ін. Організацію самостійної 
роботи студентів з іноземної мови досліджено у працях А. В. Конишевої, Н. Ф. Коряковцевої (Конышева, 2005; Коряковцева, 2010); самостійну навчальну діяльність із засвоєння нових граматичних явищ розглянуто в наукових розвідках О. П. Брусяніної (Брусянина, 2000); Т. Ю. Тамбовкіна (Тамбовкина, 2007) дослідила проблеми самонавчання іноземних мов.

Незважаючи на інтерес дослідників до проблеми, недостатньо висвітленим залишається питання самостійної роботи студентів із формування продуктивної граматичної компетентності майбутніх учителів, які вивчають англійську мову після німецької.

Мета статті - дослідити особливості самостійної роботи майбутніх учителів з вивчення граматики другої іноземної мови, визначити стратегії навчання граматики другої іноземної мови.

Методи дослідження. Для досягнення мети дослідження нами було використано методи абстрагування, аналізу й синтезу, індукції та дедукції, критичного аналізу літературних джерел, узагальнення досвіду.

Виклад основного матеріалу. Дослідження проблеми самостійної роботи майбутніх учителів з вивчення граматики другої іноземної мови передбачає з'ясування сутності самостійної роботи, ії змістового та процесуального аспектів.

Аналізуючи поняття самостійної роботи, І. П. Задорожна зауважує, що необхідно розмежовувати самостійну роботу та схоже поняття самостійної навчальної діяльності (Задорожна, 2012, с. 19). Самостійна навчальна діяльність не передбачає участі викладача, а є видом пізнавальної діяльності, що регулюється студентом і спрямована на оволодіння відповідними компетентностями. Тоді як самостійна робота трактується як форма організації самостійної навчально-пізнавальної діяльності студентів, яка керується і контролюється студентом, але визначається зовнішнім опосередкованим керівництвом викладача (Задорожна, 2012, с. 19).

Самостійна робота з іноземної мови, за визначенням А. В. Конишевої, розглядається як «вид навчальної діяльності, при якій учні з певною самостійністю, а при необхідності, за часткового керівництва вчителя виконують різноманітні завдання, докладаючи необхідні для цього розумові зусилля і виявляючи навички самоконтролю й самокорекції» (Конышева, 2005, с. 17).

Слід ще з'ясувати та проаналізувати поняття автономії, яке вживається в методичній літературі паралельно 3 поняттям «самостійна робота». Традиційно вважають, що сутність поняття автономії студента передається у визначенні автономії як «здатності брати відповідальність за власне навчання» (Little, 2007, с. 15; Benson, 2011). Автономія ще розглядається як «здатність до незалежності, критичної рефлексії, прийняття рішень, і незалежної діяльності» (Little, 1991, с. 4). Тобто у студента формується певне психологічне ставлення до процесу та змісту навчання, а спосіб його навчання 
та те, як він може перенести опановані знання в ширший контекст, демонструє його здатність до автономії (Little, 1991, с. 4).

І. П. Задорожна трактує автономію як явище, що має подвійну сутність, з одного боку, - це «спосіб організації навчального процесу, за якого студент може в тією чи іншою мірою здійснювати самоуправління навчальною діяльністю», а з іншого боку - це і «здатність студента приймати самостійні рішення на всіх етапах навчальної діяльності», рішення приймаються студентом відповідно до мети вивчення іноземної мови з усвідомленням відповідальності за результат навчання (Задорожна, 2012, с. 22).

Н. Ф. Коряковцева відзначає, що поняття автономії в навчальній діяльності має певні протиріччя, оскільки з одного боку, передбачається розвиток та становлення особистості, здатної робити самостійний вибір цінностей та відповідальної за свої рішення, а з іншого боку, ця особистість не $€$ повністю відокремленою від інших і повинна взаємодіяти з іншими людьми, нести відповідальність за результати цієї взаємодії, а саме за «процес і результат навчальної діяльності» (Коряковцева, 2010, с. 19).

Схоже зауваження висловив Д. Літл (Little, 2007). Автор пояснює, що за природою людина має здатність до пізнання за власною волею, але людина водночас залежна від інших і в навчанні ії мотивація зростає, якщо iї власні зусилля винагороджуються. Д. Літл показує, що автономія ще пов'язана з мотивацією, розвитком, рефлективністю й соціальною комунікацією (Little, 2007, с. 17-18).

Н. Ф. Коряковцева вважає інструментом для становлення автономної особистості продуктивну навчальну діяльність. Саме завдяки тому, що в такій діяльності реалізується та розвивається внутрішній креативний потенціал і відбувається самовизначення й саморозвиток особистості (Коряковцева, 2010, с. 24). Н.Ф.Коряковцева визначає автономну навчальну діяльність як «навчально-пізнавальну діяльність, що регулюється самим студентом в умовах відносної незалежності від викладача» (Коряковцева, 2010, с. 37).

Ураховуючи визначення самостійної роботи І.П. Задорожної (Задорожна, 2012, с. 24) та вагомість автономії, трактуємо самостійну роботу майбутніх учителів з формування продуктивної граматичної компетентності 3 другої іноземної мови як організовану та контрольовану студентом навчальну діяльність для оволодіння продуктивною граматичною компетентністю з другої іноземної мови та розвитку автономії в умовах зовнішнього опосередкованого управління викладачем. Вбачаємо взаємозалежність між рівнем автономії студента та реалізацією самостійної роботи студента з опанування граматичним матеріалом, а здатність здійснювати контроль своєї навчальної діяльності залежить від розвитку рефлексивних умінь. Тому необхідно дослідити особливості явища автономії, стратегії навчання, які процедурно забезпечують реалізацію самостійної 
роботи з вивчення граматики другої іноземної мови, та рефлексію, за допомогою якої розвиваються самоконтроль та самооцінка.

Дослідження особливостей реалізації автономного навчання іноземної мови у групах зі змішаним рівнем володіння мовою здійснили Д. Літтл, Л. Дам та Л. Легенхаузен. Автори розглядали автономію не просто як аспект організації навчання, а як «педагогічний імператив» (Little et al., 2017, с. 15). Визнаючи потребу дотримуватися вимог навчальних планів і програм, науковці зауважують, що особливістю занять з автономним навчанням $€$ необхідність делегувати студентам вибір цілей навчання, методів, форм, засобів контролю (Little et al., 2017, с. 15).

Дослідники вважають, що експліцитне навчання граматики в умовах організації занять на засадах автономії слід замінити використанням мови, що вивчається, проте і не заперечують, що за необхідності може відбуватися і традиційне пояснення граматики. Отримання знань 3 граматики в автономному навчанні розглядають як продукт, що має утворитися в результаті активного спілкування мовою, яка вивчається (Little et al., 2017, с. 23-26).

Автори наголошують на необхідності здійснення постійної рефлексії за процесом навчання, що має забезпечити контроль та оцінку результатів і як інструменти для контролю пропонують ведення журналів студентами та викладачем (Little et al., 2017, с. 27-28).

Оскільки вплив на розвиток концепції автономії в навчанні мали конструктивістські теорії навчання та теорії про вроджену здатність до мов, коли навчання мови відбувається через комунікацію цією ж мовою, Д. Літл вважає, що інтегральною характеристикою автономії $€$ зростання рівня володіння мовою у студентів за умови вживання мови, що вивчається, як засобу вибору, виконання завдань, так і засобу метакогнітивного пізнання та металінгвістичної рефлексії (Little, 2007, с. 23). Таким чином, Д. Літтл доходить висновку, що вивчення іноземних мов буде успішним за умови активного залучення студентів до навчального процесу з іноземної мови, застосування рефлексії не лише щодо власної навчальної діяльності, а й у формі діалогу з учителем та іншими студентами щодо процесу та змісту навчання, та використання мови, що вивчається, як засобу для виконання всіх видів активності і всієї діяльності під час заняття (Little, 2007, с. 24-25).

Питання розвитку автономії при вивченні граматики іноземної мови розглядає М. Павлак. Науковець вважає, що проблему посилення автономії слід розглядати у трьох сферах: підвищення усвідомленості студентів щодо проблем вивчення та навчання граматики, ознайомлення студентів зі стратегіями вивчення граматики, стимулювати використання комп'ютерних та інформаційних технологій у вивченні граматики (Pawlak, 2017, с. 10).

Науковець пропонує низку заходів, що мають сприяти автономії студентів у вивченні іноземних мов. Слід заохочувати студентів до 
використання підходу «відкриття» у вивченні граматики, тобто залучення різних форм індуктивного представлення матеріалу, проте не за замовчуванням, а коли дозволяє специфіка граматичної структури, наявний час та готовність студентів (Pawlak, 2017, с. 11). Готувати завдання для формування граматичних знань у співпраці, створювати можливості для використання граматичних структур, що вивчаються, у спілкуванні, заохочувати експериментувати з новими лінгвістичними формами, що передбачає завдання на демонстрацію значень, які передає певна граматична структура, в усному чи писемному мовленні (Pawlak, 2017, с. 11). Автор пропонує ознайомлювати студентів із додатковими ресурсами для вивчення граматики й забезпечувати навчання роботи з такими ресурсами (Pawlak, 2017, с. 11-12). Ефективним для розвитку автономії М. Павлак вважає використання мови, що вивчається в позааудиторний час, як з метою продукування, так і рецепції. А також створення студентами власних вправ та завдань допоможе студентам краще контролювати засвоєні граматичні знання та посилить автоматизованість використання цих знань під час виконання продуктивних видів мовленнєвої діяльності (Pawlak, 2017, с. 12). Розвиток автономії взаємозалежний від підвищення граматичної усвідомленості студентів. У свою чергу, граматична усвідомленість розвивається за допомогою здійснення студентами моніторингу та самооцінки з метою віднайдення та прогнозування труднощів у застосуванні граматичних знань (Pawlak, 2017, с. 12).

Вважаємо, що автономна діяльність студента під час вивчення граматики другої іноземної мови - це його навчальна діяльність, спрямована на підвищення рівня володіння граматичними знаннями та вміннями, яка включає готовність студента визначати цілі навчання відповідно до його потреб, розуміння ним потреби додаткового опрацювання матеріалів та пошуку ресурсів для цього, здатність обирати ті види діяльності, які будуть ефективними й відповідними під час вивчення певних граматичних явищ, здатність здійснити перенос набутих граматичних навичок та стратегій вивчення мов, а також його вміння оцінити свій прогрес із вивчення граматики за допомогою рефлексії.

При цьому роль викладача залишається вагомою, оскільки він повинен скеровувати студента у виборі оптимальних цілей навчання, які допоможуть йому досягати вищих рівнів в оволодінні знаннями та навичками, а також пропонувати такі процедури, які на даному етапі ще можуть бути невідомі студенту (Little, 2007, с. 24).

Факторами, що значно впливають на здатність до самостійної роботи, $€$ розвиток навчально-стратегічної компетентності студентів та вмінь рефлексії.

Розглядаючи питання навчально-стратегічної компетентності, Т. О. Олійник трактує її з огляду на дві складові. Авторка розмежовує навчальну 
та стратегічну компетентності. Навчальна компетентність передбачає знання про способи здійснення раціональної навчальної діяльності під час вивчення іноземних мов, уміння користуватися навчальними та комунікативними стратегіями. Тоді як стратегічна компетентність включає вміння студентів користуватися засобами, що компенсують у спілкуванні недостатність володіння іноземною мовою, сприяють самому процесу й досягненню мети спілкування (Олійник, 2013, с. 9-10).

На нашу думку, розвиток навчально-стратегічної компетентності залежить від знання і вміння застосовувати студентами навчальні стратегії щодо оволодіння граматичною компетентністю. Тому детальнішого розгляду потребує питання стратегій оволодіння граматичним матеріалом і формування граматичних навичок. Наукові дослідження свідчать, що за умов мультилінгвізму, кількість стратегій вивчення мови, які могли застосовувати студенти, залежала від їх попереднього лінгвістичного досвіду та рівнів володіння кожною з мов (Jessner, 2006, с. 127). Студенти, які вивчають другу іноземну мову, уже володіють певними метакогнітивними та когнітивними стратегіями, проте викладач повинен ознайомлювати студентів зі стратегіями, що можуть сприяти позитивному переносу знань та показати, де можливий негативний вплив першої іноземної мови або рідної мови.

Науковці зазначають, що дослідженням стратегій навчання граматики надавалося недостатньо уваги (Pawlak, 2017, с. 14; Broady \& Dwyer, 2008, с. 142; Oxford, 2017, с. 245).

Згідно з визначенням, яке запропонувала Р.Оксфорд, стратегії навчання граматики іноземної мови трактуються як «динамічні думки та способи поведінки, яких можна навчитися, і які студенти свідомо обирають і застосовують у специфічних контекстах 3 метою покращення саморегульованого, автономного розвитку їхньої граматичної компетентності з іноземної мови, що дозволяє ефективно виконувати завдання та забезпечує тривале знання граматики» (Oxford, 2017, с. 244).

Р. Оксфорд стверджує, що студенти обирають стратегії відповідно до свого стилю навчання (Oxford, 2017, с. 246). Студенти з аналітичним баченням і мисленням використовують стратегії для розгляду частин системи мови, використовуючи порівняння, зіставлення, вибудовуючи інформацію в організовану ієрархію, перевіряючи гіпотези про мову, яку вивчають. Студенти з комплексним підходом і мисленням надають перевагу пошуку загальних тенденцій у цілісній системі (Oxford, 2017, с. 246). Дослідниця також виділяє студентів, для яких неприпустима неоднозначність і вони потребують чітких указівок, покрокових пояснень і правил, і називає цей стиль конкретно-послідовним. Протилежний йому $є$ інтуїтивно-випадковий стиль, коли студенти радше витлумачують матеріал по-своєму, ігнорують пояснення викладача та легко ставляться до неоднозначності в певних 
способах навчання граматики, де переважає імпліцитність або експліцитність з використанням індуктивних методів (Oxford, 2017, с. 246). Студенти з добре розвиненими навичками граматичного аналізу краще сприймають індуктивний підхід у подачі граматичного матеріалу, тоді як студенти зі слабшими навичками аналізувати краще працюють при дедуктивному навчанні граматики (Oxford, 2017, с. 247).

Урахування таких психологічних особливостей студентів дозволить викладачеві підбирати ефективніші методи та засоби організації самостійної роботи з навчання граматики для певного складу академічної групи.

Р. Оксфорд розглядає використання стратегії вивчення граматики через призму чотирьох способів навчання граматичного матеріалу. За умов імпліцитного, сконцентрованого на значенні і лише на практиці спілкування навчання, з доступним для розуміння навчальним матеріалом, стратегією, яку можуть застосовувати студенти, є реєстрація інформації у свідомості (Oxford, 2017, с. 248). Студенти з конкретно-послідовним стилем навчання для того, щоб усвідомлено опрацювати мову за таких умов, можуть виокремлювати повторювані слова та структури, виписувати їх у зошит, організовувати по категоріях, вивчати та вживати на занятті (Oxford, 2017, с. 248). Якщо імпліцитний підхід включає певну подачу граматичних форм і правил, то передбачається, що студенти мимоволі звертатимуть на них увагу, щоб передати потрібне значення. Для такого підходу Р. Оксфорд пропонує такі стратегії вивчення граматики, як уважне сприймання висловлювань більш досвідчених осіб, а потім імітація їх висловлювань; звертання уваги студентами на граматичні структури, що спричиняють труднощі у спілкуванні та розумінні значення; здатність студентів помічати виправлення їхніх висловлювань іншими особами. Також доречним буде використання таких стратегій, як аналіз, здогадка, передбачення, аргументація, задавання питань (Oxford, 2017, с. 248). Наступний спосіб це експліцитний підхід з індуктивним навчанням граматики і тут студенти можуть використовувати стратегії визначення та пошуку джерел, ініціювати та брати участь в обговоренні граматичних правил і їх відкривання, створення та тестування гіпотез про те, як функціонує граматична структура, що вивчається, ведення записів про неї, пошук правила, перевірка власних інтерпретацій правила з більш досвідченими студентами (Oxford, 2017, с. 249). Експліцитний підхід з дедуктивним навчанням граматики передбачає, що студенти можуть попередньо переглядати, які структури вивчатимуться на занятті, розглядати правила, запропоновані викладачем або в підручнику, застосовувати ці правила, запам'ятовувати їх, запам'ятовувати зміни, які відбуваються з формою граматичної структури, складати граматичні таблиці, відразу застосовувати нові граматичні структури в контексті (Oxford, 2017, с. 249). 
Вважаємо, що поєднання елементів навчання граматики як імпліцитним, так і експліцитним способом дозволить студентам ознайомитись із більшою кількістю стратегій навчання граматики. Наприклад, при імпліцитному підході, коли студенти практикують діалогічне мовлення англійською мовою, вони можуть мимоволі проводити паралелі з висловлюваннями німецькою мовою, помічати, чи це їм перешкоджає висловлюватися англійською, чи допомагає. Реалізуючи експліцитний підхід, слід спонукати студентів до висловлювання їхніх гіпотез щодо таких міжмовних порівнянь, формулювати й занотовувати правила, виведені на основі таких зіставлень.

М. Павлак зазначає, що використання студентами стратегій сприяє зростанню експліцитних знань і здатності застосовувати граматичні правила в реальному часі в процесі опрацювання мови (Pawlak, 2017, с. 14). Ґрунтуючись на своїх попередніх дослідженнях, М. Павлак виділяє метакогнітивні, афективні (емоційні), соціальні та когнітивні стратегії навчання граматики. Метакогнітивні стратегії навчання граматики дозволяють планувати, контролювати й оцінювати процес навчання. Афективні стратегії навчання граматики дозволяють керувати емоційним станом та мотивацією у процесі навчання граматики. Соціальні стратегії навчання граматики дозволяють налагоджувати взаємодію з іншими учасниками навчального процесу під час вивчення і практичного застосування граматичних структур. Когнітивні стратегії навчання граматики полягають у безпосередній роботі 3 граматичними структурами (Pawlak, 2017, с. 14).

Розглядаючи когнітивні стратегії як такі, що дозволяють всебічно опановувати граматику, М. Павлак пропонує розглядати ці стратегії відповідно до того, яким чином вони можуть застосовуватися. Він виділяє когнітивні стратегії навчання граматики для виконання комунікативних завдань, когнітивні стратегії навчання граматики для формування експліцитних знань, когнітивні стратегії навчання граматики для засвоєння імпліцитних знань та когнітивні стратегії навчання граматики для виправлення помилок (Pawlak, 2017, с. 14).

Застосувавши запропоновану М. Павлаком (Pawlak, 2017) класифікацію стратегій, можемо виокремити стратегії для навчання граматики другої іноземної мови. Для виконання в самостійній роботі комунікативних завдань студенти як граматичні стратегії використовують звертання уваги на граматичні структури, які викликають труднощі у спілкуванні другою іноземною мовою через інтерференцію; виокремлення способів вживання граматичних структур носіями мови під час прослуховування аудіозаписів та радіопередач, переглядів фільмів та телепередач або під час безпосереднього спілкування з носіями мови; виділення способів і прикладів вживання нових граматичних структур у зразках писемного мовлення; виконання комунікативних завдань у парах 
або групах з іншими студентами; обговорення результатів порівняльного аналізу нової граматичної структури з граматичними структурами у першій іноземній мові або рідній мові та на цій основі висловлювання припущень щодо способів вживання нової граматичної структури; консультування щодо вживання граматичної структури з викладачем та зі студентами, для яких англійська мова є першою іноземною мовою.

Формування граматичних знань 3 другої іноземної мови експліцитним способом у процесі самостійної роботи відбувається за допомогою самостійного опрацювання студентами граматичних правил та додаткової роботи з довідковою літературою. Важливою стратегією для вивчення граматики другої іноземної мови $€$ порівняльний аналіз нової граматичної структури і прикладів її вживання на предмет наявності схожих граматичних структур у першій іноземній мові для пошуку можливостей для позитивного переносу або відмінностей, які можуть викликати труднощі для засвоєння нової граматичної структури. Наступним кроком має бути формулювання своїх правил вживання на основі такого порівняльного аналізу. Ведення записів прикладів вживання нових граматичних структур із використанням порівняння з аналогами в першій іноземній мові або в рідній мові теж $€$ стратегією для експліцитного формування знань з граматики.

Імпліцитний підхід до формування граматичних знань у самостійній роботі може реалізовуватися під час самостійного читання текстів та прослуховування аудіозаписів за допомогою розпізнавання нових граматичних структур і їх ідентифікації. Під час виконання завдань для діалогічного, монологічного або писемного мовлення студенти проводять зіставлення свого вживання граматичної структури зі зразками мовлення. Також імпліцитний спосіб реалізується у спробах студента імітувати зразки мовлення або вживати граматичну структуру за правилами в певних контекстах (Oxford, 2017, с. 248; Pawlak, 2017, с. 14).

Стратегії, що передбачають розвиток самоконтролю за процесом оволодіння граматикою, включають реакцію студента на відповідь та зауваження викладача, а також відслідковування та самокорекцію помилок у власних усних або письмових висловлюваннях (Pawlak, 2017, с. 14).

Проблема самооцінки й корекції студентами своєї навчальної діяльності пов'язана з уміннями студентів здійснювати рефлексію. Згідно з визначенням І. П. Задорожної, рефлексія - це «розумовий процес, що дозволяє студентам сконцентруватися на аналізі їхнього досвіду, мотивації, цілей з метою краще їх зрозуміти і його результатом стає зміна поведінки» (Задорожна, 2017, с. 8). Рефлексія повинна забезпечувати таку оцінку діяльності студента, коли перевіряється не лише правильність виконання продуктивних видів мовленнєвої діяльності, а й те, як студент набуває нового досвіду в діяльності, у результаті чого в нього мають виникати нові 
задуми і відповідне планування подальшої навчальної діяльності (Беженар, 2013, с. 485). Ще одним аспектом рефлексії є можливість для студента проаналізувати свій емоційний стан, виявити індивідуальні потреби та розвивати стратегії, що допомагають керувати мисленням (Zadorozhna et al., 2018, с. 65).

Розвиток рефлексивних умінь дозволить майбутнім учителям розвивати автономію та ефективніше оволодівати граматичними навичками з другої іноземної мови. У результаті аналізу сучасних досліджень (Беженар, 2013; Задорожна, 2012; Zadorozhna, 2017; Zadorozhna et al., 2018) з проблеми виділяємо такі рефлексивні вміння: аналізувати власні потреби та цілі у вивченні граматики другої іноземної мови; визначати власний рівень сформованості граматичних умінь з другої іноземної мови; ставити власні цілі у процесі вивчення граматики другої іноземної мови; визначати труднощі, які виникають у процесі вивчення другої іноземної мови; виявляти труднощі, які $€$ результатом інтерференції з боку першої іноземної мови або рідної мови; аналізувати власні стратегії оволодіння граматикою другої іноземної мови; прогнозувати застосування набутих стратегій з опанування граматикою першої іноземної мови для вивчення граматики другої іноземної мови; аналізувати відповідність обраних стратегій меті навчання; визначати й аналізувати причини неуспішності, та шукати шляхи подолання неуспішності; пошук альтернативних стратегій; аналіз проблеми в різних аспектах для пошуку можливих шляхів вирішення; урахування отриманого досвіду в майбутній навчальній діяльності; аналізувати свій емоційний стан щодо хвилювання, напруги, що можуть спричинити неуспішність.

Засобами, які дозволять розвивати рефлексію та підвищувати усвідомленість студентів щодо процесу вивчення іноземної мови, є бесіди, коли студенти можуть висловити свої преференції щодо аудиторного вивчення граматики, ініціювання обговорень у малих групах найбільш ефективних шляхів вивчення та навчання граматики, використовуючи досвід описаний у навчальних профілях студентів (Pawlak, 2017, с. 13). Ще одним із засобів для розвитку рефлексії може бути використання щоденників для ведення студентами записів про труднощі, з якими вони стикаються у процесі вивчення граматики та способи їх подолання. Засобами самооцінювання можуть бути аналіз аудіозаписів усних висловлювань або письмових завдань, або заповнення спеціальних таблиць відразу після виконання завдання (Pawlak, 2017, с. 13).

Отже, використання рефлексії студентами під час виконання комунікативних завдань у процесі самостійної роботи забезпечить самоконтроль та самокорекцію, аналіз труднощів, корекцію власної навчальної діяльності. 
Висновки. Самостійна робота майбутніх учителів іноземних мов із опанування граматикою англійської мови як другої іноземної мови передбачає розвиток умінь самостійно аналізувати й вивчати нові граматичні явища, використовуючи набуті знання та навички з граматики першої іноземної мови, формувати та вдосконалювати граматичну компетентність з другої іноземної мови, обирати навчальні стратегії та вибудовувати власну навчальну траєкторію для вдосконалення граматичних знань та навичок 3 другої іноземної мови, а також здійснювати аналіз та контроль власної навчальної діяльності, ії результатів. Ретельно продумана робота викладача з ознайомлення та навчання використання стратегій засвоєння граматичних знань та їх використання в комунікації підвищує ефективність самостійної роботи студентів з формування продуктивної граматичної компетентності та сприяє розвитку автономності студентів у плануванні власної навчальної діяльності. Розвиток рефлексивних умінь дозволяє студентам оцінювати власну навчальну діяльність з граматики англійської мови як другої іноземної та контролювати її результати.

Перспективи подальших наукових розвідок вбачаємо в розробці засобів для реалізації самостійної роботи з формування продуктивної граматичної компетентності майбутніх учителів у процесі навчання англійської мови після німецької.

\section{ЛІТЕРАТУРА}

Беженар, І.В. (2013). Рефлексія як основна психологічна передумова навчання студентів іншомовного писемного мовлення. Педагогіка формування творчої особистості у вищій і загальноосвітній школах, 32 (85), 481-489 (Bezhenar, I. V. (2013). Reflection as the main psychological prerequisite of teaching second language writing to the university students. Pedagogy of forming creative personality in higher and secondary education, 32 (85), 481-489).

Биконя, О.П. (2017). Теоретико-методичні засади самостійної позааудиторної роботи з англійської мови студентів економічних спеціальностей (дис... д-ра пед. наук: 13.00.02) (Bykonia, O. Р. (2017). Theoretical and methodological foundations of economic speciality students' independent extracurricular self-study work on English (DSc thesis). Kyiv).

Брусянина, О. П. (2000). Обучение студентов старших курсов языкового фракультета самостоятельной учебной деятельности по усвоению новых грамматических явлений (на материале немецкого языка) (дис. ... канд. пед. наук: 13.00.02). Екатеринбург (Brusianina, О. Р. (2000). Teaching foreign language faculty senior students independent educational activity while mastering new grammar structures: on the basis of the German language (PhD thesis). Yekaterinburg).

Гупка-Макогін, Н.І. (2016). Навчання майбутніх фрахівців з міжнародної економіки професійно орієнтованого аудіювання у процесі самостійної роботи (дис. ... канд. пед. наук: 13.00.02). Тернопіль (Hupka-Makohin, N. I. (2016). Teaching future international economics specialists professionally oriented English listening in selfstudy work (PhD thesis). Ternopil).

Долина, А. В. (2012). Методика вдосконалення фонетичної компетенції у майбутніх учителів англійської мови у самостійній роботі (дис. ... канд. пед. наук: 
13.00.02). Київ (Dolyna, А. V. (2012). Methods of improving future English teachers' phonological competence in self-study work (PhD thesis). Kyiv).

Задорожна, І.П. (2012). Теоретико-методичні засади організації самостійної роботи майбутніх учителів з оволодіння англомовною комунікативною компетенцією (дис... д-ра. пед. наук: 13.00.02). Київ (Zadorozhna, I. P. (2012). Theoretical and methodological foundations of future teachers' self-study work organization on acquiring communicative competence in English (DSc thesis). Kyiv).

Конышева, А. В. (2005). Организация самостоятельной работы учащихся по иностранному языку. Санкт-Петербург: КАРО; Минск: Издательство «Четыре четверти» (Konysheva, A. V. (2005). Organization of students' independent work on learning foreign languages. Saint Petersburg: KARO; Minsk)

Коряковцева, Н.Ф. (2010). Теория обучения иностранным языкам: продуктивные образовательные технологии. Москва: Издательский центр «Академия» (Koriakovtseva, N. F. (2010). Theory of teaching foreign languages: productive educational technologies. Moscow).

Олійник, Т. (2013). Особливості формування навчально-стратегічної компетентності. Іноземні мови, 76 (4), 9-20 (Oliinyk, T. (2013). Peculiarities of learning-strategic competence formation. Foreign Languages, 76 (4), 9-20. doi:http://dx.doi.org/10.32589/im.v0i4.121909).

Соломко, 3. К. (2014). Формування німецькомовної лексичної компетенції майбутніх юристів у процесі самостійної роботи з використанням інформаційних технологій (дис. ... канд. пед. наук: 13.00.02). Київ (Solomko, Z. K. Methodology of forming future lawyers' German lexical competence in the process of self-study work with the usage of information technologies (PhD thesis). Kyiv).

Тамбовкина, Т.Ю. (2007). Самообучение иностранным языкам как подсистема вузовского лингвистического образования (дис. ... д-ра пед. наук: 13.00.02). Москва (Tambovkina, T. Yu. (2007). Self-study of foreign languages as a subsystem of university linguistic education (DSc thesis). Moscow).

Шевкопляс, Л. В. (2017). Формування англомовної компетенції в аудіюванні майбутніх учителів у процесі самостійної роботи (дис. ... канд. пед. наук: 13.00.02). Київ (Shevkoplias, L. V. (2017). Methodology of forming future teachers' English listening competence in the process of self-study work (PhD thesis). Kyiv).

Benson, P. (2011). Teaching and researching autonomy. (2nd ed.) New York: Taylor \& Francis.

Broady, E. \& Dwyer, N. (2008). Bringing the learner back into the process: identifying learner strategies for grammatical development in independent language learning. In S. Hurd, T. Lewis (Eds.), Language learning strategies in independent settings, (pp. 141-158). Bristol: Multilingual Matters.

Jessner, U. (2006). Linguistic awareness in multilinguals. Edinburgh: Edinburgh University press.

Little, D. (1991). Learner Autonomy 1: Definitions, Issues and Problems. Dublin: Authentik.

Little, D. (2007). Language Learner Autonomy: Some Fundamental Considerations Revisited. Innovation in Language Learning and Teaching, 1 (1), 14-29. Retrieved from: https://doi.org/10.2167/illt040.0.

Little, D., Dam, L., \& Legenhausen, L. (2017). Language learner autonomy: theory, practice and research. Bristol, UK; Blue Ridge Summit, PA : Multilingual Matters.

Oxford R. L. (2017). Teaching and researching language learning strategies: self-regulation in context. Second edition. New York; London: Routledge, Taylor \& Francis Group. 
Pawlak, M. (2017). The Role of Autonomy in Learning and Teaching Foreign Language Grammar. In Pawlak M., Mystkowska-Wiertelak A., Bielak J. (Eds.), Autonomy in Second Language Learning: Managing the Resources. Second Language Learning and Teaching, (pp. 3-19). Cham: Springer. Retrieved from: https://doi.org/10.1007/978-3319-07764-2 1.

Zadorozhna I. (2017). Reflective Foreign Language Teaching and Learning of University Students. Наукові записки Тернопільського начіонального педагогічного університету імені Володимира Гнатюка. Серія : Педагогіка. (Scientific Issues of Ternopil Volodymyr Hnatiuk National Pedagogical University. Series: Pedagogy), 4, 612. doi:http://dx.doi.org/10.25128/2415-3605.17.4.1.

Zadorozhna, I., Datskiv, O., \& Levchyk, N. (2018). Development of pre-service foreign language teachers' emotional intelligence by means of reflection. Advanced Education, 5 (10), 62-68. doi:http://dx.doi.org/10.20535/2410-8286.144538

\section{PEЗЮME}

Даниленко Оксана. Самостоятельная работа по формированию продуктивной грамматической компетентности будущих учителей в процессе обучения английскому языку после немецкого.

В статье рассматривается вопрос самостоятельной работы по формированию продуктивной грамматической компетентности будущих учителей, изучающих английский язык как второй иностранный. Отмечено, что необходимость совершенствования продуктивной грамматической компетентности второго иностранного языка обусловливает поиск эффрективных стратегий обучения, способных содействовать развитию автономии студентов и формированию рефлексивных умений. Проанализированы подходы к определению понятий самостоятельная работа, автономия и рефлексия, уточнены роль учебностратегической компетентности, охарактеризованы и определены стратегии обучения грамматике второго иностранного языка.

Ключевые слова: самостоятельная работа, автономия, реслексия, самооценка, учебно-стратегчческая компетентность, стратегии обучения, грамматическая учебная стратегия, грамматическая компетентность, второй иностранный язык.

\section{SUMMARY}

Danylenko Oksana. Independent work on the formation of productive grammatical competence of future teachers learning English after German.

The article dwells on the issue of independent work on the formation of productive grammatical competence of future teachers learning English as a second foreign language. The focus on a student's learning activity and its outcomes presupposes investigation of the content and procedural aspects of students' individual work.

The purpose of the article is to explore the peculiarities of the independent work of future teachers learning English after German. The essence of individual work has been outlined and the notion of autonomy has been investigated. The interdependence of individual work and student's autonomy has been shown. The ways of autonomy development have been suggested. Analysis results show that autonomy in grammar learning can be enhanced by means of engaging students into the process of determining learning goals according to their needs, raising their awareness of the need for additional grammar practice, teaching students to search for additional resources for this practice, developing the students' ability to choose those activities that will be effective and relevant for the study of certain grammatical phenomena, the ability to transfer acquired grammatical skills and strategies for learning languages from students' 
previous linguistic experience, developing students' ability to assess their progress in learning grammar by means of reflection.

Results indicate that the efficiency of the independent work depends on the variety of strategies that students are able to implement in their studies. The strategies are teachable, and the task of the teacher is to present students with different strategies depending on the mode of grammar learning. As far as the concern of our research is the process of learning English after German, the strategies for learning second foreign language grammar in the process of individual work have been suggested. The survey emphasizes the necessity to develop students' ability to make comparisons in English and German. The comparative analysis of grammatical phenomena by means of juxtaposing grammatical structures with similar structures in English, German and Ukrainian as their native language facilitates the skills to detect possibilities for positive transfer or the negative effects of interference.

The findings of the study represent the importance of reflection for the development of self-assessment and the ability to revise their learning strategies, make necessary corrections and plan their future learning activity. The necessary reflective skills for students dealing with grammar of the second foreign language have been suggested.

Key words: independent work, autonomy, reflection, self-assessment, learningstrategic competence, learning strategies, grammatical educational strategy, grammatical competence, second foreign language.

УДК 378.147+811.111-057.21

\author{
Наталія Добровольська \\ Тернопільський національний педагогічний \\ університет імені Володимира Гнатюка \\ ORCID ID 0000-0001-9133-285X
}

DOI 10.24139/2312-5993/2020.03-04/026-039

\title{
СИСТЕМА ВПРАВ ДЛЯ ФОРМУВАННЯ В МАЙБУТНІХ ФАХІВЦІВ ІНФОРМАЦІЙНИХ ТЕХНОЛОГІЙ АНГЛОМОВНОЇ КОМПЕТЕНТНОСТІ В ЧИТАННІ ТА ГОВОРІННI
}

У статті обгрунтовано систему вправ для формування в майбутніх фахівців інформаційних технологій англомовної компетентності в читанні та говорінні. Для реалізації поставленої мети використано такі загальнонаукові методи дослідження, як аналіз, синтез, системний аналіз порівняння та узагальнення. Виокремлено принципи формування в майбутніх фахівців інформаційних технологій англомовної компетентності в читанні та говорінні (інтегрованого навчання, системності й послідовності навчальних дій, автономії, формування стійкої позитивної мотивації); особливості відбору навчального матеріалу, який використовуватиметься у вправах, зокрема, критерії відбору фахових текстів; запропоновано систему вправ, яка передбачає чотири підсистеми і спрямована на взаємопов'язане формування в студентів навичок та вмінь читання і говоріння.

Ключові слова: система вправ, формування, англомовна компетентність, читання, говоріння.

Постановка проблеми. У науковій літературі системою прийнято називати сукупність взаємопов'язаних елементів, що утворюють єдине ціле, взаємодіють між собою та мають спільну мету. Системний підхід вважається одним із провідних методологічних принципів дослідження в будь-якій галузі 
знань. Так, у методиці навчання іноземних мов йдеться про систему навчання, систему вправ, систему занять тощо. Найпростішими складовими частинами системи, тобто елементами, є вправи, спрямовані на конкретне завдання. Окрім того, вони можуть формувати невеликі групи, тобто підсистеми, що також $є$ складовими частинами системи. У свою чергу, у сукупності елементи й підсистеми називають компонентами системи, які $\epsilon$ взаємообумовленими і перебувають у взаємозалежності, тобто між ними є зв'язок. Ієрархічна залежність підсистем визначається супідрядністю їх функцій: функціонування кожної з них і всіх разом спрямоване на досягнення однієї мети.

Кожна система вирізняється структурою, що визначає внутрішню організацію, порядок і побудову системи, іншими словами, структура - це сукупність елементів і співвідношення (зв'язків) між ними. Ще однією характеристикою є мета, якою визначається ії бажаний майбутній стан, тобто конкретні цілі-результати. Останні мають бути досягнуті в межах певного інтервалу часу й іноді формулюються в термінах кінцевого продукту навчальної діяльності.

Аналіз актуальних досліджень. У методиці навчання іноземних мов проблему професійно орієнтованого читання іноземною мовою досліджували Т.Горпініч, Ю. Британ, С. Вавіліна, І. Корейба, К. Брінкер (K. Brinker) та ін. Формування іншомовної компетентності в говорінні майбутніх фахівців зосереджували увагу Л. Бондар, О. Дацків, М. Куімова, Л. Максименко, І. Федорова, В. Черниш, О. Ярошенко та ін.

У сучасній методиці існує низка робіт, у яких реалізується ідея взаємопов'язаного навчання говоріння та читання. Так, А. Томашевська запропонувала методику формування в майбутніх фармацевтів англомовної лексичної компетентності в читанні та говорінні у процесі самостійної роботи (Томашевська, 2019); Г. Кравчук представила систему вправ для навчання студентів технічних спеціальностей професійно орієнтованого англійського діалогічного мовлення на основі текстів науково-технічної реклами (Кравчук, 2010); М. Куімова створила комплекс вправ для навчання усного англійського монологічного мовлення з опорою на автентичний письмовий текст (Куімова, 2005).

Однак, невирішеним залишається питання розробки системи вправ для формування в майбутніх фахівців інформаційних технологій англомовної компетентності в читанні та говорінні.

Мета статті - обґрунтувати систему вправ для формування в майбутніх фахівців інформаційних технологій англомовної компетентності в читанні та говорінні.

Методи дослідження. Для реалізації поставленої мети у статті були використані такі загальнонаукові методи дослідження, як аналіз, синтез, системний аналіз, порівняння й узагальнення. 
Виклад основного матеріалу. Для того, щоб обґрунтувати систему вправ, необхідно проаналізувати дидактичні та методичні принципи навчання, які визначають умови організації навчального процесу. Дидактичні принципи набувають певної специфіки, зумовленої особливостями предмета «Іноземна мова».

У педагогіці принципами прийнято вважати основні вихідні положення, будь-якої теорії, науки в цілому, які в своїй сукупності визначають вимоги до організації тієї чи іншої діяльності, якими керується дослідник (Павлова, 2010). Необхідність застосування чітко сформульованих принципів навчання диктується потребою вирішити питання про те, як і який зміст навчання відбирати, які матеріали і прийоми використовувати. До дидактичних принципів належать принципи наочності, посильності, міцності, свідомості, науковості, активності, виховуючого навчання, індивідуалізації, доступності, систематичності та послідовності, колективності, проблемності, розвиваючого навчання (Фіцула, 2006, с. 88-91). Перелічені принципи взаємопов'язані. Звичайно, реалізація кожного з них окремо не може не привести до певного підвищення ефективності навчання, але запровадження всієї методичної системи в цілому $є$ значно ефективнішим.

Відзначимо, що коли йдеться про взаємопов'язане формування в майбутніх фахівців з інформаційних технологій англомовної компетентності в читанні та говорінні, то насамперед розуміється набуття професійних знань і відповідних умінь засобами іноземної мови. Тому вагомим в контексті тематики нашого дослідження є принцип інтегрованого навчання, який відображається у процесуальній спільності вищеназваних процесів навчання зі спільними цілями навчання англійської мови і спеціальності («Інформаційні технології»), їх елементів, компонентів змісту, методів, засобів і контролю результатів навчання. За цим принципом зміст іншомовного навчання фахівців визначається як цілісний, комплексний та інтегративний процес формування англомовної компетентності в тісному взаємозв'язку зі спеціальною професійною компетентністю на основі взаємопроникнення, взаємодоповнення і взаємозалежності міжпредметної інформації і способів ії засвоєння (Крупченко, 2007, с. 36).

Відповідно до принципу системності і послідовності навчальних дій, відбір змісту навчання передбачає структуровану систему повторень, де його кожне наступне вживання вдосконалює зміст і якість його вираження, що забезпечує високоякісне запам'ятовування інформації у формі логічних структур (Подласий, 2004, с. 176). На цьому етапі слід якісно проводити систематичне повторення й контроль за результатами навчання, обчислюючи коефіцієнт приросту засвоєння знань, здобутих безпосередньо під час занять і самостійно.

Ще одним дидактичним принципом організації процесу взаємопов'язаного формування англомовної компетентності в читанні та 
говорінні в майбутніх фахівців інформаційних технологій виступає принцип автономії, який передбачає індивідуалізацію навчально-пізнавальної діяльності кожного студента на основі його особистого активного прагнення до розширення і вдосконалення власних знань та вмінь, вивчаючи самостійно додаткову літературу, отримуючи консультації. Загальновідомо, що знання, здобуті студентами самостійно під час виконання дослідницьких, пошукових, творчих завдань засвоюються міцніше (Митник, 2014).

Принцип формування стійкої позитивної мотивації передбачає забезпечення сприятливих умов у навчанні, підтримання інтересу у студентів, внесення новизни у процес оволодіння цільовими компетентностями. До основних напрямів підвищення мотивації навчання студентів можна віднести:

- розвиток цілепокладання, що веде до розуміння й усвідомлення значення навчального повідомлення, його важливості для особистості і майбутньої професійної діяльності;

- створення ситуацій досягнення успіху, які передбачають підвищення активності студентів;

- усвідомлення тимчасової перспективи навчання (Овчинников, 2008);

- студентоцентроване навчання з розумінням особливостей, потреб та інтересів студентів;

- використання сучасних методів і засобів;

- зосередження на подальших професійних потребах.

Усі принципи навчання є взаємопов'язаними, взаємообумовленими і взаємодоповнювальними, створюючи систему положень, що визначають стратегію процесу формування в майбутніх фахівців з інформаційних технологій англомовної компетентності в читанні та говорінні. Тому їх теоретична обумовленість буде представлена практично під час реалізації відповідної системи вправ.

Кожна система, а в нашому випадку - системи вправ для формування в майбутніх фахівців інформаційних технологій англомовної компетентності в читанні та говорінні, має низку властивостей, які можна розділити на такі групи за: 1) цілями та функціями; 2) особливостями структури; 3) ресурсами й особливостями взаємодії 3 навчальним середовищем (Горєлова, 2015).

До першої групи властивостей системи вправ, спираючись на філософську літературу (Універсальний словник-енциклопедія, 2006; Українська мала енциклопедія, 1965), ми відносимо:

- односпрямованість (або цілеспрямованість) дій компонентів, що посилює ефективність функціонування системи;

- пріоритетність завдань і цілей системи ширшого рівня перед завданнями і цілями ії компонентів; 
- цілеспрямованість системи відображає підпорядкування ії діяльності певній цілі;

- різнонаціленість компонентів системи, тобто цілі компонентів не завжди збігаються з загальними цілями системи.

До другої групи властивостей системи вправ ми відносимо:

- цілісність - єдність всіх компонентів системи з ії функціями та завданнями;

- структурність - така побудова системи, за якої стає можливим декомпонувати її на підсистеми, групи й окремі елементи;

- ієрархічність передбачає застосування кожного компоненту системи як системи (підсистеми) ширшої глобальної системи.

До третьої групи властивостей системи вправ входять:

- комунікативність - існування складної системи зв'язків (комунікацій) із навчальним середовищем;

- інтерактивність - наявність системоутворювальних, системозбережувальних факторів;

- інтегративність - взаємопроникність властивостей всіх компонентів системи вправ;

- інтерактивність - взаємодія елементів, під час якої мета досягається інформаційним обміном компонентів.

Передумовою розробки системи вправ для формування в майбутніх фахівців інформаційних технологій англомовної компетентності в читанні та говорінні $\epsilon$ раціональний відбір навчальних матеріалів. Саме тому першочерговим завданням постає визначення одиниць навчального матеріалу та критеріїв їх відбору.

Навчання мовного та мовленнєвого матеріалу неможливе без використання текстів - як готових, так і спеціально складених (Качалов, 2005, с. 140), оскільки тексти мають здатність комунікативно мотивувати студентів до сприйняття нової професійно важливої інформації, а згодом до подальшого її застосування під час побудови власних висловлювань англійською мовою. Будь-який готовий текстовий матеріал слугує еталоном для студентів, який відображає алгоритм побудови і $є$ підґрунтям для подальшого оформлення їхнього усного мовлення (Качалов, 2005, с. 141). Цю думку підтримує також Ю. Семенчук, уточнюючи, що текст $€$ максимальною одиницею комунікації, необхідною для задоволення інформаційно-пізнавальні потреби студентів. Ангомовний текст виступає основою та зразком іншомовної комунікації (Семенчук, 2007).

Таким чином, текст трактують як навчальний матеріал, який передає інформацію певної тематики (Шарапова, 2009, с. 320), є зразком іншомовного мовлення (М. Качалов, 2005, Ю. Семенчук, 2007) та джерелом лексичних одиниць. 
На основі вивчення проблеми виокремлення критеріїв відбору навчальних матеріалів та 3 урахуванням особливостей професійно орієнтованих текстів, які характеризуються широким вживанням термінологічної лексики, виокремлюємо такі критерії відбору навчального матеріалу:

1. Автентичність.

2. Перспективність використання інформації.

3. Доступність.

4. Ситуативність.

5. Тематичність.

6. Комунікативність.

7. Продуктивність.

8. Оптимальність обсягу.

Автентичність розглядається як застосування автентичного мовного та мовленнєвого матеріалу в наближених до природних умовах «іншомовного соціуму» (Горюнова, 2011, с. 62). Ми згодні із твердженням, що автентичність - це така якість тексту, що забезпечує під час його опрацювання функціонування тих мовленнєвих механізмів, які реалізують спілкування у природних умовах реального життя. У таких текстах представлені широкий вибір лексики і правильне граматичне оформлення висловлювання, а також змістовна сторона. Автентичні текстові матеріали викликають певну реакцію, стимулюючи розумову діяльність студентів, а їхня жанрова різноманітність дозволяє сприймати інформацію з різних сфер життя: описи подій, розповіді, радіо і теленовини, лекції, розмови, інтерв'ю, оголошення тощо (Пелишенко, 1995, с. 33-36).

Перспективність використання інформації тексту передбачає, що вона може бути корисною для студентів і в процесі навчання, і під час подальшої професійної діяльності. Тексти, що відповідають такому критерію, часто слугують студентам еталоном певних комунікативних ситуацій і задають їм алгоритм відповідних поведінкових реакцій для виявлення суб'єктивно-діяльнісної позиції і для висловлення власної думки.

Доступність текстів передбачає відповідність вимогам програми, поступове ускладнення текстів, уникнення надмірних труднощів, пов'язаних або зі змістом, або з мовним оформленням тексту. Ми погоджуємось із Г. Скуратівською, яка зазначає, що для належного розуміння тексту необхідно, щоб кількість знайомих слів становила не менше 85 \%, а незнайомих - не більше 15 \% (Скуратівська, 2002, с. 74).

Тематичність забезпечує відповідність текстів тематиці, окресленій програмою, яка певною мірою повинна узгоджуватися з тематикою фахових дисциплін.

Загальновідомо, що під час відбору текстового матеріалу для навчання професійно орієнтованого англомовного мовлення враховується 
здатність текстових матеріалів імітувати майбутню професійну діяльність. Тому для формування в майбутніх фахівців інформаційних технологій англомовної компетентності в читанні та говорінні слід брати до уваги і можливість текстів викликати комунікативний ефект (Кочеткова, 2009, с. 94), тобто їхню комунікативність, що і є наступним критерієм відбору.

Щодо продуктивності текстових матеріалів, то вона забезпечує можливість для самовираження студентів через комунікацію/говоріння. Тому відбір текстів потрібно здійснювати, зважаючи на перспективність створення на їх основі комунікативних ситуацій. Професійно орієнтовані комунікативні ситуації покликані стимулювати мовленнєву реакцію студентів, які вербалізуються ними у вигляді монологічного чи діалогічного мовлення (розповідей, аргументацій, переконань, пояснень, коментарів). Крім того, критерій комунікативності реалізовується через відбір власне тих текстових матеріалів, опрацювання яких супроводжуватиметься функціональним використанням студентом англомовної лексики, зокрема у вигляді коментаря, аргументації, розповіді, переконання та пояснення (Терещук, 2013, с. 224).

Критерій оптимального обсягу текстового матеріалу або кількісний критерій передбачає визначення обсягу тексту, що буде використовуватися для формування англомовної компетентності в читанні та говорінні майбутніх фахівців інформаційних технологій, а також загальної кількості самих текстів. щодо відбору текстів за обсягом, то ми цілком підтримуємо Б. Куксу, що правомірно відбирати тексти такого розміру, загальний зміст яких студенти у змозі сприймати без погрішень (Кукса, 2012, с. 57). Загалом, обсяг тексту буде залежати від етапу навчання (початковий, просунутий), цілі та виду читання (ознайомлювальне, навчаюче, оглядове тощо).

Оптимальне застосування вищезазначених критеріїв під час відбору навчальних текстів дозволяє обрати ефективний навчальний матеріал для формування в майбутніх фахівців інформаційних технологій англомовної компетентності в читанні та говорінні

Далі пропонуємо розглянути вимоги до створення вправи як основного найменшого елементу організації навчальної діяльності, що дозволить далі визначити їх типи за певними критеріями.

Створення раціональної системи вправ уможливить формування в майбутніх фахівців інформаційних технологій англомовної компетентності в читанні та говорінні на відповідному рівні.

Згідно з організацією процесу засвоєння, система вправ має забезпечити підбір відповідних вправ; визначення послідовності їх побудови; розподіл навчального матеріалу та співвідношення його компонентів; систематичність і повторюваність вправ; взаємопов'язаність видів мовленнєвої діяльності (Пассов, 1989). 
У науково-методичній літературі поняття «вправа» визначається як спеціальне розроблене завдання, що виконується для набуття або закріплення відповідних навичок чи певних знань (Азімов та Щукін, 1999). У психологічній літературі вправа часто співставляється із вправлянням, яке розглядається як «багаторазове виконання дії з метою ії засвоєння, що ґрунтується на розумінні й супроводжується свідомим контролем і коригуванням» (Психологічна енциклопедія, 2006, с. 74). Все ж, за твердженнями науковців, серед яких і С. Рубінштейн (Рубінштейн, 2000, с. 33), вправляння загалом не збігається з навчанням і входить до змісту навчання як його органічна частина. Тому поняття «вправа» можна розглядати як форму організації вправляння, призначену для багаторазового виконання однієї або кількох операцій дії, стосовно якої формується навичка (Черноватий, 2018, с. 19-26). Звідси можна стверджувати, що змістом вправи $€$ повторне виконання певної дії, а першочерговим ії призначенням є формування навичок, тоді як кінцевою метою навчання $€$ розвиток умінь. Услід за С. Ніколаєвою вважаємо, що вправа - це спеціально розроблене і практично організоване в навчальних умовах багаторазове виконання окремих операцій, дій або діяльності 3 метою оволодіння ними до їх удосконалення (Ніколаєва, 2008).

У процесі розробки системи вправ ми враховували сучасні вимоги до вправ і дійшли висновку, що запропонована нами система повинна містити вправи, основними характеристиками яких $€$ :

- комунікативність

(комунікативні, умовно-комунікативні, некомунікативні вправи);

- спрямованість на сприйняття, розуміння, відтворення та видачу інформації (рецептивні, рецептивно-репродуктивні, рецептивнопродуктивні, продуктивні вправи);

- новизна змісту;

- наявність навчально-мовленнєві ситуації;

- урахування ступеня керованості дій студентів під час виконання вправи (вправи з повним, частковим і мінімальним керуванням);

- використання природних візуально-вербальних та спеціально створених опор;

- використання способів контролю, що відповідають характеру мовленнєвої діяльності (читання та говоріння) - рецепції та продукуванню;

- наявність опор (вправи без опор, вправи зі спеціально створеними опорами);

- функція в навчальному процесі (тренувальні, контрольні);

- місце виконання (аудиторні, домашні);

- спосіб організації або режим і форма роботи (індивідуальні, групові вправи) (Мацнєва, 2009, с. 66; Ніколаєва, 2010, с. 11-18). 
Наступним кроком у розробці системи вправ $є$ виокремлення етапів формування англомовної компетентності в читанні та говорінні, серед яких ми виділяємо підготовчий, основний та завершальний етапи.

На підготовчому етапі здійснюється формування мовленнєвих навичок читання та говоріння. Зокрема, особлива увага приділяється формуванню лексичних та граматичних навичок читання, а також лексичних, граматичних та фонетичних навичок говоріння. Зазначимо, що формування зазначених навичок здійснюється взаємопов'язано. На цьому ж етапі передбачено формування в майбутніх фахівців стратегічної усвідомленості - ознайомлення та використання стратегій читання та говоріння. Відповідно, на першому етапі реалізуються Підсистема вправ 1 та Підсистема вправ 2 (див. рис. 1).

Основний етап має на меті взаємопов'язане формування вмінь читання та говоріння, зокрема, розвиток умінь пошукового, переглядового, ознайомлювального та вивчаючого читання, умінь аналізувати інформацію, вживати засоби міжфразового зв'язку, продукувати монологпрезентацію, брати участь у діалозі-обговоренні. Основний етап передбачає реалізацію Підсистеми вправ 3 (рис. 1).

Завершальний етап спрямований на вдосконалення вмінь читання та говоріння і передбачає усні висловлювання студентів на основі прочитаної

інформації, ії аналіз у парах, групах, створення власних презентацій тощо. На завершальному етапі реалізовується Підсистема вправ 4.

Описані вище етапи та їх цілі дозволяють нам представити систему вправ для формування в майбутніх фахівців інформаційних технологій англомовної компетентності в читанні та говорінні (рис. 1), що становлять зміст кожного етапу.

Висновки та перспективи подальших наукових розвідок. Таким чином, ми обґрунтували систему вправ, спрямовану на поступове формування в майбутніх фахівців інформаційних технологій англомовної компетентності в читанні та говорінні, яка базується на виокремлених нами принципах та передбачає використання фахових текстів, відібраних за визначеними нами критеріями.

Перспективним напрямом подальших наукових досліджень може стати розробка моделі формування в майбутніх фахівців інформаційних технологій англомовної компетентності в читанні та говорінні. 


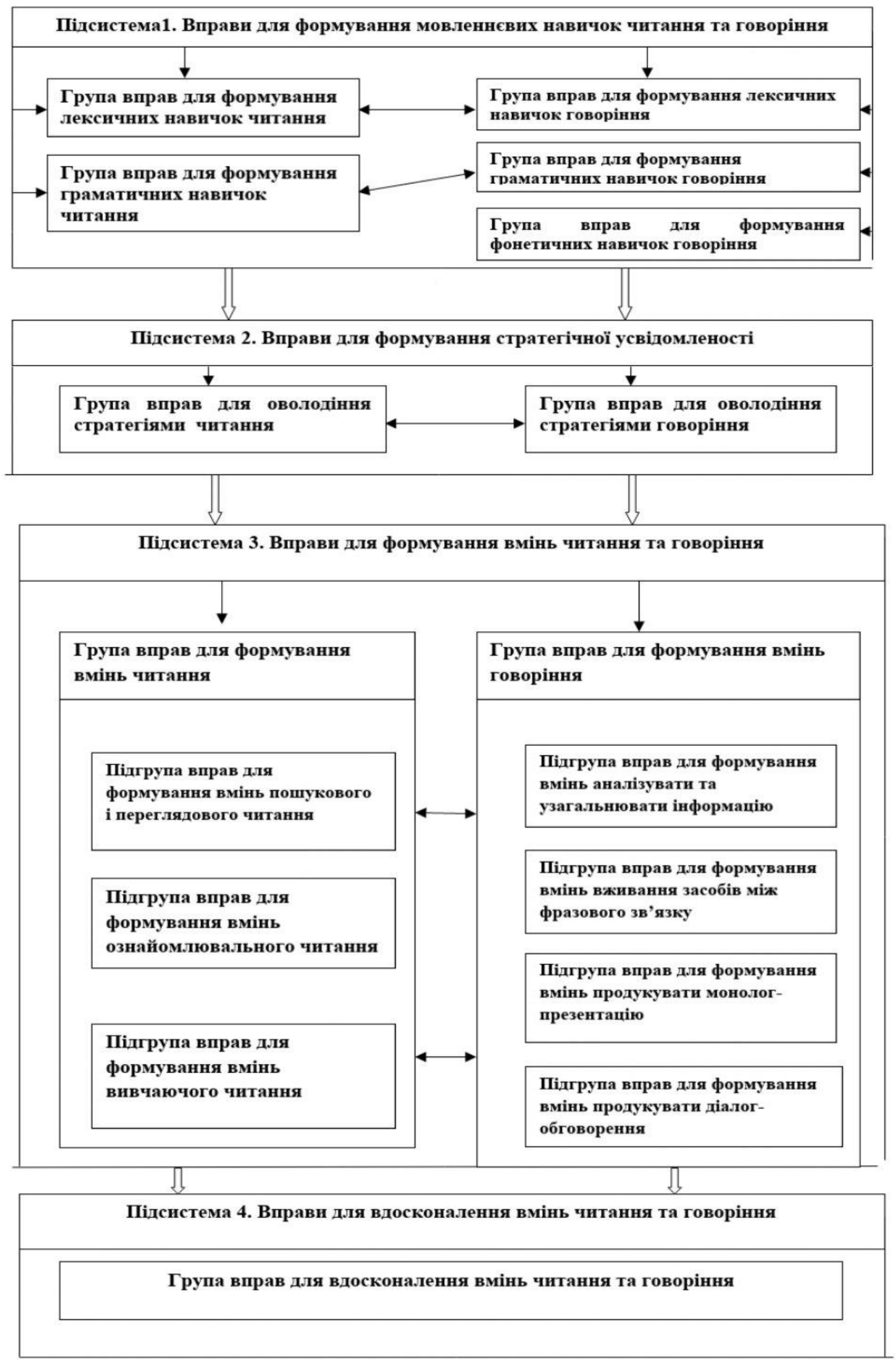

Рис. 1. Система вправ для формування у майбутніх фахівців інформаційних технологій англомовної компетентності в читанні та говорінні 


\section{ЛІТЕРАТУРА}

Азимов, Э. Г., Щукин, А.Н. (1999). Словарь методических терминов (теория и практика преподавания языков). Санкт-Петербург (Azimov, Е. H., Shchukin, A. N. (1999). Dictionary of methodological terms (theory and practice of teaching languages. Saint Petersburg).

Горєлова, Н. А. (2015). Методологія наукових досліджень (Gorelova, N. А. (2015). Research methodology). Retrieved from: https://stud.com.ua/35357/filosofiya/ metodologiya naukovih doslidzhen.

Горюнова, Е. С. (2011). Критерии отбора текстов для обучения студентов неязыковых вузов иноязычному профессиональному ориентированному чтению. Вестник Томского государственного педагогического университета, 2, 62 (Horiunova, E.S. (2011). Criteria for the selection of texts for teaching foreign language professional oriented reading for students of non-linguistic universities. Bulletin of Tomsk State Pedagogical University, 2, 62).

Качалов, Н.А. (2005). Построение модели взаимосвязанного обучения студентов неязыковых специальностей умениям устного и письменного профессиональноориентированного общения. Вестник Томского государственного педагогического университета, 2, 139-144 (Kachalov, N. A. (2005). Building a model of interconnected teaching of students of non-linguistic specialties the skills of oral and written professional-oriented communication. Bulletin of the Tomsk State Pedagogical University, 2, 139-144).

Кочеткова, Н. С. (2009). О содержании и принципах отбора учебных материалов по курсу Language for specific purposes на технических факультетах. Альманах современной науки и образования, 12, 2, 94 (Kochetkova, N. S. (2009). On the content and principles of selection of teaching materials for the course Language for specific purposes at technical faculties. Almanac of modern science and education, 12, 2, 94).

Кравчук, Ю. Г. (2010). Методика навчання студентів технічних спеціальностей професійно орієнтованого англійського діалогічного мовлення на основі текстів науково-технічної реклами (дис. ... канд. пед. наук: 13.00.02). Київ (Kravchuk, Yu. G. (2012). Methods of teaching students of technical specialties of professionally oriented English dialogic speech on the basis of texts of scientific and technical advertising (PhD thesis). Kyiv).

Куимова, М.В. (2005). Обучение устной монологической речи с опорой на аутентичный письменный текст: английский язык, неязыковой вуз (дис. ... канд. пед. наук: 13.00.02). Ярославль (Kuimova, M. V. Teaching oral monologue based on authentic written text: English, non-language universities. (PhD thesis). Yaroslavl).

Кукса, Б. В. (2012). Взаємопов'язане навчання монологічного мовлення і письма майбутніх учителів англійської мови з використанням мультимедійних засобів (дис. ... канд. пед наук: 13.00.02). Київ (Kuksa, В. V. Interrelated teaching of monologue and writing to future English teachers using multimedia tools ( $\mathrm{PhD}$ thesis). Kyiv).

Крупченко, А. К. (2007). Становление профессиональной лингводидактики как теоретико-методологическая проблема в профессиональном образовании (автореф. дис. ... д-ра пед. наук: 13.00.08). Москва (Krupchenko, А. К. (2007). The formation of professional linguodidactics as theoretical and methodological problem in professional education (DSc thesis abstract). Moscow).

Ковалів, Ю. І. (Ред.) (2007). Літературознавча енциклопедія: у 2 т. Т. 2. Київ: ВЦ Академія (Kovaliv, Y. I. (Ed.) (2007). Literary encyclopedia: in 2 volumes. Vol. 2. Kyiv).

Мацнєва, О. А. (2009). Навчання майбутніх учителів аудіювання англійського мовлення з національними та регіональними типами вимови: (дис. ... канд. 
пед. наук: 13.00.02). Київ (Matsneva, О. А. Training future teachers of English speaking with national and regional pronunciation types (PhD thesis). Kyiv).

Митник, М.М. (2014). Навчання іншомовної професійної презентації майбутніх фрахівців сфери туризму (дис. ...канд. пед. наук: 13.00.02). Одеса (Mytnyk, М. М. (2014). Training of foreign language professional presentation of future specialists in the field of tourism (PhD thesis). Odesa).

Ніколаєва, С. Ю. (2008). Основи сучасної методики викладання іноземних мов. Київ: Ленвіт (Nikolaeva, S. Yu. (2008). Fundamentals of modern methods of teaching foreign languages. Kyiv: Lenvit).

Ніколаєва, С. Ю. (2010). Цілі навчання іноземних мов в аспекті компетентнісного підходу. Іноземні мови, 1, 11-18 (Nikolaieva, S. Yu. (2010). Objectives of foreign language teaching in the aspect of competence approach. Foreign Languages, 1, 11-18).

Овчинников, М.В. (2008). Динамика мотивации учения студентов педагогического вуза и ее формирование (автореф. дис. канд. психол. наук: 19.00.07). Екатеринбург (Ovchinnikov, M. V. (2008). The dynamics of motivation for teaching students of a pedagogical university and its formation (PhD thesis abstract). Yekaterinburg).

Павлова, Л. В. (2010). Развитие гуманитарной культуры студентов вуза: Академия Естествознания (Pavlova, L. V. (2010). Development of humanitarian culture of university students. Retrieved from: http://www.rae.ru/monographs/105).

Пассов, Е.И. (1989). Основы коммуникативной методики обучения иноязычному общению. Москва: Русский язык (Passov, Е.І. (1989). Fundamentals of communicative methods of teaching foreign language communication. Moscow).

Пелишенко, А.С. (1995). Использование автентичного песенного материала в обучении иностранным языкам. Іноземні мови, 3-4, 33-36 (Pelishenko, A. S. (1995). Using authentic song material in teaching foreign languages. Foreign languages, 3-4, 33-36).

Подласый, И. П. (2004). Педагогика: 100 вопросов - 100 ответов. Москва: ВЛАДОСпреcc (Podlasy, І. Р. (2004). Pedagogy: 100 questions - 100 answers. Moscow: VLADOS-press).

Психологічна енциклопедія (2006). Київ: Академвидав (Psychological encyclopedia (2006). Kyiv).

Рубинштейн, С. Л. (2000). Основы общей психологии. Санкт-Петербург: Питер (Rubinstein, S. L. (2000). Fundamentals of general psychology. Saint Petersburg: Piter).

Семенчук, Ю. О. (2007). Формування англомовної лексичної компетенції у студентів економічних спеціальностей засобами інтерактивного навчання (дис. ... канд. пед. наук: 13.00.02). Київ (Semenchuk, Yu. О. (2007). Forming English lexical competence with students of economic specialties by means of interactive teaching (PhD thesis). Kyiv).

Терещук, В.Г. (2013). Відбір текстових матеріалів для формування англомовної лексичної компетенції. Науковий вісник Ужгородського начіонального університету. Серія: Педагогіка. Соціальна робота, 29, 224 (Tereshchuk, V.H. (2013). Selection of text materials for the formation of English lexical competence. Scientific Bulletin of Uzhhorod National University. Series: Pedagogy. Social work, 29, 224).

Скуратівська, Г. С. (2002). Навчання писемного англійського професійного мовлення студентів фрінансово-економічних спеціальностей (дис. ... канд. пед. наук: 13.00.02). Київ (Skurativska, H.S. (2002). Teaching written English professional speech to students of financial and economic specialties (PhD thesis). Kyiv).

Томашевська, А.Ю. (2019). Формування у майбутніх фрармацевтів англомовної лексичної компетентності в читанні та говорінні у процесі самостійної 
роботи (дис. ... канд. пед. наук: 13.00.02). Тернопіль (Tomashevska, А. Yu. (2019).

Development of future pharmacists' English lexical competence in reading and speaking through self-directed study (PhD thesis). Ternopil).

Онацький, Є. (Ред.) (1965). Українська мала енциклопедія: 16 кн.: у 8 т. Буенос-Айрес.

T. 7, кн. XIV) (Onatskyi, Ye. (1965). Ukrainian small encyclopedia. Buenos Aires: Litery).

Універсальний словник-енциклопедія. 4-те вид. (2006). Київ: Тека (Universal dictionaryencyclopedia (2006). Kyiv: Teka).

Черноватий, Л. М. (2018). Система вправ і завдань як категорія методики навчання перекладу. Іноземні мови, 2, 19-26 (Chernovatyi, L. M. (2018). System of exercises and tasks as a category of translation teaching methods. Foreign languages, 2, 19-26. Retrieved from: http://nbuv.gov.ua/UJRN/im 20182 4).

Фіцула, М. М. (2006). Педагогіка вищої школи. Київ (Fitsula, М. М. (2006). Pedagogy of high school. Kyiv).

Шарапова, С. И. (2009). Критерии отбора содержательно-текстовой базы для обучения студентов неязыкового вуза профессионально ориентированному чтению на иностранном языке. Известия РГПУ им .А. И. Герцена, 102, 320 (Sharapova, S. I. (2009). Criteria for selecting a content-textual base for teaching students of a nonlinguistic university to professionally oriented reading in a foreign language. Bulletin of the Herzen Russian State Pedagogical University, 102, 320).

\section{PEЗЮME}

Добровольская Наталия. Система упражнений для формирования у будущих специалистов информационных технологий англоязычной компетентности в чтении и говорении.

В статье обоснована система упражнений для формирования у будущих специалистов индормационных технологий англоязычной компетентности в чтении и говорении. Для реализации поставленной цели использованы такие общенаучные методы исследования, как анализ, синтез, системный анализ сравнения и обобщение. Выделены принципы формирования у будущих специалистов информационных технологий англоязычной компетентности в чтении и говорении (интегрированного обучения, системности и последовательности учебных действий, автономии, формирования устойчивой положительной мотивации); особенности отбора учебного материала, который будет использоваться в упражнениях, в частности, критерии отбора профессиональных текстов; предложена система упражнений, которая предусматривает четыре подсистемы и направлена на взаимосвязанное формирование у студентов навыков и умений чтения и говорения.

Ключевые слова: система упражнений, формирование, англоязычная компетентность, чтение, говорение.

\section{SUMMARY}

Dobrovolska Nataliia. System of exercises for the formation of English-speaking competence in reading and speaking of future specialists in information technologies.

The article substantiates a system of exercises for the formation of English-speaking competence in reading and speaking of future specialists in information technologies. To achieve this goal, such general scientific research methods as analysis, synthesis, systematic analysis, comparison and generalization were used. The requirements for the creation of the exercise as the main smallest element of the organization of educational activities were considered, which allowed to determine their types according to certain criteria. When developing the system of exercises for the interconnected formation of English-speaking competence in reading and speaking of future computer engineers, we took into account modern general didactic, methodological principles and the principles of the learning process. Creation of a rational 
system of exercises will enable formation in future specialists in information technologies of English-speaking competence in reading and speaking at the appropriate level. The principles of the formation of English-speaking competence in reading and speaking of future specialists in information technologies are highlighted (comprehensive training, systematization and sequence of educational actions, autonomy, formation of sustainable positive motivation); features of the selection of learning material for use in exercises, in particular, the criteria for the selection of professional texts. It should be emphasized that all the presented didactic principles of teaching are interconnected, interdependent and complementary, forming a system of positions that determine the strategy of the process of interconnected formation of English-speaking competence in reading and speaking of future specialists in information technologies. Each system, and namely the system of exercises for learning English, has a number of properties that can be divided into the following groups: 1) goals and functions; 2) features of the structure; 3) resources and features of interaction with the learning environment. A system of exercises is proposed, which provides for four subsystems and is aimed at the interconnected formation of students' reading and speaking skills. A promising direction for further research can be development of a model of the formation in future specialists in information technologies of English-speaking competence in reading and speaking.

Key words: system of exercises, formation, English-speaking competence, reading, speaking.

УДК 37.013:378:316

Олена Купенко

Сумський державний університет ORCID ID 0000-0001-9131-5179

DOI 10.24139/2312-5993/2020.03-04/039-048

\section{ПЕДАГОГІЧНА ТЕХНОЛОГІЯ НАСТАВНИЦТВА В ПРОЦЕСІ ФОРМУВАННЯ ПРОЄКТНОÏ КОМПЕТЕНТНОСТІ МАЙБУТНІХ БАКАЛАВРІВ СОЦІАЛЬНОЇ РОБОТИ}

Представлено модель забезпечуючої педагогічної технології наставництва у формуванні проєктної компетентності майбутніх бакалаврів соціальної роботи. Використані методи - аналіз і синтез, педагогічне проєктування, дослідження в дії. Проаналізовано процеси академічного наставництва (допомоги студенту поєднати в собі ролі стратега й виконавця) та наставництва на робочому місці (передавання неявних знань про професію та робоче місце). Передбачається залучення до наставництва старших студентів, студентська самоорганізація у проєктній діяльності. Підкреслюється, що робота з наставником створює для студента орієнтувальну основу професійної діяльності, адже часто майбутній сочіальний працівник покликаний стати наставником клієнтів соціальної роботи.

Ключові слова: педагогічна технологія, проєктна компетентність, бакалавр соціальної роботи, академічне наставництво, наставництво на робочому місці, Flash-наставництво, Peer-to-Peer-наставництво, дуальна освіта.

Постановка проблеми. У «Глобальних стандартах освіти та навчання соціальної роботи», розроблених і затверджених Міжнародною федерацією соціальних працівників, Міжнародною асоціацією шкіл соціальної роботи, значна увага приділяється поняттю «польова освіта» («field education») (Global standards for the education and training of the social work profession). 
Польова освіта як освіта безпосередньо в організаціях та установах соціальної сфери дозволяє студентам застосовувати знання та цінності, здобуті в навчальних аудиторіях, а також розширювати практичні навички до рівня компетентностей.

Польова освіта $€$ поширеною практикою для спеціальності «Соціальна робота» в американських університетах, наприклад, реалізується в Colorado State University, George Mason University, San Francisco State University, University of Pittsburgh та інших.

у європейській практиці для освітніх програм, які поєднують у собі потужну теоретичну підготовку та навчання безпосередньо на робочому місці, використовується термін «дуальна освіта» (Müller, 2013). Саме термін «дуальна освіта» в сенсі поєднання навчання в академічній аудиторії та на робочому місці використовується в українському нормативному полі вищої освіти (Положення про дуальну форму здобуття професійної (професійно-технічної) освіти, 2019). Аналіз методичного забезпечення польової/дуальної освіти вказує на особливого суб'єкта навчального процесу - наставника.

Виходимо з того, що наставництво (від англ. mentoring) більшою мірою орієнтується на передання досвіду від людини, яка вже пройшла певний життєвий чи професійний шлях, тій, якій цей шлях ще потрібно буде пройти. Тобто наставництво передбачає наявність більш досвідченого фахівця і менш досвідченого, певну нерівність позицій, хоча й ґрунтується на дружній, відкритій взаємодії між ними.

Наставництво представляється вельми потрібною педагогічною функцією в реаліях українських закладів вищої освіти. Актуальним $\epsilon$ розроблення відповідного методичного забезпечення з урахуванням місцевих особливостей.

Аналіз актуальних досліджень. Аналіз актуальних досліджень дозволяє виділити академічне наставництво (J. Nick, T. Delahoyde, D. Del Prato, C. Mitchell, J. Ortiz, C. Ottley, P. Young, S. Cannon, K. Lasater, D. Reising, L. Siktberg, K. L. Gee, A. N. Popper) та наставництво на робочому місці (S. D. Broek, M. Cino Pagliarello, R. de Vreede-Van Noort, P. Vroonhof, N. Durazzi, J. Secher, J. Stoumann, S. Broek, L. de Haan, I. van den Ende, S. van Loo, J. Gisin, R. Oakeley, J. Antic). Дослідники підкреслюють взаємозв'язок і взаємодоповнюваність цих двох видів наставництва. Указують на специфіку наставництва щодо програм професійної підготовки за різними спеціальностями та освітніми рівнями.

Окремої уваги заслуговує проблема організації наставництва в процесі професійної підготовки соціальних працівників в умовах сучасних українських закладів вищої освіти. Причому корисним вбачається конкретизація технологій наставництва відповідно до очікуваних компетентностей майбутніх фахівців. 
Мета статті - представлення формалізовано-описової моделі забезпечуючої педагогічної технології наставництва в процесі формування проєктної компетентності майбутніх бакалаврів соціальної роботи.

Методи дослідження. Мета статті реалізується із використанням методів аналізу та синтезу. Теоретичну базу дослідження складають наукові праці з проблеми наставництва, методичну базу - міжнародні стандарти, а також методичне забезпечення польової/дуальної освіти іноземних університетів. Відображені результати педагогічного проєктування, результативність якого перевірена з використанням методу дослідження в дії.

Виклад основного матеріалу. У ході дослідження процесу формування проєктної компетентності майбутніх бакалаврів соціальної роботи була обґрунтована доцільність інтегральної проєктної педагогічної технології у складі, базової проєктної педагогічної технології, забезпечуючої педагогічної технології селфпроєктної діяльності та забезпечуючої педагогічної технології наставництва (рис. 1).

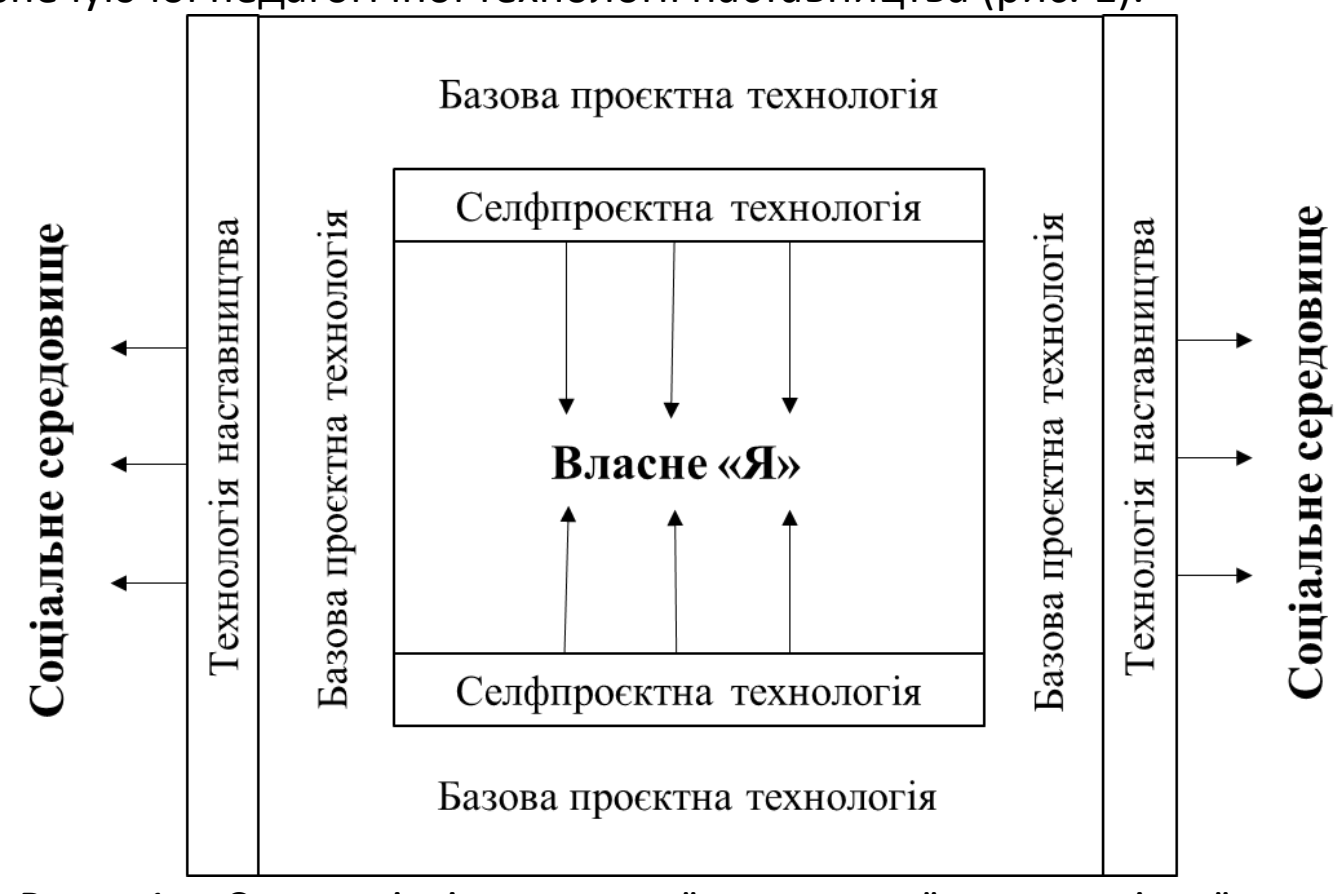

Рис. 1. Складові інтегральної проєктної педагогічної технології формування проєктної компетентності майбутніх бакалаврів соціальної роботи

Ідея студентоцентрованого навчання реалізується в технології в наданні студентам можливості для виявлення власної суб'єктності - вибору бази практики, цільової групи, змісту проєкту. При цьому на бакалаврському рівні для вибору студентів обґрунтовані такі типи проєктів: співавторство в селфпроєктах клієнтів соціальної роботи із перспективою віддання авторства; соціально-педагогічна проєктна діяльність для розвитку громад; соціальнопедагогічна проєктна діяльність у тезаурусі соціальної роботи за стандартизованими процедурами; соціально-педагогічна проєктна діяльність інноваційного характеру в умовах невизначеності. 
Пропонована інтегральна педагогічна технологія формування проєктної компетентності майбутніх бакалаврів соціальної роботи покликана не лише забезпечити набуття студентами досвіду проєктної діяльності, але й досвіду поступового ускладнення такої діяльності: розширення кола активності студентів, збільшення кількості компонентів у студентських проєктах, які вони здатні усвідомити як елементарні та включити в поле власної цілеспрямованої активності, урізноманітнюючи при цьому свою діяльність розширюваним тезаурусом, освоєними технологіями та методами соціальної роботи. При цьому має бути забезпечене розуміння студентами власних проєктів як вбудованих у ширші процеси реформування системи надання соціальних послуг в Україні. Для того, щоб студенти не лише розробили якісні проєкти, але й реалізували їх, працює наставник.

У міжнародних дослідженнях наявні два підходи до реалізації процесу наставництва: 1) у сенсі розвитку та реалізації наявного потенціалу й руху до майбутніх можливостей - початковий етап; етап розвитку; етап відділення; етап набуття нового статусу; 2) у сенсі довіри - «обмін подарунками» «дарування подарунку» від наставника майбутньому фахівцю, що стимулює підопічного, керуючись почуттям вдячності, намагатися вчинками довести, свою гідність щодо «подарунку»; підопічний удосконалює, розвиває, збагачує отриманий «подарунок», і ось у певний час він уже сам відчуває потребу передати його далі (Дудина, 2017). У єдності цих двох підходів визначається сенс наставництва: з одного боку, це чіткий алгоритм, який потрібно знати та реалізувати для досягнення потрібного результату; з іншого - це людські стосунки, без яких алгоритм не спрацює, а буде відторгнений. Обидва підходи не лише визначають форму підготовки майбутніх соціальних працівників, але й відповідають її змісту, адже в найближчому майбутньому студенти самі можуть отримати завдання стати наставниками для клієнтів соціальної роботи.

Щодо реалізації забезпечуючої педагогічної технології наставництва, то важливо з'ясувати, хто може стати суб'єктом виконання цих функцій. Від початку навчання першокурсників у закладі вищої освіти функцію академічного наставництва беруть на себе куратори академічних груп, але це лише підготовча робота одного наставника по відношенню до цілої групи. Далі формалізувати наставництво в межах бакалаврської програми за спеціальністю «Соціальна робота» вбачається можливим, зокрема, шляхом призначення студентові викладача як наукового керівника для виконання курсових робіт. Особистісна орієнтація реалізується в тому, що викладачнаставник бачить у своєму підопічному людину з ії особливими інтересами (що реалізуються під час вибору тематики курсових робіт), наявним досвідом навчальної діяльності (що вимагає прямого управління чи співуправління 3 боку наставника, або самоуправління студента), унікальну особистість. 
Взаємодія викладача та студента виходить за межі аудиторної роботи та масової освіти, будучи формалізованою з метою написання курсової роботи як авторської роботи студента. При чому процес такої взаємодії в часі регламентується графіком навчального процесу та термінами захисту курсових робіт, але він триваліший ніж 1 семестр і написання 1 курсової роботи, це послідовність курсових робіт. Крім курсових робіт - це також і виробнича практика студентів, спільні громадські активності викладачів та студентів. Саме спираючись на всі ці види діяльності і пропонується інтегральна проєктна педагогічна технологія формування проєктної компетентності майбутніх бакалаврів соціальної роботи, а також забезпечуюча педагогічна технологія наставництва.

Завдання формування проєктної компетентності студентів забезпечується таким чином низкою проєктів, реалізованих ними за наставництва та співавторства викладачів, при тому що складність та усвідомленість цих проєктів поступово зростає, а наставництво викладачів поступово мінімізується для досягнення самостійної діяльності майбутніх фахівців.

Зрозуміти сутність наставництва дозволяє модель, запропонована М. Голдсмітом та М. Рейтером. Людину пропонується розглянути у двох ролях: 1) лідер, стратег; 2) виконавець. У ролі лідера, стратега визначаються власні плани та перспективи, у тому числі щоденні плани; у ролі виконавця людина реалізує їх. У ролі стратега робляться припущення, що виконавець буде чітко слідувати наміченому плану. Однак, діє оточуюче середовище і далеко не завжди щоденні плани реалізуються. Для «з'єднання» внутрішнього стратега із внутрішнім виконавцем М. Голдсміт та М. Рейтер пропонують втручання наставника, який зближує позиції стратега та виконавця завдяки своїй об'єктивності, що дозволяє не потрапляти під вплив оточуючого середовища. Наставник нагадує людині про ії справжні наміри. Але це добровільна справа з боку підопічного. Завдяки тому, що відбуваються не лише нагадування, але й регулярне обговорення, аналіз процесу виконання запланованого, після певної кількості сесій із наставником людина навчається сама розпізнавати ситуацію, коли $€$ ризик збитися зі шляху. Настає момент об'єднання стратега та виконавця. 3 цього моменту вже не потрібна підтримка із зовні, людина стає наставником для самої себе. На цьому етапі, як підкреслюють М. Голдсміт та М. Рейтер, людина також може стати наставником і для іншої (Голдсмит та Рейтер, 2016). Останнє є особливо важливим для процесу професійної підготовки майбутніх фахівців соціальної роботи, адже таким чином здобувається можливість стати тригером змін, наставником для інших людей.

Якщо академічне наставництво більшою мірою спрямовується на усвідомлення молодою людиною того, що відбувається з нею самою, то наставництво на робочому місці спрямовуються на освоєння майбутнім фахівцем сфери професійної діяльності поза межами закладу освіти. 
Специфіка наставництва на робочому місці в профільній організації чи установі - це передавання підопічному «нематеріальних інтелектуальних активів», «неявних знань» (Нонака, 2011). Йдеться про те, що не вкладається в параграфи книжок і тексти аудиторних лекцій, що не можна зрозуміти, працюючи навіть у найсучаснішій університетській лабораторії. Це стосується як технологій професійної діяльності, так і комунікації в середині організації чи установи, а також із зовнішнім середовищем, клієнтами. Наставник надає доступ до прихованої інформації, знайомить протеже 3 неформальними сторонами життєдіяльності організації, із впливовими мережами прийняття рішень, передає знання про цінності організації (Чеглакова, 2011).

Однак, стосовно наставництва на робочому місці дослідники звертають увагу на низку суперечностей та запитань організаційного характеру (Чеглакова, 2011): про те, як зацікавити кваліфікованого співробітника профільної організації чи установи передати свої знання та досвід молодій людині - можливо, потенційному конкуренту; як мотивувати роботодавців оплачувати виконання працівниками наставницьких функцій; який буде результат, коли наставником є людина, не задоволена позицією в організації та заробітною платою. Виходячи 3 наведеного, у сучасних реаліях максимальні очікування щодо реалізації забезпечуючої педагогічної технології наставництва пов'язані з викладачем (академічним наставником), хоча перспективи вимагають активної участі наставника на робочому місці. Для активізації співпраці закладів вищої освіти та організацій, де існують потенційні робочі місця для майбутніх соціальних працівників у сучасній міжнародній практиці пропонуються різні варіанти Flash-наставництва, які не вимагають багато часу: одна година і навіть менше, щоб наставнику зустрітися з майбутнім фахівцем (можливо, відібраним за певним конкурсом чи рекомендацією представника закладу вищої освіти) і поділитися життєвим досвідом та порадами; після цієї зустрічі наставник вирішує, чи захоче він продовжити наставництво (Best Practices: Mentoring, 2008). Для активізації Flashнаставництва в інтегральній проєктній педагогічній технології формування проєктної компетентності майбутніх бакалаврів соціальної роботи передбачаються відкриті лекції від роботодавців і фахівців соціальної роботи, екскурсії в організації та установи, формат роботи «жива бібліотека». Окрема увага приділена іміджевим заходам. У якості прикладу наведемо щорічну практику відзнак «Соціальний Оскар СумДУ», присвячену дню працівників соціальної сфери України.

У міжнародній практиці зустрічається також і така важлива форма, як Peer-to-Peer-наставництво, тобто наставництво на засадах «рівний рівному», коли наставниками виступають студенти старших курсів (Best Practices: Mentoring, 2008). Відсутність вікової дистанції між студентами-наставниками 
та студентами-протеже сприяє мотивації професійного зростання у всій студентській громаді, адже наставник - один із цієї громади, «свій», такий самий, а значить у всіх $є$ реальна можливість досягти такого рівня. Співпраця студентів різних курсів вбачається зручною для формування саме проєктної компетентності як механізм синергії (самоорганізації) в студентському середовищі. Старші студенти-наставники можуть отримувати проєктні завдання від роботодавців, залучаючи до процесу виконання молодших студентів (спільно з наставниками-викладачами або самостійно), створювати проєктні групи, розробляти та реалізовувати проєкти, звітувати наставнику в організації. Додамо, що досвід наставництва на засадах «рівний-рівному» особливо корисним вбачається саме для студентів спеціальності «Соціальна робота», адже готує до майбутнього наставництва по відношенню до клієнтів соціальної роботи.

Таким чином, суб'єкти, які мають бути залучені до реалізації наставництва, $€$ доволі різноманітними. Потрібна організація їх співпраці в забезпечуючій педагогічній технології наставництва в межах інтегральної проєктної педагогічної технології формування проєктної компетентності майбутніх бакалаврів соціальної роботи. Для забезпечення такої організації визначається, що загальну координацію всіх названих суб'єктів наставництва здійснює гарант спеціальності. Пропонується за основу технології взяти етапи: початковий; розвитку; відділення; набуття нового статусу. Відповідно до цих етапів, із залученням всіх названих суб'єктів, забезпечуючу педагогічну технологію наставництва деталізуємо таким чином:

\section{- цілі:}

1) надати допомогу студентам у здобутті проєктної компетентності на засадах польової/дуальної форми освіти, тобто з ґрунтовною академічною підготовкою в закладі вищої освіти, а також практичною підготовкою безпосередньо на робочому місті;

2) надати допомогу у селфпроєктній діяльності 3 отриманням результату у розвиту власної особистості молодої людини;

3) за потреби, виконати дії корегування щодо досягнення результатів по всім складовим інтегральної проєктної педагогічної технології формування проєктної діяльності майбутніх бакалаврів соціальної роботи;

- вихідний стан - припускається рівень прямого управління з боку викладача;

- види наставництва: наставництво з елементами коучингу; академічне наставництво; наставництво на робочому місці; Flashнаставництво; Peer-to-Peer-наставництво;

- етапи (позначкою «•» виділені етапи синхронізації складових інтегральної проєктної педагогічної технології формування проєктної компетентності майбутніх бакалаврів соціальної роботи; позначкою «+» виділені додаткові етапи педагогічної технології наставництва): 
початковий етап:

- інтуїтивно-ознайомчий етап;

+ етап пропедевтики селфпроєктної діяльності;

етап розвитку, етап відділення:

- етап орієнтування в цільових групах;

+ етап залучення до реалізації громадських ініціатив викладачів;

- етап ускладнення засобів проєктної діяльності;

- дослідницький етап;

- етап орієнтування в тезаурусі та стандартах;

- етап селфпроєктної діяльності;

- етап систематизації;

+ постійні коригуючі впливи щодо формуванням проєктної компетентності;

етап набуття нового статусу:

+ етап отримання кваліфікації бакалавра соціальної роботи;

+ етап працевлаштування за спеціальністю;

- тривалість: 4 роки бакалаврської програми;

- оцінка результату: виявлені знання й досвід; виявлена професійна творчість; виявлена самостійність; виявлене сприяння реалізації прав інших людей; виявлені дії самопроєктування.

\section{Висновки та перспективи подальших наукових розвідок.}

1. Забезпечуюча педагогічна технологія наставництва найбільш детально описує процес формування проєктної компетентності майбутніх бакалаврів соціальної роботи, навіть детальніше, ніж базова проєктна технологія. Тим самим отримаємо ілюстрацію того, що проєктуючи педагогічну систему як студентоцентровану, у цій системі потрібно передбачити ретельну роботу викладача; роблячи акцент на процесах самоорганізації в студентському середовищі, потрібно зрозуміти великий обсяг зусиль педагогічного колективу для створення сприятливих умов для такої самоорганізації.

2. Перспективи зростання потужності пропонованої забезпечуючої технології наставництва, а значить і педагогічної системи в цілому, вбачаються в розвитку дуальної форми освіти, більш активному та системному залученню роботодавців і наставників на робочих місцях до процесу професійної підготовки студенті. На даний момент лише починається розбудова такої форми навчання в Україні, а значить маємо активно застосовувати Flash-наставництво й відпрацьовувати способи розвитку взаємодії між педагогами та роботодавцями.

3. Фінальним етапом забезпечуючої педагогічної технології наставництва передбачено працевлаштування випускника, який отримав кваліфікацію, за спеціальністю. Однак, у даний час розглядаємо такий фінальний етап скоріше як певний ідеальний, адже заважає низький рівень престижу спеціальності «Соціальна робота» на ринку праці і серед молоді. 
Тим не менше вбачаємо, що наукові дослідження з професійної підготовки майбутніх фахівців соціальної роботи несуть у собі потенціал для професіоналізації галузі та зростання ії престижу.

\section{ЛІТЕРАТУРА}

Голдсмит, М., Рейтер, М. (2016). Триггеры. Формируй привычки - закаляй характер. Москва: Манн, Иванов и Фербер (Goldsmith, М., Reuters, М. (2016). Triggers. Form the habits - temper the character. Moscow: Mann, Ivanov and Ferber).

Дудина, Е.А. (2017). Наставничество как особый вид педагогической деятельности: сущностные характеристики и структура. Вестник Новосибирского государственного педагогического университета, 5, 25-36 (Dudina, Е. А. (2017). Mentoring as a special type of pedagogical activity: essential characteristics and structure. Bulletin of the Novosibirsk State Pedagogical University, 5, 25-36). Retrieved from: https://cyberleninka.ru/.

Нонака, И., Такеучи, Х. (2011). Компания - создатель знания. Зарождение и развитие инноваций в японских фирмах. Москва: Олимп-Бизнес (Nonaka, I., Takeuchi, H. The company is the creator of knowledge. Origin and development of innovations in Japanese companies. Moscow: Olymp-Business).

Положення про дуальну форму здобуття професійної (професійно-технічної) освіти: Наказ Міністерства освіти і науки України (Regulations on the dual form of obtaining vocational (vocational and technical) education: Order of the Ministry of Education and Science of Ukraine) (2019). Retrieved from: https://zakon.rada.gov.ua/.

Чеглакова, Л.М. (2011). Наставничество: новые контуры организации социального пространства обучения и развития персонала промышленных организаций. Экономическая сочиология, 2, 80-98 (Chehlakova, L. M. (2011). Mentoring: new contours of the organization of social space of training and development of personnel of the industrial organizations. Economic sociology, 2, 80-98). Retrieved from: http://www.ecsoc.hse.ru/.

Best Practices: Mentoring (2008). Retrieved from: https://www.opm.gov/.

Global standards for the education and training of the social work profession. Retrieved from: https://www.iassw-aiets.org/.

Müller, S. Dual education: a win-win situation for companies and graduates. Retrieved from: https://www.alumniportal-deutschland.org/.

\section{PEЗЮME}

Купенко Елена. Педагогическая технология формирования проектной компетентности будущих бакалавров социальной работы.

Представлена модель обеспечивающей педагогической технологии наставничества в фрормировании проектной компетентности будущих бакалавров социальной работы. Использованные методы - анализ и синтез, педагогическое проектирование, исследования в действии. Проанализированы прочессы академического наставничества (помощи студенту в совмещении ролей стратега и исполнителя), наставничества на рабочем месте (передачи неявных знаний о профрессии). Предполагается привлечение к наставничеству старших студентов, студенческая самоорганизация в проектной деятельности. Подчеркивается, что работа с наставником создает для студента ориентировочную основу профессиональной деятельности, ведь часто будущий социальный работник призван стать наставником клиентов социальной работы.

Ключевые слова: педагогическая технология, проектная компетентность, бакалавр сочиальной работы, академическое наставничество, наставничество на 
рабочем месте, Flash-наставничество, Peer-to-Peer-наставничество, дуальное образование.

\section{SUMMARY}

Kupenko Olena. Pedagogical technology of mentoring in the process of formation of project competence of future bachelors of social work.

The article presents a model of pedagogical mentoring technology. Technology is a component of integral project pedagogical technology of formation of project competence of future bachelors of social work. Analysis and synthesis, pedagogical design, research in action were used for its creation.

The subjects of mentoring are the curators of academic student groups, supervisors of course work of students, mentors on the basis of practice, senior students in relation to junior. The process of academic mentoring and the process of mentoring in the workplace are analyzed. Mentoring technology is implemented during the 4-year bachelor's program.

The technology provides: initial stage (intuitive and introductory stage; stage of propaedeutics of self-project activity); stage of development and separation (stage of orientation in target groups; stage of involvement in the implementation of public initiatives; stage of complication of project activities; research stage; stage of orientation in thesaurus and standards; stage of self-project activity; stage of systematization; constant corrective influences on project competence formation); stage of acquiring a new status (stage of obtaining a bachelor's degree in social work; stage of employment in the specialty). During the implementation of the stages, a number of student projects are envisaged.

The role of the academic mentor is to help the student combine two roles - strategist and performer. The role of the mentor in the workplace is to pass on to the protégé implicit knowledge about the profession and the workplace. Under the conditions of field education, preference is given to the option of Flash-mentoring in the workplace. Peer-to-Peer mentoring is envisaged.

It is emphasized that successful work with a mentor creates for the student an indicative basis for future professional activity. After all, the future social worker is called to become a mentor for clients of social work.

Prospects for increasing the capacity of the proposed technology of mentoring are seen in the development of field education, more active and systematic involvement of employers and mentors in the workplace in the process of professional training of students.

Key words: pedagogical technology, project competence, bachelor of social work, academic mentoring, on-the-job mentoring, Flash-mentoring, Peer-to-Peer-mentoring, field education. 
Тетяна Кучай

Закарпатський угорський інститут ім. Ференца Ракоці II, М. Берегово ORCID ID 0000-0003-3518-2767

Олександр Кучай

Національний університет біоресурсів і природокористування України ORCID ID 0000-0002-9468-0486

DOI 10.24139/2312-5993/2020.03-04/049-056

\section{ПРОФЕСІЙНА ПІДГОТОВКА ФАХІВЦІВ ЕКОНОМІЧНОГО ПРОФІЛЮ В УМОВАХ НЕПЕРЕРВНОÏ ОСВІТИ}

У статті розкривається профресійна підготовка фахівців економічного профрілю в умовах неперервної освіти. Виділено основні напрями неперервної освіти. Майбутні фахівці в галузі економіки мають бути здатними до реалізації проектної діяльності, кооперації та здорової конкуренції. Необхідний пошук таких форм організації навчальної діяльності майбутніх економістів у закладах вищої освіти, які забезпечували би їх практичними навичками соціальної взаємодії та сприяли розвиткові соціальних, моральних, особистісних якостей і професійної культури в чілому. Наголошується на тому, що формування профресійної культури фахівців економічного профілю базується на загальних психолого-педагогічних принципах дидактики і виховання.

Ключові слова: професійна підготовка, фахівці економічного профілю, неперервна освіта, заклади вищої освіти.

Постановка проблеми. Неперервна освіта супроводжує процес зростання освітнього (загального і професійного) потенціалу особистості протягом життя, який організаційно забезпечений системою державних та суспільних інститутів і відповідає потребам особистості й суспільства.

Метою неперервної освіти $є$ становлення та розвиток особистості як у періоди її фізичного і соціально-психологічного дозрівання, розквіту й стабілізації життєвих сил та здібностей, так і в періоди старіння організму, коли на перший план висувається завдання компенсації сил і можливостей, що втрачаються.

Системотвірним фактором неперервної освіти $€$ суспільна потреба в постійному розвиткові особистості кожної людини. Цим визначається впорядкування безлічі освітніх структур - основних і паралельних, базових і додаткових, державних і громадських (суспільних), формальних і неформальних. Їхній взаємозв'язок та взаємозумовленість, взаємна субординація за рівнями, координація за спрямованістю і призначенням, забезпечення взаємодії між ними перетворюють всю сукупність таких структур у єдину систему (Теорія і методика професійної освіти, 2012).

Період соціально-економічних трансформацій в Україні характеризується зміною низки колишніх суспільних цінностей і культурних 
стереотипів. Докорінна зміна традиційного способу життя породжує нові пріоритетні завдання сучасної освіти, а саме: навчання навчатися (вироблення вмінь оволодівати й оперувати найрізноманітнішою інформацією); навчання працювати (формування здатності ефективно оволодівати професійними навичками, уміння знаходити вихід у найнепередбачуваніших виробничих ситуаціях, співпрацювати в колективі, співвідносити себе з конкретними фаховими ролями й ефективно їх виконувати); навчання співіснувати (розвиток таланту до налагоджування соціальних відносин, виховання здатності до емпатії, персоніфікованих відносин з іншими людьми); навчання жити (формування цілісного світогляду, уміння бачити особистісний сенс життя, прагнути до духовної зрілості, бути відповідальним за себе та інших). Економічний підхід поширюється на все життя суспільства: головним економічним ресурсом стають інформація і знання, наростає боротьба економічних суб'єктів за інноваційний ресурс і випереджальний розвиток. Відповідно, цілі вищої економічної освіти мають передбачати не лише формування у випускників ЗВО певного комплексу фахових знань, умінь та навичок (які, до того ж, в умовах «інформаційного буму» швидко застарівають), але й розвиток творчої активності особистості та їі здатності шукати і знаходити шляхи розв'язання проблем у мінливій економічній ситуації. Базовою цінністю суспільства, що трансформується, стає інноваційність - стан високої сприйнятливості людей до нових ідей, їхня готовність, бажання, здатність підтримувати й реалізовувати нововведення в усіх сферах своєї життєдіяльності. Цільовим орієнтиром діяльності сучасних $3 В 0$ у зв'язку з цим є формування в майбутніх фахівців (зокрема економістів), перш за все, інноваційного творчого мислення (Тувакова, 2013).

Актуальні дослідження і публікації. Теоретико-методологічні проблеми неперервної професійної освіти досліджували А. Алексюк, Р. Гуревич, М. Згуровський, В. Кремень, А. Лігоцький, Л. Лук'янова, В. Манько, Н. Ничкало, Л. Романишина, С. Сисоєва, Г. Терещук, В. Шахов та ін.

Мета дослідження - з'ясувати особливості професійної підготовки фахівців економічного профілю в умовах неперервної освіти.

Методи дослідження. Досягнення мети дослідження уможливило використання загальнотеоретичного методу наукового дослідження, зокрема аналізу термінологічного апарату психолого-педагогічних та соціально-філософських джерел наукового дискурсу.

Виклад основного матеріалу. Основою концепції розвитку неперервної освіти $€$ інноваційна педагогіка (розробка ефективних методів навчання впродовж життя і всеосяжного навчання, яке включає формальне, неформальне й позаформальне (спонтанне) навчання). Пріоритетним вектором освітніх процесів стає формування компетентності, розвиток знань і вмінь людей упродовж їх життя з тим, щоб вони могли 
досягати економічних і соціальних цілей за допомогою осмисленої поведінки.

Модель неперервної освіти $€$ багатокомпонентною, модульною і розгалуженою за трьома модулями (допрофесійне навчання, професійне навчання та навчання дорослих), що розкриваються основними ії складовими (родинно-сімейна, дошкільна, загальноосвітня, позашкільна, професійно-технічна, вища, післядипломна освіта); термінами життя людини (від народження до дорослого стану); різновидами освіти впродовж життя (формальна, неформальна, інформальна).

Поняття неперервності, покликане підсилити значущість поняття освіти, додати йому особливу доцільність, невипадковість, усвідомленість. Основний шлях одержання освіти - це навчання й самонавчання, тобто цілеспрямована діяльність, переосмислення навколишньої дійсності і свого місця в ній, самозбагачення, самопізнання, саморозвиток (Гулай, 2016).

Виділено основні напрями неперервної освіти:

- охоплення освітою всього життя людини;

- інтеграцію «вертикальну» (спадкоємність між окремими етапами та рівнями освіти) та «горизонтальну»;

- взаємозв'язок загальної та професійної освіти;

- відкритість, гнучкість системи освіти;

- різноманітність змісту, засобів і методик навчання та можливість вільного їх вибору;

- рівноправну оцінку й визнання освіти не по способах ії отримання, а по фактичному результату;

- наявність механізмів стимулювання мотивації особи до навчання як з боку матеріальних умов життя суспільства, так і через вплив культури та духовно-моральних цінностей.

Педагогічній концепції організації неперервності процесу навчання притаманна цілісність, сутність якої можна трактувати через такі поняття, як:

- спадкоємність (припускає поступовий перехід від одного освітнього ступеня до іншого, послідовність зміни вимог до обсягу знань, умінь і навичок на основі органічного зв'язку змісту, методів і форм навчальновиховного процесу);

- прогностичність (передбачає зорієнтованість освіти на перспективні запити і потреби як в матеріальній, так і в духовній сфері розвитку;

- сприяння професійному й особистому розвитку студентів не можливе без внесення своєчасних коректив у прогностичні моделі випускників, в ОКХ, навчальні плани та програми з урахуванням педагогічного прогнозування);

- гнучкість та динамічність (пов'язані 3 ії відкритістю, багатоступінчастістю, різноманітністю існування всіх типів закладів освіти та форм навчально-пізнавальної діяльності) (Калаур, 2015). 
Актуальним завданням професійної підготовки фахівців економічного профілю в умовах неперервної освіти $\epsilon$ формування соціальних якостей суб'єктів навчання, у т. ч. і здатності до конструктивної соціальної взаємодії як складової частини їх загальної професійної культури. Майбутні фахівці в галузі економіки мають бути здатними до реалізації проектної діяльності, кооперації та здорової конкуренції. Необхідний пошук таких форм організації навчальної діяльності майбутніх економістів у закладах вищої освіти, які забезпечували б їх практичними навичками соціальної взаємодії та сприяли розвиткові соціальних, моральних, особистісних якостей і професійної культури в цілому.

Під час підготовки майбутніх економістів важливо розвивати й соціальні компетентності, адже у процесі здійснення професійної діяльності людина вступає у взаємодію з іншими учасниками виробничого процесу і тому повинна вміти координувати свої дії з діями інших, уміти працювати в команді, організовувати спільну діяльність, конструктивно вирішувати конфліктні ситуації тощо. Сьогодні ці якості стають важливими складовими частинами професійної культури майбутніх економістів (Саркісова, 2018).

Досягнення мети, завдань формування професійної культури фахівців економічного профілю базується на загальних психологопедагогічних принципах дидактики і виховання, зокрема:

- науковості - побудова процесу формування професійної культури в магістрантів-економістів на об'єктивно-істинних знаннях, вивчення найбільш вагомих наукових досягнень у професійній галузі, здобуття наукових знань, які створюють передумови для самовизначення студентів згідно з їх здібностями, інтересами, потребами;

- природовідповідності - врахування в роботі психологопедагогічних, індивідуально-типологічних особливостей особистості, багатогранної цілісної природи людини;

- культуровідповідності - органічний зв'язок з історією народу, його мовою, культурою, культурними традиціями, звичаями, обрядами, народним мистецтвом, ремеслами і промислами, забезпеченні духовної єдності, наступності і спадковості поколінь;

- гуманізації - можливість поставити особистість магістранта в центр уваги закладу вищої освіти, забезпечити умови для його творчого розвитку та активності;

- демократизації - співпраця, співтворчість педагога і студента, віра в його творчі сили, повага до суверенітету особистості;

- інтегрованості - єдність педагогічних вимог закладу вищої освіти, сім'ї й суспільства;

- пріоритету проблемно-розвивальної і творчої діяльності забезпечення розвитку інтелектуальної, емоційно-вольової та духовної сфер особистості; 
- сенситивності - урахування найбільш сприятливих періодів розвитку особистості для сприймання певного навчального матеріалу;

- психологізації педагогічного процесу закладу вищої освіти оволодіння кожним викладачем технологією діагностики і психодіагностики професійної культури особистості студента, корекції навчально-виховного процесу (Кушнір, 2018).

Проблема підготовки фахівців в умовах неперервності тісно поєднана з механізмом особистісного розвитку студентів, який передбачає самоспостереження, самоаналіз, особистісну психокорекцію. Запорукою успішного розвитку майбутнього фахівця є усвідомлення ним необхідності глибинного самопізнання, корекції та пошуків шляхів самовдосконалення.

Сутність, структура й функції культури виступають теоретичним підґрунтям для її формування в процесі професійної підготовки майбутніх фахівців, адже культурний досвід людства $є$ системою знань, умінь, форм діяльності і відносин, способів спілкування, конкретних зразків поведінки (Фільштейн \& Журавльов, 2016).

3 метою вдосконалення освітнього процесу закладів вищої освіти економічного профілю необхідно реалізувати комплексний підхід до професійної підготовки майбутніх фахівців. Значну роль у даному напрямі відіграє активізація пізнавальної діяльності майбутніх економістів, важливе місце в якій посідають нові форми та методи навчання, зокрема використання ділових ігор.

Активність студента в навчально-виховному процесі $\epsilon$ одним із провідних принципів дидактики вищої школи. Реалізація цього принципу передбачає таку якість навчальної діяльності, під час якої досягається високий рівень мотивації, усвідомлення необхідності засвоєння знань, умінь та навичок. Практика роботи нинішніх закладів вищої освіти переконує, що особливо важливу роль у навчальній діяльності відіграє індивідуальна робота студентів, пов'язана з дослідницькою діяльністю. Визначення готовності студентів не тільки вивчати фахові економічні дисципліни, але й залучати їх до проведення економічних досліджень як інтегрального особистісного утворення, що включає стійке прагнення до творчого наукового пошуку у сфері економіки, наявність спеціальних економічних знань і вмінь, а також комплексу індивідуально-психологічних і характерологічних особливостей, які забезпечують високу ефективність професійного функціонування.

Особистісний підхід в освітянському просторі припускає гуманістично орієнтоване навчання, де головною ниткою проходить ідея прагнення особистості до реалізації власних можливостей, потреби в їх розвитку. При цьому провідними в процесі самореалізації особистості $€$ внутрішні мотиви. Дійсно, можна володіти необхідними здібностями, перетворювальними знаннями й уміннями, але ніколи ними не 
користуватися через відсутність бажання і потреби в цьому. Тому, саме мотиви, органічно пов'язані зі змістом або процесом діяльності, забезпечують ту невпинну увагу, цікавість до неї, які призводять до розвитку відповідних здібностей (Вітер, 2012).

Висновки дослідження і перспективи подальших розвідок у цьому напрямі. Становлення економічної культури фахівців в умовах неперервної освіти повинно опиратися на ідеологію та морально-етичні принципи, що призведе до економічного оздоровлення й оновлення підприємств, установ та суспільства загалом із метою вироблення відповідної культури господарювання.

Неперервна освіта фахівців економічного профілю $є$ складовою вищої освіти і спрямована на підвищення ефективності підприємницької діяльності. Для ії раціонального функціонування необхідне підвищення професійного й морального рівня суб'єктів підприємництва, щоб забезпечити ефективну та якісну організаційну й управлінську діяльність.

При цьому необхідно поєднувати високу професійну компетентність із умінням організувати справу, бути достатньо діловими, перспективно мислячими, енергійними, наполегливими й ініціативними в роботі, оскільки від підприємців очікують високої громадянської зрілості, глибоких фахових знань, здатності забезпечити предметність, конкретність і оперативність в організації та управлінні, тобто високого професіоналізму (Кицкай, 2007).

\section{ЛITEPATУPA}

Курлянд, 3. Н. (Ред.) (2012). Теорія і методика профресійної освіти. К.: Знання (Kurland, Z. N. (Ed.) (2012). Theory and methods of professional education. K.: Znannia).

Гулай, О. І. (2016). Теоретико-методичні основи професійної підготовки майбутніх фахівців будівельного профрілю в умовах неперервної освіти (дис. ... д-ра пед. наук: 13.00.04). Вінниця (Hulai, О. І. (2016). Theoretical and methodological foundations of professional training of future specialists in construction in terms of continuing education (DSc thesis). Vinnytsia).

Калаур, С. М. (2015). Педагогічна концепція організації неперервності освіти майбутніх фахівців соціальної сфери. Науковий вісник Ужгородського національного університету. Серія: Педагогіка. Сочіальна робота, 36, 71-74 (Kalaur, S. М. (2015). Pedagogical concept of continuing education of future professionals in the social sphere. Scientific Bulletin of Uzhhorod National University. Series: Pedagogy. Social work, 36, 71-74).

Саркісова, О. Ю. (2018). Групова взаємодія як чинник розвитку професійної культури майбутніх економістів. Науковий часопис НПУ імені М. П. Драгоманова, 62, 177180 (Sarkisova, O. Yu. (2018). Group interaction as a factor in the development of professional culture of future economists. Scientific journal of Drahomanov NPU, 62, 177-180).

Кушнір, Н. С. (2018). Теоретичний аспект формування професійної культури магістрантів економічного профілю. Вісник Чернігівського національного педагогічного 
університету ім. Т.Г. Шевченка, 150, 85-87 (Kushnir, N. S. (2018). Theoretical aspect of the formation of professional culture of masters of economic profile. Bulletin of Taras Shevchenko National Pedagogical University, 150, 85-87).

Фільштейн, Л. М., Журавльов, В. М. (2016). Професійна культура в аспекті підготовки фахівців. Наукові праці Кіровоградського національного технічного університету. Економічні науки, 29, 12-18 (Filstein, L. M., Zhuravlev, V. M. (2016). Professional culture in terms of training. Scientific works of Kirovograd National Technical University. Economic sciences, 29, 12-18).

Кицкай, Л. І. (2007). Економічна культура як складова економічної освіти. Режим доступу: http://novyn.kpi.ua/2007-3-2/09 Kickai.pdf (Kytskai, L. I. (2007). Economic culture as a component of economic education. Retrieved from: http://novyn.kpi.ua/2007-3-2/09 Kickai.pdf).

Вітер, С. (2012). Вимоги до майбутніх фахівців економічного профілю та якості їх професійної підготовки в умовах сьогодення. Молодь і ринок, 4, 149-153 (Viter, S. (2012). Requirements for future economic professionals and the quality of their training in today's conditions. Youth and market, 4, 149-153).

Тувакова, Н. В. (2013). Ключові аспекти фахової підготовки майбутніх економістів. Соціально-економічні проблеми сучасного періоду України, 1, 567-573 (Tuvakova, N. V. (2013). Key aspects of professional training of future economists. Socioeconomic problems of the modern period of Ukraine, 1, 567-573).

\section{PEЗЮME}

Кучай Татьяна, Кучай Александр. Профессиональная подготовка специалистов экономического профиля в условиях непрерывного образования.

В статье раскрывается профессиональная подготовка специалистов экономического профиля в условиях непрерывного образования. Выделены основные направления непрерывного образования. Будущие специалисты в области экономики должны быть способными к реализации проектной деятельности, кооперации и здоровой конкуренции. Необходим поиск таких форм организации учебной деятельности будущих экономистов в учреждениях высшего образования, которые обеспечивали бы их практическими навыками сочиального взаимодействия и способствовали развитию социальных, нравственных, личностных качеств и профрессиональной культуры в целом. Подчеркивается, что фрормирование профессиональной культуры специалистов экономического профиля базируется на общих психолого-педагогических принципах дидактики и воспитания.

Ключевые слова: профессиональная подготовка, спечиалисты экономического профиля, непрерывное образование, высшие учебные заведения.

\section{SUMMARY}

Kuchai Tetiana, Kuchai Olexander. Professional training of economic profile specialists in conditions of continuing education.

The article reveals professional training of economic specialists in the context of continuing education. The main directions of continuing education are highlighted. Future specialists in the field of economics must be able to implement project activities, cooperation and healthy competition. It is necessary to find such forms of organization of educational activities of future economists in higher education institutions, which would provide them with practical skills of social interaction and promote the development of social, moral, personal qualities and professional culture in general.

It is emphasized that formation of professional culture of economic professionals is based on the general psychological and pedagogical principles of didactics and education. 
Formation of economic culture of specialists in the context of continuing education should be based on ideology and moral and ethical principles, which will lead to economic recovery and renewal of enterprises, institutions and society as a whole in order to develop an appropriate culture of management.

Continuing education of economic specialists is a component of higher education and is aimed at improving the efficiency of entrepreneurial activity. For its rational functioning it is necessary to raise the professional and moral level of business entities to ensure effective and high-quality organizational and managerial activities.

It is necessary to combine high professional competence with the ability to organize business, be businesslike, forward-thinking, energetic, persistent and proactive in work, as entrepreneurs are expected to have high civic maturity, deep professional knowledge, ability to provide subjectivity, specificity and efficiency in organization and management, i.e. high professionalism.

Key words: professional training, economic specialists, continuing education, higher education institutions.

УДК 796:[378:37.011.3-051]

Єлизавета Кучерган

Криворізький державний педагогічний університет

ORCID ID 0000-0003-0284-4349

DOI 10.24139/2312-5993/2020.03-04/056-066

\section{ФІЗИЧНЕ САМОВИХОВАННЯ СТУДЕНТІВ ЯК СКЛАДОВА СИСТЕМИ ПРОФЕСІЙНОГО ЗДОРОВ'Я МАЙБУТНЬОГО ВЧИТЕЛЯ}

Стаття присвячена дослідженню самовиховання фізичної культури студентів як складової частини професійного здоров'я молодих учителів у системі, їх подальшої педагогічної діяльності. Збереження професійного здоров'я молодого вчителя, його адаптації до сучасних умов освітніх процесів, залежить від якісного й системного виконання комплексу фізкультурно-оздоровчих вправ, які входять у навчальні програми з фізичного виховання студентів у ВНЗ, що здатні підтримувати їхнє здоров'я в майбутньому.

Збереження здоров'я вчителя за допомогою фрізичного самовиховання в середній школі та в подальшій профресійній діяльності можливе лише у процесі взаємодії вчителя фрізичної культури з педагогічним колективом, де вчитель фрізичної культури виступає як наставник і тренер своїх колег.

Ключові слова: здоров'я, професійне здоров'я вчителя, профресійне здоров'я вчителя фрізичної культури, профресійне здоров'я вчителів інших навчальних предметів, система взаємодії вчителя фрізичної культури та вчителів інших навчальних предметів, індивідуальне фізичне самовиховання, педагогічний колектив, фізичне самовиховання педагогічного колективу, освітні процеси збереження здоров'я вчителя, освітнє середовище.

Постановка проблеми. Швидкий розвиток технологічного прогресу все більше актуалізує проблеми, що пов'язані з професійним вигоранням вчителя. Сучасний стан освітніх процесів, закладів вищої і середньої освіти можливо схарактеризувати як активне впровадження інноваційних педагогічних технологій, що вимагають від майбутніх учителів фізичної культури не тільки підвищення професійних знань, умінь і навичок своєї 
спеціальності в співпраці з дитячим колективом, а й потребують високого рівня забезпечення збереження власного професійного здоров'я, посилюючи вимоги до соціально-психологічного самопочуття та саморозвитку, їх самореалізації, як прикладу, у педагогічному колективі. Тому, на сьогодні, все більше стають актуальними проблеми взаємодії вчителя фізичної культури з учителями інших навчальних предметів, відносно збереження, їх професійного здоров'я в педагогічній діяльності.

Слід усвідомити, що вирішення цих проблем знаходиться в становленні спеціалістів фізичної культури в межах різноплановості програмного забезпечення навчальних дисциплін, засобами вдосконалення системи фізичного виховання студентів у вищій школі.

Термін «професійне здоров'я» найчастіше вживають у наукових дослідженнях на позначення трудового потенціалу особистості, тобто рівень високої працездатності й соціальної активності як національного багатства. Проблеми, пов'язані з професійним здоров'ям учителів $є$ мало дослідженими, їх вивчення потребує поглибленого та розширеного вивчення, що в сучасній науці тільки починається. Слід зазначити, що поява досліджень у цьому напрямі обумовлена багатьма причинами, які мають загальнопланетарний масштаб.

Саме з розвитком суспільства, як цивілізації, спостерігаються протиріччя між підвищенням рівня життя й погіршенням здоров'я, де головним чинником, що погіршує здоров'я вчителя, є впровадження різних ускладнених педагогічних технологій, які провокують психічні, інтелектуальні навантаження та призводять до збільшення виникнення різноманітних захворювань (Шиян, 1997).

Тому професіоналізм майбутніх педагогів повинен вбирати в себе особистісну базову сутність здоров'я, де ключовим лідером зі збереження здоров'я вчителя постає вчитель фізичної культури в школі, нинішній студент у 3ВО, що становить основу дослідження проблеми професійного здоров'я майбутнього вчителя.

Аналіз актуальних досліджень. Теорією наукових досліджень і практичних розробок фізичного самовиховання в системі здобуття вищої освіти вчителів фізичної культури та інших спеціальностей займалися О. Абдулліна, В. Беспалько, М. Боген, І. Бутенко, М. Згрязкіна, Н. Кухарєв, А. Полякова, М. Рибокова, Г. Степанова, Ю. Татур; визначення сутності й особливостей фізичного самовиховання, їх вплив на стан здоров'я в педагогічної діяльності досліджували А. Борисюк, Н. Волкова, В. Галузинський, М. Євтух, Л. Лазарчук, І. Майданюк, С. Максимюк, О. Степанов, М. Фіцула, В.Ягупов; корекцію та реабілітацію здоров'я педагога за допомогою фізкультурно-оздоровчих вправ вивчали М. Баранов, О.Бичук, Н.Грейда, А. Гуссманов, Т. Довгаль, А. Жалей, Г. Калашников, В. Кинль, О. Куц, О. Петрик, З. Скибенко, А. Шлемін. 
Педагогічна діяльність учителя, пов'язана безпосередньо 3 формуванням світоглядної системи вихованців за загальними педагогічними визначеннями, найбільш емоційно напружує особистість учителя, створюючи комплекс різних проблем, які роблять його працю надзвичайно психоемоційною, виснажливою, а тому енергетично затратною. 3 плином часу та збільшенням педагогічного стажу вчителя його фізичне та психічне здоров'я погіршується.

Виникнення негативних професійних змін обумовлені такими факторами, як:

1) професійні деструкції педагога;

2) професійна деформація педагога, де основою виступає авторитарність педагога, демонстративність, домінантність, педагогічна агресія, соціальне лицемірство, педагогічна індиферентність (байдужість), вичерпна безпорадність, неадекватна самооцінка, поведінковий трансфер (ідентифікація 3 агресором), педагогічний догматизм, рольовий експансіонізм (тотальне занурення в професію), дидактичність (намагання вчителя пояснити все самому), інформаційна пасивність, монологізм, формалізм, некомпетентність, що руйнують сенсорні системи, їх аналізатори, емоційну сферу педагога та викликають труднощі професійної діяльності, погіршуючи ії, а також виникає незадоволення результативністю своєї діяльності, власною працею, які могли бути набагато кращими та ефективнішими.

Для розширення знань із подолання негативних факторів професійних змін, ми рекомендуємо перелік тем, ознайомлення з якими сприятиме підтриманню стабілізації організму: педагогічна ортобіотика як механізм покращення професійного здоров'я вчителя; гармонізація особистості педагога та усунення професійних розладів; професійні деформації педагога; технології профілактики педагогічних криз, допомога й формування психологічного захисту від стресу; стресові ситуації, допомога та формування захисту; синдром професійного вигорання і його усунення.

Науковці виділяють групу професійного ризику пониження фізичного, психічного та духовного здоров'я вчителя, які за своєю професією багато спілкуються, тому не можуть мати від природи слабку нервову систему. Зміцненням та збереженням нервової системи від професійних деформацій може слугувати комплекс профілактичних дій за чотирма рівнями:

I) тілесний (заняття спортом);

II) емоційний (зняття м'язової напруги);

III) смисловий (раціоналізація дій);

IV) поведінковий (стереотип поведінки на роботі).

Таким чином, розглядаючи чотири рівні зміцнення та збереження нервової системи від професійних деформацій, як комплекс оздоровчих програм, який здатний захистити фізичними засобами психічне здоров'я вчителя (Проніков, 2014). Систематизуючи комплекс оздоровчих програм, 
рекомендуємо: тілесно орієнтовану терапію для зниження фізичної та психоемоційної напруги вчителів; правильне дихання при підвищенні показників частоти дихання внаслідок фізичного чи психоемоційного напруження вчителя; правильне функціонування серцево-судинної системи при підвищенні показників частоти пульсу внаслідок фізичного або психоемоційного напруження вчителя; соціальне здоров'я вчителя, його взаємозв'язок із соціальним статусом і оточуючим середовищем; систему практичних прийомів збереження професійного здоров'я.

Метою даної статті $€$ вивчення практичних дій, що впливають на фізичне самовиховання, життєву та професійну діяльність студентів/майбутніх учителів природничого факультету Криворізького державного педагогічного університету, який включає в себе такі спеціальності, як: «Фізична культура», «Біологія та практична психологія», «Біологія та хімія», «Хімія та інформатика» за допомогою проведення вільного інтерв'ювання.

Методом дослідження $€$ проведення вільного інтерв'ювання студентів, метою якого було виявлення покращення рівня різних типів здоров'я, на основі методики Людмили Сущенко:

соматичне здоров'я, яке складає рівень розвитку людського організму;

фізичне здоров'я - рівень розвитку працездатності та фізичної активності;

психічне здоров'я, що характеризує душевний комфорт, який забезпечує відповідну поведінку;

соціальне здоров'я, яке відображає нормальні взаємостосунки між людьми в суспільстві;

моральне здоров'я пов'язується істинами любові, добра, краси відповідно до здорового способу життя та досягнення більшої гармонії з собою та навколишнім середовищем на основі фізичного виховання та самовиховання (Сущенко, 2003).

Виклад основного матеріалу. В інтерв'юванні взяли участь 59 студентів природничого факультету першого року навчання в закладі вищої освіти, що вже мали семестр занять із фізичного виховання в університеті, які склали загалом - 100 \%. Студенти, які брали участь в опитуванні, розподілилися за двома напрямами, які обумовлювалися особистим ставленням до фізичного виховання та самовиховання, яке виражалося в кількості занять протягом тижня:

за першим напрямом позитивного ставлення (більше 10 годин занять на тиждень) визначилися - 25 студентів за спеціальністю ФК («Фізична культура»), що становить - 42,5 \%, які мають безпосередній зв'язок із фізичним навчанням і вихованням; 
другий напрям опосередкованого відношення до фрізичних навантажень (менше 10 годин занять на тиждень) склали - 34 студенти зі спеціальностей: БП («Біологія та практична психологія), що становить 13 чоловік; БХ («Біологія та хімія») - 8 студентів; ХІ («Хімія та інформатика») - 13 студентів, що становить 57,8 \%.

Для уточнення та більшої деталізації проведеного дослідження було поставлене таке запитання - «Яку кількість часу Ви приділяєте фізичній культурі та самовихованню протягом дня?» та п'ять додаткових питань:

1) Визначтесь за десятибальною шкалою, на скільки Ваші психологічні та духовні стани впливають на результат особистої діяльності.

2) Оцініть за десятибальною шкалою значимість фізичної культури як комплексу оздоровлення у своєму житті.

3) Зорієнтуйтесь за десятибальною шкалою, наскільки Ви стійкі до стресу в життєвих ситуаціях і чи часто стресові ситуації закінчуються депресивним станом.

4) Як часто, за десятибальною шкалою, Ви вступаєте в міжособистісні конфлікти та наскільки швидко Вас можна вивести з рівноваги.

5) Яке значення, за десятибальною шкалою, займає ЗСЖ у вашому житті.

За результатами опитування, з основного питання «Яку кількість часу Ви приділяєте фізичній культурі та самовихованню протягом дня?», студенти розділилися на дві групи: сильна група $A$ включала в себе студентів, які усвідомлюють важливість фізичної культури та займаються нею більшу частину свого вільного часу (50\% - $70 \%)$; і слабка група Б, куди ввійшли студенти, які до фізичної культури та самовиховання ставляться байдуже i фізичною культурою займаються час від часу за бажанням (10 \% - 50 \%).

Сильну групу А склали студенти, які навчаються в своїй більшості на спеціальності ФК «Фізична культура» - таких налічувалося 25 осіб, (42,5%), а також на інших спеціальностях БП («Біологія та практична психологія) 1 особа, БХ («Біологія та хімія») - 2 студенти, XI («Хімія та інформатика») 0 студентів, які в загальній кількості склали 3 особи (5,1\%) Тому разом сильну групу А склали 28 студентів (47,6 \%).

Слабку групу Б склали інші студенти на цих самий спеціальностях: ФК «Фізична культура» - таких студентів налічувалось 0 осіб $(0,0 \%)$, а також інші спеціальності БП («Біологія та практична психологія) - 12 осіб, БХ («Біологія та хімія») - 6 студентів, ХІ («Хімія та інформатика») 13 студентів, які в загальній кількості склали слабку групу Б, до якої ввійшов 31 студент (52,7 \%).

3 вище викладеного матеріалу ми бачимо, що студенти природничого факультету першого року навчання в закладі вищої освіти, які вже мали семестр занять із фізичного виховання в університеті за своїм ставленням до значимості фізичної культури розподілилися майже порівну. 
Подальше опитування, за п'ятьма наступними питаннями, дозволило виявити, що збереження й покращення здоров'я за допомогою занять із фізичного самовиховання в сильній групі А склали $(100 \%$ студентів) за різними параметрами:

- $90 \%$ - студентів за даний період почали піддаватися менше психологічно-емоційним впливам;

- 63,6 \% студентів значно краще почали почувати себе в конфліктній ситуації, рідше піддаючись провокаціям;

- 47,6 \% студентів ведуть здоровий спосіб життя та стримують себе від шкідливих звичок і мають раціональну поведінку, яка дозволяє їм берегти своє здоров'я в усіх аспектах.

У слабкій групі Б покращили своє здоров'я за допомогою занять 3 фізичного самовиховання тільки 30,4 \% за відповідними параметрами:

- всього 10 \% студентів відчули покращення за емоційною стійкістю;

- 20,4 \% склали ті студенти, які покращили свій душевний стан, але відчували себе емоційно напружено та час від часу вступали в дрібні конфлікти з іншими людьми;

- 62,7\% становлять більшість студентів, які не розглядають своє здоров'я як стратегічній потенціал, який забезпечує їм успіх у професійній діяльності вчителя, загалом не вирішують свої проблеми на внутрішньому енергетичному потенціалі за допомогою фізичних вправ, а вирішують за допомогою шкідливих звичок; тобто під час стресових ситуацій намагаються вживати тютюн і алкоголь, полегшуючи вплив емоційних переживань, на їх думку;

-86,4\% студентів слабкої групи мали слабке теоретичне забезпечення програмами фізичного самовиховання, які носять вузько спеціалізований і обмежений характер, а також непостійні в практичній реалізації. Молоді люди не мають реально комплексної програми, яка б коригувала їхнє здоров'я в студентські роки, а також у майбутньому забезпечила професійне довголіття в професійній діяльності.

Підводячи підсумок, можемо стверджувати, що студенти в сильній групі $A$, які професійно займаються фізичною культурою та присвятили себе різним видам професійного спорту, менше підлягають емоційним розладам та більш стійкі до стресових ситуацій і більш спокійні у стосунках 3 іншими людьми. Вони відповідають більш високому показнику інтегрованого здоров'я.

Студенти, що несистематично або зовсім мало займаються фізичною культурою, які потрапили до слабкої групи 5 , більше схильні до емоційних зривів і частіше беруть участь у конфліктах міжособистісних взаємовідносин та піддаються стресам. 
Тому констатуємо факт, що фізичне виховання позитивно впливає на фізичну культуру, яка забезпечує подальше збереження й покращення всіх підструктур фізичного, духовного, психологічного і соціального здоров'я.

Висновки. На основі викладеного вище можливо зробити висновки, що студенти/майбутні вчителі у своїй професійній діяльності повинні вміти досконало й правильно слідкувати за своїм фізичним, психологічним, духовним та соціальним станом здоров'я, як рятувальник піклується, доглядає за своїм фізичним станом, фізичною підготовкою та нервовою системою (чіткою реакцією); як лікар (хірург) за своїми руками, психоемоційним станом і витривалістю як фізичного, так і психологічного походження. Так і вчитель повинен використовувати такі безпечні технології навчання, які допомагатимуть йому зберігати своє здоров'я, де основним підґрунтям повинна бути фізична культура. У зв'язку з цим пропонується низка корекційно-розвивальних програм 3 фізичного самовиховання, які мають функціонально покращити всі підструктури здоров'я, що необхідні студенту, як майбутньому вчителю.

За спеціальністю вчитель фізичної культури повинен уміти слідкувати за здоров'ям колег та організовувати заходи здоров'язберігаючого напрямку 3 педагогічним колективом школи, навчати вчителів інших навчальних предметів складати комплексні програми індивідуального фізичного виховання, за якими вони могли би дбати про своє здоров'я та володіти механізмом впливу на свій організм і коригувати стани своєї нервової системи.

Отже, майбутній учитель фізичного виховання повинен індивідуально вміти скласти свою програму оздоровлення на основі знань про впливи різних чинників на його організм, керуючись своїм фізичним станом у даний момент. Така комплексна програма повинна допомогти йому та вчителям інших предметів тримати відповідний рівень нормальної, професійної діяльності в житті.

Перспективи подальших наукових розвідок. Науково-дослідницька робота студентів зі програм оздоровлення, як майбутніх учителів фізичної культури, може здійснюватися за такими напрямами подальшого місця роботи та реалізації себе, як спеціаліста, а саме:

1) майбутній учитель фізичної культури, інструктор у закладах дошкільної та загальної середньої освіти може в своїй дослідницькій діяльності орієнтуватися на індивідуальні оздоровчі програми фізичного самовиховання як для вчителів дошкільних закладів, так і вчителів закладів загальної середньої ланки;

2) майбутній тренер-викладач із різних видів спорту в дитячих спортивних школах може розпочати досліджувати індивідуальні оздоровчі програми фізичного самовиховання для груп учителів закладів загальної середньої освіти; 
3) майбутній керівник малого підприємства в сфері охорони здоров'я може дослідити програми організації навчання корекції індивідуального здоров'я за допомогою фізичного самовиховання;

4) майбутні працівники, що керуватимуть розвитком фізичної культури, спорту та спортивного туризму можуть проводити наукові дослідження в забезпеченні організації здоров'я за допомогою спортивного туризму;

5) майбутні інструктори спортивних клубів (фітнес-центрів, центрів туризму, краєзнавства та екскурсій) можуть досліджувати методичне забезпечення збереження здоров'я, інструкцій і оздоровчих програм фізичного самовиховання вчителів із урахуванням специфіки їх роботи;

6) майбутні працівники спортивно-оздоровчих таборів можуть розпочати досліджувати оздоровлення дітей за допомогою фізичного виховання й особливу увагу приділити психологічному здоров'ю дитини 3 родини педагогічних працівників.

Рекомендуємо вчителям фізичного виховання в професійній діяльності з підтримки та збереження професійного здоров'я вчителів інших предметів використовувати методичні рекомендації з курсу «Педагогічна ортобіотика» (Кучерган, 2016).

у методичних рекомендаціях курсу «Педагогічна ортобіотика» розкрита програма самостійної роботи для студентів/майбутніх учителів, яка включає в себе дві частини:

Перша частина програми має назву «Психосоматика», що в перекладі 3 латинського означає «тіло» та "душа», вона вивчає взаємовпливи душі - тіла, що дозволить студенту/майбутньому вчителю «пізнати свій організм» і «індивідуальні особливості свого організму» та в подальшій своїй професійній діяльності зберегти своє здоров'я й уникнути професійних деструкцій і деформацій.

Програма з психосоматики розпочинається 3 діагностики, яка дозволить визначити:

а) як будова тіла взаємопов'язана з особливостями характеру;

б) як по групі крові можна визначити темперамент;

в) як визначити поведінку особистості в конфліктній ситуації залежно від статури та характеру;

г) кінцевим, найголовнішим результатом діагностики $є$ визначення захворювання органів і систем організму під час стресових, конфліктних ситуацій за допомогою типу статури, темпераменту та характеру, що дає змогу студентові/майбутньому вчителю передбачити свої дії щодо збереження енергетичних запасів свого організму.

Друга частина програми має назву «Ортобіоз», вона допоможе підтримати життєві сили організму студента/майбутнього вчителя, його емоційну стабільність. Дізнатися про «основні, індивідуальні потреби свого організму», а також надасть можливість гармонійному функціонуванню свого тіла. 
Програма з ортобіозу за своєю структурою має шість тем, які включають у себе питання:

а) складання свого добового режиму дня з урахуванням добової потреби організму у воді;

б) розподіл добового раціону їжі по набору продуктів за калорійністю та їх хімічним складом;

в) кількість прийомів їжі протягом дня та інтервали між їжею;

г) тривалість прийому їжі, а також збалансування води та їжі за калорійністю з урахуванням характеру роботи за професією;

д) проаналізувати вживання різноманітних продуктів за рік, визначити ідеальний раціон свого харчування, необхідні елементи, що дозволять забезпечити нормальне функціонування залоз внутрішньої секреції;

е) визначити свій домінувальний тип сприйняття, щоб більш детально ознайомитися з його характеристикою;

є) використовуючи практичні поради, визначити свій рівень рухової активності, скласти свою мінімальну та планову систему навантаження;

ж) визначити свій хронотип, скласти індивідуальний режим добового ритму;

з) розібрати практичні дії тренінгу, який розслабляє та допомагає абстрагуватися від обставин, які напружують, і пережити їх на внутрішньому енергетичному резерві, не долучаючись до шкідливих звичок.

Даний курс методичних рекомендацій «Педагогічна ортобіотика» дозволяє студентам спеціальності «Фізична культура» допомогти студентам інших спеціальностей організувати програму із самозбереження, їх здоров'я під час розумної раціоналізації своєї професійної діяльності, а також застосовувати всі набуті знання, уміння та навички не тільки в цілях збереження власного здоров'я, а й у передачі цих знань, умінь та навичок майбутньому поколінню, застерегти своїх вихованців і колег-викладачів інших дисциплін берегти своє здоров'я за допомогою власного прикладу. Маємо надію, що це дозволить особистості вижити та пристосуватися до навколишнього світу в його негативних проявах.

\section{ЛІТЕРАТУРА}

Кучерган, Є. В. (2016). Педагогічна ортобіотика. Кривий Ріг (Kuchergan, Ye. V. (2016). Pedagogical orthobiotics. Kryvyi Rih).

Проніков, О. К. (2012). Методична підготовка майбутніх учителів фізичної культури у вищих педагогічних навчальних закладах України у 1992-2010 рр. Вісник Чернігівського національного педагогічного університету імені Т. Г. Шевченка, 100, 333-335 (Pronikov, O. K. (2012). Methodological training of future teachers of physical culture in higher pedagogical education institutions of Ukraine in 1992-2010. Bulletin of Taras Shevchenko National Pedagogical University, 100, 333-335).

Проніков, О. К. (2014). Теоретичні та методичні основи підготовки майбутніх учителів фрізичної культури у вищих педагогічних навчальних закладах України (друга половина XX- початок XXI століття) (автореф. дис. ... д-ра пед. наук: 13.00.01). Тернопіль (Pronikov, O. К. (2014). Theoretical and methodological bases 
of training future teachers of physical culture in higher pedagogical education institutions of Ukraine (second half of the XX - beginning of the XXI century) (DSC thesis abstract). Ternopil).

Сущенко, Л. П. (2003). Теоретико-методологічні засади професійної підготовки майбутніх фрахівців фрізичного виховання та спорту у вищих навчальних закладах (автореф. дис. ... д-ра пед. наук: 13.00.04). Київ (Sushchenko, L. P. (2003). Theoretical and methodological principles of professional training of future specialists in physical education and sports in higher education institutions (DSc thesis abstract). Kyiv).

Шиян, Б. М. (1996). Методика фрізичного виховання школярів. Львів (Shyian, В. М. (1996). Methods of physical education of schoolchildren. Lviv).

Шиян, Б.М. (1997). Теоретико-методичні основи підготовки вчителів фрізичного виховання в педагогічних закладах (автореф. дис. ... д-ра пед. наук: 13.00.04). Київ (Shyian, B. M. (1997). Theoretical and methodological bases of training of teachers of physical education in pedagogical establishments (DSc thesis abstract). Kyiv).

\section{PEЗЮME}

Кучерган Елизавета. Физическое самовоспитание студентов как составляющей системы профессионального здоровья будущего учителя.

Статья посвящена исследованию самовоспитания фризической культуры студентов как составной части профессионального здоровья молодых учителей в системе, а так же их дальнейшей педагогической деятельности. Сохранение профессионального здоровья молодого учителя, его адаптации к современным условиям образовательных процессов, зависит от качественного и системного выполнения комплекса фризкультурно-оздоровительных упражнений, которые входят в учебные программы по физическому воспитанию студентов в вузах и которые способны поддерживать их здоровье в будущем.

Поскольку сохранение здоровья учителя $c$ помощью фризического самовоспитания в средней школе и в дальнейшей своей профессиональной деятельности возможно только при взаимодействии учителя физической культуры с педагогическим коллективом, где учитель физической культуры выступает как наставник и тренер своих коллег.

Ключевые слова: здоровье, профессиональное здоровье учителя, профрессиональное здоровье учителя физической культуры, профрессиональное здоровье учителей других учебных предметов, система взаимодействия учителя физической культуры и учителей других учебных предметов, индивидуальное физическое самовоспитание, педагогический коллектив, физическое самовоспитание педагогического коллектива, образовательные процессы сохранения здоровья учителя, образовательная среда.

\section{SUMMARY}

Kuchergan Yelyzaveta. Physical self-education of students as a component of the system of professional health of the future teacher.

Maintaining the professional health of a teacher depends on the quality and systematic implementation of a set of physical training and health exercises that are part of the curriculum of physical education of students and can protect their health. The article is devoted to the study of everyday effects of physical education classes on the health of students as future teachers of physical education and other specialties, as well as the study of practical actions affecting physical well-being in life and professional activity of students as future teachers of Kryvyi Rih State Pedagogical University, which includes such specialties as: "Physical Culture", "Biology and Practical Psychology", "Biology and Chemistry", "Chemistry and Computer Study" through free interviews. 
The highlighted structure of different types of occupational health of teachers on the basis of structural teaching: physical health, mental health, social health and moral health, allowed to prove in more detail and thoroughly the positive impact of physical education classes on all components of the student's health as a future teacher, which improves his/her stress resistance in his/her future teaching.

The essence of improving the further professional activity of a physical education teacher at school is revealed, where maintaining health through physical self-education is possible only with the interaction of a physical education teacher with the teaching staff, where he/she acts as a mentor to his/her colleagues. Prospects for health care software, both in the teaching staff and in the school, have also been determined.

The article identifies the perspectives of scientific research of students in maintaining and improving health with a focus on relevant specialties: 1) future physical education teacher, instructor in preschool and secondary schools; 2) future coach-teacher of various sports in children's sports schools; 3) future head of a small enterprise in the field of health care; 4) future employees who will manage the development of physical culture, sports and sports tourism; 5) future instructors of sports clubs (fitness centers, centers of tourism, local lore and excursions); 6) future employees of sports and health camps, etc.

Key words: health, professional health of a teacher, professional health of a physical education teacher, professional health of teachers of other subjects, system of interaction of a physical education teacher and teachers of other subjects, individual physical selfeducation, pedagogical team, physical self-education of teaching staff, educational processes of preserving the health of teachers, educational environment.

\title{
УДК 378.141+81.28+811.114
}

\author{
Юліана Лавриш \\ Національний технічний університет України \\ «Київський політехнічний інститут ім. Ігоря Сікорського» \\ ORCID ID 0000-0001-7713-120X
} DOI 10.24139/2312-5993/2020.03-04/066-076

\section{ІНДИВІДУАЛІЗАЦІЯ НАВЧАННЯ ІНОЗЕМНИХ МОВ: ДИДАКТИЧНА МОДЕЛЬ ТА ЕКСПЕРИМЕНТАЛЬНЕ ВПРОВАДЖЕННЯ}

У статmі розглядається питання індивідуалізації навчання іноземних мов студентів інженерних спеціальностей. Запропоновано авторську дидактичну модель для забезпечення дидактичних умов ефрективної імплементації зазначеного освітнього процесу. Виокремлені компоненти моделі: ціннісно-цільовий, мотиваційнодіагностичний, змістово-технологічний, організаційно-процесуальний та результативно-рефрлексійний. Описано дидактичні принципи, на яких грунтується модель. Зазначено зміст та завдання кожного з компонентів. Доведено, що дидактична модель індивідуалізації навчання іноземних мов студентів інженерних спеціальностей має ознаки дуальної, динамічної та технологічно-адаптованої системи.

Ключові слова: індивідуалізація, дидактична модель, дидактичні принципи, іноземні мови, автономне навчання, цифрові освітні технології, саморозвиток, самоосвіта.

Постановка проблеми. У сучасних умовах розвитку освіти ключовими чинниками $€$ взаємовплив i взаємопроникнення культур, економік, соціальних трансформацій, які сприяють актуалізації проблем якості освіти. А 
саме: глобалізація освіти означає поступову трансформацію різних освітніх систем у єдину загальноєвропейську, а потім світову, при збереженні відмінностей, зумовлених традицією, культурою та ментальними особливостями сприйняття процесів саморозвитку. Динамізм сучасного світу окреслює потреби особистості в отриманні релевантних знань та навичок для швидкого реагування на суспільні та економічні зміни. У результаті з'являються нові освітні напрями, які відображають відношення особистості до навчального процесу з точки зору неперервності та індивідуалізації. Індивідуалізація передбачає формування дидактичних умов для вибудови освітніх індивідуальних траєкторій у процесі реалізації особистісної важливої діяльності суб'єкта навчального процесу з акцентом на його власний вибір освітніх ресурсів, засобів та форм навчання. Світова практика вищої освіти показує, що чим більш престижним $є$ університет, тим більшою мірою реалізується принцип індивідуалізації освіти.

Крім того, саме індивідуалізація освіти дозволяє викладачам університетів підготувати студентів до самостійного вирішення складних професійних проблем. Майбутні фахівці навчаються розпізнавати й чітко формулювати професійні проблеми, вибудовують методологію наукового і практичного пошуку, відповідно до якої самостійно вирішують складні завдання. Така робота може бути строго індивідуалізованою, і саме їі якість свідчить про рівень професійної готовності випускника університету для того, щоб стати конкурентоспроможним фахівцем на міжнародному ринку праці. Саме тому виникає питання оптимізації викладання іноземних мов, а процес індивідуалізації вкрай важливий для успішного опанування іноземною комунікативною компетентністю.

Аналіз актуальних досліджень. Результати сучасних досліджень у галузі когнітивної психології сприяють пошуку нових можливостей та підходів до навчання і трансформують базові положення педагогіки та дидактики. Сьогодні пріоритетним напрямом $є$ індивідуалізація навчання, що перетворюється з дидактичного принципу в цілісну систему, яка визначає цілі та завдання кожного аспекту начального процесу.

У зарубіжних педагогічних дослідженнях із проблем індивідуалізації навчання виокремлюють три споріднені терміни - персоналізація, диференціація та індивідуалізація. Згідно з визначенням, запропонованим експертами державного департаменту освіти США (Bray \& McClaskey, 2016), індивідуалізація - це гнучкий тип навчання, який можна адаптувати до індивідуальних освітніх потреб учнів. При цьому цілі навчання залишаються однакові для всіх, але студенти можуть вивчати матеріал із різною швидкістю відповідно до своїх потреб та можливостей. Диференціація - це тип навчання, орієнтованого на індивідуальні стилі навчання. Цілі навчання також однакові для всіх студентів, але методи чи підходи до викладання та навчання змінюються залежно від психологічних 
особливостей кожного студента. Персоналізація - це тип навчання, орієнтований на індивідуальні потреби в навчанні, з урахуванням інтересів різних учнів. У повністю персоналізованому начальному середовищі цілі, зміст навчання, а також методи змінюються відповідно до потреб студента.

у дослідженнях Л. Дікенсона (Dickenson, 1987) пропонується кілька споріднених термінів, які відображають ступені автономії студента в навчальній діяльності. Зокрема, «незалежне навчання» («independent learning») означає навчання з використанням матеріалів, запропонованих і систематизованих викладачем; «самоспрямоване навчання" ( "self-directed learning») передбачає прийняття студентом рішення щодо організації власного навчання; «самокероване навчання» («self-instruction»), яке відображає концепцію повної автономії, тобто навчання без викладача.

Серед дидактичних умов для створення навчального середовища для забезпечення індивідуалізації навчання зарубіжні дослідники (Esch, 1996; Dam, 2011; Kristmanson et al., 2013) передбачають гнучкість, адаптивність, вибірковість начальних матеріалів та ресурсів, наявність власного досвіду навчання та модель співробітництва з викладачем, особливо на початкових етапах навчання. Так, В. Почуєва (2017) у досліджені окреслює залежність рівня автономії від моделі співпраці 3 викладачем та виокремлює три типи зазначених моделей: залежна, перехідна (напівавтономна) і автономна.

Для розуміння сутності автономного навчання необхідно розмежовувати поняття «самостійної роботи» та «навчальної автономії». Це питання розглядається в дослідженнях О. Тарнопольского (2001), який зазначає, що для успішного виконання самостійної роботи студентам достатньо обрати методи та технології, у той час як для навчальної автономії важливо спочатку провести самодіагностику власних освітніх потреб та конструювання індивідуального освітнього середовища. Іншими словами, студент має свободу вибору партнерів навчальної діяльності, навчальні ресурси, форму організації та моніторингу результатів процесу.

Корелюють із ідеїями О. Тарнопольського погляди Т. Караєвої (2009) на різницю понять «самостійна робота» та «навчальна автономія». Так, дослідниця вважає, що під час самостійної роботи студент виконує завдання на основі зовнішнього керівництва з боку викладача, тоді як автономія потребує активізації власних освітніх можливостей та метакогнітивних умінь: самостійно визначити цілі, проводити вчасну самокорекцію, самоаналіз та саморефлексію. Дослідниця проблеми автономного навчання І. Задорожна (2015) пропонує розглядати автономію через взаємозв'язок двох аспектів: як форму організації навчального процесу (у якому студент керує лише навчальною діяльністю відповідно до визначених викладачем завдань та етапів), і як здатність студента до повного керування процесом від постановки мети та 
самодіагностики потреб до відповідальності за виконання й результат власної навчальної діяльності.

Саме тому виникає необхідність адаптації та пристосування навчального процесу до навчального стилю студента, який визначає характер взаємодії суб'єктів начального процесу. Забезпечення кореляції начального стилю та педагогічної дії можливе лише за умов упровадження системи індивідуалізації навчання.

3 метою досягнення ефективних рішень поставлених завдань, нами було вирішено розробити модель забезпечення дидактичних умов індивідуалізації навчання іноземних мов через інтеграцію освітніх цифрових технологій в освітній процес. Мета статті - репрезентувати зазначену модель та шляхи їі імплементації. Розробка авторської моделі була здійснена на основі авторської концепції індивідуалізації навчання іноземних мов студентів інженерних спеціальностей.

У процесі підготовки матеріалу до публікації використовувалися методи теоретичного критичного аналізу наукової та методичної літератури; спостереження за навчальним процесом та експеримент, у результаті якого було апробовано розроблену дидактичну модель.

Виклад основного матеріалу. Метою створення моделі є створення дидактичних мов ефективного функціонування змішаного навчального середовища (поєднання безпосередньої та цифрової взаємодії), що забезпечує: підвищення ефективності та якості індивідуального й автономного навчання студентів інженерних спеціальностей під час вивчення іноземної мови.

Концептуальність моделі полягає в тому, що в ході індивідуального навчання студенти самі створюють власне начальне середовище, яке сприяє досягненню освітньої мети з урахуванням особистісних здібностей та можливостей кожного учасника за допомогою цифрових освітніх технологій.

Уважаємо розвиток навичок автономного навчання та цифрової компетентності критично необхідним умінням для успішної самореалізації особистості в сучасних реаліях технократичного суспільства. Саме ці вміння входять до переліку навичок та вмінь XXI століття, концепції, яка визначає стратегічні вміння, необхідні для того, щоб відповідати вимогам часу та суспільства. Засадничим є питання про визначення дидактичних умов та стратегій для навчання студентів проектувати автономне навчальне середовище для вивчення іноземних мов відповідно до індивідуального інтелектуального профілю кожного студента.

Формування вмінь індивідуального навчання студентів інженерних спеціальностей до вивчення іноземних мов з використанням технологічних інновацій ми розглядаємо з таких позицій, як:

- цілісної організації процесу проектування дидактичних умов індивідуалізації навчання іноземних мов студентів інженерних спеціаль- 
ностей, використовуючи систему таких компонентів: ціннісно-цільового, мотиваційно-діагностичного, змістово-технологічного, організаційнопроцесуального, результативно-рефлексійного, що утворюють дидактичну систему, у якій основними механізмами формування індивідуального автономного навчання є самопізнання, саморозвиток та саморефлексія;

- розвитку вмінь аналітично-критичного аналізу інформаційних повідомлень студентами під час відбору цифрових освітніх ресурсів;

- надання студентам можливості реалізувати власний потенціал самоосвітньої діяльності під час планування власного освітнього шляху та конструювання власного начального середовища для досягнення освітньої мети;

- удосконалення іншомовної професійної компетентності під час моделювання автентичного лінгво-культурологічного середовища засобами цифрових технологій;

- стимулювання процесів самовизначення та усвідомленого ставлення до власної діяльності, що $€$ необхідним для самореалізації в особистому та професійному житті.

Зазначена модель $\epsilon$ дуальною за змістовим наповненням і передбачає розв'язання двох ключових питань: навчання вмінь індивідуальної роботи та вивчення іноземної мови. 3 метою забезпечення дуальності кожного компоненту моделі, що відображається в поєднанні зовнішніх та внутрішніх умов індивідуалізації навчання, нами були обрані такі дидактичні принципи: домінування індивідуальної роботи студентів, відкритого навчального середовища, трансформативності, неперервності освітнього процесу, сталого розвитку, гнучкості й адаптивності навчального матеріалу, інтерактивності, мультимедійності.

До системоутворювальних складових розробленої моделі відносимо ціннісно-цільовий, мотиваційно-діагностичний, змістово-технологічний, організаційно-процесуальний та результативно-рефлексійний компоненти. Доцільним вважаємо надати пояснення щодо зазначених функціональних компонентів, оскільки їхній взаємозв'язок і взаємовплив забезпечує сталість та ефективність системи.

Ціннісно-цільовий компонент визначає цінності та спрямованість системи індивідуалізації навчання іноземних мов засобами цифрових технологій і забезпечує високий рівень сформованості зазначених навичок. Ціннісно-цільовий компонент знаходить відображення в меті як результаті цілеспрямованих дій викладача, що конкретизуються через відповідні завдання: навчити індивідуально отримувати знання та підвищувати власний освітній рівень. Важливим фактором для ефективного вирішення завдань $€$ врахування попереднього навчального досвіду студентів та їхніх освітніх пріоритетів. Адже неможливо вибудувати власну освітню 
траєкторію й визначити цілі без досвіду освітньої діяльності. За допомогою зазначеного компонента реалізуються такі освітні потреби та можливості:

- безперервне самокероване навчання;

- самопізнання та самовизначення;

- мета когнітивні вміння;

- незалежність від формального навчання;

- розвиток стратегічного мислення.

Наступною складовою є мотиваційно-діагностична, яку ми вважаємо визначальною. Адже без внутрішньої мотивації не відбудеться процес навчання, навіть при визначених цілях. Діагностика потреб та мотивуючих факторів $€$ рушійним чинником для ініціювання навчання. Особистісні або професійні перспективи та стимули відіграють важливу роль під час ініціації самостійного навчання та визначають рівень сформованості готовності до автономного навчання. На цьому етапі доцільно залучати цифрові технології, адже такі властивості, як автентичність контексту, інтерактивність та мультимедійність цифрових технологій позитивно впливають на активізацію навчання. Р. Брокет та Р.Хіемстра (1994) розглядають автономне навчання як дуальний процес, що складається 3 двох аспектів: навчальний процес, у якому студенти вдосконалюють певні навички та особистісний аспект, у якому студенти через самомотивацію усвідомлюють відповідальність за процес навчання.

Відомо, що внутрішній когнітивний дисонанс стимулює появу внутрішніх мотивів. Залучення самоаналізу незмінно передбачає використання попередніх знань. Суперечність між набутими знаннями й потребою отримати нові мотивує студентів до розширення меж попереднього досвіду та стимулює застосовувати такі когнітивні стратегії:

- співвідносити нові ідеї та концепції з попередніми знаннями й досвідом;

- інтегрувати свої знання у взаємопов'язані концептуальні системи;

- оцінювати нові ідеї та пов'язувати їх із висновками;

- розуміти процес діалогу, за допомогою якого створюються знання, і критично досліджувати логіку аргументу;

- розмірковувати над власним пізнанням та процесом навчання.

Окрім когнітивних суперечностей на мотивацію впливає і дозвіл на свободу дій і вибору під час навчання. Студенти звикають, що навчанням керує лише викладач. Саме викладачі вирішують наповнення контенту навчання та ресурси, які інколи не задовольняють потреби студентів. Довіра викладачів до свідомого вибору студентів теж слугує позитивним чинником підвищення внутрішньої мотивації. А. Марку та Г. Філіппо (2005) пов'язують мотивацію навчання студентів із трьома факторами: самоефективністю, значимістю завдання та свідомим цілепокладанням. Самоефективність - це оцінка здатності та компетентності в досягненні 
успіху в завданні. Значення завдання визначається як сприйняття студентами навчальних матеріалів, що відповідають професійним інтересам та потребам, відображеним у цілях навчання. Рівень сформованості зазначених умінь та наявність мотивів-стимулів визначає готовність до індивідуалізації навчання.

Мотиваційно-діагностична складова також пов'язана з наявністю ресурсів і врахуванням рівня матеріально-технічної бази та рівня доступу до телекомунікаційних мереж студентів для реалізації автономного навчання засобами цифрових технологій, адже урізноманітнити подачу інформації (візуальна, аудіо, графічна) можливо саме засобами технологій. Важливість та значення якості інформації досліджено у працях Л. Морської (2008), яка визначає інформацію предиктором знань. Отже, чим якісніша та змістовніша інформація - тим ґрунтовнішими будуть знання. Зазначена складова функціонує та впливає на результати навчання протягом всього процесу, тому що з'являються нові цифрові ресурси 3 новими можливостями, які стимулюють бажання пізнання й самовдосконалення.

Оскільки запропонована авторська модель вирішує два ключових завдання: навчити вмінь індивідуалізації навчання та іноземній мові, то змістово-технологічний компонент має містити вирішення обох питань: надати знання про стратегії автономного навчання та вміння аналізувати відповідність контенту обраної теми й обраного цифрового ресурсу індивідуальним пізнавальним можливостям з метою вдосконалити вміння іншомовного спілкування.

Ключовими навичками автономного навчання визначають планування, моніторинг та оцінювання діяльності. Беручи до уваги гнучкі умови онлайн навчання, результати процесу планування залежать лише від студента, який сам визначає темп, час, тривалість та послідовність навчання. У той самий час, онлайн навчання пропонує більш високий рівень свободи, і це є певним викликом, якщо студент не має навичок самоорганізації. Ознайомлення студентів із системою знань щодо індивідуалізації навчання, можливостями цифрових технологій, критеріями оцінювання якості ресурсів відбувається у процесі професійної підготовки під час занять із іноземних мов на початкових етапах та участі в неформальних формах навчання.

Узагальнюючи інформацію щодо етапів становлення індивідуалізації, ми розробили схему навчання вмінь індивідуалізації навчання (рис. 1).

Засобами освітніх цифрових технологій можливо диференціювати зміст навчання та типи завдань відповідно до індивідуальних потреб та можливостей. Зазначені зміни мають бути відображені в освітніх компонентах, які регламентують зміст та послідовність процесу навчання дисципліни. Пропонуємо низку елементів та принципів, які слід ураховувати під час розробки навчальних програм: узгоджувати цілі курсу 
разом зі студентами, щоб надати їм особистісного значення й окреслити напрям дій; включити теоретичні та практичні заняття 3 навчання навчальних стратегій для індивідуального навчання; залишати вибір і простір для створення альтернативних завдань та інструкцій студентами під час вивчення окремих тем; завдання для навчання та тренування вмінь саморефлексії й самооцінювання.

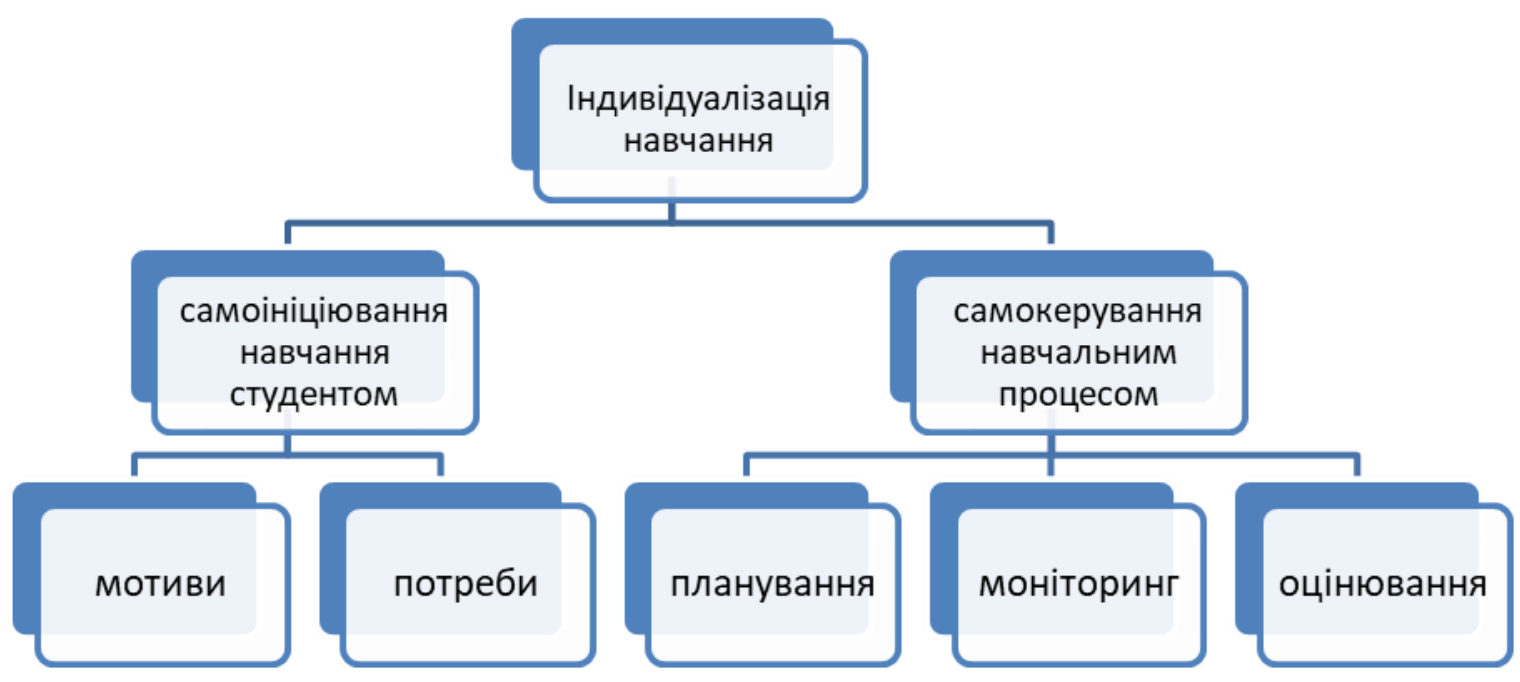

Рис. 1. Етапи індивідуалізації навчання

Для успішної реалізації мети та завдань змістово-технологічного компоненту ми виокремили три групи цифрових освітніх ресурсів відповідно до їхнього дидактичного потенціалу: для навчання автономного навчання, для вдосконалення іншомовної професійної компетентності та універсальні, які поєднують індивідуалізацію навчання іноземної мови.

Змістовий та мотиваційно-діагностичний компоненти виступають своєрідною основою для організаційно-процесуального компоненту, який проєктує реалізацію процесу навчання шляхом відбору методів, форм та рівень підтримки з боку викладача, що залежить від рівня автономності студента. Найбільш ефективним формами формальної освіти в синхронному та асинхронному режимі ви вважаємо змішане навчання, перевернуті класи, дискусії, тренінги, проектну роботу, навчання із залученням власного досвіду. Методи навчання із залученням власного освітнього досвіду включають низку інтерактивних практик (особисті журнали та історії, портфоліо, візуалізації, групові дискусії тощо), за допомогою яких учасники мають можливість дізнатися досвід інших, активно беручи участь у цьому процесі. 
Стратегія перевернутих класів передбачає оволодіння визначеним викладачем та навчальною програмою матеріалом самостійно для практичного його опанування на занятті. Ця стратегія сприяє розвиткові відповідальності за результат навчання.

Додатковою складовою в контексті автономного навчання $\epsilon$ конструктивний та інформативний зворотний зв'язок, взаємодія й підтримка студента, оскільки студенти відрізняються за рівнем самостійності та освітнім рівнем 3 навчальної дисципліни. Вчасний зворотній зв'язок та взаємодія допомагають прослідкувати динаміку процесу, якість процесу, відстежити особистісні психологічні зміни, які можуть відчувати студенти в процесі навчання залежно від проміжних результатів. Участь викладачів у процесі автономного навчання впливає на рівень саморегуляції особистісних ознак студентів.

Останнім компонентом ми визначили результативно-рефлексійний, але, відповідно до дуальності розробленої моделі, результат теж $\epsilon$ дуальним, націленим на оцінювання забезпечення внутрішніх (особистісно-динамічні утворення) та зовнішніх (забезпечення дидактичних умов) трансформацій під час індивідуального автономного навчання. Серед внутрішніх трансформацій ми виокремлюємо високий рівень відповідальності за результати власної діяльності, розвиток навичок самоконтролю та саморефлексії як ключового вміння для сталого процесу індивідуалізації навчання.

Засобами стратегій самодіагностики та розроблених критеріїв студенти разом з іншими студентами проводять оцінювання рівнів академічної та особистісної самореалізації й самооцінки. Ефективність результативно-рефлексійного компонента залежить від внутрішньої активності студентів за умов їхньої спрямованості на самопізнання та самовдосконалення. Усвідомлення себе як суб'єкта навчальної діяльності $\epsilon$ визначальним для досягнення успіху і сприяє росту академічної успішності.

Експериментальне впровадження авторської моделі було здійснено в Київському політехнічному інституті імені Ігоря Сікорського серед студентів другого курсу під час вивчення дисципліни «Англійська мова професійного спрямування». Експеримент тривав один семестр, навчання відбувалося через синхронну та асинхронну форму. Також окрім аудиторних занять, студенти брали участь у неформальних навчальних заходах. Результати експериментального впровадження були підтверджені покращеними результатами академічної успішності та результатами анкетування, проведеного серед студентів.

Висновки. Розроблена авторська дидактична модель індивідуалізації навчання іноземних мов студентів інженерних спеціальностей має ознаки дуальної, динамічної та технологічно-адаптованої системи, якій притаманна внутрішня організація і прослідковується взаємозалежність складових. 


\section{ЛІТЕРАТУРА}

Задорожна, І. П. (2015). Розвиток автономії студентів мовних спеціальностей у процесі вивчення фахових дисциплін. Вісник Чернігівського національного педагогічного університету. Серія: Педагогіка та психологія, 131, 60-65 (Zadorozhna, I. P. (2015). Developing autonomy of students specializing in linguistics in the process of studying required courses. Bulletin of Chernihiv National Pedagogical University. Series: Pedagogy and Psychology, 131, 60-65).

Караєва, Т. В. (2009). Методика навчання ділової мови з урахуванням рівня автономії студентів економічних спеціальностей (дис. ... канд. пед. наук: 13.00.02). Київ (Karaieva, T. V. (2009). Methods of teaching business language taking into account the level of autonomy of students of economic specialties (PhD thesis). Kyiv).

Морзе, Н. В., Кочарѐн, А. Б. (2015). Інформаційно-комунікаційна компетентність науково-педагогічних працівників університету: історичний розвиток формування понятійного апарату. Педагогічна освіта: Теорія і практика. Психологія. Педагогіка, 24, 20-31 (Morze, N. V., Kocharian, А. В. (2015). Information and communication competence of scientific and pedagogical workers in universities: historical evolvement of conceptual tools. Pedagogical education: theory and practice. Psychology. Pedagogics, 24, 20-31).

Морська, Л. І. (2008). Інформаційні технології у навчанні іноземних мов. Т.: Астон (Morska, L. I. (2008). Information technologies in foreign language teaching. T.: Aston).

Почуєва, В. В. (2017). Автономія студента у контексті освітньої діяльності. Актуальные научные исследования в современном мире, XXIY, 4 (24), 88-91 (Pochuieva, V. V. (2017). Student autonomy in the context of educational activities. Current scientific research in the modern world, $X X I Y, 4$ (24), 88-91).

Bray, B., McClaskey, K. (2016). How to Personalize Learning: A Practical Guide for Getting Started and Going Deeper. USA: Corwin Press.

Brockett, R. G. Hiemstra, R. (1994). Self-direction in adult learning. Perspectives on theory, research, and practice. London and New York: Routledge.

Dam, L. (2011). Developing learner autonomy with school kids: Principles, practices, results. In D. Gardner (Ed.), Fostering Autonomy in Language Learning, (pp. 40-52). Gaziantep: Zirve University.

Dickinson, L. (1987). Self-instruction in Language Learning. Cambridge University Press.

Esch, E. (1996). Promoting Learning Autonomy: Criteria for the selection of appropriate methods. In R. Pemberton, S. L. Li, W. Or, H. D. Pierson (Eds.), Taking Control: Autonomy in language learning, (pp. 33-37). Hong Kong: Hong Kong University Press.

Kristmanson, P., Lafargue, C., Culligan, K. (2013). Experiences with autonomy: Learners' voices on language learning. Canadian modern language review, 69 (4), 462-486.

Marcou, A., Philippou, G. (2005). Motivational beliefs, self-regulated learning and mathematical problem solving. In Chick, H. L., Vincent, J. L. (Eds.). Proceedings of the 29th Conference of the International Group for the Psychology of Mathematics Education, 3, pp. 297-304. Melbourne: PME.

Tarnopolsky, O. (2001). The scale of learner autonomy: Three levels in an intensive English programme. Independence. Newsletter of the IATEFL Learner Independence Special Interest Group, 29, 1-5.

\section{PEЗЮME}

Лавриш Юлиана. Индивидуализация обучения иностранных языков: дидактическая модель и експериментальная имплементация.

В статье рассматривается вопрос индивидуализации обучения иностранным языкам студентов инженерных специальностей. Предложена авторская дидактическая 
модель для обеспечения дидактических условий эфрфективной имплементации указанного образовательного процесса. Выделены компоненты модели: иенностноцелевой, мотивационно-диагностический, содержательно-технологический, организационно-прочессуальный и результативно-редрлексивный. Описаны дидактические принципы, на которых основывается модель. Указано содержание и задачи каждого из компонентов. Доказано, что дидактическая модель индивидуализации обучения иностранным языкам студентов инженерных специальностей имеет признаки дуальной, динамической и технологически адаптированной системы.

Ключевые слова: индивидуализация, дидактическая модель, дидактические принципы, иностранные языки, автономное обучение, цифровые образовательные технологии, саморазвитие, самообразование.

\section{SUMMARY}

Lavrysh Yuliana. Individualization of foreign language teaching: didactic model and experimental implementation.

The article considers the issue of individualization of foreign language teaching for engineering students. The author's didactic model for providing didactic conditions for the effective implementation of the specified educational process is offered. The components of the model are outlined: value-target, motivational-diagnostic, content-technological, organizational-procedural and result-reflective. We consider the development of skills of autonomous learning and digital competence as a critical skill for successful self-realization of the individual in the modern realities of technocratic society. These skills are included in the list of skills and abilities of the XXI century, a concept that defines the strategic skills needed to meet the requirements of time and society. The fundamental question is to determine the didactic conditions and strategies for teaching students to design an autonomous learning environment for learning foreign languages in accordance with the individual intellectual profile of each student.

This model is dual in content and involves solving two key issues: learning the skills of individual work and learning a foreign language. In order to ensure the duality of each component of the model, which is reflected in the combination of external and internal conditions of individualization of learning, we have chosen the following didactic principles: dominance of individual student work, open learning environment, transformativeness, continuity of educational process, sustainable development, flexibility and adaptability, interactivity, multimedia. Experimental implementation of the author's model was carried out at Igor Sikorsky Kyiv Polytechnic Institute among second-year students while studying the discipline "English for Professional Purposes". The experiment lasted one semester, learning took place through synchronous and asynchronous forms of learning. The didactic principles on which the model is based are described. The content and tasks of each of the components are indicated. It is proved that the didactic model of individualization of teaching foreign languages to engineering students has the features of a dual, dynamic and technologically adapted system.

Key words: individualization, didactic model, didactic principles, foreign languages, autonomous learning, digital educational technologies, self-development, self-education. 
УДК 377.620. 378.14:658

Олеся Лемішовська

Національний університет

«Львівська політехніка

ORCID ID 0000-0002-5695-0924

Ірина Яремко

Національний університет

«Львівська політехніка»

ORCID ID 0000-0001-9772-6817

DOI 10.24139/2312-5993/2020.03-04/077-091

\title{
УДОСКОНАЛЕННЯ ФАХОВИХ КОМПЕТЕНТНОСТЕЙ У ПРОЦЕСІ ПІДГОТОВКИ ВИКЛАДАЧІВ ОБЛІКОВО-ЕКОНОМІЧНИХ ДИСЦИПЛІН З ВИКОРИСТАННЯМ ІННОВАЦІЙНИХ ПЕДАГОГІЧНИХ ТЕХНОЛОГІЙ
}

\begin{abstract}
Стаття присвячена теоретичному обгрунтуванню значимості i змісту інноваційних педагогічних технологій для вдосконалення професійної компетентності майбутнього викладача професійного навчання. Наведено сучасні тенденції в розвиткові університетської освіти та проаналізовано зміст і характер пропонованих педагогічних технологій із використанням інноваційного інструментарію. Розкрито стан та проблеми використання інноваційних педагогічних технологій у вдосконаленні специфічних компетентностей викладача обліково-економічних дисциплін. На основі узагальнення тематичних досліджень $і$ практики сформульовані окремі пропозиціі щодо використання інновачійного інструментарію за досліджуваним профрілем підготовки спеціалістів.

Ключові слова: викладач обліково-економічних дисциплін, профресійна підготовка, освітні інновації, інноваційна освітня діяльність, компетентності, технології в освіті, педагогічні технології.
\end{abstract}

Постановка проблеми. У сучасному світі освіта й наука об'єктивно постають пріоритетними чинниками соціального, економічного та культурного розвитку будь-якої країни. Нові вимоги до компетентностей здобувачів вищої освіти зумовлюють необхідність докорінного перегляду узвичаєної технології і методики для модернізації навчального процесу за будь-яким напрямом підготовки спеціалістів. Набір фахових компетентностей з переважної більшості напрямів підготовки спеціалістів динамічно змінюється, а їх забезпечення вирішується шляхом упровадження інноваційних технологій. Наведене стосується визначеного авторами напряму професійної підготовки спеціалістів. У цьому контексті вкажемо, що міжнародна федерація бухгалтерів - International Federation of Accountants (IFAC) - розробляє стандарти професійної освіти. Вони гармонізовані в міжнародних масштабах і спрямовані на забезпечення дедалі зростаючих і динамічно змінюваних вимог до бухгалтерської професії. При цьому у сфері бухгалтерського навчання, як і в інших напрямах підготовки спеціалістів, «методологічний ландшафт сучасних освітніх трансформацій спрямований на 
формування інноваційної особистості», позначаються зближенням теоретичних та практичних аспектів діяльності й забезпечується на основі «процедурно-технологічних потенцій наукової теорії та модельноінформаційних здатностей практики» (Гулько, 2012, с. 471).

Магістральна спрямованість модернізації сучасної освіти лежить у координатах компетентнісного підходу, який витісняє знаннєву парадигму з дидактики. Новий зміст освітніх технологій передбачає не тільки засвоєння інформації, а більшою мірою спрямовується на вироблення аналітико-оцінних навичок, набуття здатностей приймати рішення в умовах змін професійної діяльності. Загалом можна стверджувати, що переосмислення змісту вищої освіти полягає в переході від її традиційного «пізнавального змісту» до формування моделі «розбудови потенціалу». Успішність упровадження такої моделі дедалі частіше пов'язується з такою складовою, як поєднання фахових знань і педагогічних навичок. Тобто, по суті, йдеться про поняттєвий зміст «педагогічної технології», який, наприклад, за визначенням ЮНЕСКО розкритий як «системний метод створення, застосування й визначення всього процесу викладання i засвоєння знань з урахуванням технічних і людських ресурсів у їх взаємодії, що вирішує завдання оптимізації форм освіти».

у сучасних публікаціях аргументується, що якість навчального процесу залежить від «синергетичного набору» - «педагогічна майстерність» + «професійні знання». Тому в багатьох зарубіжних публікаціях акцентованим виступає твердження про те, що професійні знання викладачів закладів вищої освіти повинні бути підкріплені педагогічними знаннями (університетська педагогіка), обґрунтовуючи «необхідність розвитку педагогічної підготовки викладачів університетів» (Asonitou; Paisey \& Paisey, 2004). Такої самої позиції дотримуються не тільки в педагогічних колах, але й авторитетних суто фахових міжнародних журналах «Бухгалтерська освіта» (Accounting Education). Узагальнено вкажемо, що розвиток педагогічних технологій у системі бухгалтерського навчання розглядається через системну сукупність усіх задіяних фахових, інструментальних і методологічних засобів у параметрі психологопедагогічних, науково-технологічних та соціально-економічних нововведень, які можуть бути реалізованими в системі освітніх інновацій.

Розгляд існуючої проблематики на сторінках журналів 3 бухгалтерської освіти пов'язується, насамперед, із тим, що в реально складених умовах глобалізації і динаміці технологічних інновацій іншого характеру і функціональної спрямованості набуває сама бухгалтерська професія. Відповідно, іншого змісту потребує й фокус освітнього процесу, який зміщується в напрям забезпечення нових компетентностей. У загальну компетентність укладається вимога, що фахівці за цим профілем підготовки повинні бути носієм економічних та соціальних зрушень, уміти 
трансформувати свої професійні знання відповідно до потреб ринку праці, нових вимог суспільно-економічного середовища, комунікативними вміннями, цінностями демократичного суспільства тощо.

Аналіз актуальних досліджень дозволяє стверджувати, що питання про важливість та доцільність упровадження інноваційних педагогічних технологій у професійну підготовку для забезпечення системи визначених компетенцій сучасного фахівця $є$ аксіоматичним. Проаналізовані тематичні літературні джерела показують, що розвиток педагогічних технологій (зміст, характер, добір інструментальних засобів) у системі педагогічної науки (прикладна педагогіка) пропонується на основі використання варіативних технологій. У комплексних дослідженнях чи окремих публікаціях кожен із науковців для сучасної дидактики пропонує найрізноманітніші версії інноваційної технології. Загалом, вітчизняні науковці розглядають ці процеси переважно виходячи з обґрунтування потреби змін до існуючої структури, стандартів та організаційних форм за певним напрямом підготовки та впровадженням новітніх засобів навчання. Науковцями пропонуються різні версії впровадження інформаційнокомунікаційних технологій з використанням інноваційних методів.

Так, наприклад, стосовно використання системних інноваційних технологій при підготовці спеціалістів за досліджуваним напрямом, К. В. Бурко наводить аргументації, що «для результативного формування фахової компетентності майбутнього спеціаліста з бухгалтерського обліку необхідно постійно вдосконалювати професійну та викладацьку майстерність науково-педагогічного складу та використовувати форми активного навчання» (Бурко, 2018). Досліджуючи стан удосконалення професійної бухгалтерської освіти, М. М.Шигун вказує на переваги, що «надаються сучасними інноваційними технологіями у сфері обліку і аудиту» та обґрунтовує, що інноваційні засоби «необхідні для радикальних змін у набутті навичок та компетенцій бухгалтерів» (Шигун, 2017, с. 335).

Загалом, можна стверджувати, що на думку більшості університетських науковців і зокрема О. А. Дубасюк, «саме завдяки інноваційному імпульсу, який надала «інформаційна хвиля» науковотехнічного прогресу, «прискорився темп цивілізаційного розвитку, а тому подальша логіка розвитку освіти $є$ логікою інноваційних реформ, які відіграватимуть значну роль у модернізації освітніх процесів» (Дубасенюк, 2004, с. 43). Розглядаючи проблематику формування інноваційного навчального середовища, О. О. Загіка акцентує на тому, що «саме освітні технології, інтерактивні методи навчання, нестандартні форми педагогічної діяльності дозволяють організовувати навчальну роботу в умовах, наближених до реальних, дають очікуваний ефект» (Загіка, 2013, с. 55). Проведений аналіз актуальних досліджень дає змогу зробити висновок, що застосування сучасних педагогічних інноваційних технологій створює 
умови для можливостей вирішення складного педагогічного завдання, у процесах формування професійної компетентності випускника.

Метою статті $€$ дослідження значимості інноваційних педагогічних технологій у процесах формування фахових компетенцій із акцентом на комунікативну компетентність викладачів обліково-економічної сфери, зокрема їх особистісне світобачення. Для реалізації поставленої мети розкрито існуючу проблематику загальнодидактичного і методичного рівня компетентнісного підходу та обґрунтовано значимість інноваційних технологій за цією спеціальністю.

Не до кінця вирішеною проблемою $\epsilon$ теоретичне розв'язання існуючих проблемних питань упровадження інновацій загалом та інноваційні методи навчання в системі формування фахових компетенцій у студентів спеціальності 011 «Освітні, педагогічні науки», які мають базову освіту за напрямом підготовки 07 «Управління та адміністрування». До найбільш проблемних слід віднести, на наш погляд, соціально-педагогічні (розвиток творчого потенціалу учасників навчального процесу) та психолого-педагогічні (готовність викладачів і студентів працювати в інноваційному режимі).

Методи дослідження. У статті використано загальнонаукові методи дослідження: теоретичні - узагальнення і теоретичний аналіз нормативних і науково-педагогічних джерел інформації для обґрунтування вихідних положень дослідження; емпіричні - метод спостереження за навчальним процесом заявленої спеціальності. Методи абстрагування й конкретизації забезпечили формулювання висновків і пропозицій стосовно теоретичних і методичних засад дослідження.

Виклад основного матеріалу. У статті розглядається забезпечення сучасних вимог до загальної компетентності випускника з використанням інновацій (інноваційна педагогічна технологія) на прикладі університетської підготовки спеціалістів у Національному університеті «Львівська політехніка» в межах галузі знань 01 «Освіта», спеціальності 011 «Освітні, педагогічні науки» («магістр з освітніх, педагогічних наук» (професійна кваліфікація «викладач обліково-економічних дисциплін»). Матеріали статті стосуються інноваційної педагогічної технології, яка розглянута через призму інтерактивного навчання, інформаційно-ціннісних технологій, технології розвитку критичного мислення.

Розгляд задекларованої проблематики значною мірою стосується навчальних дисциплін освітньо-професійної програми, які є «стиковими», тобто поєднують педагогічні і фахові знання і, відповідно, «цементують» навчальний процес за цим напрямом університетської підготовки. Серед них виділимо такі дисципліни: «Методика викладання обліковоекономічних дисциплін: інноваційні технології»; «Методика викладання обліково-економічних дисциплін: дидактичне проектування»; 
«Методологія та організація наукових досліджень в обліку й оподаткуванні». Змістове наповнення навчальної програми складається 3 педагогічних та фахово-орієнтованих дисциплін. Важливість упровадження в навчальний процес інноваційних педагогічних технологій полягає в тому, що випускники за цією спеціальністю стають викладачами бухгалтерських і фінансово-економічних предметів у коледжах, технікумах, училищах, а також у загальноосвітніх школах для викладання загальноекономічних предметів (наприклад, предмету «Фінансова грамотність»).

Стосовно задекларованого статтею напряму підготовки зауважимо, що в сучасних публікаціях у сфері бухгалтерської освіти лунають заклики до проведення більш інноваційних і прикладних наукових досліджень, які повинні базуватися на основі застосування соціологічної перспективи та введення результатів цих досліджень у навчальний процес. Науковців різних країн з подібними поглядами нині об'єднує фаховий спеціалізований журнал «Бухгалтерський облік, організація і суспільство», який публікує праці 3 вивчення проблематики ролі і значення бухгалтерського обліку в суспільстві. Автори цієї статті також дотримуються погляду, що бухгалтерський облік $€$ соціально-політичним явищем, а тому для розширення компетентностей студентів доцільним у навчальному процесі $\epsilon$ використання, крім суто фахового методологічного інструментарію, методології інших соціальних наук, що забезпечує компетентністний підхід.

Поняття компетентності Законом України «Про вищу освіту» визначено як здатність особи успішно соціалізуватися, навчатися, провадити професійну діяльність, яка виникає на основі динамічної комбінації знань, умінь, навичок, способів мислення, поглядів, цінностей, інших особистих якостей (Закон України «Про вищу освіту», 2019). Проте, на практиці (акредитація, експертні судження про якість освіти, зрештою і суспільний погляд) все ж виникає проблема об'єктивної оцінки професійних компетенцій студента. При узагальненні компетентності необхідно врахувати всі складові цього поняття, їх взаємозалежність та взаємозв'язок. На теперішній час актуальним $€$ вирішення питання вироблення конкретної методики кількісного виразу цього синтезованого поняття, оцінка якого все ще лежить у площині суб'єктивних оцінок і суджень. Реальна практика та аналіз досліджень за цією проблематикою дає змогу зробити висновок, що під цим понятям розуміють достатньо широке його змістове наповнення. У більшості випадків вважається, що під поняття «компетенція» йдеться про наперед задану вимогу до підготовки особи, її знань та досвіду діяльності у певній сфері», а зміст понятійного апарату в координатах «компетентність» виявляється в оволодінні компетенцією та включає особисте ставлення до спеціалізації та діяльності (Король, Марущак, 2014, с. 423).

В узагальненому вигляді «компетентність» як синтезоване поняття розкривається через утворення особистості. Це поняття інтегрує в собі знання, 
уміння, навички, досвід та особистісні властивості. У Державному стандарті вищої освіти компетентність визначається як набута у процесі навчання інтегрована здатність особистості, яка складається зі знань, досвіду, цінностей і ставлення, що можуть цілісно реалізовуватися на практиці (Стандарт вищої освіти України). Забезпечення вищою школою ключових компетентностей на загальному фоні концептуальної модернізації вітчизняної освіти пов'язують із інноваційними інструментальними засобами.

Багато науковців стверджують, що «інноваціями в освіті $\epsilon$ впровадження нових методів, форм і підходів до передачі знань, формування вмінь і навичок у студентів (Барабась та ін., 2016, с. 38). Стосовно цілісного (системного) педагогічного процесу, то інновацію найбільш об'єктивно слід розглядати через «введення нового в цілі, зміст, методи й форми навчання та виховання, організацію спільної діяльності викладача і студентів» (Дубасенюк, 2015, с. 5). При цьому обгрунтовується, що інноваційні технології навчання, на відміну від традиційних, є більш ефективними в засвоєнні навчального матеріалу, оскільки «спонукають студентів до творчої роботи та формують особисту позицію щодо сприйняття змісту навчання» (Вітренко, 2010, с. 133).

Педагогічна технологія найчастіше розглядається через системну сукупність і порядок функціонування всіх особистісних та інструментальних засобів, що використовуються для досягнення педагогічної мети, а їх інноваційна складова переважно розглядаються в площині інформаційнокомунікаційних технологій спілкування в різних форматах з використанням різних джерел інформації і супроводжується за допомогою аудіо, відео засобів. Найчастіше застосовується Web-сайт як один із засобів упровадження IКT. У сучасні навчальні процеси широко впроваджено мультимедіа, тобто сукупність прийомів, методів, способів продукування, обробки, зберігання, передавання аудіовізуальної інформації.

Саме поняття «інновація» має складне значення, оскільки містить у собі дві форми: власне ідеї та процеси їх практичної реалізації. При цьому основними елементами освітньої інновації $\epsilon$ ії носій, який має певну інноваційну ідею та проводить інноваційний експеримент; споживач інновації - студент чи група студентів, а також інституції, що забезпечують упровадження інновацій у навчальний процес (заклади вищої освіти; органи управління освітою; науково-методичні установи; наукововиробничі підприємства).

у системі вищої освіти виділяють технологічні, педагогічні, організаційні та економічні групи інновацій. Перші два з цих видів інновацій безпосередньо стосуються формування фахових компетентностей студентів. До технологічних інновацій в педагогікоекономічній освіті слід віднести нові технології навчання, побудову освітніх програм, а також навчально-методичні матеріали. Педагогічні інновації 
включають у себе нові методи викладання і навчання, нові форми та організацію навчальних занять (застосування інтерактивних форм та мультимедійних засобів навчання, використання телекомунікаційних методів конструювання знань, імітаційних технологій, методики відео тренінгу, комп'ютерне моделювання, технологій віртуальної реальності).

Стосовно питань модернізації бухгалтерської освіти в останні роки в Україні проведено чисельні конференції із залученням зарубіжних науковців. На цих наукових заходах розглядаються питання вдосконалення методики викладання бухгалтерського обліку, економічного аналізу і аудиту. Висновками стосовно підвищення якості професійної підготовки фахівців 3 бухгалтерського обліку, активізації навчально-пізнавальної і науководослідної діяльності студентів та розкриття їхнього творчого потенціалу, $\epsilon$ визнання необхідності розробки і впровадження в навчальний процес інноваційних технологій. До таких заходів, насамперед, відносять упровадження комп'ютерно-орієнтованих методичних систем відповідно до змісту фахових дисциплін, в основу яких покладено web технології. У предметній сфері підготовки спеціалістів вважається, «що такі інноваційні технології, як електронне, дистанційне та мобільне навчання відкривають широкі можливості для вирішення завдань із організації самостійної роботи студентів та дозволяють їм отримати доступ до навчальних матеріалів у будьякому місці та в будь-який час, що робить процес навчання більш привабливим та комфортним і стимулює до самоосвіти» (Бурко, 2018).

Важливими у процесах набуття фахових компетенцій визнаються інтерактивні методи навчання, які мають конкретну, передбачувану мету створити комфортні умови навчання, за яких кожен відчуває свою успішність, інтелектуальну спроможність (Варзацька, 2005). Активні методи навчання класифікують за різними підходами, найбільш поширеним із яких $\epsilon$ їх поділ за характером навчально-пізнавальної та ігрової діяльності (Смолкин, 1991, с. 32-38). У межах цієї класифікації вирізняють імітаційні методи (імітація різних аспектів професійної діяльності), які за змістом і характером поділяються на ігрові та неігрові.

Упровадження в навчальний процес методів першої групи забезпечують ігрові процедури і прийоми, ігрові ситуації, дидактична або навчальна гра, ділові ігри. У різних комбінаціях їх використовують під час вивчення предметів «Викладання обліково-економічних дисциплін: інноваційні технології» та предмета з вибіркового блоку «Обліковоаналітичне забезпечення менеджменту». Неігрові методи в навчальному процесі використовують для формування навичок аналізу практичних ситуацій. У теорії добре сформульовані і на практиці апробовані такі методи, як аналіз конфліктів, аналіз проблемних ситуацій, аукціон ідей, імітаційні вправи, диспути, мозкова атака, метод Case Studies, опорні сигнали, методи «Снігова куля», «Коло ідей», «Карусель», аналіз 
конкретних ситуацій та ін. Неімітаційні методи включають стажування на робочому місці, програмоване навчання, проблемну лекцію тощо.

У досліджуваній сфері підготовки спеціалістів ці методи достатньо ефективно використовуються під час вивчення предмету «Викладання обліково-економічних дисциплін: дидактичне проектування». Студенти магістерського рівня спеціальності 011 «Освітні, педагогічні науки», виступаючи в ролі викладача, проводять лекційні заняття для студентів бакалаврського рівня спеціальності 071 «Облік і оподаткування», обравши одну з дисциплін спеціальності. Опрацьоване для таких цілей навчальнометодичне забезпечення з обраної дисципліни, підготовлені матеріали за цією лекцією та набутий досвід поєднання фахових і педагогічних складових стає основою виконання курсової роботи, передбаченої навчальним планом з дисципліни «Викладання обліково-економічних дисциплін: дидактичне проектування». Переважно ці напрацювання і стають вибором теми магістерської роботи, у якій окремим розділом визначена фахова педагогічна складова.

Практика показує, що комунікативна підготовка майбутнього викладача обліково-економічних дисциплін опосередковується профілем базової спеціальності 071 «Облік і оподаткування». Виходячи з такої висхідної диспозиції розглянемо фахові компетентності, передбачені Стандартом для другого (магістерського) рівня вищої освіти спеціальності «Облік і оподаткування» і з пропонованими інноваційними методами навчання на спеціальності 011 «Освітні, педагогічні науки» (табл. 1).

\section{Таблиця 1}

\section{Інноваційні методи навчання для забезпечення фахових компетентностей другого (магістерського) рівня вищої освіти спеціальності 071 «Облік і оподаткування»}

\begin{tabular}{|c|c|}
\hline Фахова компетентність & Інтерактивні методи навчання \\
\hline $\begin{array}{l}\text { Здатність } \\
\text { використовувати облікову інформацію для } \\
\text { прийняття ефективних управлінських рішень } \\
\text { на всіх рівнях управління }\end{array}$ & $\begin{array}{l}\text { Лекції з запланованими помилками, } \\
\text { лекції проблемного характеру } \\
\text { Дидактичні, навчальні, ділові ігри }\end{array}$ \\
\hline $\begin{array}{l}\text { 3датність організовувати обліковий } \\
\text { процес та регламентувати діяльність його } \\
\text { виконавців }\end{array}$ & $\begin{array}{l}\text { Мозковий штурм, кейс метод } \\
\text { Дидактичні, навчальні, ділові ігри }\end{array}$ \\
\hline $\begin{array}{l}\text { Здатність застосовувати теоретичні, } \\
\text { методичні і практичні підходи щодо організації } \\
\text { обліку, контролю, планування та оптимізації } \\
\text { податкових розрахунків }\end{array}$ & $\begin{array}{l}\text { Робота в малих групах за методами } \\
\text { «діалог», «синтез думок», метод прес- } \\
\text { формула }\end{array}$ \\
\hline $\begin{array}{l}\text { Здатність формувати фінансову звітність } \\
\text { за міжнародними стандартами, коректно } \\
\text { інтерпретувати, } \\
\text { використовувати відповідну інформацію }\end{array}$ & $\begin{array}{l}\text { Лекції проблемного характеру } \\
\text { Дерево рішень, робота в малих } \\
\text { групах за методами «Акваріум», «Ажурна } \\
\text { пилка» }\end{array}$ \\
\hline застосовувати & Інтелектуальні тренінги, ділові ігри \\
\hline
\end{tabular}


Педагогічні науки: теорія, історія, інноваційні технології, 2020, № 3-4 (97-98)

\begin{tabular}{|c|c|}
\hline $\begin{array}{l}\text { методики аналітичного забезпечення сучасних } \\
\text { систем менеджменту }\end{array}$ & \\
\hline $\begin{array}{l}\text { Використовувати міжнародні стандарти } \\
\text { контролю якості, аудиту, огляду } \\
\text { дотриманням вимог професійної етики в } \\
\text { процесі практичної діяльності }\end{array}$ & $\begin{array}{l}\text { Лекції проблемного характеру } \\
\text { Кейс метод, дерево рішень, прес- } \\
\text { формула }\end{array}$ \\
\hline \begin{tabular}{l}
\multicolumn{1}{c}{ Здатність формулювати завдання, } \\
удосконалювати методики та впроваджувати \\
сучасні методи обліку, аналізу, аудиту й \\
оподаткування
\end{tabular} & $\begin{array}{l}\text { Багатоцільові, проблемні лекції, } \\
\text { лекції-брейнстормінг, лекції із заздалегідь } \\
\text { запланованими помилками }\end{array}$ \\
\hline $\begin{array}{l}\text { Здатність виконувати адміністративно- } \\
\text { управлінські функції у сфері діяльності суб'єктів } \\
\text { господарювання }\end{array}$ & $\begin{array}{c}\text { Лекції прес-конференції, } \\
\text { брифінги, лекції «круглий стіл» }\end{array}$ \\
\hline $\begin{array}{l}\text { Здатність здійснювати діяльність } 3 \\
\text { консультування у сфері обліку, аналізу, } \\
\text { контролю, аудиту, оподаткування }\end{array}$ & $\begin{array}{l}\text { Лекції-прес-конференції, } \\
\text { екскурсії, лекції з застосуванням зворотногі- } \\
\text { зв'язку, мозковий штурм, діагностика } \\
\text { проблеми }\end{array}$ \\
\hline $\begin{array}{l}\text { Здатність проводити наукові } \\
\text { дослідження з метою вирішення актуальних } \\
\text { завдань теорії, методики, організації та } \\
\text { практики обліку, аудиту, аналізу, контролю та } \\
\text { оподаткування }\end{array}$ & $\begin{array}{l}\text { Робота з електронними посібниками, } \\
\text { наукометричними базами даних }\end{array}$ \\
\hline
\end{tabular}

3 відомих новітніх методів у навчальний процес для набуття деякої групи визначених компетентностей під час вивчення обліково-економічних дисциплін поступового впровадження набувають відмінні від традиційних і популяризовані для навчального процесу лекції: багатоцільові, проблемні лекції, лекції-брейнстормінги, лекції із заздалегідь запланованими помилками. У ситуації, що склалася, особливого значення набувають форми дистанційного навчання, використовують лекції-конференції, лекції пресконференції, лекції-брифінги, лекції «круглий стіл». Очевидною $\epsilon$ ефективність такого виду навчальних занять, як лекції-бесіди, лекціївізуалізації, лекції-екскурсії, лекції із застосуванням техніки зворотного зв'язку (інтерактивні), бінарні лекції. Вони вважаються такими, що забезпечують більш ефективний підхід до передачі та сприйняття навчального матеріалу. На основі вже апробованих форм виділимо лекції проблемного характеру, на яких студенти знаходяться в постійному процесі «співмислення» з лектором, i зрештою стають співавторами у вирішенні проблемних завдань. Практика їх упровадження показує, що лекції такого типу сприяють активному засвоєнню, глибшому запам'ятовуванню, розвитку творчого мислення (перенесення в інші ситуації), підвищення інтересу до змістового викладання обліково-економічних дисциплін.

Для набутт навичок студентами цієї спеціальності здатності формувати адекватну обліково-економічну інформацію для прийняття ефективних управлінських рішень доцільно проводити тематичні ділові ігри. Так, 
наприклад, із дисциплін «Облік і аналіз в корпораціях» та «Обліковоаналітичне забезпечення менеджменту», що вивчаються за вибором студентів, упроваджуються заняття ігрового характеру на такі теми: «Складання корпоративної фінансової звітності», «Я - фінансовий директор корпорації», «Інформаційна база управління корпорацією», «Об'єднання капіталу на підприємствах корпоративного типу». Такі ігри мають формуються в такий спосіб, щоб забезпечити послідовне дотримання облікової діяльності на підприємствах корпоративного типу. У розвиток наведеного навчального методу під час вивчення обліково-економічних дисциплін практикується робота в малих групах за відомими методами «Діалог», «Синтез думок», «Спільний проект», «Акваріум», «Ажурна пилка», «Прес».

Однією з форм організації занять із викладання обліковоекономічних дисциплін $\epsilon$ case-study (ситуаційний аналіз) - вивчення й обговорення конкретних обліково-економічних ситуацій. Використання цього методу дозволяє навчити розуміти за теоретичними моделями реальні обліково-аналітичні процеси, аналізувати проблеми, що виникають у фаховій сфері, аргументувати власні висновки на основі теоретичного матеріалу. Педагогічна цінність цього методу полягає в тому, що у процесі навчання разом із професійними інтенсивно розвиваються й особистісні здібності, формуються практичні навички та вміння в межах визначених освітньою програмою фахових компетенцій: аналітичні (уміння класифікувати інформацію, виділяти суттєву та несуттєву, аналізувати та представляти ії), творчі (знаходити варіанти рішень та вибирати оптимальні для відповідної ситуації), комунікативні (уміння вести дискусію, переконувати оточуючих, захищати власну точку зору, переконувати опонентів, складати короткий, переконливий звіт), соціальні (оцінювати поведінку інших, удосконалювати вміння слухати, підтримувати в дискусії чи аргументувати протилежну думку).

Набуття професійних компетентностей за досліджуваним напрямом підготовки забезпечується під час проведення практичних занять 3 дисциплін, що вивчаються за напрямом 07 «Управління та адміністрування». При цьому практикується використання методу PRESformula - який базується на технології аргументованого судження, що спрямована на рефлексію студентів (розвиток здібностей ставити питання, виробляти різноманітні аргументи, приймати незалежні продумані рішення; удосконалення вмінь студентів працювати 3 інформацією, створюючи власну систему сприйняття; формування вміння переконувати та обґрунтовувати власну думку; засвоєння дисципліни на різних рівнях).

Однією з інноваційних педагогічних технологій $€$ методика PRESformula, яка може застосовуватися для закріплення вивченого матеріалу, зокрема перевірки засвоєння матеріалу, винесеного для самостійної роботи студентів. Технологічність прийому полягає в тому, що студенти для 
підсумкового контролю на практичних заняттях готують короткий виступ, що складається з кількох взаємопов'язаних елементів. В узагальненому вигляді вони структуровані таким чином: Position - позиція (у чому полягає ваша точка зору), Reason - пояснення (на чому базуються ваші судження, аргумент на підтримку вашої позиції), Example - приклад (факти, що ілюструють ваш аргумент), Summary - резюме (висновок, що треба зробити, заклик до певних дій). Підготовлене має за мету сформувати логіку студента стосовно обґрунтування своєї позиції), уміння доводити правоту своєї позиції з використання фактів, що мають місце на практиці) і сформулювати власний висновок. У такому виступі, що складається 3 декількох речень, студент чітко заявляє свою позицію, приводить тільки один аргумент, але він коректно сформульований і проілюстрований, та підтверджує правильність свого судження. При цьому студент не маєте можливості вимовляти порожніх фраз і обтічних виразів. Виступ із використанням PRES-formula займає одну-дві хвилини. ї̈ зручно використовувати не тільки в ситуації, коли час, відпущений на дискусію, обмежений, а й коли завдання педагога - навчити студента відповідати посуті, не використовуючи розмитих фраз і неясних суджень (Вагіс, 2017).

Узагальнено можна стверджувати, що головними перевагами інноваційних педагогічних технологій $€$ створення атмосфери співпраці за схемою: викладач-студент, студент-студент, студент-комп'ютер, студентвикладач. Під час практичного використання методики інтерактивного навчання для вивчення дисциплін професійного спрямування важливим $є$ дидактичне забезпечення самостійної роботи студентів із визначенням параметрів: результатів вивчення навчальної дисципліни (опис професійної компетенції студента з вивчення курсу); термінів виконання завдання, інтерактивних контактів із викладачем.

Висновки та перспективи подальших наукових розвідок. Матеріали дослідження вказують на різноманітність підходів як до самого змісту сучасних інноваційних педагогічних технологій, так і способів, форм їх упровадження в навчальний процес. Під час вибору педагогічної технології слід, насамперед, ураховувати напрям професійного навчання, зокрема специфічні особливості напряму підготовки, ключові компетентності професійної кваліфікації, а також потенціал професійно-педагогічної та методичної майстерності викладацького складу і здатності студентів до оволодіння знаннями. 3 точки зору ефективного використання інноваційної складової в системній технології важливими факторами виступають наявність і ступінь дидактичних і технічних засобів навчання.

Необхідність та ефективність упровадження в систему університетського навчання інноваційної системи педагогічних технологій підтверджується їх позитивним впливом на формування компетентностей у процесі підготовки викладачів обліково-економічних дисциплін. Такі 
спеціалісти готуються для закладів передвищої освіти, які водночас $\epsilon$ потенційно університетськими викладачами. Інноваційні технології в навчальному процесі мають великий освітній і розвивальний потенціал, забезпечують максимальну активність студентів у навчальному процесі, оптимальний час навчання, його результативність та набуття визначених компетентностей.

Інноваційні методи навчання об'єктивно сприяють підвищенню рівня засвоєння знань, вони розширюють пізнавальні можливостей студентів, забезпечують їх активну участь у процесі навчання, підвищуючи мотивацію, спрощують та пришвидшують процес контролю знань, забезпечують партнерство між викладачем та студентами. Упровадження таких методів у навчальний процес забезпечує набуття комунікативних умінь та здатності організовувати обліковий процес і роботу його виконавців, знайти адекватні теоретичні, методологічні та практичні підходи для контролю, планування й оптимізації обліково-аналітичної роботи, уміння швидко, оперативно та правильно орієнтуватися в змінах обліково-податкового законодавства.

Стосовно апробації в досліджуваній сфері підготовки спеціалістів, то можна зробити висновок про те, що застосовані в комплексі 3 традиційними інноваційні технології сприяють формуванню фахових компетентностей майбутніх викладачів-обліковців. Перспективи подальших досліджень спрямовані на використання інтерактивних методів навчання та дистанційної форми навчання у професійній підготовці викладачів досліджуваного профілю.

\section{ЛІТЕРАТУРА}

Барабась, Д., Джафаров, Д., Шпак, І. (2016). Освітні інновації та їх імплементація в Україні. Науковий вісник Одеського національного економічного університету, 3, 35-54 (Barabas, D., Dzhafarov, D., Shpak, I. (2016). Educational innovations and their implementation in Ukraine. Scientific Bulletin of Odessa National Economic University, 3, 35-54).

Бурко, К. В. (2018). Інноваційні технології навчання у підготовці фахівців з бухгалтерського обліку. Електронне наукове фрахове видання "Ефективна економіка», 5. Режим доступу: http://www.economy.nayka.com.ua/pdf/5 2018/161.pdf (Burko, K. V. (2018). Innovative learning technologies in training specialists in record-keeping. Electronic scientific professional publication "Effective Economics", 5. Retrieved from: http://www.economy.nayka.com.ua/pdf/5 2018/161.pdf).

Baric, А. (2017). Формування фахової компетентності студента як синергетичний процес. Ukrainian Journal of Educational Studies and Information Technology, 5 (2), 5-8 (Vahis, A. (2017). Formation of professional competence of the student as a synergetic process. Ukrainian Journal of Educational Studies and Information Technology, 5 (2), 5-8).

Варзацька, Л. (2005). Інтерактивні методи навчання: лінгводидактичні засади. Дивослово, 2, 5-9 (Varzatska, L. (2005). Interactive teaching methods: linguodidactic principles. Dyvoslovo, 2, 5-9).

Вітренко, О. В. (2010). Досвід використання методики інтерактивного навчання під час 
викладання професійних дисциплін зі спеціальності облік і аудит. Вісник Донецького університету економіки та права, 2, 128-133 (Vitrenko, О. V. (2010). Experience in using the methodology of interactive learning in teaching professional disciplines in the specialty accounting and audit. Bulletin of Donetsk University of Economics and Law, 2, 128-133).

Гулько, О. В. (2012). Проектна освіта як один з напрямків освітніх трансформацій: філософсько-історичний аспект. "Гілея: науковий вісник». Збірник наукових праць, 56, 471-477 (Hulko, O. V. (2012). The project education as one of the ways of educational transpormation: philosophic-historical acpect. Collection of scientific papers "Hileia: scientific herald», 56, 471-477).

Дубасенюк, О. А. (2004). Інноваційні навчальні технології - основа модернізації університетської освіти. Освітні інноваційні технології у процесі викладання навчальних дисциплін: Збірник наук.-метод. праць. Житомир: Вид-во ЖдУ, сс. 14-47 (Dubaseniuk, O. A. (2004). Innovative teaching technologies - basis for modernization of university education. Educational innovative technologies in the process of teaching. Collection of scient.-meth. works. Zhytomyr: Publication Zhytomyr's University, pp. 14-47).

Дубасенюк, О. А. (2015). Професійно-педагогічна освіта: методологія, теорія, практика. Т. 1. Житомир: Вид-во ЖДУ імені Івана Франка (Dubaseniuk, О. А. (2015). Professional and pedagogical education: methodology, theory, practice. Vol. 1. Zhytomyr: Zhytomyr Ivan Franko State University).

Загіка, О. О. (2013). Інноваційне навчальне середовище - запорука професійної компетентності та конкурентоспроможності випускника ПтН3. Професійна освіта: проблеми і перспективи, 5, 55-59 (Zagika, O. O. (2013). Innovative learning environment as a formula of professional competence and competitiveness of a vocational school graduate. Vocational education: problems and prospects, 5, 55-59).

Закон України "Про вищу освіту" (Law of Ukraine "On higher education") (2019). Retrieved from: https://zakon.rada.gov.ua/laws/show/1556-18.

Король, В. П., Марущак, О. В. (2014). Термінологічні аспекти формування професійної компетентності майбутнього фахівця. Сучасні інформаційні технології ma інноваційні методики навчання у підготовці фахівців: методологія, теорія, досвід, проблеми, 37, 421-427 (Korol, V. P., Marushchak, O. V. (2014). Terminological aspects of the formation of professional competence of the future specialist. Modern information technologies and innovative teaching methods in specialists' training: methodology, theory, experience, problems, 37, 421-427).

Смолкин, А. М. (1991). Методы активного обучения. М.: Высшая школа (Smolkin, А. М. (1991). Methods of active learning. M.: Higher School).

Стандарт вищої освіти України: другий (магістерський) рівень, галузь знань 07 Управління та адміністрування, спеціальності 071 - Облік і оподаткування (Higher education standard of Ukraine: second (master's) level, field of knowledge 07 - Management and administration, specialty 071 - Accounting and taxation).

Шигун, М. М. (2017). Професійна бухгалтерська освіта і кваліфікація: європейські орієнтири. Облік, оподаткування і контроль: теорія та методологія: зб. матеріалів міжнар. наук.-практ. інтернет-конф. Тернопіль: ТНЕУ, сс. 335-337 (Shyhun, M. M. (2017). Professional accounting education and qualifications: European guidelines. Accounting, taxation and control: theory and methodology: proceedings of international. scientific-practical internet conference. Ternopil: TNEU, pp. 335-337).

Asonitou Sofia. The necessity to develop university Teachers Pedagogical Training. A new 
Institutional Theory Approach (Department of Business Admimastration Technological

Educational Institute of Athems). Retrieved from:

https://www.researcggate.net/publication/319465046.

International Federation of Accountants (IFAC). Retrieved from: http://www.ifac.org/.

Paisey, C., Paisey, N. J. (2004). An analysis of accounting education research in Accounting Education an international journal. Accounting Education, 13 (1), 69-99.

\section{PEЗЮME}

Лемишовская Олеся, Яремко Ирина. Обеспечение профессиональной компетентности в процессе подготовки преподавателей учетно-экономических дисциплин с использованием инновационных педагогических технологий.

Статья посвящена теоретическому обоснованию значимости и содержания инновационных педагогических технологий для обеспечения профрессиональной компетентности будущего преподавателя профессионального обучения. Приведены современные тенденции в развитии университетского образования и проанализировано содержание и характер предлагаемых педагогических технологий с использованием инновационного инструментария. Раскрыто состояние и проблемы использования инновационных педагогических технологий в обеспечении специфических компетентностей преподавателя учетно-экономических дисциплин. На основе обобщения тематических исследований и практики сформулированы отдельные предложения использования инновационного инструментария по исследуемому профилю подготовки специалистов.

Ключевые слова: преподаватель учетно-экономических дисциплин, профессиональная подготовка образовательные инновации, инновационная образовательная деятельность, компетентности, технологии в образовании, педагогические технологии.

\section{SUMMARY}

Lemishovska Olesia, Yaremko Iryna. Ensuring professional competence in the process of training teachers of accounting and economic disciplines using innovative pedagogical technologies.

The article is devoted to the theoretical substantiation of the significance and content of innovative pedagogical technologies to ensure the professional competence of the future teacher of vocational training. The modern tendencies in the development of university education are given and the content and character of the offered pedagogical technologies with the use of innovative tools are analyzed. The article considers modern requirements for the general competence of the graduate with the use of innovations (innovative pedagogical technologies) on the example of university training within the field of knowledge 01 "Education", specialty 011 "Educational, pedagogical sciences" ("Master of Educational and Pedagogical Sciences", professional qualification "Teacher of accounting and economic disciplines").

The state and problems of using innovative pedagogical technologies in providing specific competences of a teacher of accounting and economic disciplines are revealed. The most problematic are socio-pedagogical (development of creative potential of participants in the educational process) and psychological and pedagogical (readiness of teachers and students to work in an innovative mode).

Innovative pedagogical technologies are considered in the article through the prism of interactive learning, information and value technologies, technologies of development of critical thinking, a set of methods, techniques, tools and forms of organization of the educational process in the parameter of psychological and pedagogical, scientific and technological and socio-economic innovations. Consideration of the declared issues largely concerns the disciplines of the educational-professional program, which combine 
pedagogical and professional knowledge and, in fact, "cement" the educational process in this area of university training. The practical experience of approbation of teaching skill by students was acquired during lectures and practical classes in the disciplines studied in the direction 07 "Management and administration". On the basis of generalization of thematic studies the guidelines for the development of innovative pedagogical technologies and use of innovative tools on a researched profile of training are formulated.

Key words: teacher of accounting and economic disciplines, vocational training, educational innovations, innovative educational activity, competence, technologies in education, educational technology.

УдК 378.016:577.1]:001.895

\section{Юлія Ліцман}

Сумський державний університет ORCID ID 0000-0001-5748-2213

Ольга Швець

Сумський національний аграрний університет ORCID ID 0000-0001-9872-3829

Наталія Осьмук

Сумський державний педагогічний

університет імені А. С. Макаренка

ORCID ID 0000-0002-0784-1350

DOI 10.24139/2312-5993/2020.03-04/091-107

\section{ОРГАНІЗАЦІЯ ЗМІШАНОГО НАВЧАННЯ ЗА ДОПОМОГОЮ « GООGLE CLASSROOM ॥ ПIД ЧАС ВИВЧЕННЯ БIООРГАНІЧНОÏ XIMIÏ ЗДОБУВАЧАМИ МЕДИЧНИХ СПЕЦІАЛЬНОСТЕЙ}

Стаття присвячена проблемі підвищення ефективності хімічної підготовки студентів спеціальності "Медицина». Обгрунтовано актуальність залучення електронного, мультимедійного та мобільного контенту в навчальний процес. Підтверджено, що умовою ефективності реалізації змішаного навчання є поєднання аудиторної та позааудиторної роботи. Здійснено експериментальну перевірку результативності застосування розробленої методики вивчення біоорганічної хімії в умовах змішаного навчання на платформі «Google Classroom». Установлено позитивний влив запропонованої методики на рівні навчальних досягнень студентів з хімії.

Ключові слова: змішане навчання, експеримент, "Google Classroom», заклад вищої освіти, здобувачі медичних спечіальностей, викладання хімії, методика викладання біоорганічної хімії.

Постановка проблеми. Цифровий контент набуває все більшого поширення в житті сучасного суспільства. Змінюеться спосіб комунікації між людьми, що призводить до розвитку нового типу мислення. У таких умовах роботодавцями висуваються нові вимоги до майбутніх фахівців. Серед яких: критичне мислення, уміння комплексно вирішувати проблеми, медіаграмотність і знання основ IT-технологій, креативність, готовність до неперервної освіти, до розвитку емоційного інтелекту. Формування таких компетентностей потребує зміни способу навчання студентів. Світова 
педагогічна спільнота запроваджує концепції електронного (e-learning), мультимедійного та мобільного навчання (m-learning). 3 одного боку, перенос навчання в електронне середовище робить його доступним у будьякий час і в будь-якому місці. Проте, для людини не менш важливим $\epsilon$ спілкування, обмін думками та емоціями. Поєднати переваги електронного і традиційного навчання дозволяє технологія змішаного навчання.

Упровадження нової технології в навчальний процес українських закладів вищої освіти потребує ґрунтовного аналізу зарубіжного й вітчизняного досвіду, удосконалення теоретико-практичних аспектів організації та супроводу змішаного навчання, розробки нових підходів до аудиторного навчання на основі розвитку живої емоційної комунікації між учасниками освітнього процесу в межах змішаного навчання під час викладання окремих дисциплін, зокрема хімічних. Для викладачів ЗВО актуальними $\epsilon$ розробка й апробація алгоритму реалізації моделей змішаного навчання.

Аналіз актуальних досліджень. Концептуальні засади змішаного навчання (blended learning) сформовані в роботах американських дослідників. Трансформація поглядів цих учених щодо дефініції поняття «змішане навчання» пройшла шлях від технологічного поєднання «online» і «face to face» підходів (Reay, 2001; Bersin, 2004) до педагогічнокомунікаційної «ефективної комбінації способів передачі інформації, моделей викладання та стилів навчання, що засновано на відкритому спілкуванні всіх учасників навчального процесу» (Heinze \& Procter, 2004).

Узагальнюючи сучасні погляди зарубіжних науковців щодо змісту поняття «змішане навчання», вітчизняні дослідники пропонують розглядати його як «цілеспрямований процес створення освітнього середовища, що поєднує очне, дистанційне та електронне навчання, у якому взаємодія суб'єктів педагогічного процесу здійснюється у процесі інтеграції безпосередньо живого спілкування та опосередкованого за допомогою технологічних засобів як синхронно, так i асинхронно» (Данисько і Семеновська, 2018, с. 4).

Адаптацією ідей зарубіжних науковців до реалій вітчизняної педагогічної науки та практики в різні часи займались О. Барна, О. Коротун, В. Кухаренко, О. Рафальська, Я. Сікора, С. Терещук, О. Чугай, Т. Шроль та інші.

У сучасній педагогічній науці накопичений певний досвід щодо реалізації моделей змішаного навчання у вищій освіті з метою формування інтегральної компетентності майбутніх фахівців різних напрямів підготовки; науковці аналізують переваги й недоліки даної технології навчання, висвітлюють проблеми щодо його впровадження та пропонують шляхи їх вирішення (Барна, 2016; Михайленко і Нестеренко, 2019; Сікора, 2016; Терещук, 2017). Більшість дослідників розглядають змішане навчання як єдність традиційного (Face to face), дистанційного (Distance learning), 
мобільного (mobile learning) та електронного (e-learning) навчання.

у публікаціях іноземних та вітчизняних учених, присвячених упровадженню змішаного навчання під час вивчення шкільного курсу хімії (Бабенко, 2017; Нетрибійчук, 2017) та хімічних дисциплін у вітчизняних закладах вищої освіти (Bernard et al., 2017; Большаніна та ін., 2020; Lo\&Tang, 2018; Seery\&O’Connor, 2015; Чхало, 2018; Williams et al., 2008) розглянуто приклади застосування як окремих елементів змішаного навчання (елементи технології BYOD в аудиторній та позааудиторній роботі, поєднання лабораторних робіт із мультимедійним відеороликами та інтерактивними веб-компонентами: URL та QR посилання, симулятори та молекулярні моделі, online-вікторини та інтерактивні дошки; залучення хмарних сервісів тощо), так і різних його моделей, особливо «перевернутий клас» та «ротаційна модель». Практика реалізації змішаного навчання підтверджує його позитивний вплив на ефективність засвоєння навчального матеріалу студентами, проте аналіз публікацій свідчить, що методика викладання дисциплін хімічного циклу в умовах змішаного навчання здобувачів медичних спеціальностей залишається недостатньо розробленою.

Мета статті: теоретико-методичне обґрунтування методики викладання біоорганічної хімії здобувачам медичних спеціальностей в умовах змішаного навчання.

Методи дослідження: Досягнення мети передбачало застосування низки методів: загальнонаукових - аналіз, синтез, абстрагування й узагальнення, що уможливили вивчення стану розробки й реалізації моделей змішаного навчання у вищій освіті; конкретно-наукові: емпіричні спостереження, опитування, анкетування, експеримент, що забезпечили перевірку авторської методики змішаного навчання; статистичні - для кількісного та якісного аналізу отриманих результатів експерименту.

Виклад основного матеріалу. Більшість найпопулярніших освітніх трендів (онлайн курси, активне навчання, едьютейнмент, персоніфікація, розвиток емоційного інтелекту, навчання впродовж всього життя) можуть бути реалізовані в межах технології змішаного навчання. Саме тому його ідеї визнаються не лише в колі вітчизняних науковців, а мають підтримку і на державному рівні. Зокрема, у Законі України «Про вищу освіту» декларується «... сприяння сталому розвитку суспільства шляхом підготовки конкурентоспроможного людського капіталу та створення умов для освіти протягом життя» (Закон України «Про вищу освіту», 2017).

У рамках реалізації вищенаведених нормативних актів у Сумському державному університеті (СумДУ) протягом чотирьох семестрів 2017-2019 р. проводився експеримент 3 апробації моделей змішаного навчання http://exp.sumdu.edu.ua/\#about. Кожен учасник експерименту надавав опис власної моделі змішаного навчання, розміщував анонси відкритих занять 
(для колег, учасників та організаторів експерименту) на сайті експерименту, проводив власні та відвідував заняття інших учасників, брав участь у методичних семінарах, аналізував результати впровадження авторської моделі змішаного навчання тощо. Організатори створювали умови для обговорення дослідження на сайті, проводили опитування викладачів та студентів щодо ефективності впроваджених моделей, відвідували заняття та знімали відео. Протягом трьох навчальних семестрів ми брали участь у цьому експерименті: розробляли та відпрацьовували авторську методику вивчення біоорганічної хімії в умовах змішаного навчання.

Біоорганічна хімія є частиною навчальної дисципліни «Біологічна та біоорганічна хімія» і викладається в II семестрі першого курсу для студентів, які навчаються за спеціальністю «Медицина» у медичних закладах III-IV рівнів акредитації. Загальна кількість годин, відведених на вивчення біоорганічної хімії становить 90, з яких 40 складає аудиторна робота (10 - лекції, 30 - практичні заняття) та 50 - самостійна робота студентів. У процесі навчання було виявлено такі суперечності:

- між недостатнім рівнем сформованості у студентів першого курсу навичок самостійної роботи та необхідністю самостійного опрацювання певної частини навчальної інформації з дисципліни;

- між недостатнім рівнем знань студентів 3 органічної хімії та необхідністю спиратися на них як на базові під час вивчення біоорганічних сполук;

- між необхідністю керування самостійною роботою студентів під час аудиторного та позааудиторного навчання й обмеженнями щодо організації цієї роботи в умовах традиційного навчання.

Таким чином, доцільність розробки та впровадження в навчальний процес методики вивчення біоорганічної хімії в умовах змішаного навчання зумовлена, по-перше, необхідністю подолання вказаних суперечностей; по-друге, - створенням більш оптимальних та ефективних умов для навчання.

Дослідження проводилося в декілька етапів.

На етапі планування було проаналізовано робочу програму й розподіл матеріалу для очної та онлайн частин, установлено обсяг навчального часу для кожної теми, відібрано та розроблено необхідні навчальні матеріали (презентації до лекційних та практичних занять, інструкції підготовки до різних видів занять та проведення лабораторних дослідів, тестові завдання для контролю навчальних досягнень, відеоматеріали тощо).

За пропозицією організаторів експерименту з апробації моделей змішаного навчання у СумДУ види навчальної діяльності було розподілено за двома категоріями: традиційна форма навчання і навчання, яке потребує залучення онлайн діяльності й використання інтернет-ресурсів.

Наступний організаційний етап дослідження передбачав 
порівняльний аналіз наявних моделей змішаного навчання і вибір платформи спілкування, що найбільш відповідають цілям і завданням нашої методики.

Наразі в науковій літературі і практиці представлено різні думки щодо класифікації моделей змішаного навчання. Найчастіше серед чотирьох основних виокремлюють ротаційну (Rotation Station Model), гнучку (Flex Model), «зроби сам» (A La Carte Model/Self-Blend) та модель збагаченого віртуального навчання (Enriched Virtual Model/Online Driver) (Patrick et al., 2015). У деяких дослідженнях пропонують шість моделей, додаючи ще Online Lab Model i Face-to-Face Driver Model (Guido, 2020). Остання класифікація побудована на поєднанні декількох критеріїв, а саме: визначення ролі викладача, місця навчання, методів планування роботи та способів доставки навчального контенту.

Проведений аналіз наявних моделей змішаного навчання, урахування специфіки навчальної дисципліни «Біоорганічна хімія» та особливостей студентської аудиторії, дозволили обрати в якості базових моделі «Face-to-Face Driver» і «Rotation Station Model».

Так, модель «Face-to-Face Driver», яка $\epsilon$ найбільш близькою до традиційного навчання з необхідністю чіткого дотримування навчального плану, розкладу занять та робочої навчальної програми (РНП) 3 дисципліни, було обрано, оскільки експеримент проводився зі студентами денної форми в межах формального навчання в університеті. Традиційна робота на лекціях, лабораторних і практичних заняттях доповнюється цифровими платформами, використанням стаціонарних і мобільних пристроїв як під час аудиторних занять, так і в позааудиторній роботі. Ця модель дає змогу підкріплювати позааудиторну навчальну діяльність студентів навчальним онлайн спілкуванням у формі надання індивідуальних та фронтальних консультацій, результатів навчання тощо. Також у межах цієї моделі відбувається втілення елементів інтерактивної діяльності під час аудиторних занять (Patrick et al., 2015).

Модель «Rotation Station Model» дає змогу залучити більшість студентів до активної навчальної діяльності під час аудиторного заняття, підвищити інтенсивність та якість взаємодії викладач - студент, студент студент; підвищити інтерес до навчального процесу та зменшити втому від нього за рахунок зміни видів діяльності та використання різних способів опрацювання навчальної інформації, зокрема, 3 використанням як традиційних, так і ІК-технологій (Patrick et al., 2015).

У якості платформи для навчального спілкування було обрано сервіс «Google Classroom». Вважаємо, що він $\epsilon$ аналогом Moodle, проте відрізняється простотою організації роботи та програмного інтерфейсу. Доступ до «Google Classroom» $€$ відкритим, реєстрація проста, користування не потребує введення паролю кожного разу. Цей сервіс має 
необхідний функціонал для комунікації, організації навчання та проведення контролю, оскільки дає змогу: розміщувати навчальнометодичні матеріали у формі текстових файлів, відеоматеріалів, інтернетпосилань; створювати завдання для студентів із зазначеним терміном виконання; пропонувати завдання в тестовій формі з використанням cepвicy "Google Forms», коментувати як завдання, так і відповіді, проводити навчальні чати з використанням системи коментарів, вести облік успішності студентів. Зауважимо, що пошук наявних у інтернет відео хімічних експериментів, певних навчальних фільмів у платформі "Google Classroom» $€$ достатньо простим і відбувається дуже швидко за рахунок введення ключового слова або слів.

Отже, для навчального спілкування в «Google Classroom» нами було створено класи: «Лекції» з біоорганічної хімії для роботи зі студентами усього лекційного потоку та для кожної групи - «Практичні заняття».

у відповідних навчальних класах Google Classroom студенти отримували навчально-методичні матеріали: робочу програму, плани занять, регламент навчальної дисципліни, список рекомендованої літератури, тексти лекцій та їх мультимедійні презентації, необхідні посилання (інтернет-джерела, відео хімічних експериментів, на інтерактивне опитування, тести тощо).

Інтеграція сервісів та інструментів Google Suite for Education дозволяє використовувати їх для підготовки навчально-методичного матеріалу. Зокрема, для створення документів i роботи 3 таблицями ми використовували інструменти «Docs» i «Sheets», пошук та збереження відеоматеріалів здійснювали за допомогою «Үou Tube», для підготовки презентацій користувалися «Slides», для додаткового спілкування «Gmail», всі файли і документи зберігали в сховищі «Driver».

За допомогою «Google Forms» створювали форми для опитування. Для таких видів тестових завдань, як: «з вибором однієї правильної відповіді», «з вибором декількох правильних відповідей», «на відповідність» систему перевірки повністю автоматизовано, інші форми завдань перевірялися вручну. Результати виконаних завдань у «Google Forms» аналізувалися й візуалізувалися у зручній для викладача та студентів формах. Можна було побачити відсотки правильних відповідей на кожне запитання, зробити висновки щодо рівня засвоєння певних понять та сформованості вмінь і використати їх для подальшого корегування навчальної роботи.

Основними організаційними формами навчання під час вивчення біоорганічної хімії були: лекції, практичні заняття та самостійна робота студентів.

Під час лекційних занять застосовували такі елементи, як: 
інтерактивне опитування, аналіз його результатів, проведення мініконсультації на підставі результатів інтерактивного опитування. Загальна тривалість лекційного заняття 80 хвилин, 50 із яких витрачалося на проведення лекції традиційним способом. Після цього студентам пропонувалося інтерактивне опитування щодо нового матеріалу за посиланням на Google-форму. У ній містився перелік запитань і понять, які потребували додаткового роз'яснення.

Наприклад, для лекції з теми: «Амінокислоти. Білки» студентам пропонувалися такі запитання:

1. Які з запропонованих питань потребують уточнення? Які сполуки називаються амінокислотами? За якими ознаками класифікують амінокислоти? Які причини існування ізомерії амінокислот? Які хімічні властивості альфа-амінокислот, зумовлені наявністю в них карбоксильної та аміногрупи? Які хімічні перетворення відбуваються з альфа-, бета-, гамаамінокислотами при нагріванні? Які типи хімічних зв'язків наявні в різних структурах білків? Які кольорові реакції амінокислот та білків?

2. Які з запропонованих термінів необхідно пояснити: альфаамінокислота, пептид, пептидний зв'язок, первинна структура білка, вторинна структура білка, третинна структура білка, четвертинна структура білка, нативна структура білка, денатурація, незамінна амінокислота?

3. Сформулюйте, будь ласка, власне запитання.

Опитування в такій формі стало звичним для студентів, відбувалося оперативно і давало змогу вчасно організувати зворотній зв'язок. На підставі одержаних результатів студентам надавалася міні-консультація.

Під час проведення практичних занять застосовували такі елементи, як: обговорення результатів домашнього інтерактивного опитування та тестування; проведення й аналіз індивідуального або групового тестування; опрацювання навчальної інформації у формі відео, мультимедійних презентацій тощо; виконання завдань за інтернет-посиланнями; консультативна бесіда у складі групи з викладачем. Приклад наповнення папки «Практичне заняття» в Google Classroom наведено на рис. 1.

Використання наведених елементів авторської методики навчання ми пропонуємо розглянути на прикладі трьох основних варіантів проведення практичних занять.

Перший - базувався на моделі «Face-to-Face Driver» та дозволив поєднати традиційну та онлайн форми діяльності студентів. Заняття починалося з аналізу результатів домашнього опитування або тестування (виявлення й попередження типових помилок). На підставі отриманих результатів відбувалося переструктурування навчальної інформації (визначалися пріоритетні за складністю розуміння блоки питань). Далі навчальна інформація опрацьовувалася під час бесіди, виконання тренувальних вправ тощо. Також на таких заняттях пропонувалась групова 
робота з підготовки відповідей на завдання за інтернет-посиланнями.

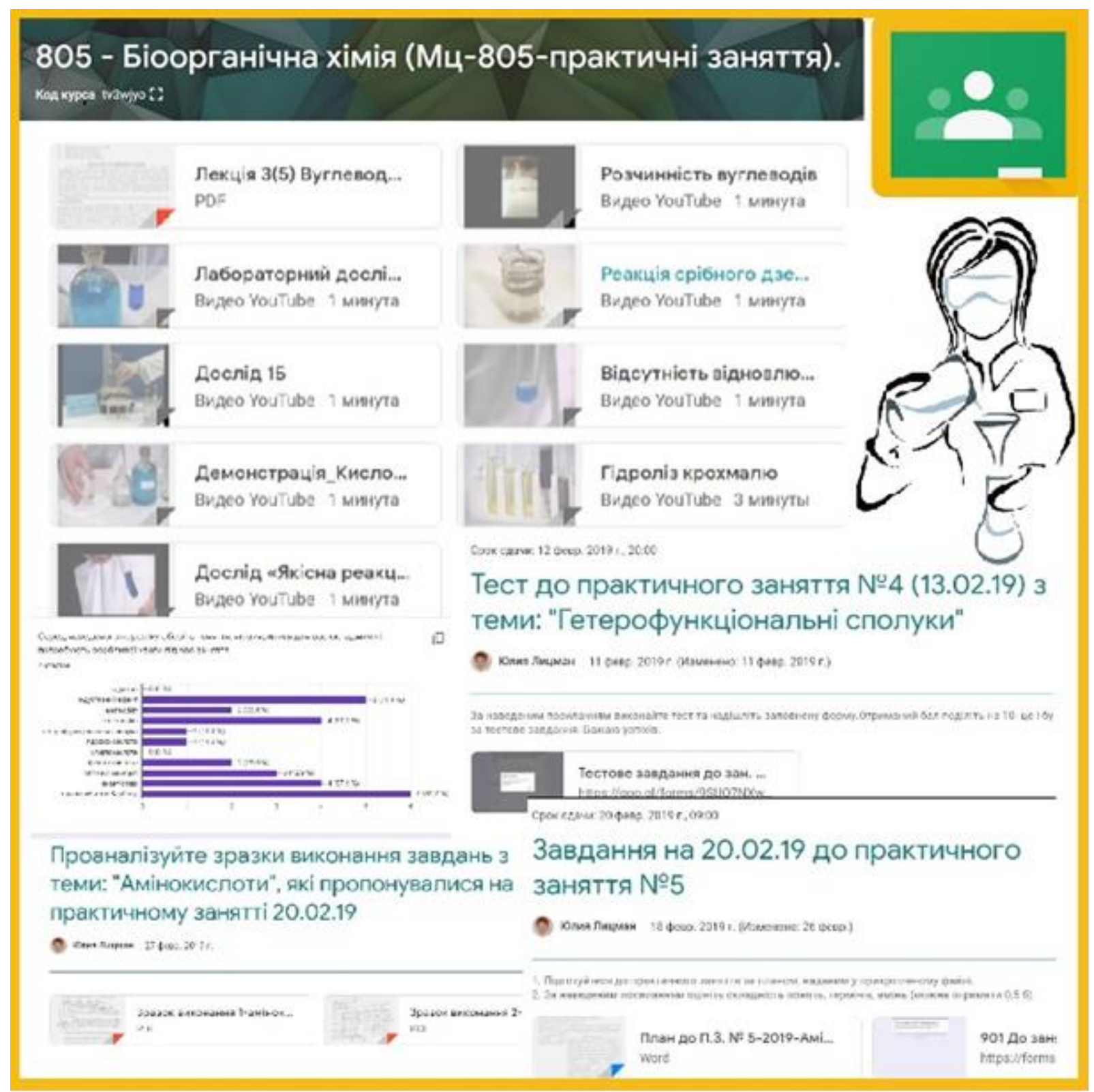

Рис. 1. Приклад матеріалів, розміщених у Google Classroom

Другий варіант проведення практичних занять застосовувався рідко (до 4 разів за семестр) і базувався на моделі «Rotation Station Model». На занятті студенти розміщувалися групами (для цього пересувалися меблі) для зручності роботи й відокремлено від інших. Кожна група самостійно певний час працювала на окремій навчальній станції («Формули», «Рівняння», «Тестування»).

Особливістю станції «Консультація» була спільна робота 3 викладачем (бесіда), що допомагала отримати пояснення викладача та студентів щодо найскладніших питань. Розподіл часу такого заняття передбачав: організаційний момент - 10 хвилин (по 5 хвилин на вступ і паузи, пов'язані зі зміною діяльності), час роботи на станціях - 60 хвили (по 
15 хвилин на кожній). Останні 10 хвилин заняття аналізувалися результати тестових завдань та надавалася консультація. Приклад видів роботи студентів на станціях практичного заняття 3 теми «Гідроксикислоти» наведено в табл. 1.

Таблиця 1

Види діяльності студентів по станціям під час вивчення теми «Гідроксикислоти»

\begin{tabular}{|c|c|c|}
\hline Станція & $\begin{array}{l}\text { Вид } \\
\text { діяльності } \\
\text { студентів }\end{array}$ & Опис діяльності \\
\hline «Формули» & Самостійно & $\begin{array}{l}\text { Виконання завдань і вправ на розпізнавання } \alpha, \beta, \gamma- \\
\text { гідроксикислот, спиртокислот та фенолокислот, } \\
\text { різних за основністю та атомністю гідроксикислот, } \\
\text { співставлення тривіальних та систематичних назв } \\
\text { гідроксикислот, знаходження асиметричного атому } \\
\text { Карбону, складання формул оптичних ізомерів } \\
\text { молочної, яблучної та винної кислот }\end{array}$ \\
\hline «Рівняння» & Самостійно & $\begin{array}{l}\text { Виконання завдань і вправ на складання рівнянь } \\
\text { хімічних реакцій, типових для гідроксикислот }\end{array}$ \\
\hline «Тестування» & Самостійно & $\begin{array}{l}\text { Виконання тестових завдань. У цьому випадку } \\
\text { відповідь на кожне запитання обговорюється у } \\
\text { групі і надсилається один узгоджений спільний } \\
\text { варіант заповнення тестової форми }\end{array}$ \\
\hline «Консультація» & $\begin{array}{l}\text { Спільно } \\
\text { викладачем }\end{array}$ & $\begin{array}{l}\text { Обговорення найскладніших понять теми. } \\
\text { Наприклад, складання рівнянь реакцій, які } \\
\text { ілюструють специфічні властивості гідроксикислот } \\
\text { (утворення лактидів, ненасичених карбонових } \\
\text { кислот, лактонів при нагріванні, реакції } \alpha- \\
\text { гідроксикислот з виділенням мурашиної кислоти), } \\
\text { спільне та відмінне в хімічних властивостях } \\
\text { спиртового та фенольного гідроксилів, оптична } \\
\text { ізомерія }\end{array}$ \\
\hline
\end{tabular}

За відсутності станції «Консультація» передбачалося збільшення часу на проходження станцій до 20 хвилин. При цьому викладач за потреби надавав консультативну допомогу. За необхідності виконання експерименту студентам пропонувалася робота на станції «Лабораторна» за інструкціями, наведеними в лабораторному журналі та супроводом лаборанта.

Усі завдання, необхідні для роботи на станціях, розміщувались у класі «Практичні заняття», а доступ надавався за ступенем їх проходження.

Як свідчать результати експерименту, умовами ефективного впровадження моделі «Rotation Station Model» у навчальний процес $є$ : ретельне планування структури заняття (час проходження групою станцій, схема ротації, вибір навчальних завдань); підготовка навчальних завдань та навчально-методичних роздаткових матеріалів; належний рівень мотивації студентів до виконання самостійної роботи; кількість студентів у 
групі не більше 16, щоб їх можна було поділити на 4 міні-групи по 3-4 студенти. Склад такої групи формувався за бажанням самих студентів, i, як правило, залишався сталим протягом усього навчального періоду

Третій варіант організації практичних занять стосувався контролю й перевірки навчальних досягнень студентів із використанням елементів змішаного навчання. Студенти проходили комп'ютерне тестування та виконували письмові роботи. Тестова частина тривала 10-12 хвилин, під час ії виконання студенти отримували однаковий варіант завдання. Проте, завдяки використанню налаштувань «перемішування відповідей» та «перемішування запитань» на власних мобільних пристроях, студенти мали по-різному скомпоновані завдання, що дозволяло отримати індивідуальні результати. Потім виконувалася письмова робота за варіантами. Останні 15 хвилин заняття обговорювалися результати тестів, що перевірялися автоматично й відображалися у «Forms», аналізувалися відповіді письмової роботи. 3 еталонами виконання різних варіантів контрольних завдань, розміщеними у класі «Практичні роботи», студенти могли ознайомитися в позаурочний час. Проте доступ до них надавався лише після написання контрольної роботи. Таким чином, використання "Google Classroom» для організації змішаного навчання дозволяє не тільки ознайомити студентів із правильними відповідями, але й проаналізувати їх.

Організація самостійної роботи студентів передбачала: підготовку до різних видів аудиторних занять за навчально-методичними матеріалами, розміщеними в «Google» класі напередодні або після занятт; проведення онлайн-консультацій та навчальних чатів; виконання індивідуальних та групових завдань; підготовка звітів і презентацій лабораторних робіт.

Ключовим елементом самостійної доаудиторної підготовки студентів до лекції було завчасне ознайомлення з ії текстом, написання коментарів щодо складності певних питань, понять тощо. На лекції студенти мали можливість користуватися опрацьованими матеріалами і робити нотатки. Перед практичними заняттями в «Google» класі студенти отримували всі необхідні навчально-методичні матеріали, зокрема, посилання на відео дослідів та план підготовки з рубриками: «Що необхідно знати?», «Що необхідно вміти?», «Що необхідно зробити?», «Перелік питань практичного заняття». Також напередодні заняття студентам пропонувалося пройти інтерактивне опитування або тестування, спрямоване на перевірку рівня розуміння ними навчальної інформації.

Індивідуальні та фронтальні онлайн консультації здійснювалися у формі коментування відповідних завдань та під час спілкування в навчальному чаті, що проводилися напередодні контрольної роботи.

Крім розглянутої вище самостійної підготовки до лекцій, практичних занять та контрольних було передбачено виконання індивідуальних завдань, у якості яких студентам пропонувалися завдання проблемно- 
пошукового характеру. Наприклад, до теми «Гетерофункціональні сполуки» студентам були надані посилання на певні відео і запропоновані такі завдання:

1. За твердженням педіатра $Є$. Комаровського, зрозуміти, що таке ацетон, можна на основі знань шкільного курсу хімії. Поясніть, які сполуки називаються ацетоновими (кетоновими) тілами; чому їх об'єднують у таку групу? Що може спричинити появу запаху ацетону в людини? За яких умов для дітей «лікування» полягає у вживанні глюкози? (https://bit.ly/2V5FjVW).

2. Чи можна використати якісну реакцію на фенол для виявлення саліцилової кислоти? Відповідь поясніть (https://bit.ly/3b1J7hJ).

3. Чи можна використати якісну реакцію багатоатомних спиртів для ідентифікації винної кислоти? Відповідь поясніть (https://bit.ly/39XXlip).

4. Пригадаємо тему «Гідроліз» з медичної хімії: У відео звучить: «додаємо розчин натрій ацетату для створення кислого середовища». Чи правильне це висловлювання? (https://bit.ly/39VHOQ1).

Студенти мали обмежений час на розміщення відповідей, які бачив лише викладач. Як правило, від групи з 15 студентів отримували 3-5 відповідей. Після цього в «Google» класі розміщувалися правильні відповіді.

Звіт із лабораторної роботи студенти оформлювали у вигляді презентації, що містила фото дослідів, опис ознак реакцій і не дублювала інформацію, записану в лабораторному журналі. Приклад виконання такого звіту можна переглянути за посиланням: https://bit.ly/2VbZiSM.

На нашу думку, ефективність вищеописаного процесу організації змішаного навчання потребує інноваційної діяльності як із боку викладача, так і студентів, що представлена на рис. 2.

Інноваційна діяльніс ть вик.ладача

1. Вибір моделі змішаного навчання та іх методична адаптащін.

2. Вибір платформи «Google Classrooms, pозмішення на ній навчальнометодичних матеріалів, інструктаж консуль тування студентів.

3. Організацін інтерактивноі діял上ності студентів під час виконання різних типів навчальних завдань
Інноваційна діяшьніс ть студента

1. Освітня діяленість в моделі змішаного навчання.

2. Оволодіння навичками роботи в «Google Classroom» та 3 іншими програмними засобамт освітнь 01 діяльності.

3. Набуття досвіду інтерактивної навальної дінльності

Рис 2. Інноваційна діяльність викладача та студента під час організації змішаного навчання

На початку впровадження авторської методики вивчення 
біоорганічної хімії в умовах змішаного навчання ми виходили $з$ припущення, що її впровадження призведе до підвищення ефективності навчального процесу. Показником ефективності навчального процесу нами було обрано рівень навчальних досягнень студентів. Для перевірки цієї гіпотези у весняному семестрі 2017-2018 н. р. у чотирьох навчальних групах студентів першого курсу спеціальності «Медицина» було проведено педагогічний експеримент, у якому брав участь 51 студент (25 осіб в експериментальній групі, 26 - у контрольній).

На початку вивчення біоорганічної хімії було проведено вхідний контроль -тестова контрольна робота з органічної хімії. Саме знання 3 цього розділу шкільного курсу хімії $\epsilon$ необхідною умовою успішного опанування хімії біоорганічних сполук. Пропонувалося три типи тестових завдань: з вибором однієї правильної відповіді, на відповідність і відкритої форми (складання структурних формул, рівнянь хімічних реакцій). Кожне завдання і, відповідно, робота в цілому, оцінювалися певною кількістю балів. Після перевірки для кожної роботи розраховувався відсоток правильного виконання за формулою:

$$
\%=\frac{n}{N} \times 100 \% \text {, де \% - відсоток правильного виконання, } \mathrm{n}-\text { загальна }
$$

кількість балів за роботу певного студента, N - максимально можлива кількість балів за роботу. За результатами студенти згідно рівнів навчальних досягнень були розподілені на чотири групи: початковий рівень - відсоток виконання завдань становив менше $60 \%$; середній - від 60 \% до 69,9 \%; достатній - від 70 \% та менше 84,9 \%; високий - понад 85 \%. Результати виконання завдань студентами представлені в табл. 2.

Таблиця 2

\section{Розподіл студентів контрольної (К) та експериментальної (Е) груп за} рівнями навчальних досягнень на початку експерименту

\begin{tabular}{|l|c|c|c|c|}
\hline $\begin{array}{c}\text { Рівень } \\
\text { давчальних }\end{array}$ & $\begin{array}{c}\text { Кількість } \\
\text { студентів } \\
\text { контрольної } \\
\text { групи (К=26) }\end{array}$ & $\begin{array}{c}\text { \% студентів, } \\
\text { які виконали } \\
\text { завдання на } \\
\text { певному рівні }\end{array}$ & $\begin{array}{c}\text { Кількість студентів } \\
\text { експериментальної } \\
\text { групи (E=25) }\end{array}$ & $\begin{array}{c}\text { \% студентів, } \\
\text { які виконали } \\
\text { завдання на } \\
\text { певному рівні }\end{array}$ \\
\hline Початковий & 2 & $7,7 \%$ & 4 & $16 \%$ \\
\hline Середній & 7 & $26,9 \%$ & 6 & $24 \%$ \\
\hline Достатній & 12 & $46,2 \%$ & 8 & $32 \%$ \\
\hline Високий & 5 & $19,2 \%$ & 7 & $28 \%$ \\
\hline
\end{tabular}

Для порівняння отриманих результатів використовували $\chi_{\text {enn }}^{2}$ (критерій хі-квадрат), який розраховували за формулою:

$$
\chi_{\text {eиn }}^{2}=N \cdot M \cdot \sum_{i=1}^{L} \frac{\left(\frac{n_{i}}{N}-\frac{m_{i}}{M}\right)^{2}}{n_{i}+m_{i}} ; \text { де емпіричне значення хі-квадрат критерію, }
$$

N та M - загальна кількість студентів в експериментальній та контрольній 
групах відповідно; $\mathrm{n}_{\mathrm{i}}$ та $\mathrm{m}_{\mathrm{i}}$ - кількість студентів експериментальної та контрольної груп відповідно, які входять до групи певного рівня навчальних досягнень (Новіков, 2004, с. 52).

На підставі отриманих результатів розраховане $\chi_{\text {enn }}^{2}=3,64$ виявилося меншим за теоретичне $\left(\chi_{\text {mео }}^{2}=7,82\right)$ для L=4 (для нашого випадку L кількість груп студентів за рівнями навчальних досягнень). Такий результат дозволив стверджувати, що на початку педагогічного експерименту рівні навчальних досягнень студентів контрольної й експериментальної груп збігаються з рівнем значущості 0,05, тобто можна вважати, що студенти контрольної та експериментальної груп практично не відрізнялися за рівнем навчальних досягнень (Новіков, 2004, с. 52).

Надалі протягом весняного семестру для студентів контрольної групи навчання відбувалося без застосування авторської методики вивчення біоорганічної хімії в умовах змішаного навчання, а для студентів експериментальної - із застосуванням указаної методики.

Наприкінці весняного семестру студентам обох груп було запропоновано виконання контрольного зрізу знань про біоорганічні сполуки. Завдання були представлені такими самими тестовими формами, що й під час вхідного контролю. Підхід до встановлення рівня навчальних досягнень залишився незмінним. Отримані результати представлено в таблиці 3.

Таблиця 3

Розподіл студентів контрольної (К) та експериментальної (Е) груп за рівнями навчальних досягнень наприкінці експерименту

\begin{tabular}{|l|c|c|c|c|}
\hline $\begin{array}{c}\text { Рівень } \\
\text { давчальних }\end{array}$ & $\begin{array}{c}\text { Кількість } \\
\text { студентів } \\
\text { контрольної } \\
\text { групи (К=26) }\end{array}$ & $\begin{array}{c}\text { \% студентів, } \\
\text { які виконали } \\
\text { завдання на } \\
\text { певному } \\
\text { рівні }\end{array}$ & $\begin{array}{c}\text { Кількість студентів } \\
\text { експериментальної } \\
\text { групи (E=25) }\end{array}$ & $\begin{array}{c}\text { \% студентів, } \\
\text { які виконали } \\
\text { завдання на } \\
\text { певному } \\
\text { рівні }\end{array}$ \\
\hline Початковий & 6 & $23,1 \%$ & 1 & $4 \%$ \\
\hline Середній & 12 & $46,2 \%$ & 5 & $20 \%$ \\
\hline Достатній & 6 & $23,1 \%$ & 11 & $44 \%$ \\
\hline Високий & 2 & $7,7 \%$ & 8 & $32 \%$ \\
\hline
\end{tabular}

На підставі отриманих результатів розраховане $\chi_{\text {enn }}^{2}=11,45$ виявилося більшим за теоретичне ( $\chi_{\text {mеор }}^{2}=7,82$ ). Такий результат дозволив стверджувати, що наприкінці педагогічного експерименту достовірність різниці рівнів навчальних досягнень студентів контрольної й експериментальної груп становить $95 \%$, тобто можна вважати, що студенти контрольної та експериментальної груп відрізнялися за рівнем навчальних досягнень.

Результати розподілу студентів обох груп за рівнями навчальних досягнень у порівнянні представлено на гістограмі (див. рис. 3). 


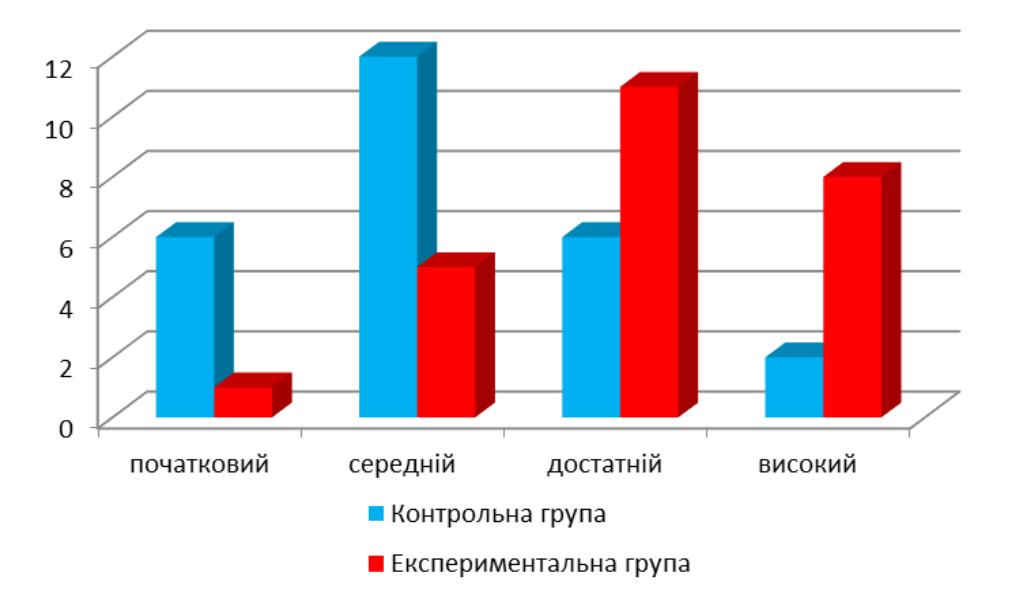

Рис. 3. Рівні навчальних досягнень студентів контрольної та експериментальної груп наприкінці експерименту.

Отже, порівняння навчальних досягнень студентів контрольної та експериментальної груп наприкінці педагогічного експерименту дозволило стверджувати, що відмінності в навчальних досягненнях студентів обох груп, які $\epsilon$ статично значущими, зумовлені тим, що в експериментальній групі, порівняно 3 контрольною, значно більша кількість студентів виконувала завдання на достатньому та високому рівнях i, відповідно, менша кількість студентів виконувала завдання на початковому та середньому рівнях.

Таким чином, аналіз результатів педагогічного експерименту засвідчив, що використання запропонованої методики вивчення біоорганічної хімії в умовах змішаного навчання сприяє підвищенню ефективності навчального процесу.

Висновки та перспективи подальших наукових розвідок. Проведене дослідження підтвердило, що змішане навчання дозволяє результативно поєднувати накопичений педагогічною наукою досвід традиційного навчання із новими інформаційно-комунікативними технологіями. Доведено позитивний вплив методики викладання біоорганічної хімії здобувачам медичних спеціальностей в умовах змішаного навчання на основі платформи «Google Classroom» на підвищення результативності освітнього процесу. Установлено, що умовами ефективного використання обраної платформи для організації змішаного навчання $€$ інноваційна діяльність викладача і студентів. Вважаємо, що вона сприяє формуванню у студентів здатності адаптуватися та діяти в новій ситуації; учитися самостійно, відповідати за професійний розвиток; визначати рівень виконання роботи, забезпечувати її якість; виявляти креативність у вирішенні завдань; працювати автономно та в команді; використовувати IKT у хімічних дослідженнях і професійній діяльності.

Перспективи подальших досліджень вбачаємо в удосконаленні запропонованої методики за рахунок урізноманітнення онлайн комунікації 
зі студентами (проведення веб-конференцій та консультацій із

використанням програм Zoom, Skype), видів навчальних завдань тощо. Також розглядаємо можливість апробації запропонованої методики для викладання хімічних дисциплін для студентів інших спеціальностей.

\section{ЛІТЕРАТУРА}

Bernard, P., Broś, P., Migdał-Mikuli, A. (2017). Influence of blended learning on outcomes of students attending a general chemistry course: summary of a five-year-long study. Chemistry Education Research and Practice, 18, 682-690. Retrieved from: https://doi.org/10.1039/C7RP00040E

Bersin, J. (2004). The Blended Learning Book: Best Practices, Proven Methodologies and Lessons Learned. San Francisco: Pfeiffer.

Guido, M. (2020, January 10). How to Put the Six Blended Learning Models into Action [+ Examples \& Download]. Retrieved from: https://www.prodigygame.com/blog/sixblended-learning-models-examples-download/

Heinze, A., Procter, C. (2004). Reflections on the Use of Blended learning. In Education in a Changing Environment, University of Salford. Retrieved from: http://usir.salford.ac.uk/1658/

Lo, C., Tang, K. (2018). Blended Learning with Multimedia e-Learning in Organic Chemistry Course. International Symposium on Educational Technology (ISET), Osaka, 2018, (pp. 23-25).

Patrick, S. (2015). Blended Learning: The Evolution of Online And Face to Face Education from 2008-2015. Retrieved from: http://www.inacol.org/wpcontent/uploads/2015/07/iNACOL_Blended-Learning-The-Evolution-of-Online-AndFace-to-Face Education-from-2008-2015.pdf

Reay, J. (2001). Blended learning - a function for the future. Knowledge Management Review, 4 (3), 6.

Seery, M., O'Connor, C. (2015). E-Learning and Blended Learning in Chemistry Education. In Javier Garc'ıa-Mart'ınez, Elena Serrano-Torregrosa (Eds.), Chemistry Education. Best Practices, Opportunities and Trends, (pp. 651-667). Weinheim: Wiley-VCH Verlag $\mathrm{GmbH} \&$ Co.

Williams, N. A., Bland, W., Christie, G. (2008). Improving student achievement and satisfaction by adopting a blended learning approach to inorganic chemistry. Chemistry Education Research and Practice, 9, 43-50. Retrieved from: https://doi.org/10.1039/b801290n

Бабенко, О. М. (2017). Впровадження моделі «ротація за станціями» у процес навчання хімії. Актуальні питання природничо-математичної освіти, 2 (10), 11-17 (Babenko, O. (2017). Implementation of the "station rotation" model in the process of chemistry teaching. Topical Issues of Science and Mathematics Education, 2 (10), 11-17).

Барна, О. В. (2016). Технологія змішаного навчання в курсі методики навчання інформатики. Відкрите освітнє е-середовище сучасного університету, 2, 24-37. Режим доступу: http://nbuv.gov.ua/UJRN/oeeemu_2016_2_4 (Barna, O. (2016). Blended learning technology in the course of methodology of teaching informatics. Open learning e-environment of the modern University, 2, 24-37. Retrieved from: http://nbuv.gov.ua/UJRN/oeeemu_2016_2_4).

Большаніна, С. Б., Диченко, Т. В., Чайченко, Н. Н. (2020). Застосування платформи МIX для організації змішаного навчання загальної хімії здобувачів інженерних спеціальностей. Інформаційні технології і засоби навчання, 75 (1), 138-152 (Bolshanina, S., Dychenko, T., Chaichenko, N. (2020). The use of MIX platform for 
organizing blended learning in teaching general chemistry to students of engineering specialties. Information Technologies and Learning Tools, 75 (1), 138-152).

Даниско, О. В., Семеновська, Л. А. (2018). Ґенеза та сучасний зміст поняття змішаного навчання в зарубіжній педагогічній теорії і практиці. Інфрормаційні технології $i$ засоби навчання, 65 (3), 1-11 (Danysko, O., Semenovska, L. (2018). Genesis and contemporary content of the concept of blended learning in foreign pedagogical theory and practice. Information Technologies and Learning Tools, 65 (3), 1-11).

Закон України "Про вищу освіту» (Law of Ukraine "On higher education") (2017). Retrieved from: http://zakon2.rada.gov.ua/laws/show/1556-18

Нетрибійчук, О. (2017). Використання хмарних сервісів і технології «перевернутого навчання» на уроках хімії. Біологія і хімія в рідній школі, 5, 2-9 (Netrybiichuk, O. (2017). Use of cloud services and technology "flipped learning" in chemistry lessons. Biology and Chemistry in native school, 5, 2-9).

Новиков, Д. А. (2004). Статистические методы в педагогических исследованиях (mиповые случаu). Москва, М3 - Пресс (Novikov, D. (2004). Statistical methods in pedagogical research (typical cases). Moscow, MZ - Press).

Михайленко, І. В. (2019). Методичні аспекти впровадження моделі змішаного навчання при вивченні вищої математики в технічних закладах вищої освіти. Педагогічні науки: теорія, історія, інноваційні технології, 6 (90), 97-108 (Mikhailenko, I. V. (2019). Methodological aspects of introduction of the model of blended learning in the study of higher mathematics in technical institutions of higher education. Pedagogical sciences: theory, history, innovative technologies, 6 (90), 97-108).

Сікора, Я. Б. (2016). Реалізація змішаного навчання у вищому навчальному закладі. Науковий вісник Ужгородського університету. Серія: «Педагогіка. Сочіальна робота», 2 (39), 236-239 (Sikora, Ya. (2016). Implementation of blended learning in a higher education institution. Scientific bulletin of Uzhgorod University. Series: "Pedagogy. Social work", 2 (39), 236-239).

Терещук, С. І. (2017). Змішане навчання як нова парадигма системи фізичної освіти. Вісник Чернігівського національного педагогічного університету. Серія: Педагогічні науки, 186-191 (Tereshchuk, S. (2017). Blended learning as a new paradigm of the physical education system. Bulletin of Chernihiv national pedagogical university. Series: Pedagogical Sciences, 186-191).

чхало, О. М. (2018). Застосування технології BYOD в освітньому процесі аналітичної хімії. Комп'ютер у школі та сім'ї, 3, 10-15 (Chkhalo, О. (2018). Application of BYOD technology in the educational process of analytical chemistry. Computer in school and family, 3, 10-15).

\section{PEЗЮME}

Лицман Юлия, Швец Ольга, Осьмук Наталия. Организация смешанного обучения с помощью «Google Classroom» при изучении биоорганической химии студентами медицинских специальностей.

Статья посвящена проблеме повышения эффрективности химической подготовки студентов специальности «Медицина». Обоснована актуальность применения электронного, мультимедийного и мобильного контента в учебном процессе. Подтверждено, что условием эдрфективности реализации смешанного обучения является сочетание аудиторной и внеаудиторной работы. Осуществлена экспериментальная проверка результативности применения разработанной методики изучения биоорганической химии в условиях смешанного обучения на платформе "Google Classroom». Установлено положительное влияние предложенной методики на уровень знаний студентов по химии. 
Ключевые слова: смешанное обучение, эксперимент, "Google Classroom", учреждение высшего образования, студенты медицинских специальностей, преподавание химии, методика преподавания биоорганической химии.

\section{SUMMARY}

Litsman Yulia, Shvets Olha, Osmuk Nataliia. Organization of blended learning with "Google Classroom" in the study of bioorganic chemistry of students of medical specialties.

The article is devoted to the problem of increasing efficiency of chemical preparation of students of specialty "Medicine". The relevance of the use of electronic, multimedia and mobile content in the educational process is substantiated. The authors' experience of using the teaching methodology of bioorganic chemistry for students in the context of blended learning with "Google Classroom" is analyzed.

It is confirmed that a combination of classroom and extracurricular work is a precondition for blended learning effectiveness. Such an organization of the educational process allows introducing elements of blended learning into various types of educational work. The expediency of using the Face-to-Face Driver and Rotation Station Model models at lectures and practical classes, in the independent work of students, is substantiated. The "Google Classroom" platform was used to communicate in the educational process and to get acquainted with methodological materials. "Google Forms" service was used to create training tests and surveys, "Slides" and "You Tube" - to develop teaching materials. The technological component of the proposed approach is provided by the devices of the participants of the educational process. The possibility of organizing a personality-centered approach by diversification of educational tasks and the possibility of processing educational information at a convenient time for each student is shown.

The importance of the innovative interaction between the teacher and students for the effective organization of blended learning is established. Experimental verification of the effectiveness of the application of the developed blended learning model in the study of bioorganic chemistry is conducted. The positive influence of the proposed methodology on the level of students' academic achievements in chemistry is confirmed. Article materials can be of practical value for chemistry teachers in higher education institutions.

Key words: blended learning, experiment, "Google Classroom", higher education, students of medical specialties, teaching of Chemistry, methods of teaching bioorganic chemistry.

УдК 37.091.313:[378.018.8:377.011.3-051

Олег Малишевський

Уманський державний педагогічний

університет імені Павла Тичини

ORCID ID 0000-0002-7653-7862

DOI 10.24139/2312-5993/2020.03-04/107-117

\section{МІЖПРЕДМЕТНА ІНТЕГРАЦІЯ ЯК ДИДАКТИЧНА УМОВА РОЗВИТКУ В МАЙБУТНІХ ІНЖЕНЕРІВ-ПЕДАГОГІВ ГОТОВНОСТІ ДО ПРОФЕСІЙНОÏ МОБІЛЬНОСТІ}

Стаття присвячена дослідженню дидактичного потенціалу міжпредметних зв'язків для розвитку професійної мобільності в майбутніх інженерів-педагогів. Висвітлено різні точки зору на розуміння понять «інтеграція» і «міжпредметні зв'язки». У статті розглянуто різні напрями інтеграційного підходу. Акцентовано на важливості міжпедметних зв'язків як дидактичної умови, що забезпечує 
вдосконалення й оптимізацію професійної підготовки майбутніх інженерів-педагогів, розвиток у них готовності до професійної мобільності. Міжпредметні зв'язки як дидактичні умови розвитку готовності до професійної мобільності розглядаємо як загальний погляд на предмет, на світ із позицій фундаментальних загальнолюдських інтересів і досвіду. Окреслено умови реалізації міжпредметного підходу. Виділено критерії відбору синтезованих тем певної навчальної дисципліни.

Ключові слова: інтеграчія, міжпредметні зв'язки, інженер-педагог, готовність до професійної мобільності, професійна мобільність, дидактичні умови, професійна підготовка, міжпредметна інтеграція.

Постановка проблеми. Одним із найбільш ефективних шляхів підвищення якості підготовки майбутніх інженерів-педагогів і розвитку в них готовності до професійної мобільності $\epsilon$ забезпечення освітньої інтеграції. У сучасній науці накопичено значний досвід розв'язання проблем інтеграції, обґрунтовано ії теоретичні засади, що спонукає до усвідомлення неминучості перетворення інтеграційних процесів у провідну закономірність розвитку освітньої теорії і практики.

Сучасний етап розвитку суспільства вимагає спеціалістів нової генерації широкого профілю, які мають фундаментальну підготовку в гуманітарній, природничій, технічній та інформаційній галузях. Такий фахівець володіє, як правило, універсально-синтетичними знаннями і здатний забезпечувати універсально-функціональну діяльність, що пов'язано з такими процесами, як універсалізація технологій і техніки, інтеграція науки й виробництва, реформація змісту інженерно-педагогічної діяльності. Виходячи зі специфіки інженерно-педагогічної підготовки, необхідно визначити спільні ознаки психолого-педагогічних та спеціальних дисциплін, які дозволили 6 утворити поле міждисциплінарного діалогу для становлення професійно мобільних фахівців. Тотальна диференціація знань в інженерно-педагогічній підготовці свідчить про необхідність формування у випускників здатності до синтезованого, системного мислення, що сприятиме розкриттю глибини і взаємозв'язку суспільних, психолого-педагогічних і галузевих процесів.

Аналіз актуальних досліджень. Теоретичні основи професійної підготовки фахівців різних галузей на засадах інтеграції досліджували І.Бардус, В.Берека, О.Глобін, Г.Голубова, Р.Гуревич, Є.Іванченко, О. Левчук, І. Малишевська, В. Сидоренко, О. Суховірський, С. Шабага та інші. Інтегративним процесам у професійній (професійно-технічній) освіті присвячено дослідження О. Булейко, Л. Васіної, Т. Волкової, Р. Горбатюка, С. Гуревича, І. Ключковської, Ю. Ковальова, І. Козловської, Д. Корчевського, О. Косарук, Л. Лук'янової, Н. Ничкало, В. Смірнової, Т. Стахмич та інших. Міжпредметна інтеграція була об'єктом дослідження М. Демянчука,
А. Джантімірова, Л. Дольнікової, І. Звєрєва,
О. Зеленяка,
О. Коломієць,
Н. Півень, С. Рибак, С. Семерікова та інших. 
Незважаючи на чималу кількість досліджень, присвячених інтеграційним процесам в освіті, недостатньо вивчено питання міжпредметної інтеграції, зокрема для формування професійної мобільності у процесі фахової підготовки інженерів-педагогів.

Мета статті - дослідження дидактичного потенціалу міжпредметної інтеграції для розвитку професійної мобільності майбутніх інженерівпедагогів.

Методи дослідження. Для досягнення поставленої мети використано комплекс взаємодоповнюючих теоретичних методів, зокрема системно-функціональний та аналітичний аналіз вітчизняних та зарубіжних наукових джерел, зіставлення різних точок зору на досліджувану проблему, узагальнення.

Виклад основного матеріалу. У сучасній науковій літературі накопичено багатий досвід вирішення проблем інтеграції (міжгалузевої (інтеграція професій), міжпредметної, форм організації навчання, теоретичного й практичного навчання тощо), її генетичних аспектів, шляхів до виокремлення об'єктивних основ, умов і чинників інтеграційних процесів.

Міжпредметний зв'язок закладено у змісті поняття «інтеграція» І. Козловською (1999), яка визначає ії як різноманітність зв'язків і взаємодій між різними рівнями організації та предметними галузями. Такий підхід заслуговує уваги, оскільки він має важливе значення для нашого дослідження в контексті інженерно-педагогічної підготовки.

І. Малишевська обґрунтовує інтеграцію як принцип «розгортання предметного матеріалу в межах кожної предметної галузі». Водночас дослідниця зазначає, що вона $є$ основою єдності будь-якої методичної системи, оскільки забезпечує «створення синтетичних, інтегрованих курсів і вдосконалення традиційних на засадах міждисциплінарності» (Малишевська, 2011, с. 102). «Втілення інтеграції як дидактичного принципу в навчальних предметах, - зазначає І. Бех, - полягає у формі об'єднання їх і представлення єдиним цілим» (Бех, 2002, с. 5).

Крім того, інтеграцію розглядають як процес і результат створення нерозривно поєднаного, що формує цілісність як єдину якість на основі багатьох інших. Інтеграція як принцип здійснення освітнього процесу ґрунтується на взаємному доповненні різних форм пізнання дійсності, чим і створює умови для становлення багатомірної картини світу і пізнання себе в ньому. У цьому розумінні вона виступає засобом універсальної освіти людини (Іванчук, 2004).

О. Косарук зазначає, що «основною метою інтеграції в педагогічному процесі професійної підготовки майбутніх спеціалістів $€$ успішне поєднання навчання й виховання студентів із виробничою працею» (Косарук, 2019, c. 74). 
Узагальнюючи вищесказане, підтримуємо І.Гузій (2018), яка зазначає, що інтеграційні процеси здатні виконувати організаційну роль в освіті, дають можливість отримати нові результати в межах тих самих компонентів, забезпечують сумісність наук і знань із різних систем завдяки загальній методології, універсальним логічним прийомам сучасного мислення. Такий підхід є важливим для розробки системи формування професійної мобільності інженерів-педагогів.

Різні аспекти інтеграції розкриває А. Бєляєва (1991), яка вважає, що їі необхідно розглядати в широкому й вузькому сенсі. У широкому сенсі інтеграцію треба розуміти як зведення змісту освіти до єдиної дидактичної форми для підготовки спеціалістів за групами професій і професій широкого профілю, об'єднаних на основі науково-технічної, соціальнотехнічної, психофізіологічної спільності, що існують у сучасному виробництві й освіті. У вузькому сенсі інтеграція - приведення загальнотехнічних, спеціальних навчальних предметів, усіх навчально-виробничих робіт до єдиного комплексу.

Варто акцентувати увагу на тлумаченні інтеграції як педагогічної категорії Р. Гуревичем. Він зазначає, що інтеграція як педагогічна категорія «становить цілеспрямоване об'єднання, синтез певних навчальних дисциплін у самостійні системи цільового призначення, спрямовані на забезпечення цілісності знань та вмінь студентів»; «важливою особливістю інтеграції $€$ те, що завдяки їй підвищується успішність та інформаційна ємність знання, рівень його узагальненості та комплексності, ущільненості й організованості» (Гуревич, 2015). Ми погоджуємося з цими тезами, адже у процесі формування професійної мобільності для інтеграції характерним $є$ більш глибоке проникнення до сутності знань і пошук загальних закономірностей, а також широке використання універсальних методів, засобів і технологій.

Найхарактерніші ознаки інтеграційного процесу формування професійної мобільності виходять із таких положень: наявність раніше роз'єднаних елементів інженерної та психолого-педагогічної підготовки; існування об'єктивних передумов для їх об'єднання; об'єднання повинно відбуватися не шляхом формального додавання, а через синтез; результатом такого об'єднання є система, що володіє властивостями цілісності. Як бачимо, очевидними стають основні чинники інтеграції, зокрема: будь-які раніше розрізнені елементи, об'єктивні передумови об'єднання їх, процес об'єднання цих елементів, ціле як результат інтеграції.

у контексті нашої роботи уваги заслуговує дослідження типології інтеграції. У Великому тлумачному словнику сучасної української мови подано такі види їі: валютна, горизонтальна, економічна, прогресивна, регресивна, соціальна. Акцентуємо на соціальній інтеграції як «наявності впорядкованих відносин між індивідами, групами» (Великий тлумачний..., с. 500), що підкреслює суб'єктивний характер професійних стосунків і 
взаємодій, поєднання особистісної та професійної складових професійного зростання, перетворення їх у якісно новий потенціал майбутнього фахівця - готовність до професійної мобільності.

На різних напрямах інтеграційного підходу акцентує І. Гузій (2018), виділяючи інтеграцію професій (спеціальностей), інтеграцію знань та інтеграцію вмінь. Перший напрям «проявляється при паралельному освоєнні декількох спеціальностей», що, на нашу думку, є актуальним у контексті практичної складової інженерно-педагогічної підготовки. Останній напрям є цікавим, оскільки у професійній діяльності важливе значення мають уміння - освоєний людиною комплексний спосіб гнучкого й успішного виконання певної дії в нестандартних, незвичайних, різноманітних ситуаціях. У вмінні є елементи автоматизму, але в цілому воно завжди здійснюється усвідомлено, при активному мисленні, залученні знань, розумового контролю й оцінок (Гузій, 2018, с. 78). Це, на нашу думку, переконливо засвідчує перелік якостей, що входять до характеристик готовності до професійної мобільності.

Розглядаючи внутрішню та зовнішню інтеграцію, Є. Іванченко вважає, що «зовнішня інтеграція виявляється на рівні керування навчальновиховним середовищем, а внутрішня - на рівні організаційно-методичного забезпечення навчально-виховного середовища та психологопедагогічному рівні» (Іванченко, 2011, с. 109). Крім того, дослідниця класифікує прояв напрямів інтеграції за різними рівнями, зокрема: керування навчально-виховним середовищем (макрорівень), методичне забезпечення навчально-виховного середовища (мезорівень), психологопедагогічний (мікрорівень) (Іванченко, 2011, с. 110). 3 позицій нашого дослідження, уваги заслуговують усі рівні, оскільки в них закладено когнітивний і діяльнісний аспекти готовності до професійної мобільності фахівця, рефлексія професійного досвіду та механізми їхнього розвитку.

у процесі аналізу науково-педагогічної літератури зафіксовано проблему інтеграції освітніх технологій: традиційних, інноваційних та інформаційних. Водночас педагогічну інтеграцію поділяють на рівні: інтеграція як єдиний предмет, інтеграція навчальних дисциплін у формі дидактичних одиниць, інтеграція окремих тем.

Міжпредметні зв'язки виконують роль дидактичного засобу, «який передбачає комплексний підхід до формування й засвоєння змісту освіти, що дає можливість здійснювати зв'язки між предметами для поглибленого, всебічного розгляду найважливіших понять, явищ, розвивати системне мислення» (Лук'янова та Аніщенко, 2014, с. 57). Вони створюють відповідні психологічні й дидактичні умови для підвищення наукового рівня знань, оптимізують процес засвоєння їх та умови вдосконалення й оптимізації освітнього процесу, а також навантаження студентів (Усова та Бобров, 1988, с. 95). 


\section{У дидактичному аспекті розглядає інтеграцію Р.Гуревич.} Підкреслюючи ії міжпредметний характер, науковець зазначає, що міжпредметні зв'язки $є$ певним відображенням у змістові й методах навчання об'єктивних зв'язків між науками. Водночас, на думку дослідника, міжпредметні зв'язки виконують певні дидактичні функції, $\epsilon$ дидактичною умовою підвищення наукового рівня знань студентів, умовою вдосконалення усього освітнього процесу. Логічну структуру дидактичної інтеграції, зазначає Р. Гуревич, здійснюють три основних елементи: база (кооперуюча дисципліна), завдання (вихідна проблема базової дисципліни), знаряддя (теоретичний і технічний інструментарій базової дисципліни) (Гуревич, 2015, с. 99). Дидактичний аспект реалізації міжпредметних зв'язків навчальних дисциплін психолого-педагогічного циклу спрямовано, у першу чергу, на вдосконалення змісту, структури і обсягів загальнопедагогічної і рівневої підготовки інженерно-педагогічних кадрів, формування в майбутніх педагогічних фахівців різних освітніх рівнів цілісної системи професійних педагогічних компетенцій.

М. Берулава (1986) виділяє три рівні дидактичної інтеграції: 1) асиміляція інструментарія (теоретичного або технічного) базової науки 3 тією, що бере участь в інтеграції; кожна з них має в цих випадках свій науковий суверенітет у навчальному процесі; 2) синтез наук, що взаємодіють на основі однієї з них (базової), який, у свою чергу, може бути як частковим, так і повним (дисциплінарним). При цьому кожна з наук зберігає свій предмет, свої концептуальні основи, тобто свій науковий статус; 3) завершення формування нової навчальної дисципліни, що носить інтегративний характер і має свій власний предмет вивчення.

У контексті вищесказаного, Н. Абрамова (Философские вопросы, 1984) розкриває змістові аспекти механізмів інтеграції, до одного з яких відносить редукцію як зведення використання домінуючої дисципліни для будь-якої галузі наукового знання. Для формування готовності до професійної мобільності інженера-педагога важко назвати провідну галузь, однак у професійній освіті переважають дисципліни психологопедагогічного циклу.

Інтегроване подання інформації - це ще і реєстр педагогічних технологій, за допомогою яких створюють особливу атмосферу навчання, коли вивчення інтегрованого змісту спрямовують на загальнолюдські цінності. Чим раніше студента вводять до інтеграційного поля понять спеціальності та пов'язаних із нею галузей знань, філософського усвідомлення дійсності, тим ефективніше вирішуються проблеми становлення його як освіченої особистості. Інтегроване подання інформації, зокрема стиснення, концентрації, узагальнення, вважаємо ефективним інструментом раціоналізації уваги, розуміння й запам'ятовування. 
Міжпредметні зв'язки у професійному навчанні $\epsilon$ конкретним виразником інтеграційних процесів, що відбуваються сьогодні в суспільстві. Ці зв'язки відіграють важливу роль у підвищенні науковотеоретичної і практичної підготовки фахівців, сприяють комплексній реалізації системи освіти й виховання, розвитку творчого і логічного мислення, вимагають активної взаємодії між суб'єктами освітнього процесу, формують уміння аналізувати факти з різних галузей знань і вирішувати поставлені завдання.

Приділяючи особливу увагу міждисциплінарному підходу, В. Кремень (2015) зазначає, що інтеграція і зв'язок між компонентами освіти приводять до формування в суб'єкта цілісного образу світу, тобто риси всебічно розвиненої особистості. Міжпредметні зв'язки передбачені і реалізуються через структуру змісту навчальних дисциплін.

Міжпредметні зв'язки виконують роль дидактичної умови підвищення ефективності освітнього процесу. Інтеграція навчальних дисциплін повинна забезпечувати систематичну єдність наскрізних проблем, тому необхідно забезпечення чітко сформульованими й логічно пов'язаними системотвірними принципами. Під інтеграцією варто розуміти не синтез дисциплін, а певний загальний погляд на предмет, на світ із позицій фундаментальних загальнолюдських інтересів і досвіду. Складність вивчення інтегрованих процесів зумовлена різноманітністю й характером дисциплін. У кожної дисципліни є своя методологія: свій апарат, своя система спрощень, предмет дослідження. Сучасний етап інтеграції професійного знання відрізняється якісно новим характером - зв'язки охоплюють не тільки методи, а й концепції, теорії, стиль наукового мислення.

Для реалізації міжпредметного підходу у професійній підготовці інженерів-педагогів необхідно дотримуватися певних умов, зокрема: обґрунтування системи опорних професійних знань і вмінь з урахуванням специфіки навчальних предметів; виявлення послідовності і способів інтеграції їх до змісту професійної освіти; визначення ефективного поєднання методів і форм роботи з формування професійної мобільності; підготовка фахівців до здійснення міжпредметних зв'язків у процесі професійної діяльності; забезпечення умов для усвідомленого розуміння процесів і виробничих ситуацій.

Інтеграційний процес в освітній діяльності становить міждисциплінарний рух знання до цілісності, що передбачає системне вивчення об'єкта, виступає логічним результатом змін у кожній системі знань, що взаємодіють, і є джерелом виникнення нових тенденцій до інтеграції їх.

Міжпредметні зв'язки виконують у професійній підготовці низку функцій.

Методологічна функція проявляється в тому, що тільки на її основі можливе формування у студентів діалектико-матеріалістичних поглядів на 
суспільство, сучасних уявлень про його цілісність і розвиток, оскільки міжпредметні зв'язки сприяють відображенню в навчанні методології сучасного пізнання, що розвивається шляхом інтеграції ідей і методів з позицій системного підходу. Вона сприяє зближенню теорії з практикою.

Освітня функція міжпредметних зв'язків полягає у формуванні таких якостей знань здобувачів вищої освіти, як системність, глибина, усвідомленість, гнучкість. Наприклад, під час вивчення дисциплін інформатичного циклу міжпредметні зв'язки виступають як засіб розвитку галузевих понять, сприяють засвоєнню зв'язків між ними й загальними поняттями.

Виховна функція міжпредметних зв'язків передбачає реалізацію комплексного підходу до виховання.

Розвивальна функція міжпредметних зв'язків визначається роллю їх у розвиткові системного і творчого мислення здобувачів вищої освіти, у формуванні їхньої пізнавальної активності, самостійності, прагнення до саморозвитку. Міжпредметні зв'язки допомагають подолати предметну інертність мислення і розширюють світогляд студентів, впливають на розвиток їх готовності до професійної мобільності.

Конструктивна функція міжпредметних зв'язків полягає в удосконаленні змісту навчального матеріалу, методів та форм організації освітньої діяльності.

Технологічна функція передбачає ущільнення інформації, усунення ії дублювання, систематизацію понять, фактів та налагодження субординації й координації.

Сукупність вищеназваних функцій міжпредметних зв'язків реалізують у процесі освітньої діяльності тоді, коли викладач застосовує все їх різноманіття.

Для створення певної моделі міжпредметних зв'язків необхідно здійснити два структурно-логічних аналізи змісту навчальних дисциплін: внутрішній і зовнішній. За допомогою внутрішнього структурно-логічного аналізу змісту тем навчальної дисципліни визначають провідні положення та основні системотвірні елементи. Зовнішній аналіз змісту тем дисциплін навчального плану здійснюють із метою визначення особливостей інтеграції дисципліни і виявлення базових міжпредметних знань, які необхідно використовувати для наукового й усебічного розкриття провідних положень певної навчальної дисципліни.

Критеріями відбору синтезованих тем навчальної дисципліни вважаємо значущість тем для розкриття сутності та основних ідей відповідної дисципліни; високий ступінь узагальнення та інтеграції знань у змісті навчальної дисципліни.

Оцінюючи ефективність здійснення міжпредметних зв'язків на основі дисциплін циклів професійно зорієнтованої гуманітарної підготовки, фундаментальної та професійної підготовки, варто зазначити, що успіх 
залежить від того, наскільки глибоко викладачі переконані в їх необхідності, достатньо обізнані із сутністю і функціями міжпредметних зв'язків, чи добре володіють практичними навичками реалізації їх у своїй діяльності, чи мають необхідні знання із суміжних дисциплін і належну методичну підготовку. Отже, реалізація міжпредметних зв'язків вимагає спільного планування змісту дисциплін загальної і професійної підготовки інженерів-педагогів.

\section{Висновки та перспективи подальших наукових розвідок.} Традиційне тлумачення інтеграції в діалектичному, синергетичному, дидактичному контекстах створює філософсько-евристичний ґрунт, що визначає сучасний характер і змістову спрямованість освітньої інтеграції.

Проблема розвитку готовності до професійної мобільності майбутнього інженера-педагога своїм змістовим наповненням утворює місця перетину навчальних дисциплін різних освітніх і наукових галузей. Такі вузлові проблеми, що виникають на межі наукових знань, створюють закономірні логічні передумови для здійснення суттєвої корекції змісту професійної підготовки і підіймають ї̈ на якісно новий соціальнофілософський і методологічний рівень.

Означені перспективи відкривають потужний потенціал міжгалузевої, міжпредметної інтеграції для формування у студентської молоді готовності до професійної мобільності. Готовність майбутніх інженерів-педагогів до професійної мобільності виступає індикатором якості практико зорієнтованої підготовки на інтеграційній основі.

\section{ЛІТЕРАТУРА}

Беляева, А.П. (1991). Дидактические принципы профессиональной подготовки в протехучилищах. Москва: Высшая школа (Beliaieva, А. Р. (1991). Didactic principles of professional training in vocational schools. Moskva).

Берулава, М.Н.(1986). Теория и методика интеграции естественно-научных и профрессионально-технических дисциплин в профтехучилищах. Челябинск (Berulava, M. N. (1986). Theory and methodology for the integration of natural science and vocational disciplines in vocational schools. Cheliabinsk).

Бех, І. Д. (2002). Інтеграція як освітня перспектива. Початкова школа, 5, 5-6 (Bekh, I. D. (2002). Integration as an educational perspective. Primary school, 5, 5-6).

Великий тлумачний словник сучасної української мови. В. Т. Бусел (ред.). (2009). Київ, Ірпінь: ВТФ «Перун» (Large explanatory dictionary of the modern Ukrainian language. In V. T. Busel (Ed.). (2009). Kyiv, Irpin: VTF "Perun").

Гузій, І.С. (2018). Напрями використання інтегративного підходу у професійній підготовці майбутніх фахівців інформаційної, бібліотечної та архівної справи. Молодий вчений, 3 (55), 76-80 (Huzii, I. S. (2018). Directions of using the integrative approach in future specialists' professional training of informational, library and archival affairs. Young scientist, 3 (55), 76-80).

Гуревич, Р.С. (2015). Інтеграція наукових знань у підготовці майбутнього вчителя технологій. Науковий часопис НПУ імені М. П. Драгоманова. Серія 5. Педагогічні науки: реалії та перспективи, 51, 97-103 (Hurevych, R. S. (2015). Scientific knowledge integration in the training of future teachers of technology. Scientific bulletin of Drahomanov NPU. Series 5. Pedagogical sciences: reality and prospects, 51, 97-103). 
Іванченко, Є. А. (2011). Напрями інтеграції у сучасних вимірах. Науковий вісник Південноукраїнського національного педагогічного університету ім. К. Д. Ушинського, 7-8, 109-119 (Ivanchenko, Үе. А. (2011). Integration directions in modern dimensions. Scientific bulletin of South Ukrainian National Pedagogical University named after K. D. Ushynskyi, 7-8, 109-119).

Іванчук, М.Г. (2004). Інтегроване навчання: сутність та виховний потенціал (Виховання особистості молодшого школяра в умовах інтегрованого підходу до навчання). Чернівці: Рута (Ivanchuk, М. Н. (2004). Integrated learning: the essence and educational potential (Upbringing of a junior student's personality in an integrated learning approach). Chernivtsi: Ruta).

Козловська, І. М. (1999). Теоретико-методологічні аспекти інтеграції знань учнів професійно-технічної школи: дидактичні основи. С. У. Гончаренко (ред.). Львів: Світ (Kozlovska, I. М. (1999). Theoretical and methodological aspects of students' knowledge integration in vocational schools: didactic fundamentals. In S. U. Honcharenko (Ed.). Lviv: Svit).

Косарук, О. М. (2019). Професійна підготовка майбутніх фрахівців інженерних спеціальностей на засадах інтеграції навчання з виробництвом (дис. ... канд. пед. наук: 13.00.04). Вінниця (Kosaruk, О. М. (2019). Professional training of future specialists in engineering specialties on the basis of training integration with production. (PhD thesis). Vinnytsia).

Кремень, В. (2015). Професійний розвиток особистості - ключове завдання в умовах євроінтеграції. Концептуальні засади профресійного розвитку особистості в умовах євроінтеграційних прочесів, В.Г. Кремень, М.Ф.Дмитриченко, Н.Г. Ничкало (ред.), (сс. 9-11). Київ: НТУ (Kremen, V. (2015). Individual's professional development is a key task in the conditions of European integration. Conceptual foundations of professional development of the personality in the conditions of the integration processes. In V. H. Kremen, M. F. Dmytrychenko, N. H. Nychkalo (Eds.), (pp. 9-11). Kyiv: NTU).

Лук'янова, Л. Б., Аніщенко, О.В.(2014). Освіта дорослих: короткий термінологічний словник. Київ; Ніжин: Видавець ПП Лисенко М. М. (Lukianova, L. B., Anishchenko, O. V. (2014). Adult education: a short glossary. Kyiv; Nizhyn).

Малишевська, І.А. (2011). Підготовка майбутнього вчителя початкових класів до використання природотерапії у роботі з учнями початкової школи (дис.... канд. пед. наук: 13.00.04). Київ (Malyshevska, І. А. (2011). Preparation of a future primary school teacher for the nature therapy use in working with primary schoolchildren. (PhD thesis). Kyiv).

Усова, А. В., Бобров, А. А. (1988). Формирование учебных умений и навыков у учащихся на уроках физики. Москва: Просвещение (Usova, А. V., Bobrov, А. А. (1988). Formation of educational abilities and skills among students at physics lessons. Moscow).

Философркие вопросы технического знания. Н. Т. Абрамова (ред.). (1984). Москва: Наука (Philosophical issues of technical knowledge. In N. T. Abramova (Ed.). (1984). Moscow).

\section{PEЗЮME}

Малышевский Олег. Межпредметная интеграция как дидактическое условие развития у будущих инженеров-педагогов готовности к профессиональной мобильности.

Статья посвящена исследованию дидактического потенциала межпредметных связей для развития профессиональной мобильности у будущих инженеров-педагогов. Освещены различные точки зрения на понимание понятий "интеграция" и "межпредметные связи». В статье рассмотрены различные направления интеграционного подхода. Акцентировано внимание на вањности 
Педагогічні науки: теорія, історія, інноваційні технології, 2020, № 3-4 (97-98)

межпредметных связей как дидактического условия, которое обеспечивает совершенствование и оптимизацию профессиональной подготовки будущих инженеров-педагогов, развитие у них готовности к профессиональной мобильности. Межпредметные связи как дидактические условия развития готовности к профрессиональной мобильности рассматриваем как общий взгляд на предмет с позиций фундаментальных общечеловеческих интересов и опыта. Определены условия реализации межпредметного подхода. Выделены критерии отбора синтезированных тем определенной учебной дисциплины.

Ключевые слова: интеграция, межпредметные связи, инженер-педагог, готовность к профессиональной мобильности, профессиональная мобильность, дидактические условия, профессиональная подготовка, межпредметная интеграция.

\section{SUMMARY}

Malyshevskyi Oleg. Interdisciplinary integration as a didactic condition for the development of future engineers-teachers' readiness for professional mobility.

The article is devoted to the study of the didactic potential of interdisciplinary links for the professional mobility development in future engineers-teachers. It has been noted that a modern specialist must have universal-synthetic knowledge to perform professional activities. In this context, the relevance and need to ensure educational integration for the engineering and pedagogical training organization has been confirmed. In the process of theoretical analysis, it has been concluded that the interdisciplinary relationship is embedded in the content of "integration" concept. Different views on the understanding of "integration" and "interdisciplinary links" concepts have been highlighted. The article considers different areas of the integration approach. Emphasis has been placed on the importance of interdisciplinary links as a didactic condition that provides improvement and optimization of future engineersteachers' professional training, the development of their readiness for professional mobility. Analytical analysis has allowed to single out didactic integration levels and to reveal its content aspects. Emphasis has been also placed on the important role of interdisciplinary links to improve the theoretical and practical training of future engineers-teachers, development of their cognitive skills, communication skills, readiness for professional mobility. We consider interdisciplinary connections as didactic conditions for the development of professional mobility readiness as a general subject view, the world from the standpoint of fundamental universal interests and experience. The conditions for the interdisciplinary approach implementation have been outlined: substantiation of basic professional knowledge and skills system; identifying the sequence and ways to integrate them into vocational education content; determining an effective combination of work methods and forms on professional mobility formation; specialists' training for interdisciplinary connections; providing conditions for a conscious understanding of processes and production situations. The interdisciplinary connections functions performed in the professional training of engineers-teachers have been defined. The criteria for synthesized topics selection of a certain academic discipline have been highlighted. It has been concluded that the interdisciplinary links implementation requires joint planning of professional training disciplines content.

Key words: integration, interdisciplinary links, engineer-teacher, readiness for professional mobility, professional mobility, didactic conditions, vocational training, interdisciplinary integration. 
удк 378.4

Тетяна Москаль

Тернопільський національний педагогічний

університет імені В. Гнатюка

ORCID ID 0000-0002-4253-1163

DOI 10.24139/2312-5993/2020.03-04/118-128

\section{НАВЧАННЯ МАЙБУТНІХ УЧИТЕЛІВ АНГЛІЙСЬКОЇ МОВИ ПРОФЕСІЙНО ОРІЕНТОВАНОÏ ДИСКУСІЇ}

У статті висвітлено проблему навчання майбутніх учителів англійської мови профресійно орієнтованої дискусії. Методи дослідження: вивчення й аналіз літератури з методики навчання іноземної мови, досвіду провідних науковців із досліджуваної теми. Результатами дослідження $є$ опис етапів навчання дискусії та класифрікація підсистеми вправ, розроблена відповідно до запропонованих етапів. Практичне значення дослідження полягає в описі етапів $i$ підбірці технологій/методів для навчання студентів професійно орієнтованої дискусії 3 метою подальшого використання цих технологій майбутніми вчителями.

Ключові слова: дискусія, принцип активного/пасивного навчання, комунікативна компетентність, підсистема вправ.

Постановка проблеми. Говоріння як вид мовленнєвої діяльності відіграє важливу роль у вивченні англійської мови. Розвиток англомовної компетентності в говорінні - одне з головних завдань навчання іноземної мови в сучасній вищій освіті. Метою формування іншомовної комунікативної компетентності $€$ не накопичення певного обсягу знань, навичок і вмінь, а здатність використовувати їх в іншомовному спілкуванні (Ніколаєва, 2013, с. 91).

Досягнення цієї мети значною мірою залежить від професійної компетентності вчителя іноземної мови і культури. Професійна компетентність учителя - це сукупність професійно-педагогічних компетентностей і наступний професійний ріст (Ніколаєва, 2013, с. 37).

Отже, забезпечення оптимальних умов для формування в майбутніх учителів англомовної компетентності в говорінні $€$ актуальним питанням, що зумовлює пошук шляхів вирішення цієї проблеми.

Зауважимо, що підготовка майбутніх учителів англійської мови передбачає розвиток умінь підтримувати та вести бесіду, обмінюватися думками, аналізувати, аргументувати сказане, давати поради, відстоювати власну точку зору. Важливим для професії вчителя, власне, у роботі 3 учнями $\epsilon$ розвиток критичного мислення, уміння взаємодіяти, співпрацювати, домовлятись, шукати і знаходити компроміс, при цьому поважати думку інших та вміти дійти згоди. Саме ці питання зумовили вибір теми дослідження та пошук оптимальних шляхів вирішення проблеми навчання майбутніх учителів професійно орієнтованої дискусії. 
Аналіз актуальних досліджень. Дослідженням інтерактивного методу дискусії займались іноземні науковці-методисти (С. Д. Брукфілд, С. Прескіл, Б. Г. Дейвіс, Х. С. Дейвіс, Дж. Хамер) та вітчизняні: Н. П. Андронік (навчання майбутніх учителів англомовної дискусії на основі автентичних поетичних творів); І. В. Зайцева (формування в майбутніх філологів компетентності в англійському діалогічному мовленні на засадах проблемних ситуацій); І. О. Сімкова (методика навчання англомовної професійно орієнтованої дискусії студентів інженерних спеціальностей); Н. М. Топтигіна (навчання дискусії на матеріалі художніх текстів у процесі вивчення англійської як другої іноземної мови). Питанню використання методу дискусії для розвитку вмінь говоріння студентів приділялася значна увага, проте питання навчання майбутніх учителів професійно орієнтованої дискусії є не вирішеним.

Метою статті $є$ обґрунтування етапів та підсистеми вправ для навчання майбутніх учителів англійської мови професійно орієнтованої дискусії.

Методи дослідження. Під час проведення дослідження використовувалися такі методи: вивчення й аналіз літератури з методики навчання іноземної мови, а також узагальнення досвіду провідних науковців із досліджуваної теми.

Виклад основного матеріалу. Для забезпечення оптимізації навчального процесу, умотивованості студентів та учнів до навчання й модернізації сучасної освіти впроваджуються інноваційні технології та методи навчання.

Активне навчання знаменує собою перехід від переважно регламентувальних, алгоритмізованих, програмованих форм і методів організації дидактичного процесу до розвивальних, проблемних, дослідницьких, пошукових, що забезпечує народження пізнавальних мотивів та інтересів, умов для творчості в навчанні (Євтушевський, 2008, с. 14).

Активне навчання - це така організація та ведення навчального процесу, що спрямована на всебічну активізацію навчально-пізнавальної діяльності студентів за допомогою широкого, бажано комплексного використання як педагогічних (дидактичних), так і організаційноуправлінських засобів (Дичківська, 2004, с. 17).

Протягом багатьох років навчання говоріння полягало тільки у відтворенні вивченого матеріалу. Навчання іноземної мови відбувалося через розвиток репродуктивних навичок - здебільшого граматичних та орфографічних, що було неефективним під час спілкування за межами закладів освіти.

Навчання говоріння майбутніх учителів через дискусію $є$ професійно орієнтованим і важливим у комунікативній поведінці студента. Метод "дискусія» має на меті колективне обговорення проблеми, під час якого учасники дослуховуються до думки кожного та, здебільшого, доходять спільної згоди. Формування у студентів умінь говоріння розвиває здатність 
користуватися мовою залежно від конкретної життєвої ситуації. Відбувається навчання говоріння через саме говоріння.

Існує багато дискусійних форм інтерактивних технологій. Серед них наступні: «евристична» бесіда, презентація, «мозковий штурм», метод «круглого столу», метод "акваріуму», метод "світлофору», обговорення аудіо- і відеозаписів, рольова дискусія (Ніколаєва, 2010, с. 282).

Для успішного застосування методу «дискусія» на практиці розглянемо механізм організації ведення дискусії. І. В. Зайцева пропонує чотири стадії в структурі організації дискусії-обміну думками, а саме: організація дискусії (оголошення теми, визначення мети, поділ студентів на групи, вибір представника групи, установлення регламенту дискусії), переддискусія/експозиція (постановка проблемного завдання, опис проблемної ситуації, обмін думками щодо проблемної ситуації в підгрупах, визначення загальної точки зору шляхом аргументації), власне дискусія (аргументація представника кожної підгрупи, представлення шляхів вирішення проблемної ситуації), аналіз дискусії (співставлення мети дискусії з отриманими результатами й висновками, оцінка результатів, виявлення їхніх позитивних і негативних аспектів, оцінювання роботи студентів, підбиття підсумків) (Зайцева, 2017, с. 6).

Ми дотримуємося думки, що організація ведення дискусії має три основні етапи: початковий, основний, заключний.

Початковий етап передбачає такі завдання:

- Представлення учасників групи.

- Повідомлення правил ведення та участі в дискусії.

- Повідомлення теми і мети дискусії.

На основному етапі відбувається підтримка балансу участі всіх учасників. Проголошуються й обговорюються питання за темою дискусії.

Під час завершального підсумкового етапу відбувається підбиття підсумків дискусії, коли розкриті всі питання або час дискусії вичерпано. Ведучий підсумовує основні ідеї, при цьому не надаючи перевагу власним. У кінці дискусії рекомендовано заощадити час, щоб кожний учасник міг висловити свою думку чи оцінку стосовно ведення дискусії, а за потреби висловити незгоду з приводу питань, які обговорювалися. Підведення підсумків може здійснювати і один із учасників дискусії.

Важливим для організації успішного проведення дискусії $\epsilon$ формування вмінь ведення дискусії в майбутніх учителів. Таке навчання дискусії можна поділити на певні етапи, які, на думку І. В. Зайцевої, $\epsilon$ певними проміжками часу (період), що мають самостійне значення, цілі та завдання (Зайцева, 2017, с. 97).

Проблема етапів навчання дискусії досліджена такими вітчизняними науковцями-методистами: І. В. Зайцевою, Н. П. Андронік, І. О. Сімковою та Н. П. Топтигіною. 
Н.П.Андронік виокремлює два етапи: підготовчий та основний. Метою першого є формування дискусійних умінь полілогічного мовлення для обговорення автентичних поетичних творів (АПТ), другого - розвиток дискусійних умінь полілогічного мовлення для обговорення АПТ (Андроник, 2009, с. 103).

Н. П. Топтигіна також пропонує розподіл навчання дискусії на два етапи: текстовий та післятекстовий. Етапи відрізняються вмінням створювати підготовлені висловлення на рівні фрази або непідготовлені монологічні висловлювання текстового рівня (Зайцева, 2017, с. 98).

Натомість, І.О.Сімкова виділяє три етапи: інформативнопідготовчий, на якому відбувається формування вмінь розпізнавати інформацію на основі аудіювання й читання, представлення власної аргументації, оцінювання альтернативних пропозицій; ситуативнодискусійний як підготовка до дискусії і проведення дискусії; формування навичок реплікування і вміння аргументування, групування точок зору, розвиток умінь дискусії та констатувально-інтерпретативний розвиток умінь дискусії й формування висновків, перевірки засвоєння навчального матеріалу, аналіз дискусії (Зайцева 2017, с. 96).

І. В. Зайцева під час проведення експериментального дослідження на базі груп студентів першого курсу виділяє п'ять етапів навчання дискусії: пропедевтичний, організаційно-мотиваційний, інформативно-підготовчий, ситуативно-дискусійний і констатувально-інтерпретаційний. Така деталізація, на її думку, зумовлена відсутністю у студентів-першокурсників належного рівня сформованих умінь, необхідних для ведення дискусій (Зайцева, 2017, с. 11).

На основі аналізу запропонованих дослідниками етапів навчання дискусії можна зробити висновок, що спільним $€$ те, що всі вищезгадані методисти виділяють підготовчий і основний етапи навчання, де перший передбачає підготовку до дискусії, а другий - її проведення.

І. О. Сімкова, у свою чергу, виділяє, окрім зазначених етапів, ще один, спрямований на підведення підсумків і аналіз проведеної дискусії.

Порівнюючи й аналізуючи вищезазначені етапи навчання дискусії, дотримуємося думки, що в навчанні професійно орієнтованої дискусії майбутніх учителів слід виділити три етапи:

1. Підготовчий етап.

Оскільки наше дослідження охоплює студентів 2-го року навчання, зазначимо, що майбутні вчителі вже мають базові навички та вміння роботи в дискусійних групах. Це зумовлено тим, що метод «дискусія» використовується під час практичних занять на першому курсі. 3 огляду на те, що формування організаційних умінь ведення дискусії в межах нового предмету є невід'ємною частиною навчання дискусії, акцентуємо увагу на доцільності формування організаційних умінь із перших аудиторних занять. 
2. Активізація професійних знань - етап, що передбачає власне професійно орієнтовану дискусію з метою інтенсифікації комунікативних умінь з опорою на текст.

3. Констатувально-інтерпретаційний етап $\epsilon$ підсумковим етапом навчання дискусії. На цьому етапі проводиться підсумок та рефлексія, проголошуються відгуки як студентів, так і викладача на проведену дискусію.

Навчання дискусії $є$ ефективним для майбутніх учителів, коли дискусія базується на матеріалах професійно орієнтованих текстів. Ведення таких дискусій надає студентам можливість використовувати знання предмету, апелює до їхнього попереднього чи теперішнього досвіду, а також проєктує та моделює професійні вміння студентів на використання в майбутньому.

3 урахуванням сформульованих нами етапів розроблено підсистему вправ для навчання майбутніх учителів англійської мови - студентів 2-го курсу професійно орієнтованої дискусії з опорою на фахові тексти.

Реалізація підсистеми вправ для навчання англомовної дискусії на основі професійно орієнтованих текстів передбачає три етапи: підготовчий, активізацію професійних знань та констатувально-інтерпретаційний етап.

Група вправ для формування організаційних умінь ведення дискусії співвідноситься з підготовчим етапом; група вправ для розвитку комунікативно-дискусійних умінь з опорою на текст співвідноситься 3 другим етапом; група вправ для формування і розвитку комунікативнодискусійних умінь завершувати дискусію співвідноситься з констатуючеінтерпретаційним етапом.

Таблиця 1

Підсистема вправ для навчання майбутніх учителів англійської мови професійно орієнтованої дискусії

\begin{tabular}{|c|c|c|}
\hline $\begin{array}{c}\text { Етап } \\
\text { навчання }\end{array}$ & Групи/підгрупи вправ & Види вправ \\
\hline \multirow[t]{5}{*}{ Підготовчий } & $\begin{array}{l}\text { 1. Група вправ для формування } \\
\text { організаційних умінь ведення дискусії }\end{array}$ & \multirow{5}{*}{$\begin{array}{l}\text { Реплікування } \\
\text { використанням готових } \\
\text { виразів/фраз/ мовленнєвих } \\
\text { кліше } \\
\text { Продукування ініціативних } \\
\text { реплік } \\
\text { Прийоми: } \\
\text { «Шумні групи» (Buzz Groups), } \\
\text { «Один - вдвох - усі разом» } \\
\text { (Think-Pair-Share) } \\
\text { Режим взаємодії: пари, п्ञ тру тагальна група }\end{array}$} \\
\hline & $\begin{array}{l}\text { 1.1. Підгрупа вправ для формування } \\
\text { вмінь починати діалог }\end{array}$ & \\
\hline & $\begin{array}{l}\text { 1.2. Підгрупа вправ для формування } \\
\text { вмінь підтримувати бесіду }\end{array}$ & \\
\hline & $\begin{array}{l}\text { 1.3. Підгрупа вправ для визначення } \\
\text { мети дискусії }\end{array}$ & \\
\hline & $\begin{array}{l}\text { 1.4. Підгрупа вправ для прогнозування } \\
\text { змісту дискусії }\end{array}$ & \\
\hline
\end{tabular}




\begin{tabular}{|c|c|c|}
\hline \multirow[t]{6}{*}{$\begin{array}{l}\text { Активізація } \\
\text { професійних } \\
\text { знань }\end{array}$} & $\begin{array}{l}\text { 2. Група вправ для розвитку } \\
\text { комунікативно-дискусійних умінь } 3 \\
\text { опорою на текст }\end{array}$ & \multirow{5}{*}{$\begin{array}{l}\text { Вправи, які містять відповіді } \\
\text { на запитання } \\
\text { Повідомлення або запит } \\
\text { інформації } \\
\text { Діалог-обговорення на } \\
\text { основі } \\
\text { прочитаного } \\
\text { Діалог-обмін думками на } \\
\text { основі апелювання до } \\
\text { власного досвіду } \\
\text { Обмін репліками (реактивні } \\
\text { та ініціативні репліки) } \\
\text { Прийоми: Метод «Круглий } \\
\text { стіл», засідання експертної } \\
\text { групи («Петельна дискусія») }\end{array}$} \\
\hline & $\begin{array}{l}\text { 2.1. Підгрупа вправ для формування і } \\
\text { розвитку вмінь аналізувати інформацію } \\
\text { тексту }\end{array}$ & \\
\hline & $\begin{array}{l}\text { 2.2. Підгрупа вправ для формування і } \\
\text { розвитку вмінь висловлення згоди чи } \\
\text { незгоди }\end{array}$ & \\
\hline & $\begin{array}{l}\text { 2.3. Підгрупа вправ для розвитку вмінь } \\
\text { аргументувати свою думку }\end{array}$ & \\
\hline & $\begin{array}{l}\text { 2.5. Підгрупа вправ для розвитку вмінь } \\
\text { давати поради і реагувати на них }\end{array}$ & \\
\hline & $\begin{array}{l}\text { 2.6. Підгрупа вправ для формування і } \\
\text { розвитку вмінь висловлювати наміри }\end{array}$ & $\begin{array}{l}\text { Режим взаємодії: пари, } \\
\text { групи та загальна група }\end{array}$ \\
\hline \multirow{4}{*}{$\begin{array}{l}\text { Констату- } \\
\text { вально- } \\
\text { інтерпрета- } \\
\text { ційний }\end{array}$} & $\begin{array}{c}\text { 3. Група вправ для формування i } \\
\text { розвитку комунікативно-дискусійних } \\
\text { умінь завершувати дискусію }\end{array}$ & \multirow{4}{*}{$\begin{array}{l}\text { Створення власних діалогів } \\
\text { (з/без використання } \\
\text { природних опор (малюнки, } \\
\text { схеми, слайди) для } \\
\text { підведення підсумків } \\
\text { Прийоми: «Два - чотири - } \\
\text { усі разом» (Ругаmid } \\
\text { Discussion), прийом } \\
\text { «Обговорення проблеми в } \\
\text { загальному колі» } \\
\text { Режим взаємодії: пари, } \\
\text { мікрогрупи (3-4 студенти)/ } \\
\text { групи та загальна група }\end{array}$} \\
\hline & $\begin{array}{l}\text { 3.1. Підгрупа вправ для формування і } \\
\text { розвитку вмінь підводити підсумки } \\
\text { дискусії }\end{array}$ & \\
\hline & $\begin{array}{l}\text { 3.2. Підгрупа вправ для формування } \\
\text { розвитку вмінь рефлексії/міркування }\end{array}$ & \\
\hline & $\begin{array}{l}\text { 3.3. Підгрупа вправ для формування і } \\
\text { розвитку вмінь висловлювати своє } \\
\text { ставлення до проведення дискусії }\end{array}$ & \\
\hline
\end{tabular}

На першому етапі передбачено виконання вправ на формування вмінь починати діалог, підтримувати бесіду, визначати мету дискусії, прогнозувати зміст дискусії. На цьому етапі виконуються керовані рецептивно-репродуктивні та репродуктивно умовно-комунікативні вправи на імітацію, відповіді на питання, на запит певної інформації, а також повідомлення інформації.

Вправи другої підгрупи включають завдання, спрямовані на розвиток таких умінь у студентів: розуміння змісту текстів, обговорення професійної проблематики за змістом текстів, уміння висловити думку стосовно даної ситуації, уміння протиставляти свою точку зору іншим.

Вправи означеної групи імітують спілкування, наближене до того, що $\epsilon$ в реальному житті. На цьому етапі використовують рецептивнопродуктивні, продуктивні комунікативні вправи нижчого рівня 
(допускається використання вербальних опор для висловлення студентів), керовані/частково керовані вправи.

Характерною для виконання вправ цієї групи є групова взаємодія (робота в парах, мікрогрупах, групах та загальною групою). Учасниками спілкування є студенти, викладач дає певне комунікативне завдання.

На меті виконання вправ 3-го етапу $\epsilon$ формування і розвиток умінь висловлювати свою думку та майбутні наміри, висловлення згоди чи незгоди, підведення підсумків дискусії, формування і розвиток умінь рефлексії/міркування, а також формування та розвиток умінь висловлювати своє ставлення до проведення дискусії. Вправи цієї групи $€$ мінімально керованими.

На цьому етапі студенти виконують вправи, що відносяться до рецептивно-продуктивних комунікативних вправ вищого рівня, здебільшого без використання опор.

Режим взаємодії: робота в парах, мікрогрупах (3-4 студенти) / групах та в загальній групі.

Прикладом ефективних дискусійних технологій, які використовуються на семінарських заняттях майбутніх учителів із предмету «Методика навчання англійської мови в ЗНЗ» на трьох етапах навчання дискусії, слугують такі дискусійні прийоми.

\section{Етап 1. Підготовчий етап}

Група вправ для формування комунікативних умінь вести дискусію

Метод « Шумні групи» (Buzz Groups)

Мета: формулювати та розвивати навички діалогічного мовлення, навчаючись співпрацювати у групі

Кількість учасників: 24

Кількість груп: 8

Час: 30 хв.

\section{Хід дискусії:}

Цей метод є прикладом роботи великої групи студентів у малих підгрупах (по троє студентів у підгрупі). Усі 8 груп студентів обговорюють одночасно одне питання. Дискусія має назву «Buzz Groups», тому що в ході обговорення виникає шум (гудіння), як у ході інтенсивної дискусії в реальному житті.

\section{Метод «Один - удвох - усі разом» (Think-Pair-Share)}

\section{Хід дискусії:}

Кількість учасників: довільна

Час: 20 хв.

Етап 1. Усім студентам пропонується 1 питання для обмірковування індивідуально.

Етап 2. Студенти об'єднуються по двоє, обмінюються ідеями в парах. 
Етап 3. Кожна пара студентів представляє результати спільного обговорення й обміну думками з усією групою студентів.

\section{Етап 2. Активізація професійних знань}

Група вправ для розвитку комунікативно-дискусійних умінь вести дискусію на базі професійно орієнтованих текстів, а також апелювання до власного досвіду.

Метод «Круглий стіл».

Мета: формулювати й розвивати навички діалогічного мовлення, навчаючись співпрацювати у групі.

Кількість учасників: 25

Кількість груп: 5

\section{Хід дискусії:}

Дискусія відбувається в 5-ти невеликих групах (по 5 студентів).

Етап 1. Студентам пропонуються питання для обговорення.

Етап 2. Студенти обмінюються думками в межах групи.

Викладач може виступати в ролі учасника одної 3 груп або спостерігати і контролювати всі групи по черзі.

Прийом «Засідання експертної групи» («Петельна дискусія») (Пометун та Пироженко, 2007).

Мета: формулювати та розвивати вміння говоріння; учитися співпрацювати з однолітками.

Кількість учасників: 24

Кількість груп: 4/6

Чac: $30-60$ хв.

Хід дискусії:

Етап 1. Усім студентам пропонується спільна проблема до обговорення. Відбувається обмін думками в групі з 4-6 учасників.

Етап 2. Після обговорення питання в малих групах відбувається виступ кожного члена групи перед аудиторією. Регламент виступу - 1-2 хв.

Етап 3. Констатувально-інтерпретаційний етап

Група вправ для розвитку комунікативних умінь завершувати дискусію, підводити підсумки, повідомляти про наміри, аналізувати ситуацію та рефлексувати.

Прийом «Обговорення проблеми в загальному колі».

Мета: прояснення певних положень, привертання уваги студентів до складних або проблемних питань у навчальному матеріалі, мотивація пізнавальної діяльності, актуалізація опорних знань тощо.

Кількість учасників: довільна

Час: від 5 до 10 хвилин.

Хід дискусії:

Етап 1. Пропонується запитання/тема для обговорення. 
Етап 2. Обговорення триває навколо запропонованої теми. Студенти висловлюються за бажанням. Обговорення триває, доки $є$ ті, хто бажає висловитися.

Етап 3. Викладач бере слово, якщо вважає за потрібне, наприкінці обговорення.

\section{Технологія «Два - чотири - усі разом» (Pyramid Discussion)}

Мета: формулювати й розвивати навички говоріння, а саме, діалогічного мовлення; спершу вчитися працювати в парах, потім у групах та в загальній групі, розвивати критичне мислення та вміння переконувати.

Кількість учасників: $24-26$

Час: 30 хв.

\section{Хід дискусії:}

Етап 1. Під час використання дискусії «Два - чотири - усі разом» студенти працюють у парах, обговорюючи запропоновану темучи проблему.

Етап 2. Дві пари об'єднуються (четверо студентів) під час обговорення тієї самої проблеми.

Етап 3. Кожних чотири студенти представляють результати обговорення в загальній групі.

Використання такого виду обговорення дискусійних питань надає можливість кожному студенту висловитися. Коли йде загальне обговорення, усі почуваються впевнено, оскільки кожний студент має можливість проговорити питання спочатку в парах, потім у групах із чотирьох учасників, а потім висловитися перед загальною групою.

Використання вищенаведених прийомів уможливлює ефективне ведення дискусії.

Результати дослідження. Результатами дослідження $є$ систематизація та розробка етапів навчання дискусії та обґрунтування підсистеми вправ для навчання майбутніх учителів професійно орієнтованої дискусії. Ефективність використання підсистеми вправ апробовано на семінарських заняттях майбутніх учителів з предмету «Методика навчання англійської мови в ЗНЗ» (2 рік навчання, денна форма).

Висновки та перспективи подальших наукових розвідок. Основним підсумком дослідження $€$ обґрунтування етапів та підсистеми вправ для навчання майбутніх учителів англійської мови професійно орієнтованої дискусії.

Перспективу подальших досліджень убачаємо в практичній розробці комплексу вправ, а також підбірці прийомів і технологій, які можуть бути використаними на кожному етапі навчання майбутніх учителів ведення професійно орієнтованої дискусії англійською мовою.

\section{ЛІТЕРАТУРА}

Андронік, Н. П. (2009). Навчання майбутніх учителів англомовної дискусії на основі автентичних поетичних творів (дис. ... канд. пед. наук: 13.00.02). Київ 
(Andronik, N. P. (2009). Teaching future English teachers discussion on the basis of authentic poetic texts (PhD thesis). Kyiv).

Андронік, Н. П. (2009). Навчання майбутніх учителів англомовної дискусії на основі автентичних поетичних творів (автореф. дис. ... канд. пед. наук: 13.00.02). Київ (Andronik, N. P. (2009). Teaching future English teachers discussion on the basis of authentic poetic texts (PhD thesis abstract). Kyiv).

Дичківська, І. М. (2004). Інноваційні педагогічні технології. Київ: Академвидав (Dychkivska, I. M. (2004). Innovative pedagogical technologies. Kyiv).

Євтушевський, В. А., Канаєва, М. О. (2008). Управління інноваційним розвитком у вищих навчальних закладах України. Проблеми освіmu, 54, 14 (Yevtushevskyi, V. A., Kanaieva, M. O. (2008). The management of innovative development at higher educational institutions of Ukraine. Problems of Education, 54, 14).

Зайцева, І. В. (2017). Формування у майбутніх філологів компетентності в англійському діалогічному мовленні на засадах проблемних ситуацій (дис. ... канд. пед. наук: 13.00.02). Київ (Zaitseva, I. V. (2017). Forming future philologists' competence in English language interaction based on problematic situations ( $\mathrm{PhD}$ thesis). Kyiv).

Зайцева, І. В. (2017). Формування у майбутніх філологів компетентності в англійському діалогічному мовленні на засадах проблемних ситуацій (автореф. дис. ... канд. пед. наук: 13.00.02). Київ (Zaitseva, I. V. (2017). Forming future philologists' competence in English language interaction based on problematic situations (PhD thesis abstract). Kyiv).

Методика навчання іноземних мов і культур: теорія і практика (2013). Ніколаєва, С. Ю. (загальн. ред.). Київ: Ленвіт (Methodology of teaching foreign languages and cultures: theory and practice (2013). In S. Yu. Nikolaieva (Ed). Kyiv: Lenvit).

Пометун, О. І., Пироженко, Л. В. (2007). Інтерактивні технології навчання: Теорія, практика, досвід. Київ (Pometun, О. І., Pyrozhenko, L. V. (2007). Interactive teaching technologies: Theory, practice, experience. Kyiv).

Пометун, О. І., Пироженко, Л. В. (2004). Сучасний урок. Інтерактивні технології навчання. Київ: Видавництво А.С.К. (Pometun, О. І., Pyrozhenko, L. V. (2004). A modern class. Interactive learning technologies. Kyiv: A.S.K.).

Сабат, С. (2014). Дискусія як метод інтерактивного навчання іноземних мов майбутніх фахівців сфери міжнародних відносин. Вісник Львівського національного університету імені Івана Франка. Серія міжнародні відносини, 35, 252-258 (Sabat, S. (2014). Discussion as an interactive method in teaching foreign languages to future specialists of international relations. Ivan Franko National University of Lviv Bulletin, International Relations Series, 35, 252-258).

Сисоєва, С. О. (2010). Інтерактивні технології навчання дорослих. Рідна школа, 11, 3-8 (Sysoieva, S. O. (2010). Interactive technologies of training of adults. Native school, 11, 3-8.

Ніколаєва, С. Ю. (Ред.) (2015). Сучасні технології навчання іноземних мов і культур у загальноосвітніх і вищих навчальних закладах. Київ: Ленвіт (Nikolaieva, S. Yu. (Ed.) (2015). Modern technologies of teaching foreign languages and cultures at general and higher education institutions. Kyiv: Lenvit).

\section{PEЗЮME}

Москаль Татьяна. Обучение будущих учителей английского языка профессионально ориентированной дискуссии.

В статье освещена проблема использования дискуссии как метода интерактивного обучения студентов - будущих учителей английского языка. Методы исследования: изучение и анализ литературы по методике обучения иностранному языку опыта ведущих ученых по исследуемой теме. Результаты исследования 
представляют описание этапов обучения дискуссии и классификацию подсистемы упражнений, разработанную в соответствии с предложенными этапами. Практическое значение исследования заключается в описании этапов и подборке техник/методов для обучения студентов профессионально ориентированной дискуссии с целью их дальнейшего использования будущими учителями.

Ключевые слова: дискуссия, принцип активного/пассивного обучения, коммуникативная компетентность, подсистема упражнений.

\section{SUMMARY}

Moskal Tetiana. Teaching professionally oriented discussions to pre-service teachers of English.

The article highlights the problem of teaching professionally oriented discussions to student teachers. The issues of active and passive learning principles have been studied in the article. The benefits of using active and interactive learning models as well as their role in teaching students have been studied and outlined. It has been proved that interactive form of learning is effective in the formation and development of students' speaking skills.

The aim of the article is to substantiate the stages and to describe the subsystem of exercises for teaching professionally oriented discussions to pre-service teachers. The following research methods: the method of study and analysis of theory, descriptive research and activity theory have been applied in the investigation.

The role of the formation of future teachers' communicative competence with the projection on the students' ability to form and develop secondary school students' speaking skills has been shown in the article.

The results of the investigation present the description of the stages of teaching discussion with their characteristics and the classification of the subsystem of exercises developed according to the suggested stages. The practical significance of the research is stipulated by the fact that the results of the investigation present the description of the stages of teaching discussions which can be used by instructors with the aim of developing student teacher' speaking skills. Techniques and methods for working on professionally oriented texts aimed at the formation and development of speaking skills have been selected and presented in the article.

Peculiarities and advantages of developing future teachers' speaking skills by the method of discussion have been revealed in the article. The use of the discussion method contributes to the formation and development of students' speaking skills, the ability to cooperate, to exchange ideas and to develop students' creativity.

The efficacy of the subsystem of exercises has been tested at the workshops in the subject of "Methodology of teaching English at a secondary school" (second-year students, full-time department). Our further research will be dedicated to the development of the subsystem of exercises as well as compiling methods and techniques effective for the formation of pre-service teachers' speaking skills through professionally oriented discussions.

Key words: discussion, active/passive learning principle, communicative competence, subsystem of exercises. 
Любов Пшенична

Сумський державний педагогічний

університет імені А.С. Макаренка

ORCID ID 0000-0002-2840-2189

DOI 10.24139/2312-5993/2020.03-04/129-146

\section{АКАДЕМІЧНА ЧЕСНІСТЬ: ПРИРОДА ЯВИЩА ТА ПРІОРИТЕТИ ПОШИРЕННЯ СЕРЕД СТУДЕНТСТВА}

Стаття раскриває природу феномена академічної чесності як категорію моралі, основою якої є етика - система моральних норм і правил, що проявляються в різних формах людських стосунків: звичаїв, релігійних норм, законів та послідовно доводить, що головним завданням університету є виховання у студентів прагнення до знань та пошуку істини, що той, хто знає, уміє, використовує, дотримується чітко визначених правил та принципів морально стійкої особистості, той і буде дотримуватися постулатів академічної доброчесності.

Подані визначення зобов'язують професорсько-викладацький склад закладу вищої освіти спонукати студентів до усвідомлення й чіткого дотримання фундаментальних чінностей вищої освіти, які $\epsilon$ прямим шляхом до підвищення якості знань, через формування академічної культури, академічної грамотності, необхідних практичних навичок усної й писемної мови у студентів, які необхідні для успішного навчання та майбутньої професійної діяльності; забезпечення їх потрібними знаннями та інструментами, оволодіння та оперування якими $\epsilon$ необхідними для повноцінного функціонування в освітній спільноті, а також на ринку праці в майбутньому, а досягнути високої якості освіти можливо лише створивши академічне середовище відповідальності та чесності.

Ключові слова: чесність, академічна доброчесність, етика, мораль, чінності, учасники освітнього процесу, принципи, стандарти.

Постановка проблеми. Виклики сьогодення спонукали українське суспільство стати на шлях змін, зокрема, у сфері вищої освіти. Українські освітяни почали усвідомлювати та працювати над утіленням європейських стандартів, що спричинило зацікавленість поняттями «академічна чесність» та «академічна доброчесність».

Міжнародний центр академічної доброчесності при Ротлендському інституті етики, Університет Клемсон в Південній Кароліні, розробив документ «Фундаментальні цінності академічної доброчесності». За цим підходом, академічна доброчесність - це відданість академічної спільноти, навіть перед лицем труднощів, шести фундаментальним цінностям: чесності, довірі, справедливості, повазі, відповідальності й мужності (Killinger, 2010).

Дані поняття належать до етичних норм, адже доброчесність у нашому світі великих протиріч $€$ саме тим наріжним каменем, який складає фундамент внутрішньої гармонії людини, чесності у способі власного життя, стійкості її характеру, чистоті духу й дотримання морального образу в усіх її 
проявах, а тому саме вища освіта зобов'язана виконувати соціальну місію, адже вона покликана виховувати інтелектуальну гідність і повагу до різноманіття думок та ідей учасників освітнього процесу.

На жаль, сучасна університетська практика демонструє порушення академічної доброчесності, що приводить до неналежного ставлення студентів та викладачів до освітньо-наукового процесу та своїх обов'язків, упередженого оцінювання чи зловживання своїми правами з боку учасників освітнього процесу, порушення етичних принципів і визначених законом правил, якими мають керуватися учасники освітнього процесу під час навчання, викладання, провадження наукової та творчої діяльності з метою забезпечення довіри до результатів навчання, наукових і творчих досягнень.

Тож упровадження академічної чесноті утверджуватиме цінність вищої освіти, сприятиме об'єктивності в судженнях і висновках, допоможе уникати обману та шахрайства й дозволить керуватися власною обізнаністю учасників освітнього процесу.

Аналіз актуальних досліджень. Друга половина XX столітт в національній системі освіти ознаменована яскраво вираженим процесом створення суспільства знань, який ставить сферу вищої освіти в центр формування соціальних і професійних еліт, робить ії відповідальною за трактування, розповсюдження й використання нових знань. Етапи історичного розвитку, проблеми реалізації академічної свободи розглядалися в наукових працях таких відомих зарубіжних науковців, як Л. Александер, А. Доусон, К. Йокояма, В. ван Олстін, І. Ордоріка, Р. Пост, Н. Рапопорт, К. Рассел, К. Сміт, Р. Стендлер, М. Тайт, Ф. Хатчесон, Е. Шилс та ін., питаннями академічної доброчесності як національної потреби та дієвого інструменту забезпечення якості вищої освіти займалися науковці Т. Фініков, Т. Добко, І. Єгорченко, В. Сацик, Є. Стадний, Д. Шулікін та ін.; академічна чесність у наукових дослідженнях представлена в роботах А. Артюхова, Ю. Єпіфанова, С. Курбатова, О. Меньшова, О. Полоцької, Н. Сорокіної та ін.; засади академічної доброчесності в боротьбі з плагіатом мають висвітлення у працях К. Афанасьєвої, А. Берлач, Л. Присяжної, А. Сідляренка, О. Чмир та ін., але шляхи виховання інтелектуальної гідності та питання поширення кращих практик академічного письма в Україні серед студентів потребує як додаткового вивчення, так і запровадження як дієвого інструменту надання й здобуття якісної вищої освіти, дотримання принципів, закладених в освітню діяльність та виховання цінностей академічної гідності.

Мета статті - дослідити природу явища «академічна чесність» та запропонувати студентству ефективні шляхи виховання в собі інтелектуальної гідності й дотримання фундаментальних цінностей академічної доброчесності. 
Методи дослідження: аналіз історичних та наукових джерел, останніх досліджень та публікацій, формулювання висновків та визначення напрямів подальших наукових розвідок.

Виклад основного матеріалу. Академічна доброчесність $€$ категорією моралі. Ще з сивої давнини людині потрібний був якийсь надзвичайний поштовх, щоб запровадити моральні норми та правила, відкрити їй світ нескінченного етичного самовдосконалення. Саме цими питаннями і займається етика - філософська дисципліна, предметом дослідження якої $€$ мораль і моральність. Етика як система моральних норм є невід'ємною частиною людства, проявляючись у різних формах людських стосунків: звичаїв, релігійних норм, законів. Будь-яка усвідомлена дія людини по відношенню до іншої людини, природи або самої себе оцінюється з позиції моралі. Перші спроби виявлення й узагальнення моральних процесів представлені в роботах Анаксимандра й Геракліта.

Предметом етичних міркувань ранніх філософів виступає існування єдиного універсального світоустрою, доступного для осягнення розумом людини, адже знаючи світовий порядок, людина може змінити свої внутрішні якості, сформувати чесноти.

у цей час чесноти належали не до моральності, а до способу світосприймання, якості людської душі оцінювалися по здатності особистості протистояти зовнішньому світу, а уявлення про форми й способи суспільних відносин розглядалися на основі людських, а не божественних установлень: законів, соціальних і правових норм.

у V в. до н.е. чесноти набувають цивільних рис, які забезпечувалися відповідною законодавчою базою. Моральне обличчя громадян набуває великого значення для успішності в суспільних справах. На думку Демокрита, прекрасне, справедливе, доброчесне - це лише встановлені людьми найменування корисних для виживання властивостей людини, що дають життя й задоволення. На жаль, людина не знає меж задоволенню і дуже часто зловживає ним. За твердженням Демокрита, шлях розуміння міри лежить через людський розум, який є моральною цінністю.

Сократ і Платон зробили предметом своїх досліджень моральні чесноти, дали загальні визначення таким основним етичним поняття, як «благо», «прекрасне», «чеснота», «користь», «щастя» тощо.

Вперше в науковий обіг Аристотель увів термін «етика» (від грец. Etos - характер, склад душі). Аристотель вважав моральність придбаною якістю душі, адже для досягнення етичних чеснот необхідно встановити контроль розуму над пристрастями.

Основою християнської етики $є$ Золоте правило моральності: «I так у всьому, як хочете, щоб із вами чинили люди, так чиніть і ви з ними, тому що в цьому закон і пророки», яке тісно пов'язане з любов'ю до Бога. 
Християнська етика стверджувала, що людина, яка не належить до церкви, не може бути моральною в істинному розумінні слова.

Для епохи Відродження природні закони доповнюють i підтверджують божественні. В основі етичної теорії лежить антитеза особистість - суспільство.

Початок становлення української етичної думки співпадає 3 розквітом Київської Русі XI ст. - XII ст., коли складається притаманний українській духовній традиції тип мислення, а філософська думка розвивається в тісному зв'язку з релігією.

Просвітницькі ідеї української етики складалися й розривалися в Києво-Могилянській академії, адже етика посідала тут одне з чільних місць. Етичні курси професорів були побудовані у формі диспутів на основі етики Аристотеля, де з'ясовувалися глибокі тлумачення про добро і зло, про моральну мету людських учинків, про кінцеву мету та цільові принципи людських дій, про волю та їі зв'язок із інтелектом і низка інших, не менш актуальних питань.

Нові підходи до тлумачення моральних чеснот етична теорія набуває у XIX-XX ст. Етичний радикалізм розглядає можливість удосконалення людського духу не засобами моральної саморефлексії особистості, а шляхом удосконалення соціальних інституцій за умови якісної зміни суспільного життя.

Етика XX століття не хоче підкорятися вже раніше створеним моделям у буденному існуванні, а демонструє світу власні поняття чеснот. Доброчесність в етичному світі XX сторіччя передбачала здійснення основних переоцінок людських цінностей до життя, породжувалися загальні зразки класичних понять моралі, тому що моральні цінності - це найголовніші риси в людському житті.

Екскурс у минуле світової культури виявляє важливу особливість їі розвитку, яка полягає в тому, що проблеми морального буття людини завжди викликали пильний інтерес із боку найвидатніших мислителів. Розвивалася культура й одночасно розвивалась їі етична самосвідомість. Жоден великий філософ минулого не оминув увагою питання моральності, аналізуючи не тільки дійсне, а й розмірковуючи про належне.

Чесність є поняттям етики, вона є однією із граней людських чеснот, моральною якістю й відображає одну з найважливіших вимог моральності, яка за своєю основою визначає результат певних позитивних моральних якостей. Дотримання чесності є основою життєдіяльності людини, сутністю їі життя, унормованим стандартом поведінки в суспільстві: правдивість, принциповість, вірність взятим зобов'язанням, щирість перед іншими і перед самим собою.

Чесність виникає як відображення людських спільнот, адже людина не повинна вчиняти так, щоб ії поведінка принижувала гідність їі сім'ї, роду 
або стану. У цьому сенсі значення поняття чесність сягає сивої давнини, в епоху рицарства, а ії розквіт припадає на часи середньовіччя. Людина честі має піклуватися про власну репутацію, репутацію сім'ї, соціальної групи, до якої вона належить.

Змінювалися епохи, устрої суспільства, люди, але безперечною рисою морального прогресу $є$ те, що належність до людей честі визначається вже не зовнішніми ознаками, а покликом серця, вихованням, внутрішнім цінностями самої особистості. Найбільш вираженим для історії людської моральності останніх століть $€$ те, що ідея чесності в системі моральних пріоритетів все більше поступається своїм місцем ідеї людської гідності.

Етика розглядає чесність як позитивну якість, але, на жаль, все більше людей у своїх практичних справах допускають дрібний обман. У широкому розумінні чесність - це правдивість - якість, якої нас навчають від народження батьки, але доросле життя людини вносить у це поняття свої корективи, адже правдивість і чесність не завжди потрібна.

Головним завданням університету є виховання у студентів прагнення до знань та пошуку істини. У процесі освітньої діяльності й вільних дискусій учасники освітнього процесу підтримують прагнення до навчання, стимулюють вивчення і дослідження ідей, долають перешкоди, передають знання. Потяг до знань і пошук істини мають життєво важливе значення для діяльності особистості, а свідома брехня та нечесність в академічній діяльності вважаються особливо небезпечними.

Університет - це місце, де сповідуються принципи академічних свобод, що сприяють досягненню академічних цілей: наукові дослідження, викладання, розширення освіти і знань.

Академічна чесність (academic integrity) - це сукупність цінностей та принципів, яких повинні дотримуватись учасники освітнього процесу, вона передбачає гідну та свідому поведінку під час виконання письмових контрольних робіт, складання іспитів, написання курсових і кваліфікаційних робіт, проведення досліджень та інших видів освітньої діяльності.

Університетська спільнота повинна дотримуватися об'єктивності в судженнях і висновках, уникати обману й шахрайства, керуватися власною обізнаністю.

Сутність поняття академічна чесність становлять сукупність етичних принципів та визначених законом правил, якими мають керуватися учасники освітнього процесу в освітній діяльності, у процесі викладання та провадження наукової діяльності 3 метою забезпечення довіри до результатів навчання та наукових досягнень, вона відіграє надзвичайно важливу роль у науковому світі, колі вчених, викладачів та студентів, вона $\epsilon$ моральним ядром академічної культури.

Академічна культура не може бути запозичена чи перенесена 3 культур інших країн світу. Ми вивчаємо європейські та світові практики для 
розробки власних методів і засобів запровадження та розвитку академічної культури, які будуть адаптовані до реалій соціальноекономічного розвитку нашої держави, правового регулювання даної проблеми та рис українського менталітету.

Українська вища школа - це своєрідна модель суспільства. Навчання в закладі вищої освіти припадає на період становлення й формування цінностей, установок і моделі поведінки, які визначатимуть місце і роль молодої людини в дорослому житті, дозволить сформувати у стінах університету не просто фахівця, а соціально активного і відповідального громадянина, лідера, який здатен допомогти змінити світ та інших людей на краще і саме в цьому виявити свою значимість і потрібність для суспільства.

Академічна доброчесність як загальноприйнятне поняття дозволяє охопити різні сфери академічного життя, де кожному із учасників відведена його особлива унікальна роль, визначені права, обов'язки та відповідальність, що виражаються в сукупності етичних принципів та визначених законом правил, а тому охоплює спектр від індивідуального до колегіального вимірів, де індивідуальний - зосереджений на професійній етиці конкретної особи, на їх власних цінностях і орієнтирах, які забезпечують їм репутацію та повагу в академічному середовищі.

Науково-педагогічний працівник, науковець, здобувач вищої освіти члени академічної спільноти, а тому належать до інституційного виміру й забезпечують упровадження принципів академічної доброчесності в освітньо-науковий процес закладу вищої освіти. Їх обов'язок - сформувати та закріпити у студентів стійкі правила академічної доброчесності, виховати прагнення до їх дотримання та в усіх сферах життя.

Поодинокі, разові заходи не можуть привести до цілісності утвердження принципів академічної доброчесності, а тому повинна працювати система, яка дозволить імплементувати законодавчу й нормативно-правову бази і забезпечить стале функціонування системи вищої освіти.

Разом із тим академічна доброчесність у колегіальному вимірі - це дотримання ії постулатів у світовому академічному просторі, що забезпечує гарантування та підвищення якості освіти, довіри до результатів навчання, викладання, наукових та творчих досягнень.

Позицію і поведінку учасника освітнього процесу визначають не тільки особистісні, наукові, педагогічні, громадські досягнення, а й система відносин, дотримання норм та правил поведінки з колегами, здобувачами вищої освіти, роботодавцями, стейкхолдерами, адміністрацією. Важливим засобом імплементації академічної доброчесності в державні освітні та наукові системи є введення цього поняття через Закони України.

Слід зазначити, що Законом України «Про освіту» від 05.09.2017 року вперше на нормативному рівні закріплено поняття «академічна доброчесність». Стаття 42 Закону України «Про освіту» дає визначення 
поняття академічна доброчесність, визначає чинники, за допомогою яких передбачено дотримання академічної доброчесності здобувачами освіти, педагогічними, науково-педагогічними та науковими працівниками; указує на прояви академічної недоброчесності та притягнення до академічної та іншої відповідальності за порушення академічної доброчесності.

Пунктом 5 ст. 42 «Академічна доброчесність» визначено, що за порушення академічної доброчесності педагогічні, науково-педагогічні та наукові працівники закладів освіти можуть бути притягнені до академічної відповідальності, а саме:

- відмова у присудженні наукового ступеня чи присвоєнні вченого звання;

- позбавлення присудженого наукового (освітньо-творчого) ступеня чи присвоєного вченого звання;

- відмова в присвоєнні або позбавленні присвоєного педагогічного звання, кваліфікаційної категорії;

- позбавлення права брати участь у роботі визначених законом органів чи обіймати визначені законом посади (Про освіту, 2017, с. 380).

Пунктом 6 цієї статті визначена відповідальність здобувачів вищої освіти за порушення академічної доброчесності й зазначено, до якої академічної відповідальності вони можуть бути притягнуті:

- повторне проходження оцінювання (контрольна робота, іспит, залік тощо);

- повторне проходження відповідного освітнього компонента освітньої програми;

- відрахування із закладу освіти (крім осіб, які здобувають загальну середню освіту);

- позбавлення академічної стипендії;

- позбавлення наданих закладом освіти пільг з оплати навчання (Про освіту, 2017, с. 380).

Визначення академічної доброчесності представлено у ст. 1 Закону України «Про вищу освіту», а у ст. 63 закріплені обов'язки осіб, які навчаються в закладах вищої освіти щодо дотримання академічної доброчесності, також законом передбачено відкликання диплому про порушення вимог академічної доброчесності.

Сьогодні на обговорення академічної спільноти Міністерством освіти і науки України представлено проект Порядку скасування рішення про присудження ступенів вищої освіти та присвоєння відповідної кваліфікаці, який викликав неоднозначні відгуки, але червоною ниткою проходить думка про те, що академічної доброчесності потрібно дотримуватися.

Перед університетською академічною спільнотою стоїть головне завдання: виховати у здобувачів вищої освіти потребу в дотриманні академічної доброчесності, навчити студентів академічного письма, 
сорормувати, починаючи з моменту їх вступу до університету, вимоги щодо оформлення власних думок, публічних виступів, візуальних презентацій, написання тез виступів, статтей, наукових досліджень тощо.

Так склалося і вже стало традицією, що опанування навичок якісного академічного письма - це складний процес, що потребує наполегливих і тривалих зусиль як із боку професорсько-викладацького складу, так і від здобувачів вищої освіти. Саме на молодь покладаються великі надії щодо утвердження й поширення високих етичних і моральних ідеалів та належних стандартів доброчесності у процесі освітньо-наукової діяльності, тому пояснення викладачами основних засад академічної доброчесності студентам та молодим науковцям у процесі освітньо-наукової та виховної діяльності стає одним із найбільш важливих завдань.

Життєва аксіома: хто знає, уміє, використовує, дотримується чітко визначених правил та принципів морально стійкої особистості, той і буде дотримуватися постулатів академічної доброчесності. У першу чергу в суспільстві та освіті ці правила притаманні педагогічним, науковопедагогічним та науковим працівникам, які беззаперечно зобов'язані дотримуватися принципів академічної доброчесності. Принципи академічної доброчесності вперше були визначені у статті «Викладачі та академічна доброчесність» (видання "Synthesis: Law and Policy in Higher Education», редактор Г. Павел):

- утверджувати важливість академічної доброчесності;

- плекати любов до навчання;

- ставитися до студента як до самостійної особистості;

- створювати атмосферу довіри в аудиторії;

- заохочувати відповідальність студентів за академічну доброчесність;

- формулювати чіткі очікування для студентів;

- розробляти справедливі та значимі форми оцінювання;

- обмеження можливості для академічної нечесності;

- кидати виклик академічній нечесності, коли такі випадки трапляються;

- допомагати визначати й підтримувати загальноуніверситетські стандарти академічної доброчесності (Центр академічної доброчесності).

Визначені постулати зобов'язують професорсько-викладацький склад закладу вищої освіти спонукати студентів до усвідомлення й чіткого дотримання фундаментальних цінностей вищої освіти через формування академічної культури, академічної грамотності, необхідних практичних навичок усної й писемної мови у студентів, які необхідні для успішного навчання та майбутньої професійної діяльності; забезпечення їх необхідними знаннями та інструментами, оволодіння та оперування якими 
$€$ необхідними для повноцінного функціонування в освітній спільноті, а також на ринку праці в майбутньому.

У закладах вищої освіти запроваджуються навчальні дисципліни «Основи академічного письма», «Академічна культура та доброчесність», «Академічна доброчесність у наукових дослідженнях», «Правові аспекти академічної доброчесності», «Основи академічного письма» та інші, які трансформують академічну доброчесність 3 міфу у стале понятт, формують у студентів розуміння принципів академічної культури, базових засад академічної доброчесності та навичок ії дотримання; розвиток навичок публічного виступу та наукової дискусії; уміння використання мови академічного письма як мистецтва самопрезентації; формування культури оформлення наукового тексту, отримують необхідну інформацію про порушення академічної доброчесності та можливі санкції, вчаться писати відповідно до поставлених викладачем критеріїв та вимог.

Результатом вивчення цих дисципліни є засвоєння студентами поняття академічної чесності та нечесності, особливості стилю академічного письма; уміння оперувати навичками усного й писемного наукового мовлення; збирати факти, працювати з фаховими текстами, самостійно шукати і опрацьовувати джерела, виявляти власні аналітичні, критичні та творчі здібності, критично оцінювати власну працю та працю інших авторів.

Дієвим засобом щодо ознайомлення першокурсників, здобувачів вищої освіти та співробітників із основами академічної доброчесності та поглиблення навичок доброчесного академічного спілкування $\epsilon$ розширене інформаційне поле, яке охоплює найрізноманітніші види і засоби інформування та навчання: проведення перших лекцій із навчальної дисципліни «Вступ до фаху»; доступ до онлайн-ресурсів, які розміщені на сайті у формі навчальних модулів, навчальних посібників 3 етики, допоміжних матеріалів, що стосуються правил цитувань та посилань; ознайомлення з сайтом університету та всією нормативноінструктивною базою, представленою на ньому; проведення лекцій квестів, вебінарів, наукові конференції, круглі столи, конкурсів соціальних відео проектів та соціальної реклами, створення інформаційних бюлетенів, створення та розсилка листа новин, створення банерів і плакатів з даної тематики, проведення семінарів зі здобувачами освіти 3 питань інформаційної діяльності Університету, коректності написання наукових, навчальних посібників, статей, курсових та кваліфікаційних робіт, правил опису джерел та оформлення цитувань; інформація, яка стосується питань інтелектуальної власності та відповідальності за порушення її юридичних та моральних аспектів; інформація та спеціальне навчання учасників освітньо-наукового процесу з метою вдосконалення академічних навичок щодо правил користування електронними системами співставлення текстів 
із метою виявлення плагіату, які є доступними в системі Інтернет та ті, які використовуються в університеті.

Значний об'єм роботи щодо інформування та навчання здобувачів вищої освіти з правилами та нормами академічної доброчесності покладається на випускові кафедри, центри та науково-дослідні лабораторії. Так, у Сумському державному педагогічному університеті імені А. С. Макаренка під керівництвом доктора педагогічних наук, професора, завідувача кафедри української мови і літератури О.М.Семеног результативно працює науково-дослідна лабораторія «Академічна культура дослідника», основними функціями якої $\epsilon$ здійснення наукових досліджень та прикладних розробок із питань формування академічної культури дослідника в системі: заклад загальної середньої освіти - бакалаврат - магістратура - аспірантура педагогічних закладів вищої освіти, спрямованих на:

- проведення теоретичних та експериментальних досліджень актуальних проблем формування академічної культури суб'єктів дослідницького навчання;

- керівництво науковими дослідженнями докторами філософії, підтримка наукових досліджень докторів філософії, обдарованих студентів, залучення їх до науково-дослідної діяльності;

- удосконалення наукової кваліфікації науково-педагогічних працівників університету;

- науково-методичне забезпечення формування академічної культури дослідника: учнів старшої школи, бакалаврів, магістрів, докторів філософії);

- використання результатів досліджень у процесі підготовки бакалаврів, магістрів, науково-педагогічних кадрів вищої кваліфікації;

- організацію наукових досліджень, проведення науково-методичних конференцій, семінарів, нарад у співпраці з установами Національної академії педагогічних наук України, закладами вищої освіти, закладами післядипломної освіти та загальноосвітніми школами.

Дотримання академічної доброчесності здобувачами освіти забезпечить самостійне виконання навчальних завдань, завдань поточного й підсумкового контролю результатів навчання; допоможе правильно здійснювати посилання на джерела інформації в разі використання ідей, розробок, тверджень, відомостей; убезпечить від порушення норм законодавства про інтелектуальну власність, авторське право й суміжні права; виховає потребу в наданні достовірної інформації про результати власної освітньої, наукової, творчої діяльності, використані методик досліджень і джерел інформації.

А ще, у процесі реалізації заходів університетом та активної участі в них студентства, здобувач вищої освіти повинен чітко усвідомити та 
протистояти категоріям академічної недоброчесності, феномен якої $\epsilon$ багатогранним та може набувати різних проявів і відтінків. У його основі лежить отримання певних преваг через навмисне порушення загальноприйнятих в академічному середовищі моральних і правових норм, що завдають нищівного удару по якості освітньої діяльності та якості наукових досліджень, перетворюючи їх на протилежні феномени дипломовану псевдоосвіту та небезпечну псевдонауку.

Основними проявами академічної не доброчесності, які визначені на законодавчому рівні $€$ :

- академічний плагіат - оприлюднення (частково або повністю) наукових (творчих) результатів, отриманих іншими особами, як результатів власного дослідження (творчості) та/або відтворення опублікованих текстів (оприлюднених творів мистецтва) інших авторів під іменем власної особи, без зазначення авторства та належного оформлення посилань. Плагіат може мати місце як при виконанні завдань освітнього процесу, так і в науковій діяльності.

- самоплагіат - оприлюднення (частково або повністю) власних раніше опублікованих наукових результатів як нових наукових результатів, який передбачає використання власних попередніх праць автора в іншому контексті, без посилань на те, що такий текст вже був раніше використаний або опублікований;

- фабрикація - вигадування даних чи фактів, що використовуються в освітньому процесі або наукових дослідженнях;

- фальсифікація - свідома зміна чи модифікація вже наявних даних, що стосуються освітнього процесу чи наукових досліджень;

- списування - виконання письмових робіт із залученням зовнішніх джерел інформації, крім дозволених для використання, зокрема, під час оцінювання результатів навчання;

- обман - надання завідомо неправдивої інформації щодо власної освітньої (наукової, творчої) діяльності чи організації освітнього процесу; формами обману $\epsilon$ зокрема, академічний плагіат, самоплагіат, фабрикація, фальсифікація та списування;

- хабарництво - надання (отримання) учасником освітнього процесу чи пропозиція щодо надання (отримання) коштів, майна, послуг, пільг чи будь-яких інших благ матеріального або нематеріального характеру 3 метою отримання неправомірної переваги в освітньому процесі;

- необ'єктивне оцінювання - свідоме завищення або заниження оцінки результатів навчання здобувачів вищої освіти;

- хибне співавторство - внесення до списку авторів наукової чи навчально-методичної праці осіб, які не брали участь у створенні продукту (Про освіmy, 2017). 
Кожен учасник освітньо-наукового процесу повинен усвідомлювати, що життя та діяльність, які не відповідають стандартам і традиціям академічної доброчесності, істотно деформують освітнє середовище, роблять його непрозорим та нездатним надавати супротив зовнішнім негараздам, обмежують спроможність до утвердження власних позицій. Успіх на шляху до подолання цих явищ може бути досягнутим за умови утвердження в українській академічній спільноті норм нетерпимості та несприйняття будь-яких корупційних проявів, утвердження високих морально-етичних принципів та стандартів і створення дієвих механізмів та процедур, здатних забезпечити їх добре ім'я.

Сповідуючи принципи академічної доброчесності, здобувач вищої освіти повинен бути готовим до перевірки робіт на предмет академічного плагіату за допомогою спеціалізованих програмних засобів, для цього він повинен бути обізнаним та кваліфіковано вміти користуватися інформаційною базою з питань академічної доброчесності. 3 цією метою на веб-сайті університету створюється інформаційна рубрика «Академічна доброчесність», яка систематично поповнюється інформаційними та методичними матеріалами, використання яких сприяє інформаційній грамотності й попередженню плагіату, усвідомленню переваг чесного навчання, несе просвітницьку функцію, за допомогою якої стає можливим попередження випадків порушення принципів академічної доброчесності.

Упровадження принципів академічної доброчесності в українських закладах вищої освіти - це питання підняття якості вищої освіти та репутації самого закладу, підвищення їхнього рейтингу, визнання дипломів університетів на європейському та світовому рівнях, підвищення конкурентоспроможності випускників цих закладів. Як указує Л. Семененко, досягнути високої якості освіти можливо лише створивши середовище відповідальності та чесності (Семененко, 2016, с. 145-150).

А тому університети створюють, запроваджують та чітко дотримуються таких правових документів, як Кодекс академічної доброчесності, який є актом етичного регулювання академічної діяльності закладу вищої освіти - збіркою морально-етичних правил професійної поведінки та норм навчальної, наукової та творчої діяльності членів академічної спільноти університету, які ґрунтуються на попередньому досвіді, ціннісних орієнтаціях, ідеалах, світогляді членів академічної спільноти університету, регламентують стандарти соціальної поведінки учасників освітнього процесу, приписуючи обов'язковість їх виконання усіма учасниками академічної діяльності.

Кодекс академічної доброчесності - це документ, що схвалюється вищим колегіальним органом управління закладу вищої освіти i $\epsilon$ обов'язковим до виконання всіма учасниками освітнього процесу. Метою створення Кодексу академічної доброчесності $€$ прагнення університету 
створити середовище, яке сприяє обміну знаннями, упровадженню інновацій, інтелектуальному розвитку учасників освітнього процесу, підтриманню особливої університетської культури взаємовідносин, запровадження та поширення інституту «академічної відповідальності» за порушення норм і принципів академічної доброчесності, і як результат забезпечення якісної вищої освіти та отримання вагомих наукових результатів.

Студентська молодь складає особливу соціальну категорію молодих людей, яка за характером своєї діяльності, поглядами, ціннісними орієнтаціями, світоглядними і громадянськими якостями відіграє головну роль у генеруванні та розповсюдженні ціннісно-нормативних орієнтирів суспільства, а студентське життя забезпечує як подальший розвиток особистісних якостей, так і соціалізацію студента як особистості, набуття необхідних для практики професійних знань та навичок, формування професійних, світоглядних і громадських якостей майбутнього фахівця, розвиток його професійних здібностей, становлення рис характеру, формування соціальних цінностей у зв'язку з професіоналізацією. Тож реалізуючи своє право на якісну освіту, здобувачі вищої освіти усвідомлюють свої морально-етичні зобов'язання дотримуватися правил академічної доброчесності, зокрема, у навчанні:

- дотримуватися принципів чесності, довіри, справедливості, поваги, відповідальності;

- обстоювати цінності академічної доброчесності та дотримуватися ії правил у всіх видах діяльності в університетському просторі та за його межами;

в особистій поведінці:

- дотримуватися етичних норм спілкування та співпраці в університетському просторі та за його межами;

- усвідомлювати неприпустимість публічного коментування приватного життя чи особистих якостей студентів, викладачів та інших членів університетської спільноти.

Так, у Сумському державному педагогічному університеті імені А. С. Макаренка вченою радою ухвалено Кодекс академічної доброчесності, метою якого $€$ :

- формування академічних цінностей та високої академічної культури учасників освітнього процесу Університету;

- визначення принципів i встановлення норм академічної доброчесності як невід'ємної складової професійної етики та корпоративної культури;

- формування сприятливого академічного середовища для забезпечення високоякісного освітнього процесу, отримання вагомих наукових результатів, що містять об'єктивну новизну, установлення 
взаємодовіри і взаємоповаги між всіма членами колективу, адміністрацією та особами, що навчаються;

- забезпечення всебічного розвитку інтелектуального, професійного та особистісного потенціалу всіх учасників академічної спільноти;

- виховання еліти України, формування громадянської позиції учасників освітнього процесу Університету;

- забезпечення якості освітньої діяльності та якості вищої освіти в Університеті;

- формування високого рівня наукових та творчих, професійних і загальних компетентностей здобувачів освіти;

- утвердження в учасників освітнього процесу моральних та духовних цінностей, соціальної активності й відповідальності;

- виховання здобувачів освіти відповідальними, професійними, здатними до свідомого спрямування своєї діяльності;

- забезпечення необхідних умов для реалізації здобувачами освіти їх здібностей і талантів;

- підвищення позитивного іміджу та ділової репутації Університету у вітчизняному та європейському освітньому просторі;

- підвищення іміджу, престижу та репутації Сумського державного педагогічного університету імені А. С. Макаренка як потужного навчальнонаукового та високодуховного центру Слобожанщини та України, забезпечення його публічності, прозорості та відкритості (Кодекс академічної доброчесності Сумського державного педагогічного університету імені А. С. Макаренка).

Ухвалення Кодексу не $\epsilon$ єдиним усвідомленням академічною спільнотою всіх проявів академічної недоброчесності. Наступним кроком $\epsilon$ створення та діяльність комісії з етики та академічної доброчесності колегіального, експертно-консультативного органу, метою якого $є$ сприяння дотриманню етичних принципів і стандартів, фундаментальних принципів академічної доброчесності та розв'язанню етичних конфліктів між членами університетської спільноти. Важливо, щоб ролі членів комісії були деталізовані та придатні до реального впровадження, адже існування правил академічної доброчесності лише на папері без реальної роботи зведуть нанівець ініціативу та будуть грубим порушенням ідеї 42 статті Закону.

Сурова реальність сьогодення не розглядає доброчесність як пріорітет, адже незаплямованим залишитись у суспільстві, де корупція, плагіат і брехня - це норма, - важко. Професорсько-викладацький склад університету завжди наголошував на принципах доброчесності, зосереджує свою увагу на цих цінностях, формуванні нової академічної культури, яка базується на довірі, чесності, прозорості, реальному навчанні, справжній науковій роботі, ураховуючи те, що академічна доброчесність безпосередньо впливає на те, яку молодь виховує система 
вищої освіти в країні, які цінності закладаються під час навчання в університеті та яким є секрет їх успіху в майбутньому.

Система забезпечення академічної доброчесності Університету також включає в себе підписання Декларації про академічну доброчесність учасниками освітньо-наукового процесу як вияв особистого прагнення кожного учасника освітньо-наукового процесу добровільного виконання принципів і норм Кодексу академічної доброчесності. Декларації розроблені та затверджені для двох категорій учасників освітнього процесу: науково-педагогічних, педагогічних і наукових працівників та Декларація здобувача вищої освіти.

Підписання Дикларації про академічну доброчесність академічної спільноти університету науково-педагогічними, педагогічними і науковими працівниками університету $\epsilon$ важливим кроком на шляху утвердження високих етичних норм та доброчесності в академічній спільноті Університету, справою честі кожного макаренківця, проявом бажання здійснювати власну освітню, наукову, творчу діяльність, дотримуючись місії, візії, цінностей, корпоративної культури Університету, найвищих моральних і правових норм академічної доброчесної поведінки, керуючись законодавством України, етичними вимогами до професійної та наукової діяльності, виконання вимог Кодексу академічної доброчесності університету.

Ректор, проректори та члени Вченої ради стали першими з-поміж співробітників та здобувачів вищої освіти Університету, хто власноручним підписом засвідчив про підтримку ідей сповідування принципів і виконання зобов'язань, зазначених у деклараціях.

Декларацією про академічну доброчесність члена академічної спільноти Університету здобувач вищої освіти заявляє про підтримку політики Університету з академічної доброчесності та зобов'язується у своїй навчально-науковій, творчій діяльності дотримуватися зазначених у Кодексі академічної доброчесності Університету основних принципів та фундаментальних цінностей академічної доброчесності та етики академічних взаємовідносин, а також загальнолюдських норм моралі; не використовувати ідеї, твердження, відомості, тексти тощо без посилання на джерела; використовувати лише достовірні джерела інформації, не вдаватися до фальсифікації чи фабрикування даних, самостійно виконувати навчальні завдання, завдання поточного та підсумкового контролю (для осіб із особливими освітніми потребами ця вимога застосовується 3 урахуванням їхніх індивідуальних потреб і можливостей), уникати будьяких видів та форм академічної недоброчесності у власній освітній практиці та правомірно перешкоджати таким проявам у діяльності інших здобувачів, учасників освітнього процесу, надавати достовірну інформацію щодо результатів власної освітньої, наукової, творчої, спортивної, громадської діяльності. 
Чи складно досягати задекларованих правил? Так, але якщо особа планує їх досягти, то вона здолає будь-які перешкоди, які створюють бар'єр для недоброчесності. У першу чергу - це повага до себе, феномен, що складається з дуже простих речей, які кожен з нас може легко засвоїти. Найкращий спосіб досягти гармонії з собою - це поводитися так, щоб ти ніколи не відчував неповагу до себе, а вагомим ключем до цього $\epsilon-$ залишатися вірним собі і тому, що вважаєш правильним, незважаючи ні на що і ні на кого, адже, як вважає Е. Фромм, джерело норм моральної поведінки слід шукати в самій природі людини, що характер зрілої і продуктивної особистості $\epsilon$ джерелом доброчинності, а зло - це байдужість до себе, це саморуйнування, а тому, щоб бути впевненим у своїх цінностях, людина має знати саму себе і свою здатність до добра (Фромм, 1998, с. 31-32).

Висновки. Отже, ми дійшли висновку, що феномен академічної доброчесності $€$ багатогранним та може набувати різних проявів, він охоплює сукупність етичних принципів та визначених законом правил, якими мають керуватися учасники освітнього процесу в освітній діяльності, у процесі викладання та провадження наукової діяльності $з$ метою забезпечення довіри до результатів навчання та наукових досягнень, він відіграє надзвичайно важливу роль у науковому світі, колі вчених, викладачів та студентів, $€$ моральним ядром академічної культури й забезпечує гідну та свідому поведінку особистості протягом усього життя. Він потребує постійної роботи над собою.

Запропоновані шляхи вивчення й розуміння природи його походження уможливлять розроблення та імплементацію ефективної політики університету щодо забезпечення академічної доброчесності як під час освітньо-наукового процесу, так і в повсякденному житті, адже студенти повинні здобути якісну освіту, необхідну передусім для них самих, бо саме від цього залежить їх майбутнє, а роботодавці, приймаючи молоде покоління на роботу, мають бути упевнені в якості дипломів, виданих університетами.

Зважаючи на еволюційний процес упровадження академічної доброчесності, наступним кроком у підтримці ії принципів та протидії академічній недоброчесності в університетському середовищі буде дослідження академічної свободи, внутрішьої відповідальності здобувачів вищої освіти, про їх належне, сумлінне ставлення до виконання своїх академічних обов'язків, що ґрунтується на високому рівні правосвідомості й розумінні свого високого статусу.

\section{ЛITEPATУРA}

Killinger, B. (2010). Doing the Right for the Right Reason. McGill-Queen`s University Press. Кодекс академічної доброчесності Сумського державного педагогічного університету імені А. С. Макаренка (Code of Academic Integrity of Sumy State Pedagogical University 
Педагогічні науки: теорія, історія, інноваційні технології, 2020, № 3-4 (97-98)

named after A. S. Makarenko). Retrieved from:

https://sspu.edu.ua/universytet/edusci/normatyvno-pravova-baza.

Про освіту (2017). Закон України від 05.09.2017 року. Відомості Верховної Ради України (BBP), 38-39 (On education (2017). Law of Ukraine of September 5, 2017. Bulletin of the Verkhovna Rada of Ukraine, 38-39).

Семененко, Л. П. (2016). Академічна доброчесність - запорука якісної освіти. Роль бібліотеки у створенні когнітивного ресурсу суспільства знань: технології, освіта, наука, сс. 145-150. Режим доступу: http://bit.ly/2ekakCW (Semenenko, L. P. (2016). Academic integrity - a key to quality education. The role of the library in creating a cognitive resource of the knowledge society: technology, education, science, pp. 145-150. Retrieved from: http://bit.ly/2ekakCW).

Центр академічної доброчесності. Десять принципів академічної доброчесності для викладачів. Режим доступу: https://drive.google.com/file/d/OByePGdGpHh6Wb3Qzc2F3ODBuZWM/view (Center for Academic Integrity. Ten principles of academic integrity for teachers. Retrieved from: https://drive.google.com/file/d/OByePGdGpHh6Wb3Qzc2F3ODBuZWM/view).

Фромм, Э. (1998). Психоанализ и этика. Москва (Fromm, Е. (1998). Psychoanalysis and ethics. Moscow).

\section{PEЗЮME}

Пшенична Любов. Академическая чесность: природа явления и приоритеты распространения среди студентов.

Статья раскрывает природу феномена академической чесности как категорию морали, основой которой есть этика - система моральних норм и правил, которые проявляються в разных фрормах человеческих отношений: обрядах, религиозных нормах, законах и последовательно утверждает, что главной задачей университета есть воспитание у студентов стремления к знаниям и поиску истины, что тот, кто знает, умеет, использует, придерживается чётко определённых правил и принципов морально устойчивой личности, mот и будет придерживаться норм академической доброчесности.

Данные утверждения обязуют профессорско-преподавательский сосотав высшего ученого заведения направлять студентов к осмыслению и чётко придерживаться фундаментальних ченностей высшего образования, которые ведут к повышению качества знаний через формирование академической культуры, академической граммотности, необходимых практических навыков устной и письменной речи; управление знаниями и инструментами, умение пользоваться которыми необходимы для полноценного функционирования в образовательной среде, а также на рыке труда в будущем, а достичь высокого качества образования можно только создав академическую среду ответственности и чесности.

Ключевые слова: чесность, академическая доброчесность, этика, мораль, ценности, участники образовательного процесса, принципы, стандарти.

\section{SUMMARY}

Pshenychna Liubov. Academic integrity: the nature of phenomenon and its distribution priorities among students.

The article reveals the nature of phenomenon of the academic integrity as the morality category, the basis of which is ethics - a system of moral norms and rules manifested in various forms of human relations: customs, religious norms, laws and consistently. It argues that the main task of the university is to educate students and search for the truth that he who knows, knows how to use, adheres to clearly defined rules and principles of a morally stable personality, he will adhere to the postulates of academic integrity. 
The given definitions oblige the teaching staff of the higher education institution encouraging students to understand and strictly adhere to the fundamental values of higher education, which are a direct way to improve the quality of knowledge through the formation of academic culture, academic literacy, necessary practical skills of oral and written language, which are necessary for successful training and future professional activity; providing them with the necessary knowledge and tools, mastery and operation of which are necessary for the full functioning of the educational community and the labor market in the future, and to achieve high quality education is possible only by creating an academic environment of responsibility and honesty.

Key words: honesty, academic honesty, ethics, morality, values, participants of the educational process, principles, standards.

\title{
удк 378
}

\author{
Ліліана Хімчук \\ ДВНЗ «Прикарпатський національний \\ університет імені Василя Стефаника», \\ ORCID ID 0000-0002-9243-3131
}

DOI 10.24139/2312-5993/2020.03-04/146-159

\section{КОНСТРУКТИВНА ПЕДАГОГІЧНА ВЗАЕМОДІЯ ЯК ОДНА З БАЗОВИХ КОМПЕТЕНТНОСТЕЙ МАЙБУТНІХ УЧИТЕЛІВ ПОЧАТКОВОЇ ШКОЛИ}

У статті розглядається явище конструктивної педагогічної взаємодії як базової компетентності майбутніх учителів початкових класів. Вона трактується як здатність педагога реалізувати навчально-виховні завдання шляхом використання комунікативних стратегій, що характеризуються позитивним взаємовпливом суб'єктів навчального процесу, а саме: «мова приймання» (мова схвалення та пасивне слухання); "активне слухання»; «комунікативні висловлювання»; "безпрограшне розв'язання конфліктів». Проаналізовано різні підходи до визначення педагогічної взаємодії, використання комунікативних стратегій, розроблених американським ученим-гуманістом Т. Гордоном та їх вплив на розвиток конструктивної педагогічної взаємодії. У статті розглянуто комунікативну стратегію "мови приймання», окреслено принципи, на яких вона повинна грунтуватися, а також описано стратегію "активного слухання», виокремлено ї̈ елементи.

Ключові слова: базова компетентність, педагогічна взаємодія, педагогічна стратегія, стратегія "мови приймання», стратегія "активного слухання», майбутні вчителі.

Постановка проблеми. Стрімкий технологічний розвиток суспільства не тільки вимагає від освітян формування нових професійних компетентностей, пов'язаних із активним і швидким удосконаленням цифрових технологій, а й впливає і на роль учителя, надаючи їй нового значення в освітній системі. Учителі, оволодіваючи новими професійними вміннями, що певною мірою відрізняються від традиційних, опановують і нові ролі: навчальних консультантів, наставників, тренерів, які вміють налагоджувати позитивну безконфліктну взаємодію зі всіма суб'єктами навчального процесу. Виконуючи роль навчальних консультантів, учителі покликані стимулювати учнів ще й до взаємодії з навчальним контентом, 
ставлячи за мету не тільки усвідомлено сприймати викладений у ньому зміст, а й критично ставитися до наданої їм інформації, вчитися проектувати, створювати й трансформувати ії.

Роль навчальних консультантів полягає в наданні рекомендацій, пропозицій учням, щоб допомогти їм у навчальному процесі сформувати необхідні в житті вміння, та все ж найважливішим у цій ролі $\epsilon$ надання різних видів підтримки, щоб допомогти досягти як найповнішої реалізації поставлених перед учнями навчальних цілей. До першочергових функцій учителів-консультантів належить підсилення й розвиток когнітивних та креативних процесів в учнів, а саме: інтелектуальної допитливості, умінь визначати проблеми і розв'язувати їх, здатності створювати нові знання самостійно й співпрацюючи з іншими.

Як зазначає дослідниця наративного підходу в освітніх практиках Л.І.Тимчук: «Для вчителя XXI століття $\epsilon$ неможливим оволодіти всім обсягом постійно зростаючих знань, натомість він має бути експертом у розробці навчальних стратегій, які 6 давали відповіді на питання «як зробити?», «як знайти або винайти щось?», або "як застосувати те, що вміємо й знаємо, щоб отримати щось нове?». Завданням вчителя $\epsilon$ моделювання начального процесу так, щоб всі його учасники відчували вчительську впевненість, відкритість, наполегливість і відданість учням у пізнавальному процесі осягнення невідомого. Все це вимагає від учителів глибше знати своїх учнів, якісно взаємодіяти з ними й творчо підходити до проектування навчальних програм та їх реалізації» (Тимчук, 2015).

Майбутні вчителі початкових класів - це, у першу чергу, творці позитивного світобачення, цікавої й безпечної пізнавально-активної реальності, у якій разом із учнями створюють нові знання, нові інформаційні повідомлення, навчають експериментувати, захоплено пізнавати світ, співпрацювати, щиро спілкуватися й дружити, радіти своїм здобуткам та досягненням інших. Професійна підготовка таких фахівців можлива лише за умови опанування ними не тільки новими педагогічними технологіями та стратегіями, а й новою педагогічною взаємодією, що одухотворює навчальний процес, робить його атрактивним, позитивним, творчим.

Аналіз актуальних досліджень. Одним із важливих напрямів педагогічних досліджень у вітчизняному освітньому просторі останніх років постає проблема педагогічної взаємодії - проблема співробітництва, діалогу та партнерства у взаємовідносинах суб'єктів навчального процесу. Увага наукового співтовариства й педагогічної спільноти прикута до вивчення різних аспектів педагогічної взаємодії, що в педагогічному просторі використовується для окреслення відносин суб'єктів навчального процесу. Педагогічна взаємодія в усі часи $€$ основоположною, невичерпною за своєю природою, складовою діяльності вчителя. У ії основі відображено складний синтез об'єктивних та суб'єктивних знань, 
досвіду (про загальні закономірності розвитку людини, особливості їі розвитку в конкретних умовах та ін.), які необхідно ефективно застосовувати в професійній діяльності педагога.

Проблема взаємодії суб'єктів навчально-виховного процесу завжди була актуальною. Від ії̈ успішного розв'язання безпосередньо залежать ефективність упровадження нових освітніх технологій у педагогічну практику, рівень духовного зростання особистості. Необхідність пошуку розв'язання різноаспектних проблем розвитку педагогічної взаємодії, спонукала їі досліджувати як видатних учених і педагогів минулого (Г. Ващенко, П.Каптєрєв, Я. А. Коменський, А. Макаренко, О. Сухомлинський, Й. Песталоцці, Я. Чепіга), так і наших сучасників.

Підготовка майбутнього вчителя до різних видів взаємодії суб'єктів освітнього процесу висвітлена у працях таких науковців, як А. Авраменко, А. Вербицький (групова взаємодія), Л. Велитченко, Н. Волкова, І. Зязюн, Є. Коротаєва, Л. Ковальчук, О. Матвієнко, М. Лещенко (педагогічна взаємодія), В. Казанська (співробітництво у навчанні), І. Кобзарева (особистісно орієнтована взаємодія), Ю. Костюшко, М. Рибакова (конфлікт та взаємодія в освітньому процесі). Психологічні засади взаємодії як форми спілкування розробляли Л. Виготський, О. ЛеонтьєВ, Б. Ломов та ін. Аналіз науково-педагогічної літератури свідчить, з одного боку, про різноманітність підходів до проблеми «взаємодія», а з іншого - дає підстави стверджувати, що зазначений феномен має широке практичне використання.

Водночас, на даний момент не існує єдиного підходу до визначення сутності цього поняття й ідея педагогічної взаємодії суб'єктів навчального процесу в системі формальної та неформальної освіти ще не знайшла належного осмислення і втілення у процес підготовки майбутніх педагогів. Різноманіття підходів до тлумачення цього поняття свідчить не тільки про актуальність його дослідження, а й про відкриття нових граней потенціалу педагогічної взаємодії щодо відкриття широких перспектив для вдосконалення вітчизняної системи освіти, формування нових концептуальних засад на рівні дуальної взаємодії «учитель - учень», «викладач - студент», де сторони виступають як рівноправні, паритетні, зацікавлені партнери.

Мета статті - вивчити досвід формування конструктивної педагогічної взаємодії шляхом використання різних комунікативних стратегій.

Методи досліджень: для реалізації поставленої мети були використані загальнонаукові методи дослідження, зокрема аналіз, синтез, порівняння та узагальнення.

Виклад основного матеріалу. Педагогічна взаємодія $є$ надзвичайно важливим чинником успішності навчального процесу й тому потребує ґрунтовного вивчення для подальшого розвитку та вдосконалення педагогічної теорії й практики, розбудови української системи освіти в 
світлі викликів цифрового суспільства. Реагуючи на серйозні проблеми, що виникають у процесі трансформації системи освіти в державі, виникає необхідність більш ґрунтовного вивчення й вирішення цієї проблеми проблеми підготовки учителів початкових класів до конструктивної педагогічної взаємодії зі всіма учасниками навчального процесу.

Термін «педагогічна взаємодія» в науковому просторі має широкий діапазон трактувань і «педагогічна взаємодія» визначається як: спеціально організовані контакти педагога з дитиною (тривалі або тимчасові), метою яких $є$ зміни в поведінці, діяльності та відносинах дитини; безпосередній або опосередкований вплив суб'єктів цього процесу один на одного, що породжує їх взаємну обумовленість і зв'язок, яка виступає як інтегруючий фактор педагогічного процесу та сприяє появі особистісних новоутворень у кожного з суб'єктів цього процесу. У сучасному педагогічному словнику довіднику з професійної педагогіки термін «педагогічна взаємодія - це процес впливу викладача та тих, хто навчається, один на одного, що передбачає їх взаємну зміну суб'єкт-суб'єктних позицій. Виходячи з науковопедагогічного підходу, педагогічна взаємодія має особистісно орієнтований характер, а саме: створення атмосфери тепла; емоційного комфорту; сприятливих умов для усвідомленого навчання; надання свободи вибору діяльності тим, хто навчається; урахування індивідуальних особливостей та можливостей кожного хто, навчається» (Марченко, с. 130).

Проведений аналіз наукової психолого-педагогічної літератури дає підстави стверджувати, що поняття «педагогічна взаємодія розглядається в переважній більшості в контексті спілкування. Важливою в цьому аспекті $€$ думка відомого психолога О. Леонтьєва, який зазначає: «...центральним моментом спілкування (комунікації) $€$ не «передача інформації», а взаємодія з іншими людьми як внутрішній механізм життя колективу, причому взаємодія розуміється як обмін ідеями, інтересами, як засвоєння знань та суспільно-історичного досвіду» (Леонтьев, 1975, с. 107).

Більшість дослідників розглядають поняття «педагогічної взаємодії» як таке, що виражає реальну передачу досвіду від покоління до покоління на основі принципу «свідомість від свідомості, особистість від особистості» й засвідчує наявність у педагогічній та історично-культурній реальності усвідомленої та цілеспрямованої діяльності, метою якої $є$ становлення та генеза людської особистості.

Український учений Л. Велитченко розглядає педагогічну взаємодію як «системне явище в педагогічному процесі, що зазнає впливу з боку соціальної системи у плані статусно-рольових відносин у суспільстві, регламентується нормативними документами в системі освіти, визначається практикою закладу освіту, реалізується вчителем, діяльність якого є основою для розвитку діяльності учня» (Велитченко, 2005). На думку вченого, загальна закономірність педагогічної взаємодії полягає у 
відтворенні й засвоєнні соціального, групового, міжособистісного досвіду вчителем та учнем. До структури педагогічної взаємодії вчений відносить наступні взаємозалежності: освітню, педагогічну, соціально-психологічну, міжособистісну систему, а також особистості та діяльність учителя та учнів, усвідомлення ними інтерактивного досвіду, регулятивні та виконавчі елементи взаємодії (Велитченко, 2005).

У дослідженні Л. Ковальчук знаходимо підхід, що розглядає педагогічну взаємодію як систему синергетичної взаємодії суб'єктів навчального процесу, що розгортається на рівні різних підсистем і спрямована на освіту, виховання, розвиток, формування особистості (Ковальчук, 2005). Дослідниця О. Марченко виокремлює такі характеристичні ознаки педагогічної взаємодії: наявність єдиної мети як усвідомленого й запланованого результату; чіткий розподіл функціональних обов'язків між учителем і учнями в навчально-педагогічній діяльності; виникнення спілкування (Марченко).

Поглиблений інтерес у вітчизняному науково-педагогічному просторі до підвищення рівня компетентності та якісної підготовки майбутніх учителів початкових класів зумовлює необхідність розробки нових підходів, педагогічних стратегій у формальному й неформальному навчанні педагогічних кадрів, що пов'язані з розвитком педагогічно доцільних та позитивних відносин у системі налагодження ними педагогічної взаємодії.

Надзвичайно вагомим є концептуальний підхід академіка І. Зязюна до проблеми педагогічної взаємодії. «У педагогічній дії, - зазначав учений, - $\epsilon$ два рівнозначні суб'єкти за змістовною сутністю - Людина і Людина. Вони мають створювати один одному відчуття спокою, рівноваги, благополуччя, щастя. Як це зробити, знає передусім педагог. Він має навчити цього своїх учнів незалежно від предмета викладання. Навчити ненав'язливо, нетенденційно, мимовільно. Навчити своєю Поведінкою, своїм Статусом, своїми Знаннями, своєю Людяністю, своєю Свободою, своєю Любов'ю, своїм Щастям, своїм Талантом» (Зязюн, 2000, с. 74).

Осмислення та об'єктивне оцінювання взаємодії в педагогічній діяльності було й залишається важливим для будь-якої освітньої системи, адже в умовах педагогічної взаємодії результат, як правило, має тільки дві взаємозаперечуючі характеристики: він позитивний (успішний, конструктивний) або негативний (деструктивний). Позитивна (конструктивна) педагогічна взаємодія приносить ії учасникам радість, задоволення від навчального процесу, розкриття життєвих сил, здібностей та талантів, людина стає відкритою до світу й інших людей. Слушною є думка видатного ученогопедагога М. Лещенко, яскравої представниці вітчизняної гуманістичної школи педагогічної майстерності І. Зязюна: «Учитель, який відкритий до співпраці 3 учнями, поважає вихованців, не пригнічує їх незадовільними оцінками за 
помилкові твердження на шляху до усвідомлення істини, протистоїть тенденції зробити з учнів «слухняні механізми» і всіляко сприяє розквіту їхніх обдарувань» (Лещенко, 2003, с. 17).

Неконструктивна педагогічна взаємодія супроводжується негативом, призводить до появи страху, тривожних очікувань, панічного настрою, що веде до втрати довіри, розуміння у відносинах, відчуження, деструктивних відносин, людина стає замкненою, відсторонюється від інших, їі життєвий потенціал нівелюється й руйнується. Це стає складною, а інколи, й непереборною перешкодою у процесі розвитку та вдосконалення особистості.

Тому надзвичайно важливою й необхідною якісною характеристикою професійної компетентності майбутніх учителів початкових класів вважаємо сформованість у них умінь налагоджувати позитивно-конструктивну педагогічну взаємодію зі всіма суб'єктами навчально-виховного процесу.

В аспекті підготовки майбутніх учителів початкових класів до конструктивної педагогічної взаємодії, цікавим, на нашу думку, є досвід відомого американського вченого-психолога, визначного педагогагуманіста, представника школи комунікативної педагогіки, автора методики ефективного спілкування Томаса Гордона. Численні наукові праці вченого стали всесвітньо відомими психолого-педагогічними бестселерами й присвячені саме проблемі міжособистісного спілкування, а заснований ним фонд «Гордон Трейнінг Інтернешенел» (Gordon Training International) ефективно функціонує в різних країнах світу готуючи фахівців, не тільки для освітньої, а й інших галузей суспільної діяльності

у вітчизняному освітньому просторі науковий доробок ученого досліджувала представниця науково-гуманістичної школи М. П. Лещенко С. Д. Ісаєва (Ісаєва, 2015). У її посібнику «Комунікативна педагогіка Томаса Гордона» представлено життєвий і творчий шлях американського вченого, який виокремив причини педагогічних невдач і поразок та запропонував стратегії ефективної педагогічної взаємодії (Ісаєва, 2014). У контексті нашого дослідження вважаємо за необхідне звернутися до розробленої Томасом Гордоном системи, що базується на засадах гуманістичної психології та клієнт-центрованій та групо-центрованій терапії та дозволяє реалізувати в професійній підготовці вчителів початкових класів принципи демократичної педагогічної взаємодії. Адже, як наголошував учений: «визначальним чинником, що впливає на ефективність навчання, $є$ якість стосунків між учителями і учнями незалежно від вікових особливостей і специфіки предмету, який викладається» (Ісаєва, 2015, с. 88).

Основоположним у системі підготовки учителів Томаса Гордона $\epsilon$ те, що вони повинні оволодіти навичками успішного педагогічного спілкування з учнями на рівні психологів-професіоналів. На думку вченого, втілити в життя концептуальні засади розробленої ним системи можливо 
лише за умови наявності у вчителів наступних особистісних та професійних якостей та вмінь: аутентичність, емпатійність, застосовувати мову приймання, володіти стратегіями конструктивного розв'язання конфліктів, постійно вдосконалювати педагогічну майстерність взаємодії з учнями. Сформованість таких умінь у майбутніх учителів початкових класів й компетентне їх використання у професійній діяльності дозволить «встановити унікальний вид стосунків - правдиву, відкриту, чесну, теплу і взаємно турботливу комунікацію учителів з учнями, що зробить школу більш гуманною» (Ісаєва, 2015, с. 87).

Дослідивши численні праці вченого, С. Д. Ісаєва звертає увагу на не, що Томас Гордон визначальним чинником, котрий впливає на ефективність навчання, визначав саме якість педагогічної взаємодії між вчителями та учнями. Учений виокремив і обґрунтував засадничі вимоги до особистості учителя, що, на його думку, є основою його конструктивної педагогічної взаємодії з учнями:

- бути аутентичним;

- відкрито виражати свої почуття;

- мати право на власну позицію у виховному процесі;

- виражати незгоду з поведінкою учня;

- відмовитися від погроз у разі невиконання учнем його волі й наказів;

- надавати можливість учням вибору власних цінностей;

- ділитися своїми культурними цінностями, але не нав'язувати їх;

- надавати учням можливість самореалізації й саморозвитку (Ісаєва, 2015, с. 87-89).

Окрім сформульованих Т. Гордоном засадничих вимог до особистості вчителя та концептуальних засад демократичної педагогічної взаємодії, ученим були визначені педагогічні стратегії, що допомагають у налагодженні та реалізації позитивних стосунків між учителем і учнем, а також узгоджують зміст та види навчальної діяльності, окреслюють шляхи передачі, опрацювання й обміну навчальною інформацією. До них належать такі:

- стратегія «мови приймання» (мова схвалення та пасивне слухання);

- стратегія «активного слухання»;

- стратегія «комунікативних висловлювань»;

- стратегія «безпрограшного розв'язання конфліктів»;

- стратегія «змінення навколишнього середовища» (Ісаєва, 2015, c. 90).

Коротко схарактеризуємо запропоновану Т. Гордоном стратегію «мови приймання». її сутність, з точки зору американського вченого, полягає у прийнятті людиною іншої людини такою, якою вона $є$, а також у ретельному підбиранні конструктивних висловлень під час спілкування та 
проведення терапевтичних бесід. Томас Гордон визначив визначає три принципи, на яких повинна ґрунтуватися мова приймання:

1. Завжди сприймати іншу людину такою, якою вона $\epsilon$.

2. Формулювати й викладати думки у спілкуванні, які сприятимуть конструктивному діалогу.

3. Надавати поради щодо вирішення проблем учнів, оволодівши прийомами терапевтичної бесіди (Ісаєва, 2015, с. 91).

Багаторічний досвід досліджень та практичної діяльності привів ученого до переконання, що коли учнів приймають як дорослих, це має вагомий позитивний вплив на вихованців, дозволяє встановити з ними ефективну комунікативну взаємодію. Коли учень відчув, що до нього ставляться з повагою й небайдужістю, у нього виникає стимул реалізувати свій особистісний потенціал, вдосконалюватися, змінюватися на краще. Однак, як показує практика шкільного навчання, більшість учителів сповідують переконання, що якщо приймати учня таким, яким він є, то він таким і залишиться. Звідси, кращим виховним прийомом, який використовують такі вчителі, стає виявлення й наголошення на недоліках учнів, що апріорі стає мовою неприймання. Але вони більш ніж переконані в тому, що саме таке вказування як найкраще допомагає учню.

Щире використання мови приймання дає можливість учню розкритися, відкрити доступ до потаємних струн своєї душі, поділитися своїми сумнівами, турботами, переживаннями. Слід зазначити, що саме непідробне, справжнє приймання й використання відповідної мови вчителем у спілкуванні призводить до налагодження конструктивної педагогічної взаємодії з учнем, сприяє благотворним, позитивним змінам у розвитку його особистості. Не приймання ж учителем учня призводить до появи в дитини надзвичайно небезпечного стану, коли дитина замикається в собі, почувається неповноцінною, непотрібною, постійно відчуваючи дискомфорт та небажання взаємодіяти з учителем. 3 цього приводу Томас Гордон зазначає: «Приймання іншої людини такою, якою вона $€$, виявляється в демонстрації своєї любові і поваги до неї. Слова також підштовхують людину до конструктивних змін, якщо це доброзичливі слова. Від того, як учителі розмовляють зі своїми учнями, залежить, чи впливатимуть вони на них конструктивно чи деструктивно» (Ісаєва, 2015, с. 91).

Не секрет, що «словом можна вилікувати, або вбити» тож коли мова йде про вербальну комунікацію в процесі педагогічної взаємодії, будь-яка розмова вчителя з учнем може зруйнувати їх людські взаємовідносини або, навпаки, зміцнити їх, віддалити їх один від одного, або зблизити. Отже вчителю завжди слід пам'ятати, що результат його розмови з учнем перебуває в цілковитій залежності від ії якості, наскільки правильно він зможе обрати слова, тональність розмови в кожній конкретній ситуації. У цьому контексті важливою складовою педагогічної взаємодії $\epsilon$ 
сформованість у майбутнього вчителя початкових класів умінь проводити терапевтичну бесіду, що є виключно важливим методом надання вчителем допомоги учню під час особистої комунікації. У такому комунікативному процесі виявляються індивідуальні особливості учня, з'ясовуються особистісні проблеми, налагоджуються й підтримуються рівні (паритетні) відносини. Учитель надає допомогу, яку потребує учень (вона може стосуватися проблематики, що хвилює учня, навчальної діяльності, його стосунків в колективі та ін.).

Відносно сформованості вмінь проводити терапевтичну бесіду Т.Гордон зазначає: «Основне завдання вчителя полягає в тому, щоб допомогти учню подивитися на свої проблеми і життєві складнощі з різних точок зору, продемонструвати й обговорити ті сторони взаємин, які, будучи джерелами труднощів, звичайно не усвідомлюються і не контролюються. У результаті застосування терапевтичної бесіди учні почуваються краще, охоче розповідають про себе, чіткіше виражають свої почуття, знаходять відчуття власної значущості й самоповаги, краще розвиваються, і в них зникають острахи перед життєвими проблемами» (Ісаєва, 2015, с. 91-92).

У процесі проведення терапевтичної бесіди основним завданням, яке повинен розв'язати вчитель, є надання допомоги учню, можливості розглянути його проблеми й життєві труднощі з різних сторін і точок зору, продемонструвати та роз'яснити ті аспекти взаємовідносин, які, стаючи причиною виникаючих складнощів, учень не усвідомлює й не може контролювати. Результатом використання терапевтичних бесід $\epsilon$ покращення самопочуття учнів, вони охочіше розповідають про себе, чіткіше висловлюють свої почуття, діляться думками, відновлюють відчуття власної гідності та самоповаги, краще розкривають свої здібності, позбавляються страху перед життєвими викликами та проблемами.

Т. Гордон зазначає, що «небагато вчителів володіють інтуїтивним вмінням вести терапевтичну бесіду. Більшості з них для початку необхідно забути про деструктивні підходи (авторитарне та ліберальне спілкування), які зводять бар'єри між людьми, і лише після цього засвоювати стратегію безпрограшного розв'язання конфліктних ситуацій» (Ісаєва, 2015, с. 92).

Результати досліджень, проведених Томасом Гордоном, свідчать про те, яке колосальне значення для конструктивної педагогічної взаємодії в педагогічному процесі має вміння учителя слухати учня. Він доречно зауважує: «Природа наділила кожного вчителя, за деякими сумними винятками, можливістю чути, і в кожного $\epsilon$ свій досвід того, як прислухатися до дітей. Вчителі роблять це кожний день. Однак, те, що, як їм здається, вони чують, часто буває не тим, що намагаються передати їм діти» (Ісаєва, 2015, с. 92). Учений рекомендує вчителям ознайомитися й використовувати стратегію «активного слухання», яка допоможе з легкістю 
перевірити точність їх сприймання й переконатися, що вони чують саме те, що учні хочуть їм повідомити. Це необхідно для того, щоб запевнити учнів у тому, що їх учитель не лише почув, а й правильно зрозумів. Т. Гордон у процесі досліджень переконався, що учитель може допомогти учневі, завдяки досконалому вивченню стратегії «активного слухання».

Ця стратегія характеризує тип реакції одного співрозмовника на висловлене інформаційне повідомлення іншого. 3 точки зору вченого, активне слухання - це виявлена в ході розмови зворотна реакція вчителя на висловлену учнем проблему. Вона спрямована на уникнення комунікаційних блокад у педагогічній взаємодії й містить такі елементи:

1) невербальна концентрація уваги на співрозмовнику за допомогою експресії поглядом, мімікою і жестом;

2) використання підтримуючих, заохочувальних до ведення подальшої розмови простих вербальних форм («ага», «так-так», «розумію»);

3) пасивне слухання як виявлення акцептації проблеми (приймання реальної ситуації, що викликала проблему);

4) віддзеркалення проблеми (уважне повторення вчителем фраз, висловлених учнем для підтвердження правильного розуміння того, що почуто) (Ісаєва, 2015, с. 92-93).

Томас Гордон наголошував на тому, що оволодіння вчителями стратегією активного слухання сприятиме ефективності використання інших педагогічних стратегій. Оскільки її використання допомагає вносити ясність у проблемні питання, розвивати допитливість і створювати позитивний мікроклімат, у якому учні можуть вільно думати, розмірковувати, дискутувати та здобувати знання.

Слушними в контексті формування компетентності конструктивної педагогічної взаємодії в майбутніх учителів початкових класів $\epsilon$ рекомендації Т. Гордона щодо систематичної роботи з удосконалення їх комунікативних компетентностей, що відіграють важливу роль у налагодженні спілкування з учнями. Учений наголошував на необхідності систематичного поглиблення знань про специфіку міжособистісної комунікації, не тільки підвищувати рівень комунікативних умінь, а й системно вправлятися в їх реалізації на практиці, прагнути, щоб вони стали природними якостями й звичним способом поведінки. Крім того, щоб урізноманітнити процес навчання, зробити його більш захоплюючим, варто й учнів ознайомити з засадничими положеннями налагодження конструктивних міжособистісних взаємовідносин, позиціонувати їх як партнерів зі створення позитивної і комфортної для всіх атмосфери в класі.

Доцільним у налагодженні конструктивної педагогічної взаємодії як у класі, так і в закладі освіти $€$ й навчання стратегії «безпрограшного розв'язання конфліктів» учнів та вчителів-колег. Слід зазначити, що 
реалізація цих педагогічних стратегій буде більш успішною за умови, що і батьки оволодіють уміннями вибудовувати конструктивні взаємини 3 дітьми. У даному процесі майбутні учителі початкових класів повинні бути готові виступити в ролі їх консультантів та наставників. Таким чином, реалізація запропонованої Т. Гордоном педагогічної системи допомагає в підвищенні начальних досягнень учнів, сприяє творчій реалізації всіх суб'єктів навчального процесу й може суттєво вплинути на формування налагодження конструктивної педагогічної взаємодії.

Висновки та перспективи подальших розвідок. Для майбутніх учителів початкових класів, які у XXI столітті будуть працювати й виконувати ролі вже не тільки вчителя, а й консультанта, наставника, координатора, тьютора, образ, бачення сучасної школи та навчального процесу повинен суттєво відрізнятися від попередніх підходів. У реаліях сьогодення важливо й доцільно, щоб студенти переосмислили, ким $є$ і ким повинен бути вчитель. Бажано i, навіть, необхідно змінити бачення ролі сучасного педагога, трактуючи себе в майбутньому не стільки традиційними вчителями, скільки успішними та досвідченими учнями, які знають, уміють і хочуть допомагати іншим.

Тому, говорячи про розвиток базових компетентностей у майбутніх учителів початкових класів, слід чільне місце в їх ієрархії відвести саме професійним умінням налагоджувати конструктивну педагогічну взаємодію, що сприяє встановленню позитивної комунікації зі всіма суб'єктами педагогічного процесу, знаходженню нових шляхів і способів посилення навчальної творчості, упровадженню інновацій у навчання, мотивує та стимулює навчальну діяльність учнів. На нашу думку, розвиток цієї базової компетентності в майбутніх учителів початкових класів не буде ефективним без опанування комунікативної педагогіки Т. Гордона, розроблених ним педагогічних стратегій «мови приймання», «активного слухання», «комунікативних висловлювань», «безпрограшного розв'язання конфліктів», «змінення навчального середовища».

Таким чином, готуючи майбутніх учителів початкових класів у закладах вищої освіти й намагаючись сформувати в них базові компетентності, наполягаємо на тому, що чільне місце серед них повинна зайняти компетентність конструктивної педагогічної взаємодії. Пї̈ слід формувати під час вивчення психолого-педагогічних дисциплін із виваженим та осмисленим упровадженням такого, що вже довів свою ефективність, досвіду американського вченого-гуманіста Томаса Гордона, щодо створення психологічно-комфортної, як для вчителя, так і для учнів, атмосфери навчання, що сприяє розвитку всіх суб'єктів навчальновиховного процесу. Це дозволить вдосконалити не тільки систему підготовки педагогічних кадрів, а й систему конструктивної педагогічної взаємодії у вітчизняній освіті в цілому. 
Подальших досліджень потребує вивчення та реалізація досвіду комунікативної педагогіки в процесі підготовки учителів початкових класів до налагодження конструктивної педагогічної взаємодії в системі післядипломної перепідготовки педагогічних кадрів.

\section{ЛІТЕРАТУРА}

Велитченко, Л. К. (2005). Педагогічна взаємодія: теоретичні основи психологічного аналізу. Одеса: ПНЦ АПН України (Velytchenko, L. К. (2005). Pedagogical interaction: theoretical bases of psychological analysis. Odessa: PNC APN of Ukraine).

Волкова, Н. П. (2005). Профресійно-педагогічна комунікація: теорія, технологія, практика. Донецьк: Видавництво ДНУ (Volkova, N. Р. (2005). Professional and pedagogical communication: theory, technology, practice. Donetsk: DNU Publishing House).

Зязюн, І. (2000). Педагогіка добра: ідеали і реалії. Київ: МАУП (Ziaziun, І. (2000). Pedagogy of good: ideals and realities. Kyiv: MAUP).

Ісаєва, С. Д. (2014). Комунікативна педагогіка Томаса Гордона. Київ: ПанТот (Isaieva, S. D. (2014). Communicative pedagogy of Thomas Gordon. Kyiv: PanTot).

Ісаєва, С. Д. (2015). Комунікативна педагогіка у науковій спадщині американського вченого Томаса Гордона (1918-2002 рр.) (дис. ... канд. пед. наук: спец. 13.00.01). Суми (Isaeva, S. D. Communicative pedagogy in the scientific heritage of the American scientist Thomas Gordon (1918-2002) (PhD thesis). Sumy).

Ковальчук, Л. (2005). Педагогічна взаємодія викладача і студентів під час використання нових інформаційних технологій навчання у процесі вивчення педагогічних дисциплін. Вісник Львівського університету.19, 4. 2, 17-25 (Kovalchuk, L. (2005). Pedagogical interaction of teacher and students during the use of new information technologies in the process of studying pedagogical disciplines. Bulletin of Lviv University, 19, part 2, 17-25).

Леонтьев, А. А. (1975). Деятельность. Сознание. Личность. Москва: Политиздат (Leontiev, A. A. (1975). Activity. Consciousness. Personality. Moscow: Politizdat).

Лещенко, М. П. (2003). Щастя дитини єдине щастя на землі: До проблеми педагогічної майстерності. Київ: ACMI (Leshchenko, М. P. (2003). The happiness of the child is the only happiness on earth: To the problem of pedagogical skill. Kyiv: ASMI).

Марченко, О. Психолого-педагогічні аспекти взаємодії вчителя й учнів у спільній пошуково-пізнавальній діяльності в умовах особистісно-орієнтованого навчання. Режим доступу: http://www.slideshare.net/alexandermarchenko925/ss15744300 (Marchenko, O. Psychological and pedagogical aspects of teacher-student interaction in joint search-cognitive activity in the conditions of personality-oriented learning. Retrieved from: http://www.slideshare.net/alexandermarchenko925/ss$15744300)$.

Семенова, А. В. (2006). Словник-довідник з професійної педагогіки. Одеса: Пальміра (Semenova, A. V. (2006). Dictionary-reference book on professional pedagogy. Odessa: Palmyra).

Тимчук, Л. І. (2015). Цифрові наративи в навчанні майбутніх магістрів освіти: історія, реалії, перспективи розвитку. Київ: Видавництво «LAT\&K» (Tymchuk, L. I. (2015). Digital narratives in the teaching of future masters of education: history, realities, prospects for development. Kyiv: LAT \& K Publishing House). 


\section{PEЗЮME}

Химчук Лилиана. Конструктивное педагогическое взаимодействие как одна из базовых компетентностей будущих учителей начальной школы.

В статье рассматривается явление конструктивного педагогического взаимодействия как базовой компетентности будущих учителей начальных классов. Она трактуется как способность педагога реализовать учебновоспитательные задачи путем использования коммуникативных стратегий, характеризующихся положительным взаимовлиянием субъектов учебного процесса, а именно: "речь приема» (речь одобрения и пассивное слушание); "активное слушание»; "коммуникативные высказывания»; "беспроигрышное решение конфликтов». Проанализированы различные подходы к определению педагогического взаимодействия, использование коммуникативных стратегий, разработанных американским ученым-гуманистом $T$. Гордоном и их влияние на развитие конструктивного педагогического взаимодействия. В статье рассмотрена коммуникативная стратегия "языка принятия», указаны принципы, на которых она должна основываться, а также описана стратегия "активного слушания», выделены ее элементы.

Ключевые слова: базовая компетентность, педагогическое взаимодействие, педагогическая стратегия, стратегия языка принятия, стратегия активного слушания, будущие учителя.

\section{SUMMARY}

Khimchuk Liliana. Constructive pedagogical interaction as one of the basic competences of future primary school teachers.

The article considers the phenomenon of constructive pedagogical interaction as a basic competence of future primary school teachers. It is interpreted as teacher's ability to implement educational tasks using communicative strategies characterized by the positive interaction of the subjects of the educational process, namely: "Language of acceptance" (language of approval and passive listening); "Active listening"; "Communicative statements"; "Win-win conflict resolution". Different approaches to the definition of pedagogical interaction, the use of communicative strategies developed by the American humanist T. Gordon and their influence on the development of constructive pedagogical interaction are analyzed.

The article considers the communicative strategy of the "language of accetance", the essence of which is to accept another person as he is, as well as in the careful selection of constructive statements during communication and therapeutic conversations. It also outlines the principles, on which the language of acceptance should be based, namely: always perceive another person as he is; formulate and present ideas in communication that will promote constructive dialogue; provide advice on solving students' problems by mastering the techniques of therapeutic conversation.

The author also describes the strategy of "active listening" in the article. The strategy characterizes the type of reaction of one interlocutor to the expressed information message of another. The strategy of "active listening" is interpreted as the feedback of the teacher to the problem expressed by the student revealed during the conversation and aimed at avoiding communication blockages in pedagogical interaction. It contains the following elements: nonverbal concentration of attention on the interlocutor through the expression of looks, facial expressions and gestures; the use of supportive, encouraging to talk further simple verbal forms ("yes", "I see"); passive listening as a detection of problem acceptance; reflection of the problem. 
The author emphasizes the need for systematic deepening of students' knowledge about the specifics of interpersonal communication, and the expediency of increasing the level of communication skills so that they become natural qualities and habitual behavior.

Key words: basic competence, pedagogical interaction, pedagogical strategy, strategy of the language of acceptance, strategy of active listening, future teachers.

удк 378.018.8:373.5.011.3-051:004]:378.147

\author{
Андрій Шуляк \\ Уманський державний педагогічний \\ університет імені Павла Тичини \\ ORCID ID 0000-0001-6615-0341 \\ DOI 10.24139/2312-5993/2020.03-04/159-170
}

\title{
ІНФОРМАТИЗАЦІЯ МЕТОДІВ АКТИВНОГО НАВЧАННЯ В ПІДГОТОВЦІ МАЙБУТНІХ УЧИТЕЛІВ ІНФОРМАТИКИ ДО ВИКОРИСТАННЯ ОСВІTHІХ WЕВ-PЕСУРСІВ У ПРОФЕСІЙНІЙ ДІЯЛЬНОСТІ
}

у статті на основі аналізу наукових джерел виокремлено методи активного навчання в підготовці майбутніх учителів інформатики до використання освітніх webресурсів у профресійній діяльності, розкрито иляхи їх інфрорматизації. Запропоновано використовувати методи активного навчання як самостійні педагогічні розробки, так $і$ в поєднанні з традиційними на різних етапах навчального процесу. Визначено характерні ознаки методів активного навчання. Передбачено перспективу подальших досліджень у напрямі розкриття взаємоузгодженості у використанні методів активного навчання, інноваційних форм, засобів та інформаційних технологій.

Ключові слова: методи активного навчання, підготовка фрахівців, майбутні учителі інформатики, освітні wеb-ресурси, професійна діяльність, гіперпосилання, сайт, інфрорматизація.

Постановка проблеми. У сучасних умовах від майбутніх педагогів потрібно не стільки наявність певного набору професійних знань у тій чи іншій сфері діяльності, скільки практичні вміння та навички, що забезпечують готовність виконувати професійні завдання і функції в різних, часом навіть нестандартних ситуаціях. Швидке старіння знань, що транслюються вищою школою, викликає необхідність сформувати у здобувачів вищої освіти такі якості, які дозволять їм самостійно й ефективно перетворювати, розвивати і доповнювати свої знання, а також використовувати їх із прикладною метою. Таким потенціалом володіють методи активного навчання, які спрямовані на формування вмінь і навичок самостійно отримувати і структурувати необхідну інформацію, виокремлювати проблеми і здійснювати пошук шляхів їх раціонального вирішення, критично аналізувати отримані знання й застосовувати їх для реалізації поставлених завдань.

У межах дослідження використовуватимемо поняття «методи активного навчання», оскільки вважаємо, що аналог «активні методи навчання» не $є$ коректним, оскільки метод сам по собі активний і пасивних методів не існує в принципі. Активність може бути застосована 
безпосередньо до навчального процесу і характеризує ступінь залученості в нього студентів.

У загальному сенсі під методами активного навчання розумітимемо методи, що змінюють характер навчання з репродуктивного на довільну внутрішньо детерміновану діяльність студентів із напрацювання й перетворення власного досвіду.

Аналіз актуальних досліджень. Дослідники (І.Гирка, 2015, О. Данилова, 2010, М. Жалдак, 2011, О. Коротун, 2019, А.Ляш, 2015, Р. Магомедов, 2017, Н. Морзе, 2003, М. Ниматулаєв, 2002, С. Овчаров, 2010, О. Спірін, 2007, Г. Стеценко, 2010, М.Сурхаєв, 2010, Г.Ткачук, 2011, А. Шихмурзаєва, 2015) одностайні в тому, що будь-який метод навчання вимагає для реалізації в освітньому процесі адекватних йому засобів навчання, зокрема й на базі веб-ресурсів. У цьому сенсі можна стверджувати про інформатизацію методів навчання.

Мета статті: виокремити методи активного навчання в підготовці майбутніх учителів інформатики до використання освітніх web-ресурсів у професійній діяльності, розкрити шляхи їх інформатизації.

Методи дослідження: аналіз наукових джерел із проблеми дослідження, що дало змогу виокремити та розкрити шляхи інформатизації методів активного навчання в підготовці майбутніх учителів інформатики до використання освітніх web-ресурсів у професійній діяльності.

Виклад основного матеріалу. Методи активного навчання можуть використовуватися як самостійні педагогічні розробки, так і в поєднанні $з$ традиційними на різних етапах навчального процесу. Визначаємо такі ознаки методів активного навчання: проблемність, адекватність навчальнопізнавальної діяльності характеру майбутніх практичних (посадових) завдань і функцій студента, індивідуалізація, самостійність взаємодії студентів із навчальною інформацією, взаємонавчання, мотивація. Розглянемо за відокремленими ознаками методи активного навчання майбутніх учителів інформатики до використання освітніх web-ресурсів у професійній діяльності.

Метод проєктів в інформатиці $€$ гнучкою моделлю організації навчального процесу, орієнтованою на творчу самореалізацію особистості студента, розвиток його інтелектуальних можливостей, вольових якостей і творчих здібностей у ході виконання творчих проєктів.

Проєктування як метод навчання в ЗВО пов'язаний зі створенням колективних або індивідуальних інформаційних продуктів, які можна використовувати в навчанні. Найчастіше це набір електронних освітніх ресурсів за певною тематикою, що містить сайт, декілька презентацій, аудіо-, фото-, відеоматеріали та довідкову інформацію у вигляді текстових файлів. У проєкт можуть включатися електронні таблиці і бази даних.

У межах нашого дослідження розглянемо три типи проєктів, реалізація яких доцільна під час організації навчання студентів до 
використання веб-ресурсів: інформаційні, практико-орієнтовані, навчальні, телекомунікаційні.

Інформаційні проєкти припускають діяльність зі збору інформації, представленої, наприклад, у мережі Інтернет або на локальних електронних носіях, за вузькою тематикою, її аналізу, подальшої систематизації та подання у вигляді анотації до знайденого ресурсу і посилання на цей ресурс. Ці анотації можуть використовуватися студентами під час самостійного вивчення окремих тем або розширення знань із відповідних тем. Тому анотації до інформаційних ресурсів повинні бути точними й досить детальними. Тематика інформаційних проєктів може бути найрізноманітнішою: анотації зі списком наявних web-ресурсів до конкретних підручників або тем відповідного курсу, аналіз ринку мультимедійних навчальних програмних комплексів тощо.

При виконанні практико-орієнтованого проєкту студенти самостійно визначають тип веб-ресурсу, підбирають програмні засоби розробки, навчальний матеріал на основі структурування знань предметної галузі, селекції структурних елементів, упорядковують їх під час синтезу конкретних освітніх ресурсів. Виконання цього проєкту передбачає розробку продуманої структури, навіть сценарію всієї діяльності його учасників із визначенням функцій кожного з них, чіткі виходи й участь в оформленні кінцевого продукту. Особливо важливою є хороша організація координаційної роботи в плані поетапних обговорень, коригування спільних та індивідуальних зусиль, із організації презентації отриманих результатів і можливих способів їх упровадження в практику, організації систематичної зовнішньої оцінки проєкту.

Метод проєктів органічно поєднується з навчанням у співпраці (cooperative learning) або методом навчальної співпраці - навчання в малих групах, що потребує звернення до розуміння слова «помилка». Швидше за все, помилку можна визначити, як невірну дію або твердження, що виходять із неправильного судження, неадекватного знання або неуваги, що вказує на необхідність додаткової практики і більшого тренування, щоб оволодіти необхідним умінням або знанням. Такий проєкт $€$ навчальним, під яким розумітимемо самостійну практичну діяльність студентів, організовану на основі використання освітніх webресурсів, що мають соціально значущу мету спрямовану на досягнення конкретного результату. Фіналом проєкту $\epsilon$ створення та розміщення в мережі Internet навчального web-ресурсу у вигляді сайту (набір пов'язаних між собою html-файлів).

Студенти в групах розробляють план спільних дій, знаходять джерела інформації, способи досягнення цілей, розподіляють ролі, висувають і обговорюють ідеї. 
Надзвичайно високий педагогічний ефект може дати спеціально організована спільна робота в мережі. Ії̈ основу складають навчальні проєкти, які виконуються спільно кількома (географічно рознесеними) групами студентів, пов'язаними між собою комп'ютерною мережею.

Різноманітність у способі життя, культурі, мові, географічному положенні - необхідна умова телекомунікаційних проєктів (Ниматулаєв, 2002, с. 119).

Телекомунікаційний проєкт $€$ одним із напрямів використання засобів ІКТ в освітньому процесі. Як приклад створення навчального проєкту 3 інформатики запропоновано телекомунікаційний проєкт «Освітній портал закладу загальної середньої освіти».

Завданнями проєкту $\epsilon$ такі: створити систему безперервного навчання «освітній портал - школа - учитель - учень - батьки суспільство»; розглянути можливість використання освітнього порталу для контролю знань учнів за допомогою різних навчальних тестів; створити доступ до новітніх навчально-методичних розробок учителів, як власної школи, так і інших шкіл і 3ВО; визначити можливості зворотного зв'язку «учитель - учень»; визначити можливості організації індивідуального навчання школярів.

Основною функцією створення освітнього порталу $\epsilon$ методична підтримка навчального процесу (освітні стандарти, електронний журнал, навчально-методичні матеріали, навчальні завдання, завдання для самостійної роботи, розклад занять тощо).

Ефективним методом професійної підготовки майбутніх учителів інформатики до використання освітніх web-ресурсів у професійній діяльності $\epsilon$ case-study, мета якого - спільний аналіз конкретної ситуації і вибір практичного вирішення з подальшою оцінкою запропонованих варіантів.

Метод case-study полягає в тому, що на початку навчання складається індивідуальний план і кожен студент отримує певний «кейс», що включає мультимедійний відеокурс, пакет навчально-методичної літератури, навчальні програми і віртуальну лабораторію, а також електронний робочий зошит. Електронний робочий зошит являє собою оригінальний путівник із досліджуваного курсу і містить рекомендації щодо змісту навчального матеріалу, тести, контрольно-вимірювальні завдання для самоперевірки, практичні і творчі завдання. Вивчаючи навчальний матеріал, студент може отримувати допомогу електронною поштою, пересилати результати виконаних лабораторних робіт і практичних завдань.

Виділимо лише деякі переваги: супровід лекцій звуком і анімацією; можливість роботи з електронною бібліотекою самостійно як у закладі освіти, так і вдома; наочність, тобто можливість демонстрації відеоматеріалів, ілюстрацій, різних схем тощо; можливість нелінійної роботи з матеріалом, забезпеченого гіперпосиланнями; використання 
інтерактивних завдань на семінарах, а також демонстрація анімаційних прикладів вирішення практичних завдань.

Отже, кейс-метод сприяє формуванню у студентів самостійного мислення, уміння враховувати і вислуховувати іншу думку, аргументовано висловлювати свою, виробляє позитивну мотивацію й інтерес до навчання. За допомогою цього методу учні мають можливість проявляти і вдосконалювати аналітичні та оцінні навички, працювати в колективі, знаходити найбільш раціональні рішення поставленої проблеми, опановувати вміння практичного використання матеріалу.

Кейс активізує школярів, розвиває аналітичні й комунікативні здібності, залишаючи учнів один на один із реальними проблемними ситуаціями (Магомедов, 2017, с. 84).

Для складання кейс-задач у якості зразків ми використовували професійні завдання і ситуації.

Професійно-значущим методом для підготовки майбутнього вчителя інформатики $€$ метод «е-портфоліо», оскільки дозволяє накопичувати матеріал, який свідчить про розвиток його інформаційних умінь.

Крім того, у майбутнього вчителя повинна бути сформована особиста «шкала цінностей», за допомогою якої він зміг би виявляти свої успіхи або невдачі в розвиткові інформаційних умінь. Метод «е-портфоліо» допомагає майбутньому вчителю навчитися адекватно оцінювати власні досягнення та можливості, робити висновки про необхідність виправляти помилки й самовдосконалюватися.

Застосування е-портфоліо, як методу оцінки, засноване на тому, що студенти протягом вивчення інформатичних дисциплін у межах предметного і професійного циклів, збирають всі свої роботи (результати роботи студентів за всі роки навчання, що відображають їх досвід аналізу та оцінки якості ISO, створення й використання інтерактивних електронних освітніх ресурсів, розробки та корекції методичного супроводу уроків на основі ISO та ін.) (Куликова, 2014, с. 84).

На наш погляд, е-портфоліо $€$ web-ресурсом: набором підтверджень умінь, представлених в електронній формі у вигляді web-сторінок, об'єднаних гіперпосиланнями (Везиров, 2009, с. 87).

Т. Везиров виділяє такі етапи створення е-портфоліо як мультимедіа або гіпермедіа продукту:

1) визначення вмісту портфоліо і цілей його формування. На цьому етапі основне завдання - визначити умови, у яких проходитиме оцінка портфоліо, зокрема особливості «аудиторії», тобто тих, кому адресований портфоліо. Це допомагає структурувати подальшу роботу;

2) обробка матеріалів портфоліо. На цьому етапі основне завдання, відібрати матеріал у портфоліо, перевести його в електронну форму, відібрати програмне забезпечення, відповідне завданням, умовам 
демонстрації і зберігання (презентація в аудиторії, за допомогою глобальної або локальної мережі, передача роботодавцю на будь-якому носії);

3) написання рефлексивних матеріалів портфоліо. Для робочого портфоліо рефлексія проводиться в ключових точках навчання, наприклад, по завершенню освоєння деяких закінчених фрагментів предметних галузей. Для портфоліо для працевлаштування, рефлексії передує опис педагогічної практики або реальної роботи за фахом. Для оцінного портфоліо рефлексія подається у вигляді рецензії;

4) створення зв'язків і оформлення портфоліо. На цьому етапі проводиться не тільки технічний процес створення портфоліо у вигляді мультимедіа або гіпермедіа-продукту, але й формування змісту, побудова структури гіперпосилань, що пов'язують різні елементи;

5) презентація портфоліо. Залежно від форми та аудиторії, презентація портфоліо може бути різною. Однак, у будь-якому випадку вона повинна завершуватися отриманням зворотного зв'язку і рефлексією з приводу того, чи досягнуті поставлені цілі, а також плануванням майбутніх дій із розвитку портфоліо (Везиров, 2009, с. 88).

Захист (якісна оцінка) е-портфоліо виконується студентами на заліковому занятті з використанням ігрових методів, а саме - ділової гри, у ході якої кожен студент отримує можливість провести часткову апробацію підготовлених навчально-методичних продуктів, виконати самооцінку свого е-портфоліо за запропонованими викладачем питаннями на основі проведеної ділової гри й отримати експертний висновок одного 3 однокурсників, що містить особисту думку щодо переглянутої роботи, рекомендації та побажання (прийом, експертиза). Отже, кожен студент отримує можливість зробити відповідний висновок про досягнуті чи недосягнуті поставлені цілі й завдання, якість виконаної роботи, обґрунтованість підібраних засобів і технологій.

Завдання, спрямовані на аналіз наявних веб-ресурсів вирішуються студентами за допомогою технології веб-квест. Веб-квест (webquest) у педагогіці - проблемне завдання 3 елементами рольової гри, для виконання якого використовуються інформаційні ресурси Інтернет. Тематика веб-квестів може бути найрізноманітнішою, проблемні завдання можуть відрізнятися ступенем складності. Результати виконання веб-квесту, залежно від досліджуваного матеріалу, можуть бути представлені у вигляді усного виступу, комп'ютерної презентації, есе, веб-сторінки тощо.

Однією з організаційних форм пізнавальної діяльності майбутніх учителів інформатики $€$ «круглий стіл», що дозволяє закріпити отримані раніше знання, заповнити відсутню інформацію, сформувати вміння вирішувати проблеми, зміцнити позиції, навчити культурі ведення дискусії. Характерною особливістю «круглого столу» $\epsilon$ поєднання тематичної дискусії з груповою консультацією. 
В основі «круглого столу» в формі дебатів - вільне висловлювання, обмін думками щодо запропонованих студентами тематичних тез. Учасники дебатів наводять приклади, факти, аргументують, логічно доводять, пояснюють, дають інформацію тощо.

Процедура дебатів не допускає особистісних оцінок, емоційних проявів. Обговорюється тема, а не ставлення до неї окремих учасників.

В основі асоціативного методу лежить створення інформаційноосвітнього середовища, що обумовлює можливість для студентів вивчення навчального матеріалу не в поданій викладачем послідовності, а вільно, керуючись своїми асоціаціями, схильностями, пріоритетами.

Метод «фальсифікації» або метод «вимушеного припущення» пов'язаний із реалізацією в освіті концепції, відповідно до якої у процесі навчання студент ставиться в ситуацію, яка змушує його висловлювати певні припущення, гіпотези. Після цього середовище надає йому інформацію, що дає можливість розвивати й обґрунтовувати цю гіпотезу. Якщо ж гіпотеза не виправдовується, студент заохочується до корекції гіпотези або висунення нової. Таким чином, студент отримує нові знання.

Модифікацією методу «вимушених припущень» $\epsilon$ метод «прецеденту». Відмінність його від попереднього методу полягає в тому, що після висунення гіпотези студенту надається інформація про наявні прецеденти розв'язання поставленої проблеми. Прецеденти дають можливість студенту оцінити висунуту гіпотезу, порівняти з уже наявними варіантами розв'язання задачі і за необхідності коригувати гіпотезу. У якості основи використання методу прецеденту, М.Сурхаєв називає психологічні аргументи, оскільки прецедентне міркування - природний розумовий процес (Сурхаєв, 2010).

Найбільш відомий із методів - навчальне комп'ютерне моделювання. Сучасна концепція навчального комп'ютерного моделювання визначає чотири освітніх дії, які називаються так: послідовність моделей, завдання, пояснення, робочі гіпотези. Завдання першої дії полягає в тому, щоб увести студентів у предметну галузь, пропонуючи йому послідовність відповідних моделей. Потім пропонуються завдання на дослідження, оптимізацію, прогноз тощо. Освітні дії реалізуються в навчальній моделі на основі класифікації різних типів пояснень: структурні, функціональні, за аналогією тощо. Робочі гіпотези - це інструмент для формування та обґрунтування різних припущень. Інструменти включають елементи, необхідні для розробки гіпотез дії, відносини, умови.

Розвиток засобів дистанційного навчання породив новий метод навчання - навчальні відеоконференції. Цей метод заснований на організації дискусії між студентами за допомогою комп'ютерних телекомунікацій, яка спрямовується одним або декількома викладачами, що дозволяє студенту в режимі on-line отримувати відео- і аудіо- 
інформацію, а також дозволяє транслювати відеоконференції і виступи, різноманітні електронні документи (таблиці, відеоматеріали, текст, комп'ютерну анімацію, графіки).

Метод «реіфікації» ґрунтується на гіпотезі, що спільні дискусії 3 певних проблем ініціюють прояв неформальних знань на практиці. Використання можливостей нового середовища дозволяє організувати віртуальні навчальні групи, що працюють в асинхронному режимі. На основі дискусій створюються бази даних і бази знань, доступні студентам.

Завдання викладача, що використовує метод інформаційного ресурсу, - підібрати потрібні ресурси й зорієнтувати в них студента. Можуть бути різні варіанти реалізації цього методу: гіпертекстовий каталог і коротка анотація інформаційних ресурсів; конспект лекцій у гіпертекстовому вигляді $з$ посиланнями (де це необхідно) на інформаційні ресурси, які сприяють розширенню навчального матеріалу і поглибленню знань студентів; електронний підручник із вбудованими в нього посиланнями на відповідні інформаційні ресурси.

Основні відмінності цього методу від стандартних методів програмованого навчання й методу роботи з літературою полягають у тому, що інформаційні ресурси географічно рознесені, тобто знаходяться на різних серверах; кількість ресурсів і зв'язків між ними може бути практично необмеженою; гіпертекстова система подачі інформації дозволяє студенту знаходити власну траєкторію проходження навчального матеріалу, поглиблювати й розширювати знання за своїм бажанням і можливостями; гіпермедіа технології, що використовуються у web-просторі Internet, дозволяють за необхідності вбудовувати в навчальний матеріал ілюстрацію, анімацію, відеоролики, озвучувати інформацію (Ниматулаєв, 2002, с. 124).

Отже, основна ідея методу інформаційного ресурсу - закріплення й розширення теоретичних знань шляхом орієнтації студента у величезній кількості найрізноманітнішої інформації, яка йому необхідна і задовольняє його пізнавальні потреби.

В основі методу демонстраційних прикладів лежать дидактично адаптовані інформаційні моделі алгоритмів і структур даних, тому метод демонстраційних прикладів можна застосувати не тільки під час навчання програмуванню, але й під час навчання інших розділів інформатики.

Метод демонстраційних прикладів ефективний під час вивчення основ мови гіпертекстової розмітки HTML (HyperText Markup Language). Це мова компонування документів і специфікації гіперпосилань, яка використовується для кодування документів у системі World Wide Web. Засобами HTML задаються синтаксис і розміщення спеціальних вбудованих вказівок, відповідно до яких браузер відображає вміст документа: текст, зображення і дані інших типів, підтримувані конкретним оглядачем. Іншими словами, HTML - це набір тегів, якими, відповідно до бажаного ефекту, позначається 
текст. Існують певні способи подання інформації та навігації, описані в стандарті HTML. Тому під час вивчення мови гіпертекстової розмітки HTML необхідно показати основні набори тегів, їх конструкцію, синтаксис і семантику, а також показати, яким чином ця група тегів відображається браузером. У цьому сенсі метод демонстраційних прикладів виявляється дуже ефективним.

До основних переваг застосування методу демонстраційних прикладів під час вивчення основ мови HTML можна віднести: 1) підвищення наочності вивчення; 2) високий ступінь самостійності студентів під час вивчення навчального матеріалу; 3) значне зменшення затрат часу на виклад навчального матеріалу і демонстрацію; 4) формування навичок читання HTML-документів; 5) формування навичок використання фрагментів HTML-документів для створення власних сторінок. Пункти 4 і 5 важливі ще й тому, що, по суті, web-простір, що складається 3 величезної кількості HTML-документів, різних за оформленням, способами навігації тощо, $\epsilon$ гігантською базою зростання знань у всіх галузях, а в галузі інформаційних технологій особливо вимагає використання навчальних завдань, що стимулюють пошук нових, творчих підходів, інтеграції знань інших дисциплін (Ниматулаєв, 2002, с. 127).

3 метою стратегічного планування власної самоосвіти студенти можуть використати популярний у менеджменті метод SWOT-аналізу, що полягає у виявленні факторів внутрішнього й зовнішнього середовища та поділі їх на чотири категорії: Strengths (сильні сторони), Weaknesses (слабкі сторони), Opportunities (можливості) i Threats (загрози), за допомою таких сервісів: Gliffy (http://www.gliffy.com/), Realtimeboard (www.realtimeboard.com) тощо. Ефективність організації та реалізації самоосвітньої діяльності майбутніх фахівців у мережі Інтернет досягається шляхом правильного здійснення певних кроків: пошук джерел інформації відповідно до поставлених навчальних завдань; виділення й первинна обробка відомостей; опрацювання різноформатної інформації і прийняття рішення на її основі; створення та подача інформаційних продуктів.

Висновки та перспективи подальших наукових розвідок. Доцільним для застосування в організації навчання майбутніх учителів інформатики у процесі їх підготовки до використання веб-ресурсів $€$ впровадження таких методів активного навчання: метод проєктів, навчання у співпраці (cooperative learning); метод кейсів (case-study), ігрові методи (ділова гра); метод «е-портфоліо», круглий стіл, асоціативний метод; метод «фальсифікації»; метод інформаційних ресурсів; навчання з використанням телеконференцій; метод «реіфікації», метод демонстраційних прикладів, метод прецеденту; навчальне моделювання; метод доцільно підібраних завдань, метод SWOT-аналізу.

Вищезазначені методи взаємопов'язані і можуть використовуватися узгоджено. Так, відповідно до методу «фальсифікації», студент ставиться в 
ситуацію, яка змушує його висловлювати самостійні припущення. Але, щоб він міг будувати певний умовивід, йому мають бути створені умови, підібрані навчальні завдання, для вирішення яких потрібні певні організаційні форми навчання, під них повинні бути підібрані певні засоби навчання. Щоб вирішити навчальну задачу за допомогою методу «реіфікації», необхідно організувати мережеву взаємодію студентів для спільного обговорення вирішуваної проблеми, тобто використання сучасних інформаційних технологій допомагає організувати віртуальні навчальні і професійні групи студентів, що працюють в асинхронному режимі над поставленим завданням.

Перспективу подальших досліджень вбачаємо в розкритті взаємоузгодженості у використанні методів активного навчання, інноваційних форм, засобів та інформаційних технологій.

\section{ЛІТЕРАТУРА}

Везиров, Т.Т. (2009). Формирование профрессиональных умений будущих учителей математики и информатики на основе web-технологий (дис. ... канд. пед. наук: 13.00.08). Махачкала (Vezirov, Т. T. (2009). Formation of professional skills of future teachers of mathematics and informatics on the basis of web-technologies (PhD thesis). Makhachkala).

Гирка, І.В. (2015). Організаційно-педагогічні умови формування професійної компетентності майбутніх учителів інформатики в процесі фахової підготовки. Обріï, 1, 64-67 (Hyrka, I. V. (2015). Organizational and pedagogical think about the formulation of professional competence of maybutny teachers of informatics in the process of phase training. Obrii, 1, 64-67).

Данилова, О.В. (2010). Подготовка студентов педагогического вуза к разработке электронных образовательных ресурсов (дис. ... канд. пед. наук: 13.00.08). Чебоксары (Danilova, O. V. (2010). Preparation of students of a pedagogical university for the development of electronic educational resources ( $\mathrm{PhD}$ thesis). Cheboksary).

Жалдак, М.І. (2011). Система підготовки вчителя до використання інформаційнокомунікаційних технологій в навчальному процесі. Науковий часопис НПУ імені М. П. Драгоманова. Серія 2: Комп'ютерно-орієнтовані системи навчання, 11, 3-15 (Zhaldak, M. I. (2011). The system of teacher training for using information and communication technologies in the educational process. The scientific bulletin of the NPU named after M. P. Drahomanov. Series 2: Computer-based systems, 11, 3-15).

Коротун, О. В. (2019). Основи професійної підготовки майбутніх учителів інформатики в закладах вищої освіти. Науковий часопис НПу імені М. П. Драгоманова. Серія 5: Педагогічні науки: реалії та перспективи, Вип. 69, 109-112 (Korotun, О. V. (2019). The fundamentals of professional training of future teachers of informatics in the higher education institutions. The scientific bulletin of the NPU named after M. P. Drahomanov. Series 5: Pedagogical sciences: realities and perspectives, Issue 69, 109-112).

Куликова, Н. Ю. (2014). Методика формирования готовности будущего учителя информатики к использованию интерактивных средств обучения (дис... канд. пед. наук: 13.00.02). Волгоград (Kulikova, N. Yu. (2014). Methodology for the formation of the readiness of the future teacher of informatics to use interactive teaching aids (PhD thesis). Volhohrad).

Ляш, А.А. (2015). Методика обучения будущих учителей информатики к использованию информационно-образовательных систем в профессиональной деятельности (дис. ... канд. пед. наук: 13.00.02). Мурманск (Liash, A. A. (2015). 
Methods of teaching future teachers of informatics in the use of information and educational systems in professional activity (PhD thesis). Murmansk).

Магомедов, Р. М. (2017). Подготовка учителей информатики к использованию новых организационных форм в образовательном прочессе (дис.... д-ра пед. наук: 13.00.02). Москва (Mahomedov, R. M. (2017). Training teachers of informatics for the use of new organizational forms in the educational process (DSc thesis). Moscow).

Морзе, Н.В. (2003). Система методичної підготовки майбутніх вчителів інформатики в педагогічних університетах (автореф. дис. ... д-ра пед. наук: 13.00.02). Київ (Morze, N. V. (2003). The system of methodological training of future teachers of informatics in pedagogical universities (DSc thesis abstract). Kyiv).

Ниматулаев, М.М. (2002). Подготовка учителей информатики в педвузе к использованию wеb-технологий в профессиональной деятельности (дис.... канд. пед. наук: 13.00.02). Москва (Nimatulaiev, М. М. (2002). Training of teachers of informatics at the pedagogical institute for the use of web-technologies in professional activity (PhD thesis). Moscow).

Овчаров, С. М. (2010). Індивідуально-диференційована система професійного навчання майбутніх учителів інформатики. Полтава: ACMI (Ovcharov, S. M. (2010). The system of professional education of the most important teachers of informatics is individually differentiated. Poltava: ASMI).

Спірін, О.М. (2007). Теоретичні та методичні засади професійної підготовки майбутніх учителів інформатики за кредитно-модульною системою. Житомир: Вид-во ЖДУ ім. І. Франка (Spirin, О. М. (2007). Theoretical and methodological foundations of the professional training of computer science teachers for the credit-modular system. Zhytomyr).

Стеценко, Г.В. (2010). Методика використання освітніх веб-ресурсів у процесі підготовки майбутніх учителів інформатики (автореф. дис. ... канд. пед. наук: 13.00.02). Київ (Stetsenko, H. V. (2010). Methods of using educational web resources in the process of preparation of future teachers of informatics (PhD thesis abstract). Kyiv).

Сурхаев, М.А. (2010). Развитие системы подготовки будущих учителей информатики для работы в условиях новой информационнокоммуникационной образовательной среды (дис. ... д-ра пед. наук: 13.00.02; 13.00.08). Москва (Surkhaiev, М. А. (2010). Development of the system of training future teachers of informatics for work in a new information and communication educational environment (DSc thesis). Moscow).

Ткачук, Г.В.(2011). Методика використання освітніх веб-ресурсів у процесі підготовки майбутніх учителів інформатики. Умань: Видавець «Сочінський» (Tkachuk, H. V. (2011). Methods of using educational web resources in the process of preparation of future teachers of informatics. Uman).

Шихмурзаева, А. Б. (2015). Формирование ИКТ-компетентности студентов бакалавриата в условиях информационно-педагогической среды (профиль «Информатика») (дис. ... канд. пед. наук: 13.00.08). Махачкала (Shikhmurzaieva, A. B. (2015). Formation of ICT competence of undergraduate students in the information and pedagogical environment (profile "Informatics") (PhD thesis). Makhachkala).

\section{PEЗЮME}

Шуляк Андрей. Информатизация методов активного обучения в подготовке будущих учителей информатики к использованию образовательных web-ресурсов в профессиональной деятельности.

В статье на основе анализа научных источников выделены методы активного обучения в подготовке будущих учителей информатики к использованию 
образовательных wеb-ресурсов в профессиональной деятельности, раскрыты пути их информатизации. Предложено использовать методы активного обучения как самостоятельные педагогчческие разработки, так и в сочетании с традиционными на разных этапах учебного процесса. Определены характерные признаки методов активного обучения. Предусмотрено перспективу дальнейших исследований в направлении раскрытия согласованности в использовании методов активного обучения, инновационных фрорм, средств и информационных технологий.

Ключевые слова: методы активного обучения, подготовка специалистов, будущие учителя информатики, образовательные шеb-ресурсы, профрессиональная деятельность, гиперссылки, сайт, информатизация.

\section{SUMMARY}

Shuliak Andrii. Informatization of active learning methods in the preparation of future computer science teachers for the use of educational web-resources in professional activities.

The article, which is based on the analysis of scientific sources, identifies methods of active learning in the preparation of future teachers of computer science to use educational webresources in professional activities, and reveals the ways of informatizing them. We offer to use methods of active training such as independent pedagogical developments, and in combination with traditional ones at various stages of educational process. We give the definition of methods of active learning which means methods that change the nature of learning from reproductive to arbitrary internally determined activity of students to develop and transform their own experience.

Characteristic features of active learning methods are determined: problem-solving, adequacy of educational-cognitive activity, nature of future professional activity, individualization, independence of students' interaction with educational information, mutual learning, and motivation.

We consider it expedient to apply the following methods of active learning in the organization of training of future teachers of computer science in their preparation for the use of web resources: the method of projects, cooperative learning; case-study method, game methods (business game); e-portfolio method, round table, associative method; the method of "falsification"; method of information resources; training using teleconferences; method of "reification", method of demonstration examples, method of precedent; educational modeling; method of expediently selected tasks, method of SWOT-analysis. We revealed the essence of each method, its pedagogical effect, potential, and methods of informatization. The interrelation and coherence of the proposed new methods of active learning are determined.

We managed to provide the prospect of further research in the direction of revealing the coherence in the use of active learning methods, innovative forms, tools and information technologies.

Key words: methods of active learning, training, future teachers of computer science, educational web-resources, professional activity, hyperlinks, site, informatization. 
РОЗДІЛ ІІ. ПРОБЛЕМИ ПОРІВНЯЛЬНОЇ ПЕДАГОГІКИ

\title{
УДК 378.015.3:001.895:378.094:61(73) «19»
}

\author{
Алла Куліченко \\ Запорізький державний медичний університет \\ ORCID ID 0000-0003-1469-3816 \\ DOI 10.24139/2312-5993/2020.03-04/171-181
}

\section{ОГЛЯД ІННОВАЦІЙНОЇ ДІЯЛЬНОСТІ АМЕРИКАНСЬКИХ МЕДИЧНИХ КОЛЕДЖІВ УПРОДОВЖ 1934-1939 РР. У ПРАЦЯХ Г. ВАЙСКОТТЕНА}

Статтю присвячено аналізу праць Г. Вайскоттена, зокрема «Тенденції в медичній практиці» (1937), “Медична освіта у Сполучених Штатах Америки 19341939 рр.: підготовано для Ради з питань медичної освіти та лікарень Американської медичної асоціації» (1940) та "Тенденції в медичній практиці: аналіз розподілу й характеристик випускників медичних коледжів 1915-1950 рр.» (1960), які висвітлюють інноваційну діяльність американських медичних коледжів у 1934-1939 рр. З'ясовано, що Велика депресія негативно вплинула на розвиток медичної освіти США. Проте, установлено, що під час економічної кризи у США Г. Вайскоттен провів а) опитування випускників 1930 р. та 1935 р. щодо кар'єрних успіхів; б) перевірку медичних коледжів США та Канади.

Ключові слова: американська медична освіта, Велика депресія, медичні коледжі, опитування випускників, інспектування, Г. Вайскоттен, «Доповідь» Вайскоттена, інноваційна діяльність, медичні дослідження.

Постановка проблеми. Від початку існування людства прослідковується тенденція бінарних опозицій «занепад - відродження» / «криза - розвиток» у всіх сферах життя. На зміну старому приходить нове, досконаліше за попереднє - нові можливості, погляди, концепції, технології тощо. Для американського народу різка зміна способу життя відбулася в середині осені 1929 р. під назвою «Велика депресія». Р. Марго слушно зауважує, що «Велика депресія - для економіки, як великий вибух - для фізики» (Margo, 1993). А. Мартинов зазначає, що «криза 1930-х рр. розпочалася відразу після доби процвітання, яке настало для США внаслідок перемоги країн Антанти в Першій світовій війні» (Мартинов, 2011).

Дослідник додає, що досі «в історичній літературі триває дискусія навколо питання, коли саме завершилася ця криза. Частина істориків уважає, що мова має йти про середину 1930-х рр., коли визначилася тенденція подолання кризи за допомогою різних інноваційних (курсив наш. - А.К.), як на той час, соціальних і політичних технологій. Причому вони були діаметральними за своїми характеристиками: від методів державного регулювання ринкової економіки, запропонованих президентом США Ф. Рузвельтом, і до жорстких авторитарних заходів нацистського та різного ґатунку фашистських режимів» (Мартинов, 2011).

Б. Штайншауер указує на те, що «30-ті роки були важкими для американської медицини. Мало хто міг дозволити собі медичну допомогу під 
час Великої депресії, і розрив між гомеопатичною та науковою медициною зростав після доповіді про медичні школи, яку замовив Фонд Карнегі 3 поліпшення викладання. Американська медична асоціація закрила більшість шкіл, які викладали гомеопатію, пропагуючи рослинні засоби й комплексне лікування. Більшість наукових медичних шкіл, що відповідали суворим вимогам, були у складі престижних університетів» (Steinshouer, n.d).

На думку Р. Вілбура, соціальні та економічні заворушення, спричинені кризою в усьому світі, загальмували значну частину прогресу, що відбувався в медичній освіті Америці наприкінці XIX ст. (Wilbur, 1940) й початку XX ст.

3 метою повторної перевірки 89 медичних шкіл, що продовжили функціонувати після "Доповіді» Флекснера та готували спеціалістів у перші п'ять років Великої депресії, Американська медична асоціація ухвалила рішення про залучення до складу Ради з питань медичної освіти та лікарень Американської медичної асоціації Германа Гейтза Вайскоттена (1884-1972). Його завданням була ретельна інспекція тогочасних 79 американських і 10 канадських шкіл упродовж 1934-1939рр. 3 подальшою публікацією отриманих результатів.

Аналіз актуальних досліджень. У розвідці увагу сфокусовано на таких працях Г. Вайскоттена: «Тенденції в медичній практиці» (1937), «Медична освіта у Сполучених Штатах Америки 1934-1939 рр., підготована для Ради з питань медичної освіти та лікарень Американської медичної асоціації» (1940), відомої як «Доповідь» Вайскоттена, та «Тенденції в медичній практиці: аналіз розподілу й характеристик випускників медичного коледжу, 1915-1950» (1960).

Доробки Г. Вайскоттена згадують зарубіжні дослідники, зокрема Дж. Вайс, П. Войчеч, С. Грейсен, В. Кешткар, В. Молл, Дж. Монаган, Р. Разаее, Дж. Шафер та ін. Крім того, до результатів перевірки Г. Вайскоттена, зафіксовані в «Доповіді», зверталися у 1955 р. об'єднана державна урядова комісія; у 1985 р. Комітет з питань харчування в медичній освіті, Рада з питань харчування, Національна наукова рада США та ін.

Варто зазначити, що у вітчизняному науковому просторі увагу на окресленому питанні не було зосереджено. Однак, інтерпретацію певних моментів «Доповіді» Вайскоттена, що стосуються інноваційної діяльності американських медичних коледжів у другій половині 1930-х рр., наведено у праці «Інноваційна діяльність у медичній освіті США (10-40 рр. ХХ ст.)» (Куліченко, 2020) авторки цього дослідження.

Метою статті $\epsilon$ аналіз праць Г. Вайскоттена 1937, 1940 та 1960 рр. 3 виокремленням інноваційної діяльності в американській медичній освіті 1934-1939 рр.

Для досягнення мети дослідження було використано такі методи: бібліографічний - дозволив виявити науково-педагогічні джерела різних 
років із зазначеної проблеми; контент-аналіз, узагальнення, систематизація, що забезпечили виокремлення з праць Г. Вайскоттена певних аспектів інноваційної діяльності американських медичних коледжів у 1934-1939 рр. та подання їх цілісного огляду.

Виклад основного матеріалу. Перед тим, як перейти до розгляду «Доповіді» Вайскоттена з приводу огляду інноваційної діяльності американських медичних коледжів у 1934-1939 рр., зупинимося на одній із ключових діяльностей Г. Вайскоттена в зазначений період, а саме опитуванні випускників, які отримали медичних фах у США та Канаді. Пов'язуємо цей момент із інноваційною діяльністю медичних коледжів університетів США 3 підготовки кадрів та управління людськими ресурсами. Оскільки результати подібних опитувань дають змогу закладам вищої освіти зосередитися не тільки на якіснішій підготовці майбутніх фахівців з тієї чи іншої спеціальності як у теоретичному, так і практичному аспектах, а й залучити потенційних вступників із віддалених регіонів країни.

За пропозицією Ф. Запффе, секретаря Асоціації американських медичних коледжів, у різні роки першої половини XX ст. Г. Вайскоттен проводив валідне дослідження-опитування 34174 випускників 1915 - 1950 рр. $з$ метою з'ясування їх кар'єрних досягнень та напрямів медичної практики. Значну увагу було зосереджено на випускниках періоду Великої депресії. Так, випускників 1930 р. із США та Канади було опитано через шість років після закінчення медичних коледжів (у 1936 р. - А.К.), випускників 1935 р. - через 15 років (у 1950 р. - А.К.) (Weiskotten, 1937; Weiskotten et al., 1960), у зв'язку з поступовим виходом Північної Америки з масштабної економічної кризи та її участю у Другій світовій війні.

Для нашого дослідження важливими $€$ випускники-респонденти 1930 р., оскільки отримання ступенів припало на початок світової економічної кризи, а діяльність - на їі розпал. Кожному випускникові було надіслано опитувальник (див. рис. 1), форма якого змінювалася впродовж наступних років. У свою чергу, випускники мали повернути поштою або особисто, якщо була така нагода, заповнені опитувальники Г. Вайскоттену (Weiskotten, 1937; Weiskotten et al., 1960).

За статистикою, випускникам 1930 р. 63 медичних коледжів США та 9 закладів медичної освіти Канади було надіслано 4958 опитувальників, а повернуто - 3710, що склало 74,8 \%. Результати опитування свідчили, що більшість випускників була невдоволена їх тогочасною професійною діяльністю. Коментарі респондентів свідчили про бажання а) кардинально змінити вектор медичної діяльності; б) отримати інші або вужчі спеціалізації, ніж ті, з яких практикували; в) пройти резидентуру або знайти можливість для післядипломного навчання 3 обраної спеціалізації; г) виконувати наукові дослідження. Проте, незважаючи на вищезазначене, 
випускники 1930 р. мали щирі наміри служити народу, попри скрутне становище в країні (Weiskotten,1937).

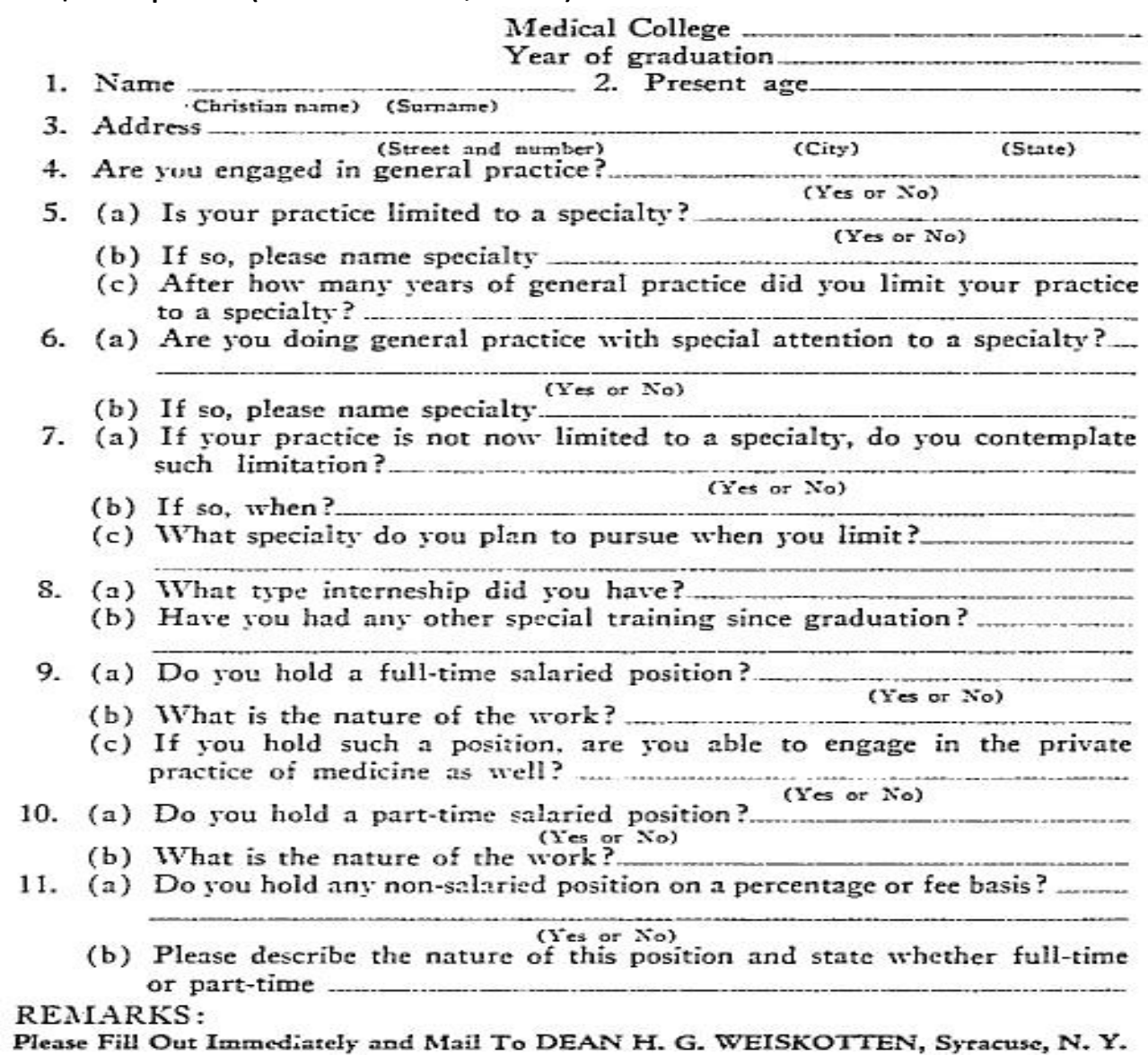

Рис. 1. Зразок опитувальника для випускників медичних коледжів США та Канади 1930 р. Джерело: (Weiskotten,1937)

Наведемо фрагмент відгуку, що належить випускникові одного 3 американських медичних коледжів 1930 р.: «Я активно працюю хірургом. Я перебуваю на посадах без платні. П’ятдесят відсотків моєї праці - ие благодійність. Я не очікую на платню, бо лікарня в моєму місті занадто зубожіла через політику країни. Проте я роблю все можливе, щоб урятувати хворих» (цит за: Weiskotten, 1937).

Г. Вайскоттен зауважував: «Жорсткіші умови вступу до медичних коледжів вочевидь не вплинули на загальний вік (24 роки - А.К.) студентів на момент випуску (1930 р. - А.К.). Значний відсоток випускників канадських медичних коледжів практикують у США. Проте, відсоток тих, хто зостався працювати в США становить 24, що на 15 \% менше, порівняно з випускниками 1925 р. На територіальний розподіл випускників у США, скоріше впливає стан економіки, аніж населення» (Weiskotten,1937).

У 1934 році американська Рада з медичної освіти та лікарень ініціювала проведення нового інспектування всіх медичних коледжів 3 урахуванням змін у медичній освіті та проблем, що виникли під час останнього масштабного огляду в 1919-1922 рр. Для якісного проведення 
комплексної перевірки Рада з медичної освіти та лікарень, ураховуючи численні напрацювання та розвідки з медичних освітніх питань, додала Г. Вайскоттена до ії складу та просила взяти участь як Асоціацію американських медичних коледжів, так і Федерацію державних медичних рад. Загалом, більшість перевірок та звітів виконував Г. Вайскоттен упродовж 1934-1939 рр. (Academic quality and..., 2017).

Станом на 1935 р. було перевірено 45 медичних коледжів і надано на розгляд попередні результати: необхідність перегляду освітніх стандартів, особливо стосовно поширеної практики деяких коледжів приймати велику кількість студентів, деякі з яких були некваліфікованим для продовження медичних досліджень (Academic quality and..., 2017).

Результатом тривалої перевірки медичних шкіл стала в 1940 р. розвідка Г. Вайскотена «Медична освіта у Сполучених Штатах Америки 1934-1939 рр.: підготовано для Ради з питань медичної освіти та лікарень Американської медичної асоціації» у співавторстві 3 А. Швіталлою, деканом медичного коледжу Університету Святого Луїса, В. Каттером, секретарем Ради з питань медичної освіти та лікарень Американської медичної асоціації, та Д. Андерсоном, доктором медицини.

У вступі до «Доповіді»Г. Вайскоттен зі співавторами зазначають, що «під час світової війни (першої - А.К.) було мало можливостей для розвитку інноваційної діяльності в медичній освіті, але за наступні півтора десятиліття деякі коледжі змогли досягти значних успіхів. <...> Цей розвиток, окрім фінансового аспекту, стосувався значною мірою викладання клінічних дисциплін та необхідних клінічних приміщень. Також спостерігалося постійне збільшення кількості студентів, які попередньо здобули освіту в гуманітарних коледжах та вступали на медичну спеціальність» (Weiskotten, 1940).

П. Войчеч вважає, що у 1940 р. «Доповідь» Вайскоттена продемонструвала невдоволення доклінічною освітою», оскільки проголошене в «Доповіді» Флекснера «наукове підґрунтя медицини» для навчального плану часто призводило до розділу доклінічних та клінічних дисциплін (Wojciech, 2009). Р. Разаее та В.Кешткар додають, що «Доповідь» Вайскоттена стала своєрідним маніфестом з цього приводу (Rezaee \& Keshtkar, 2013).

Що стосується інноваційної діяльності загалом у медичній освіті в 1934-1939 рр., констатуємо, що організація комплексної перевірки тогочасних медичних коледжів США та Канади $є$ яскравим прикладом управлінських інновацій.

«Конфіденційна доповідь Ради з питань медичної освіти та лікарень Американської медичної асоціації для медичних коледжів США та Канади», яку наведено в додатку А «Доповіді» Вайскоттена (Weiskotten, 1940), є доказом принципово нового підходу до тогочасних перевірок 
закладів медичної освіти. Цей документ складається з двох частин. Першу частину, яка $є$ обгрунтуванням перевірки медичних коледжів, присвячено загальним принципам, меті перевірки, плану звіту, джерелам інформації, методам опрацювання інформації, структурі графічних зображень, що містять опрацьовану інформацію (pattern map). У другій частині подано детальний опис загальних критеріїв (структура, керівництво, бібліотека, факультети, освітня програма, клінічні заклади або приміщення, фінансування) та критеріїв, що стосуються доклінічних й клінічних кафедр.

Загалом, у документі йшлося про:

- шість доклінічних кафедр, а саме про кафедру анатомії; біохімії; фізіології; фармакології; бактеріології; патології;

- чотири клінічні кафедри - медицини; хірургії; гінекології; педіатрії (Weiskotten, 1940).

На рис. 2 наведено оцінку двох протилежних медичних коледжів за частиною II. «Конфіденційної доповіді Ради з питань медичної освіти та лікарень Американської медичної асоціації для медичних коледжів США та Канади», подану Г. Вайскоттеном у 1940 р.

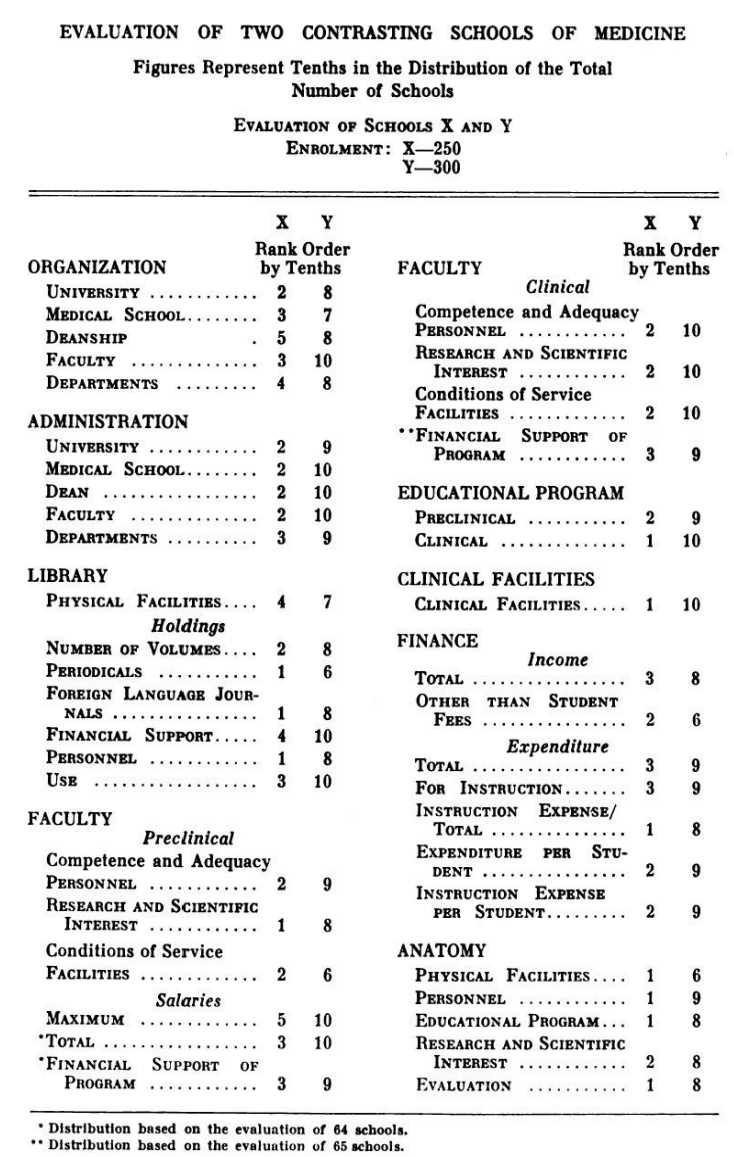

\begin{tabular}{|c|c|c|c|c|c|}
\hline \multicolumn{6}{|c|}{$\begin{array}{l}\text { EVALUATION OF TWO CONTRASTING SCHOOLS OF MEDICINE- } \\
\text { Figures Represent Tenths in the Distribution of the Total } \\
\text { Number of Schools } \\
\text { Evaluarion of SchooLs X AND Y } \\
\text { ENRoLment: } \mathrm{X}-250 \\
\text { Y }-300\end{array}$} \\
\hline \multirow{2}{*}{\multicolumn{3}{|c|}{$\underset{\text { Rank Order }}{\text { X }} \underset{\text { by Tenths }}{\text { Y }}$}} & \multirow{2}{*}{\multicolumn{3}{|c|}{$\begin{array}{c}\text { X Y } \\
\text { Rank Order } \\
\text { by Tenths }\end{array}$}} \\
\hline & & & & & \\
\hline $\begin{array}{l}\text { Physical Facilitirs } \ldots \ldots \\
\text { PrRsonngz } \ldots \ldots \ldots \ldots \ldots\end{array}$ & $\begin{array}{l}1 \\
2\end{array}$ & $\begin{array}{l}3 \\
6\end{array}$ & $\begin{array}{l}\text { Physical Fachities.... } \\
\text { Personnke } \ldots \ldots \ldots \ldots \ldots\end{array}$ & $\begin{array}{l}2 \\
3\end{array}$ & $\begin{array}{l}10 \\
10\end{array}$ \\
\hline $\begin{array}{l}\text { Educational Proeram.... } \\
\text { Reskarch and Scibntific }\end{array}$ & 1 & 6 & $\begin{array}{l}\text { Edvcational Program.... } \\
\text { ResBarch and Scirntipic }\end{array}$ & 2 & 10 \\
\hline INTBREST $\ldots \ldots \ldots \ldots \ldots$ & 1 & 6 & & 3 & 10 \\
\hline Evaluation $\ldots \ldots \ldots \ldots$ & 1 & 4 & FACILITIES. . & 1 & 10 \\
\hline PHYSIOLOGY & & & CLBRK & 2 & 10 \\
\hline Faciutribs.... & $\begin{array}{l}1 \\
3\end{array}$ & $\begin{array}{r}7 \\
10\end{array}$ & Ev & 2 & 10 \\
\hline Educational Program....................... & 3 & 10 & Physical Fac & 2 & 10 \\
\hline $\begin{aligned} \text { RESEA } \\
\text { INT }\end{aligned}$ & & & Personnke & 2 & 10 \\
\hline $\begin{array}{r}\text { INTBREST } \\
\text { EvalUation }\end{array} \ldots \ldots \ldots \ldots \ldots$ & $\begin{array}{l}3 \\
2\end{array}$ & $\begin{array}{l}9 \\
9\end{array}$ & $\begin{array}{l}\text { Educational Program.. } \\
\text { Reskarch aNd Scirntipic }\end{array}$ & 1 & 10 \\
\hline HARMACOLOGY & & & & 2 & 9 \\
\hline Physical Facilities.... & 5 & 6 & $\begin{array}{l}\text { Cuinical FaciL } \\
\text { CigRKSHIP } \ldots\end{array}$ & $\begin{array}{l}1 \\
2\end{array}$ & $\begin{array}{l}10 \\
10\end{array}$ \\
\hline PrasonnRL & 1 & $\begin{array}{l}9 \\
8\end{array}$ & $\begin{array}{l}\text { Clebrkship } \\
\text { Evaluation }\end{array}$ & 2 & 10 \\
\hline $\begin{array}{l}\text { DNAL Program.. } \\
\text { H AND Scibntific }\end{array}$ & & & OBSTETRICS & & \\
\hline $\begin{array}{r}\text { INTRRBST } \\
\text { EvALUATION }\end{array} \ldots \ldots \ldots \ldots \ldots$ & $\begin{array}{l}1 \\
2\end{array}$ & $\begin{array}{l}7 \\
8\end{array}$ & Physical Fac & 2 & 10 \\
\hline BACTERIOLOGY & & & Educational Prog & 1 & 10 \\
\hline FACHITI & 2 & 5 & $\begin{array}{l}\text { RgSBARCH AND } \\
\text { INTBREST . }\end{array}$ & 1 & 10 \\
\hline $\begin{array}{l}\text { Pras } \\
\text { Educ }\end{array}$ & 1 & 9 & FACIUITIBS ..... & & 10 \\
\hline STIFIC & & & & 1 & \\
\hline & 1 & 9 & Eval & 1 & 10 \\
\hline Evaluation $\ldots \ldots \ldots \ldots$ & 1 & 9 & ED & & \\
\hline PATHOLOG & & & 政 & 3 & 10 \\
\hline FACILITIES. . & 2 & 4 & & 2 & 10 \\
\hline Persol & 3 & 7 & EDU & 1 & 10 \\
\hline Para & 3 & 7 & RESBARCH AND & 3 & 10 \\
\hline AND SciEntific & 3 & 7 & $F_{A C I L}$ & 2 & 10 \\
\hline Curs & 2 & 9 & & 2 & 10 \\
\hline Evaluation & 3 & 7 & Evaluation & 2 & 10 \\
\hline
\end{tabular}

Рис. 2. Частина ІІ. «Конфіденційної доповіді Ради з питань медичної освіти та лікарень Американської медичної асоціації для медичних коледжів США та Канади» на прикладі двох протилежно оцінених медичних коледжів. Джерело: (Weiskotten, 1940)

Г. Вайскоттен указував на відсутність єдності у функціонуванні як державних, так і приватних університетів, у складі яких були медичні 
коледжі (Weiskotten, 1940). Проте, вважаємо, що наведений у «Доповіді» аналіз організації освітнього процесу кожного медичного коледжу, його позитивний досвід також був проявом інноваційної діяльності.

Цікавим прикладом організаційної інноваційної діяльності $\epsilon$ призначення декана медичного коледжу. Традиційно, кандидатуру декана, освітяна-медика, обговорювала та призначала Рада попечителів закладу освіти. Однак, існували й інші варіації призначення:

- контролююча рада призначала декана;

- першим кроком до призначення було подання президентом університету кандидатур(и) на розгляд Радою попечителів;

- спеціальна об'єднана комісія Ради попечителів та професорськовикладацький склад медичного коледжу обирали й призначали декана;

- професорсько-викладацький склад медичного коледжу рекомендував Раді попечителів призначити певного кандидата;

- декана обирала щорічно керівна рада медичного коледжу шляхом таємного голосування, результати надавала адміністративній канцелярії університету, представник якої інформував контролюючу раду (Weiskotten,1940).

Однією з інновацій були коледжі соціального обслуговування (або соціальної роботи) у тринадцяти університетах. Важливим було те, що між ними та медичними коледжами, що підпорядковувалися цим університетам, існували освітні взаємозв'язки. Крім того, один університет відкрив коледж

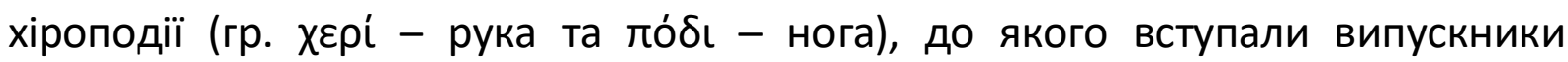
середньої школи, які опановували трирічну навчальну програму та ділили деяке обладнання зі студентами-медиками. у двох університетах функціонували коледжі гігієни та охорони здоров'я. Крім того, разом із коледжами медицини існували коледжі фармації, медсестринства, стоматології, ветеринарної медицини, які більш-менш спиралися на навчальну програму з медичного напряму для створення своїх навчальних планів. Зазначені коледжі запрошували викладати окремі дисципліни професорсько-викладацький склад з медичних коледжів (Weiskotten, 1940).

На думку авторів «Доповіді», така співпраця суттєво впливала на медичну освіту. Медичні коледжі не залишалися осторонь від коледжів фармації, медсестринства, стоматології, ветеринарної медицини та ін. Однак, водночас, вони не могли витрачати занадто багато своїх освітніх ресурсів, виконуючи обов'язки керівного органу у складі певного університету (Weiskotten, 1940).

Що стосується вступу до медичного коледжу, станом на 1934 р. разом із гуманітарними коледжами функціонували коледжі з дворічним терміном навчання (junior colleges), цілі, задачі, методи викладання були схожі на ті, що були в закладах середньої освіти. Однак, таких випускників приймали неохоче, указуючи на неналежну попередню підготовку, 
непристосованість до навчання в медичному коледжі та до університетського життя зокрема (Weiskotten, 1940).

у більшості випадків медичні коледжі після завершення чотирьохрічного курсу навчання присвоювали випускникам ступінь доктора медицини. Однак, деякі вимагали завершити інтернатуру впродовж п'ятого року й присвоювали ступінь бакалавра медицини, у результаті чого випускники були стажистами під загальним керівництвом медичних коледжів (Weiskotten, 1940).

Нові підходи, методи попередження, діагностування та лікування різних хвороб вплинули на концептуальне оновлення навчального плану в медичних коледжах. 3'явилися нові багаточисленні спецкурси, медичні коледжі переглянули вимогу до вступу в бік часткового послаблення. Г. Вайскоттен зазначав, що освітяни-медики «почали прагнути, щоб їхні студенти створили міцне підґрунтя для подальшого кар'єрного зростання в галузі медицині. Визнання широких освітніх цілей є одним із найвагоміших унесків, який колинебудь було зроблено для розвитку професійної освіти» (Weiskotten, 1940).

Важливим також було залучення студентів до опрацювання теоретичного матеріалу в медичних бібліотеках та тісного зв'язку з професорсько-викладацьким складом медичних коледжів. Спостерігалася мінімізація запам'ятовування матеріалу з підручників та виконання набору дидактичних вправ (Weiskotten, 1940). Вважаємо, що такі нововведення мали на меті мотивувати студентів до проведення теоретичних i практичних наукових досліджень, розробок і відкриттів.

Під час доклінічного навчання увагу було сфокусовано на людському феномені під час викладання фундаментальних принципів теоретичних медичних наук. Це стимульовано студентів до навчання та успішної професійної діяльності. Також відбулося переосмислення ролі студента в період дворічного клінічного навчання. Студент ставав невід'ємною частиною фахових дисциплін, передбачених навчальним планом медичної практики до отримання ступеня (clinical clerkship).

у 1930-ті університетські медичні коледжі активно створювали спеціальні фонди для організації медичних досліджень, які підтримували меценати, влада штатів, керманичі країни та ін. Тож, як бачимо, проведення досліджень було одним із ключових моментів в американській медичній освіті зазначеного періоду. Перспективних молодих науковців залучали до участі у проєктах під керівництвом професорсько-викладацького складу медичних коледжів з наданням необхідного обладнання, матеріалу, приміщень, окресленням хронологічного періоду виконання досліджень.

Значну кількість годин було відведено на дисципліни «Бактеріологія» та «Імунологія», оскільки «найбільших успіхів з 1890-х до 1930-х. було 
досягнуто в царині бактеріології, нові напрацювання якої легко застосовували в клінічній медицині» (Weiskotten, 1940).

Г. Вайскоттен окреслив такі пріоритетні напрями розвитку інноваційної діяльності університетів, у складі яких були медичні коледжі:

- фінансове та матеріальне заохочення медичних коледжів, особливо під час здійснення прикладних досліджень;

- проведення окремого дослідження щодо розробки спеціальних навчальних програм для нових, супутніх галузей, для таких професій, як лабораторні технології, дієтологія, управління закладами охорони здоров'я, лікувальна фізкультура, ерготерапія тощо;

- спрямування університетом достатньої незалежної фінансової підтримки на створення й підтримку нових навчальних програм, пов'язаних із медициною;

- установлення тісної рівноправної співпраці між медичними коледжами та коледжами фармації, медсестринства, стоматології, ветеринарної медицини тощо, які існують у межах одного університету;

- розроблення змістовних програм післядипломної медичної освіти лише компетентним професорсько-викладацьким складом та керівництвом медичних коледжів;

- створення окремих коледжів післядипломної медичної освіти;

- запровадження усної бесіди (interview) з претендентом на здобуття медичної освіти з метою визначення його психоемоційного стану, ставлення до обраного медичного коледжу, медичної освіти й майбутньої діяльності;

- створення окремих кафедр імунології та бактеріології;

- посилення уваги до курсів з бактеріології та імунології в контексті 4-річного навчального плану для майбутніх лікарів тощо (Weiskotten,1940).

Висновки та перспективи подальших наукових розвідок. Отже, 1930-ті роки були пов'язані зі світовою економічною кризою, яка не оминула й США. Велика депресія негативно позначилася на розвитку американської медичної освіти. Проте, у середині 1930-х рр. Г. Вайскоттен провів дослідженняопитування випускників 1930 р. з метою з'ясування їх кар'єрних успіхів за спеціальністю. Відповіді були неоднозначними, проте всі одноголосно мали наміри допомагати хворим, незважаючи на кризову ситуацію в країні.

у 1934-1939 рр. Г. Вайскоттен також провів масштабне інспектування медичних коледжів США та Канади. Під час цієї перевірки, попри недоліки, було виокремлено й цікаві приклади інноваційної діяльності, зокрема процедура призначення декана медичного коледжу; організація коледжів соціального обслуговування (або соціальної роботи), хіроподії, гігієни та охорони здоров'я, фармації, медсестринства, стоматології, ветеринарної медицини тощо; концептуальне оновлення навчального плану в медичних коледжах у зв'язку з появою нових підходів, методів попередження, діагностування та лікування різних хвороб; залучення студентів до 
опрацювання теоретичного матеріалу в медичних бібліотеках; тісний зв'язок студентів із професорсько-викладацьким складом медичних коледжів; проведення медичних дослідженнях; актуалізація дисциплін «Бактеріологія» та «Імунологія». Крім того, Г. Вайскоттен запропонував загальні пріоритетні напрями інноваційної діяльності американських медичних коледжів.

Перспективами подальших досліджень є висвітлення інноваційної діяльності американських медичних коледжів у воєнний та повоєнний періоди - у 1940-х і 1950-х рр.

\section{ЛІТЕРАТУРА}

Куліченко, А. К. (2020). Інноваційна діяльність у медичній освіті США (10-40рp. XXст.). Педагогічні науки: теорія, історія, інноваційні технології, 7 (81), 3-18 (Kulichenko, A. K. (2020). Innovative activity in US medical education (1910s-1940s). Pedagogical sciences: theory, history, innovative technologies, 7 (81), 3-18).

Мартинов, А. Ю. (2011). Історична компаративістика світових економічних криз (XXпочаток XXI ст.). Український історичний журнал, 5, 131-146 (Martynov, A. Yu. (2011). Historical comparative studies of world economic crises (XX- early XXI ${ }^{\text {st }}$ century). Ukrainian Historical Journal, 5, 131-146).

Academic quality and public accountability in academic medicine. The 75-year history of the LCME (2017). Retrieved from: http://www.lcme.org/wpcontent/uploads/filebase/articles/October-2017-The-75-Year-History-of-theLCME_COLOR.pdf.

Margo, R. A. (1993). Employment and unemployment in the 1930s. Journal of Economic Perspectives, 7 (2), 41-45.

Rezaee, R., Keshtkar, V. (2013). Basic sciences curriculum in medical education. Journal of Advances in Medical Education \& Professionalism, 1 (1), 28-32.

Steinshouer, B.J. (n.d.). Medical schools in the 1930s. Retrieved from: https://www.theclassroom.com/medical-schools-1930s-8432730.html

Weiskotten, H. G. (1937). Trends in medical practice. Journal of the Association of American Medical Colleges, 12 (5), 321-355.

Weiskotten, H. G., Schwitalla, A. M., Cutter, W. D., Anderson, H. H. (1940). Medical education in the United States 1934-1939: prepared for the Council on medical education and hospitals of the American medical association. Chicago: American medical association.

Weiskotten, H. G., Wiggins, W. S., Altenderfer, M. E. (1960). Trends in Medical Practice: An Analysis of the Distribution and Characteristics of Medical College Graduates, 19151950. Journal of Medical Education, 35 (12), 1071-1121.

Wilbur, R. L. (1940). Foreword. In Weiskotten, H. G., Schwitalla, A. M., Cutter, W. D., Anderson, H. H. (1940), Medical education in the United States 1934-1939: prepared for the Council on medical education and hospitals of the American medical association (pp. n.a.). Chicago: American medical association.

Wojciech, P. (2009). Basic sciences in medical education: Why? How? When? Where? Medical Teacher, 31 (9), 787-789. DOI: 10.1080/01421590903183803.

\section{PEЗЮME}

Куличенко Алла. Обзор инновационной деятельности американских медицинских колледжей в течение 1934-1939 гг. в работах Г. Вайскоттена.

Статья посвящена анализу работ Г. Вайскоттена, в частности «Тенденции в медицинской практике» (1937), "Медицинское образование в Соединенных Штатах Америки 1934-1939 гг.: подготовлено для Совета по вопросам медицинского 
Педагогічні науки: теорія, історія, інноваційні технології, 2020, № 3-4 (97-98)

образования и больниц Американской медицинской ассоциации» (1940) и «Тенденции в медицинской практике: анализ распределения и характеристик выпускников медицинских колледжей 1915-1950 г2.» (1960), освещающих инновационную деятельность американских медицинских колледжей в 1934-1939 г2. Обнаружено, что Великая депрессия негативно повлияла на развитие медицинского образования США. Однако, определено, что во время экономического кризиса в США Г. Вайскоттен провел а) опрос выпускников 1930 г. и 1935 г. по поводу их карьерных успехов; б) проверку медицинских колледжей США и Канады.

Ключевые слова: американское медицинское образование, Великая депрессия, медицинские колледжи, опросы выпускников, инспектирование, Г. Вайскоттен, "Доклад» Вайскоттена, инновационная деятельность, медицинские исследования.

\section{SUMMARY}

Kulichenko Alla. Review of innovative activity in American medical colleges during 1934-1939 in the works by H. Weiskotten.

The article deals with analysis of the works by $\mathrm{H}$. Weiskotten, in particular, "Trends in Medical Practice" (1937), "Medical Education in the United States 1934-1939: Prepared for the Council on Medical Education and Hospitals of the American Medical Association" (1940) and "Trends in Medical Practice: An Analysis of the Distribution and Characteristics of Medical College Graduates, 1915-1950" (1960). These works highlight the innovative activities of US medical colleges in 1934-1939.

To achieve the objective of the study, the author applies such methods as (i) bibliographic one - to identify scientific and pedagogical sources of different years on the problem; (ii) content analysis, generalization, systematization - to determine certain aspects of the innovative activities of US medical colleges in 1934-1939 and to present them in a comprehensive review.

Note that in the 1930s there was the global economic crisis, which also touched the United States. The Great Depression negatively affected the development of American medical education. However, in the mid-1930s, H. Weiskotten surveyed graduates of 1930 to determine their career success in the field of medicine. The answers were ambiguous, but all graduates unanimously intended to help their patients sick, despite the crisis in the country.

Moreover, during 1934-1939, H. Weiskotten also conducted a large-scale inspection of US medical colleges and those in Canada. Within this inspection, despite the shortcomings, there were interesting examples of innovative activities such as:

- appointing the dean of the medical college;

- organization of colleges of social services (or social work), hygiene and health care, pharmacy, nursing, dentistry, veterinary medicine, etc.;

- conceptual upgrading of the curriculum in medical colleges due to the emergence of new approaches, methods of prevention, diagnosis, and treatment of various diseases;

- close relations between students and the teaching staff of medical colleges;

- conducting medical research;

- actualization of disciplines "Bacteriology" and "Immunology" and so on.

As for the further research, we will cover the innovative activities of US medical colleges in the 1940s and 1950s.

Key words: American medical education, Great Depression, medical colleges, surveys, inspection, $H$. Weiskotten, Weiscotten Report, innovative activity, medical research. 


\section{УДК 37.018.43:004.738.5]:37.045"374.5".614.46COVID-19}

Оксана Шпарик

Інститут педагогіки НАПН України

ORCID ID 0000-0001-7507-4950

DOI 10.24139/2312-5993/2020.03-04/182-193

\section{COVID-19 I ШКІЛЬНА ОСВІТА: ВИВЧЕНІ УРОКИ ДЛЯ КИТАЮ}

У статті розглянуто проблему організації навчального процесу в умовах сучасної пандемії. Аналізуються дії китайського уряду з протидії впливу COVID-19 на шкільну освіту. Автор робить висновок, що надійна комунікаційна платформа, відповідні цифрові ресурси, зручні інструменти навчання, різноманітні методи навчання, гнучкі навчальні організачії, ефективні служби підтримки та тісна співпраця між урядом і школою - че ключові елементи, на які орієнтувався уряд Китаю для забезпечення широкомасштабного онлайн-навчання. Набутий досвід $i$ можливості зумовлюють певні тенденції в майбутньому розвитку шкільної освіти Китаю, а саме зміщення уваги і зусиль у бік кардинального покращення змістової та технологічної дигіталізації шкільної освіти у процесі подальших освітніх рефрорм.

Ключові слова: шкільна освіта, дистанційне навчання, пандемія COVID-19, начіональна онлайн-платформа, цифрові навчальні платформи, Китай.

Постановка проблеми. За даними ЮHЕСКО, у розпал пандемії COVID19 у світі постраждала рекордна кількість $(1,598,099,008)$ дітей та молоді. 194 країни Азії, Європи, Близького Сходу, Північної Америки та Південної Америки оголосили або запровадили закриття шкіл та університетів. За їхніми оцінками, у цей період майже 91,3 \% здобувачів освіти не відвідували заклади освіти (UNESCO, 2020). Система загальної освіти зіткнулася $з$ безпрецедентним викликом - сьогодні вона повинна виконувати свої функції в ситуації, коли єдиний перевірений століттями освітній інструмент, очну класно-урочну модель, неможливо використовувати. Важливо нагадати, що в сучасному світі система загальної освіти, крім функції навчання (передачі знань і навичок), виконує ще й функцію позитивної соціалізації і соціальної підтримки (зокрема харчування) дітей і молоді з бідних сімей. Нещодавно всі ці функції реалізовувалися лише за умови очного відвідування школи, коледжу, університету. У зв'язку з цим освітянська спільнота активно розпочала пошук та відпрацювання ефективних інструментів для організації навчального процесу в новій реальності. А міжнародне наукове співтовариство мобілізувало свої зусилля, зокрема, шляхом обміну та надання загальнодоступних результатів досліджень і безпрецедентного реформування їхніх методів роботи (Постійне представництво України при ЮНЕСКО, 2020).

Аналіз актуальних досліджень. Аналіз останніх досліджень і публікацій свідчить про актуалізацію педагогічного пошуку шляхів та інструментів протидії впливу COVID-19 на освіту. Перед освітянами постало багато проблем, на які необхідно знайти ефективні рішення. Зокрема, 
вплив пандемії на освітній процес та далекосяжні наслідки, що це може означати в перспективі для освіти. Крім технологічних, технічних та емоційних проблем у налагодженні освітнього процесу, такі події спонукають до переосмислення цінностей в освіті. Всі ці відповіді потребують ґрунтовного осмислення. Деякі відповіді на ці та інші питання знайшли висвітлення в наукових працях зарубіжних учених (D. Wu, T. Wu, Q. Liu, Z. Yang (Di Wu et al., 2020); R. H. Huang, D. J. Liu, N. Amelina, J. F. Yang, R. X. Zhuang, T. W. Chang, W. Cheng (Huang et al., 2020); C. Petrie, K. Aladin, P. Ranjan, R. Javangwe, D. Gilliland, S. Tuominen, L. Lasse (Petrie et al., 2020); J. Liberman, V. Levin, D. Luna-Bazaldua, M. Harnisch (Liberman et al., 2020); C. Li, L. Farah (Li \& Lalani, 2020) та інші.

Українські вчені також долучилися до боротьби з пандемією коронавірусу та ії наслідками в різних сферах соціального життя. Зокрема, дослідники при КПІ ім. Ігоря Сікорського (О.С. Войтко, Н. В. Горбань, І. М. Джигирей, Б. Р. Дудка, К. В. Єфремов, Ю. П. Зайченко, М. З. Згуровський, П. О. Касьянов, О.П. Купенко, М.М. Перестюк, І.О. Пишнограєв, В.В.Путренко) здійснили прогнозоване моделювання ймовірних фаз подальшого розвитку коронавірусної інфекції в Україні (Світовий центр даних, 2020). О. Корнієвський досліджував виклики та перспективи розвитку громадянського суспільства в умовах пандемії коронавірусу COVID-19 (Корнієвський, 2020). Наукові співробітники відділу психології праці Інституту педагогічної освіти і освіти дорослих ім. І. Зязюна (В.В.Рибалка, Е. О. Помиткін, О. М. Ігнатович, Н. В. Павлик, О. В. Іванова, О. В. Радзімовська, 3. Л. Становських, Є. М. Калюжна, Т. В. Кабиш-Рибалка) зосередили свою увагу на концептуальних та практичних питаннях психологічної профілактики і гігієни особистості у протидії пандемії COVID-19 (Рибалка та ін., 2020; Психологія і педагогіка у протидії пандемії, 2020). Наукові співробітники відділу порівняльної педагогіки Інституту педагогіки НАПН України (О.І. Локшина, О. З. Глушко, А. П. Джурило, С. М. Кравченко, Н. В. Нікольська, М. М. Тименко, О.М. Шпарик) підготували аналітичну довідку, де проаналізовано досвід країн світу з реагування на COVID-19 в освіті та узагальнено рекомендації провідних міжнародних організацій щодо організації навчання в умовах пандемії (Локшина та ін., 2020). Служба освітнього омбудсмена С. Горбачова провела онлайн-опитування батьків дітей, які навчаються в закладах загальної середньої освіти, представила орієнтовну модель проблем, з якими учні та їхні батьки зіткнулися під час карантину і надала пропозиції щодо якісної організації дистанційного навчання для загальноосвітніх шкіл України (Освітній омбудсмен України, 2020).

Метою статті $€$ огляд дій китайського уряду з протидії впливу COVID19 на освіту. Ефективний досвід країни, де визначені заходи безпеки спрацювали й сприяли спаду епідемії можуть бути цікавими в перспективах їхнього використання в Україні. 
Методи дослідження. Методологічну основу дослідження становлять системно-комплексний принцип науково-педагогічного пошуку, а саме аналіз джерел із проблеми дослідження та нормативних документів, структурно-логічний аналіз, узагальнення та систематизації результатів дослідження.

Виклад основного матеріалу. Уперше закриття шкіл через коронавірус відбулося 23 січня в місті Ухань, епіцентрі епідемії. До 8 лютого вже було закрито заклади освіти й центри, дитячі садочки по всьому Китаю. Ця подія вплинула на 278 млн. дошкільнят та учнів початкових та середніх шкіл, більшість із яких перейшли на онлайннавчання вдома (UNESCO, 2020). У межах загальнодержавного контролю над епідемією влада відклала початок нового шкільного семестру, який повинен був розпочатися 17 лютого.

Для того, щоб діти могли в цей період продовжувати навчатися вдома, у Китаї було розроблено загальну національну освітню онлайнплатформу (国家教育资源公共服务平台). Цю освітню платформу (проект Міністерства освіти Китаю і Міністерства промисловості та інформаційних технологій) було відкрито для учнів початкових та середніх шкіл для того, щоб надати їм безкоштовні ресурси для навчання доки вони не зможуть повернутися до своїх звичайних аудиторій. За два дні платформу візитували понад 23 мільйони відвідувачів з 31 регіону Китаю.

Національна платформа забезпечує навчальними ресурсами з шести модулів: освіта з профілактики епідемій, моральна освіта, освіта на спеціальні теми, шкільні предмети, електронні навчальні матеріали та медіа освіта. Контент платформи містить матеріали для скачування (підручники для початкової та середньої школи, що входять до переліку освітнього стандарту), китайські класичні літературні твори і фільми, мотиваційні відео для дітей та батьків про заняття під час карантину.

Навчальний розділ включає в себе відеоуроки з 12 шкільних предметів молодшої та старшої середньої школи, які було записано в різних школах Пекіна, Шанхаю та інших великих містах. Учень може обрати клас, предмет і тему, яка його цікавить. Для доступу до платформи всім школам і їхнім учням було надано доступ з логінами і паролями, за допомогою яких діти могли ознайомитися з усім контентом. Частина уроків знаходилася й у відкритому доступі. У перший тиждень було розміщено 169 уроків, щотижня вони поповнювалися.

За підтримки китайських телекомунікаційних та технологічних гігантів, таких як China Mobile, China Unicom i China Telecom, а також Alibaba, Baidu i Huawei, було забезпечено можливість отримати доступ до освітньої платформи 50 мільйонам учнів одночасно.

Паралельно чотири канали Китайського телебачення транслювали уроки для початкових та середніх шкіл. Зокрема, за перший тиждень 
вийшло в ефір 75 уроків. Телевізійна мережа охопила навіть віддалені райони зі слабким сигналом і райони без доступу до кабельного телебачення.

Початкові та середні школи по всій країні зобов'язали відкривати онлайн-програми за допомогою офіційних освітніх веб-сайтів, щоб гарантувати, що понад 180 мільйонів учнів займаються «керованим» навчанням вдома (China Global Television Network, 2020).

Інтернет-освітні компанії та платформи симультанно пропонували численні безкоштовні онлайн-курси відповідно до шкільних планів. Як повідомляється, майже 600000 вчителів використовували мобільний додаток для корпоративного зв'зку DingTalk (Alibaba Group) для проведення своїх онлайн-занять. Також з середини лютого 2020 р., після того, як уряд Китаю зобов'язав учнів відновити навчання через онлайн-платформи, у Китаї широко почала застосовуватися навчальна платформа Tencent. Ця платформа дозволяє швидко залучати велику кількість користувачів одночасно. Крім цього, викладачі використовували такі продукти Tencent, як мережа обміну швидкими повідомленнями QQ та систему для передачі текстових і голосових повідомлень WeChat. Це призвело до найбільшого «інтернет-руху» в історії освіти, де приблизно 730 тис., або 81 \% учнів шкіл в Ухані відвідували заняття через Інтернет-школу Tencent.

Через перехід шкіл на дистанційне навчання, а також для підвищення ефективності навчання, в Китаї почали активно застосовуються адаптивні навчальні інструменти. На освітніх просторах Китаю десятки мільйонів учнів використовували такі програми позакласного навчання, як Squirrel Al Learning та Shanghai ALO7, цифрові навчальні платформи 17ZuoYe та GSX Techedu.

Squirrel Al Learning застосовує передовий алгоритмний адаптивний навчальний інструмент на основі штучного інтелекту. Основний принцип роботи полягає у виявленні слабких сторін учнів і складанні індивідуального навчального плану таким чином, щоб заповнити виявлені прогалини. Так, наприклад, усі теми з певного предмету, які учні мають пройти в середній школі, розбиваються на детальні елементи, маленькі підтеми. Учні проходять тест, який допомагає виявити ті підтеми, які даються їм найбільш важко. Програма виявляє пов'язані теми, які так само можуть потребувати додаткової уваги та визначає, у якому порядку та за допомогою яких практичних завдань тому чи іншому учню буде легше освоїти потрібний матеріал. Роль вчителя у таких заняттях $€$ мінімальною. Весь навчальний та робочий процес проходить через ноутбук. Учні вирішують свої завдання, а вчителі моніторять навчальний процес у режимі реального часу. Якщо вони бачать на екранах, що система не може вирішити якесь питання, то підходять до відповідного учня і допомагають. Деякі експерти зауважують, що така технологія $\epsilon$ прикладом хоч і 
індивідуального, але традиційного підходу до навчання (орієнтованою на здачу іспитів), тоді за адаптивної технології приділяється увага сильним сторонам та інтересам учня. Ґрунтуючись на цих аспектах пропонується програма навчання. Подібний підхід обрано за основу в Al07, де процес пізнання відбувається через критичне мислення, гнучкість розуму, креативність, лідерство та інші корисні навички. На відміну від технології Squirrel, тут не намагаються замінити вчителів, а лише прагнуть доповнити та розширити можливості традиційної класної кімнати.

Інтелектуальна шкільна платформа 17zuоуе використовує останні новітні та інноваційні підходи в онлайн навчанні. Платформою користуються сім мільйонів школярів і 146 тисяч вчителів. Учитель на 17zuoye може підібрати відповідні завдання, проконтролювати їх виконання, виставити бали. Для спілкування з класом $є$ чат. Доступ до аналізу даних дозволяє проаналізувати у деталях прогрес. Учні отримують призначені вчителем завдання через додаток. До багатьох завдань включено ігрові елементи. Бали відображаються відразу ж, після автоматичної перевірки, а неправильно виконані завдання можна переробити. Учитель має можливість прокоментувати кожне завдання. Учні з одного класу можуть виконувати завдання разом, спілкуючись у чаті. Платформа орієнтована на персоналізацію навчання - система аналізує роботу кожного учня й автоматично регулює складність завдань. Наприклад, якщо дитина не може кілька разів поспіль відповісти на питання, їй буде запропоновано простіші вправи. Якщо вчителі використовують у класі електронні підручники, система синхронізує з ними матеріали домашньої роботи. На основі аналізу прогресу дітей за семестр система пропонує завдання для фінального тесту. Батькам платформа надає зв'язок з учителем і можливість контролювати прогрес своєї дитини. Вони отримують доступ до домашніх завдань і можуть підключитися до їх виконання. Батьки мають можливість бачити оцінки та коментарі вчителя і зв'язуватися з ним у чаті. Вони також отримують звіти, за допомогою яких можуть простежити, скільки часу дитина витрачає на виконання завдань, що в неї виходить, а що ні. Платформу було розроблено для підвищення ефективності освітнього процесу, розвитку навчального інтересу учнів та обізнаності батьків із навчальною ситуацією.

GSX Techedu - це освітня edtech компанія та провідний інтернетпостачальник послуг із репетиторських занять у Китаї. GSX Techedu пропонує шкільні курси, що охоплюють усі початкові та середні класи, а також курси іноземної мови, професійні та за інтересами.

На думку китайських освітян, використання цифрових навчальних платформ у домашніх умовах може допомогти дітям залишатися зайнятими, забезпечити їм цінний досвід навчання та дозволить зберегти відчуття неперервності навчання. Проте, одні вважають, що незапланований і 
швидкий рух до онлайн навчання без підготовки, недостатньої пропускної здатності призведе до поганого користувальницького досвіду, що не сприятиме стійкому зростанню дистанційного навчання в подальшому. Інші вважають, що з'явиться нова гібридна модель освіти, зі значними перевагами; що інтеграцію інформаційних технологій в освіту буде пришвидшено і що онлайн-освіта з часом стане невід'ємною складовою шкільної освіти. Безперечно, теперішня ситуація змінює і спосіб викладання: учителі мають можливість ефективно співпрацювати зі своїми учнями через групові чати, відео зустрічі, голосування, обмін матеріалами. Багато хто 3 викладачів зазначає, що буде користуватися онлайн інструментами для підтримки навчання і після карантину.

Закриття шкіл через коронавірус у Гонконзі відбулося після новорічного свята 3 лютого. Ця подія вплинула на 900 тис. вихованців дитячих садків, учнів початкових та середніх шкіл. На думку викладачів та директорів, - це наймастабніший, успішний досвід в історії Гонконгу навчання в Інтернеті. Як зазначила директорка однієї середньої школи, більшість із ії 900 учнів відчули, що онлайн-уроки значною мірою відповідають якості уроків у класі, додавши, що відвідуваність цих уроків склала майже 99 \%. Багато викладачів використовували технологію вебкамери для спілкування «обличчям до обличчя», як-от Google Hangouts Meet, Zoom та Microsoft Teams. Це давало їм можливість проводити уроки в прямому ефірі і бачити обличчя своїх учнів, тому вони знали, які з них беруть участь, а які ні. В інших школах використовувалася технологія конференц-дзвінків (conference call technology), яка, хоча і не передбачає використання відео, проте уможливлює задіяти значну кількість учасників. Оскільки деякі учні, налаштовані на заняття, відчували себе більш комфортно, коли брали участь у аудіодзвінках. Деякі школи записували уроки та завантажували відео в Інтернеті, щоб учні могли їх самостійно переглядати. Проте, згодом з'ясувалося, що не всі уроки є ефективними в онлайн режимі. Наприклад, наукові досліди часто не можуть бути відтворені вдома. Крім того, закриття шкіл загострило питання соціальної справедливості, оскільки багато учнів із сімей із низьким рівнем доходу не мали доступу до комп'ютерів та Інтернету вдома.

У Гонконзі вчителі організовували онлайн-навчання на основі рекомендацій і навчальних ресурсів, що почали надаватися Бюро розвитку освіти з початку лютого 2020 р. Понад 80 \% учителів, опитаних Федерацією працівників освіти Гонконгу, повідомили, що витрачали більше часу на підготовку до онлайн-навчання, ніж на навчання в класі. Багато $з$ них повідомляли про труднощі у взаємодії з учнями.

У Шанхаї уроки для учнів початкової школи щодня транслювалися по громадському телебаченню. Здебільшого учні використовували програмний додаток для отримання завдань і спілкування зі своїми 
вчителями. Учителі в Шанхаї також наголошували на деяких проблемах через швидкий перехід на дистанційне навчання, зокрема на додатковому часі, що витрачається на підготовку онлайн-завдань та оцінювання, та обмеженні часу для професійного навчання і планування уроків.

3 метою пом'якшення впливу на широкосмугові мережі, якими мільйони учнів користувалися одночасно, а також запобіганню надмірному псуванню зору дітей, Уряд Китаю орієнтував освітній процес на урізноманітнення форматів навчання. Навчальні матеріали, які транслювалися онлайн та розміщувалися на електронних платформах, було синхронізовано з національними та муніципальними курикулами. Учителі та батьки могли отримати доступ до рекомендацій щодо використання онлайн матеріалів (Локшина та ін., 2020).

Освітяни вважають, що завдяки наступним діям, вони змогли швидко та якісно забезпечити безперебійне навчання в умовах карантину:

1. Роль уряду: рішучі, чіткі своєчасні дії. 3 січня 2020 р. чиновники прийняли багато важливих рішень щодо карантинних заходів у закладах освіти, а також доступних ресурсів для підтримки навчання. Паралельно із закриттям шкіл уряд Китаю у співпраці з сімома найбільшими китайськими приватними edtech компаніями посилив освітні онлайн-платформи. Хоча платформи існували і до кризи, викликаної епідемією COVID-19, розробники додали нові інструменти планування та навчальні матеріали, щоб допомогти вчителям впроваджувати якісне навчання. Після 8 лютого 2020 р. Міністерство освіти співпрацювало індивідуально 3 кожним провінційним відділом освіти, щоб визначити дати відкриття шкіл. Хоча школи відкривалися в різних регіонах у різний час, проте уряд давав чіткі сигнали про відповідні зміни.

2. Тимчасове обмеження у викладанні нового контенту. Не всі учні мали можливість відвідувати онлайн-заняття. Особливо у віддалених регіонах, де доступ до Інтернету і цифрових пристроїв нерівномірний. Стурбоване такою ситуацією, Міністерство освіти 4 лютого оголосило, що вчителям заборонено розпочинати нові навчальні теми до початку нового семестру. Більш того, Міністерством було рекомендовано використовувати ресурси з психічного здоров'я, онлайн-контент, який стосується особистого благополуччя i розважальний навчальний контент. Так, наприклад, адміністратор однієї з початкових шкіл у Пекіні зазначав, що для учнів їхньої школи обов'язковими були тільки онлайн-курси з психічного здоров'я. Більш того, вчителя активно заохочували учнів до курсів фізичного виховання на дому. Проте учні мали можливість брати уроки і $з$ інших навчальних предметів.

3. Скорочення часу онлайн-занять. Китайці провели дослідження, які показали, що онлайн-сесії тривалістю від 15 до 30 хвилин найбільш ефективні. Міністерство освіти запропонувало скоротити час онлайн- 
занять. Наприклад, провінційний відділ освіти Гуандун випустив докладні інструкції, як обмежити кожне онлайн-заняття 20 хвилинами. Синхронні онлайн-заняття вимагають великої концентрації і тому можуть легко втомити учнів. Тому, на їхню думку, обмеження часу перед екранами гаджетів у поєднанні 3 активними діями «поза екраном» можуть підвищити концентрацію уваги учнів і зменшити втому.

4. Підтримка вчителів. Ключовим аспектом до швидкого освоєння нових форматів навчальної роботи були надзвичайна адаптивність і потужний творчий потенціал викладачів. Вони демонстрували наполегливість, рішучість та спільне вирішення проблем. Безумовно, школами також було вжито додаткових заходів для підтримки навчального процесу, який необхідно було поновити за тиждень. Учителі працювали в командах, неакадемічний персонал і адміністратори складали розклад, реєстрували учнів, організовували онлайн-списки класів, розробляли інструкції і навчали персонал роботі в Інтернеті, створювали онлайн-чати через WeChat, щоб учителі могли допомагати однин одному обмінюватися ідеями, порадами й відповідати на питання.

5. Активне спілкування з батьками та врахування їхньої думки. Через карантин батьки були змушені активно долучатися до навчального процесу своїх дітей. Тому дуже важливо було дозволити їм поділитися своїми враженнями. Наприклад, деякі школи опитували батьків своїх учнів вже через 10 днів після початку віддаленого навчання, співробітники школи аналізували батьківські пропозиції щотижня. І, на їхню думку, деякі батьки пропонували корисні ідеї. Так, у відповідь на їхні відгуки, деякими школами було скорочено онлайн час для молодших школярів (10 хвилин онлайн-заходів, а потім 20 хвилин автономної роботи). Інші батьки запропонували зараховувати допомогу по господарству як частину курсу фізичного виховання. Тому школа запропонувала батькам надсилати відео про те, як їхні діти виконують роботу по дому.

6. Швидке впровадження програмного забезпечення Edtech компаній у шкільний процес. Великі технологічні компанії швидко розробили нові онлайн-інструменти навчання для підтримки вчителів і учнів. Dingding, корпоративне комунікаційне програмне забезпечення, розроблене Alibaba Group, швидко запустило навчальну онлайнплатформу для шкіл, яка стала широко використовуватися для прямих трансляцій уроків. Tencent запустив програмне забезпечення Tencent Meeting, яке також підтримує сеанси прямої трансляції. Tencent перенесла свої сервери, зазвичай призначені для ігрового бізнесу, для підтримки онлайн-класів. Завдяки впізнаваності бренду та стабільності своїх серверів, їх було швидко впроваджено в школах. Так, наприклад, вчителі з однієї пекінської середньої школи протестували кілька платформ і вибрали Tencent Meeting через легкість інтерфейсу і стабільність. 
7. Надання особливої уваги соціальним та емоційним потребам. На думку китайських освітян, приділення пильної уваги соціальним і емоційним потребам учнів, учителів та їхніх сімей має вирішальне значення для створення середовища, що сприяє навчанню (Ning \& Corcoran, 2020).

Отже, в умовах пандемії COVID-19 Китаєм було орієнтовано освітній процес на урізноманітнення форматів навчання та впроваджено комплексний підхід до організації навчального процесу, поєднуючи онлайн навчання з іншими традиційними інструментами. Серед базових інструментів онлайн освіти Китаєм було використано: всенаціональний централізований центр електронного навчання, освітні онлайн платформи, телебачення і радіомовлення. Багато китайських практиків розглядають навчальні платформи як ефективний інструмент та підтримувальну систему навчання, які $€$ корисними та дійсно необхідними як викладачам, так і учням. До підтримки онлайн навчання долучилися міжнародні корпорації/компанії.

Висновки та перспективи подальших наукових розвідок. Отже, досвід Китаю показує, що надійна комунікаційна платформа, відповідні цифрові ресурси, зручні інструменти навчання, різноманітні методи навчання, гнучкі навчальні організації, ефективні служби підтримки та тісна співпраця між урядом і школою - це ключові елементи, на які орієнтувався уряд Китаю для забезпечення широкомасштабного онлайн-навчання. Набутий досвід і можливості зумовлюють певні тенденції в майбутньому розвитку шкільної освіти Китаю, а саме зміщення уваги і зусиль у бік кардинального покращення змістової та технологічної дигіталізації шкільної освіти у процесі подальших освітніх реформ. Перспективи подальших досліджень складають аспекти, пов'язані з упровадженням дистанційного навчання в умовах пандемії та ефективними інструментами для організації навчального процесу в новій реальності.

\section{ЛІТЕРАТУРА}

Корнієвський, О. (2020). Громадянське суспільство в умовах пандемії коронавірусу COVID-19: виклики та перспективи розвитку. Режим доступу: https://niss.gov.ua/news/statti/gromadyanske-suspilstvo-v-umovakh-pandemiikoronavirusu-covid-19-vikliki-ta-perspektivi (Korniievskyi, O. (2020). Civil society in the context of the COVID-19 coronavirus pandemic: challenges and prospects. Retrieved from: https://niss.gov.ua/news/statti/gromadyanske-suspilstvo-vumovakh-pandemii-koronavirusu-covid-19-vikliki-ta-perspektivi).

Локшина, О. І., Глушко, О. З., Джурило, А. П., Кравченко, С. М., Нікольська, Н. В., Тименко, М. М., Шпарик, О. М. (2020). Відповідь світової спільноти на виклики COVID-19 в освіті (лютий-травень 2020 р.). Київ. Режим доступу: http://undip.org.ua/news/library/zbirniki detail.php?ID=9918 (Lokshyna, O. I., Hlushko, O. Z., Dzhurilo, A. P., Kravchenko, S. M., Nikolska, N. V., Tymenko, M. M., Shparyk, O. M. (2020). The response of the world community to the challenges of 
Педагогічні науки: теорія, історія, інноваційні технології, 2020, № 3-4 (97-98)

COVID-19 in education (February-May 2020). Kyiv. Retrieved from: http://undip.org.ua/news/library/zbirniki detail.php?ID=9918).

Освітній омбудсмен України (2020). Результати опитування батьків «Навчання дітей під час карантину». Режим доступу: https://eo.gov.ua/wpcontent/uploads/2020/04/Rezul-taty-opytuvannia-22Navchannia-ditey-pid-chaskarantynu22.pdf (Educational Ombudsman of Ukraine. (2020). Results of a parents' poll "Teaching children under quarantine". Retrieved from: https://eo.gov.ua/wpcontent/uploads/2020/04/Rezul-taty-opytuvannia-22Navchannia-ditey-pid-chaskarantynu22.pdf).

Постійне представництво України при ЮНЕСКО (2020). ЮНЕСКО мобілізує зусилля 3 метою просування відкритої науки і зміцнення співпраці в контексті протидії COVID-19. Режим доступу: https://unesco.mfa.gov.ua/news/yunesko-mobilizuyezusillya-z-metoyu-prosuvannya-vidkritoyi-nauki-i-zmicnennya-spivpraci-v-konteksiprotidiyi-covid-19 (Permanent Mission of Ukraine to UNESCO (2020). UNESCO mobilizes efforts to promote open science and strengthen cooperation in the context of countering COVID-19. Retrieved from: https://unesco.mfa.gov.ua/news/yuneskomobilizuye-zusillya-z-metoyu-prosuvannya-vidkritoyi-nauki-i-zmicnennya-spivpraci-vkonteksi-protidiyi-covid-19.

Кремень, В. Г. (Ред.) (2020). Психологія і педагогіка у протидії пандемії COVID-19. Київ: TOB «Юрка Любченка». Режим доступу: http://ipood.com.ua/data/NDR/COVID19/COVID19 new.pdf (Kremen, V. H. (2020). Psychology and pedagogy in counteracting the pandemic COVID-19. Kyiv. Retrieved from: http://ipood.com.ua/data/NDR/COVID19/COVID19 new.pdf).

Рибалка, В. В., Помиткін, Е. О., Ігнатович, О. М., Павлик, Н. В., Іванова, О. В., Радзімовська, О. В., ... Кабиш-Рибалка, Т. В. (2020). Психологічна профрілактика $і$ гігієна особистості у протидії пандемії COVID-19. Київ: Інститут педагогічної освіти і освіти дорослих імені Івана Зязюна НАПН України. Режим доступу: http://ipood.com.ua/e-library/pozaplanova-produkciya/psihologichna-profilaktika-igigiena-osobistosti--u-protidi-pandemi-covid-19/ (Rybalka, V. V., Pomytkin, E. O., Ihnatovych, O. M., Pavlyk, N. V., Ivanova, O. V., Radzimovska, O. V., ... KabyshRybalka, T. V. (2020). Psychological prevention and personal hygiene in counteracting the pandemic COVID-19. Kyiv: Ivan Ziaziun Institute of Pedagogical and Adult Education of the National Academy of Pedagogical Sciences of Ukraine. Retrieved from: $\quad$ http://ipood.com.ua/e-library/pozaplanova-produkciya/psihologichnaprofilaktika-i-gigiena-osobistosti--u-protidi-pandemi-covid-19/).

Світовий центр даних з геоінформатики та сталого розвитку (2020). Форсайт COVID-19: сплеск після послаблення карантинних заходів. Режим доступу: http://wdc.org.ua/en/covid19-post-quarantine-outbreak (World Data Center for Geoinformatics and Sustainable Development (2020). Foresight COVID-19: fourth stage of the quarantine measures weakening. Retrieved from: http://wdc.org.ua/en/covid19-post-quarantine-outbreak).

CBS News (2002). What back-to-school looks like for students in China's coronavirus epicenter of Wuhan. Retrieved from: https://www.cbsnews.com/news/coronaviruswuhan-schools-reopen-china-covid-epicenter-seniors-exams-today-2020-05-06/.

China Global Television Network (2020). China launches national cloud learning platform as teaching goes online amid epidemic. Retrieved from: https://news.cgtn.com/news/2020-02-19/China-launches-national-cloud-learningplatform-for-online-education-Ods9XruOR2/index.html 
Di Wu, Tiantian Wu, Qun Liu, Zhicong Yang. (2020). The SARS-CoV-2 outbreak: What we know. International Journal of Infectious Diseases. https://doi.org/10.1016/i.ijid.2020.03.004.

Huang, R. H., Liu, D. J., Amelina, N., Yang, J. F., Zhuang, R. X., Chang, T. W., \& Cheng, W. (2020). Guidance on Active Learning at Home during Educational Disruption: Promoting student's self-regulation skills during COVID-19 outbreak. Beijing: Smart Learning Institute of Beijing Normal University. Retrieved from: https://iite.unesco.org/wp-content/uploads/2020/04/Guidance-on-Active-Learningat-Home-in-COVID-19-Outbreak.pdf.

HundrED (2020). Spotlight on quality education for all during Covid-19 crisis. Retrieved from: https://hundred.org/en/collections/quality-education-for-all-during-coronavirus.

Li, C. \& Lalani, F. (2020). The COVID-19 pandemic has changed education forever. This is how. Retrieved from: https://www.weforum.org/agenda/2020/04/coronavirus-educationglobal-covid19-online-digital-learning/.

Liberman, J., Levin, V., Luna-Bazaldua, D., Harnisch, M. (2020). High-stakes school exams during COVID-19 (Coronavirus): What is the best approach? Retrieved from: https://blogs.worldbank.org/education/high-stakes-school-exams-during-covid-19coronavirus-what-best-approach.

Ning, A. \& Corcoran, B. (2020). How China's Schools Are Getting Through COVID-19. Retrieved from: https://www.edsurge.com/news/2020-04-20-how-china-s-schoolsare-getting-through-covid-19.

Petrie, C., Aladin, K., Ranjan, P., Javangwe, R., Gilliland, D., Tuominen, S., Lasse, L. (2020). Spotlight on quality education for all during Covid-19 crisis. Retrieved from: https://hundred-

cdn.s3.amazonaws.com/uploads/report/file/15/hundred_spotlight_covid-19 digital.pdf.

UNESCO (2020). COVID-19 Impact on Education. Retrieved from: https://en.unesco.org/covid19/educationresponse.

\section{PEЗЮME}

Шпарик Оксана. COVID-19 и школьное образование: выученные уроки для Китая.

В статье рассмотрена проблема организации учебного процесса в условиях современной пандемии. Анализируются действия китайского правительства по противодействию влияния COVID-19 на школьное образование. Автор делает вывод, что надежная коммуникационная платформа, соответствующие цифровые ресурсы, удобные инструменты обучения, разнообразные методы обучения, гибкие учебные организации, эфррективные службы поддержки и тесное сотрудничество между правительством и школой - это ключевые элементы, на которые ориентировалось правительство Китая для обеспечения широкомасштабного онлайн-обучения. Приобретенный опыт и возможности обусловливают определенные тенденции в будущем развитии школьного образования Китая, а именно смещение внимания и усилий в сторону кардинального улучшения содержательной и технологической дигитализации образования в прочессе дальнейших образовательных реформ.

Ключевые слова: школьное образование, дистанционное обучение, пандемия COVID-19, национальная онлайн-платформа, цифровые учебные платформы, Китай. 


\section{SUMMARY}

Shparyk Oksana. COVID-19 and School Education: Lessons Learned for China.

The article deals with the problem of organizing of educational process in the context of current pandemic and analyzes the actions of the Chinese government to resist the impact of COVID-19 on school education. The methodological basis of the research is the systemintegrated principle of scientific and pedagogical search.

It was found that thanks to the following actions, the Chinese were able to quickly and efficiently provide uninterrupted secondary education under quarantine conditions: 1) the China government has made many important decisions on quarantine measures in education institutions, as well as available resources to support training. In parallel with the school closures, the Chinese government, in partnership with seven of China's largest private edtech companies, has strengthened online education platforms; 2) implementation of temporary restriction in teaching of new content; 3) reducing the time of online classes; 4) extreme adaptability and powerful creativity of teachers; 5) active communication with parents, as well as consideration of their opinions; 6) rapid implementation of edtech software in the school process; 7) giving special attention to social and emotional needs.

The author concludes that reliable communication platforms, appropriate digital resources, user-friendly teaching tools, various teaching methods, flexible teaching organizations, effective support services, and strong government-school collaboration are key elements that the Chinese government has focused on to enable widespread online learning. The gained experience and opportunities determine certain trends in the future development of school education in China, namely, a shift in attention and efforts towards a radical improvement in the content and technological digitalization of school education in the process of further educational reforms. Prospects for further research include aspects related to the implementation of distance learning by teachers and effective tools for organizing of educational process in a new reality.

Key words: secondary education, distance learning, pandemic COVID-19, National Cloud-Platform for Educational Resources, digital learning platforms, China. 


\section{РОЗДІЛ ІІІ. ПРОБЛЕМИ ІСТОРІЇ ПЕДАГОГІКИ}

\section{УдК 373.5.091.33:811.11](477.85)"1918/1940"}

Ольга Гоменюк

Тернопільський національний педагогічний університет імені Володимира Гнатюка

ORCID ID 0000-0001-5398-5593

DOI 10.24139/2312-5993/2020.03-04/194-206

\section{МЕТОДОЛОГІЧНІ ЗАСАДИ РОЗВИТКУ МЕТОДИКИ НАВЧАННЯ ГЕРМАНСЬКИХ МОВ НА БУКОВИНІ (ПЕРША ПОЛОВИНА ХХ СТ.)}

у статті обгрунтовано методологічні засади дослідження проблеми розвитку методики навчання германських мов на Буковині (першої половини XX cm.). Визначено, що вибір методологічного інструментарію зумовлений міждисциплінарним характером дослідження та базується на загальнонауковому й конкретно-науковому рівнях. Виокремлені рівні наукового пізнання уможливили грунтовне вивчення проблеми з урахуванням особливостей методики навчання германських мов на Буковині в зазначений хронологічний період.

Ключові слова: методологічні засади, методика навчання германських мов загальнонауковий рівень, конкретно-науковий рівень, міждисциплінарність, методологічні підходи, методи, принципи, історико-педагогічний процес.

Постановка проблеми. Характерними рисами наукових досліджень $€$ цілеспрямованість, формулювання та розв'язання конкретних наукових завдань, пошук бібліографічних джерел та добір фактичного матеріалу, відкриття невідомих явищ і закономірностей, введення нових гіпотез та ідей, вирішення й обґрунтування розглянутих питань, систематизація нових знань, аргументованість, репрезентація одержаних результатів. 3 метою вирішення поставлених завдань в історико-педагогічних працях, важливо визначити методологічні підходи, принципи і методи, що утворюють методологічну систему дослідження розвитку методики навчання германських мов у різних типах шкіл Буковини в першій половині XX ст.

Аналіз актуальних досліджень. У наш час багато науковців звертаються до вивчення питань, пов'язаних із формуванням системи методологічного апарату в історико-педагогічних дослідженнях. Проблемам методологічного забезпечення наукових досліджень присвячено праці видатних педагогів-науковців, а саме: О. В. Адаменко, Л. Д. Березівської, Л. Ц. Ваховського, С.У.Гончаренко, Н. М. Гупана, І.А. Зязюна, О. С. Падалки, С. О. Сисоєвої, О. В. Сухомлинської, Є. М. Хрикова та ін. Однак, методологічні основи розвитку методики навчання германських мов на Буковині в першій половині XX ст. не були предметом спеціального наукового дослідження. 
Мета статті полягає у визначенні й обґрунтуванні методологічного інструментарію дослідження проблеми розвитку методики навчання германських мов на Буковині в першій половині XX ст.

Методи дослідження. Для реалізації поставленої мети використано аналіз, порівняння, систематизацію та узагальнення спеціальної науковопедагогічної літератури, що уможливило виокремлення методологічних засад розвитку методики навчання германських мов у різних типах шкіл буковинського краю в першій половині XX ст.

Виклад основного матеріалу. Необхідною умовою розвитку будьякої наукової діяльності $\epsilon$ послідовність виконання та оформлення результатів наукового дослідження на основі методологічних засад.

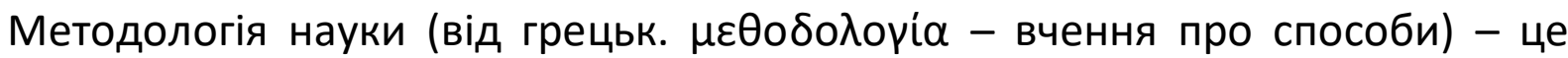
система методологічних і методичних принципів та прийомів, операцій і форм побудови наукового знання (Зацерковний та ін., 2017, с. 72).

Методологія вивчає всі компоненти наукової пізнавальної діяльності в їх взаємозв'язку. Ії̈ завдання полягають у дослідженні механізмів, можливостей і перспектив формування нового знання в їх залежності від досліджуваного об'єкта, історично сформованих пізнавальних засобів, цілей і установок суб'єкта пізнання (Пунченко, 2014, с. 29).

Функції методології полягають у наступному:

- визначає способи здобуття наукових знань, що відображають динамічні процеси та явища;

- спрямовує, передбачає особливий шлях, на якому досягається певна науково-дослідницька мета;

- забезпечує всебічність отримання інформації щодо процесу чи явища, що вивчається;

- допомагає введенню нової інформації до фонду теорії науки у вигляді нових понять, категорій, законів, гіпотез, ідей, теорій;

- забезпечує уточнення, збагачення, систематизацію термінів і понять у науці;

- створює систему наукової інформації, яка базується на об'єктивних фактах, і логіко-аналітичний інструмент наукового пізнання;

- організує використання нових знань у практичній діяльності (Зацерковний та ін., 2017, с. 72).

Отже, методологія забезпечує процес наукового пізнання методами, прийомами, формами і способами науково-дослідницької діяльності. Методологічне обґрунтування окреслює загальний підхід до дослідження, розкриваючи конкретніші твердження. Вони виступають методологічними орієнтирами, що розвивають систему наукового знання.

Необхідно зазначити, що методологічний апарат нашого дослідження зумовлений міждисциплінарним напрямком роботи. Як зазначає український історик І. Рассоха, методи міждисциплінарного дослідження являють собою 
сукупність низки синтетичних, інтегративних способів, які виникли в результаті сполучення елементів різних рівнів методології, спрямованих переважно на стики наукових дисциплін. Ці методи обумовлені поглибленням взаємозв'язків наук, які призводять до того, що результати, прийоми і методи однієї науки широко використовуються в інших (Рассоха, 2011, с. 51). Тому міждисциплінарний характер історії методики навчання германських мов розглядаємо як соціально-історичну парадигму ретроспективних методичних досліджень, яка визначає перевагу методологічних зв'язків та закономірностей взаємодії педагогіки, психології, лінгвістики, історії України та методики навчання германських мов.

Методологічний інструментарій нашого дослідження базується на загальнонауковому та конкретно-науковому рівнях. Підходам кожного рівня притаманна власна специфіка, які безпосередньо не застосовуються ізольовано, а лише в поєднанні з іншими.

До загальнонаукового рівня методології, який застосовується в більшості наукових досліджень, ми відносимо системний, синергетичний i парадигмальний підходи. На нашу думку, саме вони дадуть змогу комплексно розглянути історико-соціальні та освітньо-організаційні передумови, самоорганізацію процесу навчання, у тому числі учасників педагогічного процесу, а також уможливлять виділення багатоваріантності й альтернативності шляхів подальшого розвитку методики навчання германських мов.

Системний підхід - це напрям у спеціальній методології науки, завданням якого $€$ розробка методів дослідження й конструювання складних за організацією об'єктів як систем. Системний підхід у педагогіці спрямований на розкриття цілісності педагогічних об'єктів, виявлення в них різноманітних типів зв'язків та зведення їх у єдину теоретичну картину (Гончаренко, 1997, с. 305).

Сутність системного підходу полягає в тому, що відносно самостійні компоненти розглядаються не ізольовано, а в їх взаємозв'язку та розвитку. Він дозволяє виявити інтегративні системні властивості і якісні характеристики складових елементів системи. Предметний, функціональний та історичний аспекти системного підходу потребують реалізації в єдності таких принципів дослідження, як історизм, конкретність, урахування всебічних зв'язків і розвитку (Загальні підходи i принципи наукового дослідження).

Кожну конкретну науку, об'єкт чи діяльність можна вивчати як певну систему, що складається із взаємопов'язаних елементів, компонентів, підсистем, а також визначених цілей, функцій, структури та складу. Адже системою називають сукупність об'єктів із їх відносинами і зв'язками, що володіє такими ознаками: цілісністю (певною незалежністю системи від зовнішнього середовища і від інших систем), зв'язністю (наявністю зв'язків, 
що дозволяють за допомогою переходів по них від елемента до елемента з'єднувати декілька будь-яких елементів системи), функцією (наявністю цілей, що не $\epsilon$ простою сумою цілей елементів, що належать системі) (Гуменюк та Корець, 2014, с. 63).

Системний підхід дає змогу досліджувати будь-яке історикопедагогічне явище як системне утворення, окреслюючи ознаки системи: наявність сукупних елементів, кожен із яких $€$ мінімальною одиницею, що має межу подільності в рамках цієї системи; наявність певних зв'язків і відношень між елементами системи; функціонування системи та ії властивості зумовлені їі структурною специфікою; наявність у системі певного рівня цілісності, тобто внутрішніх інтегративних якостей, що виникають унаслідок взаємодії їі елементів; наявність спільної структури, яка об'єднує всі елементи системи й забезпечує повноту названих елементів та узгодженість усіх їхніх функцій; наявність зв'язків з іншими системами; спрямованість системи на вирішення якоїсь проблеми (Кузнецова, 2001, с. 57).

Навчання германських мов у закладах загальної середньої освіти на Буковині визначаємо як систему, функціонування якої зумовлено багатьма чинниками. Основними з них виступають характер соціального замовлення на певному етапі розвитку суспільства, підходи, принципи, мета навчання й виховання та зміст навчання.

Навчання германських мов - спеціально організований процес, у ході якого в результаті взаємодії вчителя та учня здійснюється засвоєння та відтворення іншомовного мовленнєвого досвіду відповідно до поставленої мети (Методика навчання іноземних мов і культур, 2013, с. 29). 3 огляду на цільове призначення методики навчання германських мов на Буковині в зазначений хронологічний період, виділимо такі структурні компоненти системи:

1. Мета навчання германських мов: передбачення кінцевих результатів педагогічної діяльності.

2. Зміст навчання германських мов: обсяг навчальної інформації, яку учень повинен засвоїти у процесі навчання.

3. Завдання навчання германських мов: засвоєння знань 3 германських мов та формування вмінь практично застосовувати ці знання в повсякденному житті чи для досягнення професійних цілей.

4. Засоби навчання германських мов: об'єкти матеріальної та духовної культури, які використовують у навчально-виховному процесі і завдяки яким реалізується мета навчання германських мов.

5. Форми навчання германських мов: шкільні заняття, виконання домашніх завдань, відвідування гуртків, товариств.

6. Методи навчання германських мов: способи взаємопов'язаної діяльності педагога та учнів, які спрямовані на вирішення завдань процесу навчання. 
7. Результат навчання германських мов: володіння IM на відповідному рівні.

Структурні елементи системи взаємопов'язані між собою та взаємодіють із зовнішнім середовищем, формуючи та проявляючи свої властивості, однак, зберігаючи при цьому стійкість свого функціонування. Одним із системотвірних факторів $€$ мета, яка виступає головним призначенням системи. Структурні компоненти системи навчання германських мов взаємодіють під впливом зовнішніх та внутрішніх чинників, створених людиною (науково-методичні засади, нормативноправова база). Результат виступає фактором впорядкованості в системі навчання германських мов, оскільки має вплив на всю систему. Разом із тим, організація навчального процесу впливає на його результати і створює умови для досягнення цілей навчання.

Роль штучно сформованого зовнішнього середовища в системі навчання виконує школа, яка утворена за замовленням суспільства. Згідно $з$ соціально-економічними умовами та з урахуванням розвитку і потреб учнів, формулюється «соціальне замовлення» для школи, що спрямоване на виховання певного типу особистості. Оформлення визначеної суспільством мети здійснюється за допомогою нормативно-правових документів і законодавчих актів. Мета навчання певною мірою визначає відповідний зміст навчання взагалі, навчання германських мов зокрема. Структуру змісту навчання формують певні компоненти, які пов'язані з відбором завдань, що реалізується за допомогою різноманітних засобів та форм.

Ураховуючи складність та багаторівневість структури системи, визначається кількість рівнів ієрархії організації та управління системою. Для системи навчання германських мов на Буковині визначено розподіл регіональних освітніх систем управління за такими рівнями: 1) Міністерство віровизнань і освіти Румунії; 2) XIV окружний шкільний інспекторат Буковини; 3) Чернівецький повітовий шкільний ревізорат; 4) школа.

Отже, застосування системного підходу допомогло обґрунтувати сутність поняття «методика навчання германських мов» та окреслити тематичний словник нашого дослідження, який включає поняття, що належать до організаційно-педагогічного підґрунтя навчання германських мов, а саме: “система навчання германських мов», «нормативно-правова база навчання германських мов», «науково-методичне забезпечення навчання германських мов», «організація навчання германських мов», «зміст навчання германських мов», «результат навчання германських мов».

Сутність синергетичного підходу полягає в дослідженні процесів самоорганізації та становлення нових упорядкованих структур. Він реалізується в дослідженні систем різної природи: фізичних, біологічних, соціальних, когнітивних, інформаційних, екологічних тощо (Зацерковний та ін., 2017, с. 59). 
Предметом синергетики $€$ механізми спонтанного формування i збереження складних систем, зокрема тих, які перебувають у стані стійкої нерівноваги із зовнішнім середовищем. У сферу ії вивчення потрапляють нелінійні ефекти еволюції систем будь-якого типу, кризи й біфуркації нестійкої фази існування, які передбачають множинність сценаріїв подальшого розвитку (Зацерковний та ін., 2017, с. 59-60).

Біфуркаційні процеси - це стан системи, який визначає подальший ії розвиток і $\epsilon$ наслідком неврівноважених процесів всередині системи, викликаних нарощуванням флуктуацій, згасити які система самостійно не здатна. Це явище породжує хаос або дисипативність, що визначається як особливий стан структури системи, відхилення від рівноваги. У так званій точці біфуркації, викликаної флуктуаціями, система випробовується на стійкість. Точка біфуркації являє собою переломний, критичний момент у розвитку системи, у якому вона здійснює вибір шляху (Вознюк, 2012, с. 92). Синергетика, намагаючись відтворити загальні принципи процесів самоорганізації складних систем, у тому числі й соціальних, формує новий стиль синергетичного мислення, провідними рисами якого $€$ імовірнісне бачення світу, зосередження уваги на нелінійності, але водночас цільності і стійкості соціальних структур, системному ефекті їх додавання, наслідком дії якого є пряма залежність поведінки елементів, що утворюють систему від особливостей їх субординаційної, координаційної й автономної взаємодії (Панфілов та Романова, 2019, с. 72).

О. Вознюк вважає, що синергетика постає новим міждисциплінарним напрямом, своєрідною міждисциплінарною рефлексією, предметом якої $є$ механізми самоорганізації у природних, соціальних, педагогічних системах, що постають відкритими сутностями. У сфері педагогічної думки останнім часом набуває розвитку педагогічна концепція синергізму, а методологія синергетики починає активно впроваджуватися у сферу педагогіки, що позначилось на розробці синергетичного підходу до аналізу освітніх реалій та формуванні педагогічної синергетики (Вознюк, 2012, с. 214).

Використання в дослідженні синергетичного підходу реалізується в процесі самостворення й саморозвитку біфуркацій у методиці навчання іноземних мов на Буковині, які позначилися на вивченні германських мов (німецької та англійської мов).

Парадигмальний підхід в історії педагогіки - ґенеза теоретичних положень, що дає змогу науковцям та практикам виявити, сформулювати й описати цілісні моделі освіти (Рупташ, 2014, с. 23). Парадигма - це сукупність знань, переконань, припущень, цінностей, методів і прийомів пізнання, світоглядний каркас сприйняття дійсності, спільний для певної групи суб'єктів. У межах нашого дослідження для кращого усвідомлення використання парадигмального підходу в методиці навчання германських мов вважаємо за необхідне розглянути принципи парадигмального підходу, до яких належать: 
1. Принцип системно-цілісної будови зрілої парадигми, що вимагає формування ії «дисциплінарної матриці» - компонентного складу 3 чотирьох нормативних підсистем (включаючи «зразки», «моделі», «символи» і «цінності»), що зважають на специфіку відповідної галузі науки або сфери соціального життя.

2. Принцип наукової евристичності парадигми, що полягає в її здатності допомагати в рішенні нових пізнавальних проблем.

3. Принцип домінування однієї парадигми, що припускає наявність пануючого теоретико-нормативного зразка, відповідно до якого будуються дослідження.

4. Принцип часової обмеженості існування парадигми, що виражає певну тривалість її домінування, у межах конкретного історичного періоду.

5. Принцип якісної несумірності парадигм, що означає, що кожна нова парадигма $€$ іншим баченням світу в порівнянні з попередньою (Утюж, 2014, с. 124).

Використання принципів парадигмального підходу в дослідженні дозволяє визначити закономірні етапи трансформації якісних змін у методиці навчання германських мов.

Вивчення історико-педагогічного процесу засвідчує, що науковопедагогічне знання традиційно розвивалося через безперервне висунення нових гіпотез і створення таких концепцій, у яких та чи інша проблема знаходила поглиблене й усебічне висвітлення. Тим самим не відбувалося спростування загальної ідеї, вираженої у формі гіпотези, концепції й теорії, а зазнавала критики лише та конкретна форма її вияву, яку мала ця гіпотеза, концепція і теорія в кожний конкретний час. Розвитку педагогічного знання властивий динамізм, що вимагає поліпарадигмального підходу до вивчення історико-педагогічного процесу (Коваленко, 2012, с. 30). Поліпарадигмальний підхід передбачає історіографічне висвітлення логіки розвитку історико-педагогічної проблематики, процес взаємодії різних парадигм та механізм зміни домінувальної парадигми в конкретних історичних умовах (Гупан, 2002, с. 53).

Дослідження особливостей розвитку методики навчання германських мов на Буковині здійснювалося в загальній парадигмі методики навчання іноземних мов в краї, обґрунтовуючи передумови становлення методики навчання германських мов, що нерозривно пов'язане зі здобутками історії педагогіки та історичної науки.

Міждисциплінарність у нашому дослідженні, застосування методологічного інструментарію в історичному ракурсі методики навчання германських мов зумовлює застосування комплексу конкретно-наукових підходів $i$ методів, які представлені регіональним, хронологічним підходами, методами критичного аналізу літературних джерел, вивчення та узагальнення позитивного досвіду роботи вчителів німецької та англійської мови. 
На думку Я. Верменич, історична регіоналістика являє собою поле ретроспективного дослідження процесів життєдіяльності людських спільнот і комунікативних зв'язків у межах регіонів, що історично склалися. Розвиваючи традиції «землеописань» в історіографії, нині вона дістала можливість виходу на новий рівень міждисциплінарного синтезу - 3 аналізом “семіотики культурного простору», регіональної самосвідомості, асиміляційних і трансформаційних процесів (Верменич, 2014, с. 14). Таким чином, регіоналістика, як міждисциплінарний науковий напрям, займається процесами, що мали значний вплив на адміністративнотериторіальні, національно-етнічні та освітньо-організаційні чинники розвитку методики навчання германських мов Буковини.

Використання регіонального підходу в нашому дослідженні дає змогу визначити особливості становлення та розвитку освіти в буковинському регіоні та розкрити історико-соціальні, територіальні, освітньо-організаційні характеристики Буковини в складі Румунії (1918-1940 рр.).

Для нашого дослідження досить важливим $€$ хронологічний підхід, який дає можливість висвітлити історичний матеріал у хронологічній послідовності, а також проаналізувати закономірності розвитку історичного явища на всіх етапах. Визначення хронологічних меж дослідження $\epsilon$ істотною складовою будь-якої історико-педагогічної розвідки. Питання періодизації постають перед кожним дослідником, який розпочинає свою роботу. Насамперед, хронологічний вимір залежить від проблеми дослідження, її масштабності (Сухомлинська, 2005, с. 45). Хронологічний підхід використовуємо в ході розробки періодизації методики навчання германських мов на Буковині, опису навчальних програм та підручників, підходів, принципів, методів навчання німецької та англійської мови.

Серед сучасних методів дослідження особливе місце відводимо методу критичного аналізу літературних джерел і методу вивчення й узагальнення позитивного досвіду роботи вчителів, які дають змогу розкрити сутність об'єкта дослідження.

Метод критичного аналізу літературних джерел дозволив простудіювати навчальні програми, підручники з німецької і англійської мови та публікації в періодичних виданнях того часу, що уможливило виокремлення способів реалізації методів навчання германських мов на Буковині (прямого і змішаного методів).

Вивчення та узагальнення позитивного досвіду роботи вчителів дало можливість скласти уявлення про особливості процесу навчання германських мов, визначити прийоми, які використовували в межах реалізації методів навчання германських мов на Буковині.

На конкретно-науковому рівні ми розглядаємо методи, що використовують в історичних дослідженнях: історико-структурний, 
історико-генетичний, історико-порівняльний, історико-системний і метод термінологічного аналізу.

Історико-структурний метод (розподіл явищ та процесів минулого на складові) зумовив структуризацію дослідження, яке базується на встановленні передумов розвитку методики навчання германських мов на Буковині в першій половині XX ст., дослідженні навчальних програм та планів, детальному аналізі підручників з німецької і англійської мови, визначенні особливостей реалізації методів навчання германських мов на Буковині, а також виділенні етапів розвитку методики навчання германських мов на Буковині в досліджуваний період.

Історико-генетичний метод полягає в послідовному розкритті властивостей, функцій і змін досліджуваної реальності у процесі їі історичного розвитку, що дозволяє повною мірою наблизитися до відтворення реальної історії об'єкта. За логічною сутністю історикогенетичний метод $€$ аналітично-індуктивним, а за формою вираження інформації про досліджувану реальність - описовим. Історико-генетичний метод дає можливість виявити причинно-наслідкові зв'язки й закономірності історичного розвитку, охарактеризувати історичні події й особистості в їхній індивідуальності та образності (Драч, 2014, с. 6-7).

Історико-порівняльний метод - сукупність пізнавальних засобів, процедур, які дозволяють виявити схожість і відмінність між явищами, що вивчаються, визначити їхню генетичну спорідненість (зв'язок за походженням), загальне й специфічне в їхньому розвитку (Зацерковний та ін., 2017 , с. 57). Об'єктивною основою для порівнянь $€$ те, що суспільно-історичний розвиток - це повторюваний, внутрішньо обумовлений, закономірний процес. Історико-порівняльний метод дає можливість розкривати сутність досліджуваних явищ за подібністю й відмінністю їхніх властивостей, а також здійснювати порівняння в просторі й часі (Драч, 2014, с. 7).

у нашому дослідженні історико-порівняльний метод дав змогу порівняти особливості методики навчання германських мов на Буковині на різних етапах розвитку. Реконструкція подій та явищ минулого, формулювання висновків на базі порівняння й зіставлення дали змогу розробити періодизацію методики навчання германських мов, типологію змістових форм, установити змістово-процесуальну основу методики навчання германських мов.

Історико-системний метод обумовлений поглибленням історичних аспектів освітологічних досліджень як із погляду цілісного охоплення соціальної реальності, так і з погляду розкриття внутрішніх механізмів функціонування й розвитку різних освітніх систем в різні історичні епохи. Об'єктивна основа системного підходу й методу наукового пізнання єдність у суспільно-історичному розвитку одиничного (індивідуального), особливого й загального. Конкретно ця єдність виявляється в суспільно- 
історичних системах різного рівня. Зокрема, функціонування й розвиток освітніх систем включає й синтезує ті основні компоненти, 3 яких складається соціальна реальність, а саме індивідуальні і неповторні події, історичні ситуації та процеси. За внутрішнім змістом ці компоненти являють собою конкретну й цілеспрямовану діяльність людей і нерозривно взаємопов'язані з нею (Драч, 2014, с. 8).

За допомогою історико-системного аналізу нам вдалося сформувати цілісну картину з комплексним урахуванням основних характеристик процесу навчання германських мов на Буковині в першій половині XX ст.

Ураховуючи принципи історико-системного підходу, методику навчання германських мов як систему розглядаємо в межах загальної середньої освіти Буковини, на яку мали вплив історико-соціальні, політичні та економічні процеси. Разом із тим в основі дослідження закладено, що сутність змісту та організації методики навчання германських мов залежить від системи взаємозв'язків: урядової політики в галузі освіти, суспільної думки, розвитку педагогічної науки та методики навчання IM в Румунії загалом і на Буковині зокрема. Відмітимо, що в нашому дослідженні розглядаємо лише зміни, які відбулися в методиці навчання германських мов з огляду на зміни шкільної системи освіти на Буковині на початку XX століття.

Метод термінологічного аналізу дав змогу розтлумачити деякі терміни, пов'язані з предметом дослідження: «навчальна програма», «підручник», «підхід», «принцип», «метод» тощо. Загальновідомо, що для пояснення педагогічних та методичних термінів пропонуються кілька тлумачень. 3 метою уникнення невизначеності формулювань у процесі розгляду певних явищ дослідження важливо було пояснити значення відповідних термінів.

Висновки. Отже, аналіз дослідження розвитку методики навчання германських мов на Буковині в першій половині XX ст. здійснювався на підґрунті дворівневого методологічного апарату, який забезпечив застосування певних підходів, методів, формулювання принципів до опису наукового дослідження й пошуку конструктивних оптимальних рішень досліджуваної проблеми. Міждисциплінарність у контексті нашого дослідження зумовила вибір методологічного інструментарію. Загальнонауковий та конкретно-науковий рівні уможливили ґрунтовне вивчення проблеми з урахуванням особливостей методики навчання германських мов на Буковині в зазначений хронологічний період.

Перспективи подальших наукових досліджень вбачаємо у визначенні та обґрунтуванні етапів розвитку методики навчання германських мов на Буковині (1918-1940рр.).

\section{ЛІТЕРАТУРА}

Верменич, Я. В. (2001). Історична регіоналістика в Україні. Український історичний журнал, 6, 3-26 (Vermenych, Ya. V. (2001). Historical regionalism in Ukraine. Ukrainian Historical Journal, 6, 3-26). 
Верменич, Я. В. (2014). Історична регіоналістика. Київ: Інститут історії України НАН України (Vermenych, Үa. V. (2014). Historical regionalism. Kyiv: Institute of History of Ukraine, National Academy of Sciences of Ukraine).

Вознюк, О. В. (2012). Педагогічна синергетика: генеза, теорія і практика. Житомир: Вид-во ЖДУ імені Івана Франка (Vozniuk, O. V. (2012). Pedagogical synergetics: genesis, theory and practice. Zhytomyr: Publishing house of Zhytomyr Ivan Franko State University).

Гончаренко, С. У. (1997). Український педагогічний словник. Київ: Либідь (Honcharenko, S. U. (1997). Ukrainian Pedagogical Dictionary. Kyiv: Lybid).

Гуменюк, Т. Б., Корець, М. С. (2014). Системний підхід як складова освітньої інноватики. Наука і освіma, 7, 63-67 (Humeniuk, T. B., Korets, M. S. (2014). Systems approach as a component of educational innovation. Science and education, 7, 63-67).

Гупан, Н. М. (2002). Українська історіографія історії педагогіки. Київ: А.П.Н. (Hupan, N. M. (2002). Ukrainian historiography of the history of pedagogy. Kyiv: A.P.N.).

Драч, О. О. (2014). Сучасні історико-освітні дослідження: традиції та новації методології. Вісник Черкаського університету. Серія: «Історичні науки», 9 (302), 5-11 (Drach, О. О. (2014). Modern historical educational research: methodological traditions and innovations. Bulletin of Cherkasy University. Series: "Historical Sciences", 9 (302), 133-136).

загальні підходи i принципи наукового дослідження. Режим доступу: https://studfile.net/preview/6441043/page:2/ (General approaches and principles of scientific research. Retrieved from: https://studfile.net/preview/6441043/page:2/).

Зацерковний, В. І., Тішаєв, І. В., Демидов, В. К. (2017). Методологія наукових досліджень. Ніжин: НДУ ім. М. Гоголя (Zatserkovnyi, V. I., Tishaiev, I. V., Demydov, V. К. (2017). Research methodology. Nizhyn: Nizhyn Mykola Gogol State University).

Коваленко, Є. І. (2012). Методологічна функція історії педагогіки у становленні майбутнього педагога. Наукові записки Ніжинського державного університету імені Миколи Гоголя. Психолого-педагогічні науки, 4, 27-35 (Kovalenko, Ye. I. (2012). The methodological function of the history of pedagogy in formation of prospective teachers. Scientific Notes of Nizhyn State University named after Mykola Gogol. Psychological and pedagogical sciences, 4, 27-35).

Кузнецова, А. Г. (2001). Развитие методологии системного подхода в отечественной педагогике. Хабаровск (Kuznetsova, А. H. (2001). Development of a Methodology for a Systems Approach in Domestic Pedagogy. Khabarovsk).

Лабінська, Б. І. (2013). Історичні нариси з методики навчання іноземних мов на західноукраїнських землях (друга половина XIX - перша половина XX cm.). Київ: КНЛУ (Labinska, В. І. (2013). Historical sketches on the methodology of teaching foreign languages in the Western Ukrainian lands (the second half of the XIX - the first half of the $X X$ century). Kyiv: KNLU).

Ніколаєва, С. Ю., Бігич, О. Б., Бориско, Н. Ф., Борецька, Г. Е. (2013). Методика навчання іноземних мов і культур: теорія і практика. Київ: Ленвіт (Nikolaieva, S. Yu., Bihych, O. B., Borysko, N. F., Boretska, H. E. (2013). Methods of Teaching Foreign Languages and Cultures: Theories and Practice. Kyiv: Lenvit).

Панфілов, О. Ю., Романова, І. В. (2019). Синергетичний підхід в осмисленні освіти. Вісник Національного юридичного університету імені Ярослава Мудрого, 3 (42), 71-80. DOI: https://doi.org/10.21564/2075-7190.42.170335 (Panfilov, O. Yu., Romanova, I. V. (2019). Synergetic approach to interpretation of education. Bulletin of the National Law University named after Yaroslav Mudryi, 3 (42), 71-80. DOI: https://doi.org/10.21564/2075-7190.42.170335). 
Пунченко, О. П. (2014). Методологічні новації у сучасному науковому пізнанні. Гуманітарний вісник ЗДІА, 57, 27-37 (Punchenko, О. Р. (2014). Methodological innovations in the modern scientific knowledge. Humanitarian Bulletin of Zaporizhzhia State Engineering Academy, 57, 27-37).

Рассоха, І. М. (2011). Конспект лекцій з навчальної дисципліни «Методологія та організація наукових досліджень». Харків: ХНУМГ (Rassokha, I. М. (2011). Compendium of Lectures on the "Methodology and organization of scientific research". Kharkiv: O. M. Beketov National University of Urban Economy in Kharkiv).

Рупташ, О. В. (2014). Парадигмальний підхід у гуманітарних науках. Нова парадигма, 122, 20-32. Режим доступу: http://nbuv.gov.ua/UJRN/Nopa 20141225 (Ruptash, O. V. (2014). A Paradigm Approach in the Human Sciences. New Paradigm, 122, 2032. Retrieved from: http://nbuv.gov.ua/UJRN/Nopa_2014_122_5).

Сухомлинська, О. В. (2005). Історико-педагогічне дослідження та його «околиці». Шлях освіmu, 4, 43-47 (Sukhomlynska, O. V. (2005). Historical and pedagogical research and its "surroundings". The way of education, 4, 43-47).

Утюж, І. Г. (2014). Використання парадигмального підходу в освіті. Політологічний вісник, 74, 120-128. Режим доступу: http://nbuv.gov.ua/UJRN/Pv 20147411 (Utiuzh, I. H. (2014). The use of Paradigms approach in Education. Politology bulletin, 74, 120-128. Retrieved from: http://nbuv.gov.ua/UJRN/Pv_2014_74_11).

\section{PEЗЮME}

Гоменюк Ольга. Методологические основы развития методики обучения германских языков на Буковине (первая половина XX ст.).

В статье обоснованы методологические основы исследования проблемы развития методики обучения германских языков на Буковине (первой половины XX в.). Определено, что выбор методологического инструментария обусловлен междисциплинарным характером исследования и базируется на общенаучном и конкретно-научном уровне. Выделенные уровни научного познания позволили основательно изучить проблему с учетом особенностей методики обучения германских языков на Буковине в указанный хронологический период.

Ключевые слова: методологические основы, методика обучения германских языков, общенаучный уровень, конкретно-научный уровень, междисциплинарность, методологические подходы, методы, историко-педагогчческий прочесс.

\section{SUMMARY}

Homeniuk Olha. Methodological fundamentals of the development of Germanic languages teaching methods in Bukovyna (first half of the XX century).

The article deals with the methodological basis of the development of Germanic languages teaching methods in Bukovyna in the first half of the XX century.

Characteristic features of scientific research are formulation and solution of scientific problems, the search of bibliographic sources and selection of factual material, introduction of new hypotheses and ideas, systematization of new knowledge, representation of the results.

The purpose of the article is to define and substantiate the methodological tools for studying the problem of the development of Germanic languages teaching methods in Bukovyna (first half of the XX century).

To achieve this goal, we have chosen the following research methods: analysis, comparison, systematization, and generalization of scientific and pedagogical literature. They allowed us to single out the methodological basis for the development of Germanic languages teaching methods in different types of schools in Bukovyna region (in the first half of the twentieth century). 
It has been used a two-level methodological apparatus for the analysis of the research on the development of Germanic languages teaching methods in Bukovyna in the first half of the twentieth century.

The general scientific level of the methodology includes systems, synergetic, and paradigmatic approaches. In our opinion, they will allow us to consider comprehensively historical, social, educational, organizational preconditions. As a result, we will be able to allocate multivariate and alternative ways of further development of Germanic languages teaching methods.

At the specific scientific level, it has been applied regional, chronological approaches, methods of critical analysis of literary sources, study and generalization of German and English teachers' positive experience.

It has been determined that the choice of methodological tools is based on the interdisciplinary character of the research. Due to the general and specific scientific levels, we have studied the problem thoroughly, taking into account the peculiarities of Germanic languages teaching methods in Bukovyna in the period under investigation. Thus, the applied approaches, methods, principles made it possible to describe the study and to search for constructive solutions to the problem.

Further research prospects include defining and substantiating the stages of the development of Germanic languages teaching methods in Bukovyna in 1918-1940.

Key words: methodological fundamentals, Germanic languages teaching methods, general scientific level, specific scientific level, interdisciplinarity, methodological approaches, methods, principles, historical and pedagogical process. 


\section{РОЗДІЛ IV. ПРОБЛЕМИ ЗАГАЛЬНОЇ ПЕДАГОГІКИ}

\section{УДК 373.3.011.3-051]:37.09:376(045)}

Тамара Бондар

Мукачівський державний університет ORCID ID 0000-0001-9484-9336

DOI 10.24139/2312-5993/2020.03-04/207-217

\section{ГОТОВНІСТЬ УЧИТЕЛЯ ПОЧАТКОВОЇ ШКОЛИ ДО ДІЯЛЬНОСТІ В УМОВАХ ІНКЛЮЗИВНОї ОСВІТИ}

У статті проаналізовано категорії «готовність», "готовність учителя початкової школи до діяльності в умовах інклюзивної освіти». Констатовано відмінності в підходах до трактування готовності. Подано авторську дефініцію поняття «готовність учителя початкової школи до інклюзивної діяльності», що інтерпретоване як усвідомлення вчителем початкової школи здатності (нездатності) провадити професійну діяльність в умовах інклюзивної школи. Виокремлено чинники, що впливають та підвищують рівень психологічної готовності учителів початкової школи до професійної діяльності в умовах інклюзивної освіти.

Ключові слова: готовність, професійна готовність, психологічна готовність, учитель початкової школи, інклюзивна освіта, інклюзивна компетентність, діти з особливими освітніми потребами, діти з інвалідністю.

Постановка проблеми. Сучасний розвиток освіти в Україні актуалізує проблему готовності педагогічних працівників до провадження діяльності в умовах інклюзивного середовища. Ухвалення Закону України «Про внесення змін до деяких законів України щодо доступу осіб з особливими освітніми потребами до освітніх послуг» від 6 вересня 2018 р. декларує рівний доступ до освіти особам з особливими освітніми потребами (далі ООП). Зміни до Законів України «Про дошкільну освіту», «Про загальну середню освіту», «Про професійно-технічну освіту», «Про позашкільну освіту» акцентують на відповідальності держави за створення належних умов для здобуття освіти дітьми з ООП, зважаючи на індивідуальні потреби в умовах інклюзивного навчання; на необхідності забезпечувати право на навчання дітей з ООП за допомогою найбільш доцільних для таких осіб методів і способів спілкування, зокрема через навчання жестовою мовою та рельєфно-крапковим шрифтом (шрифтом Брайля); на реалізації права дитини з ООП бути зарахованою до початкової школи закладу загальної середньої освіти (далі - 33СО).

У листі Міністерства освіти і науки України від 5 серпня 2019 р., що містить методичні рекомендації стосовно організації навчання осіб з ООП у закладах освіти у 2019-2020 н.р., зосереджено увагу на основних положеннях Закону України та інших важливих нормативно-правових актах у галузі інклюзивної освіти. Такою $є$ вимога щодо обов'язковості утворення інклюзивної групи чи класу в разі звернення особи з ООП або ії батьків до закладу освіти. Нова українська школа потребує педагогічних працівників, 
здатних реалізувати законодавчі ініціативи України в галузі розвитку інклюзивної освіти, що передбачають створення рівних можливостей для всіх категорій дітей в Україні.

Аналіз актуальних досліджень. У науково-педагогічній літературі проблема готовності вчителів початкової школи до професійної діяльності в умовах інклюзії потрактована на підставі аналізу різних чинників. Законодавчу й нормативно-правову базу розвитку інклюзивної освіти в Україні вивчають М.Гриньова, М. Захарчук, А. Кузьмінський, Н. Лалак, І. Малишевська, Ю. Найда, Т. Сак, М. Сварник, О. Софій та ін. Особливості реформування педагогічної освіти для підвищення інклюзивної готовності вчителів початкових класів студіюють І. Демченко, А. Колупаєва, І. Кузава, О. Мартинчук, С. Миронова, Н. Мукан, Т. Семенченко, С. Шандрук та ін. Окремі аспекти організації інклюзивного навчання в закладах загальної середньої освіти досліджують В. Бондар, Л. Будяк, Л. Пелех (методологічні засади), Е. Данілавічютє, М. Євтух, І. Зарубінська (професійна підготовка педагога), Н. Бібік, Л. Даниленко, С. Литовченко, В. Синьов, О. Таранченко (компетентнісний підхід) та ін.

Посилене зацікавлення науковців проблемою готовності вчителів початкових класів до професійної діяльності в умовах інклюзивного закладу освіти зумовлене потребами розв'язання суперечностей між соціальним замовленням суспільства на компетентного педагога, здатного забезпечити рівний доступ до якісної освіти всім дітям, та недостатньо ефективними підходами до організації професійної діяльності вчителів початкової освіти, необхідністю підвищення ії дієвості; між сучасним станом професійної підготовки майбутніх учителів початкової школи й потребою активізації форм і методів пізнавальної діяльності студентів, підвищення рівня їхньої активної самостійності, налагодження суб'єктсуб'єктних взаємин; між реальними вимогами Нової української школи до професійних якостей учителя початкової школи та змістом програми й обсягом професійно значущої інформації, часу на перевірку засвоєного навчального матеріалу, передбаченого в навчальних планах; між реальним і необхідним рівнем готовності вчителів початкової школи до професійної діяльності в умовах інклюзивного середовища.

Мета статті полягає у виокремленні умов, що забезпечують належний рівень готовності вчителів початкової школи до професійної діяльності в інклюзивному закладі освіти.

Методи дослідження. Для реалізації окресленої мети використано теоретичні методи, що вможливили вивчення психолого-педагогічної літератури з порушеної проблеми, опрацювання законодавчої й нормативно-правової бази в галузі інклюзивної освіти, наукових праць, що характеризують зміст готовності вчителів початкових класів до професійної діяльності в умовах інклюзивного закладу освіти; аналіз, синтез, індукція, 
дедукція, узагальнення, порівняння - для з'ясування природи основних понять та обґрунтування практичних механізмів забезпечення готовності вчителів початкової школи до професійної діяльності в умовах інклюзивного середовища на засадах компетентнісного підходу.

Виклад основного матеріалу. Аналіз науково-педагогічних праць засвідчує, що процес упровадження інклюзивної освіти в Україні вирізняється особливою складністю через недостатній рівень компетентності педагогічних працівників узагалі й учителів початкової школи зокрема. Це доводить низький рівень готовності педагогів початкової школи до провадження професійної діяльності в умовах інклюзивного середовища закладу освіти. Необхідність запровадження інклюзивного навчання, що детерміноване законодавчою базою в галузі освіти, потребує інноваційних підходів до розв'язання проблеми підвищення готовності вчителів початкової школи до інклюзивної діяльності.

Ґрунтовний аналіз психолого-педагогічних розвідок із проблеми готовності вчителів початкової освіти до діяльності в умовах інклюзивної освіти вможливив виокремлення низки підходів до трактування термінів «готовність» i «готовність до інклюзивної діяльності». У словнику психологічних термінів «готовність» представлена як активно-дієвий стан особистості, установка на певну поведінку, мобілізованість сил на виконання завдання. Для готовності до дій потрібні знання, уміння, навички, наполегливість і рішучість виконати такі дії. Готовність до певного виду діяльності передбачає мотиви та здібності. Психологічними передумовами появи готовності до виконання конкретної діяльності $€$ їі розуміння, усвідомлення відповідальності, бажання досягти успіху, окреслення послідовності дій і способів роботи. Відчуття готовності може бути ускладнене через пасивне ставлення до завдань, безтурботність, байдужість, відсутність плану дій і наміру максимально використати свій досвід. Брак готовності призводить до неадекватних реакцій, помилок, неузгодженості психічних процесів із вимогами конкретної ситуації (Побірченко, 2007). У кінці XX ст. та на початку XXI ст. У вітчизняній педагогіці й психології термін «готовність» витлумачували як психологічний стан особистості, що акцентує увагу на ціннісних і мотиваційних аспектах діяльності педагогів (Бондар, 2020).

Поширеним у вітчизняному психолого-педагогічному дискурсі $\epsilon$ цитування праць російських дослідників А. Альохіної, М. Алексєєвої, Є. Агафонової (Алехина и др., 2011), що присвячені вивченню проблеми готовності педагогів до професійної діяльності в інклюзивному середовищі. Апелюючи до наукових джерел, Л. Коврігіна, Л. Москалюк, З. Савчук та ін. описують готовність педагога до роботи з дітьми з особливими освітніми потребами через призму двох компонентів: професійної готовності та психологічної готовності. До професійної готовності вчені зараховують 
інформаційну готовність, володіння педагогічними технологіями, знання основ психології та корекційної педагогіки, знання індивідуальних відмінностей дитини, готовність педагогів моделювати урок і використовувати варіативність у процесі навчання, знання індивідуальних особливостей дітей із різними порушеннями в розвитку, готовність до професійної взаємодії та навчання. Психологічна готовність, на думку науковців, охоплює емоційне прийняття дітей із різними типами порушень у розвитку (прийняття - відторгнення), готовність залучати дітей із різними типами порушень до діяльності на уроці, задоволеність власною педагогічною діяльністю (Алехина и др., 2011, сс. 85-86; Савчук та Москалюк, 2017, с. 44; Коврігіна, 2017, с. 11).

Такий підхід відрізняється від міркувань американських науковців. 3 огляду на історичні передумови виникнення терміна «готовність» («еfficaсу») як психолого-педагогічної категорії, варто брати до уваги дослідження компанії «РАНД» («RAND»; 1974-1976 рр.) у США. У зв'язку з посиленням уваги до забезпечення дітей із особливими освітніми потребами якісною й доступною освітою (1974р.), а також до чинників, що впливають на покращення навчальної діяльності учнів, у США проведено низку ґрунтовних досліджень на національному рівні. Теоретичним підґрунтям для студій послугувала теорія соціального научіння Дж. Роттера (J. Rotter) і соціальнокогнітивна теорія А. Бандури, що розроблена в 1974 р.

Подальший розвиток поняття готовності вчителя до професійної діяльності «teacher efficaсу» у межах соціально-когнітивної теорії А. Бандури дав змогу виокремити в їі структурі важливу компоненту - психологічну готовність «self-efficacy» (1977р.) (Бондар, 2020). Учений уважав, що психологічна готовність як складник готовності педагога $є$ рушієм досягнення окресленої мети (у цьому випадку - упевненість учителя в здатності залучити учня з ООП в освітній процес, попри всі перешкоди). Психологічна готовність («self-efficacy») - усвідомлення вчителем особистої здатності впливати на успішність усіх учнів в умовах інклюзивної школи. Саме психологічна готовність детермінує можливий успіх чи невдачу в професійній діяльності, впливає на ставлення вчителя до освітнього процесу взагалі. Що вища психологічна готовність учителя («self-efficacy»), то кращі успіхи учнів (Armor, 1976, с. 31; Henson, 2001). Вища психологічна готовність учителя включати дітей із ООП до середовища масової школи корелює з більшою ймовірністю того, що реалізація інклюзивної освіти в Україні як державна ініціатива не перетвориться на чергову декларацію.

Значущість впливу психологічної готовності на нашу поведінку й мотивацію до дії спонукала А. Бандуру до подальших досліджень стосовно виокремлення чинників, які впливають на формування психологічної готовності. Науковець представляє чотири чинники (джерела), що вможливлюють підвищення рівня психологічної готовності до професійної 
діяльності в інклюзивному середовищі: досвід майстерності («mastery experiences»), фізіологічні та емоційні стани («emotional and physiological states»), досвід спостереження («vicarious experiences»), словесне переконання («verbal persuasion»). Найпотужнішим джерелом готовності називають досвід фаховості (професійності) учителя. Формуванню впевненості у власних силах, а отже, зростанню продуктивності професійної діяльності, сприяє відчуття задоволення від успішно проведеного уроку. I, навпаки, надмірне занепокоєння або хвилювання через невпевненість у власних силах спричинюють зневіру, посилюють відчуття нефаховості чи некомпетентності.

Для формування психологічної готовності важливо в межах фахового досвіду виокремити причини успіху. Рівень психологічної готовності вчителя зростає, якщо успіх аргументують внутрішніми (керованими) чинниками: достатній рівень знань, наявність певних умінь. Рівень психологічної готовності не змінюється, якщо успіх пояснюють удачею або втручанням інших сил. Серед чинників, що мають потужний вплив на підвищення рівня психологічної готовності вчителя, варто назвати досвід спостереження. Споглядаючи за діяльністю вчителя-наставника, спостерігач (учитель, майбутній учитель) формує власну психологічну готовність. Варто звернути увагу на той факт, що рівень психологічної готовності залежить від ступеня ідентифікації (схожості) спостерігача 3 наставником. Що ближче спостерігач ідентифікує себе з наставником, то вищий рівень психологічної готовності. Велике значення в ситуації наставництва також має особа вчителя-наставника, із яким спостерігач порівнює себе. Якщо вчитель-наставник демонструє високий рівень фаховості, психологічна готовність спостерігача посилюється. Коли в діяльності старшого за досвідом професійної діяльності колеги простежувані помилки, упевненість спостерігача, тобто рівень психологічної готовності, знижується. Із-поміж чинників або джерел психологічної готовності А. Бандура виокремлює фізичний та емоційний стан учителя. Негативний досвід, який учитель переживає внаслідок невпевненості, напруженості, формує негативне ставлення до учнів і до професійної діяльності, зокрема, гальмує розкриття творчого потенціалу вчителя. Позитивна налаштованість допомагає вчителеві долати перешкоди, посилює відчуття майстерності, професійної компетентності.

Останнім фактором впливу на формування психологічної готовності А. Бандура називає словесне переконання. Психологічна готовність учителя, попри досвід професійної діяльності, залежить від похвального слова. Підґрунтям для посилення мотивації вчителя, підвищення ініціативи й відповідальності за майбутнє дитини слугують палка промова колеги, похвала директора чи батьків учня, розмови про компетентність і здатність впливати на учнів, висока успішність учнів, позитивні установки адміністрації. 
Ситуація успіху та віра інших осіб спонукають особистість учителя започатковувати нові стратегії, запроваджувати інновації, долати перешкоди й досягати успіху, що $є$ наслідком зростання рівня психологічної готовності (Бандура, 1986). Отже, спільна одиниця для всіх чотирьох чинників, що впливають на підвищення психологічної готовності, - це досвід, який переживає вчитель у різних ситуаціях: досвід від проведеного уроку, досвід від спостереження, досвід переживання й досвід від похвали.

Нині помітний ще один чинник, на який звертає увагу психолог Дж. Медокс (J. Maddux). Ідеться про так званий досвід уяви («imaginal experiences»), що прогнозує вміння візуалізувати власну успішну поведінку в конкретній ситуації (Maddux, 2005).

Нагальною постає проблема вимірювання рівня психологічної готовності вчителя початкової школи до діяльності в умовах інклюзивної школи. У науковому полі американських досліджень на сьогодні не існує уніфікованого, визнаного інструменту для вимірювання готовності педагога до професійної діяльності. Опитувальник «Шкала педагогічної готовності» («Teacher Efficacy Scale») Ш. Гібсон та М. Дембо еволюціонує з 1984 р. Внесок науковців у вдосконалення цього опитувальника став результатом багатьох інших модифікацій і розроблення подібних інструментів. Основною проблемою розроблення опитувальника визнають той факт, що дві ключові тези, які формують уявлення про вплив учителя на успішність учня, перебувають у двох різних теоретичних площинах: в аспекті теорії соціального научіння Дж. Роттера «Я не можу зробити неможливе, оскільки мотивація й успішність учня залежать від сім'ї», що описує «локус контролю» (дослідження корпорації «РАНД»), та у вимірі психологічної готовності («self efficaсу») А. Бандури «якщо я дуже постараюсь, я зможу "достукатися» навіть до найважчого та невмотивованого учня». Положення шкали містили елементи обох теоретичних концепцій, що призвело до активних наукових пошуків у напрямі вдосконалення інструменту (Бондар, 2016, с. 72).

Критерієм для виокремлення умов підвищення психологічної готовності вчителя початкової школи в умовах інклюзивної освіти в Україні слугують основні чинники впливу за А. Бандурою, що сприяють формуванню психологічної готовності. Перша умова посилення психологічної готовності вчителя початкової школи в умовах інклюзивної освіти - систематичне підвищення кваліфікації вчителя. Ця умова вможливлює реалізацію основного чинника впливу на психологічну готовність - підвищення фаховості (професійності) чи професійної компетентності (фаховий термін сучасного педагогічного дискурсу). Нині вчитель початкової школи має змогу систематично вдосконалювати знання й уміння, накопичувати навчальні, сертифіковані години, прослуховувати різні курси. Саме накопичувальна система робить процес підвищення кваліфікації систематичним, а 
необхідність у постійному професійному розвиткові модернізує здатність учителя до розв'язання питань інклюзивної освіти.

Важливе питання пов'язане зі змістом освіти, що позначається на підвищенні кваліфікації вчителів початкової школи. Більшість закладів післядипломної підготовки педагогічних працівників, забезпечуючи потреби інклюзивної школи, включають до навчальних планів окремі дисципліни інклюзивного спрямування, наприклад: “Основи інклюзивного навчання», «Основи дефектології та інклюзивної освіти», «Інклюзивна педагогіка», «Основи соціалізації осіб з особливими потребами», «Основи інклюзивної освіти», «Інклюзивна освіта в початковій школі». Як переконує досвід США, що витратили з 1975 до 1980 років 31 мільйон доларів для реформування підготовки вчителів, включення однієї-двох додаткових дисциплін до навчального плану перекваліфікації унеможливлює ефективність програми підготовки й перепідготовки інклюзивних педагогів. Зміст усіх дисциплін закладів вищої педагогічної освіти та курсів підвищення кваліфікації повинен охоплювати потреби диверсифікованого контингенту учнів. Наприклад, у переліку категорій інвалідності найбільш поширена категорія труднощів у навчанні, що станом на 2017-2018 рр. сягає 34\%; порушення мови або мовлення - $19 \%$; інші порушення здоров'я - $14 \%$; порушення інтелектуального розвитку - $6 \%$; емоційні порушення - $5 \%$; аутизм - $10 \%$; множинні порушення - 2 \%; затримка розвитку - 7 \%; порушення слуху - $1 \%$; ортопедичні порушення - $1 \%$; порушення зору - 0,4\%; травматичне порушення мозку - 0,4\%; глухота, сліпота - 0,02 \% (National Center for education statistics, 2019). Ці розлади впливають на здатність обробляти інформацію, вони пов'язані зі слуханням, мисленням, спілкуванням, читанням, письмом, рахуванням. Ідентифікація нозології лише маркує тип психолого-педагогічного супроводу й забезпечує загальну інформацію щодо планування та реалізації індивідуального навчального плану. Попри спільність психолого-педагогічного супроводу, кожен учень потребує реалізації індивідуальних запитів, що стає відповідальністю вчителя закладу загальної середньої освіти. Обов'язкове знання категорій інвалідності та їх поширення дає змогу вчителям реалізувати загальні стратегії інклюзії; розуміти загальні характеристики й ООП учнів.

Формуючи зміст освіти, зважають на вплив полікультурності, варіативності й міждисциплінарності. Постає необхідність інтегрування змісту інклюзивної підготовки до всіх предметів навчального плану.

Зміст курсів підвищення кваліфікації потрібно постійно оновлювати, зважаючи на динаміку розвитку цілей освіти й охоплюючи такі основні напрями: знання спеціального законодавства в галузі освіти; умови фінансування; психолого-педагогічний супровід; партнерське викладання; співпраця з колегами, педагогами спеціальної освіти, асистентами; уміння користуватися доказовими методами; оцінювання; спостереження за учнями 
для з'ясування індивідуальних потреб і сильних сторін; знання та вміння реалізовувати зміст індивідуального навчального плану; створення позитивного освітнього середовища для всіх учнів; взаємини із сім'ями дітей з інвалідністю; методи виховання поведінки; диференційоване навчання.

Одна з умов, що стимулює підвищення рівня психологічної готовності, - розвиток інституту наставництва. У Комунальному закладі «Житомирський обласний інститут післядипломної педагогічної освіти» обласної ради наставництво в широкому розумінні трактують як шефство досвідчених працівників над молодими педагогами, які мають стаж роботи до 3 років або потребують методичної допомоги, та новопризначених учителів школи. Основне завдання наставництва для педагога-початківця інклюзивного класу - розвиток і вдосконалення процесу формування основних професійних якостей, вироблення власного стилю діяльності, покращення фахової майстерності. Серед низки напрямів роботи інституту наставництва (Коврігіна, 2017, с. 13) на особливу увагу заслуговує надання змоги вчителям початкової школи відвідувати заняття досвідчених наставників. Взаємовідвідування занять і позакласних заходів $\epsilon$ обов'язковим в інституті наставництва, що функціює при Житомирському обласному інституті післядипломної педагогічної освіти. Подальше обговорення занять та заходів, планування занять з огляду на рекомендації й побажання вчителя-наставника підвищують рівень психологічної готовності вчителів початкових класів до діяльності в інклюзивному класі.

Наступна умова, що сприяє підвищенню рівня психологічної готовності вчителя початкової школи в умовах інклюзивної освіти, створення сприятливого інклюзивного освітнього середовища. Реалізація цієї умови потребує організації системного підвищення кваліфікації для всіх спеціалістів: методистів, які відповідають за інклюзивну освіту, директорів і заступників директорів із навчальної діяльності, учителів, асистентів учителя 33СО, асистентів вихователя дошкільних закладів освіти (Д3О), учителів-логопедів, учителів-дефектологів, сурдопедагогів та ін. Крім професійної компетентності всього педагогічного колективу, важливим чинником стає створення позитивного психологічного клімату в колективі на основі взаємопідтримки, командної роботи й поваги. Для посилення психологічної готовності вчителів, особливо вчителів без достатнього досвіду діяльності в умовах інклюзивної освіти, колеги повинні бути уважними до діяльності один одного, щедрими на визнання успіху інших педагогів, стриманими в критиці недоліків.

Вивчаючи питання соціальної адаптації дітей із ООП, О. Іваній наголошує на значущості середовища з толерантними типами взаємодії, серед яких - діалог, співпраця, опіка. Науковець стверджує, що емоційний і когнітивний компоненти в структурі діалогової взаємодії забезпечують високий рівень емпатії, відчуття партнера, уміння сприймати його таким, 
яким він $\epsilon$, відсутність стереотипності стосовно інших людей, гнучкість мислення (Іваній, 2019, с. 394). Культура заохочення членів колективу до успіху, емпатія прогнозують формування в учителів готовності до заохочення учнів з інвалідністю досягати успіху.

у сучасних умовах, маркованих постійним зростанням вимог до професійної діяльності вчителів початкової школи, політичним лідерам також необхідно переосмислити державну політику стосовно ставлення до вчителя, змінити систему заохочення, що сприяла 6 активному залученню педагогів до розроблення інклюзивних стратегій.

Висновки. Підсумовуючи, наголосимо, що готовність учителя - це насамперед психологічна готовність, стан особистості, усвідомлення вчителем власної здатності (нездатності) до виконання певної діяльності. Готовність учителя початкової школи до інклюзивної діяльності витлумачена як усвідомлення вчителем початкової школи здатності (нездатності) провадити професійну діяльність в умовах інклюзивної школи. Мета професійної діяльності - створення всім учням умов для гармонійного розвитку особистості. Виконання окресленого завдання в контексті інклюзивної школи потребує високого рівня психологічної готовності вчителя початкової школи, оскільки кожен учень, попри особисті особливі потреби, має право на увагу вчителя. Рівень психологічної готовності вчителя залежить від досвіду професійної діяльності, спостереження за досвідченими фахівцями, переживання різного фізичного й емоційного стану, підбадьорення. Серед умов, що сприяють підвищенню психологічної готовності вчителів початкової школи в умовах інклюзивної освіти, виокремлено такі: систематичний професійний розвиток через підвищення професійної кваліфікації; розвиток інституту наставництва для здобуття досвіду спостереження; створення позитивно налаштованого освітнього середовища, де вчитель здатний забезпечити якісну освіту всім дітям.

Перспективи подальших наукових розвідок пов'язані з вивченням вітчизняного й зарубіжного досвіду організації інституту наставництва, а також зі студіюванням особливостей організації педагогічної інтернатури для випускників закладів вищої педагогічної освіти.

\section{ЛІТЕРАТУРА}

Алехина, С. В., Алексеева, М.Н., Агафонова, Е. Л. (2011). Готовность педагогов как основной фактор успешности инклюзивного процесса в образовании. Психологчческая наука и образование, 1, 83-91 (Alekhina, S. V., Alekseeva, M. A., Agafonova, E. L. (2011). Preparedness of Teachers as the Main Factor of Success of the Inclusive Process in Education. Psychology and Education, 1, 83-91).

Бондар, Т. І. (2016). Готовність учителя ЗНЗ США до реалізації інклюзивної освіти. Вісник Черкаського університету, 11, 65-72 (Bondar, T. І. (2016). Teacher efficacy as a main factor to implement inclusive education in the USA. Cherkassy University Collection of Publications, 11, 65-72). 
Бондар, Т.І. (2020). Труднощі перекладу психолого-педагогічного концепту «готовність». Language: Codification, Competence, Communication, 2, 7-20 (Bondar, T. I. (2020). The notion of efficacy as a psychological educational concept: translation difficulties. Language: Codification, Competence, Communication, 2, 7-20).

Іваній, О. (2019). Принципи рівності, недискримінації та толерантності в реалізації права на освіту дітьми з особливими освітніми потребами. Педагогічні науки: теорія, історія, інноваційні технологіï, 8 (92), 390-401 (Ivanii, О. (2019). Principles of equality, non-discrimination and tolerance in the realization of the right for education of children with special educational needs. Pedagogical Sciences: theory, history, innovative technologies, 8 (92), 390-401).

Коврігіна, Л.М. (2017). Формування готовності вчителя до роботи 3 дітьми 3 особливими освітніми потребами в умовах інклюзивного навчання. Освіта ma розвиток обдарованої особистості, 11 (66), 10-16 (Kovripina, L. M (2017). Formation of teacher's readiness to work with children with special educational needs in the context of inclusive education. Education and development of a gifted personality, 11 (66), 10-16).

Побірченко, Н. А. (2007). Психологічний словник. Київ: Науковий світ (Pobirchenko, N. А. (2007). Psychological dictionary. Kyiv).

Савчук, 3., Москалюк, Л. (2017). Психологічна готовність учителя до роботи в інклюзивному просторі: теоретичний аспект. Особлива дитина: навчання $i$ виховання", 2, 42-47 (Savchuk, Z., Moskaliuk, L. (2017). Psychological readiness of teachers to work in inclusive space: theoretical aspect. Special Child: Education and Upbringing, 2, 42-47).

Armor, D., Conroy-Oseguera, P., Cox M., King, N., McDonnell, L., Pascal, A. Pauly, E., \& Zellman, G. (1976). Analysis of the school preferred reading programs in selected Los Angeles minority schools. (REPORT NO. R-2007-LAUSD). Santa Monica, CA: Rand Corporation. (ERIC Document Reproduction Service No. 130 243). Retrieved from: http://files.eric.ed.gov/fulltext/ED130243.pdf.

Bandura, A. (1977). Self-efficacy: Toward a unifying theory of behavioral change. Psychological Bulletin, 84, 191-215. Retreived from: https://www.uky.edu/ eushe2/Bandura/Bandura1977PR.pdf.

Bandura, A. (1986). Social foundations of thought and action: A social cognitive theory. Englewood Cliffs, NJ.: Prentice-Hall.

Henson, R. K. (2001). Teacher self-efficacy: Substantive implications and measurement dilemmas. Paper presented at the Annual Meeting of the Educational Research Exchange, College Station, TX. Retreived from https://www.uky.edu/ eushe2/Pajares/EREkeynote.PDF.

Maddux, J. E. (2005). Self-efficacy: The power of believing you can. In C. R. Snyder \& S. J. Lopez, (Eds.), Handbook of positive psychology, (pp. 227-287). New York: Oxford University Press.

\section{PEЗЮME}

Бондарь Тамара. Готовность учителей начальной школы к деятельности в условиях инклюзивного образования.

В статье представлен анализ категорий «готовность», «готовность учителя начальной школы к деятельности в условиях инклюзивного образования». Констатировано различие в подходах к определению готовности. Представлено авторское определение готовности и готовности учителя начальной школы $к$ инклюзивной деятельности, которое истолковываем как осознание учителем начальной школы способности (неспособности) выполнять профессиональную 
Педагогічні науки: теорія, історія, інноваційні технології, 2020, № 3-4 (97-98)

деятельность в условиях инклюзивной школы. Выделены факторы, влияющие на уровень психологической готовности учителя и условия, обеспечивающие повышение психологической готовности учителей начальной школы в условиях инклюзивного образования.

Ключевые слова: готовность, профессиональная готовность, психологическая готовность, учитель начальной школы, инклюзивное образование, инклюзивная компетентность, дети с особыми образовательными потребностями, дети с инвалидностью.

\section{SUMMARY}

Bondar Tamara. In-service primary school teacher efficacy for inclusive education.

The article debates the issue of primary school in-service teacher efficacy who are challenged to work in the inclusive regular school environment. It is emphasized that primary school teacher efficacy is referred to as self-efficacy, primarily a psychological condition, teachers' conviction of the ability and capacity to perform certain professional activities. The primary school teacher efficacy for inclusive education is accordingly interpreted as the conviction of an in-service primary school teacher of his/her ability (inability) to provide quality education to all children and children with disabilities in the inclusive regular school environment. We prove that approaches to conceptualize the notion of efficacy differ in Ukraine and the USA. The reason for the differences lies in an approach that the RAND corporation used to explore teachers' attitude to state initiatives. The tool to explore the issue integrated a key concept of A. Bandura's social cognitive theory and J. Rotter's social learning theory. This research also resulted in identifying the concept of self-efficacy by A. Bandura. He also stated that there are four different sources that influence the level of in-service primary teacher self-efficacy including mastery experiences, vicarious experiences, verbal persuasion, physiological and emotional states. In other words, the level of teacher self-efficacy depends on the experience of professional activity, role models observation, experience of stress and positive emotions, verbal persuasion. It is also proved that for the in-service primary school teacher to be efficacious in the regular school inclusive environment it is necessary to provide certain conditions. These conditions include in-service continuous professional development, professional supervision of teachers-beginners offered by master teachers who have gained successful mastery experiences through active involvement in inclusive education, provision of safe, friendly environment conducive for teaching and learning, and state support meant to increase the prestige of teaching as a profession in Ukraine.

Prospects for further research include an attempt to explore domestic and foreign experience in organizing mentoring and to compare approaches to establishing teaching internships for graduates who want to pursue teaching as their profession.

Key words: efficacy, teacher efficacy, self-efficacy, in-service primary school teacher, inclusive education, inclusive competence, children with special educational needs, children with disabilities. 
УДК 316.7:005.591.6]:005.3327

Наталія Максимовська

Харківська державна академія культури

ORCID ID 0000-0002-3028-5727

Анжела Поляничко

Сумський державний педагогічний

університет імені А. С. Макаренка

ORCID ID 0000-0003-3729-3452

DOI 10.24139/2312-5993/2020.03-04/218-227

\section{ПОДІЄВИЙ МЕНЕДЖМЕНТ ЯК ЧИННИК ІННОВАЦІЙНОГО РОЗВИТКУ СОЦІОКУЛЬТУРНОЇ СФЕРИ}

Метою статті є розгляд основ інноваційного розвитку соціокультурної сфери та управління спеціальними подіями як фоктору стимулювання сочіокультурних новацій. Приділяється увага методологічним підходам, які сформовані в сучасній научі, щодо аналізу подієвого менеджменту, зокрема філософсько-комунікаційному, освітньому. Акцент робиться на організаційноуправлінських засадах менеджменту подій, уточнюються провідні теоретичні позиції вдосконалення соціокультурних процесів через регулювання сучасного Івенту.

Ключові слова: сочіокультурна сфера, прикладна культурологія, інновачії, спеціальні події, менеджент спеціальних подій.

Постановка проблеми. Встигає не той, хто пильнує за часом, а той, хто рухає час. Соціокультурна сфера має не тільки відповідати вимогам сьогодення, але й закладати перспективи подальшого розвитку культури, адже має вирішальне значення для співтворчості соціальних груп, просування змін, зміцнення та трансформування ціннісної основи людської життєдіяльності. Для сучасного стану розбудови соціокультурної сфери властиві інноваційні явища, зокрема спеціальні події, в основу яких покладається соціальна творчість та креативна управлінська діяльність. Відтак, мають бути вдосконалені методологічні засади та теоретичні підвалини загальної системи управління соціокультурними процесами на основі прикладної культурології, а також сучасного Івенту як прояву її новітніх форм.

Стандартні та уніфіковані моделі соціально-культурної діяльності, які були на часі, лише певної мірою сприяють поступовому просуванню новітніх форм взаємодії в культурному просторі, за їх допомогою неможливе здійснення якісного системного переходу до нових засад організації й управління в сфері культури. Отже, дослідження потребують, з одного боку, наукові засади розвитку прикладної культурології в сучасних умовах, з іншого, актуальні чинники креативного розвитку держави та суспільства, зокрема спеціальні події, як явища та носії інноваційного потенціалу.

Аналіз актуальних досліджень. Інновації в соціокультурній сфері загалом та її складових досліджували М. Аріарський, О. Дубасенюк, І. Дутковський, 3. Остропольська, А. Флієр та ін. Івент-технології та подієвий 
менеджмент вивчали С. Герасимов, Д. Голдблатт, Н. Кочубей, Т Лохина, О. Радіонова, Г. Тульчинский, У. Хальцбаур та ін. Комунікаційний потенціал спеціальних подій відстежували Ю. Азарова, О. Каверіна та ін. Події в освітній сфері стали предметом досліджень А. Вотінцева, М. Самакаєвої та ін. Особливості розвитку й застосування івент-менеджменту в Україні відстежували І. Антоненко, В.Данилова, О. Хитрова. Однак, подієвий менеджмент як чинник інноваційного розвитку соціокультурної сфери не розглядався вченими. Метою публікації $\epsilon$ дослідження інноваційного потенціалу спеціальних подій, визначення особливостей управління ними в контексті запровадження інновацій в соціокультурному просторі.

Методами дослідження $€$ аналіз для виявлення наукових фактів та створення теоретичної бази дослідження; порівняння та співставлення позицій учених щодо предмету публікації й досягнення ії мети; узагальнення тенденцій розвитку інноваційного потенціалу сучасної соціокультурної сфери.

Виклад основного матеріалу. Розвиток соціокультурної сфери зумовлений законодавчими актами. У Всезагальній декларації ЮНЕСКО про культурне різноманіття (2001) зазначалося, що культурне багатство $€$ джерелом творчості, а політика в галузі культури є каталізатором розвитку креативних практик. У Законі України «Про культуру» (2011) зазначається, що серед іншого основними засадами державної політики в сфері культури $\epsilon$ сприяння створенню єдиного культурного простору, утвердження гуманістичних ідей, забезпечення свободи творчості та ін. Це було певним чином відображено в Довгостроковій стратегії розвитку української культури - стратегії реформ (2016), після ухвалення якої був запущений механізм пошуку провідних механізмів анонсованих змін. Зокрема, метою вказаної стратегії $\epsilon$ створення умов для сприяння творчій активності громадянина і формування в Україні громадянського суспільства європейського рівня. Провідним завданням стратегії стало виведення сфери культури і творчості з периферії суспільно-політичних інтересів.

Доволі абстрактна наукова уява про соціокультурну сферу загалом знижує ефективність управлінських процесів та не дозволяє систематизувати вплив подієвих технологій. Не маючи на меті поглибленого уточнення цього поняття, будемо зважати на те, що соціокультурна сфера являє собою єдність трьох підсистем: інституціональної, діяльнісної і технологічної (Кочубей, 2015, с. 30). Складові соціокультурної сфери узагальнено представлені соціальними інститутами духовного виробництва, освітньо-виховними, науковопросвітницькими, культурно-дозвіллєвими, санаторно-курортними та спортивно-оздоровчими, туристсько-екскурсійними, відомчими культурноосвітніми, розважально-комерційними установами, закладами охорони та зберігання культурних цінностей, засобами поширення культури тощо (Кочубей, 2015). Така характеристика складових загальної сфери потребує 
вдосконалення, водночас, ілюструє необхідність усвідомлення специфіки й поліпшення процесу регулювання соціально-культурної взаємодії в напрямі запровадження інновацій.

Згідно із законом України «Про інноваційну діяльність», «інновації новостворені (застосовані) і (або) вдосконалені конкурентоздатні технології, продукція або послуги, а також організаційно-технічні рішення виробничого, адміністративного, комерційного або іншого характеру, що істотно поліпшують структуру та якість виробництва і (або) соціальної сфери» (Про інноваційну діяльність Закон України). На нашу думку, у контексті розвитку соціально-культурної сфери актуальними $є$ послуги, які істотно впливають на якість взаємодії в цьому просторі й зумовлюють реалізацію креативних практик, що сприяють прояву інновацій.

Синтез філософсько-педагогічного знання дозволяє аналізувати поняття «розвиток» як незворотну, цілеспрямовану, закономірну зміну матеріальних та ідеальних об'єктів; ... перехід можливості в дійсність (Філософрський енциклопедичний словник, 2002). Водночас, «розвиток - процес закономірних змін, переходу з одного стану в інший, більш досконалий; перехід від старого якісного стану в інший, від простого до складного, від нижчого до вищого» (Мардахаєв, 2002, с. 237). Вочевидь, у такому сенсі відображається вдосконалення об'єкта, підвищення його дієздатності.

На нашу думку, інноваційний розвиток соціокультурної сфери - процес системних якісних змін на основі інновацій, постійного пошуку вдосконалення й нововведень (поширення нових ідей, послуг та їх реалізація) з метою поліпшення соціальної взаємодії, інтеграції соціальних суб'єктів засобами креативних технологій та практик. Інноваційний розвиток соціокультурної сфери має особливості: пов'язані 3 розвитком інформаційного суспільства та зумовленими ним глобальними процесами; поєднанням традицій та інновацій, що існують поряд і взаємодоповнюють одне одного; специфікою системи управління, яка складається із взаємопов'язаних елементів регулювання складових соціокультурної сфери; поширенням креативних практик, які стають осередками стимулювання творчої взаємодії.

Оскільки креативність $€$ основою інноваційних змін, зокрема в соціокультурній сфері, увагу привертають спеціальні подієві технології як втілення творчих, унікальних соціокультурних практик в умовах сучасного стану розвитку культури. Івент (з англ. event - подія) або спеціальна подія розглядатимуться як тотожні, оскільки відображають однакове лексичне значення в різних мовах.

Серед дослідників зарубіжного подієвого менеджменту (Д. Гольдблатт, У. Хальцбаур та ін.) У. Хальцбаур акцентує на тому, що «перетворення заходу в реальну подію, що викликає особливі переживання, сприяє подовженому збереженню ефекту впливу» 
(Хальцбаур, 2007, с. 5). На нашу думку, якщо під час такої події стимулювати атмосферу креативної взаємодії, то створюються передумови для вироблення інновацій, оскільки емоції та переживання дозволяють поєднати конструктивні дії й винайти нестандартне рішення.

С. Герасимов, Н. Кочубей, Т Лохина, Г. Тульчинский єдині в думці, що в широкому сенсі «спеціальні події - це явище суспільного життя, що організуються з метою привернення широкої уваги конкретної аудиторії та численної публіки до організації, ії діяльності, керівництву, розвитку соціальних комунікацій та соціального партнерства» (Герасимов, 2009, с. 12; Кочубей, 2015). Звісно, що організація соціокультурної сфери має привертати увагу до власної діяльності, але має бути розширене розуміння спеціальної події в напрямі виявлення її культуротворчого інноваційного потенціалу.

Підвищення рівня соціальної суб'єктності в процесі спеціально організованої взаємодії в соціокультурній сфері сприятиме запровадженню креативних ідей, оскільки для івента характерні особливості: «активна участь, залученість, переключення від стану монотонної роботи, здивування, позитивне сприйняття, емоційність, символіка, задоволеність» (Герасимов, 2009 , с. 16). Таке одухотворення може стати підґрунтям для вироблення ідей і рішень, які $є$ дійсно новітніми чи можуть стати основою нововведень.

У сучасному соціо-гуманітарному науковому просторі доробки вчених стосовно аналізу спеціальних подій умовно можна поділити на філософськокомунікативний, освітній, управлінський напрями. Зокрема, певною мірою сформованим $€$ комунікативний напрям, який тісно пов'язаний із прикладною культурологією. Наприклад К. Каверіна визначає поняття «спеціальна подія» як «цілеспрямовано організоване дійство для трансляції ідей, цінностей, повідомлень, які виражають та слугують досягненню світоглядних, інформаційних, репутаційних, іміджевих, некомерційних, комерційних цілей будь-якої спільноти, що поєднана певними аксіологічними основами, соціальними, конфесійними, корпоративними принципами та поглядами» (Каверіна, 2015, с. 151). Таке трактування доволі широко презентує це явище через аксіологічну та ідеологічну спрямованість, акцентує на значному символічному капіталі. Однак, звужувати подію тільки до організації комунікацій вважаємо недоцільним, адже під час ії здійснення реалізується креативна ідея, позиціонується атрибутивність культури, виявляється просоціальна спрямованість тощо.

Освітній напрям представлений у сенсі бачення події як певного інструменту надання освітньо-культурних послуг. Дослідники А. Вотинцев, М. Самакаєва (спеціальні події в позиціонуванні закладу вищої освіти); А. Прохоров (спеціальна подія як інструмент просування освітніх послуг); М. Чередиліна (подієвість як категорія в теорії освіти) та ін. зокрема зважають на те, що спеціальна подія $є$ складовою загального позиціонування закладу освіти в освітньо-культурному просторі. Так, «спеціальна подія - ретельно 
спланована акція, що відбувається в межах загальної комунікаційної програми i, зазвичай, $€$ одним із ії ключових етапів. Саме в момент проведення спеціальної події можливе максимальне наповнення інформаційного поля навколо закладу вищої освіти» (Вотинцев, 2014, с 82). Відтак, учені надають значення події, але звужується ії зміст та значення.

Також маємо враховувати доробки вітчизняних і вузько спрямованих досліджень, які в Україні тільки розпочато. Наприклад, І. Антоненко серед особливостей розвитку івент-менеджменту в Україні зокрема визначає підвищення якості послуг, розширення їх спектру, застосування гнучкої цінової політики тощо (Антоненко, 2012). О. Хитрова та Ю. Харитонова, досліджуючи стан і тенденції подієвого менеджменту в Україні, зазначають про необхідність «створення умов для взаємопроникнення сфер відповідальності event та public relations; збільшення обсягу ринку за допомогою розширення спектра послуг; ретельний відбір професійних кадрів» тощо (Хитрова та Харитонова, 2018, с. 30). В. Данилова розглядає роль спеціальних художніх подій у процесі створення та трансляції сучасної культури (Данилова, 2017).

3 огляду на всі перераховані дослідження, очевидною $є$ необхідність удосконалення управління спеціальними подіями - подієвий менеджмент. Це менеджерський напрям, який представлений у роботах С. Герасимова, Н. Кочубей, Т. Лохиної, В. Новаторова, О. Радіонової, Г. Тульчинського та ін. Наприклад, В.Новаторов стверджує, що івент-маркетинг $є$ трендовою технологією соціально-культурної діяльності та має сприяти просуванню на цільові сегменти ринку організації чи ії товару, що відбувається шляхом організації спеціальних подій (Новаторов, 2014). Автор зазначає, що у сфері культури та мистецтва зокрема переважає некомерційний маркетинг; домінувальним товаром у сфері культури $€$ послуга; уся соціокультурна діяльність ґрунтується на творчій праці фахівців; соціальна місія організацій культури та мистецтва зобов'язує їх не йти за ситуативними потребами аудиторії, але цілеспрямовано формувати їх шляхом просвіти, виховання та розвитку особистості та ін. (Новаторов, 2014). Очевидно, що спеціальні події $\epsilon$ квінтесенцією налагодження взаємодії з метою реалізації ефективних послуг та креативної взаємодії всіх учасників соціокультурного процесу.

Спеціальні події потенційно мають інноваційний ефект і мають існувати управлінські механізми, які максимізують цей потенціал, створюють умови для його якнайефективнішого виявлення. Подієвий менеджмент спрямований на створення організаційних, управлінських, ресурсних умов для актуалізації інноваційного потенціалу спеціальної події. На нашу думку, управління подією стає синонімом управління інновацією в соціокультурній сфері, адже уможливлює реалізацію провідних функцій менеджменту та застосування інноваційних механізмів водночас. 
Загалом, у наявній літературі описано дещо подібні процеси, що свідчить про узгодженість поглядів на організаційно-управлінські засади івенту. Так, Д. Гольдблатт зважає на ретельну розробку та реалізація плану, ефективне застосування людських та часових ресурсів, фінансову підтримку, керівництво, координацію, маркетинг, етику та ризик-менеджмент у спеціальних подіях (Голдблатт, 2010). У. Хальцбаур описує стратегію успіху, приділяє увагу концепції івенту, його маркетингу, логістиці, менеджменту інформації як управлінським механізмам (Хальцбаур, 2007). Важливе значення надається забезпеченню безпеки, правим основам та відповідальності, проект-менеджменту, контролінгу (Герасимов, 2009), зокрема відбувається створення поступового алгоритму ефективної події, що доводить ії технологічність. Позиції фахівців $\epsilon$ схожими, що уможливлює застосовування цих інструментів у подієвому менеджменті, зокрема з метою інноваційного розвитку соціокультурної сфери.

Зміни соціокультурного простору зумовлюють застосування прикладної культурології як наукової основи менеджменту спеціальних подій. Зокрема І. Мурзина зазначає, що «прикладна культурологія займається обґрунтуванням та безпосередньою розробкою способів, підходів та технологій, які сприяють організації та регуляції культурних процесів у суспільстві» (Мурзіна, 2012, с. 5). Тобто вказується на прямий зв'язок менеджменту культури та, на наш погляд, удосконалення управління спеціальними подіями як чинником запровадження інновацій.

Зважаючи не те, що «прикладна культурологія досліджує галузь культурної політики (ії сутність, принципи, пріоритети, об'єкти та суб'єкти дії) та соціокультурного проектування (методологію та методики розробки й реалізації програм соціокультурної діяльності); звертається до аналізу механізмів, що забезпечують культурозбережувальну діяльність і визначає iï напрями» (Мурзіна, 2012, с. 6), можна стверджувати, що саме прикладний напрям культурології $\epsilon$ основою подальших досліджень менеджменту соціокультурної діяльності загалом та подієвого менеджменту зокрема.

Ураховуючи попередні узагальнення, можна зробити висновки, які сприятимуть розбудові теоретико-практичних засад подієвого менеджменту в напрямі підвищення ступеню його інноваційності та розвитку креативного потенціалу. По-перше, методологічною основою управління спеціальними подіями $є$ прикладна культурологія, яка зумовлює подальші дослідження івенту й визначення його культуротворчої спрямованості. По-друге, під час планування спеціальної події мають обґрунтовано використовуватися вже відомі загальні та специфічні функції менеджменту, його сучасні механізми та новітні досягнення, водночас, має проектуватися простір креативної комунікації для посилення творчої взаємодії. По-третє, актуальні напрями менеджменту (ризик менеджмент, 
креативний менеджмент тощо) мають ураховуватися під час організації спеціальної події в соціокультурному просторі, однак ступінь інноваційності має бути гармонізований між традиційними та новітніми формами. По-четверте, доцільно застосовувати управління подією як соціокультурним проектом, що дозволяє структурувати систему його ефективної реалізації, визначати життєвий цикл та вчасно оцінювати ефективність. По-п'яте, осучасненню спеціальних подій та наданню йому інноваційності додає переміщення культурних послуг (івент-проектів) у віртуальне середовище, де менеджмент має власну специфіку, зокрема застосовуються Інтернет-комунікації.

Висновки та перспективи подальших наукових розвідок. Одним із креативних стимулів удосконалення соціокультурного простору $\epsilon$ спеціальна подія, яка $€$ емоційно неповторною, справляє позитивне враження та підвищує ступінь творчої взаємодії. Дослідивши проблему інноваційного розвитку соціокультурної сфери засобами спеціальних подій, визначено, що існує потреба створення управлінських умов для розвитку їх креативного потенціалу, зокрема: під час планування спеціальної події мають обґрунтовано використовуватися вже відомі загальні та специфічні функції менеджменту, проектуватися простір креативної комунікації; актуальні напрями менеджменту мають ураховуватися під час реалізації спеціальної події, однак ступінь інноваційності має бути збалансованим; доцільно застосовувати управління подією як соціокультурним проектом на основі методології прикладної культурології. Подієвий менеджмент $є$ інструментом розкриття інноваційного потенціалу івенту, якщо враховує усталені управлінські технології в поєднанні з новітніми засобами та формами діяльності у сфері культури, що й буде перспективою подальших досліджень.

\section{ЛІТЕРАТУРА}

Антоненко, І.Я. (2012). Особливості розвитку та застосування Івент-менеджменту в Україні. Сучасний менеджмент і економічний розвиток: реферативний збірник матеріалів постійно діючої міжнародної науково-практичної конференції 1 вересня 2011 р. - 29 лютого 2012. Суми: СумДПУ (Antonenko, І. Үа. (2012). Characteristic features of development and usage of Event-management in Ukraine. Contemporary management and economic development: review collection of materials from an ongoing international research and practice conference from September 1, 2011 to February 29, 2012. Sumy: Sumy State Pedagogical University.

Вотинцев, А, Самакаева, М. (2014). Специальные события в позиционировании высшего учебного заведения. Екатеринбург (Votyntsev, A., Samakaieva, M. (2014). Special events in self-presentation of a higher education institution. Yekaterinburg).

Всеобщая декларация ЮНЕСКО о культурном разнообразии. Режим доступу: https://www.un.org/ru/documents/decl_conv/declarations/cultural_diversity.shtml (UNESCO Universal Declaration on Cultural Diversity. Retrieved from: https://www.un.org/ru/documents/decl conv/declarations/cultural diversity.shtml).

Герасимов, С., Тульчинский, Г., Лохина, Т. (2009). Менеджмент специальных событий в срере культуры. СПб.: Издательство «Лань»; Издательство «Планета музыки» 
(Herasimov, S., Tulchinskii, H., Lokhyna, T. (2009). Special event management in the field of culture: St. Petersburg: "Lan" Publishing office, "Planeta muzyki" Publishing house).

Голдблатт, Дж. (2010). Special Event. Москва: ЭКСпО (Goldblatt, J. (2010). Special Event. Moscow: EKSPO).

Данилова, В. (2017). Спеціальні художні події в процесі створення та трансляції сучасної культури. Українська культура: минуле, сучасне, шляхи розвитку, 25 (Danylova, V. (2017). Special artistic events in the process of creating and transmitting contemporary culture. Ukrainian culture: past, present, paths of development, 25).

Довгострокова стратегія розвитку української культури - стратегія реформ. Режим доступу: https://zakon.rada.gov.ua/laws/show/119-2016-\%D1\%80 (Long-term development strategy for development of Ukrainian culture - strategies for reforming. Retrieved from: https://zakon.rada.gov.ua/laws/show/119-2016-\%D1\%80).

Каверина, Е. А. (2014). Событийные коммуникации в пространстве культуры XX века. Общество. Среда. Развитue (Terra humana), 2 (31), 151-155 (Kaverina, E. A. (2014). Event-based communications in the cultural space of the $X X^{\text {th }}$ century. Society. Environment. Development (Terra humana), 2 (31), 151-155).

Каверина, Е.А. (2011). Культуротворческий потенциал событийных коммуникаций. Ценности и смыслы, 2 (11), 54-60 (Kaverina, Е. А. (2011). Culture-creation potential of event-based communications. Values and purposes, 2 (11), 54-60).

Кочубей, Н.В. (2015). Сочіокультурна діяльність. Суми: Університетська книга (Kochubei, N.V. (2015). Sociocultural activity. Sumy: University book).

Мардахаев, Л.В. (2002). Словарь по социальной педагогике. Москва: «Академия» (Mardakhaev, L. V. (2002). Social pedagogy dictionary. Moscow).

Мурзина, И.Я. (2012). Прикладные культурологические исследования: проблемные поля. Режим доступу: https://cyberleninka.ru/article/n/prikladnyekulturologicheskie-issledovaniya-problemnye-polya/viewer (Murzina, I. Ya. (2012). Applied cultural study research: issue field. Retrieved from: https://cyberleninka.ru/article/n/prikladnye-kulturologicheskie-issledovaniyaproblemnye-polya/viewer).

Новаторов, В.Е. (2014). Ивент-маркетинг как трендовая технология социальнокультурной деяльности. Вестник МГУКИ, 2 (58), 175-180 (Novatorov, V. Е. (2014). Event-marketing as a trending technology of sociocultural activity. MSACU Reporter, 2 (58), 175-180).

Про інноваційну діяльність Закон України. Режим доступу: https://zakon.rada.gov.ua/laws/show/40-15 (On innovational activity Act of Ukraine. Retrieved from: https://zakon.rada.gov.ua/laws/show/40-15).

Про культуру: Закон України від 14 груд. 2010 р. № 2778: станом на 28.12.2014 p. Режим доступу: http://zakon4.rada.gov.ua/laws/show/2778-17. (On culture: Act of Ukraine dated December 14, 2010 No. 2778: as of 28.12.2014. Retrieved from: http://zakon4.rada.gov.ua/laws/show/2778-17).

Прохоров, А. (2014). Специальное событие как инструмент продвижения образовательных услуг. Вестник ТГУ. Гуманитарные науки. Опыт организации современного образования, 4 (Prokhorov, A. (2014). Special event as an instrument of promoting educational services. TSU Reporter. Humanities. Experience of organizing contemporary education, 4).

Радіонова, О. М. (2015). Конспект лекцій з курсу «Івент-технології». Харків: ХНУМГ ім. О. М. Бекетова (Radionova, О. М. (2015). Compendium of lectures for the "Eventtechnologies" course. Kharkiv). 
Філософський енциклопедичний словник (2002). Київ: Абрис (Encyclopedical dictionary of philosophy (2002). Kyiv: Abris).

Хальцбаур, У., Йеттингер, Э., Кнаусе, Б., Мозер, Р., Целлер, М. (2007). Евентменеджмент. Москва: Эксмо (Khaltsbaur, U., Yettinger, Ye., Knause, B., Mozer, R., Tseller, M. (2007). Event-management. Moscow: Eksmo).

Хитрова, О. А., Харитонова, Ю. Ю. (2018). Стан і тенденції розвитку Івент-менеджменту в Україні. Науковий вісник Міжнародного гуманітарного університету. Серія: Економіка і менеджмент, 30, 27-31 (Khitrova, O. A., Kharitonova, Yu. Yu. (2018). State and development tendencies of Event-management in Ukraine. Scientific bulletin of International Humanitarian University. Series: Economy and management, 30, 27-31).

\section{PEЗЮME}

Максимовская Наталия, Поляничко Анжела. Событийный менеджмент как фактор инновационного развития социокультурной сферы.

Целью статьи является изучение основ инновационного развития социокультурной среры и управления специальными событиями как фактор стимулирования социокультурных новаций. Уделяется внимание методологическим подходам, которые срормированы в современной науке, относительно анализа событийного менеджмента, в том числе философско-коммуникационному, образовательному. Акцентируется на организационно-управленческих основах менеджмента событий, уточняются основные теоретические позиции усовершентствования социокультурных процессов через регулирование современного Ивента.

Ключевые слова: социокультурная сфрера, прикладная культурология, инновации, специальные события, менеджмент специальных событий.

\section{SUMMARY}

Maksymovska Nataliia, Polianychko Anzhela. Event-management as a factor of innovative development of sociocultural field.

The aim of this work is to study the contemporary state of sociocultural field's development, for which innovative processes and phenomena are inherent, particularly effective supervision over special events. Social creativity and creative supervisory activities act as a foundation for novelties, which manifest themselves in special cultural events, which become significant factors of creative development for state and society as bearers of innovative potential.

The research methodology is based on theoretical guidelines of applied cultural studies. Methods of analysis, comparison and justification of personal research positions are used. Author utilizes generalization of existing event-management models and proposals for its improvement.

Results. Author investigated theoretical positions, which become the scientific foundation for improving special events supervision: during planning of a special event, already known general and specific functions of management must be utilized, and creative communication space must be formed; topical management directions should be taken into account during implementation of a special event, however the grade of innovation should be balanced; it is reasonable to utilize event supervision as a sociocultural project.

Novelty. Applied cultural studies methodology was utilized for the analysis of eventmanagement for the first time. Structuring of contemporary studies was performed according to available scientific approaches, mainly communicative and educational. Proposals regarding improvement of special events supervision were formulated in order to stimulate innovative development of sociocultural field.

The practical significance. Results of this study should be used while conducting contemporary sociocultural activities, during planning and implementation of special events 
that are aimed culture creation, as well as during training of applied cultural studies and culture management specialists.

Key words: sociocultural environment, applied cultural studies, innovations, special events, special events management.

УдК 378.147:811.111

Анастасія Малота

Тернопільський національний педагогічний університет імені Володимира Гнатюка ORCID ID 0000-0003-0645-6781 DOI 10.24139/2312-5993/2020.03-04/227-236

\section{ЛІНГВІСТИЧНІ ОСОБЛИВОСТІ ПРОФЕСІЙНО ОРІЕНТОВАНОГО УСНОГО СПІЛКУВАННЯ СОЦІАЛЬНОГО ПРАЦІВНИКА АНГЛІЙСЬКОЮ МОВОЮ}

Метою статті $\epsilon$ розкриття лінгвістичних характеристик професійно орієнтованого усного спілкування сучасного сочіального працівника англійською мовою. Для досягнення поставленої мети нами були обрані такі методи дослідження: теоретичний аналіз спеціальної науково-методичної літератури стосовно профресійно орієнтованого усного спілкування сучасного сочіального працівника англійською мовою та синтез, узагальнення інформації з наведеного питання. $у$ результаті дослідження розглянуто такі складові професійно орієнтованого усного спілкування соціального працівника англійською мовою, як володіння спеціальною лексикою, здатність проявляти емоційний інтелект та здатність до персуазивного спілкування.

Ключові слова: профресійно орієнтоване усне спілкування, соціальний працівник, спеціальна лексика, термінологія, професіоналізм, жаргон, емоційний інтелект, персуазивність.

Постановка проблеми. Гуманізація сучасного українського суспільства, його орієнтація на кожного окремого індивіда незалежно від його фізичних, соціальних та інших можливостей, зумовлює винятковість ролі соціального працівника на сучасному етапі розвитку країни. Соціальний працівник - це та людина, що надає матеріально-побутову допомогу й морально-правову підтримку громадянам, що стикаються 3 труднощами у зв'язку із соціальними проблемами, екологічними катастрофами, міжнаціональними конфліктами й війнами, втратою близьких, родини, житла тощо, а отже, діяльність такої особи неодмінно пов'язана зі спілкуванням з іншими особами, у тому числі іноземцями, тому виховання в майбутніх соціальних працівників здатності до іншомовної комунікації постає новим викликом сучасної системи освіти.

Аналіз актуальних досліджень. Питання навчання фахівців різних сфер професійно орієнтованому усному іншомовному спілкуванню досліджено в роботах А. О. Анісімової (2005), В. П.Боса (2018), О.С. Конотоп (2010), Т.І.Коробейнікова (2013), Я.В.Окопна (2016), А. Р. Онуфрів (2016), Л. В. Шевкопляс (2016). Проблемам навчання іноземним мовам майбутніх соціальних працівників присвячено роботи Д. М. Годлевської (2007), Т. В. 
Ковтун (2011), С. А. Сура (2005). Особливості професійно орієнтованого спілкування соціального працівника висвітлено в роботах А. О. Кабанцової (2011), Н. О. Майструк (2011), Т. П. Спіріної (2016). Однак, із мінливістю світу і суспільства змінюються й особливості професійно орієнтованого усного спілкування соціального працівника англійською мовою, тому це питання потребує висвітлення з позицій сучасної науки.

Метою статті $\epsilon$ розкриття мовних характеристик професійно орієнтованого усного спілкування сучасного соціального працівника англійською мовою.

Методи дослідження включають теоретичний аналіз спеціальної науково-методичної літератури стосовно професійно орієнтованого усного спілкування сучасного соціального працівника англійською мовою та синтез, узагальнення інформації з наведеного питання.

Виклад основного матеріалу. У наш час науково-технічної революції, бурхливого розвитку наук кожна спеціальна галузь користується мовними засобами, якими іменують i характеризують поняття i явища, що $\epsilon$ предметом наукового дослідження саме цієї галузі (Nagy, 2014). Як слушно зазначає О.Л.Канюк, успіх професійної діяльності в багатьох сферах залежить від комунікативної компетентності фахівців. До таких сфер належить і соціальна робота (2017, с. 115). Оскільки у своїй діяльності соціальний працівник використовує спеціальну лексику, термінологію, професіоналізми, жаргонізми, то доцільною $€$ характеристика мови для спеціальних цілей, що об'єднує в собі усі ці мовні явища.

Фахові мови - це підвиди загальновживаної мови, що включають лексичні одиниці загальновживаної мови. М. Коанка (2011) визначає «загальновживану мову» як «немарковану, неспеціальну мову». Спеціалізована мова відрізняється від загальної мови, а поняття «загальна мова» (general language) позначає всю мову в ії різновидах: «загальновживану мову» (common language) та «спеціальну мову» (specialized language) разом. Різниця, що фактично існує між загальновживаним мовленням та спеціальним мовленням полягає в тому, що загальновживані лексичні одиниці використовуються в ситуаціях, які можна кваліфікувати як немарковані (Coanca, 2011).

І. К. Негі (2014) зазначає, що спеціальна і загальновживана мова мають багато спільних ознак, і тому визначення поняття «спеціальна мова» має включати такі характеристики: 1) відмінні елементи спеціальних мов $\epsilon$ не окремими явищами, а взаємозалежними наборами характеристик; 2) мета комунікації $\epsilon$ більш важливою, ніж інші, додаткові функції; 3) особливий характер спеціальної мови виражається відмінностями в предметній області, знаннях комунікантів та сфері використання (Nagy, 2014, с. 266). 
Т. М. Кабре (1999) використовує термін «спеціальна мова» на позначення субкоду загальновживаної мови, який характеризується такими особливостями: 1) спеціальні предметні поля - це ті поля, що не $є$ частиною загальних знань комунікантів; вони $\epsilon$ результатом певного навчального процесу; 2) мовці, які мають такий тип знань, є користувачами спеціальних мов, іншими словами, фахівцями предметних галузей, хоча тут варто вказати на різницю між творцями спеціалізованого спілкування та його адресатами; 3) спілкування спеціальними мовами зазвичай формальне й відбувається в ситуаціях, що регулюються професійними чи науковими факторами; 4) спеціальні мови характеризуються низкою мовних (одиниці та правила) та текстових особливостей (тексти та типи документів); 5) структурно спеціальна мова не $€$ монолітною підмножиною, а дозволяє допустити варіації залежно від використання та комунікативної ситуації, включаючи ступінь абстракції, комунікативну мету, географічні, історичні та соціальні діалекти, особистий стиль; крім того, спеціальні мови поділяють низкою прагматичних та мовних характеристик, тим самим дозволяючи нам називати їх як підмножину загальної мови в певному ступені єдності (Cabré, 1999, с. 65-66).

Загальнонародним фондом мови користуються всі їі носії, незалежно від місця проживання, способу життя, суспільного становища, освіти, вікових і статевих особливостей. Загальновживана лексика - це відкрита підсистема, яка може поповнюватись елементами лексики обмеженого вживання. Загальновживана лексика кількісно перевищує спеціальну й охоплює всі лексико-граматичні класи слів, будучи основою всіх функціональних стилів сучасної мови, усного й писемного ії різновидів (Кулішенко, 2014, с. 162). Спеціальна ж лексика (лексика обмеженого використання) не має загального поширення і функціонує у вузькому колі носіїв мови, пов'язаних між собою територіальною, професійною, соціальною близькістю. Кількісно це менший шар словника мови; ця лексика підпорядкована загальнонародній і функціонує в різних сферах професійної діяльності та мовленні різних соціальних груп людей (Кулішенко, 2014, с. 162).

Спеціальна лексика - це «слова чи словосполучення, які називають предмети й поняття, що належать до різних сфер трудової діяльності людини і не $€$ загальновживаними» (Розенталь, 2001, с. 522). Іншими словами, спеціальна лексика - це слова чи словосполучення, які позначають певні поняття і $€$ стійкими, відтворюваними елементами в системі спеціального знання, посідаючи в ній певні класифікаційні місця (Гречко, 2003, с. 176). С. В.Гриньов (2008) зауважує, що спеціальна лексика - це «сукупність лексичних одиниць (у першу чергу термінів) спеціальних галузей знання, що створює особливий шар лексики, який найшвидше зазнає свідомого регулювання й упорядкування» (Гринев-Гриневич, 2008, с. 5). 
Спеціальна лексика мови характеризується такими важливими особливостями: 1) вторинним використанням лексичних одиниць, значення яких розвивається на основі їх первісного загального використання; 2) спеціальним утворенням штучних позначень; 3) обмеженістю сфери використання; 4) неможливістю прямого перекладу на інші мови; 5) неможливістю довільних замін окремих елементів без узгодження 3 традицією галузі; 6) своєрідним ставленням до таких мовних явищ, як полісемія, антонімія; 7) підвищеним денотативним зв'язком (Суперанская, 2005, с. 42).

Співвіднесеність у сфері наукової мови зі спеціальним (науковим, технічним, виробничим) поняттям чи об'єктом, на думку Т. С. Пристайко (1996), спостерігається в номінативних одиницях трьох класів: термінах, професіоналізмах і номенклатурних знаках (Пристайко, 1996, с. 38). Слід зазначити, що обсяг і межі класів спеціальної лексики, які виділяються, хиткі й невиразні, оскільки існують і проміжні класи мовних одиниць. Переходи ж мовних одиниць з одного класу до іншого мало помітні, що значною мірою ускладнює однозначне розв'язання проблеми класифікації спеціальної лексики (Павлова, 2008).

Оскільки соціальний працівник послуговується інструментарієм соціально-психологічних наук (Крылов, 2019), лексика соціального працівника повинна збагачуватися одиницями спеціальної лексики, що належать до: 1) термінології: abuse "жорстоке ставлення», direct-care «безпосередня допомога», liberation «звільнення», maladjustment «нездатність адаптуватися» (Крылов, 2019, с. 5), наприклад: The mission of the social worker is to promote and support individual's and community's wellbeing and to fight social injustice (Scheyett); 2) професіоналізмів: large-scale «широкий, масовий», occupational «професійний», planner «планувальник», common-interest groups «групи за інтересами» (Крылов, 2019, с. 16), наприклад: So we learn the social-based interventions that can help to solve the problems (Scheyett); 3) жаргонізмів: manic «людина 3 біполярним розладом», psychosis «психоз, втрата контакту з реальністю» (Psychology Jargon), наприклад: Well, who helps the new parents to find the specialist or figure out how to pay huge hospital bills? (Scheyett).

Однак, уміння використовувати спеціальну лексику не $\epsilon$ запорукою успішного спілкування 3 клієнтом. У ситуації усного професійно орієнтованого спілкування важливу роль відіграє соціальний інтелект «здатність розуміти інших і діяти або поводитися мудро по відношенню до оточуючих» (Андреева, 2008, с. 88) та емоційний інтелект - ступінь розвитку таких людських якостей, як самосвідомість, самоконтроль, мотивація, уміння ставити себе на місце інших людей, навички роботи 3 людьми, уміння налагоджувати взаєморозуміння з іншими (Лучинкіна, 2011, с. 222). 
До мовних маркерів емоційного інтелекту соціального працівника можна віднести: 1) емоційну та емотивну лексику (I mean, any woman in your situation will struggle where they're constantly being put down (Jasmine)); 2) вигуки (Yeah, it must be very difficult (Jasmine)); 3) компліменти, похвалу (And it's really courageous of you to be able to come in and share your story with me (Jasmine)); 4) уміння уникати неприємної розмови та змінювати ії напрям (You know we're here to provide you the best hope we can possible (Jasmine)); 5) уміння дякувати, вибачатись, співчувати (Also it make sense that you're feeling the way you are (Jasmine)).

Емоційний інтелект майбутнього соціального працівника також тісно пов'язаний із персуазивністю комунікації, що розуміється як особлива форма реалізації ментально-мовленнєвої діяльності адресанта ставить на меті переконання адресати в необхідності прийняття ним рішення щодо здійснення певних дій в інтересах адресанта. У персуазивній комунікації взаємодіють процес переконання, спрямований на прийняття адресатом раціональної аргументації адресанта, і процес умовляння («зваблювання»), який підсилює аргументацію і впливає на емоційну сферу адресата, апелює до його почуттів (Скрябіна, 2011, с. 70).

Персуазивність характеризується використанням таких прийомів: 1) вибір слів і виразів, референційно однакових, але з прагматичної точки зору приналежних до різних систем світосприйняття і ціннісних орієнтацій (так, коли несприятлива ситуація в родині іменується трагедією, співрозмовник відчуває співчуття соціального працівника): So from what I've gathered it sounds like a real tragedy for you (Jasmine); 2) вибір найбільш відповідних граматичних форм, як, наприклад, використання пасивної граматичної конструкції з метою маскування агента: So, it is obvious that you're being verbally abused (Jasmine); 3) вибір послідовності характеристики: Үоu're actually want to leave this relationship because you don't feel like it's safe for your children and yourself (Jasmine), де на перший план ставляться діти, яких потрібно убезпечити; 4) використання супрасегментних засобів - емфази, інтонації тощо: You should seriously consider your work preferences to determine if it is indeed a good fit for you (Jasmine); 5) вибір імпліцитних обґрунтувань: So you mentioned your parents are supportive (Jasmine) як засіб «натякнути» клієнтові, де шукати підтримки. Сюди ж можна віднести й стилістично забарвлену комбінаторику слів, коли мовні одиниці нейтрального стилю, вжиті в одному ряді з негативно маркованою лексикою, набувають негативних конотацій (Шелестюк, 2009, с. 9).

Граматико-синтаксичні виражальні мовні засоби, що використовуються в мовленні соціального працівника, об'єднуються поняттям «стилістичний синтаксис», що розуміється як фіксований, традиційний набір синтаксичних засобів, сукупність продуктивних і часто вживаних експресивно та емоційно насичених синтаксичних побудов у 
мовленні автора, причому ці мовні одиниці забезпечують особливу виразність тексту та виконують певні стилістичні функції у сприйнятті, розумінні й актуалізації змісту (Дегтярьова, 2009, с. 28). До основних граматико-синтаксичних засобів, що використовуються в мовленні соціального працівника, належать: 1) вставні конструкції: So, you know, I wouldn't have to share with anybody without your permission of course (Jasmine); 2) імперативи: So, keep you things like car keys, your license, ID for the kids and things like that just in case you need to get up and as a matter of emergency (Jasmine); 3) широке вживання модальних дієслів: So, уоu can't help everyone but you can help this woman (Jasmine)); 4) використання займенника уои як засобу створення зв'язку із клієнтом: So, I guess I got what you told me (Jasmine).

Отже, специфіка професійно орієнтованого усного спілкування соціального працівника англійською мовою полягає в тому, що у своєму мовленні соціальний працівник повинен вдало комбінувати не лише загальновживану і спеціальну лексику, а й мовні маркери емоційного інтелекту та засоби створення персуазивності, що дозволяє майбутньому соціальному працівникові досягти ефективної комунікації як з колегами, так і 3 клієнтами.

Висновки та перспективи подальших наукових розвідок. Мовлення соціального працівника характеризується, у першу чергу, необхідністю комунікації як зі спеціалістами-колегами, так і з неспеціалістами-клієнтами, що зумовлює необхідність володіння майбутнім соціальним працівником як спеціальною, так і загальновживаною лексикою. Спеціальна лексика, якою послуговується соціальний працівник, постає частиною спеціальної лексики, що розуміється як слова чи словосполучення, які позначають спеціальні поняття і $€$ стійкими, відтворюваними елементами в системі спеціального знання, посідаючи в ній певні класифікаційні місця. Характерними рисами спеціальної лексики $€$ застосування вторинної номінації при створенні штучних позначень, обмеженість сфери використання, домінуванням денотативного компонента значення над конотативним. У межах спеціальної лексики найчастіше виділяють такі класи, як терміни, професіоналізми та номенклатурні знаки, однак межа між цими одиницями $є$ розмитою. Окрім того, важливим аспектом комунікації соціального працівника із колегами та клієнтами є здатність проявляти емоційний інтелект, що проявляється як здатність розуміти інших і діяти або поводитись мудро по відношенню до оточуючих та реалізується через використання емоційної й емотивної лексики, вигуків, компліментів, похвали, здатність засобами мови уникати неприємної розмови та змінювати їі напрям, а також дякувати, вибачатись, співчувати. Мовлення соціального працівника повинне володіти і персуазивністю умінням переконання адресата в необхідності прийняття ним рішення 
щодо здійснення певних дій в інтересах адресанта, що репрезентується в мовленні соціального працівника як здатність оперувати такими засобами, як евфемізм, емфаза, граматико-синтаксичні та стилістичні засоби мови. Граматико-синтаксичний аспект комунікації соціального працівника включає широке використання вставних конструкцій, модальних дієслів та займенника уои як засобу створення контакту з клієнтом.

Результати проведеного дослідження дозволяють окреслити такі перспективи для подальших розвідок, як ґрунтовне вивчення мовлення соціального працівника в контексті спілкування з колегами та клієнтами, а також розробка критеріїв мовної та мовленнєвої компетенції для соціального працівника, що дозволить здійснити об'єктивну оцінку мовної підготовки майбутнього соціального працівника у закладі вищої освіти.

\section{ЛІТЕРАТУРА}

Андреева, И.Н. (2008). Об истории развития понятия «эмоциональный интеллект». Вопросы психологии, 5, 83-95 (Andreeva, І. N. (2008). On the history of the development of the concept of "emotional intelligence". Issues of Psychology, 5, 83-95).

Анісімова, А. О. (2009). Формування граматичних навичок говоріння німецькою мовою після англійської у майбутніх перекладачів (дис. ... канд. пед. наук: 13.00.02). Київ (Anisimova, А. О. (2009). Forming grammatical skills of speaking German after English for the future translators (PhD thesis). Kyiv).

Боса, В.П. (2018). Формування мовленнєвої компетентності майбутніх учителів іноземних мов у прочесі вивчення фахових дисциплін (автореф. дис. ... канд. пед. наук: 13.00.04). Житомир (Bosa, V. Р. (2018). Forming speech competence of future teachers of foreign languages in the process of studying professional disciplines (PhD thesis abstract). Zhytomyr).

Годлевська, Д. М. (2007). Формування професійної комунікативної компетентності майбутніх соціальних працівників в умовах педагогічного університету (дис. ... канд. пед. наук: 13.00.05). Київ (Hodlevska, D. М. (2007). Forming professional communicative competence of future social workers in the conditions of pedagogical university (PhD thesis). Kyiv).

Гречко, В. А. (2003). Теория языкознания. Москва: Высш. школа (Hrechko, V. А. (2003). Theory of Linguistics. Moscow: Higher school).

Гринев-Гриневич, С. В. (2008). Терминоведение. Москва: Издат. центр «Академия» (HrinevHrynevych, S. V. (2008). Terminology. Moscow: Publishing Center "Academy").

Дегтярьова, І. (2009). Стилістичний синтаксис української постмодерністської прози. Українська мова, 3, 27-38 (Dehtiariova, І. (2009). Stylistic syntax of Ukrainian postmodernist prose. Ukrainian language, 3, 27-38).

Канюк, О. Л. (2017). Про роль мовленнєвої компетенції у формуванні культури іншомовного професійного спілкування майбутніх фахівців соціальної роботи. Науковий вісник Ужгородського університету. Серія: «Педагогіка. Соціальна poбoma», 1 (40), 115-117 (Kaniuk, O. L. (2017). On the role of speech competence in the formation of a culture of foreign language professional communication of future social workers. Scientific Bulletin of Uzhhorod University. Series: "Pedagogy. Social Work", 1 (40), 115-117).

Ковтун, Т.В. (2011). Подготовка социального педагога в педагогическом колледже (дис. ... канд. пед. наук: 13.00.06). Ставрополь (Kovtun, T. V. (2011). Training of a social pedagogue in a pedagogical college (PhD thesis). Stavropol). 
Конотоп, О. С. (2010). Методика навчання майбутніх філологів англійського діалогічного спілкування з використанням відеофонограми (дис. ... канд. пед. наук: 13.00.02). Київ (Konotop, О. S. (2010). Methodology of teaching future philologists English dialogic communication using video phonograms (PhD thesis). Kyiv).

Коробейнікова, Т. І. (2013). Формування англомовної компетентності в діалогічному мовленні майбутніх учителів з використанням інформаційно-комунікаційних технологій (дис. ... канд. пед. наук: 13.00.02). Київ (Korobeinikova, Т. І. (2013). Forming English language competence in dialogic speech of future teachers with the use of information and communication technologies (PhD thesis). Kyiv).

Крылов, Е. В. (2019). Английский для социальных работников = English for Social Workers. Минск: БГУ (Krylov, Е. V. (2019). English for Social Workers. Minsk: BGU).

Кулішенко, Л., Матюшенко, С. (2014). Лексика навчального процесу. Світогляд Філософрія - Релігія, 7, 162-169 (Kulishenko, L., Matiushenko, S. (2014). Vocabulary of the educational process. Worldview - Philosophy - Religion, 7, 162-169).

Лучинкіна, А.І. (2011). Динаміка емоційного інтелекту під впливом RPG. Збірник наукових праць Інституту психології імені Г. С. Костюка НАПНУ, 13 (2), 221-228 (Luchinkina, A. I. (2011). Dynamics of emotional intelligence under the influence of RPG. Collection of scientific works of the G. S. Kostiuk Institute of Psychology of the National Academy of Pedagogical Sciences of Ukraine, 13 (2), 221-228).

Майструк, Н. О., Кабанцова, А. О. (2011). Професіоналізація комунікативної компетентності соціального працівника. Вісник НТУУ «КПІ». Політологія. Сочіологія. Право, 3 (11), 70-74 (Maistruk, N. O., Kabantsova, А. О. (2011). Professionalization of communicative competence of a social worker. Bulletin of NTUU "KPI". Politology. Sociology. Law, 3 (11), 70-74).

Окопна, Я. В. (2016). Проблеми формування професійно орієнтованої комунікативної компетентності в діалогічному мовленні майбутніх туризмознавців (німецька мова після англійської). Науковий часопис НПУ імені М. П. Драгоманова. Серія 16: Творча особистість учителя: проблеми теорії і практики, 27, 63-66 (Okopna, Ya. V. (2016). Problems of forming professionally oriented communicative competence in dialogic speech of future tourism experts (German language after English). Scientific journal of NPU named after M. P. Drahomanov. Series 16: Creative personality of a teacher: problems of theory and practice, 27, 63-66).

Онуфрів, А. Р. (2016). Етапи формування англомовної професійно орієнтованої компетентності в усному академічному спілкуванні майбутніх маркетологів на основі презентації. Науковий вісник Ужгородського національного університету. Серія: Педагогіка. Соціальна робота, 2, 284-288 (Onufriv, A. R. (2016). Stages of forming English-speaking professionally oriented competence in oral academic communication of future marketers on the basis of presentation. Scientific Bulletin of Uzhhorod National University. Series: Pedagogy. Social Work, 2, 284-288).

Павлова, О. (2008). Терміни, професіоналізми і номенклатурні знаки (до проблеми класифікації спеціальної лексики). Режим доступу: http://vlp.com.ua/files/09_38.pdf (Pavlova, O. (2008). Terms, professionalisms and nomenclature signs (towards the problem of classification of special vocabulary). Retrieved from: http://vlp.com.ua/files/09 38.pdf).

Пристайко, Т. С. (1996). Лексико-номинативная организация специального текста. Днепропетровск: УкО IMA - прес (Pristaiko, T. S. (1996). Lexical and nominative organization of the special text. Dnepropetrovsk: UCO IMA - press).

Розенталь, Д.э., Теленкова, М. (2001). Словарь-справочник лингвистических терминов. Москва: ООО «Изд-во Астрель», ООО «Изд-во АCT» (Rozental, D. E., 
Telenkova, M. (2001). Dictionary of linguistic terms. Moscow: Astrel Publishing House LLC, AST Publishing House LLC).

Скрябіна, В.Б. (2011). Персуазивні стратегії любовного дискурсу: комунікативнопрагматичний аспект (на матеріалі англомовної художньої прози XX століття) (дис. ... канд. філол. наук: 10.02.04). Київ (Skriabina, V. В. (2011). Persuasive strategies of love discourse: communicative-pragmatic aspect (on the material of English fiction of the XX century) (PhD thesis). Kyiv).

Спіріна, Т. П. (2016). Принципи професійного спілкування майбутніх соціальних педагогів. Київський університет імені Бориса Грінченка, 4, 23-32 (Spirina, T. P. (2016). Principles of professional communication of future social educators. Borys Hrinchenko University of Kyiv, 4, 23-32).

Суперанская, А. В., Подольская, Н. В., Васильева, Н. В. (2005). Общая терминология: Терминологическая деятельность. Москва: Едиториал УРСС (Superanskaia, A. V., Podolskaia, N. V., Vasilieva, N. V. (2005). General terminology: Terminological activity. Moscow: URSS editorial).

Сура, Н.А. (2005). Навчання студентів університету професійно орієнтованого спілкування іноземною мовою (автореф. дис. ... канд. пед. наук: 13.00.04). Луганськ (Sura, N. A. (2005). Teaching university students professionally oriented communication in a foreign language (PhD thesis abstract). Luhansk).

Шевкопляс, Л. В. (2016). Вправи для формування англомовної компетенції в аудіюванні майбутніх учителів у процесі самостійної роботи. Вісник Чернігівського національного педагогічного університету. Серія: Педагогічні науки, 141, 216222 (Shevkoplias, L. V. (2016). Exercises for forming English-language competence in listening for future teachers in the process of independent work. Bulletin of Chernihiv National Pedagogical University. Series: Pedagogical Sciences, 141, 216-222).

Шелестюк, Е. В. (2009). Речевое воздействие: онтология и методология исследования (автореф. дисс. ... доктора филол. наук: 10.02.19). Челябинск (Shelestiuk, E. V. (2009). Speech Impact: Ontology and Research Methodology (PhD thesis abstract). Cheliabinsk).

Cabré, T. M. (1999). Terminology. Theory, methods and applications. In Sonneveld, H., Wright, S. E. (Eds.), Terminology and Lexicography Research and Practice, (pp. 60-75). Amsterdam / Philadelphia: John Benjamins Publishing Company.

Coanca, M. (2011). Common language vs. specialized language. Retrieved from: ftp://ftp.repec.org/opt/ReDIF/RePEc/rau/iisomg/SP11/JISOM-SP11-A22.pdf.

Jasmine, A. How to Interview Clients by Social Worker / Domestic Violence. Retrieved from: https://www.youtube.com/watch?v=WSVroHs-EFw.

Nagy, I. K. (2014). English for Special Purposes: Specialized Languages and Problems of Terminology. Acta Universitatis Sapientiae, Philologica, 6.2, 261-273.

Psychology Jargon.

Retrieved

from: http://jargontime.blogspot.com/p/psychology.html\#: :text=These\%20are\%20some\% 20examples\%20of,ABA\%20\%2D\%20Applied\%20Behavior\%20Analysis.

Scheyett, A. Social workers as super-heroes. Retrieved from: https://www.youtube.com/watch?v=A27QjpQ_leo.

\section{PEЗЮME}

Малота Анастасия. Лингвистические особенности профессионально ориентированного устного общения социального работника на английском языке.

Целью статьи является раскрытие лингвистических характеристик профрессионально ориентированного устного общения современного социального работника английском языке. Для достижения поставленной цели нами были выбраны 
следующие методы исследования: теоретический анализ специальной научнометодической литературы касательно профрессионально ориентированного устного общения современного социального работника английском языке и синтез, обобщение информации по данному вопросу. В результате исследования рассмотрены такие составляющие профессионально ориентированного устного общения социального работника английском языке, как владение специальной лексикой, способность проявлять эмоциональный интеллект и способность к персуазивности общения.

Ключевые слова: профрессионально ориентированное устное общение, социальный работник, специальная лексика, терминология, профрессионализм, жаргон, эмоциональный интеллект, персуазивность.

\section{SUMMARY}

Malota Anastasiia. Linguistic features of professionally oriented oral communication of a social worker in English.

Humanization of modern Ukrainian society, its focus on each individual, regardless of his physical, social and other capabilities, determines the uniqueness of the role of social worker at the present stage of development. A social worker is a person who provides material assistance and moral and legal support to citizens who face difficulties due to social problems, environmental catastrophes, interethnic conflicts and wars, loss of relatives, family, housing, etc., and therefore, the activity of such a person is inevitably associated with communication with other persons, including foreigners, so education of future social workers' ability to communicate in another language is a new challenge of the modern education system.

The aim of the article is to disclose the linguistic characteristics of professionally oriented oral communication of a modern social worker in English. To achieve this aim, we have chosen the following research methods: theoretical analysis of special scientific and methodological literature regarding professionally oriented oral communication of a modern social worker in English and synthesis of information on this issue. As a result of the study, we determined such components of a professionally oriented oral communication of a social worker in English as the ability to use special vocabulary, to show emotional intelligence and to persuade others.

The characteristic features of special vocabulary in the language of social worker are the use of terms, professionalisms and jargon units. In its turn, emotional intelligence is manifested as the ability to understand others and act or behave wisely towards others and is realized through the use of emotional vocabulary, exclamations, compliments, praise, ability to avoid unpleasant conversation and change its direction, as well as to thank, apologize, sympathize. The speech of a social worker needs to be persuasive - to convince the addressee of the need to decide on certain actions in the interests of the addressee which is represented in the speech of the social worker as the ability to use such means as euphemism, emphasis, grammatical and stylistic language means.

Key words: professionally oriented oral communication, social worker, special vocabulary, terminology, professionalism, jargon, emotional intelligence, persuasiveness. 
Удк 373.3.011

Раїса Пріма

Східноєвропейський національний університет імені Лесі Українки ORCID ID 0000-0002-3278-1900

Дмитро Пріма

Східноєвропейський національний університет імені Лесі Українки ORCID ID 0000-0002-2102-9932

DOI 10.24139/2312-5993/2020.03-04/237-244

\section{ПРОЄКТНА ДІЯЛЬНІСТЬ УЧИТЕЛЯ ПОЧАТКОВОЇ ШКОЛИ: TЕОРЕТИЧНІ АСПЕКТИ}

Метою статmі є розкриття деяких аспектів проєктної діяльності вчителя початкової школи, сутнісних ознак методу проєктів, проєктної технології. у статmі використано методи дослідження: теоретичні (аналіз довідкових видань, науковопедагогічної літератури); інтерпретаційно-аналітичний метод, узагальнення. у контексті пошуку нових засобів і методів формування творчої особистості, ії життєво важливих компетентностей актуалізовано проєктну діяльність як одну з найпродуктивніших складових освітнього процесу, що створює умови для творчого саморозвитку й самореалізації учнів. Проаналізовано різні підходи щодо дефініцій «проєкт», "навчальний проєкт», "метод проєктів», «проєктна технологія», сутнісні ознаки яких поглиблюють розуміння поняття «проєктна діяльність».

Ключові слова: учитель початкової школи, метод проєктів, навчальний проєкт, проєкт, проєктна діяльність, проєктна технологія, технологія навчання.

Постановка проблеми. В Україні триває процес модернізації і реформування освітньої системи в контексті входження до світового простору, пошуку нових засобів і методів формування творчої особистості, іï життєво важливих компетентностей. При цьому однією 3 найпродуктивніших складових освітнього процесу, що створює умови для творчого саморозвитку та самореалізації учнів, формує всі необхідні життєві компетенції, визначені Радою Європи як основні в XXI столітті полікультурні, мовленнєві, інформаційні, політичні та соціальні, є проєктна діяльність - технологія становлення особистості, передусім молодшого школяра, як активного учасника проєктно-життєвого простору, покликаного сприяти саморозвитку творчої, компетентної, гармонійної людини. Ми виходимо з того, що компетентнісно спрямована освіта передбачає внесення суттвих змін у змістову, проєктно-технологічну, виховну, управлінську архітектоніку української школи, коли в структурі навчання посилюється роль і значення освоєння способів діяльності, підвищення їхньої технологічності, створення умов для активної соціальної дії, проєктної, дослідницької діяльності (Єрмаков, 2006). 
Аналіз актуальних досліджень засвідчив, по-перше, наявність наукових розробок, де розкриваються теоретичні засади проєктної діяльності (В. Гузеєв, О. Коберник, О. Пєхота, С. Сисоєва та ін.), аналізується iї зміст і значення (А. Вдовиченко, В. Сидоренко, А. Терещук та ін.), теоретично обґрунтовується метод проєктів і проєктна технологія (В. Зверєва, В. Лазарєв, М. Поташник, Г. Селевко та ін.), висвітлюються проблеми організації проєктної діяльності в початковій школі (Т. Башинська, Л. Коваль, О. Онопрієнко, В.Тименко та ін.). По-друге, відсутність єдиного погляду науковців щодо проблеми проєктної діяльності вчителя початкової школи.

Метою статті $€$ розкриття деяких аспектів проєктної діяльності вчителя початкової школи, сутнісних ознак методу проєктів, проєктної технології.

Виклад основного матеріалу. Передусім відзначимо, що серед дефініцій, що формують уявлення про проєктну діяльність учителя початкової школи загалом, виокремлюємо такі поняття, як «проєкт», «навчальний проєкт», «метод проєктів», «проєктні технології». А відтак, розкриємо їх сутність. Так, за Новим тлумачним словником української мови, проєкт - це «1. Сукупність документів (розрахунків, креслень, макетів тощо), необхідних для зведення споруд, виготовлення машин, приладів тощо. 2. Попередній текст якого-небудь документа, що виноситься на обговорення, затвердження; начерк. 3. Задуманий план дій; задум, намір» (Новий тлумачний словник української мови, 2008, с. 6).

На думку А. Лебедєва, проєкт - «сукупність певних дій, документів для створення реального об'єкта, предмета, різного роду теоретичного продукту. Це завжди творча діяльність» (Лебедев, 2002).

За твердженням О. Онопрієнко, у педагогічній літературі поняття «проєкт» (від лат. projectus - кинутий уперед) визначається, по-перше, як результат перетворювальної діяльності; по-друге, як мета і результат проєктування (Онопрієнко, 2013, с. 10).

Як слушно відзначає Н. Тализіна, «проєкти виступають у ролі доповнень і трансформ; вони спрямовані на те, щоб змінити існуючий стан справ. За змістом проєктування є перетворенням вже існуючих об'єктів у нову форму». Конструктивною вважаємо думку вченої, відповідно до якої проєктування є рушійним механізмом справді розвиваючого утворення, позаяк «предметом проєктування і $€$ створення умов (засобів, механізмів) розвитку системи утворення загалом, переходу з одного стану в інший» (Талызина, 1988, с. 115-116).

Нам імпонує позиція О. Пєхоти, згідно з якою проєкт характеризується як практика особистісно орієнтованого навчання у процесі конкретної праці учня, на основі його вільного вибору, 3 урахуванням його інтересів. При цьому вчена зауважує, що у свідомості учня це виглядає так: «Все, що я пізнаю, я знаю, для чого це мені треба і де 
я можу ці знання застосувати». Для педагога ж - це прагнення знайти розумний баланс між академічними знаннями, уміннями та навичками (Освітні технології, 2003).

Цінними нам видаються наукові узагальнення Р. Михайлишин щодо виокремлення науковцями різних категорійних ознак поняття "проєкт», а саме: С. Кримський - систематична форма організації діяльності у взаємозв'язку з ії теоретичними і практичними аспектами; Л. Ващенко інноваційна форма організації освітнього середовища, в основі якої лежить комплексний характер діяльності тимчасового колективу в умовах активної взаємодії з навколишнім середовищем; А. Мойсеєв - форма побудови цілеспрямованої діяльності; О. Пометун - цільовий акт діяльності, в основу якого покладено інтереси людини (Михайлишин, 2016, с. 44-45).

Заслуговує на увагу думка $€$. Полат, що визначає проєкт як сукупність навчально-пізнавальних прийомів, за допомогою яких учні набувають знання та навички в процесі планування та самостійного виконання певних практичних завдань із обов'язковою презентацією результатів (Полат, 2002); як спосіб досягнення дидактичної мети через детальну розробку проблеми (технології), що повинна завершитися цілком реальним, відчутним практичним результатом, оформлення тим чи іншим чином (Полат, 2000, с. 3).

Отже, крізь призму викладеного цілком правомірно стверджувати, що домінантною ідеєю, що утворює змістове ядро поняття «проєкт», $\epsilon$ «прагматична спрямованість на результат, який досягається за умови вирішення тієї чи іншої практично або теоретично значущої проблеми (А. Хуторськой). А відтак, виникає необхідність внести уточнення стосовно трактування поняття «навчальний проєкт».

Звертаємо увагу на те, що різноплановістю підходів відзначається й дефініціювання категорії «навчальний проєкт». Так, В.Симоненко навчальний (творчий) проєкт характеризує як самостійно розроблені та виготовлені товари (послуги) від ідеї до їі втілення, що має суб'єктну або об'єктну новизну і виконується під контролем та консультуванням учителя (Симоненко, 1999). За А. Хуторським, навчальний проєкт - це форма організації занять, яка передбачає комплексний характер діяльності всіх його учасників з отриманням освітньої продукції за певний проміжок часу (Хуторской, 2001).

У контексті окресленої проблеми оригінальним (і певною мірою контекстним) нам видається авторське бачення російського науковця $\epsilon$. Полата і щодо трактування поняття «навчальний проєкт» як об'єднаної навчально-пізнавальної творчої діяльності учнів-партнерів, організованої на основі комп'ютерних телекомунікацій, які мають спільну проблему, мету, узгоджені методи, способи діяльності, спрямовані на досягнення загального результату сумісної діяльності (Полат, 2002). 
Попри те, що кожне з наведених визначень поняття «навчальний проєкт» має певний сенс, однак, погоджуючись із О. Онопрієнко, вважаємо, що для початкової школи прийнятним $€$ розуміння навчального проєкту як особливого виду навчально-пізнавальної діяльності учнів, спрямованої на вирішення проблеми, пов'язаної зі створенням освітнього продукту, який має суб'єктивну чи об'єктивну цінність, а метод проєктів слід розглядати як спосіб організації такої діяльності (Онопрієнко, 2013, с. 17).

Стосовно методу проєктів, то за визначенням С. Пілюгіної, - це особистісно-орієнтований метод навчання, заснований на самостійній діяльності учнів щодо розробки проблеми й оформлення їі практичного результату.

На наш погляд, суттєва особливість методу проєктів акумульована у визначенні І. Зимньої та Т. Сахарової: «Проєкт - самостійно планована й реалізована учнями робота, у якій мовленнєве спілкування вплетене в інтелектуально-емоційний контекст іншої діяльності» (Зимняя, 1991, с. 9).

Як слушно відзначає К. Мелашенко, метод проєктів - це педагогічна технологія, що передбачає певну сукупність навчально-пізнавальних прийомів, які дозволяють розв'язати ту чи іншу проблему в результаті самостійних дій учнів із обов'язковою презентацією цих результатів (Мелашенко, 2006, с. 13).

У контексті окресленої проблеми конструктивною вважаємо думку вчених щодо виокремлення характерних ознак методу проєктів, як-от:

- наявність певної значущої для учнів проблеми;

- вихідний момент - інтереси дітей;

- домінування принципу самостійності в діяльності учнів;

- використання різноманітних форм діяльності школярів: індивідуальна, парна, групова;

- зв'язок теорії з практикою;

- зв'язок із реальним життям;

- забезпечення максимальної пізнавальної активності учнів;

- розвиток творчих навичок школярів, критичного мислення, умінь самостійно шукати інформацію;

- використання різноманітних методів, засобів навчання;

- здійснення монопредметних, міжпредметних та надпредметних зв'язків ;

- інтегрування знань, умінь із різних галузей науки і мистецтва;

- із об'єктів навчання учні перетворюються на суб'єктів навчання;

- включає в себе елементи особистісно орієнтованого навчання, педагогіки співробітництва, діяльнісного підходу в навчанні (Метод проектів: особливості застосування в початковій школі, 2009).

Отже, як бачимо, метод проєктів ґрунтується на ідеї спрямованості навчально-пізнавальної діяльності школярів на результат, що отримується 
через вирішення певної теоретично-практично значущої для учня проблеми. При цьому зовнішній результат - візуальний: його можна побачити, осмислити, оцінити, застосувати на практиці. Внутрішній же результат досвід діяльності - стане надбанням учня лише завдяки поєднанню компетенції й цінності, знання та вміння, що особливо важливо в молодшому шкільному віці, коли закладаються і формуються підвалини ціннісних настанов, особистісних якостей і ставлень. Із таких позицій застосування методу проєктів у початковій школі має на меті стимулювати інтерес учнів до певних проблем і розв'язувати ці проблеми через діяльність.

Крізь призму окресленого цілком правомірно стверджувати про різноаспектність підходів науковців щодо трактування змісту поняття «метод проєктів», про відсутність єдиної й чіткої парадигми його використання, що розуміється контекстно як метод, технологія навчання, вид навчання та діяльність, а також констатувати наявність у наукових текстах поруч із традиційним уживанням терміну «метод проєктів» відносно нового поняття «проєктна технологія».

Сутність проєктної технології, за Т.Подобєдовою, полягає у функціонуванні цілісної системи дидактичних засобів (змісту, методів, прийомів тощо), що адаптує освітній процес до структурних і організаційних вимог навчального проєктування (Подобєдова, 2005) як специфічного індивідуально-творчого процесу, що вимагає від кожного учасника оригінальних рішень, і водночас, як процес колективної творчості.

Проєктна діяльність, за Енциклопедією освіти, характеризується як конструктивна і продуктивна діяльність особистості, спрямована на розв'язання життєво значущої проблеми, досягнення кінцевого результату в процесі цілевизначення, планування і здійснення проєкту. Вона належить до унікальних способів людської практики, пов'язаної із передбаченням майбутнього, створенням його ідеального образу, здійсненням та оцінкою наслідків реалізації задумів. Проєктування виступає як творча, інноваційна діяльність, оскільки завжди спрямована на створення об'єктивно і суб'єктивно нового продукту (Енциклопедія освіти, 2008, с. 717).

Зауважимо, для успішного впровадження проєктної діяльності необхідно, щоб педагог із учителя перетворився на помічника, порадника, який завжди поруч із учнем. Суттєво, що при цьому проєктна діяльність розширює учню поле нової для нього діяльності, сприяючи тим самим появі широкого кола інтересів, і потім, через них, здійснює вплив на формування його переконань та світогляду (Матяш, 2000, с. 148).

Таким чином, резюмуючи викладене і погоджуючись із Н. Дереклеєвою, вважаємо, що проєктна діяльність учителя, зокрема початкової школи, має значний педагогічний потенціал, який розкривається через: сприяння соціальному розвитку тих, хто навчається; розвиток управлінських умінь у суб'єктів навчального процесу (робота в 
групі, планування, розподіл обов'язків тощо); формування соціальних навичок кооперування, спільного прийняття рішень, розуміння й оцінювання того, як індивідуальні внески можуть скласти успішне ціле; серію продуктивної діяльності, де все спрямоване на досягнення кінцевого результату - продукту: ті, хто навчається, можуть реально відчути радість успіху; розвиток незалежності, тому що ті, хто навчаються, приймають власні рішення; сприяння розвитку тих, хто навчається, почуття впевненості у власних можливостях, адже передбачає презентацію та захист отриманих результатів; позитивний вплив на емоційний і персональний розвиток того, хто навчається (Дереклеева, 2001).

Висновки та перспективи подальших наукових розвідок. Отже, нами проаналізовано дефініції «проєкт», «навчальний проєкт», «метод проєктів», «проєктна технологія», сутнісні ознаки яких поглиблюють розуміння поняття «проєктна діяльність». Для вчителя початкової школи реалізація ціннісних настанов проєктної діяльності спричиняє зміни професійної позиції вчителя, коли з носія знань він перетворюється на організатора пізнавальної діяльності своїх учнів, забезпечує досягнення нової якості освітнього процесу, трансформуючи його у простір «вирощування нових компетенцій, які стимулюють самоорганізацію педагогічної системи як відкритої, спрямованої на становлення особистості як суб'єкта життєтворчості; існування проєктно-технологічного типу організаційної культури діяльності» (Енциклопедія освіти, 2008, с. 718). Відтак, перспективи подальших наукових розвідок пов'язуємо 3 розкриттям виховних можливостей проєктної діяльності сучасного вчителя початкової школи.

\section{ЛІТЕРАТУРА}

Єрмаков, І. (2006). Компетентнісний потенціал проектної діяльності. Школа (Шкільний cвim), 5, 5-11 (Yermakov, I. (2006). Competence potential of project activity. School (School world), 5, 5-11. Retrieved from: old.ippo.edu.te.ua/files/metod_work/structure mw/09_kompetent_potencial.pdf

Новий тлумачний словник української мови, Т. 3 (2008). Київ: Аконіт (New explanatory dictionary of the Ukrainian language, Vol. 3 (2008). Kyiv: Aconite).

Лебедева, А. И., Иванова, Е. В. (2002). Метод проектов в продуктивном обучении. Школьная технология, 5,116-120 (Lebedeva, A. I. \& Ivanova, Е. V. (2002). Project method in productive learning. School technology, 5, 116-120).

Онопрієнко, О. В. (2013). Проектна діяльність у початковій школі: методичний посібник. К.: ТОВ «СІTIПРІHТ» (Onoprienko, О. V. (2013). Project activity in primary school: manual. Kyiv: CITYPRINT LLC.).

Талызина, Н.Ф. (1988). Формирование познавательной деятельности младших школьников. М.: Просвещение (Talyzina, N. F. (1988). Formation of cognitive activity of junior schoolchildren. Moscow: Enlightenment).

Пєхота, О. М., Кіктенко, А. З., Любарська, О. М. та ін. (2003). Освітні технології. Київ: IC. A.C.K. (Pekhota, O. M. \& Kiktenko, A. Z., Liubarska, O. M. et al. (2003). Educational technologies. Kyiv: IS. A.S.K). 
Михайлишин, Р. (2016). Метод проектів у початковій школі як педагогічна технологія. Вісник Львівського університету. Серія педагогічна, 30, 43-53 (Mykhailyshyn, R. (2016). The method of projects in primary school as a pedagogical technology. Bulletin of Lviv University. Pedagogical Series, 30, 43-53).

Полат, Е., Петрова, И., Бухаркина, М., Моисеева, М. (2004). Что такое проект? Відкритий урок, 5-6, 10-17 (Polat, E. \& Petrova, I., Bukharkina, M., Moiseeva, M. (2004). What is a project? Open lesson, 5-6,10-17.

Полат, Е. С. (2000). Метод проектов на уроках иностранного языка. Иностранные языки в школе, 3, 3-9 (Polat, E. S. (2000). Method of projects in foreign language lessons. Foreign languages in school, 3, 3-9).

Симоненко, В. Д., Ретивых, М. В., Матяш, Н. В. (1999). Технологическое образование школьников: теоретико-методологчческие аспекты. Брянск: Изд. БГпУ (Simonenko, V. D. \& Retivykh, M. V., Matyash, N. V. (1999). Technological education of schoolchildren: theoretical and methodological aspects. Briansk: Ed. BGPU).

Хуторской, А. В. (2001). Современная дидактика. Санк-Петербург: Питер (Khutorska, А. V. (2001). Modern didactics. Saint Petersburg: Piter).

Новіков, А. М., Новіков, Д. А. (2007). Методологія. М.: Синтег (Novikov, А. M. \& Novikov, D. A. (2007). Methodology. M.: Sinteg).

Зимняя, И. А., Сахарова, Т. Е. (1991). Проектная методика обучения английскому языку. Иностранные языки в школе, 3, 9-12 (Zimniaia, І. А., Sakharova, T. Е. (1991). Project methods of teaching English. Foreign languages in school, 3, 9-12).

Мелашенко, К. М. (2006). Технологія проектного навчання. Завуч, 13 (271), 12-14 (Melashenko, K. M. (2006). Project learning technology. Zavuch, 13 (271), 12-14).

Метод проектів: особливості застосування в початковій школі (2009). Київ: Вид.-во КМПУ ім. Б. Грінченка (Project method: features of application in primary school (2009). Kyiv).

Подобєдова, Т. Ю. (2005). Підготовка майбутніх вчителів гуманітарного профрілю до педагогічного проектування (автореф. дис. канд. пед. наук: 13.00.04). Луганськ (Podobedova, T. Yu. (2005). Preparation of future teachers of the humanities for pedagogical design (PhD thesis abstract). Luhansk).

Енциклопедія освіти (2008). Київ: Юрінком Iнтер (Encyclopedia of Education (2008). Kyiv: Yurinkom Inter).

Матяш, Н. В. (2000). Генезис и сущность понятия «Проектная деятельность школьников». Технологическое образование сельских школьников в современных условиях. 146-154 (Matiash, N. V. (2000). Genesis and essence of the concept of "Project activity of schoolchildren". Technological education of rural schoolchildren in modern conditions, 146-154).

Дереклеева, Н. И. (2001). Научно-исследовательская работа в школе. М.: Вербум-М (Derekleeva, N. I. (2001). Research work at school. M.: Verbum-M).

\section{PEЗЮME}

Прима Раиса, Прима Дмитрий. Проектная деятельность учителя начальной школы: теоретические аспекты.

Целью статьи является раскрытие некоторых аспектов проектной деятельности учителя начальной школы, сущностных признаков метода проектов, проектной технологии. В статье использованы методы исследования: теоретические (анализ справочных изданий, научно-педагогической литературы); интерпретационно-аналитический метод, обобщение. В контексте поиска новых средств и методов формирования творческой личности, ее жизненно важных компетентностей актуализирована проектная деятельность как одна из наиболее 
значимых составляющих образовательного процесса, что создает условия для творческого саморазвития и самореализачии учащихся. Проанализированы различные подходы относительно дефиниций «проект», «учебный проект», "метод проектов», «проектная технология», сущностные признаки которых углубляют понимание понятия «проектная деятельность».

Ключевые слова: учитель начальной школы, метод проектов, учебный проект, проект, проектная деятельность, проектная технология, технология обучения.

\section{SUMMARY}

Prima Raisa, Dmitry Prima. Project activities of primary school teachers: theoretical aspects.

The purpose of this article is to reveal some aspects of the project activity of the primary school teachers, essential features of project method, project technology. The article used research methods: theoretical (analysis of reference books, academic literature); interpretation-analytical method, synthesis. In the context of finding new means and methods of creative personality formation, its vital competencies updated project activity as one of the components of the educational process, which creates conditions for creative selfdevelopment and self-realization of students. There were analyzed different approaches regarding the definitions of "project", "training project", "project method", "project technology", the essential characteristics which enhance the understanding of the concept of "project activities". It is noted that dominant idea that constitutes the semantic core of the concept of "project", is a "pragmatic focus on the result achieved under the solution of this or that practically or theoretically significant problem".

There are selected characteristic features of the method of projects: there is a significant problem for students; first of all - children's interests; the dominance of the principle of independence in students activities; using various forms of school activity: individual, steam room, group; communication theory and practice; communication with real life; maximizing cognitive students' activity; development of creative students' skills, critical thinking skills to search for information; using a variety of methods and means of training; implementation of interdisciplinary connections; integration of knowledge from various branches of science and art; training students which become subjects of the study; including elements of student-centered learning, pedagogy of cooperation, activity-based approach to teaching. There were identified resent attitudes of scientists regarding interpretation of the notion "project method", the lack of a unified and distinct paradigm of its use, that context is understood as a method, technology of teaching, type of training and activities, the availability of scientific texts, alongside the traditional use of the term "project method" in relation to a new concept of "project technology". It defines the essence of project technology and project activities and prospects for the further research.

Key words: primary school teacher, project method, educational project, project activities, project technology, education technology. 
UDC 372.851

Oleksandr Shkolnyi National Dragomanov Pedagogical University ORCID ID 0000-0002-3131-1915

Yurii Zakhariichenko National University "Kyiv-Mohyla Academy" ORCID ID 0000-0001-7436-3435 DOI 10.24139/2312-5993/2020.03-04/245-254

\section{MODERN THEMATIC PREPARATION FOR EIA IN MATHEMATICS IN UKRAINE: TEXT PROBLEMS AND MATHEMATICAL ANALYSIS}

In modern realities, the relevance of research on thematic preparation for the IEA in mathematics is undeniable. Based on the author's experience of systematization and repetition of the school mathematics course in preparation for IEA, we propose to divide the entire mathematics course into 10 logical content blocks: "Numbers and expressions", "Functions", "Equations and systems of equations", "Inequalities and systems of inequalities", "Text problems", "Elements of mathematical analysis", "Plane geometry", "Space geometry", "Coordinates and vectors", "Elements of combinatorics and stochastics".

In this article, we provide thematic tests of the content blocks "Text problems" and "Elements of mathematical analysis", as well as answers to them. We also solve some of the basic tasks of these tests and give some methodological comments on these solutions. Traditionally, these topics cause significant difficulties for students in preparing for the test, so it is advisable for the teacher to pay special attention to them. We believe that a properly organized thematic systematization and repetition of the mathematics school course will allow students to successfully complete the IEA in mathematics and to help teachers achieve this success.

Key words: IEA in mathematics, SFA in mathematics, thematic preparation, educational achievements of students, thematic tests, basic tasks, text problems, mathematical analysis.

Introduction. External Independent Assessment (EIA) is now the main instrument of assessing the quality of mathematical preparation for Ukrainian senior school students. Also it is used for conducting the State Final Attestation (SFA) of academic achievements of graduates, as well as a tool for competitive selection of applicants to Ukrainian universities. Therefore, there is no doubt about the relevance and the need for research on different aspects of preparation for the EIA in mathematics.

One such aspect is the systematic and thematic repetition of the course of school mathematics. Based on our many years of experience in preparing for EIA, during this repetition we divide the whole mathematics course into 10 thematic blocks: "Numbers and expressions", "Functions", "Equations and systems of equations", "Inequalities and systems of inequalities", "Text problems", "Elements of mathematical analysis", "Geometry on the plane", "Geometry in the space", "Coordinates and vectors", "Elements of combinatorics and stochastics". 
This division allows constant repetition of the same material throughout the preparation process for the EIA. For example, different properties of elementary functions we can repeat during the studying of thematic blocks 2 , 3,4 , and 6 . This permits the teacher constantly to keep the student in a tone, when he or she would forget something important, but can't do this, because proposed thematic training system doesn't allow it.

Analysis of relevant research. The problem of preparing students for EIA in mathematics is systematically regarded in scientific and pedagogical publications in Ukraine. Permanently publish the results of their research in this area Valentyna Bevz, Mykhailo Burda, Hryhorii Bilianin, Olha Bilianina, Olha Vashulenko, Larysa Dvoretska, Oksana Yerhina, Oleksandr Ister, Vadym Karpik, Arkadii Merzliak, Yevhen Nelin, Victor Repeta, Oleksii Tomashchuk, Mykhailo Yakir and others. During the last 15 years, our author's team has been constantly working to provide methodological support for the process of preparation for the EIA in mathematics. The theory and methodology of assessing the academic achievement of senior school students in Ukraine is adduced in the monograph (Shkolnyi, 2015). For the training and systematization of the school mathematics course, we use the methodological set of books (Zakhariichenko et al., 2019a; 2019b). Previously, we had considered many different aspects of thematic preparation for independent testing in Ukraine, but since then the contingent of EIA participants has changed significantly, as well as the methodological views of our author's team on this problem are also progressed.

The aim of the article is to give some methodological advice to teachers and tutors regarding the thematic training of senior school students to EIA in mathematics. In particular, we present in this article two thematic tests related to the topics "Text problems" and "Elements of mathematical analysis", and also provide author's solution of the some basic tasks of these tests with methodological comments for them.

Research methods. In order to achieve this goal, we use in this paper some theoretical methods, such as an analysis of methodological literature on the research subject. Also, we apply some empirical methods: observation of the preparation process of the students during their studying on training courses for the EIA in mathematics and analysis of the results of their achievements. The research also used a set of methods of scientific cognition: a comparative analysis to find out different views on the problem and determine the direction of research; systematization and generalization for the formulation of conclusions and recommendations; generalization of author's pedagogical experience and observations.

Research results. Text problems have always been difficult to learn in school course of mathematics, because they required not only purely mathematical knowledge and skills, but also the skills of mathematical 
modeling of processes and phenomena of reality. Forming students' competences in this field is one of the most important tasks of the modern mathematics course in the school. Solving text problems enhances students' motivation to study mathematics, and these tasks show how important mathematical methods are in real life.

Mathematical analysis tasks have a different function - they develop the graduates' abstract thinking and help them feel the inner beauty of mathematics. However, the path to understanding this beauty lies in the hard work of the teacher and the student. The teacher should find clear examples of the tasks that reveal the essence of the basic concepts of mathematical analysis, and the student have to be persistent and diligent in performing the tasks selected by the teacher.

We believe that in preparing for the EIA, it is advisable to refrain from a variety of task forms in the repetition and systematization of the material of each topic, limiting only to open-ended tasks with full explanation, as they are the most effective for teaching mathematics and feedback. However, after finishing each of the 10 thematic blocks, it is natural to carry out a diagnostic thematic test in which to use all forms of test tasks inherent in the EIA math test.

Thematic test "Text problems".

Tasks 1-7 have five answer choices, only one of which is correct. Choose the correct answer, in your opinion.

1. The duration of the short film was 4 minutes. How many seconds did this movie last?

\begin{tabular}{|l|l|l|l|l|}
\hline A & B & C & D & E \\
\hline 400 & 40 & 240 & 24 & 2400 \\
\hline
\end{tabular}

2. The log $13 \mathrm{~m}$ long should be cut into two parts so that one part is $5 \mathrm{~m}$ shorter than the other. What length should be the smaller part of the cutted $\log$ ?

\begin{tabular}{|l|l|l|l|l|}
\hline A & B & C & D & E \\
\hline $5 \mathrm{~m}$ & $8 \mathrm{~m}$ & $2 \mathrm{~m}$ & $4 \mathrm{~m}$ & $9 \mathrm{~m}$ \\
\hline
\end{tabular}

3. To prepare 4 servings of cheese dumplings, you need a grams of cheese. How many grams of cheese are needed to prepare 12 such servings?

\begin{tabular}{|c|c|c|c|c|}
\hline $\mathbf{A}$ & B & C & D & E \\
\hline$\frac{3}{a}$ & $3 a$ & $\frac{a}{48}$ & $48 a$ & $\frac{a}{3}$ \\
\hline
\end{tabular}

4. 60 seats are reserved in the high-speed train, which is $\frac{5}{12}$ from the total number of seats in the train. How many seats in this train?

\begin{tabular}{|l|l|l|l|l|}
\hline A & B & C & D & E \\
\hline 25 & 119 & 288 & 35 & 144 \\
\hline
\end{tabular}

5. The cost of the first cake is $m$ UAH, and the second cake's cost is $30 \%$ less than the first. Determine the cost of the second cake (in UAH). 


\begin{tabular}{|l|l|l|l|l|}
\hline $\mathbf{A}$ & $\mathbf{B}$ & $\mathbf{C}$ & $\mathbf{D}$ & $\mathbf{E}$ \\
\hline $0,7 m$ & $m-30$ & $1,3 m$ & $m+30$ & $0,3 m$ \\
\hline
\end{tabular}

6. Only pencils and pens in the 4:1 ratio, respectively, are on the table. Specify a number that can represent the total number of items on this table.

\begin{tabular}{|l|l|l|l|l|}
\hline A & B & C & D & E \\
\hline 14 & 41 & 36 & 15 & 27 \\
\hline
\end{tabular}

7. Mary for 4 hours drove $36 \mathrm{~km}$. What distance will a girl travel in 3 hours, if she moves at the same speed?

\begin{tabular}{|l|l|l|l|l|}
\hline A & B & C & D & E \\
\hline $48 \mathrm{~km}$ & $144 \mathrm{~km}$ & $27 \mathrm{~km}$ & $9 \mathrm{~km}$ & $12 \mathrm{~km}$ \\
\hline
\end{tabular}

In the task 8 for each of the three rows of data marked with numbers, select the one correct, in your opinion, variant marked with a letter.

8. Match the beginning of the sentence $(1-3)$ and its end $(A-E)$ so that the correct statement will be formed.

Beginning of the sentence

End of the sentence

1 Number 513

A is simple number.

2 Number 109

B is even number.

3 Number 344

C is divided into 5 without a rest.

D is divided into 7 without a rest.

E is divided into 9 without a rest.

Solve tasks 9-11. Record the numeric answers you received in decimal or integer.

9. During the motorcycle show, two motorcyclists started to line up at the same time towards each other at constant speeds of $20 \mathrm{mps}$ and $16 \mathrm{mps}$.

1) How many meters in the first 4 seconds of movement did a motorcyclist pass, whose speed was slower?

2) Calculate the distance (in meters) that was between the motorcyclists at the time they started their traffic, if known that they met after 5 seconds.

10. The first tap fills the mineral water bath for 10 minutes, and the second tap fills it for 15 minutes. In what time (in minutes) will these two taps fill the bath, working together?

11. During the day, the tourist group made two crossings - flat $(9 \mathrm{~km}$ long) and mountainous ( $5 \mathrm{~km}$ long). During the flat transition, the group moved at a constant speed of $x \mathrm{~km}$ per hour, and during the mountain, it decreased that speed by $2 \mathrm{~km}$ per hour. Find out $x$, if you know that the total movement time of the group was 4 hours.

Solve the task 12. Write down sequential logical actions and explanations of all stages of task solving, make reference to the mathematical facts from which one or another statement follows. If necessary, illustrate the task solving with drawings, graphs, etc.

12. There are two solutions of the same acid, the concentration of acid in the first solution is $40 \%$ and in the second - is $10 \%$. 
1) Mix 300 grams of the first solution and 200 grams of the second. Find the concentration of acid in the resulting mixture.

2) How many grams of water should be added to 150 grams of the first solution so that the acid concentration in it becomes the same as in the second solution?

3) In what ratio (the weight of the first solution to the weight of the second solution) do you need to mix the two solutions to obtain the solution with $22.5 \%$ acid concentration?

Answers to the test "Text problems"

\begin{tabular}{|l|l|l|l|l|l|l|l|l|l|l|}
\hline $\mathbf{1}$ & $\mathbf{2}$ & $\mathbf{3}$ & $\mathbf{4}$ & $\mathbf{5}$ & $\mathbf{6}$ & $\mathbf{7}$ & $\mathbf{8}$ & $\mathbf{9}$ & $\mathbf{1 0}$ & $\mathbf{1 1}$ \\
\hline $\mathrm{C}$ & $\mathrm{D}$ & $\mathrm{B}$ & $\mathrm{E}$ & $\mathrm{A}$ & $\mathrm{D}$ & $\mathrm{C}$ & $1-\mathrm{E}, 2-\mathrm{A}, 3-\mathrm{B}$ & $1) 64 ; 2) 180$ & 6 & 4,5 \\
\hline
\end{tabular}

12. 1) $28 \%$, 2) 450 gram, 3) 5:7.

\section{Solutions and comments to tasks of test "Text problems".}

Task 5 (term of the task see above). Solution. To find the percentage of the number, you need to transfer that percentage into fractions and then multiply that fraction by a given number. Therefore, the discount for the second cake is equal to $0,3 \cdot \mathrm{m}$. Then the price of the second cake with a discount is equal to $m-0,3 m=0,7 m$ and the correct answer is $\mathbf{A}$.

Comment. One can solve this problem in another way. Let the price of the first cake be $100 \%$. Then the price of the second cake will be $100 \%-30 \%$ $=70 \%$ of the first cake price. Further, according to the rule given above, we have that the price of the second cake is $0,7 \mathrm{~m}$.

Different ways of solving show the student that almost any practical task has many alternative ways of getting the needed result. This contributes to the formation of an adequate outlook of the children and leads to a constant search for alternative solutions in different situations in their own life. In addition, the rule of finding the percentage of a number, unlike the method of using proportions, is simple and straightforward, and this rule works better in situations where the condition contains not a specific number but a parameter.

Task 11 (term of the task see above). Solution. According to the task term, the time of flat and mountain transitions are $\frac{9}{x}$ hours and $\frac{5}{x-2}$ hours respectively. Because the total time for the whole trip was 4 hours, we obtain the equation $\frac{9}{x}+\frac{5}{x-2}=4$. After solving of this equation, we will have $x_{1}=4,5$ and $x_{2}=1$. Obviously, the second solution does not satisfy the task term and the answer is $\mathbf{4 , 5}$.

Comment. The solution of this problem illustrates well all the steps of the mathematical modeling process. First, you need to separate the essential data from the irrelevant ones and make an equation that is a mathematical model of the practical problem. The condition of the task gives a little hint to the student exactly how to make this equation, because the variable whose value is to be 
found is already present in it. Next, you need to solve the mathematical problem correctly, that is, get the root equations. Finally, at the last stage, the student have to determine, which solutions of the mathematical problem will be the solutions of the practical problem and which do not satisfy its condition. The presence of such tasks enriches children, allows to develop their thinking and to form practical skills in the real world.

Thematic test "Elements of mathematical analysis".

Tasks 1-7 have five answer choices, only one of which is correct. Choose the correct answer, in your opinion.

1. Geometric progression $\left(b_{n}\right)$ is given by the formula $b_{n}=4 \cdot 3^{n-1}$. Calculate $b_{3}$.

\begin{tabular}{|l|l|l|l|l|}
\hline A & B & C & D & E \\
\hline$\frac{4}{3}$ & 4 & 12 & 13 & 36 \\
\hline
\end{tabular}

2. The first and second members of the geometric progression are 12 and 3 respectively. Calculate denominator $q$ of this progression.

\begin{tabular}{|l|l|l|l|l|}
\hline A & B & C & D & E \\
\hline 0,25 & -9 & 6 & 9 & 4 \\
\hline
\end{tabular}

3. Calculate the seventh term of the arithmetic progression, if the sum of the first 6 terms and first 7 terms of it are $S_{6}=22$ and $S_{7}=-4$ respectively.

\begin{tabular}{|c|c|c|c|c|}
\hline A & B & C & D & E \\
\hline 18 & $-\frac{11}{2}$ & -26 & $-\frac{2}{11}$ & 26 \\
\hline
\end{tabular}

4. Find the derivative of the function $y=4-\cos x$.

\begin{tabular}{|l|l|l|l|l|}
\hline A & B & C & D & E \\
\hline$y^{\prime}=-\sin x$ & $y^{\prime}=\sin x$ & $y^{\prime}=4 x-\sin x$ & $y^{\prime}=-\cos x$ & $y^{\prime}=4 x+\sin x$ \\
\hline
\end{tabular}

5. The figure shows a fragment of the function graph $y=f(x)$. Specify the number that can be the value of $f^{\prime}(3)$.

\begin{tabular}{|l|l|l|l|l|}
\hline A & B & C & D & E \\
\hline-3 & 0 & $-0,4$ & 0,7 & $-\sqrt{2}$ \\
\hline
\end{tabular}

6. It is known that $f^{\prime}(x)=x(x-4)$. Specify the interval at which the function $y=f(x)$ is decreased.

\begin{tabular}{|l|l|l|l|l|}
\hline A & B & C & D & E \\
\hline$(-\infty ;-3)$ & $(5 ;+\infty)$ & $(-2 ; 2)$ & $(3 ; 7)$ & $(1 ; 3)$ \\
\hline
\end{tabular}

7. Calculate the integral $\int_{0}^{1} \sqrt[3]{x} d x$. 


\begin{tabular}{|c|c|c|c|c|}
\hline A & B & C & D & E \\
\hline$\frac{4}{3}$ & $\frac{1}{3}$ & $\frac{3}{4}$ & $\frac{1}{4}$ & 1 \\
\hline
\end{tabular}

In the task 8 for each of the three rows of data marked with numbers, select the one correct, in your opinion, variant marked with a letter.

8. The figure shows a graph of a linear function $y=f(x)$. Match the beginning of the sentence $(1-3)$ and its end $(A-E)$ so that the correct statement will be formed.

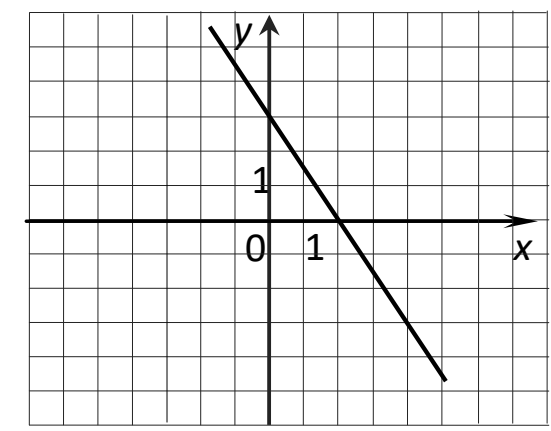

Beginning of the sentence

1 The value of $f(4)$ equals to

2 The value of $f^{\prime}(0)$ equals to

3 The value of $\int_{0}^{2} f(x) d x$ equals to
End of the sentence
A 3
B 0
C $-\frac{2}{3}$
D $-\frac{3}{2}$
E -3

Solve tasks 9-11. Record the numeric answers you received in decimal or integer.

9. The first three elements of an arithmetic progression $\left(a_{n}\right)$ have the form: $a_{1}=2 ; a_{2}=x ; a_{3}=3 x+20$. Find: 1$)$ the value of $x ; 2$ ) the fourth element of this progression.

10. It is known that $f(x)$ is odd and $\int_{-3}^{0} f(x) d x=15$. Calculate $\int_{-3}^{3}(5+f(x)) d x$

11. It is known that $x+y=10$. Find the smallest value of the expression $x^{2}+y^{2}$.

Solve the task 12. Write down sequential logical actions and explanations of all stages of task solving, make reference to the mathematical facts from which one or another statement follows. If necessary, illustrate the task solving with drawings, graphs, etc.

12. Let $f(x)=x^{3}-6 x^{2}+50$. Find:

1) the largest and smallest value of the function $f(x)$ on the segment $[-2 ; 5]$; 
2) the equation of the tangent drawn to the graph $f(x)$ at the point whose abscissa $x_{0}=1$;

3) the area of curved trapezoid bounded by the graph $f(x)$, abscissa axis and straight lines $x=1$ and $x=3$.

Answers to test "Elements of mathematical analysis»

\begin{tabular}{|l|l|l|l|l|l|l|l|l|l|l|}
\hline $\mathbf{1}$ & $\mathbf{2}$ & $\mathbf{3}$ & $\mathbf{4}$ & $\mathbf{5}$ & $\mathbf{6}$ & $\mathbf{7}$ & $\mathbf{8}$ & $\mathbf{9}$ & $\mathbf{1 0}$ & $\mathbf{1 1}$ \\
\hline $\mathrm{E}$ & $\mathrm{A}$ & $\mathrm{C}$ & $\mathrm{B}$ & $\mathrm{D}$ & $\mathrm{E}$ & $\mathrm{C}$ & $\begin{array}{l}1-\mathrm{E}, 2-\mathrm{D}, 3- \\
\mathrm{A}\end{array}$ & $\begin{array}{l}1)-22 ; 2)- \\
70\end{array}$ & 30 & 50 \\
\hline
\end{tabular}

12. 1) $f_{\min }=18, f_{\max }=50$, 2) $y=-9 x+54$; 3) 68 .

Solutions and comments to tasks of test "Elements of mathematical analysis".

Task 5 (term of the task see above). Solution. Since the function shown in the figure increases at a point $x_{0}=3$, then by the well-known theorem of differential calculus the derivative $f^{\prime}(3)>0$ and the correct answer can be $\mathbf{D}$ only.

Comment. This problem can be solved in another way using the geometric content of the derivative. In fact, by the figure, the tangent to the function graph $f(x)$ in the point $x_{0}=3$ forms a sharp angle with the positive direction of the abscissa axis. The tangent of this angle is obviously a positive number.

This task does not contain cumbersome technical calculations, it aims at understanding the essence of the concept of the derivative. Unfortunately, such problems cause difficulties for those students, who pay attention only to the technique of calculating derivatives and the use of known algorithms. Therefore, the teacher should emphasize that the good differentiation technique does not guarantee proper mastery of the subject matter.

Task 9 (term of the task see above). Solution. 1) Using the criterion of arithmetic progression, we get that $a_{2}=\frac{a_{1}+a_{3}}{2}$, whereof $x=\frac{2+3 x+20}{2}$ and $x=-22$.

2) Find the difference of this progression: $d=a_{2}-a_{1}=-22-2=-24$. Thus, $a_{4}=a_{1}+3 d=2+3 \cdot(-24)=-70$.

Comment. The second part of this task can also be solved using the arithmetic progression criterion, but we think that during the repetition we need to use so many formulas associated with the topic as possible. The above given solution of item 2) allows to repeat the definition of the difference of arithmetic progression and the formula of its general term.

During considering arithmetic and geometric progressions it is also important to emphasize that their names originate precisely from the characteristic properties (criteria) of these sequences. Indeed, each element of the arithmetic (geometric) progression, starting with the second, is the arithmetic (geometric) mean of the two adjacent elements of that progression. Such an emphasis contributes to the growth of cognitive interest in children, 
both to the mentioned progressions and to other sequences that have numerous practical applications.

Conclusions. Text problems and mathematical analysis tasks have a significant worldview in the learning process. They contribute to the formation of practical competences and development of abstract and critical thinking of the children. That is why the EIA test in mathematics contains tasks on these topics. During preparation for the test, the teacher has an opportunity to pay attention to such tasks, further emphasizing their importance.

We believe that well-organized thematic preparation for external independent assessment in mathematics will allow teachers to cope with the problems encountered by students in the systematization and repetition of the school mathematics course. We sincerely hope that the suggested methodological tips will be useful for all experts involved in this process. In future publications, we plan to continue to look at the repetition features for all of the above thematic blocks, as well as provide the summary test for each such block with solutions to the basic tasks and with providing of methodological comments to them.

\section{REFERENCES}

Shkolnyi, O. V. (2015). The basic of theory and methodology of educational achievements for senior school students in Ukraine. Kyiv: Dragomanov NPU Publishing.

Zakhariichenko, Yu. O., Shkolnyi, O. V., Zakhariichenko, L. I., Shkolna, O. V. (2019a). Full course of math in tests. Encyclopedia of test items. In 2 parts. Part 1. Tasks of different levels. 9-th edition. Kharkiv: Ranok.

Zakhariichenko, Yu. O., Shkolnyi, O. V., Zakhariichenko, L. I., Shkolna, O. V. (2019b). Full course of math in tests. Encyclopedia of test items. In 2 parts. Part 2. Theoretical information. Thematic and final tests. 3-rd edition. Kharkiv: Ranok.

\section{АНОТАЦІЯ}

Школьний Олександр, Захарійченко Юрій. Сучасна тематична підготовка до ЗНО з математики в Україні: текстові задачі і математичний аналіз.

у сучасних умовах актуальність досліджень, присвячених тематичній підготовці до зно з математики, не викликає сумнівів. Спираючись на авторський досвід систематизації й повторення шкільного курсу математики під час підготовки до зНО, ми пропонуємо поділ всього курсу математики на 10 логічних змістових блоків: "Числа і вирази», "Функції», "Рівняння та системи рівнянь», "Нерівності та системи нерівностей», "Текстові задачі», "Елементи математичного аналізу», "Планіметрія», "Стереометрія», "Координати $i$ вектори», "Елементи комбінаторики і стохастики».

у цій статті ми наводимо тематичні тести змістових блоків "Текстові задачі» та "Елементи математичного аналізу», а також відповіді до них. Також ми розв'язуємо окремі базові задачі цих тестів та подаємо методичні коментарі до цих розв'язань. Традичійно саме наведені теми викликають значні труднощі в учнів під час підготовки до тестування, тому вчителю доцільно звернути на них особливу увагу. Ми вважаємо, що належним чином організована тематична систематизація й повторення шкільного курсу математики дозволить учням успішно скласти зНО з математики, а вчителям сприяти досягненню цього успіху. 
Ключові слова. ЗНО з математики, ДПА з математики, тематична підготовка, навчальні досягнення учнів, тематичні тести, базові задачі, текстові задачі, математичний аналіз.

\section{PEЗЮМЕ}

Школьный Александр, Захарийченко Юрий. Современная тематическая подготовка к ВНО по математике в Украине: текстовые задачи, математический анализ.

В современных условиях актуальность исследований, посвященных тематической подготовке к ВНО по математике, не вызывает сомнений. Опираясь на авторский опыт систематизации и повторения школьного курса математики при подготовке к ВНО, мы предлагаем разделение всего курса математики на 10 логических смысловых блоков: "Числа и выражения», "Функции», "Уравнения и системы уравнений», "Неравенства и системы неравенств», "Текстовые задачи», "Элементы математического анализа", "Планиметрия", "Стереометрия", «Координаты и векторы», "Элементы комбинаторики и стохастики».

Ключевые слова: ВНО по математике, ГИА по математике, тематическая подготовка, учебные достижения учащихся, тематические тесты, базовые задачи, текстовые задачи, математический анализ. 


\title{
РОЗДІЛ V. ПРОБЛЕМИ МИСТЕЦЬКОї ОСВІТИ
}

\section{UDC 378.016:78}

\author{
Olena Enska \\ Sumy State Pedagogical University \\ named after A. S. Makarenko \\ ORCID ID 0000-0001-8860-3495 \\ Svitlana Kramska \\ Sumy State Pedagogical University \\ named after A. S. Makarenko \\ ORCID ID 0000-0002-1114-1402
}

DOI 10.24139/2312-5993/2020.03-04/255-265

\section{PECULIARITIES OF EMOTIONAL CULTURE FORMATION OF FUTURE TEACHERS OF ART PROFILE IN CONDITIONS OF THE HIGHER SPECIAL EDUCATION INSTITUTION}

The article substantiates the concept of "emotional culture of the teacher", defines its essence, reveals significance of the content of educational material in the context of formation of this phenomenon for the specialties "Musical Art" and "Choreography". The article outlines practical and methodological directions of nurturing the culture of emotions of the future specialist of art profile, enriching his emotional sphere in the course of work on an artistic image in educational repertoire samples on a specialty.

Key words: emotional culture, artistic image, teacher of art profile, choreography, musical art.

Introduction. The National Doctrine of Education Development of Ukraine in the XXI century emphasizes creation of conditions for the formation of the future teacher's professional culture as a priority task of modernity. The effectiveness of solving the problems of modernization of our education system at the present stage of its development depends to a large extent on this. That is why among the priority areas of modern art and pedagogical science an important place is occupied by the study of the range of issues of the future specialist's professional culture formation, in particular his/her emotional culture.

Analysis of relevant research. Various aspects of culture formation have attracted attention of many scholars. M. Bakhtin, M. Berdiaiev, H. Skovoroda, E. Fromm and others studied different issues of spiritual culture. The problem of moral culture formation was reflected in the works of T. Bilenko, 0 . Bohdanova, S. Ikonnykova, V. Tolstykh and others. The essence of aesthetic culture is defined in the works of M. Boholiubska, V. Butenko, O. Yeremenko, M. Kyiashchenko, M. Leizerov, O. Mykhailychenko, H. Padalka, H. Poliakov, L. Tsvetkova and others. T. Antonenko, V. Bachynin, L. Koval, N. Krylova, $H$. Shevchenko and others in their studies focus on finding the means and ways to form a culture of feelings in the younger generation. 
Psychological aspects of the culture of feelings and emotions are reflected in the works by B. Ananiev, L. Bozhovych, V. Viliunas, L. Vyhotskyi, H. Kostiuk, S. Rubinstein, B. Teplov, P. Jacobson and others. Problems of emotional culture are covered in the works of L. Abolin, P. Anokhin, M. Bakhtin, A. Bielkin, V. Viliunas, P. Halperin, O. Kyrychuk, M. Leizerov, V. Lysovskyi, O. Rudnytska, O. Chebykin, N. Chepelieva, P. Jacobson, T. Yatsenko. In recent decades, the problem of emotional culture of the individual has attracted attention of such scientists as I. Annienkova, V. Blahova, V. Dodonov, I. Mohylei, V. Semke, L. Sokolova, S. Rapport, M. Teleshevska. In their opinion, emotional culture is not only an important component of spiritual culture, but also an integral part of professional culture, one of the criteria for assessing the future teacher's pedagogical skills. Scientists believe that combination of thoughts, feelings, emotions and ideas help the future teacher to perceive the world around him/her in all its material and spiritual wealth, to find the best noble feelings, to pass them on to his/her students, to encourage them to self-improvement. Psychologists and teachers note that emotional processes play an important role in the formation of the personality, and emotional culture is an integral part of his/her spiritual culture. Emotions help to reveal inner world of the person, influence his/her actions, play the role of regulator of human communication. Humanization of education, along with other transformations of the traditional pedagogical process involves assertion of self-worth and uniqueness of the human personality, appeal to the inner world of the person, emancipation of his/her emotional life, attention to emotional states and manifestations of the student and, consequently, to emotional aspects of education and upbringing. Only a humanistically oriented teacher with a developed emotional culture can realize him/herself in all these directions. Modern pedagogical technologies provide for the comprehensive harmonious development of the individual, disclosure of his/her creative potential, creation of conditions for self-development, self-realization in various types of education institutions, which should become a school of professional and emotional development of future specialists.

The aim of the article is to substantiate theoretically a set of pedagogical approaches to the formation of emotional culture of the future art teacher in the process of higher professional education (based on the study of artistic image in samples of educational repertoire in specialties "Music" and "Choreography").

Research methods. To achieve the goal of the study, the following research methods were used: analytical - to study pedagogical, psychological, methodological and art sources in order to solve the chosen problem; method of generalization - to highlight the conceptual apparatus of the work, formulate its theoretical provisions, disclose methodological aspects and make conclusions.

Research results. Of particular interest in art pedagogy is the concept of "emotional culture of the teacher". Based on the philosophical, psychological and pedagogical analysis of the concepts of "emotions" and "culture", the emotional 
culture of the future specialist is considered as a complex personal entity, integrated professionally significant quality that has acquired value orientation, systemic character, integrity, ability to self-management and self-regulation; it allows to identify, understand, regulate one's own emotions, experiences, take into account the emotional state of one's students and teach them how to regulate their own behavior and guide the mood of others, and thus functionally ensures development of the teacher's personality, meets personal and professional needs, ensures pedagogical efficiency (Annienkova, 2003, p. 7).

The emotional culture of a teacher is a meaningful, original in pedagogy and incompletely studied phenomenon, which is of great interest in the modern process of training art teachers. Of course, for teaching children art (in our context it is musical art and choreography), for developing the ability to teach young performers or students to feel and see the beauty of the world in melodic combinations of musical sounds with plasticity of movement, the future teacherartist must have a high level emotional culture during professional training, which will allow him/her, in turn, to understand the depths of the most beautiful arts with the romantic names "Music" and "Choreography" and determine the success of his/her professional activity. That is why emotional culture is an indicator of artistic and pedagogical professionalism, important characteristics of which are the ability of the teacher-artist to manage his/her own emotional state and mood of his/her students, mastering the techniques of emotional regulation of professional behavior and methods of students' emotional upbringing.

In modern conditions there is an urgent need to use in the pedagogical practice of higher education institutions a variety of such forms and methods of future teachers' emotional upbringing, which will ensure a high level of formation of their emotional culture. These can be communicative and emotional trainings, pedagogical and psychological sketches, playing business games, emotional situations, etc.

The study of this issue has led to the delineation and specification of practical areas of work on the formation of future art teachers' emotional culture, which can be carried out in the educational process at the faculties of training specialists in art specialties. The search for new approaches to solving this problem has led to identification of new ways and opportunities in the direction outlined above.

For example, it can be quite interesting, useful and effective to use in the process of special training of art teachers specialized seminars on the formation of emotional culture of the future teacher (a similar program can be found in the research of an author-scientist I. Mohilei) (Mohilei, 2000, p. 12), inclusion in the activities in the outlined direction of socio-psychological, emotional and communicative trainings, strengthening of the personalconcretizing approach in individual training of students-choreographers and musicians, pedagogical practice and concert-performance activity of students. 
Taking into account the above mentioned, one of the important places in the process of future art specialists' emotional upbringing, primarily, belongs to the group and individual forms of training in the specialties "Musical Art" and "Choreography". For conducting classes in the outlined specialties, the most effective can be disciplines of professional cycle, since they occupy the most important place among other disciplines in the educational process.

In art pedagogy there is an opinion that success of professional training largely depends on the selection of appropriate educational material for the formation of emotional culture of the future teacher, on the pedagogical and creative conditions created in the classroom to provide students with theoretical information and correctly chosen methods of emotional selfregulation, which are important components of emotional culture.

Undoubtedly, one of the main conditions for the formation of emotional culture of the future art teacher is professionally selected educational material. Proper selection of a variety of genres and styles of repertoire, its construction according to the level of complexity and sequence of study of certain educational patterns, work on artistic images in both musical works and choreographic productions - all this helps to maintain students' interest in creativity and art itself. In addition, it can cause a wide range of their emotional experiences, aimed at emotional culture upbringing. From this perspective, educational creative material can become for future professionals an emotionally vivid source of knowledge about the way of life, color and spiritual content of the historical epoch. Indicative in this regard was, is and always will be the work of classics and luminaries of art.

Undoubtedly, classical samples, being a "model of taste", absorb the unity of form and content, harmonious clarity and completeness, depth and subtlety of the embodiment of feelings. The emotional imagery of the work, which reflects all the characteristic phenomena of life in all its diversity, creates the possibility of influencing the emotional sphere of the individual and through it on the aesthetic consciousness and artistic taste" (Padalka, 2001, p. 190).

Thus, we can assume that formation of emotional culture of future art teachers is largely determined by the level of formation of their ability to image-emotional thinking, the essence of which is to reflect connections and relationships of the objective world by creating images and operating them. "Figurative thinking reflects essential connections of reality in a specific way by embodying them in movement and changing the images of ideas, i.e. through the transformation of ideas" (Itelson, 2005, p. 193). Scientists note that the image arises when the task set before a person awakens in him/her a personal attitude, affects his feelings, emotions, needs and interests. "Virtually any task ... leads to the mechanism of representation only when it acquires a certain emotional significance for the person" (Itelson, 2005, p. 212). 
Thus, in the outlined aspect, the scientist S. Rapport emphasizes the leading role of emotional basis in the processes of artistic and figurative thinking. He sees the difference between artistic and figurative thinking from logical in the fact that the first characterizes desire to reveal a person's attitude to reality, while the second is abstracted from it (Rapport, 1973, p. 52).

The process of thinking of the performer, which includes operation of musical-auditory and motor representations, is one of the types of representation of pitch and rhythmically organized sounds and experience of their expressive meaning, which is reflected in the movement. As a result of perception and transformation of creative (musical, choreographic) impressions, they necessarily include an emotional component. In this context, B. Teplov notes that "... to understand a work of art means, first of all, to feel it, to experience it emotionally and already on this basis to think about it. Promotion of art must begin with feeling, it must go through it, without feeling art is impossible" (Teplov, 2005, p. 10).

But it should be emphasized that artistic perception is not limited to feelings. The performer's consciousness is able not only to perceive artistic phenomena, but also to process them, revealing constructive and logical connections. Therefore, creative knowledge of the performed material can be defined as the unity of emotional and rational basis. "Only penetration into the expressive and semantic subtext of intonation, on the one hand, and understanding of the logical organization of sound structures, on the other, emphasizes $H$. Tsypin - create in their synthesis musical thinking in the true sense of the term" (Tsypin, 1975, p. 23).

Highlighting this problem, it is important to note that the source of the creative process is always the image, in which the central place belongs to emotions.

Undoubtedly, emotion that reveals a person's attitude to the events of reality, their evaluation, determines that the primary image (allegedly, the imageimpulse) for any person of art always has a deep personal meaning. In art pedagogy there are interesting thoughts on this subject. Such an image-impulse is presented by scientists-artists as a "figurative idea coming from the world of social phenomena", this phenomenon is also interpreted in science as "an emotionimage born of a deep human experience". It should be noted that the image (in the context of this topic -an artistic image in a choreographic composition or in a musical work) can also be a specific image - a visual image of an event, object, phenomenon, which arose during direct observation, experience or by association". We often come across a similar image, which is considered in the work as "musical intonation-image", which may consist of a technological detail, melodic warm-up, harmonic inversion, timbre effect, which may be otherwise heard by the director of the choreographic composition or musical-performing team and presented in a new artistic and figurative context (Mohilei, 2000, p. 16). 
It should be noted that in L. Vygotsky's psychological research "emotion" is considered as the main component of the creative process. The function of emotion, according to his interpretation, lies in selecting and organizing different information. It is important to understand that emotion (as a psychological phenomenon) has "... the ability to pick up impressions, thoughts and images that are in tune with the mood we have at the moment. ... This feeling selects individual elements of reality and combines them into a connection that is determined from within by our mood, and not from the outside, by the logic of these images themselves. This influence of the emotional factor on the fantasy, which combines ..., is called the law of the general emotional sign" (Boholiubska, 1986, p. 13).

It is quite natural that emotional perception of creative material, experience of a synthetic image and its artistic transmission can cause various emotional processes in the minds and psyches of students of art specialties. When repeated, such processes, entrenched in emotional memory, contribute to the emergence of emotional settings to the creative attitude to art and the surrounding reality.

Working on an artistic image in a piece of art forms in future teachersartists an artistic, emotional attitude to the real world. In the process of working in a choreographic or music class, students learn to operate with figurative-visual, figurative-auditory representations, to create in the imagination new figurative representations and combinations of elements of sound or movement, visual and verbal material. Positive emotions arise not only from listening to and understanding the purpose of specific interesting professional techniques, but also from the feeling of freedom of performance technique and muscular load that appear during work or performance, from the student's awareness of the emotional content of the material chosen for study.

But we should return to the emotional sphere of the student, where the basis is rightly considered to be positive experiences arising from thoughtful execution and awareness of the feasibility and beauty of educational material, the ability to "live" the image and reproduce the author's artistic idea by the performing team. Therefore, the first acquaintance with one's emotions, arising in the process of theoretical and practical classes in the specialty, occurs during acquaintance with musical content of the material, with presentation of the choreographic palette of artistic movement and plasticity, work on technical and performance techniques. This is the first training of expressing emotion with the help of the performing apparatus, which is possible on the basis of combining the content of creative material with the means of its expression in the direct manifestation of the corresponding emotions.

Based on the experience of researchers on this issue, we can also recommend active use of exercises that teach the "art of intonation" for the development of intonation. It is appropriate to use the exercise "musical 
dialogue", which will help develop future skills of musical abilities, will promote a more conscious understanding of musical phrasing and its reflection in movement or dance, will stimulate performance improvisation. This will ensure development of musicality (of both students-musicians and future teachers of choreography), enhance the ability to operate with figurative representations in close semantic connection with the artistic idea of the work, the desire to improvise.

Outlining methodological approaches to the formation of emotional culture of future art teachers, it may be interesting to use carefully selected exercises, taking into account the specifics of the chosen specialty. These can be exercises of a wide range of performance, taking into account the aspect of improving not only technical performance skills, but also the direct focus of the educational material (both musical and choreographic) on the development of students' emotional culture.

Going deeper into the methodological approaches to the formation of emotional culture of future teachers-artists, it is important not to lose in practice of working on educational material resistance to the emotionally expressive basis of all elements of artistic language, which can significantly expand various manifestations of emotional state. For example, pedagogical observations in the chosen plan reveal that the sound of "minor" in a musical composition (chosen to be performed by musicians or as an accompaniment in the work of choreographers) causes a special emotional sensitivity and almost always gives increased emotional reaction of students. A conscious attitude to "major" and "minor", assimilation of their emotional expressive qualities not only enriches artistic perception and creative imagination, but also significantly expands the possibilities of various expression of feelings and moods during the performance of the work both in the performing team and the audience.

The next effective factor of emotional culture of the future teacher of art profile is the language of music. Melody, musical form, dynamic palette of shades, timbre, tempo variety - all these components of musical language activate the work of all the senses of the student and can influence development of the personality in general.

It is common knowledge that in the classes of the professional cycle we use several works of different sounds. We'd like to note that the nature of music is especially felt by students in contrasting works. Therefore, it is advisable to transfer students from one emotional state to another, from a holistic perception of the nature of the work or composition to understanding peculiarities of its musical and artistic language, and then again to a holistic perception, but at a higher professional level.

It is worth noting that in the process of working on the artistic image, students improvise in the classroom, conveying the pass-through action of various dynamics and its shades, articulation, strokes, phrasing and original performance interpretation. 
It can be interesting and useful in terms of emotional culture development to create such emotional learning situations that will make students-artists not only feel the emotional content of the performance material, but also think, above all, about its ideological meaning. In purposeful work on the piece, one should start, first of all, from students' direct emotional response, awareness of the peculiarities of musical and artistic language, it is appropriate to go through the mental process to a higher level of development - creativity.

It should be emphasized that gradual complication of variable "structures" of emotional stimuli (and performance material should be considered as a kind of system of emotional development that can provoke students' emotional reaction), should support such an important component as emotional interest based on positive emotions of surprise, admiration, "tasting".

It is quite natural that in the process of emotional empathy for the musical and artistic image and awareness of the content of the choreographic work, students get acquainted and master a range of expressive means, learn to understand their relationship with the emotional content of music and movement. It is a kind of programming of the formation of the student's culture of emotions, which improves his ability to understand the unique world of artistic images. Deep penetration into the artistic image is a real school of experiences. By moderate, purposeful actions on the emotional world of the future art teacher, we understand aesthetic emotions, form new emotional relationships that will be transferred to other, similar in meaning situations. Psychologists believe that such processes do not go unnoticed. Aesthetic emotions, which arise under the influence of artistic images of various works, go through a complex process of intellectual and moral enrichment and grow to the level of a generalized worldview (Itelson, 1970, p. 198).

Speaking about methodological directions of the process of forming teachers-artists' emotional culture, we should stress the importance of conversations with students about art, music, choreography, fine arts, people's characters, moral problems facing humanity, linking all these topics with artistic images of art pieces, which concentrate and present the whole set of universal values. It is important to get the student interested in the possibility of a new interpretation and originality of the work presentation, the sound of new intonation reliefs, which are reflected in the choreographic masterpieces. After all, a sense of interest, surprise is of great importance in creative activities. Undoubtedly, the language of music is the language of emotions, subtle mental movements, which requires expressive emotional performance.

It is well known that the first acquaintance with a highly artistic work is quite bright and strong. That is why great importance should be attached to the emotional and extremely expressive illustration of the work, which will convey its content in a dramatic sequence. Undoubtedly, only emotional performance can evoke vivid impressions and emotions in students, become entrenched in memory, and evoke creative imagination. 
It is worth noting that when working on an educational creative sample, a high level of emotional enthusiasm does not appear at the first lessons. It occurs later, when students understand the structural features of the work. It is believed that the work on creating an artistic image is very complex and even unforeseen, because in this type of activity, personal creative qualities of the student as a leader of the creative process and as a performer are nurtured. It is important that in this process of creating an artistically colored image, students' experiences of various emotional states of cogitation, sadness, joy and other emotional nuances were involved. Only emotionally saturated work on the creative material and the artistic image in it, a kind of filling of the performance material with emotions can cultivate the emotional culture of the future art specialist.

The very moment of performing a work with a meaningfully experienced and emotionally colored artistic image gains great importance in the process of forming the emotional culture of future teachers of art profile. It is especially important in the case of a concert performance, which is considered as a result of work on the piece of art, as a kind of a stage of the future specialist's professional growth.

Conclusions and prospects for further research. An important component of the future art teacher's professional development is the level of his/her emotional culture formation. It involves the search for and implementation of interesting and effective ways of organizing the educational process, which will ensure its effectiveness. Educational and cognitive activities of students majoring in "Musical Art" and "Choreography" should be aimed at understanding the role of emotional culture in their professional activities. Teachers should encourage future art specialists to learn the basics of emotional culture, create a favorable emotional atmosphere in the classroom, provide conditions for students' active work on the application of acquired knowledge, skills and abilities in educational activities, develop individual models of interaction with students.

\section{REFERENCES}

Аннєнкова, І. П. (2003). Формування емоційної культури майбутніх учителів у процесі вивчення педагогічних дисциплін (автореф. дис. ... канд. пед. наук). Одеса (Annienkova, I. P. (2003). Formation of emotional culture of future teachers in the process of studying pedagogical disciplines (PhD thesis abstract). Odesa).

Благова, Т. О. (2009). Особливості професійної підготовки майбутніх учителів-хореографів у системі педагогічної освіти. Збірник наукових праць. Полтава, 145-153 (Blagova, Т. О. (2009). Features of professional training of future teachers-choreographers in the pedagogical education system. Collection of scientific works. Poltava, 145-153).

Боголюбська, М.С. (1986). Музыкально-хореографическое искусство в системе эстетического и нравственного воспитания. Москва (Boholiubska, M. S. (1986). Musical and choreographic art in the system of aesthetic and moral education. Moscow).

Выготский, Л.С. (1991). Воображение и творчество в детском возрасте: Психологический очерк. Москва: Просвещение (Vygotsky, L. S. (1991). Imagination and creativity in childhood: A psychological essay. Moscow: Enlightenment).

Ительсон, Л.Б. (1970). Лекции по общей психологии. Владимир: Издво ВГПИ 
им. П. И. Лебедева-Полянского (Itelson, L. В. (1970). Lectures on general psychology. Vladimir).

Могилей, І. В. (2000). Формування емоційної культури майбутніх учителів музики (автореф. дис. ... канд. пед. наук). Харьков (Mohilei, I. V. (2000). Formation of emotional culture of future music teachers (PhD thesis abstract). Kharkiv).

Падалка, Г.М. (2001). Мистецька освіта студентської молоді: сучасні підходи. Молодь в сучасному світі: Морально-естетичні та культурологічні виміри, 188-192. К.: Вид. МУлП (Padalka, Н. М. (2001). Art education of student youth: modern approaches. Youth in the Modern World: Moral-Aesthetic and Cultural Dimensions, 188-192. Kyiv).

Полякова, Г.О. (2002). Реалізація завдань художньо-естетичної освіти майбутніх вчителів спеціальностей мистецтва. ХДУ збірник наукових праць «Педагогічні науки», Вип. XXX, 144-152 (Poliakova, H. O. (2002). Implementation of the tasks of art and aesthetic education of future teachers of art specialties. KhSU Collection of scientific works "Pedagogical sciences", Vol. XXX, 144-152).

Раппорт, С.Х. (1973). Художественное представление и художественный образ. Эстетические очерки, Вып. 3, 45-95. Москва: Музыка (Rapport, S. Н. (1973). Artistic performance and artistic image. Aesthetic Essays, Vol. 3, 45-95. Moscow: Music).

Теплов, Б. М. (1947). Психологические вопросы художественного воспитания. Вып. 11. Известия АПН РСФСР (Teplov, В. М. (1947). Psychological issues of art education. Issue 11. News of the RSFSR Academy of Pedagogical Sciences).

Цвєткова, Л. Ю. (2005). Методика викладання класичного танцю. Київ (Tsvietkova, L. Yu. (2005). Methods of teaching classical dance. Kyiv).

Цыпин, Г.М. (1975). Развитие учащегося-музыканта в прочессе обучения игре на инструменте. М.: Изд-во МГПИ им. В. И. Ленина (Tsypin, Н. М. (1975). Development of a student-musician in the process of learning to play an instrument. Moscow).

\section{PEЗЮME}

Энская Елена, Крамская Светлана. Особенности формирования эмоциональной культуры будущих педагогов творческого профиля в условиях учреждения высшего специального образования.

В статье обосновывается понятие "эмочиональная культура педагога", определяется его суть, раскрывается значимость содержания учебного материала в контексте формирования данного феномена для специальностей «Музыкальное искусство» и “Хореография». Обозначаются практические и методические направления воспитания культуры эмоций будущего специалиста творческого профиля, выявляется практическая ценность обогащения его эмоциональной сферы в процессе работы над художественным образом в образцах учебного репертуара по специальности.

Ключевые слова: эмоциональная культура, художественный образ, педагог творческого профиля, хореография, музыкальное искусство.

\section{АНОТАЦІЯ}

Енська Олена, Крамська Світлана. Особливості формування емоційної культури майбутніх педагогів мистецького профілю в умовах закладу вищої спеціальної освіти.

Емоційна культура педагога - це багате за змістом, оригінальне в педагогіці, надзвичайно цікаве й неповно вивчене явище, що викликає сьогодні глибокий інтерес у сучасному процесі підготовки фахівців мистецького профілю.

Науковці вважають, що поєднання думок, почуттів, емочій та ідей допомагають майбутньому вчителеві сприймати навколишній світ у всьому його матеріальному та духовному багатстві, знаходити в собі найкращі шляхетні почуття, передавати їх своїм вихованцям, спонукати їх до самовдосконалення.

Mema cmammi полягає в теоретичному обгрунтуванні сукупності 
педагогічних підходів до формування емочійної культури майбутнього педагога мистецького профрілю у прочесі вищої професійної освіти (на матеріалі вивчення художнього образу у зразках навчального репертуару за фрахом «Музичне мистецтво» $i$ «Хореографрія»).

Успіх фахового навчання багато в чому залежить від створених на заняттях педагогічних і творчих умов для подання студентам теоретичної інформації, методично вірної побудови практичних занять, а також вірно обраних прийомів емоційної саморегуляції вихованців, які виступають важливими компонентами їх емоційної культури.

Але однією з ключових умов формування емоційної культури майбутнього педагога з мистецтва є професійно підібраний навчальний матеріал. Вірний підбір різноманітного за жанрами та стилями репертуару, його побудова за рівнем складності й послідовність вивчення певних навчальних зразків, робота над художніми образами як у музичних творах, так і в хореографічних постановках - усе че допомагає підтримувати інтерес студентів до творчості і, безумовно, самого мистецтва. До того ж, робота над художнім образом обраного високохудожнього зразка може викликати досить широкий спектр їх емоційних переживань, спрямованих на виховання саме емочійної культури. У такому ракурсі навчальний творчий матеріал може стати для майбутніх фахівців емочійно-яскравим джерелом пізнання образу життя, колориту й духовного змісту історичної епохи. Показовою в цьому плані була, $\epsilon$ і буде завжди творчість класиків та корифреїв мистецтва.

Культура емоцій фрахівця мистецького профілю передбачає пошук $i$ впровадження цікавих $i$ дієвих шляхів організації навчання, що забезпечить ефективність даного прочесу. Навчально-пізнавальна діяльність студентів спеціальностей "Музичне мистецтво» $і$ "Хореографія" має бути спрямована на усвідомлення ролі емочійної культури в їх профресійній діяльності. Викладачі мають стимулювати майбутніх фахівців з мистецтва до вивчення основ емочійної культури, створювати сприятливу емочійну атмосферу на заняттях, забезпечувати умови активної роботи студентів щодо застосування набутих знань, умінь і навичок у навчально-пізнавальній діяльності, розробляти індивідуальні моделі взаємодії з вихованцями.

Ключові слова: емочійна культура, художній образ, педагог мистецького профрілю, хореографія, музичне мистецтво. 
УДК 37.032

Ольга Лобова

Сумський державний педагогічний університет імені А. С. Макаренка

ORCID ID 0000-0001-7028-043X

Аліна Сбруєва

Сумський державний педагогічний університет імені А. С. Макаренка ORCID ID 0000-0002-1910-0138

Марина Бойченко

Сумський державний педагогічний університет імені А. С. Макаренка

ORCID ID 0000-0002-0543-8832

DOI 10.24139/2312-5993/2020.03-04/266-276

\section{ФОРМУВАННЯ КУЛЬТУРНОЇ КОМПЕТЕНТНОСТІ ШКОЛЯРІВ У ПРОЦЕСІ МИСТЕЦЬКОÏ ОСВІТИ В «НОВІЙ УКРАЇНСЬКІЙ ШКОЛІ»}

Статтю присвячено проблемі фрормування ключової культурної компетентності як одного з провідних орієнтирів Нової української школи. Метою $\epsilon$ розкриття окремих шляхів формування культурної компетентності школярів у процесі мистецької освіти. Застосовано методи аналізу й узагальнення наукових джерел, теоретичне моделювання, педагогічний експеримент тощо.

Схарактеризовано шляхи формування культурної компетентності $в$ навчальній діяльності (за підручниками «Мистецтво» О. Лобової) та позаурочній роботі (за методикою А. Шевченко). Окреслено основні напрями підготовки майбутніх педагогів до формування культурної компетентності школярів.

Ключові слова: формування культурної компетентності, концепція «Нова українська школа», загальна мистецька освіта, дидактико-методична система, підручники "Мистечтво», вокально-джазова культура підлітків, підготовка педагогів до формування культурної компетентності учнів.

Постановка проблеми. Сучасними стратегічними орієнтирами загальної освіти в Україні є закони «Про освіту» (2017, зі змінами 2020 р.), «Про загальну середню освіту» (2020) й концепція «Нова українська школа», масове впровадження якої розпочалося з 2018-2019 навчального року. В основу цих документів покладено компетентнісний підхід, що передбачає формування у школярів низки ключових компетентностей: вільне володіння українською мовою, здатність спілкуватися рідною та однією з іноземних мов; здатність до навчання впродовж життя; математична, екологічна, інформаційно-комунікаційна компетентності тощо.

Однією з ключових визначено культурну компетентність, яка $\epsilon$ стрижневою для мистецької освітньої галузі. Формування цієї компетентності $€$ провідним завданням викладача мистецьких дисциплін, музичного мистецтва зокрема. Така місія зумовлює актуальність 
досліджень у галузі теорії та практики формування культурної компетентності учнів у сучасній українській школі.

Аналіз актуальних досліджень. Загальна освіта в Україні ґрунтується на низці нормативних документів. 14 грудня 2016 року була затверджена концепція «Нова українська школа», конструктивний аналіз якої зроблений провідними фахівцями відділу початкової освіти Інституту педагогіки НАПН України, українськими вченими та педагогами-практиками ще на етапі ії громадського обговорення (Н. Бібік, О. Онопрієнко, О. Савченко та ін.). Ідеї концепції було розвинуто в новому законі «Про освіту», прийнятому у 2017 й поновленому у 2020 році, у законі «Про загальну середню освіту» (2020) та в Державному стандарті початкової освіти, затвердженому в лютому 2018 року.

Інновацією проектів концепції Нової української школи стало застосування компетентності «загальнокультурна грамотність» або «обізнаність та самовираження у сфері культури». У попередньому стратегічному освітньому орієнтирі (Державному стандарті початкової загальної освіти 2011 року) ії аналогом була загальнокультурна компетентність, ґрунтовний аналіз якої здійснили українські вчені В. Болгаріна, С. Мельник, О. Пометун, С. Троянська та ін. Проте в законі «Про освіту» 2017 року дефініцію «загальнокультурна грамотність» було замінено на поняття «культурна компетентність». Його застосовано й у новому Державному стандарті початкової освіти.

Дослідження культурних феноменів відзначено надзвичайним розмаїттям та багатомірністю (Uvarova, 2019). У педагогіці поняття «культурна компетентність» також ще не набуло однозначного трактування. У мистецькій освіті дотичними є педагогічні дослідження, спрямовані на формування окремих аспектів культурної компетентності: музичної та музично-естетичної культури (Л. Масол, Д. Кабалевський, О. Лобова, О. Ростовський, Л. Школяр та ін.); вокальної культури (Л. Гавриленко, Чжу Цзюньцяо та ін.); вокально-джазової культури (А. Шевченко) тощо. Важливою $\epsilon$ проблема підготовки майбутніх педагогів до формування культурної компетентності учнів, різні аспекти якої розкрито у працях Г. Ніколаї, О. Олексюк, Г. Падалки, О. Ребрової, М. Ткач, О. Щолокової та ін. Зокрема, питанням вокальної підготовки студентів присвячено праці Н. Овчаренко, О. Матвєєвої, О. Чеботаренко, Н. Кьон (Ovcharenko, 2019) та ін.

Аналіз наукових праць свідчить, що актуальності набуває не лише обґрунтування ключової культурної компетентності, а й дослідження теорії та практики їі формування, у мистецькій освіті зокрема.

Мета статті. У зазначеному контексті метою нашої публікації $\epsilon$ розкриття окремих шляхів формування культурної компетентності школярів у процесі загальної мистецької освіти учнів в умовах Нової української школи (у навчальній і позаурочній діяльності). 
Методи дослідження. Для реалізації мети застосовано методи узагальнення наукових джерел, аналізу навчальної літератури, теоретичне моделювання, педагогічний експеримент тощо.

Виклад основного матеріалу. Нормативним підґрунтям освіти в нашій країні $€$ закони «Про освіту», «Про дошкільну освіту», «Про позашкільну освіту», «Про професійно-технічну освіту», «Про вищу освіту», «Про повну загальну середню освіту» та ін. Навчання школярів безпосередньо регламентують закони «Про освіту» (зі змінами 2020 р.), «Про повну загальну середню освіту» (2020), а також концепція «Нова українська школа» (2016).

Згідно із зазначеними документами, метою освіти є всебічний розвиток людини як особистості й найвищої цінності суспільства, ї̈ талантів, інтелектуальних, творчих і фізичних здібностей, формування цінностей і необхідних для успішної самореалізації компетентностей, виховання відповідальних громадян, які здатні до свідомого суспільного вибору та спрямування своєї діяльності на користь іншим людям і суспільству, збагачення на цій основі інтелектуального, економічного, творчого, культурного потенціалу Українського народу, підвищення освітнього рівня громадян задля забезпечення сталого розвитку України та її європейського вибору.

За основу сучасної загальної освіти узято компетентнісний підхід, що передбачає зміщення акцентів з процесу накопичення знань, умінь і навичок у площину формування й розвитку в учнів здатності ефективно діяти і творчо застосовувати набуті знання та досвід у практичній діяльності. За концепцією «Нової української школи» вихідна категорія нашого дослідження «компетентність» тлумачиться як динамічна комбінація знань, способів мислення, поглядів, цінностей, навичок, умінь, інших особистих якостей, що визначає здатність особи успішно провадити професійну та/або подальшу навчальну діяльність.

В основу компетентнісного підходу покладено ключові компетентності, яких потребує кожна людина для особистої реалізації, розвитку, активної громадянської позиції, здатні забезпечити життєвий успіх молоді в суспільстві знань (Концепція..., 2016). Зокрема, до них віднесено: здатність спілкуватися рідною (у разі відмінності від державної) та однією з іноземних мов; математична; компетентності в галузі природничих наук, техніки і технологій; екологічна; інформаційно-комунікаційна; здатність до навчання впродовж життя; громадянські та соціальні компетентності; культурна; підприємливість та фінансова грамотність, інноваційність.

у державних документах у галузі освіти статусу ключової набула культурна компетентність, трактування якої зазнали різноманітних трансформацій. Спочатку культурна компетентність розумілась виключно в значенні належності до різних культур. Уперше цей термін було 
застосовано в медичній практиці щодо правильної постановки діагнозу та лікування іноземних пацієнтів як представників «іншої» культури. Тривалий час феномен культурної компетентності поширювався не лише на людину, а й на організації та розумівся як система цінностей і принципів, рівень навичок і знань, що уможливлюють співпрацю фірми 3 людьми різної етнічної або расової приналежності.

У сучасних інформаційних джерелах культурна компетентність ототожнюється з рівнем адаптованості людини до культурного, комунікаційного, техногенного сучасного середовища; умінням орієнтуватися в інформаційному потоці та достатньо вільно почуватися в сучасному полікультурному глобалізованому світі. Досить часто ця категорія замінюється поняттям «міжкультурна» компетентність, що тлумачиться як здатність особистості ефективно взаємодіяти з людьми, що представляють різні культури.

у педагогічних працях зустрічаємо трактування культурної компетентності як здатності індивіда до інтелектуально-розумового зростання шляхом постійного безперервного пізнання нового та вивчення культурної спадщини попередників, їх мудрості та культурних цінностей, а також наявності навичок спілкування та взаємодії з людьми, що належать до різних культур (Гусєва, 2018).

У чинному Державному стандарті початкової освіти та типових освітніх програмах визначення культурної компетентності не наводиться (Державний стандарт, 2018; Типові програми, 2018). Водночас, зазначено, що ця компетентність передбачає залучення учнів до різних видів мистецької творчості (образотворче, музичне та інші види мистецтв) шляхом розкриття й розвитку природних здібностей, творчого вираження особистості.

У концепції Нової української школи знаходимо трактування ключової компетентності «обізнаність та самовираження у сфері культури», що тлумачиться як здатність розуміти твори мистецтва, формувати власні мистецькі смаки, самостійно виражати ідеї, досвід та почуття за допомогою мистецтва. Ця компетентність передбачає глибоке розуміння власної національної ідентичності як підґрунтя відкритого ставлення та поваги до розмаїтяя культурного вираження інших (Концепція..., 2016).

Ґрунтуючись на сучасних підходах, ключову культурну компетентність школяра можна розглядати як інтегроване особистісне утворення, що поєднує знання, погляди, цінності, уміння та навички у сфері національної та світової культури, спроможність сприймати, на доступному рівні аналізувати й оцінювати культурні феномени, практично застосовувати набутий досвід культурної діяльності в житті. Формування культурної компетентності школярів у мистецькій освіті можемо визначити як спеціально організований, цілеспрямований процес опанування дитиною знань, умінь і навичок, цінностей і досвіду культурної діяльності засобами мистецтва (у навчальній і позаурочній роботі). 
Реалізація культурного компонента освіти $€$ одним із провідних завдань викладача художньо-естетичних дисциплін, зокрема, учителя музики, у праці якого цей напрям набуває актуального та цілком реального наповнення. На наш погляд, феномен культурного виховання учнів стосується, насамперед, розширення меж власне музичного виховання на загальномистецькі обрії, що передбачає:

- формування в дітей потреб у мистецтві, культурі як невід'ємній, необхідній та прекрасній частині людського життя;

- виховання любові до національної культури засобами ознайомлення школярів із народним, класичним і сучасним мистецтвом України;

- формування «мистецько-інтернаціональних» якостей через залучення дітей до найкращих надбань світової культури;

- становлення культури сприймання й розуміння творів різних видів мистецтва (літературного, образотворчого, театрального тощо);

- прийняття та застосування в житті культурних надбань, національних і загальнолюдських культурних цінностей тощо.

Основними векторами формування культурної компетентності школярів у мистецькій освіті можна виділити:

1) національний, що передбачає опанування культурної спадщини, традицій та цінностей рідного народу;

2) інтеркультурний, спрямований на розуміння, осягнення та прийняття культурних традицій, цінностей і феноменів інших народів.

Розглянемо можливості формування ключової культурної компетентності у навчальній діяльності, зокрема за підручниками Ольги Лобової «Мистецтво» для 1-3 класів, що є переможцями Всеукраїнських конкурсів підручників і видані за державним замовленням для учнів закладів загальної освіти (Лобова, 2018; 2019; 2020).

Представлена в підручниках дидактико-методична система передбачає формування таких складників культурної компетентності:

1. Формування культурної спрямованості учнів (усвідомлення цінності культури в житті людини; інтерес до освоєння культурних цінностей у процесі пізнання мистецтва; плекання позитивного ставлення та пошани до культурної спадщини рідного та інших народів). Відповідні функції підручника реалізуються через низку завдань, що допомагають дитині усвідомити роль культури та мистецтва у власному та суспільному житті, сприяють розвиткові потреб у спілкуванні з мистецтвом, художніх смаків та культурно-ціннісних орієнтацій. Навчально-методичний апарат підручника розроблено так, щоб постійно підтримувати увагу та стимулювати пізнавальну діяльність школярів. Цьому сприяють спонукальні формулювання навчальних завдань, а також подання матеріалу у формі гри, з використанням казкових образів, ребусів, головоломок, кросвордів. Зміст підручника надає можливість кожній дитини проявити себе і досягти успіху в різних видах мистецької діяльності. 
2. Формування культурної обізнаності націлено на інтегроване опанування теоретичних і практичних основ культури й відбувається в тісному зв'язку з практичною діяльністю. На становлення цього складника спрямовано навчальну інформацію щодо національної та світової культури, специфіки різних видів мистецтв, формування навичок розуміння та первинного аналізу літературних, візуальних, сценічних творів; використання народних і авторських, літературних і живописних творів; різні види мистецької діяльності, домінувальними серед яких $€$ сфери музичного та образотворчого мистецтв. Зміст кожної чверті завершено блоком завдань для тематичного контролю, а рубрика «Твої мистецькі канікули» містить пропозиції щодо організації культурної діяльності дітей у вільний час.

3. Розвивальний компонент дидактико-методичної системи спрямовується на культурний, музичний та художній розвиток дитини, розширення культурного світогляду, формування загальнокультурного мислення, мовлення тощо. Пріоритетним $€$ творчий розвиток дітей, тож у всіх видах діяльності передбачено завдання креативного типу: ритмічні, вокальні, пластичні імпровізації; різні види малювання, ліплення, аплікації; театралізація музичних творів тощо. Наприклад, у темі, присвяченій театру, дітям запропоновано розіграти виставу за піснею "Два півники», виконати в ролях пісню «Ходить гарбуз по городу», на прикладі цієї пісні придумати й, за бажанням, виготовити фігурки для пальчикового театру. Урахування різних рівнів розвитку учнів забезпечується різноманітністю навчального матеріалу, наявністю завдань на вільний вибір.

4. Виховний компонент спрямовано на становлення потреби в музичному самовдосконаленні, на формування культури спілкування 3 мистецтвом в умовах урочної та дозвіллєвої діяльності, культури поведінки в театрі, музеї тощо. Також передбачено вплив на моральне, емоційноестетичне, комунікативне, трудове, екологічне, національно-патріотичне та інтернаціональне виховання школярів.

Багато завдань націлені на ознайомлення дітей із національним фольклором і творчістю українських митців, культурними традиціями та пам'ятками нашої країни тощо. Наприклад, у рубриці «Твої мистецькі канікули» другокласникам запропоновано ознайомитися з українськими традиціями зимових свят та здійснити «віртуальну подорож» театрами різних міст України.

У змісті підручників для учнів початкової школи представлено низку фольклорних творів для слухання та виконання: народних танців (гопак, козачок, метелиця, аркан, коломийка), поспівок і пісень (дитячих, жартівливих, побутових, дум, колядок, щедрівок, веснянок тощо). Під час ознайомлення 3 цими творами відбувається не лише поступове опановування школярами знань про види та жанри вітчизняного фольклору, а й формуються почутя любові до національної культури та поваги до народу, що зміг створити і зберегти скарбницю таких непересічних цінностей. 
Принагідно подаються різноманітні відомості щодо історії фольклорного мистецтва, національних музично-культурних традицій тощо. Так, ознайомлення другокласників із українським народним танцем «Аркан» передбачає не лише аналіз власне музичних аспектів твору (характеру музики, інструментів для виконання), а й розповідь про історію виникнення танцю, розгляд національного вбрання виконавців, наслідування танцювальних рухів за поданим у підручнику зразком.

Суттєвого виховного значення в змісті музичної освіти школярів набуває ознайомлення 3 кобзарським мистецтвом - його історією, жанровими особливостями, зразками творів, постатями видатних кобзарів.

Паралельно з фольклорним аспектом, протягом усього терміну навчання в початкових класах, відбувається послідовне ознайомлення 3 професійною музикою України: відомостями про життя і творчість провідних представників національного музичного мистецтва (М. Лисенка, К. Стеценка, М. Леонтовича, Л. Ревуцького, В. Косенка та ін.), вокальними й інструментальними творами сучасних українських композиторів.

Реалізація інтеркультурного компонента загальної мистецької освіти відбувається через залучення дітей до найкращих надбань народної та професійної світової культури. При цьому вважаємо доцільним не обмежуватися мистецтвом кількох обраних країн, а надавати учням можливість ознайомитися з культурою широкого кола країн близького й далекого зарубіжжя.

Передумовами «музично-інтернаціонального» виховання школярів $\epsilon$ ознайомлення з піснями, танцями та мистецькими традиціями різних народів, з життям і творчістю видатних діячів світової музичної культури. Зокрема, у нових підручниках для початкової школи запропоновані для розучування зразки білоруського («Савка та Гришка»), польського («Зозуля»), чеського («Полька»), латиського («Ой-я, жу-жу»), естонського («У кожного свій музичний інструмент»), французького («Танець каченят», «Пастуша пісня»), бразильського («Потяг»), норвезького («Камертон») дитячого фольклору.

Протягом усього курсу навчання музики школярі дізнаються про життя і творчість видатних представників світової музичної культури (Й. С. Баха, В.А. Моцарта, Л. Бетховена, Е.Гріга, Ф.Шопена та ін.), принагідно ознайомлюючись із мистецтвом і культурними традиціями відповідних країн та епох. Виховна мета означених напрямів навчальної роботи - розвиток інтересу та поваги до мистецтва інших країн - $\epsilon$ важливою не лише в загальнокультурному контексті. На наш погляд, вона $\epsilon$ кроком до поступового прищеплення дитині інтернаціональних почуттів, підготовки до життя в глобалізованому середовищі, а також своєрідною «профілактикою» гостроактуальної в сучасному суспільстві проблеми расизму тощо. 
Інтеркультурне виховання дітей засобами мистецької діяльності відбувається не лише на шкільних уроках мистецтва. Прикладом реалізації цього напряму в позаурочній роботі сучасної школи (у також у школах мистецтв) є методика формування вокально-джазової культури підлітків на заняттях з естрадного співу, розроблена викладачем Сумської дитячої школи мистецтв № 1 Анастасією Шевченко.

Як зазначається, спів традиційно є провідною формою музичної діяльності школярів у закладі загальної освіти. Про його значення в українській школі свідчить факт, що в XX столітті протягом тривалого часу шкільний предмет мав назву «Співи». Наразі вокальна культура трактується не лише як комплексна підготовленість людини в галузі співу, а й як невід'ємна частина музичної культури особистості. Тож учитель музичного мистецтва має бути різнобічно підготовлений до організації вокальної роботи зі школярами, що передбачає оволодіння і власною співочою культурою, і методичним арсеналом навчання дітей співу (Лобова, 2017).

У контексті дослідження А. Шевченко вокально-джазова культура трактована як складна інтегрована якість особистості, що визначається гармонійним поєднанням умотивованості і здібностей, знань, умінь і навичок виконавця в галузі джазового співу та $є$ важливою умовою успішної вокальноджазової діяльності. Компонентами вокально-джазової культури підлітків визначені мотиваційно-ціннісний; компетентнісно-когнітивний; особистіснорозвивальний та виконавсько-творчий (Шевченко, 2019).

Методологічну основу методики становлять системно-структурний, особистісно-розвивальний, діяльнісний, компетентнісний і культурологічний підходи. 3 ними пов'язано комплекс запропонованих дидактичних принципів (систематичності й послідовності, наочності, урахування вікових та індивідуальних особливостей, принцип єдності художньо-емоційного і технічного, принцип комплексного формування вокально-джазової культури).

У дослідженні виділено дві групи методів формування вокальноджазової культури підлітків: загальні вокально-педагогічні методи (концентричний; пошуковий; фонетичний; уявного або внутрішнього співу; порівняльного аналізу) та спеціальні методи формування вокально-джазової культури: «слухацько-джазова скарбничка» (накопичення музично-слухового досвіду в галузі джазової музики, аналіз і порівняння вокальних мотивів та імпровізацій джазових виконавців - слухання, аналіз, підбір на слух, копіювання голосом); технічні вокально-джазові вправи (метроритмічні вправи на розвиток чуття ритму джазових творів («Scat drums» та ін.), поспівки для виховання базових елементів джазового співу); творчі вокально-джазові завдання (інтерпретація та імпровізація у джазовому стилі) (Шевченко, 2019).

Висновки та перспективи подальших наукових розвідок. Згідно 3 сучасними вимогами, стрижневим напрямом загальної мистецької освіти 
визначено формування ключової культурної компетентності школярів інтегрованого особистісного утворення, що поєднує знання, погляди, цінності, уміння та навички у сфері національної та світової культури, спроможність сприймати, на доступному рівні аналізувати й оцінювати культурні феномени, практично застосовувати набутий досвід культурної діяльності в житті.

Формування ключової культурної компетентності відбувається в навчальній і позаурочній діяльності. У першому випадку засобами організації цього процесу можуть бути шкільні підручники. Зокрема, у підручниках «Мистецтво» Ольги Лобової представлена дидактико-методична система, що передбачає цілісне формування складників культурної компетентності учнів: культурної спрямованості, обізнаності, розвиненості і вихованості. У процесі роботи з підручниками відбувається вплив на національний та інтернаціональний вектори культурної компетентності учнів.

Прикладом реалізації інтеркультурного напряму в позаурочній роботі сучасної школи (а також у школах мистецтв) є методика формування вокально-джазової культури підлітків на заняттях з естрадного співу, розроблена Анастасією Шевченко. Запропоновані в ії контексті наукові підходи, дидактичні принцип, етапи та методи формування вокальноджазової культури підлітків довели свою ефективність у процесі використання на заняттях 3 естрадного співу в музичних школах і позаурочній роботі закладів загальної освіти.

Ознайомлення 3 запропонованими шляхами культурного становлення школярів у навчальній і позаурочній роботі сприятиме вдосконаленню професійно-педагогічної підготовки майбутніх учителів до формування культурної компетентності учнів. Цей напрям вважаємо перспективним для подальших досліджень.

\section{ЛІТЕРАТУРА}

Гусева, О. (2018). Культурна компетентність учителя. Retrieved from: https://vuzlit.ru/345129 (Husieva, O. Teacher's cultural competence. Retrieved from: https://vuzlit.ru/345129).

Державний стандарт початкової освіти. Режим доступу: https://www.schoollife.org.ua. (State standard of elementary education of the school. Retrieved from: https://www.schoollife.org.ua).

Концепція реалізації державної політики у срері реформування загальної середньої освіти "Нова українська школа" на період до 2029 року. Режим доступу: https://www.kmu.gov.ua/ua/npas/249613934. (Concept of realization of state policy in the sphere of reforming of general secondary education "New Ukrainian School" for the period till 2029. Retrieved from: https://www.kmu.gov.ua/ua/npas/249613934).

Лобова, О. (2018). Мистецтво: підручник інтегрованого курсу для 1 класу закладів загальної середньої освіти. Київ: Школяр (Lobova, О. (2018). Arts: an integrated course textbook for 1 grade of general secondary education institutions. Kyiv: Shkoliar).

Лобова, О. (2019). Мистецтво: підручник інтегрованого курсу для 2 класу закладів загальної середньої освіти. Київ: Школяр (Lobova, О. (2019). Arts: an integrated course textbook for 2 grade of general secondary education institutions. Kyiv: Shkoliar). 
Лобова, О. (2020). Мистецтво: підручник інтегрованого курсу для 3 класу закладів загальної середньої освіти. Київ: Школяр (Lobova, О. (2020). Arts: an integrated course textbook for 3 grade of general secondary education institutions. Kyiv: Shkoliar).

Лобова, О. В. (2017). Педагогічні основи музично-хореографічної підготовки майбутніх вихователів дошкільних навчальних закладів. Педагогічні науки: теорія, історія, інноваційні технологіï, 8 (72), 12-23 (Lobova, O. V. (2017). Pedagogical bases of musical and choreographic preparation of future educators of preschool educational institutions. Pedagogical sciences: theory, history, innovative technologies, 8 (72), 12-23).

Типові освітні програми. Режим доступу: https://mon.gov.ua/ua (Typical educational programs. Retrieved from: https://mon.gov.ua/ua).

Шевченко, А. С., Лобова, О. В. (2019). Методика формування вокально-джазової культури підлітків на заняттях з естрадного співу. Науковий вісник Південноукраїнського національного педагогічного університету імені К. Д. Ушинського, 2 (127), 80-87 (Shevchenko, A., Lobova, O. (2019). Methodology of teenagers' vocal-jazz culture formation at pop singing lessons. Scientific Bulletin of the South Ukrainian National Pedagogical University named after KD Ushinsky, 2 (127), 80-87).

Ovcharenko, N., Matveieva, O., Chebotarenko, O., \& Koehn, N. (2019). Methodological Readiness of Musical Art Master's Degree Students: A Theoretical Research. Journal of History Culture and Art Research, 8 (4), 166-176. doi: http://dx.doi.org/10.7596/taksad.v8i4.2285.

Uvarova, T. (2019). Cultural Multidimensionality in Research Practices. Journal of History Culture and Art Research, 8 (2).

\section{PEЗЮME}

Лобова Ольга, Сбруева Алина, Бойченко Марина. Формирование культурной компетентности школьников в процессе художественного образования в «Новой украинской школе».

Статья посвящена проблеме формирования ключевой культурной компетентности как одного из ведущих ориентиров Новой украинской школы. Цель статьи - раскрыть отдельные пути формирования культурной компетентности школьников в процессе художественного образования. Использованы методы анализа и обобщения научных источников, теоретическое моделирование, педагогический эксперимент и др.

Охарактеризованы пути формирования культурной компетентности в учебной деятельности (по учебникам "Искусство» О. Лобовой) и внеурочной работе (по методике А. Шевченко). Определены основные направления подготовки будущих педагогов к формированию культурной компетентности школьников.

Ключевые слова: формирование культурной компетентности, концепция "Новая украинская школа», общее художественное образование, дидактикометодическая система, учебники "Искусство», вокально-джазовая культура подростков, подготовка педагогов к формированию культурной компетентности учащихся.

\section{SUMMARY}

Lobova Olga, Sbruieva Alina, Boychenko Marina. Formation of schoolchildren's cultural competence in the process of art education in the «New Ukrainian School».

The article is devoted to the topical issue of key cultural competence formation as one of the leading landmarks of the New Ukrainian School. The purpose of the study is to reveal some ways of schoolchildren's cultural competence formation in the process of general art education. In the study the methods of generalization of scientific sources, analysis of educational literature, theoretical modeling, pedagogical experiment, etc. have been used. 
According to modern requirements, the core direction of general art education is formation of schoolchildren's key cultural competence - an integrated personal entity that combines knowledge, attitudes, values, skills and competences in the field of national and world culture, ability to perceive, analyze and evaluate cultural phenomena at an accessible level, use acquired cultural activity experience in everyday life.

Formation of key cultural competence occurs in educational and extracurricular activities. In the first case, the textbooks are the means of organizing this process. In particular, Olga Lobova's "Art" textbooks present a didactic-methodological system that provides for the holistic formation of the components of pupils' cultural competence: cultural orientation, awareness, development and upbringing. While working with textbooks, the national and international vectors of pupils' cultural competence are influenced.

An example of implementation of intercultural direction in the extracurricular work of the modern school (also in art schools) is methodology of teenagers' vocal-jazz culture formation at pop singing lessons, developed by Anastasia Shevchenko. Proposed in its context scientific approaches, didactic principle, stages and methods of teenagers'vocal-jazz culture formation have proved their effectiveness in the process of implementation at pop singing lessons in music schools and extra-curricular work of general education institutions.

Acquaintance with proposed ways of schoolchildren's cultural competence formation in educational and extra-curricular work will help improve future teachers professional and pedagogical training in the aspect of pupils' cultural competence formation.

Key words: cultural competence formation, concept of "New Ukrainian School", general art education, didactic and methodological system, textbooks "Art", vocal-jazz culture of teenagers, teachers preparation for the formation of pupils' cultural competence.

UDC 37.013:793.3

\author{
Olena Moskalenko \\ National Aviation University \\ ORCID ID 0000-0003-3182-6801 \\ Oleksandr Skrypnyk \\ NFA Kropyvnytskyi \\ ORCID ID 0000-0001-5417-8953
}

DOI 10.24139/2312-5993/2020.03-04/276-290

\title{
EXPERIMENTAL VERIFICATION OF THE EFFICIENCY OF THE STRUCTURAL- FUNCTIONAL MODEL OF FORMATION OF PERSONAL-PROFESSIONAL IMAGE OF FUTURE CHOREOGRAPHY TEACHERS
}

In the article the author analyzes experimental verification of the effectiveness of the structural-functional model of the formation of personal and professional image of future teachers of choreography in the process of professional training. The author considers professional image of a future choreography teacher as a holistic image of a teacher, which is a harmonious combination of his/her unique external and internal and personalprofessional qualities, life positions, professional knowledge and choreographic skills, which emphasize the unique personality of the future teacher and have a significant impact on the professional functions in the field of choreography. Indicators and criteria for the formation of the professional image of the future teacher of choreography are determined.

Key words: professional image, future choreography teacher, levels, indicators and criteria of formation, experimental verification. 
Introduction. In the context of renewal of all sectors of our country, in particular the education system as one of the main sources of intellectual potential of society, the priority is to improve the quality of teacher training. There is a growing need for cultural development of the individual as one of the main factors of successful existence and development of the state, which provides for further humanization of the education system and conditions for the development of the spiritual and moral sphere of the individual.

Choreography, as one of the arts, is changing in accordance with development of social relations and the requirements of today, which put in the first place a return to universal values, folk traditions and culture. The mentality of society is revealed through culture and art, so choreographic culture has a direct impact on the cultural and spiritual development of the younger generation and preservation of cultural values (Демчук, 2013).

Changes in the system of art education and practical activities in the field of choreographic art necessitate training of specialists - future teachers of choreography, focused on mastering professional skills and abilities and acquiring cultural and spiritual values necessary for full professional self-realization. Important is formation of a teacher-choreographer as a harmoniously developed personality, in whom the mind is successfully combined with physical development, external attractiveness, good manners, individuality, which has adequate selfesteem and developed self-concept, which is the basis for forming his/her personal and professional image (Марченко, 2016, p. 127). The value of forming the personal and professional image of the future teacher of choreography is due to the fact that in modern market conditions it allows the specialist to be in demand, provides emotional and creative interaction with students in professional and sociocultural activities, strengthens self-improvement, promotes self-realization, relieves professional stress, complexes, etc.

Analysis of relevant researchs. Scientific investigations of domestic and foreign scientists on the problems of theory and practice of image formation belong to N. Barnei, A. Panasiuk, H. Pocheptsov, S. Ulanova, V. Shepel and others. Formation of the professional image of a specialist was the subject of research by M. Apraksina, M. Woodcock, F. Henova, N. Huzii, F. Kuzin, N. Skrypachenko and others.

A number of researchers reduce the image to a mental image (A. Panasiuk, L. Mitina, V. Shepel), to an external image (L. Brown, M. Spilchain), to the content, functions, set of external and internal features and motivation to create the image of the teacher's personality. (P. Byrd, A. Kaliuzhnyi, T. Klimova, I. Kriskunova, J. Popova, S. Yandarova and others), to the ability to create impressions, opinion about oneself (I. Hoffmann, F. Kuzin, E. Petrova, I. Fedorov and others).

The essence of the professional image of a specialist and the peculiarities of his/her effective self-presentation are considered in the studies of I. Aliokhina, V. Bebik, F. Kuzin, N. Skripachenko, E. Utkin, D. Francis and others. Theoretical 
principles of teaching choreographers are set out in the works of A. Vaganova, K. Holeizovskyi, R. Zakharov, V. Uralska and others. Problems of professional training of teachers-choreographers are considered in the works of Yu. Bogachova, A. Borisov, Y. Hromov, I. Izmailova, O. Popova, L. Telegina and others.

The aim of the study is to analyze the experimental verification of the effectiveness of the structural-functional model of the formation of personal and professional image of future teachers of choreography in the process of professional training.

Research methods. Professional development of a teacher is a long process that requires constant improvement of professional competences. Throughout his/her activity, the teacher is constantly learning, improving his/her scientific and methodological base, solving various educational tasks. However, an important component in the professional development of a teacher is his/her professional image. The formation of the teacher's image is a longer and more complex process, as it covers not only professional development and increasing the level of professional competence, but also the emotional sphere. An important component of the teacher's image is his/her authority, which is manifested in the influence of the teacher on students and their attitude to the teacher. A teacher who has a high level of image, influences students through their attitude, behavior, language, personal example, manner of communication, professional conscience and responsibility.

In the modern psychological and pedagogical literature there are many definitions of the concept of "image". Most of them testify that the image (from the Latin imago, imag - image) is "the image of a famous person or thing, which is created by the media, literature, imagination or the individual" (Демчук, 2013).

In the Great Explanatory Dictionary of the modern Ukrainian language, the concept of "image" is defined as "advertising, representative image of someone (for example, a public figure), which is created for the population" (Великий тлумачний словник сучасної української мови, 2005, р. 492).

The category of professional image is most substantially analyzed in scientific works devoted to the study of the image of a particular profession manager, teacher, lawyer, doctor, etc. In recent years, a number of scientific papers have appeared on the problem of forming the professional image of a teacher, which is becoming extremely important for the educational process. After all, a modern teacher is a person of a new formation who works with children, parents, establishes contacts at various levels - both at school and with public organizations, commissions, including international ones. This means that the teacher must have certain skills to create his/her own image, which would provide his/her desire for professional development, active life position, positive thinking and thus would allow more productive contacts in the professional sphere (Хомуленко та ін., 2005, р. 78). 
Summarizing the views of scientists in the field of psychological and pedagogical research, we'd like to conclude that "professional image of the future teacher of choreography" is a holistic image of a teacher, which is a harmonious combination of his/her unique external and internal and personal qualities, life positions, professional knowledge and choreographic skills, which emphasize the unique personality of the future teacher and have a significant impact on the implementation of his/her professional functions in the field of choreography. The professional image of the future teacher of choreography includes such components as the holistic image of the teacher, external characteristics, internal features, procedural reserves, value orientations, etc.

The professional image of a teacher is modeled under the influence of a specific professional environment in which the specialist works, and reflects the results of his systematic work on himself during the formation of a creative personality (Навроцька, 2014, р. 9). In order for a choreography teacher to successfully perform his/her main professional functions (teach, develop and educate), it is necessary for him/her to have certain professional and personal qualities and to be an authority for his/her students. It should be noted that these significant qualities of a choreography teacher will be assessed and presented differently by teachers and students. One of the tasks of the research was to find out which professional and personal qualities are important for an authoritative choreography teacher. To this end, a survey was conducted in which various subjects of the educational process took part, namely: students of the Faculty of Arts - future teachers of choreography and teachers of choreography with experience of five years or more. At the stage of the survey, 354 people (290 students and 64 choreographers) took part in the study. The survey was conducted on the basis of the Central Ukrainian Volodmyr Vynnychenko State Pedagogical University, Zhytomyr State University, Kyiv University named after B. Hrinchenko and Rivne State University for the Humanities. To identify the professional and personal characteristics of choreography teachers, such research methods as the method of ranking and questionnaires were chosen.

Let's analyze some questions of the questionnaire. Answering the question "What is image?", students-future teachers of choreography gave different answers, but the most common definitions, which, according to respondents, characterize this phenomenon, are: "A holistic view of an object that remains in people's memory"; "A set of human traits - his style of clothing, manner of speaking, worldview, life position"; "Appearance, reputation and authority". These definitions show that choreographers generally understand the essence of the concept of "image", although they do not fully reproduce all its components in the answers provided.

To the question "What types of image do you know?" choreographers named the following: human image, image of the organization, business, 
personal, professional, political, advertising, external, internal, positive, negative, traditional image. Such answers allow us to say that students have an idea of the image, are interested in this problem, are familiar with the classifications and some types of image.

Answers to the question "What is the image of a teacher?" were as follows: "is how teachers are perceived by others - students, parents, colleagues", "professional competence', "established interaction with students", "love and respect for students", "a set of personal characteristics communication, tact, tolerance, benevolence", "psychological means and methods of influencing students, to which the teacher turns in order to increase his/her authority". Thus, the components of the teacher's image, students consider: personal qualities, external characteristics, culture of communication, mastery of psychological techniques, professional competence, pedagogical tact, authority. Of course, these are the main components of the teacher's image, but not all.

To the question "What is your professional image?" students and teachers gave the following answers: "my professional image is a choreographic skill", "professional skill", "interaction and sociability in a dance group", "aesthetic culture", "ability to create a team", "perception of me in a dance group", "Ability to conduct dance events", "my choreography skills". Such diverse answers indicate that it is difficult for both students and teachers to determine the type of image, because, in our opinion, it was not created comprehensively and purposefully, because they lacked the necessary knowledge about the image.

This is confirmed by the answers of students and choreographers to the question "What do you lack to create your professional image?". The answers of teachers-choreographers were mainly as follows: "low motivation", "lack of time and money", "underfunding, weak material base", "lack of organization of the course, methodological seminar by the management". Students focused more on the following answers: "there is a lack of professional advice, interest, specific practical methods of image creation", "insufficient knowledge of image creation".

The next question was "Do you think that a positive image of a teacher can affect the quality of teaching choreographic disciplines?". The vast majority of students and teachers ( $89 \%$ ) believe that the quality of teaching choreographic disciplines depends on how the teacher presents him/herself, his/her appearance and perception of the team, organizational skills, mood, charisma, tact.

"In your opinion, does the professional image of a choreography teacher affect the atmosphere in a dance group?". The answer to this question was also unequivocal. $93 \%$ of respondents believe that a positive image of a teacher influences the atmosphere in a dance group and "sets the tone" not only in the whole work of the group, but also in the reputation of the dance group in various public events, international competitions and trips. 
Using the ranking method, it was found out that students - future teachers of choreography prefer the professional component in creating an image. The most important skills of a teacher-choreographer are knowledge of the professional disciplines and methods of their teaching (84\%); constant analysis and reflection of his/her activities, self-development and self-improvement (66\%); knowledge of motives, needs and interests of students (53\%).

According to the results of the survey, future teachers of choreography consider the student as an equal partner (43.5\%) and they prefer a democratic style of teaching and the relationship between a teacher and a student. They want to involve students in decision-making, listen to their opinions, take into account the personal qualities of students, not just success. For future teachers-choreographers such methods of influence as motivation, advice, encouragement, motivation to action are important. Future teachers of choreography are open to communication with students and colleagues, have a stable emotional state, psyche and balance, which are transmitted to students, contributing to the effectiveness of learning.

In addition, it should be noted that almost a third of choreography teachers ( $35.4 \%$ ) believe that a teacher should be a leader in the dance group and should have a reputation as a "strong teacher". These teachers view the student as an object of influence, not an equal partner. They must make their own decisions, establish strict control over compliance. At the same time, they understand that the presence of authoritarian tendencies in the teaching process does not promote mutual understanding and a creative atmosphere in choreography classes. Note that the more experience the teacher had, the more he showed an authoritarian style of teaching. Such discrepancies between the answers of students and teachers-choreographers were foreseen, because during their work teachers face many problems that demotivate them, make them more vulnerable and in some way lead to frustration in their profession.

A small number of student respondents among the important factors of the teacher's professional image indicated social and behavioral characteristics. Thus, $7.2 \%$ of respondents are aware of the importance of their future profession and are ready to overcome various difficulties for the sake of its prestige; $15.4 \%$ of respondents are ready to improve their strengths and work to eliminate shortcomings; $11.7 \%$ of students expressed readiness for "selfpresentation" as prospects for their professional development. However, it should be noted that students and teachers did not have a clear idea of selfpresentation, image creation and considered it something more relevant to TV and show stars than to choreography teachers.

At the same time, the personal qualities of future teachers, such as responsibility $(7.1 \%)$, were not left out of the attention of choreographer students; self-criticism (1.7\%); business acumen (2.7\%); willingness to come to the aid of others (9.4\%); modesty (4.2\%). Among these factors, the leading 
positions were occupied by such traits as communicativeness (75.3 \%), charisma (25.6\%), external presentability (49.3\%), sincerity and friendliness (82\%), which indicates their importance in the perception by students.

The main skills of students-choreographers and teachers-practitioners are as follows: the ability to approach the student and in any situation to remember that the student is a separate individual, to protect his dignity (teachers - $78.4 \%$, students - $69.4 \%$ ); ability to speak competently and correctly, have choreographic terminology and a rich vocabulary (teachers $34.8 \%$, students - $29.5 \%$ ); ability to conduct a dialogue and establish interaction (teachers $-36.4 \%$, students $-28.7 \%$ ); ability to keep the distance "teacher-student" (teachers - $55.7 \%$, students - $34.5 \%$ ); knowledge and skills of professional disciplines and methods of their teaching (teachers $-95.3 \%$, students $-94.7 \%$ ); variable creative solution of choreographic and pedagogical tasks (teachers $-48.9 \%$, students - $54.6 \%$ ). In general, teachers were more active, and this is due to the fact that they have more experience and can say that it is more important for teaching. The answers turned out to be more unambiguous for teachers and students regarding the knowledge and skills of professional disciplines and methods of their teaching. But in the issue of variable creative solution of choreographic and pedagogical tasks, students were more active, they consider these skills important in the work of a choreographer and in creating his/her professional image.

Thus, at the stage of questionnaires, the results of the study showed that the priority knowledge, qualities and skills that significantly affect formation of the professional image of the future teacher of choreography, are knowledge of professional disciplines and methods of their teaching them; analysis and reflection of their activities, self-development and self-improvement; knowledge of motives, needs and interests of students, personal qualities that inspire confidence in students; willingness to come to the rescue. Analysis of the respondents' answers has shown that a positive image of a teacher can affect the quality of teaching choreographic disciplines to the atmosphere in a dance group. Respondents indicated a dominant style of the teacher-student relationship as democratic (some teachers-practitioners prefer a combined authoritariandemocratic style), which is the most acceptable for reputation and professional image. Among personal characteristics, the leading positions occupied such traits as communicativeness, charisma, external presentability, sincerity and friendliness, and so on.

Research and experimental work was organized from 2018 to 2020 on the basis of Vinnytsia State Pedagogical University named after M. Kotsiubynsky, Poltava State Pedagogical University named after V. G. Korolenko, Kryvyi Rih State Pedagogical University. 290 future teachers of choreography took part in the pedagogical experiment. The process of forming the professional image of future choreography teachers as part of a pedagogical experiment involved three stages: 
1) diagnostic, the main purpose of which was to identify interest in the process of professional image formation, the desire for self-improvement and professional self-development through a system of professional training;

2) stimulating, which was implemented in the clear implementation of tasks for the formation of professional image in the process of professional training and in the acquisition of previously acquired knowledge, skills and abilities; in activating the cognitive interest of future teachers of choreography to the formation of professional image and in improving the acquired knowledge on the peculiarities of the formation of professional image;

3) evaluative and effective, achieved through creative independent activity of future teachers of choreography; focused on ensuring the strength of knowledge to further improve the professional image.

For conducting experimental research during 2018-2020 from future teachers of choreography the control and experimental groups were formed: CG - 142 persons, EG - 148 persons.

To study the dynamics of the indicators of criteria - individual-axiological, professional-pedagogical and external-behavioral - two sections were made: the first - at the ascertaining stage of the experiment, the second - after the molding stage of the experiment. Sections were implemented in the experimental and control groups using the same methods.

We study the training of future choreography teachers in the process of professional training separately for each of the criteria defined in the model: 1) individual-axiological, 2) professional-pedagogical; 3) external-behavioral.

Analysis of the results of the formation of the professional image of future teachers of choreography in the process of professional training is conducted with the help of diagnostic techniques:

Personality-axiological criterion was identified using the method "Diagnostics of polymotivational tendencies in the self-concept of personality" (according to S. M. Petrova); methods "Psychogeometric self-assessment of the personality" (according to S. Delinger in the adapted version of A. A. Aleksieiev, L. A. Hromova); methods "Determination of life values of the individual" ("Must-test") (according to P. N. Ivanov, E. F. Kolobova); methods "Socioperceptual assessment of personality and activity characteristics of the coach" (according to Yu. Khanin, A. Stambulov).

To analyze the professional and pedagogical criteria used the test "Knowledge of the essence of the future choreography teacher's professional image" (author's development); method "Level of readiness for professional and pedagogical self-development" (adapted version by M. Fetiskin); method "Diagnostics of the effectiveness of pedagogical communications" (modified version of the questionnaire by $A$. Leontiev).

The external-behavioral criterion was identified using the method "What do you know about your style?" (author's development); study of the "self- 
concept" of self-formation and improvement of the image of a professional (Campbell's SCC method); methods "Diagnostics of communicative social competence (CSC)"; methods "Psychological assessment of organizational abilities of the individual within an organized group" (by L. I. Umansky, A. M. Lutoshkin, A. S. Chernyshov, N. P. Fetiskin).

Thus, at the ascertaining stage of the experiment the diagnostics of the initial levels of formation of the professional image of future choreography teachers in the process of professional training is performed, the initial state of the researched system, the level of knowledge and skills of future choreography teachers are clarified; formation of qualities of researched persons, the initial conditions in which experiment is carried out, an initial condition of participants of pedagogical influence are characterized.

Diagnostics of the levels of formation of future choreography teachers' professional image in the process of professional training is performed on the basis of empirical data obtained at this stage.

Table 1

Levels of formation of future choreography teachers' professional image in the process of professional training in EG at the ascertaining and after molding stages of the experiment (generalized indicators)

\begin{tabular}{|c|c|c|c|}
\hline \multirow{4}{*}{ Group } & \multicolumn{3}{|c|}{ Level } \\
\hline & Low & Average & High \\
\hline & \multicolumn{3}{|c|}{ Points } \\
\hline & 2 & 6 & 9 \\
\hline $\begin{array}{l}\mathrm{EG}(\mathrm{y}) \mathrm{n} 2=148 \\
\text { ascertaining }\end{array}$ & 44 & 82 & 22 \\
\hline $\begin{array}{l}\mathrm{EG}(\mathrm{y}) \mathrm{n} 2^{`}=148 \\
\text { molding }\end{array}$ & 20 & 87 & 41 \\
\hline The difference, in \% & $-16,9$ & $+3,6$ & $+13,3$ \\
\hline
\end{tabular}

The characteristic of vibrations in a pre-juvenile vipad is a number of choreography teachers in the EG, which may be the singing stage of the formation of a professional image in the process of phase training according to the criteria. Uniformity of vibrations, like a zero hypothesis, revised for an additional $\chi 2$ - criterion (for the drop of vibrations of the same frequency (on the cob and in the experiment)):

$$
\begin{gathered}
\chi_{\text {емп }}^{2}=\frac{(44-20)^{2}}{20}+\frac{(82-87)^{2}}{87}+\frac{(22-41)^{2}}{41}=28,800+0,287+8,805 \\
=37,892 .
\end{gathered}
$$

The validity of the inequality $\left[x^{\wedge} 2\right)$ _emp $>\chi 2 \mathrm{kr}(37,892>5,99)$ at the significance level $\alpha=0,05$ makes it possible to reject the null hypothesis and accept the alternative about the non-homogeneity of the samples and the reliability of the discrepancy. The EG showed a significant change in the 
distributions of the generalized number of participants in the experiment, who have a certain level of professional image formation by all criteria.

To check the equality of the average sample distributions at the ascertaining and after the molding stages of the experiment according to the $\mathbf{Z}-$ criterion, it is necessary to calculate the average sample and corrected sample variances s_y ${ }^{\wedge} 2$.

$$
\begin{aligned}
& \bar{y} \text { (const) }=5,257 ; s_{y}^{2}=5,580 \\
& \bar{y} \text { (form) }=6,291 ; s_{y}^{2}=4,602 . \\
& \mathrm{Z}_{e m p}=\frac{|5,257-6,291|}{\sqrt{\frac{5,580}{148}+\frac{4,602}{148}}}=3,947 .
\end{aligned}
$$

3,947>1,96 ([Z_emp> Z)_crit), thus, at the level of significance $\alpha=0,05$ we reject the null hypothesis, accepting the alternative that the average sample scores of the participants of the experiment with EG at the ascertaining and after the molding stages of the experiment differ significant.

To find the accuracy of the mean sampling and confidence interval, determine the standard deviations $s_{y}$ and the accuracy of estimating the average sample $\delta_{y}$ :

$\mathrm{E} \Gamma(y)$ (const).: $s_{y}=2,362 ; \delta_{y}=0,381$;

$(4,876 ; 5,638)$ - confidence interval.

$\mathrm{E} \Gamma(y)$ (form): $s_{y}=2,145 ; \delta_{y}=0,346$;

$(5,945 ; 6,637)$ - confidence interval.

The distribution of choreography teachers from the experimental group according to the levels of professional image formation in the process of professional training on the ascertaining and after the molding stages of the experiment according to the generalized indicators is reflected in the diagrams (Fig. 1).

EG ascertaining stage

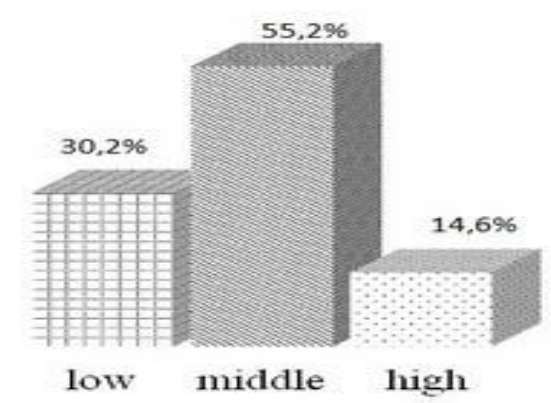

EG molding stage

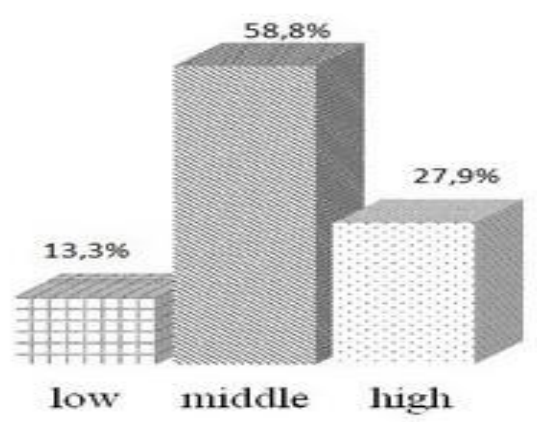

Fig. 1. Diagrams of distribution of choreography teachers within EG according to the levels of formation of professional image in the process of professional training at the ascertaining and after the molding stages of the experiment (generalized indicators), in \% 
The low level of formation of the professional image of choreography teachers in the process of professional training according to all criteria in the EG decreased by $16.9 \%$. At the same time, the average and high level of professional image formation increased by $3.6 \%$ and $13.3 \%$, respectively.

Thus, according to the calculations of generalized indicators, it was found out that the experimental group according to the results of the ascertaining and molding stages of the experiment was not qualitatively homogeneous, and quantitative indicators differ significantly, which allows to witness positive changes in the pedagogical impact on this group.

The results of comparing the levels of formation of the professional image of choreography teachers in the process of professional training of CG and EG (generalized indicators) on the ascertaining and after the molding stages of the experiment will be presented in table 2 .

Table 2

The results of comparing the levels of formation of choreography teachers' professional image in the process of professional training in CG and EG (generalized indicators) at the ascertaining and after the molding stages of the experiment, in \%

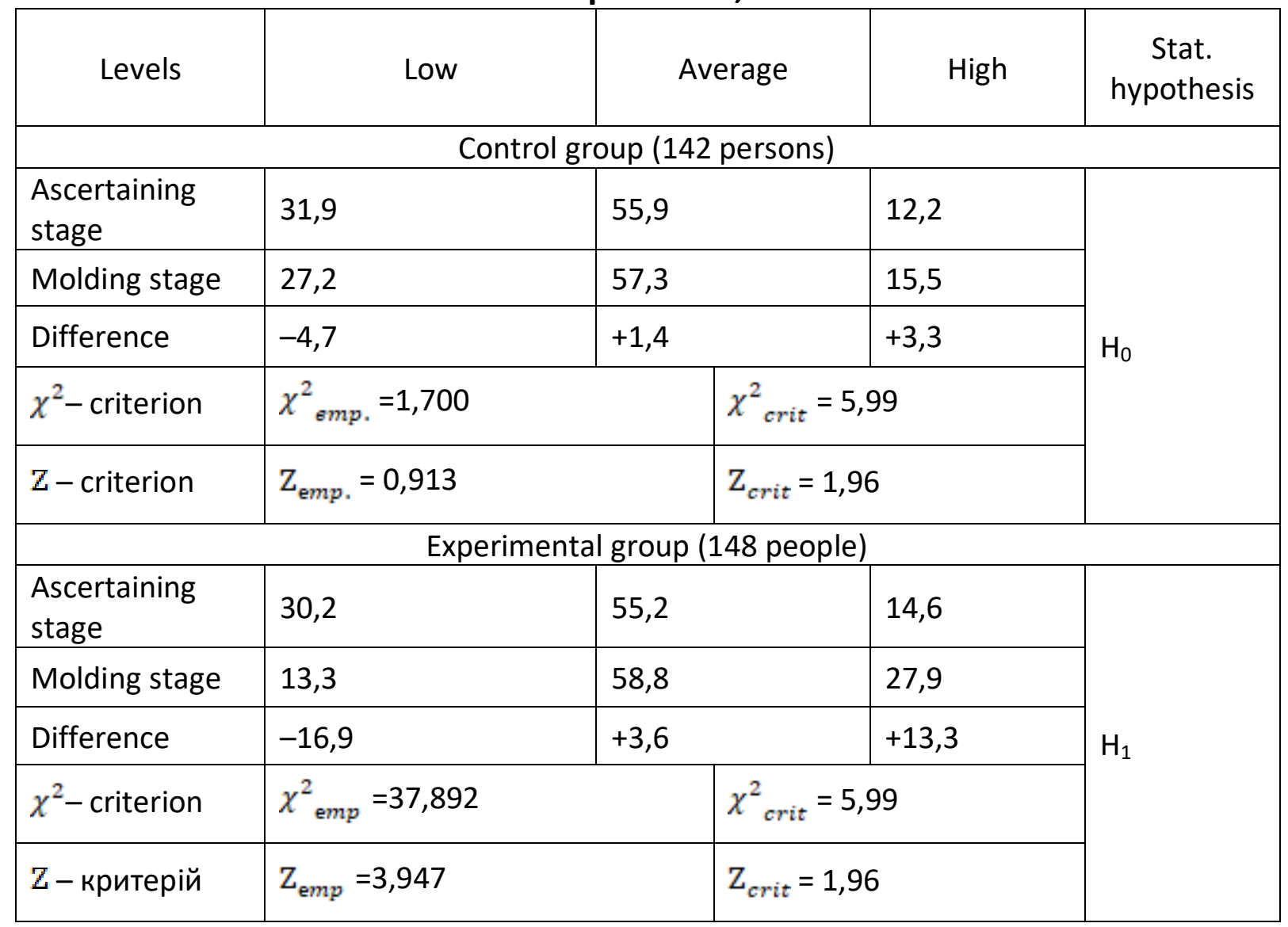

Therefore, after the molding experiment there were positive changes in both study groups. In the control group, these changes were not significant, and in the experimental group - led to a significant increase in the quality level 
of the group. This confirms the effectiveness of the structural and functional model of forming the professional image of future teachers of choreography in the process of professional training.

The process of forming future choreography teachers' professional image took place in accordance with the stages of the pedagogical experiment: diagnostic, stimulation stage, molding stage and stage of professional image formation in the process of professional training. The proposed author's methods of forming a professional image are implemented in the process of planned educational seminars and events for future teachers of choreography in the process of professional training. These methods have proved their effectiveness and contributed to positive changes in the process of forming the professional image of future choreography teachers.

According to the results of the ascertaining stage of the experiment, the insufficient level of formation of the professional image of future choreography teachers in the process of professional training and the need to create pedagogical conditions for its effective formation were confirmed.

Thus, the low level of formation of the professional image of future choreography teachers in the process of professional training was found in 30.7 $\%$ of respondents, including: $50.6 \%$ - in the CG and $49.4 \%$ - in the EG. At the average level, $55.5 \%$ of people were recorded: $49.1 \%$ - in the CG, $50.9 \%$ - in the EG. A high level is met by $13.8 \%$ of respondents, namely: $45.0 \%$ - in the CG and $55.0 \%$ - in the EG. Using Pearson's $\chi 2$-criterion, it was found out that at the ascertaining stage of the experiment the studied groups turned out to be qualitatively homogeneous according to all criteria: individual-axiological, professional-pedagogical and external-behavioral. Quantitative indicators of these groups, which were checked using the Z-test, did not differ significantly.

Thus, before the start of the molding experiment, the principle of uniformity of qualitative and quantitative indicators of the control and experimental groups is observed, which prevents distorted results and ensures the objectivity of the conclusions.

The use of the developed structural-functional model and pedagogical conditions of formation of professional image of future choreography teachers in the process of professional training testified to the intensity of deepening of knowledge in EG compared to CG.

After the molding stage of the experiment in the control group decreased by $4.7 \%$ the number of participants in the experiment with a low level of professional image of future teachers of choreography. At the same time, the number of respondents in this group with average and high levels of professional image formation increased by $1.4 \%$ and $3.3 \%$, respectively. The positive changes achieved by the control group were not significant.

The indicators of systematization, validity and depth of knowledge of future choreography teachers who studied using the developed methods were 
higher than those who studied according to the traditional program. This is demonstrated by the results obtained during the study: after the molding stage of the experiment in the experimental group decreased by $16.9 \%$ the number of participants with a low level of professional image of future choreography teachers. At the same time, the number of respondents with average and high levels of professional image formation increased by $3.6 \%$ and $13.3 \%$, respectively. The group has grown significantly qualitatively, and its quantitative indicators after the experiment significantly exceed the corresponding indicators before the experiment.

Conclusions. The results of the implementation of the proposed pedagogical conditions and structural-functional model of forming the professional image of future choreography teachers in the process of the molding stage of the experiment confirmed the hypothesis on the effectiveness of their influence. A statistically significant discrepancy between the indicators of the formation of the professional image of future choreography teachers with EG at the control stage of the experiment testified to the feasibility of further implementation of the developed measures in training of future choreography teachers. Using Pearson's $\chi 2$ test and $Z$ test, it is proved that in EG the results of the molding stage of the experiment are higher than in CG - at a significance level of 0.05 for all criteria of professional image formation of future choreography teachers in the process of professional training: individual-axiological, professional-pedagogical and external-behavioral.

\section{REFERENCES}

Великий тлумачний словник сучасної української мови (2005). Київ; Ірпінь: ВТФ «Перун» (Large explanatory dictionary of the modern Ukrainian language (2005). Kyiv; Irpin: VTF "Perun").

Демчук, Т. П. (2013). Напрямки вивчення іміджу викладача вищої школи. Вісник Національної академії Державної прикордонної служби України. Психологічні науки, 3.2 Режим доступу: nbuv.gov.ua/cgibin/irbis nbuv/cgiirbis 64.exe?!21DBN=LINK\&P21DBN=UJRN\&Z21ID=\&S 21REF=10\&S21CNR=20\&S21STN=1\&S21FMT=ASP meta\&C21COM=S\&2 S21P03=FILA $=$ \&2 S21STR=Vnadps $2013 \quad 3$ 29. (Demchuk, T. P. (2013). Areas of studying the image of a high school teacher. Bulletin of the National Academy of the State Border Guard Service of Ukraine. Phycological Sciences, 3. Retrieved from: http://www.irbisnbuv.gov.ua/cgibin/irbis nbuv/cgiirbis 64.exe?I21DBN=LINK\&P21DBN=UJRN\&Z21ID=\&S 21REF=10\&S21CNR=20\&S21STN=1\&S21FMT=ASP meta\&C21COM=S\&2 S21P03=FILA $=$ \&2 S21STR=Vnadps 2013329

Навроцька, М. М. (2014). Імідж педагога в освітньому просторі. Таврійський вісник oсвimu, 1 (45), 4. I, 8-12 (Navrotska, M. М. (2014). The image of a teacher in the educational space. Taurian Bulletin of Education, 1 (45), P. I, 8-12).

Марченко, В. С. (2016). Формування професійного іміджу сучасного вчителя. Наука $і$ ocвima, 1, 120-125 (Marchenko, V. S. (2016). Formation of professional image of a modern teacher. Science and education, 1, 120-125).

Хе, Сюефей (2019). Удосконалення музичної підготовки майбутнього вчителя хореографії в умовах вищої педагогічної освіти (автореф. дис. ... канд. пед. наук 
за спеціальністю: 13.00.02 - теорія та методика музичного навчання). Київ (Не, Xuefei (2019). Improving the musical training of future teachers of choreography in terms of higher pedagogical education (DSc thesis abstract). Kyiv).

Хомуленко, Т. Б., Падафет, Ю. Г., Скоріна, О. В. (2005). Теоретичні та практичні аспекти дослідження іміджу. Харків: ВД «ІНЖЕК» (Khomulenko, T. V., Padaphet, Yu. H., Skorina, O. V. (2005). Theoretical and practical aspects of image research. Kharkiv: VD “INTZEK”).

\section{PEЗЮМЕ}

Москаленко Елена, Скрипник Александр. Экспериментальная проверка действенности структурно-функциональной модели формирования личностнопрофессионального имиджа будущих учителей хореографии в процессе профессиональной подготовки.

В статье автор анализирует экспериментальную проверку действенности структурно-функциональной модели формирования личностно-профессионального имиджа будущих учителей хореографии в процессе профессиональной подготовки. Профессиональный имидж будущего учителя хореографии автор рассматривает как челостный образ педагога, который является гармоничным сочетанием его уникальных внешних, внутренних и личностно-профрессиональных качеств, жизненных позиций, профессиональных знаний и хореографического мастерства, которые подчеркивают неповторимую индивидуальность личности будущего учителя и оказывают существенное влияние на реализацию его профессиональных функций в области хореографии. Определены показатели и критерии сформированности профрессионального имиджа будущего учителя хореографии.

Ключевые слова: профессиональный имидж, будущий учитель хореографии, уровни, показатели и критерии сформированности, экспериментальная проверка.

\section{АНОТАЦІЯ}

Москаленко Олена, Скрипник Олександр. Експериментальна перевірка дієвості структурно-функціональної моделі формування особистісно-професійного іміджу майбутніх учителів хореографії в процесі фахової підготовки.

У статті автор аналізує експериментальну перевірку дієвості структурнофункціональної моделі формування особистісно-професійного іміджу майбутніх учителів хореографії в прочесі фрахової підготовки. Професійний імідж майбутнього вчителя хореографії автор розглядає як чілісний образ педагога, який є гармонійним поєднанням його унікальних зовнішньо-внутрішніх та особистісно-профресійних якостей, життєвих позицій, фахових знань і хореографічної майстерності, які підкреслюють неповторну індивідуальність особистості майбутнього вчителя та справляють суттєвий вплив на реалізацію його професійних функцій у галузі хореографії. Визначено показники та критерії сформованості професійного іміджу майбутнього вчителя хореографії.

Результати реалізації запропонованих педагогічних умов та структурнофункціональної моделі формування професійного іміджу майбутніх викладачів хореографії у прочесі формувального етапу експерименту підтвердили гіпотезу дисертації про ефрективність їх впливу. Статистично значуща невідповідність показників формування професійного іміджу майбутніх учителів хореографії з ЕГ на контрольному етапі експерименту засвідчила доцільність подальшого впровадження розроблених заходів у підготовці майбутніх учителів хореографії. Використовуючи тест х2 Пірсона ma Z-тест, доведено, що в ЕГ результати формувального етапу експерименту вищі, ніж у КГ- на рівні значущості 0,05 для всіх критеріїв формування професійного іміджу майбутніх викладачів хореографії в 
процесі професійної підготовки: індивідуально-аксіологічний, професійно-педагогічний та зовнішньо-поведінковий.

Ключові слова: професійний імідж, майбутній учитель хореографії, рівні, показники та критерії сформованості, експериментальна перевірка.

\section{Удк 378:37.011.3-051:74}

\section{Олександр Тимохов}

Південноукраїнський національний педагогічний

університет імені К. Д. Ушинського

ORCID ID 0000-0002-2443-372X

Олег Ткачук

Південноукраїнський національний педагогічний

університет імені К. Д. Ушинського

ORCID ID 0000-0002-5276-3558

DOI 10.24139/2312-5993/2020.03-04/290-300

\section{ФОРМУВАННЯ КРЕАТИВНОСТІ МИСЛЕННЯ В МАЙБУТНІХ ФАХІВЦІВ ДЕКОРАТИВНО-ПРИКЛАДНОГО МИСТЕЦТВА}

У статті досліджується френомен креативності мислення та необхідність ії формування у студентів закладів вищої освіти спеціальності 023 (Образотворче мистецтво, декоративне мистецтво, реставрація). Для розв'язання окреслених завдань, досягнення мети дослідження використані загальнонаукові методи теоретичного рівня. Вивчалася, аналізувалася й систематизувалася філософська, психолого-педагогічна і навчально-методична література з проблем креативності мислення. Визначено, що сприяння розвитку у студентів креативності мислення є чи не основним завданням педагога-вихователя. Заняття з фахових дисциплін, що формують спеціальність 023 (Образотворче мистецтво, декоративне мистецтво, реставрація) вимагають від педагога дотримання вище озвученшї вимоги .

Ключові слова: декоративно-прикладне мистецтво, творче мислення, креативне мислення, виховання майбутнього фрахівця.

Постановка проблеми. У наш час суспільство зазнає значних трансформаційних змін. Не оминули вони і сферу освіти. I хоча ці зміни носять переважно еволюційний характер, вони все ж вимагають негайного реагування та впровадження нових принципів проведення освітнього процесу.

Новітні інформаційні технології, запровадження в Україні норм та принципів Болонської системи, та й, насамперед, намагання залучитися до євроінтеграційних процесів ставлять перед освітянами задачі пов'язані із забезпеченням конкурентноздатності не лише самих освітніх послуг, а й кінцевого результату фаху здобувачів - якість та системність знань, отриманих за період навчання, уміння компетентно ними розпоряджатися, і що найголовніше, виховання у студента рис креативної особистості, здатної реагувати на зміни в соціокультурній сфері.

Сучасний інформаційний простір, що постійно розширюється, не дає вже можливості просто ретранслювати певний об'єм знань для 
формування професійних рис фахівця. Навпаки, найбільш актуальною проблемою в освітній галузі постає створення умов для забезпечення студента інструментарієм самостійного пошуку, відбору й аналізу інформації, а також уміння нею ефективно розпоряджатися.

Художні твори в сфері декоративно-прикладного мистецтва мають, як правило, не лише суто художню, але й ужиткову цінність, тобто можуть використовуватися в повсякденній діяльності людини. Отже, креативність під час їх створення, на нашу думку, є однією з основних компетентностей майбутніх фахівців декоративно-прикладного мистецтва.

Аналіз актуальних досліджень. У педагогіці і психології накопичений значний науковий досвід досліджень із теорії творчості (Л. С. Виготській, А. Н. Леонтьев, И.Я. Лернер, С. Л. Рубінштейн та ін.) Сутність творчості дослідники розглядають як через особу, їі характеристики (В. С. Біблер, Д. Б. Богоявленська, Я. І. Пономарьов та ін.), так і через процеси, що мають місце в творчій діяльності (Л. С. Виготській, С. Л. Рубінштейн та ін.).

Питаннями активізації навчально-пізнавальної діяльності студентів, яка би сприяла оптимальному розвитку їх творчих здібностей, займалися відомі психологи і педагоги - Г. С. Альтшуллер, Ю. К. Бабанській, В. С. Ільін, М. М. Льовіна, П.І. Підкасистий, С. Л. Рубінштейн, Б. М. Теплов, Г.І. Щукина, В.С. Юркевич та ін. У роботах цих авторів обґрунтовується мета, задачі, зміст і структура навчально-пізнавальної діяльності, аналізуються фактори ії оптимізації.

Проблема ролі індивідуально-психологічних особливостей особистості студентів у процесі розвитку їх творчого потенціалу знайшла своє відображення в дослідженнях В.І. Андрєєва, Л. С. Виготського, І. С. Кона, Б. Т. Ліхачева, Н. А. Менчинської, Д. В. Ушакова, І. С. Якиманської та ін.

Методичні розробки власне в галузі декоративно-прикладного мистецтва - Є.А. Антанович, Ю.Г. Божко, В.М. Вільчинський, Т. П. Ковальчук, Е. Н. Серпіонова, М. Н. Фішер та ін.

Огляд сучасних досліджень і практика педагогічної освіти дозволяють говорити про зростаючий інтерес суспільства до даної проблеми.

Проте недостатньо вивченими залишилися такі питання, як:

- виявлення умов організації навчально-пізнавальної діяльності студентів, яка б забезпечувала оптимальний розвиток їх творчих здібностей у процесі навчання;

- розвиток творчих здібностей студентів у процесі самонавчання;

- педагогічні умови сприяння розвитку творчих здатностей та креативності мислення у студентів у галузі декоративно-прикладного мистецтва.

Мета дослідження - дослідити феномен креативності мислення та ступеню необхідності його формування у студентів закладів вищої освіти спеціальності 023 (Образотворче мистецтво декоративне мистецтво, реставрація). 
Методи дослідження: для розв'язання окреслених завдань, досягнення мети дослідження використані загальнонаукові методи теоретичного рівня. Вивчалася, аналізувалася й систематизувалася філософська, психолого-педагогічна і навчально-методична література 3 проблем творчого та креативного мислення.

Виклад основного матеріалу. Однією з найбільш актуальних, як на наш розсуд, проблемою формування здатності до професійної діяльності майбутнього фахівця спеціальності декоративно-прикладне мистецтво $€$ проблема креативності та розвитку творчих здібностей.

Декоративно-прикладне мистецтво $\epsilon$ абсолютно невід'ємною ланкою в системі образотворчих мистецтв. Орієнтація фахівців, тим більш імовірно, майбутніх педагогів, в основному на візуальні мистецтва (малюнок, живопис, графіка, скульптура тощо) й нехтування іншими видами образотворчого мистецтва само по собі контрпродуктивне. А введення спеціальності ДПМ у закладах вищої освіти дає широкі можливості для всебічного розвитку спеціаліста в даній сфері.

В українській мові поряд із терміном «декоративне мистецтво» вживається термін "ужиткове мистецтво», що вказує на його частково утилітарний характер. I хоча далеко не всі витвори декоративного мистецтва $€$ утилітарними, тим не менш це так.

Ужиткове мистецтво - один із найдавніших видів художньої діяльності опанований людством. Декоративні твори супутні людині не тільки в побуті, а й майже в усіх сферах діяльності. I тому мають неабиякий повсякденний вплив, як на конкретну людину, так і на суспільство в цілому. Як на нашу думку, саме побутові декоративні твори формують первинний художній смак у людини. Адже саме вони супроводжують людину з перших днів ії існування, що, звичайно, не заперечує вплив інших видів мистецтв.

Одним із фундаментальних базових прошарків культури любого народу $\epsilon$ народне образотворче мистецтво, яке в переважній частині випадків має ознаки ужитковості, або декоративності.

Народне декоративно-прикладне мистецтво формувалося віками і його декоративні елементи несуть певний культурний код конкретної місцини, народу, нації тощо. Саме ці твори служать елементами культурної самоіндитифікації особистості. У якості прикладу можна привести хоча би пасхальні писанки, або святкові вишиванки. I, навпаки, декоративний виріб, придбаний у якості сувеніра, може досить дієво вказати чужинцеві на самобутність і певний рівень культури конкретного народу.

Народне мистецтво, і декоративне в тому числі, формувалося не спонтанно і тим більш не хаотично, під впливом об'єктивних зовнішніх чинників, як-то: клімат та природа місцевості, технічні можливості для розвитку певних ремесел, загальна культура та менталітет народу. 
Згодом окремі ремесла сформувалися в народні художні промисли, що існують і понині. I хоча їх вивчення також $€$ важливим, все ж, як на нашу думку, їх ґрунтовне вивчення слід прив'язувати до місцин, де вони історично склалися.

Услід за народним мистецтвом виникло й високе мистецтво, яке вже загалом носить більш інтернаціональний характер. Проте, роль декоративно-прикладного мистецтва залишилася значною.

Якщо поглянути на образотворче мистецтво в його історичній ретроспективі, то слід відмітити, що декоративне мистецтво розвивалось абсолютно синхронно з іншими його видами. Кожний художній стиль, напрям, течія вносили свої корективи в усі види мистецтв і декоративноприкладне мистецтво не є виключенням.

Отже, можна обґрунтовано стверджувати, що декоративноприкладне мистецтво $€$ необхідною й невід'ємною ланкою образотворчого мистецтва загалом.

3 початком масового товарного виробництва саме ужиткові, утилітарні якості декоративних виробів стали поступово відходити на другий план, 3 огляду на більш високу ціну штучних, вироблених вручну творів.

Проте значення художньо-естетичної складової лишилося незмінним. I хоча суто практична потреба в ручних декоративних виробах значно знизилась, потреба в них все ж залишається значною.

Одночасно виросли й вимоги до художніх якостей декоративних творів.

Мистецтво та культура в цілому не стоять на місці, а це вимагає від митця і фахівця саме сучасних декоративних рішень.

Сьогоденне соціальне середовище, що бурхливо змінюється, потребує фахівців у галузі декоративно-прикладного мистецтва, які могли би своєчасно та креативно реагувати на виклики сучасного соціокультурного буття.

Особливої актуальності проблема активізації творчих здібностей набуває через те, що некреативна, нетворча людина, тобто така, що мислить та діє за певним шаблоном, не зможе гідно конкурувати в мистецькому середовищі. Художник, позбавлений креативності, або просто творчо пасивний може існувати лише в якості ремісника, майстра, копіювальника, виконавця чужих ідей та задумів.

Метою ж освітнього процесу на художньо-графічних факультетах $€$ саме виховання художника-митця. I хоча освітній та виховний процеси тісно пов'язані, у даному випадку ми акцентуємо увагу саме на виховному процесі, адже творчості не можна навчити, митця в людині можна лише виховати.

Саме ці положення дають нам право вважати, що обрана нами тема актуальна, а теоретичні розробки, що є складовою нашої роботи, доцільні для використання в організації освітньо-виховного процесу, як на художньографічних факультетах, так і в інших закладах освіти мистецького спрямування. 
Творчість - діяльність людини, спрямована на створення якісно нових, невідомих раніше духовних або матеріальних цінностей (нові твори мистецтва, наукові відкриття, інженерно-технологічні, управлінські чи інші інновації тощо). Необхідними компонентами творчості є фантазія - уява, психічний зміст якої міститься у створенні образу кінцевого продукту (результату творчості).

Творчість може розглядатися у двох аспектах: психологічному й філософському. Психологія творчості досліджує процес, психологічний «механізм» протікання акту творчості як суб'єктивного акту індивіда. Філософія розглядає питання про сутність творчості, що по-різному ставилося в різні історичні епохи.

Одним із перших виділяє поняття творчості давньогрецький філософ Платон і ця творчість має універсальний характер. Так, у діалозі «Бенкет» зустрічається таке визначення творчості: усякий перехід із небуття в буття - це творчість, і, отже, створення будь-яких творів мистецтва й ремесла можна назвати творчістю, а всіх творців - їхніми творцями (Платон, 1965, с. 161).

Фундаментальні зміни прийшли з початком християнської епохи, 3 концепцією створення (лат. creatio) Богом світу з нічого. «Creatio» мало інше значення ніж «facere» («робити»), це творення розглядалося як вольовий акт і вже не використовувалося по відношенню до людської діяльності.

Епоха Ренесансу, навпаки, просякнута вірою в безмежні творчі можливості людини. Поступово «творчість» все більше усвідомлюється, насамперед, як художня творчість, виникає інтерес до постаті художника й самого акту творчості, все виразніше виступає і тенденція розглядати історію як продукт людської творчості. Проте тривалий час таке розуміння творчості наражалося на критику через тлумачення терміну як акту творення з нічого.

В епоху Просвітництва творчість пов'язується зі здатністю людини до уявлення. Англійські емпіристи трактували творчість як певну комбінацію вже існуючих елементів, творчість таким чином була близька винахідництву. Завершена філософська концепція творчості у XIII столітті спеціально аналізує творчу діяльність у вченні про продуктивну здатність уяви, що виступає як сполучна ланка між розумом і чуттєвим досвідом. Погляд на художника як на генія, що творить із натхнення, досяг своєї кульмінації в епоху Романтизму, творчість художника і філософа вважалася вищою формою людської життєдіяльності, у якому людина стикається з «абсолютом».

В ідеалістичній філософії кінця IX - XX століть творчість розглядається переважно у протилежності механічно-технічній діяльності. При цьому, якщо філософія життя протиставляє технічному раціоналізму творчий природний початок, то екзистенціалізм підкреслює духовно-особистісну природу творчості. У філософії життя найбільш розгорнута концепція творчості дана А. Бергсоном: творчість як безперервне народження нового становить сутність життя. Уся дійсність розглядається філософом як 
«безперервний ріст і нескінченна творчість» (Бергсон, 1907, с. 38). Найбільш адекватною формою існування вважають творчість і екзистенціалісти. М. Бердяєв розглядає творчість як "діло богоподібної свободи людини, розкриття в ній образу Творця» (Бердяев, 2000).

Філософія прагматизму і позитивізму, навпаки, розглядає творчість як винахідництво, мета якого - вирішувати задачу, поставлену певною ситуацією. Марксистська філософія визначає творчість як діяльність людини, що перетворить природний і соціальний світ відповідно до потреб людини й людства на основі об'єктивних законів дійсності.

У психології творчість вивчається головним чином у двох аспектах: як психологічний процес творення нового і як сукупність властивостей особистості, які забезпечують її включеність у цей процес.

Англійський учений (Воллес, 1924) розподілив творчий процес на 4 фази: підготовку, дозрівання (ідеї), осяяння (інсайт) й перевірку. Подібні стадії виділяв і А. Пуанкаре, описуючи процес здійснення їм декількох математичних відкриттів (Пуанкаре, 1909, с. 128). На думку вченого, творчий процес починався із постановки задачі, далі проходив процес несвідомої роботи, раптового знаходження ключа для розв'язання i, нарешті, заключна обробка результатів.

У сучасному науковому тезаурусі достатньо багато визначень поняття «креативність». Не беручись аналізувати кожне з них, спробуємо дати своє, що найорганічніше вписується в канву нашого дослідження.

Креативність нерідко ототожнюють із творчими здібностями або творчими можливостями, що розуміються як здатність людини до нестандартного, нешаблонного мислення, але на відміну від креативності, жодні з них не передбачають, в обов'язковому порядку, досягнення кінцевого результату, вони швидше орієнтовані на сам творчий процес.

Тому, на наш погляд, оптимальним буде таке формулювання «креативність» - здатність використовувати творчі можливості, здібності, знання й уміння для отримання оригінального, нестандартного - нового рішення поставленої задачі з участю уяви і фантазії.

Креативність діагностувати дуже важко, оскільки творчість спонтанна. Можна виявити креативність, але не можна достеменно точно визначити некреативність. Креативність не завжди піддається розвитку. Помічено, що в процесі навчання, пов'язаного 3 рутиною й рішенням стандартних алгоритмізованих задач, кількість висококреативних учнів зменшується.

Американський психолог А. Маслоу дійшов думки про те, що існує два типи креативності: первинної і вторинної. «Первинна креативність - це спадщина, що $є$ в кожної людини, загальне й унікальне надбання. Вона безумовно виявляється в усіх здорових дітей, хоча більшість людей, зростаючи, втрачає їі» - вважає А. Маслоу. Йдеться про фундаментальну потенційну можливість, яка дана всім людським істотам від народження. 
Але часто вона втрачається, пригнічується або спотворюється в міру того, як людина залучається до якогось певного соціуму.

Первинна креативність виникає з підсвідомості і $€$ джерелом нових відкриттів, реальної новизни ідей, що відхиляються від того, що вже існує.

Разом із тим, А. Маслоу виділяє і вторинну креативність. Він вважає, що науку можна визначити як метод, завдяки якому нетворчі люди можуть творити і створювати відкриття.

Звідси витікає, що у процесі становлення фахівця й подальшого його вдосконалення необхідно як зберегти і розвинути первинну, так i сформувати й постійно підтримувати вторинну креативність.

Креативність $€$ вищим рівнем інтелектуальної активності, мислення, дефініцією яких може бути сукупність розумових і особових здібностей (якостей), що впливають на становлення і прояв творчості. За твердженням психологів, кожна психічно нормальна людина володіє певним творчим потенціалом, творчими здібностями, які треба розвивати, і якомога раніше.

Основна мета креативної системи освіти - «розбудити» в людині творця і розвинути в ньому закладений творчий потенціал, виховати сміливість думки, упевненість у своїх творчих силах, здатність генерувати нові нестандартні ідеї, виховати потребу в творчому способі життя.

Важливі педагогічні вимоги до освітнього процесу в сенсі формування креативності мислення:

- його спадкоємність і безперервність;

- можливість включення студента в активне освітнє середовище;

- уміння самостійно управляти творчим процесом;

- уміння підвести свої знання під професійно значущі критерії оцінки діяльності фахівця.

Креативна система навчання у ЗВО передбачає:

- систему інтелектуальної підтримки мислення як дидактичний засіб;

- забезпечення цілісності вузівських знань за рахунок системи інтегральних ресурсів;

- застосування в процесі пошукової діяльності основних інтелектуальних інструментів (проблемна ситуація - виявлення і постановка творчої задачі, цілеспрямований пошук багатоваріантних рішень; оцінка й вибір оптимального варіанту рішення за критеріями освітнього стандарту);

- використання принципу «Docendo docimus» - «Навчаючи вчимося самі» в процесі навчання і контролю за просуванням у творчій діяльності;

- розвиток професійного інтересу за допомогою інтеграції теоретичного навчання з елементами методології творчості.

Ця класифікація умовна, але вона дозволяє чіткіше уявити собі теоретичні основи креативної системи в цілому. Критеріями оцінки ефективності формування структури творчого системного мислення студентів можуть служити: 
- їх здатність здійснювати системний аналіз проблемної ситуації;

- здатність виділяти з хаотичної ситуації головну задачу і коректно ії формулювати, ухвалювати нестандартні рішення, сутність яких спрямована на досягнення оптимального кінцевого результату в діяльності.

Організуючим суб'єктом у застосуванні креативної системи освіти є викладач.

Під час застосування традиційного навчання накопичені знання, як правило, не цілком відповідають ідеальній моделі підготовки кваліфікованого фахівця. Використання креативних технологій дозволить успішно справитися 3 даною проблемою. Стимулювання навчальнопізнавальної діяльності студентів, розвитку творчої, проблемноевристичної домінанти мислення стає можливим на основі креативності навчання. А саме - створення в процесі навчання, не стільки проблемної, скільки творчої ситуації, у межах якої студенту, під керівництвом педагога, пропонується самому визначити бажану мету, поставити творчі завдання, визначити можливості як стандартного, так і нестандартного їх рішення, i, врешті-решт, одержати оригінальний кінцевий результат.

Творчість за природою свою спирається на бажання зробити щось, що до тебе ще ніким не було зроблено, або на те, що б зробити по-новому (по-своєму) те, що до тебе вже існувало. Інакше кажучи, наявність творчих задатків у людині - це завжди прагнення вперед, до кращого, до прогресу, до досконалості i, звичайно, до прекрасного в найвищому й ширшому значенні цього поняття.

Без творчої фантазії не зсунутися з місця в жодній області людської діяльності, але, щодо мистецтва, то тут важливу роль відіграє також процес сприйняття.

Послуговуємося тим, що означений процес розпочинається 3 чуттєвого сприймання саме художньої форми твору (комплексу зображально-виражальних засобів, системи образів тощо), що дає певний імпульс усьому цьому складному психічному процесу й викликає адекватну реакцію у глядача. Навіть незначна, на перший погляд, художня деталь, здатна викликати у свідомості призабуті враження та уявлення, і в глибині свідомості розпочнеться процес сприймання як суто особистісний (Захарова, 2017, с. 177-187).

Розмова про розвиток у людині творчих умінь веде нас до дуже важливої і актуальної в наших умовах проблеми: про відмінність між фахівцем-творцем і фахівцем-ремісником. Ця надзвичайно важлива проблема найтіснішим чином пов'язана з проблемами естетичного виховання компетентно-креативного митця.

Справжній фахівець-творець відрізняється від рядового фахівцяремісника тим, що прагне створити щось понад того, що йому «згідно 3 інструкцією» належить створювати. Ремісник же задовольняється тим, що 
створює лише те, що належить. До більшого й до кращого він не прагне і не хоче обтяжувати себе подібними прагненнями. Його не можна обвинуватити в поганій роботі - адже він робить все, що йому належить, i, можливо, навіть добре робить.

Але таке, загалом, формальне ставлення до своєї праці, у якій би області це не було, не тільки не рухає життя вперед, але й навіть служить гальмом, тому що по відношенню до життя стояти на місці не можна: можна тільки або рухатися вперед, або відставати.

Творчий процес дуже важкий. Адже творець повинен працювати над рішенням задачі, не знаючи, чи $€$ в цієї задачі рішення, не знаючи, чи зможе він його знайти, до тих пір, поки воно не буде знайдене в неусвідомленому вигляді.

Не всі здатні на такий духовний пошук. Не всім, хто здатний на це, дарується успіх. Але, якщо комусь вдається вирішити по-справжньому творчу задачу, то творець переживає могутній емоційний підйом, який нерідко порівнюють із релігійним екстазом або закоханістю.

Слід відмітити, що робота фахівця в галузі декоративно-прикладного мистецтва, особливо на початку, передбачає, перш за все, вивчення технології та опанування технічними навичками виготовлення виробів. Проте орієнтувати навчальний процес суто на технічні питання, нехтуючи творчою складовою, украй контрпродуктивно в сенсі виховання майбутніх фахівців.

Висновки та перспективи подальших наукових розвідок. Розвиток творчих можливостей студентів, особливо мистецьких спеціальностей, $\epsilon$ необхідною та невід'ємною складовою навчально-виховного процесу в закладах вищої освіти.

Сприяння розвитку у студентів креативності мислення $\epsilon$ чи не основним завданням педагога-вихователя.

Заняття $з$ фахових дисциплін, що формують спеціальність 023 (Образотворче, декоративне мистецтво, реставрація) абсолютно точно вимагають від педагога дотримання вище озвучених вимог.

Для успішної роботи педагог повинен не тільки добре знати положення сучасної педагогічної науки, але й уміти їх активно реалізовувати.

Мета ж процесу освіти полягає в тому, що 6 із урахуванням життєвого досвіду студентів, їх вікових особливостей включити всі наявні методи пізнання в процес розвитку особистості та залучити їх до творчої креативної діяльності.

\section{ЛITEPATУPA}

Адамар, Ж. (1970). Исследование психологии процесса изобретения в области математики. Москва. Режим доступу: http://www.egamath.narod.ru/Math/Hadamard.htm (Adamard, J. (1970). A Study of the Psychology of the Invention Process in Mathematics. Moscow. Retrieved from: http://www.egamath.narod.ru/Math/Hadamard.htm). 
Бергсон, А. (1907). Творческая эволющия. Глава III. Режим доступу: http://www.bimbad.ru/docs/bergson_creative_evolution.pdf (Bergson, A. (1907). Creative evolution. Chapter III. $\quad$ Retrieved from: http://www.bimbad.ru/docs/bergson_creative_evolution.pdf).

Бердяев, Н. А. (2000). Смысл творчества. Гл. III. Творчество и искупление. Режим доступу: http://www.vehi.net/berdyaev/tvorch/03.html (Berdiaiev, N. A. 2000). The Meaning of Creativity. Ch. III. Creativity and redemption. Retrieved from: http://www.vehi.net/berdyaev/tvorch/03.html.

Захарова, В. (2017). Роль сприймання художнього твору у процесі його реалізації. Педагогічні науки: теорія, історія, інновачійні технологіï, 6 (70) (Zakharova, V. (2017). The role of perception of a work of art in the process of its realization. Pedagogical sciences: theory, history, innovative technologies, $6(70))$.

Маслоу, А. (1908-1970). Новые рубежи человеческой природы. Режим доступу: http://nkozlov.ru/library/psychology/d3647 (Maslow, H. (1908-1970). The Farther Reaches of Human Nature. Retrieved from: http://nkozlov.ru/library/psychology/d3647).

Платон (1965). Избранные диалоги. М.: Художественная литература (Platon (1965). Selected Dialogues. M.: Artistic literature).

Платонов, К. И. (1972). Проблемы способностей. М.: Наука (Platonov, К. І. (1972). Problems of Ability. M.: Science).

Пуанкаре, А. (1909). Математическое творчество. Режим доступу: http://www.bimbad.ru/biblioteka/article_full.php?aid=1403\&binn_rubrik_pl_articles=112. (Poincare, A. (1909). Mathematical creativity. Retrieved from: http://www.bimbad.ru/biblioteka/article_full.php?aid=1403\&binn_rubrik_pl_articles=112).

Ротенберг, В. С., Бондаренко, С. М. (1989). Мозг. Обучение. Здоровье. М.: Просвещение (Rotenberg, V. S., Bondarenko, S. M. (1989). Brain. Training. Health. M.: Education.

Симоненко, С. Н. (1997). К проблеме изучения механизмов визуального мышления. Одесса: Наука і освіта (Simonenko, S. N. (1997). To the problem of studying the mechanisms of visual thinking. Odessa: Science and education).

\section{PEЗЮME}

Тимохов Александр, Ткачук Олег. Формирование креативности мышления у будущих специалистов в области декоративно-прикладного искусства.

В статье исследуется феномен креативности мышления и необходимость ее формирования у студентов высших учебных заведений специальности 023 (Изобразительное искусство, декоративное искусство, реставрация). Для решения определенных задач, достижения цели исследования использованы общенаучные методы теоретического уровня. Изучалась, анализировалась и систематизировалась философская, психолого-педагогическая и учебно-методическая литература по проблемам креативности мышления. Определено, что содействие развитию у студентов креативности мышления является едва ли не основной задачей педагогавоспитателя. Занятия по специальным дисциплинам, формирующие специальность 023 (Изобразительное искусство, декоративное искусство, реставрация) требуют от педагога соблюдения выше озвученных требований.

Ключевые слова: декоративно-прикладное искусство, творческое мышление, креативное мышление, воспитания будущего специалиста. 


\section{SUMMARY}

Timokhov Aleksander, Tkachuk Oleg. Formation of creative thinking of future specialists of decorative and applied arts.

The article examines possibilities of students' creative thinking formation in higher education institutions in the 023 specialty (Fine Arts, Decorative Arts, Restoration). To solve the outlined tasks and achieve the aim of the study, we used the general scientific methods of theoretical level: analysis, synthesis, generalization, systematization, classification.

The article considers such issues as development of creative abilities, formation of creative thinking, education of a future specialist in the area of decorative and applied arts.

It has been determined that development of creative abilities of students, especially of the art specialties, is a necessary and integral part of the educational process in higher education institutions, where development of creative thinking is the main task of an educator.

For successful work educator must not only be aware of the basic provisions of modern pedagogical science, but also be able to implement them actively in the content of teaching aimed at comprehensive individual development.

The purpose of didactics is to include all available methods of cognition in the process of development of the personality according to the life experience, their age peculiarities and involve them into creative activating area in arts.

Key words: decorative and applied arts, creative thinking, education of the future specialist. 


\title{
РОЗДІЛ VІ. ПРОБЛЕМИ СПЕЦІАЛЬНОЇ ОСВІТИ
}

\author{
Удк 37.013:376
}

\author{
Світлана Литовченко \\ Інститут спеціальної педагогіки і психології \\ імені Миколи Ярмаченка НАПН України \\ ORCID ID 0000-0003-0001-4667 \\ DOI 10.24139/2312-5993/2020.03-04/301-311
}

\section{ДИСТАНЦІЙНЕ НАВЧАННЯ ДІТЕЙ ІЗ ПОРУШЕННЯМИ СЛУХУ: РЕКОМЕНДАЦІї УЧАСНИКАМ КОМАНДИ СУПРОВОДУ}

Ураховуючи інноваційність проблеми, метою статті $\epsilon$ розроблення рекомендацій педагогам та батькам щодо забезпечення потреб дітей із порушеннями слуху в умовах дистанційного навчання. Використано методи теоретичного аналізу літературних джерел, нормативних документів та результатів сучасних досліджень, а також узагальнення зарубіжного та національного практичного досвіду. Обгрунтовано, що в першу чергу доцільно враховувати особливості розвитку та навчальної діяльності конкретної дитини й обирати з порад, які складені за нозологічним принципом. Визначено специфічні моменти забезпечення слухової та візуальної доступності навчального матеріалу для учнів із порушеннями слуху, дотримання яких сприятиме підвищенню ефективності освітнього процесу.

Ключові слова: діти, порушення слуху, потреба, дистанційне навчання, рекомендації, слухова доступність, візуальна доступність.

Вступ. Протягом останніх десятиріч наша країна вибудовує суспільні відносини на основі демократичних цінностей, що сприяє утвердженню філософії толерантності, а відтак соціальної моделі сприйняття інвалідності, за якої, на відміну від медичної, обмеження розглядаються як результат дискримінації з боку суспільства, а не стану людини.

Позитивним результатом означених тенденцій виступає нова освітня концепція («Нова Українська школа»), яка ґрунтується на дитиноцентрованих принципах та передбачає реалізацію особистісно орієнтованого, компетентнісного, інклюзивного підходів. У широкому сенсі інклюзивність розглядають як доступність здобуття освіти на різних рівнях; пристосування (адаптацію) освітнього середовища до дитини, а не навпаки; можливість навчатися за індивідуальною освітньою траєкторією; надання підтримки й супроводу відповідно до освітніх потреб.

Затвердження в Україні інноваційного інструментарію «Міжнародна класифікація функціонування, обмеження життєдіяльності і здоров'я» (МКФ) впроваджує функціонально-компетентнісний підхід до визначення особливих освітніх потреб дитини; теорію функціонування, що пояснює закономірності та особливості розвитку, обмеження життєдіяльності, пов'язані зі станом здоров'я, з позиції організму, особи та суспільства. 
Рамковий Закон України «Про освіту» (2017р.) проголошує базовими принципи недискримінації, урахування багатоманітності людини, ефективного залучення та включення до освітнього процесу всіх його учасників.

Постановка проблеми. Поточний рік увійшов в історію як рік пандемії та введення безпрецедентних обмежень у всіх сферах життя більшості країн. У березні 2020 року в Україні було введено карантин та встановлено заборону відвідувати заклади освіти на період здійснення заходів щодо запобігання виникненню й поширенню коронавірусної хвороби (COVID-19). Система освіти перейшла на дистанційний формат, що стало викликом для всіх учасників освітнього процесу; особливо складним навчання в «умовах віддаленості» виявилося для дітей із особливими потребами, серед яких окрему групу займають діти з порушеннями слуху.

Загалом, національна система спеціальних шкіл для дітей із порушеннями слуху, у тому числі у складі навчально-реабілітаційних центрів, налічує понад 50 закладів (на тимчасово окупованих територіях та в анексованому Криму залишилося 6 спеціальних шкіл); у Києві та обласних центрах працюють заклади дошкільної освіти для дітей з порушеннями слуху або дошкільні групи при школах; збільшується кількість спеціальних та інклюзивних груп/класів, у яких навчаються діти з порушеннями слуху; вихователі та вчителі інклюзивних закладів не $є$ сурдопедагогами, працюють у команді з фахівцями зі спеціальної педагогіки.

Категорія дітей із порушеннями слуху досить розмаїта. Ступінь порушення слуху може суттєво відрізнятися: легкий, помірний, важкий, повний. Відповідно можливості слухового сприймання коливаються від труднощів у сприйманні та розумінні тихого мовлення в шумному середовищі (мінімальне зниження слуху), тихого та віддаленого мовлення в тиші (зниження слуху I ступеня); можливості сприймати розмовне мовлення тільки з близької відстані - 2-3 м (зниження слуху II ступеня), лише гучне мовлення на близькій відстані (зниження слуху III ступеня) до стану, коли залишаються певні слухові відчуття, що дають змогу сприймати гучні звуки довкілля та окремі звуки мовлення (зниження слуху IV ступеня) або можливість сприймати розмовне мовлення лише через слух відсутня, відтак слух не $є$ головним «комунікаційним» каналом для сприймання та продукування мовлення (глухота).

Варто зазначити, що ступінь зниження слуху та можливість сприймати розмовне мовлення є основними критеріями за медичного (аудіологічного) підходу до проблеми глухоти. Відповідно до соціокультурного підходу, глухий (нечуючий) - людина, яка користується жестовою мовою, як основним засобом спілкування, відчуває свою приналежність до культури глухих, усвідомлює себе як представника спільноти глухих, лінгвокультурної меншини. Важливим критерієм $\epsilon$ 
наявність порушення слуху в батьків та мова, якою спілкуються в родинні (словесна чи жестова); рівень слуху не визначальний (приміром, людина 3 легким чи помірним порушенням слуху, яка в тихому приміщенні сприймає мовлення, при підвищенні шуму таку можливість втрачає, використовує жестову мову і відтак є «глухою»).

У Саламанській декларації (1994р.), де проголошено пріоритетним інклюзивний підхід в освіті, також зазначено: «Освітня політика повинна повністю враховувати індивідуальні відмінності та особливості. Важливість мови жестів як засобу комунікації між глухими, наприклад, повинна бути визнана; необхідно вжити відповідні заходи для забезпечення того, щоб усі глухі люди мали доступ до освіти на своїй національній мові жестів. 3 огляду на особливі потреби в комунікації глухих і глухих/сліпих осіб їх освіту, можливо, доцільніше організовувати у спеціальних школах і спеціальних класах та підрозділах звичайних шкіл».

Водночас, сьогодні стрімко розвиваються медико-технічні засоби компенсації порушень слуху: надпотужні слухові апарати та кохлеарна імплантація (введення системи електродів до внутрішнього вуха пацієнта), що поряд із упровадженням програм неонотального скринінгу, раннього втручання створюють можливості для розвитку слухового сприймання та формування словесного мовлення як засобу комунікації, розширюють вибір освітніх маршрутів для таких дітей.

Зазначимо, що додаткові послуги для дітей із порушеннями слуху включають розвиток слухового (слухо-зорового, слухо-зоро-тактильного) сприймання, усного та писемного мовлення; формування жестомовної комунікативної компетентності; музично-ритмічні заняття тощо; сучасні підходи характеризуються застосуванням гнучких, максимально індивідуалізованих планів та програм із врахуванням наявного рівня розвитку, потенційних можливостей дитини, очікувань та запитів батьків.

Таким чином, діти з порушеннями слуху здобувають освіту у спеціальних (переважна більшість) та інклюзивних умовах і потребують супроводу та різних стратегій підтримки в освітньому середовищі.

Потреби дитини, визначенні фахівцями інклюзивно-ресурсних центрів та учасниками команди супроводу закладу освіти мають бути забезпечені в різних умовах навчання. Сьогодні карантин висуває нові вимоги - забезпечення потреб дитини й в умовах дистанційного формату.

Аналіз актуальних досліджень. Зважаючи на новизну проблеми, наукові публікації з питань організації дистанційного навчання дітей із порушеннями слуху нечисленні (Н. Адамюк, 2020; В. Жук, 2020; А. Замша, 2020). Актуальним у контексті проблеми $\epsilon$ праці, присвячені сучасним підходам до освіти дітей із особливими освітніми потребами (Е. Данілавічютє, 2018; В. Засенко та ін., 2016; А. Колупаєва, 2019; О. Таранченко, 2019; J. Deppeler, 2015; T. Loreman, 2015), особливостям 
організації освітнього середовища для дітей із порушеннями слуху (С. Кульбіда та ін., 2019), питанням дистанційного навчання дітей із особливими освітніми потребами (О. Чеботарьова та ін., 2020). Наявний перший практичний досвід дистанційного навчання дітей із порушеннями слуху, визначилися нагальні проблеми.

Із початком карантину Міністерством освіти і науки України запроваджено платформу, де вміщується інформація про зміни в освітньому процесі, введені через вимушене дистанційне навчання http://mon-covid19.info/. 22 червня 2020 року на офіційному сайті МОН України представлено на громадське обговорення проєкт «Положення про дистанційну форму здобуття загальної середньої освіти», спрямований урегулювати реалізацію дистанційного навчання за двома напрямами: дистанційною формою як окремою формою здобуття освіти; шляхом використання технологій дистанційного навчання в різних формах (денної, вечірньої, заочної, мережевої, екстернатної, сімейної (домашньої), педагогічному патронажі) здобуття освіти.

У проєкті враховано особливості дистанційного навчання під час карантину (надзвичайних обставин), а також передбачено умови для реалізації змішаного навчання; поповнено термінологічну систему педагогічної галузі: «асинхронний режим», «електронні освітні ресурси 3 навчальних предметів (інтегрованих курсів)», «інформаційнотелекомунікаційна система дистанційного навчання (електронна освітня платформа)», «електронне освітнє середовище», «синхронний режим» тощо.

Окремі пункти Положення деталізують особливості дистанційного навчання осіб із особливими освітніми потребами, забезпечення додаткових психолого-педагогічних та корекційно-розвиткових занять (послуг) у зазначених умовах.

У професійній спільноті приділяється значна увага питанням дистанційної освіти дітей із особливими освітніми потребами, зокрема дітей із порушеннями слуху. Наводимо думки педагогів-практиків у контексті проблеми: у процесі навчання дітей із порушеннями слуху значна частина часу має бути відведена на індивідуальні роз'яснення та консультації; серед проблемних питань: недостатнє технічне забезпечення учнів та педагогів, різні можливості батьків щодо допомоги в навчанні, психологічні наслідки соціальної ізоляції, а також через нерозуміння матеріалу, зниження мотивації до навчання; для учнів із порушенням слуху більшою мірою важливе безпосереднє спілкування, можливість бачити «обличчя вчителя». Більшість педагогів зазначають, що дистанційне навчання для дітей із порушеннями слуху можливо розглядати виключно як тимчасовий вимушений захід.

Проте дистанційний формат може періодично застосовуватися, діти будуть навчатися з дому, відтак педагоги мають бути готові до відповідної організації освітнього процесу та корекційно-розвивального супроводу. 
Мета статті - на основі аналізу теоретичних аспектів проблеми та наявного практичного досвіду розробити рекомендації учасникам команд супроводу щодо дистанційного навчання дітей із порушеннями слуху (на період дії надзвичайних обставин).

Теоретичні основи дослідження. Проблема визначення потреб $\epsilon$ актуальною в контексті організації дистанційного навчання; їі вивченню присвячено дослідження українських науковців Е. Данілавічютє, А. Колупаєвої, О. Таранченко, О. Федоренко та ін.

Об'єктивне визначення потреби покликано сприяти усуненню бар'єрів, які перешкоджають повноцінній участі дитини в освітньому процесі та успішному функціонуванню в соціумі.

У Законі України «Про освіту» (2017р.) зазначено: «особа 3 особливими освітніми потребами - особа, яка потребує додаткової постійної чи тимчасової підтримки в освітньому процесі 3 метою забезпечення ії права на освіту». Вочевидь така підтримка реалізується через відповідні психолого-педагогічні та корекційно-розвиткові послуги, спеціальне обладнання, наявність асистента вчителя та/або асистента дитини, необхідні адаптації та/або модифікацій в освітньому процесі.

Важливими положеннями щодо врахування потреб під час організації навчання, зокрема й дистанційного, учнів із порушеннями слуху $є$ такі:

- кожна дитина унікальна, її потреби індивідуальні;

- на часі відмова від опори на категорії порушень, натомість насамперед урахування індивідуальних особливостей розвитку, потреб кожної дитини;

- проєктуючи навчання, у першу чергу враховуємо особливості розвитку та навчальної діяльності конкретної дитини та обираємо з порад, які складені за нозологічним принципом (типом порушення/типологічними відмінностями);

- ураховуємо сильні сторони, що дитина може і що може запропонувати система освіта в разі виникнення потреби;

- задоволення особливих освітніх потреб здійснюється через адаптації/модифікації освітнього середовища (змісту, процесу, методів, матеріалів, ресурсів, очікувальних результатів), використання додаткового обладнання, послуг тощо;

- міра прояву й специфічність особливих освітніх потреб визначають специфіку підтримки учнів у процесі навчання.

У підготовці матеріалів статті використано методи теоретичного аналізу літературних джерел, нормативних документів та результатів сучасних досліджень, представлених у виданнях, включених до Переліку наукових фахових видань України, наукометричних баз даних Index Copernicus, Google Scholar та ін.; а також узагальнення практичного досвіду дистанційного навчання дітей із порушеннями слуху. 
Виклад основного матеріалу. Пропонуємо ключові рекомендації щодо використання технологій дистанційного навчання та організації безбар'єрного електронного освітнього середовища для учнів із порушеннями слуху (на період дії надзвичайних обставин), які стануть у нагоді як педагогам та фахівцям, що забезпечують супровід, так і батькам.

Необхідно акцентувати, що он-лайн навчання значної кількості учнів із порушеннями слуху передбачає більшою мірою:

- індивідуальну допомогу, консультування, оскільки особливості та потреби в кожної дитини різні;

- співпрацю з батьками, допомогу їм, забезпечення інформацією та матеріалами;

- час для адаптації до змін в організації навчання;

- потребує більше зусиль, і відповідно, більше виснажує ніж навчання у класі (необхідність дивитися на екран, утримувати увагу; «не звичне» сприймання вчителя, зображення себе та однокласників тощо);

- може зумовити перегляд освітніх потреб учнів у зв'язку зі зміною формату навчання.

Тривале позбавлення живого спілкування 3 однолітками, 3 педагогами, які підтримують, може негативно виплинути на соціальний розвиток учнів.

Важливе значення для організації навчання учнів із порушеннями слуху мають:

- ступінь прояву порушення; вид, час, якість слухопротезування (слуховий апарат, кохлеарний іпмлант, слуховий апарат кісткової провідності), рівень розвитку слухового сприймання та мовлення;

- провідний спосіб комунікації/основні засоби спілкування (словесна, жестова мови), підхід, за якого відбувалося попереднє навчання;

- наявність комплексних порушень;

- індивідуальні особливості дитини.

Варто зазначити, що одним із основних у навчанні дітей із порушеннями слуху $\epsilon$ бар'єр у налагодженні комунікації, отриманні інформації в повному обсязі. Узагальнюючи основні підходи, можна визначити специфічні для організації дистанційного навчання моменти:

- учні з порушеннями слуху можуть мати різні освітні потреби (у залежності від специфіки реабілітації одним важливіший якісний мікрофон, іншим - артикуляція, наявність підписів);

- для жестомовних учнів (для яких основним чи одним із основних засобів спілкування $€$ українська жестова мова) освітній процес має будуватися на основі двомовності (бімодально-білінгвального навчання);

- перш ніж планувати адаптації для учня з порушеннями слуху, варто дізнатися, який формат буде найзручнішим (те, що працювало у класі, може не допомагати в режимі он-лайн, наприклад, якщо в класі 
учень сприймав матеріал на слухо-зоровій основі 3 допомогою звукопідсилюючого обладнання, в умовах віртуального класу необхідними будуть послуги перетворення аудіо інформації в текстову тощо). У даному контексті влучним є вислів - Remain Flexible, because it Won't be «One Size Fits All» (Залишайтеся гнучкими, це не буде «один розмір для всіх»).

У межах слухової доступності важливими $€$ : забезпечення якісного звуку, відсутність зайвих шумів, відлуння, трансляція без гальмування; можливість бачити обличчя вчителя та однокласника, який говорить (під час відповідей на питання, обговорення, спілкування); чітка артикуляція, нормальний темп та гучність мовлення того, хто говорить.

Забезпечення доступності під час відео конференції: камери вчителя та учнів мають бути включені, кут та відстань розташування камери, рівень освітлення в кімнаті мають забезпечувати можливість добре бачити обличчя мовця (учасник, який у даний момент не говорить, може тимчасово відключити камеру, щоб зберегти «пропускну спроможність»); питання для обговорення доцільно вводити у вікні чата, щоб учень із порушеннями слуху міг читати питання та відповіді додатково до їх прослуховування; за можливості включити функцію додавання підписів/субтитрів у режимі реального часу, відповідно учень зможе бачити презентацію, обличчя вчителя чи іншого учасника та\або підписи; варто встановити «правила спілкування в он-лайн класі»: для того, щоб легше відрізнити голос однієї людини від іншої, доцільно кожному назвати своє ім'я перед тим, як розпочати говорити; той, хто не говорить, вимикає мікрофон, щоб мінімізувати фоновий шум; одночасно має говорити лише один; запропонувати функцію підняття руки; за можливості використовувати якісне обладнання (камери, мікрофони/гарнітура) та Інтернет зв'язок всіх учасників.

Дітям зі зниженим слухом набагато складніше зрозуміти мовлення в шумній обстановці, такі перешкоди можуть спричинити проблеми з увагою, втомлюваність під час прослуховування, дратівливість тощо. Щоб забезпечити необхідні умови вдома рекомендуємо: зменшити фоновий шум (зачинити вікна та двері, вимкнути чи відійти від приборів, що "шумлять», дистанціюватися від інших членів родини); перевірити обладнання, яким користується дитина для он-лайн навчання; використовувати додаткові технології для підсилення звуку під час роботи з комп'ютером.

Візуальна доступність включає: підкріплення словесної інформації наочністю (малюнки, фото, схеми, відео, драматизації, інсценування тощо); використання чітких покрокових візуальних інструкцій; доступність слухової інформації через друкований текст, підписи (матеріали, що використовуються для навчання, надаються в текстовому варіанті для учнів старших класів та батьків); на візуальних носіях (відео, фільми) мають бути доступні субтитри (автоматично створені субтитри можуть мати значну кількість помилок, тому не варто розглядати їх як повноцінне забезпечення доступності). 
Для жестомовних учнів дистанційне навчання здійснюється українською жестовою мовою або із супроводом/перекладом українською жестовою мовою; детальна інформація про проведення он-лайн уроків українською жестовою мовою розміщена на сайтах Інституту спеціальної педагогіки і психології імені Миколи Ярмаченка НАПН України http://ispukr.org.ua/ та Українського товариства глухих (УТОГ) https://utog.org/.

Результати дослідження дають підстави зробити такі висновки:

1. Аналіз нормативних документів, психолого-педагогічної літератури свідчить про актуальність проблеми організації супроводу та підтримки дітей з порушеннями слуху в різних умовах навчання. Втім, через те, що дистанційна форма $\epsilon$ інноваційною у вітчизняній практиці, питання організації навчання за такого підходу для дітей із порушеннями слуху залишаються недостатньо вивченими і методично обґрунтованими. На перший план виступає необхідність підготовки рекомендацій щодо розроблення та використання електронних освітніх ресурсів, проведення навчальних занять із урахуванням індивідуальних потреб дітей із порушеннями слуху. Актуальним $€$ наявний досвід навчання під час дії карантинних обмежень, який слід удосконалювати шляхом співпраці.

2. На основі узагальнення даних визначено специфічні моменти організації дистанційного навчання учнів із порушеннями слуху, надано ключові рекомендації для педагогів та батьків щодо забезпечення слухової та візуальної доступності навчального матеріалу.

3. Дистанційну форму здобуття освіти для дітей із порушеннями слуху слід розглядати лише на період дії надзвичайних обставин; такий формат не здатний замінити навчання дітей у класі, безпосередню роботу з учителем.

Ми звичайно не врахували всі можливі аспекти організації он-лайн навчання дітей із порушеннями слуху, доцільними $€$ подальші дослідження.

Перспективи подальших наукових розвідок. Актуальним є вивчення міжнародного досвіду й узагальнення пропозицій педагогів-практиків спеціальних та інклюзивних закладів освіти; розроблення методичних рекомендацій для вчителів, які навчають дітей із порушеннями слуху різних вікових груп; удосконалення електронних освітніх ресурсів, наповнення їх якісним апробованим контентом, адаптованим до різних потреб учнів; поширення прикладів вдалої практики, внесення відповідних тем до програм підвищення кваліфікації педагогічних працівників. На часі також підготовка рекомендацій щодо «переходу» від дистанційного формату навчання до звичайної роботи в класі чи групі. 


\section{ЛІТЕРАТУРА}

Данілавічютє, Е. А. (2018). Діти з особливими освітніми потребами в інклюзивному середовищі. Особлива дитина: навчанні і виховання, 3 (87), 7-18 (Danilovichute, E. A. (2018). Children with special educational needs in an inclusive environment. Special child: education and upbringing, 3 (87), 7-18).

Закон України «Про освіту» (Law of Ukraine "On education") (2017). Retrieved from: https://zakon.rada.gov.ua/laws/show/2145-19/print.

Засенко, В. В., Колупаєва, А. А., Таранченко, О. М. (2016). Освіта дітей з особливими потребами: від інституалізації до інклюзії. Національна доповідь про стан $i$ перспективи розвитку освіти в Україні, В.Г. Кремінь (ред.), (сс. 68-77). К.: Педагогічна думка (Zasenko, V. V., Kolupaieva, А. А., Taranchenko, O. М. (2016). Education of children with special needs: from institutionalization to inclusion. In V. G. Kremin (Ed.), National Report on the State and Prospects of Education Development in Ukraine, (pp. 68-77). K.: Pedagogical thought).

Інститут спеціальної педагогіки і психології імені Миколи Ярмаченка НАПН України. Замша, А. В., Адамюк, Н.Б. (2020). Дистанційне навчання дітей з порушеннями слуху. Режим доступу: http://ispukr.org.ua/?cat=5\&paged=3\#.Xz1qcdQS9H0 (Mykola Yarmachenko Institute of Special Pedagogy and Psychology of the National Academy of Pedagogical Sciences of Ukraine. Zamsha, A. V., Adamiuk, N. B. (2020). Distance learning of children with hearing impairments. Retrieved from: http://ispukr.org.ua/?cat=5\&paged=3\#.Xz1qcdQS9HO).

Інститут спеціальної педагогіки і психології імені Миколи Ярмаченка НАПН України. Жук, В.В. (2020). Як підготувати та провести індивідуальне корекційне заняття з дитиною з порушенням слуху дистанційно? Практичні поради. Режим доступу: http://ispukr.org.ua/?p=5702\#.Xz1q-tQS9HO (Mykola Yarmachenko Institute of Special Pedagogy and Psychology of the National Academy of Pedagogical Sciences of Ukraine. Zhuk, V. V. (2020). How to prepare and conduct an individual correctional lesson with a child with hearing impairment remotely? Practical advice. Retrieved from: http://ispukr.org.ua/?p=5702\#.Xz1q-tQS9H0).

Інститут спеціальної педагогіки і психології імені Миколи Ярмаченка НАПН України. Чеботарьова, О. В. та ін. (2020). Порадник батькам: практичні рекомендації під час дистанційного навчання дітей з інтелектуальними порушеннями. Режим доступу: http://ispukr.org.ua/?p=5762\#.Xz1pztQS9H0 (Mykola Yarmachenko Institute of Special Pedagogy and Psychology of the National Academy of Pedagogical Sciences of Ukraine. Chebotariova, O. V. et al. (2020). Parent's guide: practical recommendations for distance learning of children with intellectual disabilities. Retrieved from: http://ispukr.org.ua/?p=5762\#.Xz1pztQS9HO).

Колупаєва, А. А., Таранченко, О. М. (2019). Навчання дітей з особливими освітніми потребами в інклюзивному середовищі: навчально-методичний посібник. Харків: Ранок (Kolupaieva, А. А., Taranchenko, О. М. (2019). Teaching children with special educational needs in an inclusive environment: a textbook. Kharkiv).

Кульбіда, С. В. та ін. (2019). Навчання дітей із порушеннями слуху. Харків: Ранок. (Kulbida, S.V. et al. (2019). Teaching children with hearing impairments. Kharkiv).

Проєкт "Положення про дистанційну форму здобуття загальної середньої освіти» (Draft "Regulations on the distance form of general secondary education") (2020). Retrieved from: https://mon.gov.ua/ua/news/mon-proponuye-dlya-gromadskogoobgovorennya-proyekt-polozhennya-pro-distancijnu-formu-zdobuttya-zagalnoyiserednoyi-osviti. 
Саламанська декларація про принципи, політику та практичну діяльність у галузі освіти осіб з особливими освітніми потребами та Рамки Дій щодо освіти дітей з особливими освітніми потребами (The Salamanca Statement on Principles, Policies and Practices in Special Needs Education and Framework for Action on Special Needs Education) (1994). Retrieved from: https://zakon.rada.gov.ua/laws/show/995 001-94\#Text.

Canadian Association of the Deaf. Retrieved from: http://cad.ca/.

Center On Online Learning and Students with Disabilities. Retrieved from: http://www.centerononlinelearning.res.ku.edu/.

Deppeler, J., Loreman, T., and Smith, R. (2015). Teaching and learning for all. In J. Deppeler, T. Loreman, R. Smith, and L. Florian. (Eds.), Inclusive pedagogy across the curriculum. International perspectives on inclusive education (pp. 1-10). London: Emerald Group Publishing.

Hearing Loss Community. Retrieved from: https://www.hearinglikeme.com/online-learningfor-deaf-students/.

\section{PEЗЮМЕ}

Литовченко Светлана. Дистанционное обучение детей с нарушениями слуха: рекомендации участникам команд сопровождения.

Учитывая инновационность проблемы, целью статьи является разработка рекомендаций педагогам и родителям по обеспечению потребностей детей с нарушениями слуха в условиях дистанционного обучения. Использованы методы теоретического анализа литературных источников, нормативных документов и результатов современных исследований, а также обобщение зарубежного и национального практического опыта. Обосновано, что в первую очередь целесообразно учитывать особенности развития и учебной деятельности конкретного ребенка и выбирать из советов, которые составлены по нозологическому принципу. Определены специфические моменты обеспечения слуховой и визуальной доступности учебного материала для учащихся с нарушениями слуха, соблюдение которых будет способствовать повышению эфрфективности образовательного процесса.

Ключевые слова: дети, нарушение слуха, потребность, дистанционное обучение, рекомендации, слуховая доступность, визуальная доступность.

\section{SUMMARY}

Lytovchenko Svitlana. Online learning for children with hearing impairments: recommendations for support teams.

The article presents the main innovations in the education of children with special educational needs, outlines current issues of education and support of children with hearing impairments in the modernization of education in Ukraine.

Given the innovative nature of the problem, the aim of the article is to develop recommendations for teachers and parents to meet the needs of children with hearing impairments in online learning. Methods of theoretical analysis of literature sources, normative documents and results of modern research, as well as generalization of foreign and national practical experience are used.

It is substantiated that first of all it is expedient to consider features of development and educational activity of the concrete child and to choose from councils which are made on a nosological principle. Special educational needs are met through adaptations/modifications of the educational environment (content, process, methods, materials, resources, expected results), use of additional equipment/technologies, services, etc. It is emphasized that distance learning for students with special educational needs involves more individual 
assistance, counseling; cooperation with parents, helping them, providing information and materials; time to adapt to changes in the organization of training; requires more effort, and therefore more exhausting than "normal" training; may lead to a review of students' educational needs due to a change in learning format.

Specific aspects of ensuring auditory and visual accessibility of educational material for students with hearing impairments have been identified, compliance with which will help increase the efficiency of the educational process.

Key words: children, hearing impairment, need, online learning, recommendations, hearing accessibility, visual accessibility. 


\section{MICT}

\section{РОЗДІЛ І. ПРОБЛЕМИ ПЕДАГОГІКИ ВИЩОЇ ШКОЛИ}

Бахмат Наталія. Підготовка вчителів до формування підприємницької компетентності учнів закладів загальної середньої освіти

Даниленко Оксана. Самостійна робота з формування продуктивної граматичної компетентності майбутніх учителів у процесі навчання англійської мови після німецької

Добровольська Наталія. Система вправ для формування в майбутніх фахівців інформаційних технологій англомовної компетентності в читанні та говорінні

Купенко Олена. Педагогічна технологія наставництва в процесі формування проєктної компетентності майбутніх бакалаврів соціальної роботи 39

Кучай Тетяна, Кучай Олександр. Професійна підготовка фахівців економічного профілю в умовах неперервної освіти 49 Кучерган Єлизавета. Фізичне самовиховання студентів як складова системи професійного здоров'я майбутнього вчителя . 56

Лавриш Юліана. Індивідуалізація навчання іноземних мов: дидактична модель та експериментальне впровадження 66

Лемішовська Олеся, Яремко Ірина. Удосконалення фахових компетентностей у процесі підготовки викладачів обліково-економічних дисциплін з використанням інноваційних педагогічних технологій

Ліцман Юлія, Швець Ольга, Осьмук Наталія. Організація змішаного навчання за допомогою «GOOGLE CLASSROOM» під час вивчення біоорганічної хімії здобувачами медичних спеціальностей

Малишевський Олег. Міжпредметна інтеграція як дидактична умова розвитку в майбутніх інженерів-педагогів готовності до професійної мобільності ...

Москаль Тетяна. Навчання майбутніх учителів англійської мови професійно орієнтованої дискусії.

Пшенична Любов. Академічна чесність: природа явища та пріоритети поширення серед студентства.

Хімчук Ліліана. Конструктивна педагогічна взаємодія як одна 3 базових компетентностей майбутніх учителів початкової школи 146

Шуляк Андрій. Інформатизація методів активного навчання в підготовці майбутніх учителів інформатики до використання освітніх web-ресурсів у професійній діяльності 
РОЗДІЛ ІІ. ПРОБЛЕМИ ПОРІВНЯЛЬНОЇ ПЕДАГОГІКИ

Куліченко Алла. Огляд інноваційної діяльності американських медичних коледжів упродовж 1934-1939 рр. у працях Г. Вайскоттена .... 171 Шпарик Оксана. COVID-19 і шкільна освіта: вивчені уроки для Китаю ..... 182

\section{РОЗДІЛ ІІІ. ПРОБЛЕМИ ІСТОРІЇ ПЕДАГОГІКИ}

Гоменюк Ольга. Методологічні засади розвитку методики навчання германських мов на Буковині (перша половина XX ст.) 194

\section{РОЗДІЛ IV. ПРОБЛЕМИ ЗАГАЛЬНОЇ ПЕДАГОГІКИ}

Бондар Тамара. Готовність учителя початкової школи до діяльності в умовах інклюзивної освіти

Максимовська Наталія, Поляничко Анжела. Подієвий менеджмент як чинник інноваційного розвитку соціокультурної сфери

Малота Анастасія. Лінгвістичні особливості професійно орієнтованого усного спілкування соціального працівника англійською мовою

Пріма Раїса, Пріма Дмитро. Проєктна діяльність учителя початкової школи: теоретичні аспекти

Школьний Олександр, Захарійченко Юрій. Сучасна тематична підготовка до ЗНО з математики в Україні: текстові задачі і математичний аналіз.

\section{РОЗДІЛ У. ПРОБЛЕМИ МИСТЕЦЬКОЇ ОСВІТИ}

Енська Олена, Крамська Світлана. Особливості формування емоційної культури майбутніх педагогів мистецького профілю в умовах закладу вищої спеціальної освіти. 255

Лобова Ольга, Сбруєва Аліна, Бойченко Марина. Формування культурної компетентності школярів у процесі мистецької освіти в «Новій українській школі». 266

Москаленко Олена, Скрипник Олександр. Експериментальна перевірка дієвості структурно-функціональної моделі формування особистісно-професійного іміджу майбутніх учителів хореографії в процесі фахової підготовки 276

Тимохов Олександр, Ткачук Олег. Формування креативності мислення в майбутніх фахівців декоративно-прикладного мистецтва ..... 290

\section{РОЗДІЛ VІ. ПРОБЛЕМИ СПЕЦІАЛЬНОÏ ОСВІТИ}

Литовченко Світлана. Дистанційне навчання дітей із порушеннями слуху: рекомендації учасникам команди супроводу 301 


\section{СОДЕРЖАНИЕ}

\section{РАЗДЕЛ І. ПРОБЛЕМЫ ПЕДАГОГИКИ ВЫСШЕЙ ШКОЛЫ}

Бахмат Наталья. Подготовка педагогов к формированию предпринимательской компетентности учащихся учреждений общего среднего образования

Даниленко Оксана. Самостоятельная работа по формированию продуктивной грамматической компетентности будущих учителей в процессе обучения английскому языку после немецкого

Добровольская Наталия. Система упражнений для формирования у будущих специалистов информационных технологий англоязычной компетентности в чтении и говорении 26

Купенко Елена. Педагогическая технология формирования проектной компетентности будущих бакалавров социальной работы 39 Кучай Татьяна, Кучай Александр. Профессиональная подготовка специалистов экономического профиля в условиях непрерывного образования

Кучерган Елизавета. Физическое самовоспитание студентов как составляющей системы профессионального здоровья будущего учителя. 56 Лавриш Юлиана. Индивидуализация обучения иностранных языков: дидактическая модель и експериментальная имплементация 66

Лемишовская Олеся, Яремко Ирина. Обеспечение профессиональной компетентности в процессе подготовки преподавателей учетно-экономических дисциплин с использованием инновационных педагогических технологий

Лицман Юлия, Швец Ольга, Осьмук Наталия. Организация смешанного обучения с помощью «Google Classroom» при изучении биоорганической химии студентами медицинских специальностей

Малышевский Олег. Межпредметная интеграция как дидактическое условие развития у будущих инженеров-педагогов готовности к профессиональной мобильности

Москаль Татьяна. Обучение будущих учителей английского языка профессионально ориентированной дискуссии.

Пшенична Любов. Академическая чесность: природа явления и приоритеты распространения среди студентов

Химчук Лилиана. Конструктивное педагогическое взаимодействие как одна из базовых компетентностей будущих учителей начальной школы 146

Шуляк Андрей. Информатизация методов активного обучения в подготовке будущих учителей информатики к использованию образовательных web-ресурсов в профессиональной деятельности 159 


\section{РАЗДЕЛ ІІ. ПРОБЛЕМЫ СРАВНИТЕЛЬНОЙ ПЕДАГОГИКИ}

Куличенко Алла. Обзор инновационной деятельности американских медицинских колледжей в течение 1934-1939 гг. в работах Г. Вайскоттена

Шпарик Оксана. COVID-19 и школьное образование: выученные уроки для Китая

РАЗДЕЛ III. ПРОБЛЕМЫ ИСТОРИИ ПЕДАГОГИКИ

Гоменюк Ольга. Методологические основы развития методики обучения германских языков на Буковине (первая половина XX ст.) ........ 194

\section{РАЗДЕЛ IV. ПРОБЛЕМЫ ОБЩЕЙ ПЕДАГОГИКИ}

Бондарь Тамара. Готовность учителей начальной школы к деятельности в условиях инклюзивного образования 207

Максимовская Наталия, Поляничко Анжела. Событийный менеджмент как фактор инновационного развития социокультурной сферы.

Малота Анастасия. Лингвистические особенности профессионально ориентированного устного общения социального работника на английском языке.

Прима Раиса, Прима Дмитрий. Проектная деятельность учителя начальной школы: теоретические аспекты.

Школьный Александр, Захарийченко Юрий. Современная тематическая подготовка к ВНО по математике в Украине: текстовые задачи, математический анализ

\section{РАЗДЕЛ V. ПРОБЛЕМЫ ХУДОЖЕСТВЕННОГО ОБРАЗОВАНИЯ}

Энская Елена, Крамская Светлана. Особенности формирования эмоциональной культуры будущих педагогов творческого профиля в условиях учреждения высшего специального образования ... 255 Лобова Ольга, Сбруева Алина, Бойченко Марина. Формирование культурной компетентности школьников в процессе художественного образования в «Новой украинской школе» 266 Москаленко Елена, Скрипник Александр. Экспериментальная проверка действенности структурно-функциональной модели формирования личностно-профессионального имиджа будущих учителей хореографии в процессе профессиональной подготовки 276 Тимохов Александр, Ткачук Олег. Формирование креативности мышления у будущих специалистов в области декоративно-прикладного искусства

РАЗДЕЛ V. ПРОБЛЕМЫ СПЕЦИАЛЬНОГО ОБРАЗОВАНИЯ

Литовченко Светлана. Дистанционное обучение детей с нарушениями слуха: рекомендации участникам команд сопровождения 300 


\section{CONTENTS}

\section{SECTION I. PROBLEMS OF HIGHER EDUCATION}

Bakhmat Nataliia. Preparation of teachers for the formation of entrepreneurial competence of students of general secondary education institutions

Danylenko Oksana. Independent work on the formation of productive grammatical competence of future teachers learning English after German

Dobrovolska Nataliia. System of exercises for the formation of English-speaking competence in reading and speaking of future specialists in information technologies

Kupenko Olena. Pedagogical technology of mentoring in the process of formation of project competence of future bachelors of social work.

Kuchai Tetiana, Kuchai Olexander. Professional training of economic profile specialists in conditions of continuing education

Kuchergan Yelyzaveta. Physical self-education of students as a

component of the system of professional health of the future teacher 56

Lavrysh Yuliana. Individualization of foreign language teaching:

didactic model and experimental implementation.

Lemishovska Olesia, Yaremko Iryna. Ensuring professional competence in the process of training teachers of accounting and economic disciplines using innovative pedagogical technologies

Litsman Yulia, Shvets Olha, Osmuk Nataliia. Organization of blended learning with "Google Classroom" in the study of bioorganic chemistry of students of medical specialties

Malyshevskyi Oleg. Interdisciplinary integration as a didactic condition for the development of future engineers-teachers' readiness for professional mobility.

Moskal Tetiana. Teaching professionally oriented discussions to pre-service teachers of English

Pshenychna Liubov. Academic integrity: the nature of phenomenon and its distribution priorities among students.

Khimchuk Liliana. Constructive pedagogical interaction as

one of the basic competences of future primary school teachers

Shuliak Andrii. Informatization of active learning methods in the preparation of future computer science teachers for the use of educational web-resources in professional activities. 


\section{SECTION II. PROBLEMS OF COMPARATIVE EDUCATION}

Kulichenko Alla. Review of innovative activity in American medical colleges during 1934-1939 in the works by H. Weiskotten.

Shparyk Oksana. COVID-19 and School Education:

Lessons Learned for China.

\section{SECTION III. PROBLEMS OF HISTORY OF EDUCATION}

Homeniuk Olha. Methodological fundamentals of the development of Germanic languages teaching methods in Bukovyna (first half of the $X X$ century)

\section{SECTION IV. PROBLEMS OF PEDAGOGIES}

Bondar Tamara. In-service primary school teacher efficacy for inclusive education

Maksymovska Nataliia, Polianychko Anzhela. Event-management as a factor of innovative development of sociocultural field..

Malota Anastasiia. Linguistic features of professionally oriented oral communication of a social worker in English

Prima Raisa, Dmitry Prima. Project activities of primary school teachers: theoretical aspects.

Shkolnyi Oleksandr, Zakhariichenko Yurii. Modern thematic preparation for EIA in mathematics in Ukraine: text problems and mathematical analysis

\section{SECTION V. PROBLEMS OF ART EDUCATION}

Enska Olena, Kramska Svitlana. Peculiarities of emotional culture formation of future teachers of art profile in conditions of the higher special education institution

Lobova Olga, Sbruieva Alina, Boychenko Marina. Formation of schoolchildren's cultural competence in the process of art education in the "New Ukrainian School» 266

Moskalenko Olena, Skrypnyk Oleksandr. Experimental verification of the efficiency of the structural-functional model of formation of personal-professional image of future choreography teachers 276 Timokhov Aleksander, Tkachuk Oleg. Formation of creative thinking of future specialists of decorative and applied arts 290

\section{SECTION V. PROBLEMS OF SPECIAL EDUCATION}

Lytovchenko Svitlana. Online learning for children with hearing impairments: recommendations for support teams 301 
Педагогічні науки: теорія, історія, інноваційні технології : наук. П 24 журнал / голов. ред. А. А. Сбруєва. - Суми : Вид-во СумДПУ імені А. С. Макаренка, 2020. - № 3-4 (97-98). - 318 с.

ISSN 2312-5993

ISSN 2414-9799 (Online)

DOI журнала 10.24139/2312-5993

DOI номера 10.24139/2312-5993/2020.03-04

Key title: Pedagogični nauki: teoriâ, istoriâ, innovacijni technologiï Abbreviated key title: Pedagog. nauki: teor. istor. innov. tehnol.

Свідоцтво про державну реєстрацію друкованого засобу масової інформації КВ № 15795 - 4267Р від 27.10.2009 р.

Комп'ютерне складання та верстання: І. А. Чистякова

Підписано до друку 17.08.2020.

Формат 60х84/16. Гарн. Calibri. Папір офсет. Друк ризогр.

Ум. друк. арк. 18,48 Ум. фарб.-відб. 18,48.

Обл. вид. арк. 21,46. Тираж 100 пр. Вид. № 45.

Виготовлювач:

ФОП Цьома С.П., 40002, м. Суми, вул. Роменська, 100.

Тел.: 066-293-34-29.

Свідоцтво суб'єкта видавничої справи:

серія ДК, № 5050 від 23.02.2016. 